\title{
DESENVOLVIMENTO DE SISTEMAS HÍBRIDOS DE PLANEJAMENTO E PROGRAMAÇÃO DA PRODUÇÃO COM FOCO NA IMPLANTAÇÃO DE MANUFATURA ENXUTA
}

\section{RICARDO RENOVATO NAZARENO}

\author{
Tese apresentada ao Departamento de \\ Engenharia de Produção da Escola de \\ Engenharia de São Carlos - \\ Universidade de São Paulo, para \\ obtenção do título de Doutor em \\ Engenharia de Produção. \\ Área de concentração: Gerência de \\ produção
}

ORIENTADOR: Prof. Associado Antonio Freitas Rentes

São Carlos

2008 
AUTORIZO A REPRODUÇÃO E DIVULGAÇÃO TOTAL OU PARCIAL DESTE TRABALHO, POR QUALQUER MEIO CONVENCIONAL OU ELETRÓNICO, PARA FINS DE ESTUDO E PESQUISA, DESDE QUE CITADA A FONTE.

Ficha catalográfica preparada pela Seçăo de Tratamento da Informação do Serviço de Biblioteca - EESC/USP

Nazareno, Ricardo Renovato

Desenvolvimento de sistemas híbridos de planejamento e programação da produção com foco na implantação de manufatura enxuta / Ricardo Renovato Nazareno; orientador Antonio Freitas Rentes. - São Carlos, 2008.

Tese (Doutorado-Programa de Pós-Graduação e Área de Concentração em Engenharia de Produção) -- Escola de Engenharia de São Carlos da Universidade de Săo Paulo, 2008 .

1. Administração da produção. 2. Produção enxuta. 3. Sistemas híbridos de planejamento e programação. 4. Alta variedade de itens. I. Título. 
Candidato: Engenheiro RICARDO RENOVATO NAZARENO

Dissertação defendida e julgada em 20/10/2008 perante a Comissão Julgadora:

Prof. Associado ANTONIO FREITAS RENTES (Orientador)

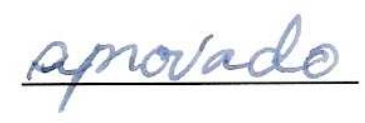

(Escola de Engenharia de São Carlos/USP)

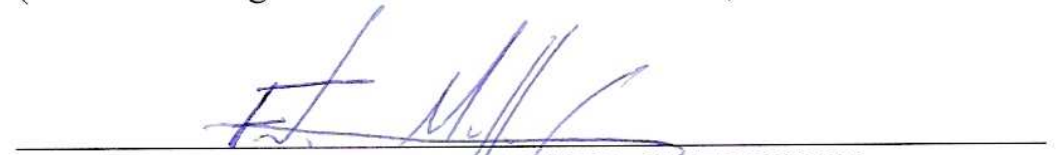

Prof. Associado FABIO MULLER GUERRINE

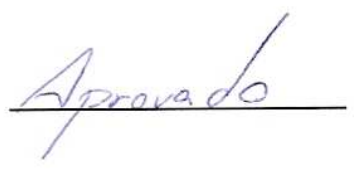

(Escola de Engenharia de São Carlos/USP)

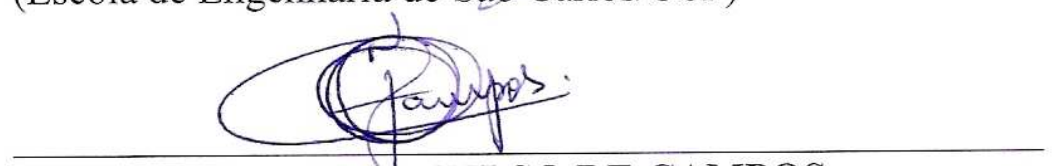

APROVADO

Prof. Dr. FERNANDO CELSO DE CAMPOS

(Universidade Metodista de Piracicaba/UNIMEP)
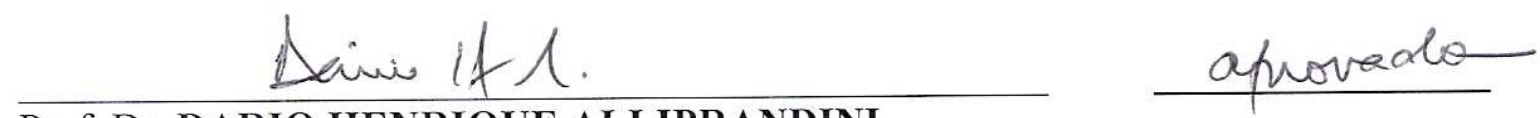

Prof. Dr. DARIO HENRIQUE ALLIPRANDINI

(Faculdades ETAPA)

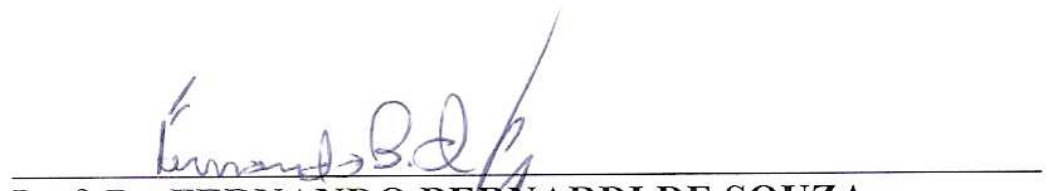

\section{APREV $/ A D O$}

Prof. Dr. FERNANDO BERNARDI DE SOUZA

(Universidade Estadual Paulista "Júlio de Mesquita Filho/UNESP/Campus de Bauru)

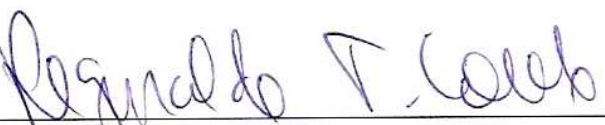

Prof. Associado REGINALDO TEIXEIRA COELHO

Coordenador do Programa de Pós-Graduação em

Engenharia de Produção

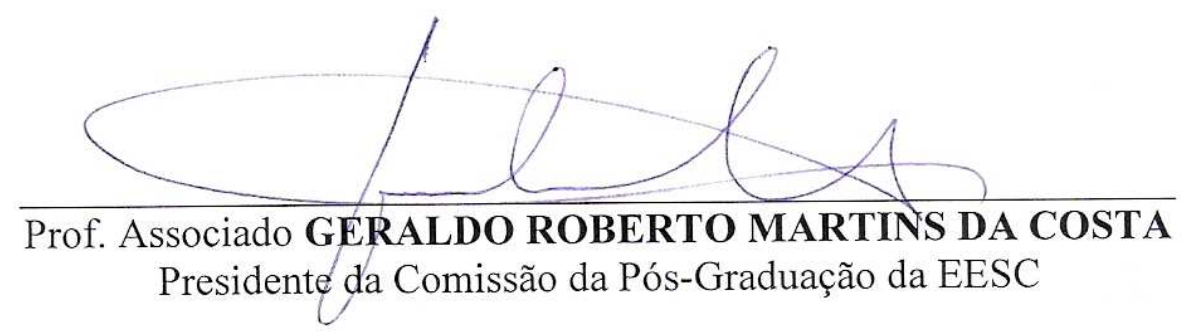




\section{SUMÁRIO}

\section{RESUMO}

\section{Abstract}

1 APRESENTAÇÃO DO TRABALHO..................................................18

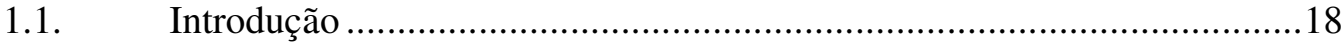

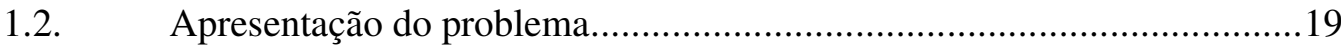

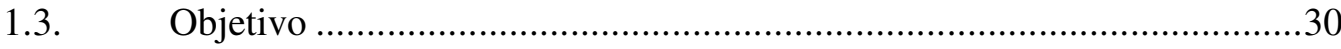

1.4. Metodologia de pesquisa e de desenvolvimento do trabalho ...................31

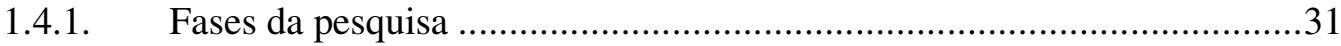

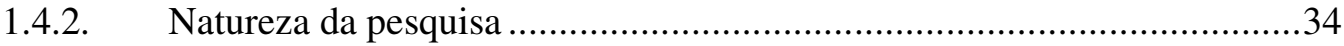

1.4.3. Abordagem do problema de pesquisa....................................................

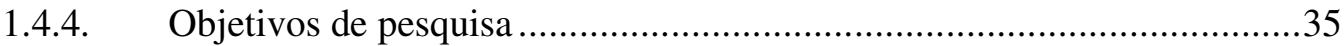

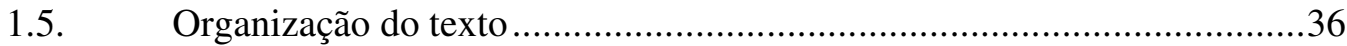

2 REVISÃO BIBLIOGRÁFICA ..................................................38

2.1. O Modelo Toyota de Produção e o Sistema de Manufatura Enxuta .........39

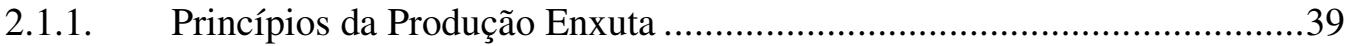

2.1.2. As sete categorias dos desperdícios na produção..................................42

2.1.3. Sistemas Empurrados versus Puxados................................................45

2.2. Sistemas de Planejamento, Programação e Controle da Produção: Visão

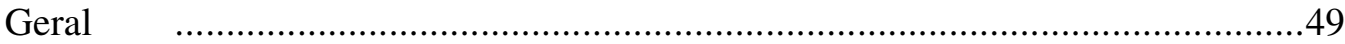

2.3. Funções de um Sistema de PCP .....................................................

2.3.1. Função planejamento da capacidade .....................................................52

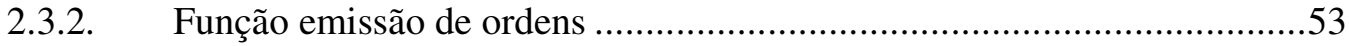

2.3.3. Função programação e controle da produção .........................................58 
2.4. Tipos de sistemas de PCP 60

2.4.1. Sistemas OPOQ (Order Point Order Quantity - Ponto de Pedido Quantidade Pedida) .60

2.4.2. Sistemas PBC (Periodic Batch Control) ..............................................61

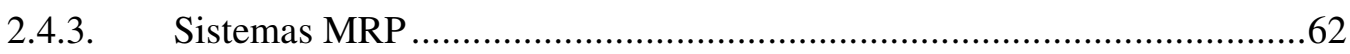

2.4.4. Sistemas Kanban (JIT/Lean Production) ...........................................63

2.4.5. Sistemas Tambor-Pulmão-Corda (Drum-Buffer-Rope) da Teoria das

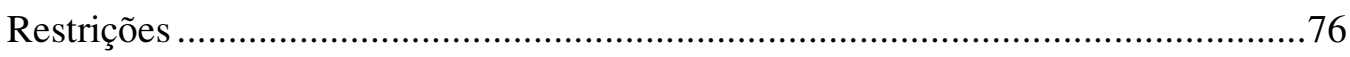

2.5. Fatores que influenciam na escolha dos sistemas de PCP .....................80

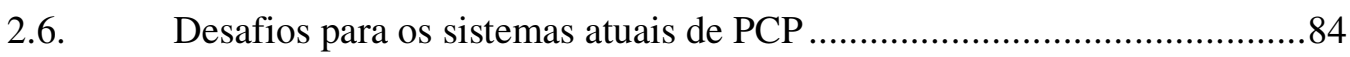

2.6.1. Alta Variedade de Produtos e Componentes ...........................................85

2.6.2. Sistemas híbridos de programação e controle da produção.......................86

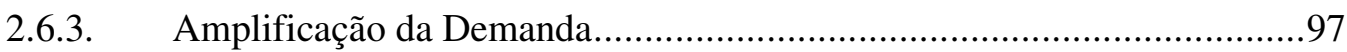

2.6.4. Instabilidade da demanda e dos processos em sistemas puxados. ............99

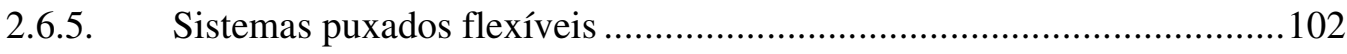

2.6.6. O processo puxador: onde e como programar e nivelar o fluxo de valor?...

3 MÉTODO PARA DESENVOLVIMENTO DE SISTEMAS HÍBRIDOS DE PLANEJAMENTO E PROGRAMAÇÃO PARA AMBIENTES DE PRODUÇÃO ENXUTA........................................................................117

3.1. Projeto macro do sistema híbrido de planejamento e programação da produção 119

3.1.1. Definição dos pontos de supermercado .............................................122

3.1.2. Definiç̧ão dos pontos de pulmão ……..............................................128

3.1.3. Definiçãa do processo puxador ..........................................................130

3.2. Definição das subfamílias de programação e controle ...........................132 
3.3. Dimensionamento do tamanho dos pontos de pulmões e supermercados....

3.3.1. Dimensionamento do tamanho dos pontos de pulmões 138

3.3.2. Dimensionamento do tamanho dos pontos de supermercados 139

3.3.2.1. Identificar o recurso gargalo do loop de cada supermercado 141

3.3.2.2. Calcular o TPT (“Toda Parte Toda...") ou EPEI (“Every Part Every Interval..." de cada loop 142

3.3.2.3. Revisão do TPT para cada subfamília de controle 151

3.3.2.4. Calcular o número de cartões para cada item do supermercado 154

3.3.2.5. Definir a distribuição dos cartões no quadro semáforo 157

3.4. Definição das sistemáticas de programação e controle da produção ......159

3.4.1. Programação e controle dos itens MTO ............................................159

3.4.2. Programação e controle dos fluxos puxados........................................161

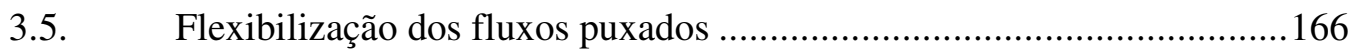

3.5.1. Definição dos períodos de ajuste do tamanho dos supermercados .........167

3.5.2. Estratégias para ajuste fino do sistema puxado numa mesma janela de

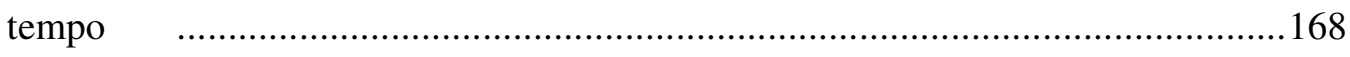

3.5.3. Definição da forma de se ajustar o tamanho do supermercado: Alteração da quantidade de itens por cartão versus alteração da quantidade de cartões .

3.6. Programação e nivelamento do processo puxador ................................177

3.6.1. Nivelar e balancear o mix de produção no processo puxador ................178

3.6.2. Definir o intervalo pitch para programação do processo puxador ...........182

3.6.3. Criar uma rotina de busca contínua pelo nivelamento da demanda........186

3.7. Planejar e acompanhar a implantação .............................................. 190

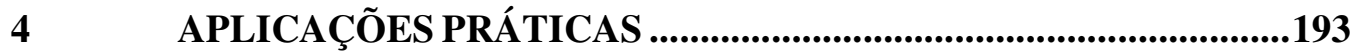

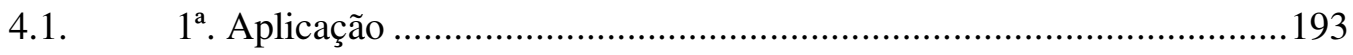


4.1.1. Projeto macro do sistema híbrido de planejamento e programação........195

4.1.2. Definição das subfamílias de programação e controle ...........................198

4.1.3. Dimensionamento do tamanho do supermercado ...............................200

4.1.4. Definição das sistemáticas de programação e controle ..........................205

4.1.4.1. Programação e controle dos itens MTO .............................................205

4.1.4.2. Programação e controle dos fluxos puxados..........................................205

4.1.5. Flexibilização dos fluxos puxados .......................................................206

4.1.6. Programação e nivelamento do processo puxador ................................206

4.1.7. Preparação e acompanhamento da implementação...............................208

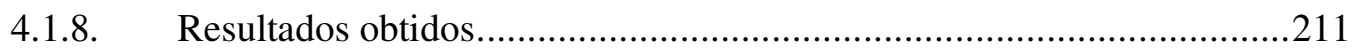

4.1.9. Considerações sobre a $1^{\mathrm{a}}$. aplicação ................................................212

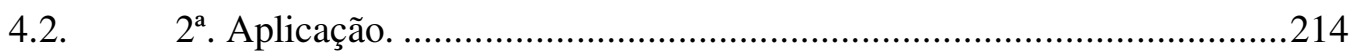

4.2.1. Projeto macro do sistema híbrido de planejamento e programação da

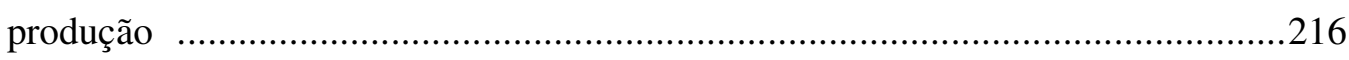

4.2.2. Definição das subfamílias de programação e controle ..........................219

4.2.3. Dimensionamento do tamanho do supermercado ..............................222

4.2.4. Definição das sistemáticas de programação e controle .........................2225

4.2.4.1. Programação e controle dos itens MTO ...........................................222

4.2.4.2. Programação e controle dos fluxos puxados........................................226

4.2.5. Flexibilização dos fluxos puxados ..................................................22

4.2.6. Programação e nivelamento do processo puxador ...............................2230

4.2.7. Preparação e acompanhamento da implantação....................................235

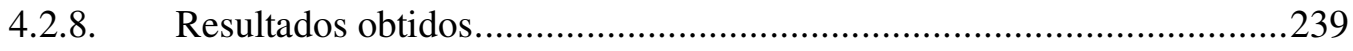

4.2.9. Considerações sobre a $2^{\mathrm{a}}$. aplicação ...............................................240

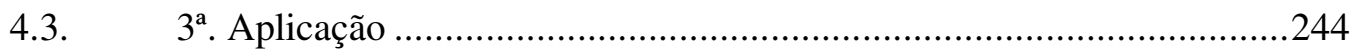


4.3.1. Projeto macro do sistema híbrido de planejamento e programação........247

4.3.2. Definição das subfamílias de programação e controle ..........................250

4.3.3. Dimensionamento do tamanho dos supermercados ............................252

4.3.4. Definição das sistemáticas de programação e controle ..........................254

4.3.4.1. Programação e controle dos itens MTO .............................................254

4.3.4.2. Programação e controle dos fluxos puxados......................................25

4.3.5. Flexibilização dos fluxos puxados .......................................................260

4.3.6. Programação e nivelamento do processo puxador ................................262

4.3.7. Preparação e acompanhamento da implementação ...............................263

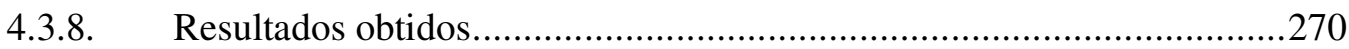

4.3.9. Considerações sobre a $3^{\mathrm{a}}$. aplicação ................................................22

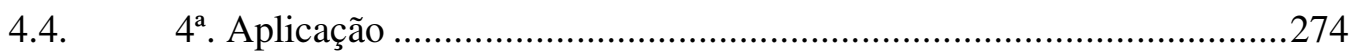

4.4.1. Projeto do sistema híbrido de planejamento e programação ..................276

4.4.2. Definição das subfamílias de programação e controle ..........................220

4.4.3. Dimensionamento do tamanho dos pulmões e supermercados...............281

4.4.4. Definição das sistemáticas de programação e controle .........................28

4.4.4.1. Programação e controle dos itens MTO/ETO......................................285

4.4.4.2. Programação e controle dos fluxos puxados......................................287

4.4.5. Flexibilização dos fluxos puxados ..............................................28

4.4.6. Programação e nivelamento do processo puxador ...............................289

4.4.7. Preparação e acompanhamento da implantação....................................2296

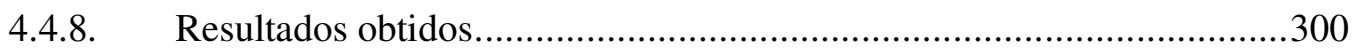

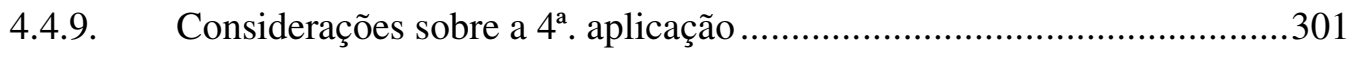

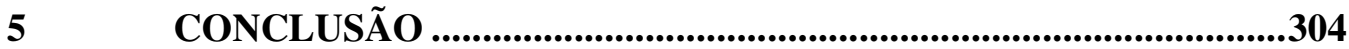

5.1.1. Conclusões em cada etapa da metodologia de pesquisa adotada.............305 


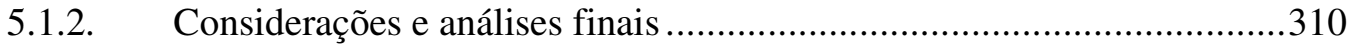

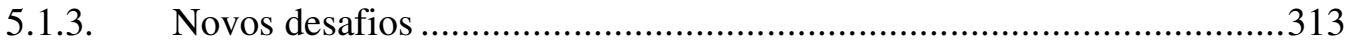

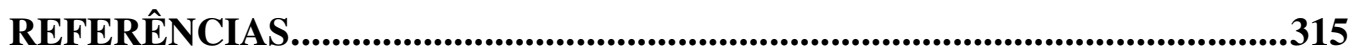




\section{LISTA DE FIGURAS}

Figura 1: Fluxo de valor tradicional em um sistema de produção enxuta ................20

Figura 2: Variação de demanda em volume e mix e sua transmissão e amplificação

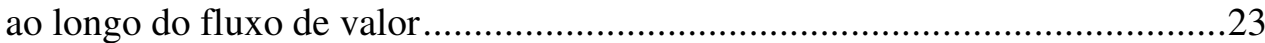

Figura 3: Visão Ilustrativa de um Sistema Híbrido .............................................25

Figura 4: Visão esquemática de fluxo de valor com os problemas apresentados ......29

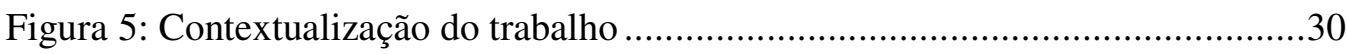

Figura 6:Método de pesquisa baseado no ciclo de desenvolvimento incremental ou

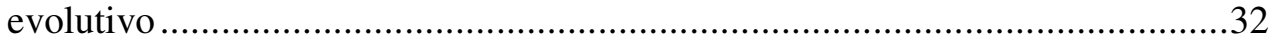

Figura 7: As quatro categorias do modelo Toyota ................................................40

Figura 8: Categorias de desperdícios .............................................................43

Figura 9: Proporção das atividades que agregam valor (AV) e das que não agregam valor (NAV) nas empresas e o enfoque das melhorias na produção enxuta ......44

Figura 10:Alguns ícones definidos para Mapeamento do Fluxo de Valor ................46

Figura 11: Visão geral de um sistema empurrado ............................................47

Figura 12: O sistema de puxar elimina a necessidade de se programar todas as

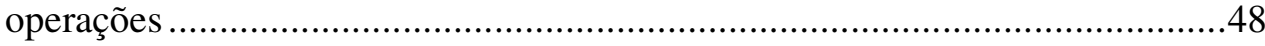

Figura 13: Modelo de Transformação ..............................................................49

Figura 14: Estrutura Genérica de um Sistema de Planejamento e Controle da

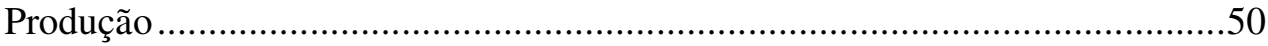

Figura 15: Dinâmica do sistema kanban .............................................................64

Figura 16: Exemplo de controle da produção com Kanban de Sinal ........................67

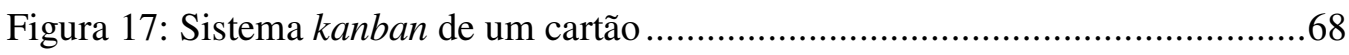

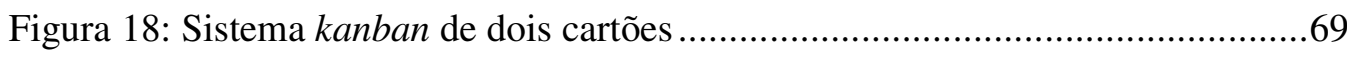

Figura 19: Sistemática de distribuição dos cartões no quadro de semáforo ..............71

Figura 20: A aplicação dos sistemas JIT, MRP e TPC depende de várias variáveis..82

Figura 21: Sistemas Puxados x Empurrado x Híbridos ........................................... 84

Figura 22: Visão Ilustrativa de um Sistema Híbrido ...........................................87

Figura 23: Marcação de itens kanban como fantasmas na estrutura do MRP ...........88

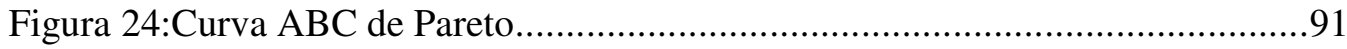

Figura 25: Sistema Puxado de Reposição ............................................................92

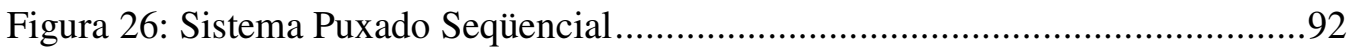


Figura 27: Takt time - sincroniza o ritmo da produção com a demanda ..................93

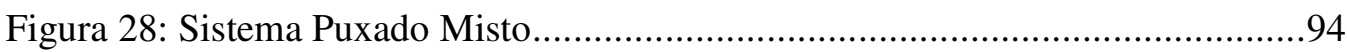

Figura 29: Fatores contemplados para definição do nível de estoque de um

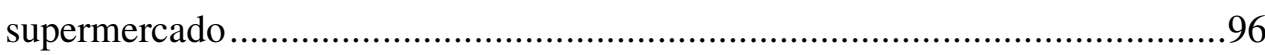

Figura 30: Gráfico de Amplificação da Demanda...............................................98

Figura 31:Influência da amplitude de variação da demanda no tamanho do estoque 99

Figura 32: Inputs e outputs de decisões de processos............................................ 105

Figura 33: Criando modos de administrar a demanda ao longo do ano ...................106

Figura 34: Exemplo de quadro de elementos de trabalho para 3 produtos ..............109

Figura 35:Opção de balanceamento 1, nivelar a programação e manter a mão de obra constante - produzir os produtos numa seqüência fixa

Figura 36: Opção de balanceamento 2, nivelar a programação e criar um FIFO direto para a expedição.

Figura 37: Opção 3, Nivelar a programação com um supermercado e, ao mesmo tempo, produzir diretamente para a expedição

Figura 38: Opção 4, Balancear o takt time e adicionar operadores quando um produto excede o takt time 113

Figura 39: Balanceamento dos operadores com base nos elementos de trabalhado do

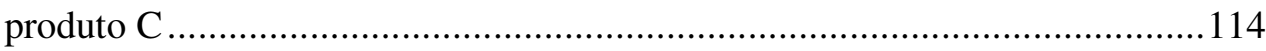

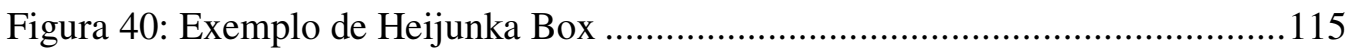

Figura 41: Supermercado regulador em fluxo com alta variedade de itens, recursos compartilhados e altos tempos de set up

Figura 42: Supermercado pulmão em fluxo com alta volatilidade da demanda ......124

Figura 43: Supermercado pulmão para combater a falta de sincronização na chegada de itens. 125

Figura 44: Supermercado de segurança em fluxo com problemas de retrabalho, atrasos e paradas não programadas. 125

Figura 45: Supermercado pulmão em fluxo com baixa tolerância de espera pelo cliente externo 126

Figura 46: Lógica de um sistema de dois kanbans

Figura 47: Pontos de controle com pulmões de sincronização de fluxos de valor em paralelo. 129 
Figura 48: Definição do processo puxador num sistema puxado de reposição .......130

Figura 49: Definição do processo puxador num sistema puxado seqüencial

Figura 50: Processo puxador em sistemas ETO ou MTO com fluxos em paralelo .132

Figura 51: Visão Ilustrativa de um Sistema Híbrido ...........................................133

Figura 52: Dimensionamento da quantidade de itens por loop de pulmões ............138

Figura 53: Fatores a serem contemplados no cálculo de supermercado..................139

Figura 54: identificação do recurso gargalo através do cálculo do TPT..................142

Figura 55: Corte de um MFV com supermercados calculados baseado nos dois tipos de TPT (transporte e produção) .................................................................144

Figura 56: Sistemática de distribuição dos cartões na faixa amarela baseada em disparos a partir do consumo da primeira peça da caixa. 158

Figura 57: Sistemática de distribuição dos cartões na faixa amarela com disparos a partir do consumo da últma peça da caixa ................................................158

Figura 58: Sistemática de programação por quantidade fixa e períodos variáveis com kanbans de produção 162

Figura 59: Sistemática de programação por quantidade fixa e períodos variáveis com kanbans de sinal e duas gavetas. 163

Figura 60: Sistemática de reposição por período fixo (a cada 3 dias) e quantidades variáveis. 164

Figura 61: Distribuição diária dos itens com TPT de 3 dias e amarração dos dias do TPT com agenda do mês 165

Figura 62: Flexibilização do tamanho do supermercado por janelas de tempo (Duggan, 2002)

Figura 63: Ajuste fino do tamanho do supermercado dentro das janelas de tempo.169

Figura 64: Procedimento para empenho de itens do supermercado

Figura 65: Ajuste do supermercado com redução da quantidade de itens por cartão (tamanho do kanban). 173

Figura 66: Ajuste do supermercado com redução da quantidade de cartões 174

Figura 67: Ajuste do supermercado com aumento da quantidade de itens por cartão

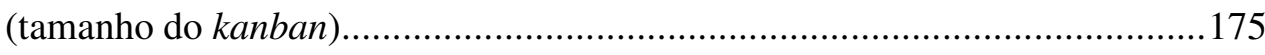

Figura 68: Ajuste do supermercado aumentando a quantidade cartões..................176 
Figura 69: Exemplo proposto de quadro de programação e nivelamento da produção 182

Figura 70:Quantidade de intervalos pitch por cartão. 183

Figura 71: Desnivelamento gera desperdícios e sobrecargas...............................187

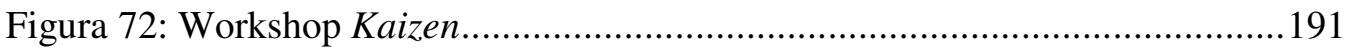

Figura 73: Mapeamento de Fluxo de Valor Situação Atual.....................................194

Figura 74 - Mapeamento de Fluxo de Valor Situação Futura .................................196

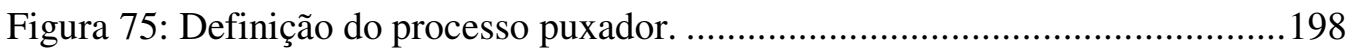

Figura 76: MFV’s para cada subfamília de controle. ...........................................200

Figura 77: Identificação dos loops de produção................................................201

Figura 78: Revisão dos pontos de supermercado. ..............................................204

Figura 79: MFV Macro com linha de tempo....................................................204

Figura 81: Sistema de impressão de kanbans....................................................209

Figura 82: Quadros de kanban e de programação. .............................................210

Figura 83: Recursos de armazenagem dos itens do supermercado. .......................210

Figura 86: Otimização do espaço físico ocupado................................................211

Figura 87: Visão Esquemática da Situação Atual ...............................................215

Figura 88: Definição dos pontos de supermercado - 2 ${ }^{\mathrm{a}}$. Aplicação .........................217

Figura 89: Definição do processo puxador. ....................................................219

Figura 90: Identificação dos loops de produção..................................................222

Figura 91: Identificação do recurso gargalo...................................................223

Figura 92: MFV macro implementado para os itens em supermercado. .................2225

Figura 93: Planilha para visualização de picos no consumo dos itens do

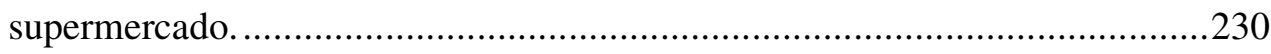

Figura 94: Criação de fluxo e cronoanálise dos elementos de trabalho da família 1.

Figura 95: Quando de programação, controle e nivelamento do processo puxador

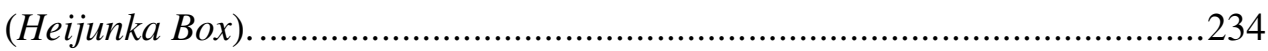

Figura 96: Programação as atividades da semana do evento kaizen .......................236

Figura 97: Equipe kaizen em trabalho de implantação ........................................236

Figura 98: Separação de excessos durante a formação dos supermercados ............237

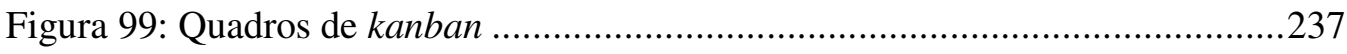


Figura 100: Heijunka Box com cartões ordem de produção .................................238

Figura 101: Plano de controle para sustentabilidade das melhorias .......................239

Figura 102: Principais processos produtivos da $3^{\text {a }}$. aplicação...............................244

Figura 103: Visão esquemática do Mapa Macro de Fluxo de Valor Situação Atual246

Figura 104: Definição dos pontos de supermercado...........................................248

Figura 105: Definição do processo puxador .......................................................249

Figura 106: MFV da situação implementada com a linha de tempo .......................252

Figura 107: Identificação dos loops de produção..................................................253

Figura 108: Mix diário do TPT para reposição do loop do super de corte laser .......255

Figura 109: Quadro macro de programação da reposição compassada dos kanbans .256

Figura 110: Quadro macro de programação nivelada e balanceada da reposição

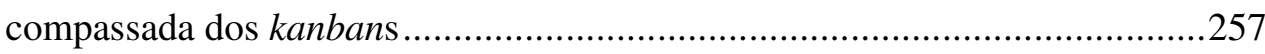

Figura 111: Cronoanálise do item mais representativo da família ........................258

Figura 112: Criação de fluxo e padronização da família 1 ....................................259

Figura 113: Heijunka Box para programação das cabines de solda .......................260

Figura 114: Tela de sofware desenvolvido para dimensionamento e ajuste dos

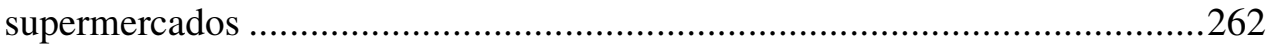

Figura 115: Reunião de abertura e treinamento para o evento kaizen ...................263

Figura 116: Início das atividades do Evento Kaizen ...........................................264

Figura 117: Substituição de um estoque empurrado para a solda por um

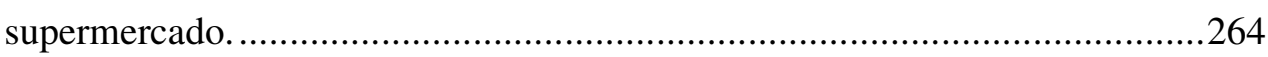

Figura 118: Liberação de áreas nobres ocupadas por supermercados e estoques em

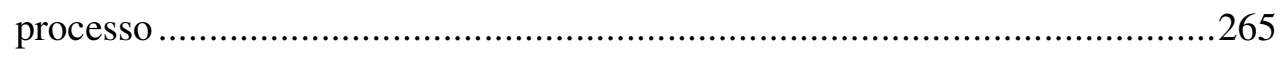

Figura 119: Reorganização do Supermercado para a Solda (S2) ...........................266

Figura 120: Setor de solda é substituído por células de solda...............................266

Figura 121: Substituição de um estoque empurrado para a montagem por um supermercado. 267

Figura 122: Substituição de um estoque empurrado para a expedição por um supermercado de produtos acabados........................................................268

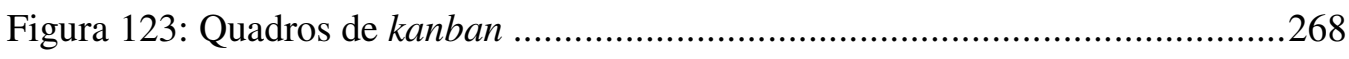

Figura 124: Plano de controle para sustentabilidade das melhorias .......................269 
Figura 125: Fechamento e replicação das melhorias para toda a fábrica 269

Figura 126: Gráfico de variação do lead time ao longo da implantação 270

Figura 127: Gráfico do índice de faturamento mensal por funcionário ao longo da implantação 271

Figura 128: Visão esquemática do mapa macro de fluxo de valor da situação anterior

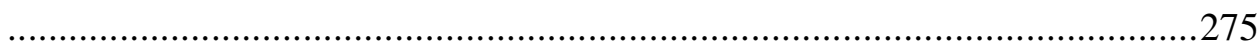

Figura 129: Definição dos pontos de supermercado - 4 ${ }^{\mathrm{a}}$. Aplicaçãa …....................277

Figura 130: Definição do processo puxador ......................................................279

Figura 131: Identificação dos loops de produção................................................280

Figura 132: MFV da situação implantada com a linha de tempo..........................282

Figura 133: MFV da situação anterior do fluxo de internos ................................283

Figura 134: MFV da situação implantada do fluxo de internos - 4a . Aplicação......283

Figura 135: MFV da situação implantada com a linha de tempo............................284

Figura 136: Visão esquemática do loop 3 de montagem do rotor..........................286

Figura 137: Quadro de programação sincronizada do gargalo com os demais fluxos

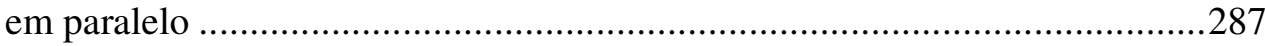

Figura 138: Supermercado de mancais (loop 8) e quadros de kanban ao fundo......288

Figura 139: Sistema visual de PCP com planejamento de cima para baixo. ...........291

Figura 140: Quadro de programação nível 1......................................................291

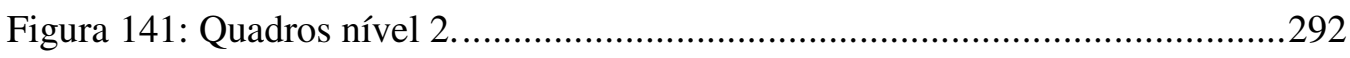

Figura 142: Quadros nível 3: programação do chão de fábrica. ............................292

Figura 143: Sistema visual de PCP com controle de baixo para cima. ..................293

Figura 144:Reuniões diárias para controle e atualização dos quadros. ...................294

Figura 145: Curva de carregamento da empresa ao longo de 2007.......................294

Figura 146: Máscara de nivelamento de vendas................................................295

Figura 147: Visualização da ocupação da capacidade produtiva...........................296

Figura 148: Reunião de abertura e treinamento para o evento kaizen .....................297

Figura 149: Preenchimento dos quadros de programação nível 1.........................297

Figura 150: Fixação e preenchimento dos quadros nível 2 ..................................298

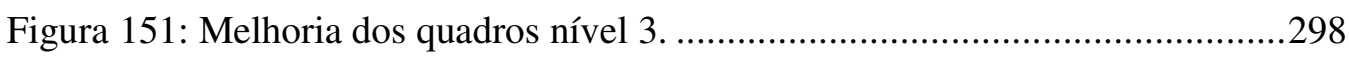

Figura 152: Quadros kanban para programação dos fluxos puxados.....................299

Figura 153: Setor de solda é substituído por células de solda - $3^{\text {a }}$. Aplicação .........299 
Figura 154: Evolução da produtividade global ao longo da implantação................301

Figura 155: Metodologia de pesquisa e as aplicações. ............................................304 


\title{
Lista de Abreviaturas e Siglas
}

\author{
ATO - Assembly-to-Order \\ BTO - Buy-to-Order \\ CONWIP - Constant Work in Process \\ FKS - Flexible Kanban System \\ GKS - Generalized Kanban System \\ JIT - Just in Time \\ LT - Lead Time \\ MFV - Mapa do Fluxo de Valor \\ MRP - Material Requirement Planning \\ MTO - Make-to-Order \\ MTS - Make-to-Stock \\ OPT - Optimized Production Technology \\ PCP - Planejamento e Controle da Produção \\ PP - Processo Puxador \\ STP - Sistema Toyota de Produção \\ TPC - Tambor-Pulmão-Corda \\ TPT - Toda Parte Todo \\ VA - Valor Agregado
}




\section{RESUMO}

NAZARENO, R. R. (2008). Desenvolvimento de sistemas híbridos de planejamento e programação da produção com foco na implantação de manufatura enxuta. São Carlos, 319p. Tese (Doutorado) - Escola de Engenharia de São Carlos, Universidade de São Paulo, 2008.

Este trabalho tem como objetivo principal a proposição de um método de desenvolvimento de sistemas híbridos de planejamento e programação da produção para ambientes de manufatura enxuta que possuam alta variedade de itens, estruturas complexas, variabilidade de lead times e demanda flutuante. Nestes ambientes existe uma grande dificuldade na definição das estratégias para a adoção do sistema mais adequado de planejamento e programação da produção. A maioria das empresas acaba adotando um tratamento genérico de planejamento e programação para todos os itens. O método foi desenvolvido a partir de uma ampla revisão bibliográfica em torno de sistemas de planejamento, programação e controle da produção, de suas respectivas funções, dos desafios para os sistemas atuais, bem como dos princípios e das principais práticas e ferramentas enxutas. Em seguida, o método foi testado em quatro aplicações práticas nas quais a essência da discussão em torno de um sistema de planejamento e programação da programação migrou do tradicional conflito entre sistemas kanban versus MRP, puxar versus empurrar, para o desafio de se criar um ambiente no qual estes dois sistemas, juntamente com outros, devem coexistir em harmonia.

Palavras-chave: Produção enxuta. Sistemas híbridos de planejamento e programação. alta variedade de itens. 


\section{AbStract}

NAZARENO, R. R. (2008). Development of hybrid systems for planning and scheduling focusing on implementation of lean manufacturing. São Carlos, 319p. Thesis (Ph.D.) - School of Engineering of São Carlos, University of São Paulo, 2008.

This work has as main goal to propose a method of developing hybrid systems for planning and scheduling for lean manufacturing environments that have high variety of items, complex structures, variability of lead times and fluctuating demand. In these environments there is great difficulty in defining the strategies to adopt the most appropriate system of planning and scheduling. Most companies just adopting a generic treatment planning and programming for all items. The method was developed from an extensive literature review around systems of planning and scheduling of production, their respective roles, the challenges to the current systems as well as the principles and practices of the major tools and dried. Then, the method was tested in four practical applications in which the essence of the debate on a system of planning and scheduling migrated from traditional conflict between kanban systems versus MRP, pull vs. push, to the challenge of creating an environment in which these two systems, along with others, must coexist in harmony.

Key words: Lean production. Hybrid systems for planning and and scheduling. High variety of items. 


\section{APRESENTAÇÃO DO TRABALHO}

\subsection{Introdução}

O paradigma da Produção Enxuta, adotado pelas organizações como resposta às pressões exercidas pelo mercado, iniciou-se no Japão a partir do final da década de 40. No entanto, o despertar para esses conceitos, por parte do mundo ocidental, veio a ocorrer apenas no final da década de 80 , em especial com o lançamento do livro "A máquina que mudou o mundo" de Womack e Jones (1992). Neste livro foram publicados os resultados de uma pesquisa realizada pelo Massachuets Institute of Technology (MIT) acerca do desempenho superior das empresas automotivas japonesas, mais especificamente da Toyota Motor Company, frente às empresas automotivas americanas. O Sistema Toyota de Produção (STP) foi criado a partir da identificação dos desperdícios pertinentes à produção e da criação de uma série de ferramentas para combatê-los.

O STP é elegante por sua simplicidade, e também complexo quando se considera todos os aspectos deste sistema de produção. É fácil entender os conceitos gerais. Técnicas simples de gestão visual ajudam no que cada pessoa deve saber e fazer em diferentes situações. Todavia, gerentes e engenheiros estão sempre perplexos quando são eles a desenhar e projetar o seu próprio sistema.

Em meados da década de 90, outros tipos de empresas tentaram aplicar o STP, fazendo exatamente da forma como a Toyota vem fazendo. Em outros cenários, características como diferentes tipos de clientes, demanda por diferentes tipos de produtos customizados, demanda desnivelada e contratos curtos formaram os primeiros céticos com relação à aplicação universal das ferramentas do STP.

Duggan (2002) atenta para o fato de que é necessário sair do cenário automotivo e contemplar esses novos desafios. Os princípios do STP funcionam em qualquer ambiente, mas desde que sejam aplicados e customizados apropriadamente. 
A própria Toyota fez isso com relação ao sistema de produção em massa, ao criar o STP como uma resposta à pequena demanda por veículos na Japão.

\subsection{Apresentação do problema}

A Toyota desenvolveu uma metodologia de mapeamento simples, usada extensivamente pela Toyota's Operation Management Consulting Division, que foca o fluxo de material e informação e ajuda a identificar os desperdícios que impedem este fluxo. Rother e Shook (1998) estudaram esta metodologia e a tornaram disponível para o mundo acadêmico e empresarial, chamando-a de Análise do Fluxo de Valor.

Um fluxo de valor consiste em todas as ações, tanto de agregação quanto as de não agregação de valor, exigidas para fazer um produto, desde a matéria prima até o produto acabado, ou do pedido até a entrega, ou ainda, da concepção ao lançamento. Incluem as ações para processar as informações vindas do cliente e as ações para transformar o produto em seu caminho fluxo abaixo. Portanto, é composto pelo fluxo de materiais e de informações (LEAN ENTERPRISE INSTITUTE - LEI, 2003).

A figura 1 mostra um desenho esquemático de um fluxo de valor tradicional em um sistema de produção enxuta. 


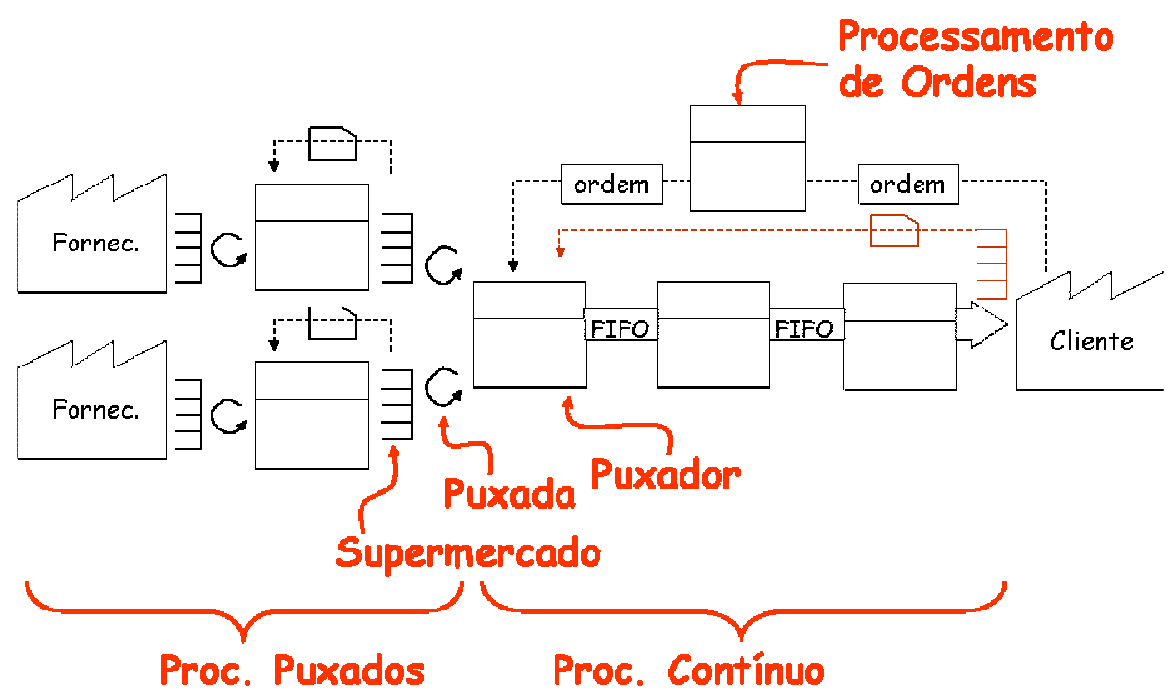

Figura 1: Fluxo de valor tradicional em um sistema de produção enxuta Fonte: Rentes et al. (2005)

Um fluxo de valor ideal é composto, fluxo abaixo, pelo maior fluxo contínuo possível próximo ao cliente, e, fluxo acima, por uma série de fluxos puxados abastecendo o fluxo contínuo.

Um fluxo contínuo significa produzir e movimentar continuamente um item, ou um lote pequeno de itens, ao longo de uma série de etapas de processamento. Em cada etapa se realiza apenas o que é exigido pela etapa seguinte, sem nenhuma interrupção entre elas. Este tipo de fluxo consiste numa das maneiras mais eficientes de se produzir, pois aumenta a rapidez e reduz a formação dos estoques intermediários. Pode ser conseguido de várias maneiras, desde a utilização de linhas de montagem até células manuais (ROTHERS; SHOOK, 1998).

Este fluxo contínuo começa com um processo denominado puxador, o qual é disparado pelo pedido do cliente. Conseqüentemente, o fluxo contínuo é usualmente controlado por uma política de atendimento da demanda do tipo ATO (Assembly To Order - Montar sob Pedido). Algumas vezes, ele pode ser projetado com uma política MTS (Make To Stock - Produzir para Estoque) sempre que um supermercado de peças acabadas for necessário para atender a demanda do cliente de pronta entrega. Já o sistema de produção puxada fluxo acima normalmente é controlado por kanban, que é uma ferramenta essencialmente voltada para políticas de atendimento da demanda do tipo MTS (RENTES et al., 2005). 
De acordo com Taal et al. ${ }^{1}$ (1997 apud SCARPELLI, 2004), os sistemas de produção baseados na lógica de se produzir apenas no momento necessário demandam, na elaboração do programa mestre, a suavização da carga, uma repetitividade estável de produtos padronizados, número limitado de opções de mix poucas mudanças de engenharia e a inexistência de grandes sazonalidades.

Com isso, a obra de Rother e Shook passou a apresentar algumas limitações, por contemplar predominantemente características típicas do setor automotivo na época. Algumas destas características são (DUGGAN, 2002):

* Um produto maduro que muda de um modo gradual: mudanças menores a cada dois ou três anos e mudanças significativas de cada quatro a seis anos.

* Opções limitadas de partes: várias configurações de produto acabado a partir de poucas opções de componentes.

* Projetos cuja venda estava voltada para um ou poucos clientes (normalmente grandes montadoras).

* Uma programação cuidadosamente nivelada. A Toyota fabrica o mesmo número e mix de carros todos os dias ao longo dos meses e trabalha duro para manter a programação nivelada. Isto implica numa demanda nivelada de motores, transmissões e demais partes fornecidas.

\& Contratos de longo prazo com as montadoras.

O tipo de estrutura apresentado na figura 1 é adequado para uma alta variedade de produtos acabados com baixa variedade de componentes, de modo a viabilizar uma política de atendimento da demanda do tipo "Montar sob Pedido" (ATO - Assembly to Order). Um bom exemplo é a Dell Computers, que produz uma variedade extremamente grande de produtos acabados a partir de uma quantidade relativamente pequena de componentes (RENTES et al., 2005).

\footnotetext{
${ }^{1}$ TAAL, M.; WORTMANN, J. (1997). Integrating MRP and finite capacity planning. Production Planning and Control; v.8, n.3, p.245-254.
} 
Um primeiro problema com alta variedade de produtos é quando estes produtos são formados por uma grande variedade de componentes, sobretudo nas situações desprovidas de projetos modulares que simplifiquem a estrutura do produto. Este problema tende a aumentar ainda mais em estruturas mais complexas, ou seja, com grande número de níveis e grande número de itens por nível.

Um segundo problema é que, por questões estratégicas, é cada vez mais comum o surgimento, no portfólio de empresas de alta variedade de produtos acabados e componentes, de itens que apresentam baixo volume e baixa freqüência de demanda, conferindo-lhes o desafio de se tornarem enxutas num ambiente como este (JINA et al., 1997).

A fim de satisfazer critérios ganhadores de pedidos, tais como rapidez e flexibilidade, algumas empresas tem adotado políticas de formação de estoques, resultando no desperdício de superprodução. Esta categoria de desperdício tende a gerar outros desperdícios, como esperas e estoques desnecessários.

Smalley (2005) discorre, em um estudo de caso, que as programações dos clientes previstas com bastante antecedência formavam a base para as programações semanais enviadas para cada área de produção pelo sistema computadorizado de Planejamento das Necessidades de Materiais (MRP). Entretanto, as programações semanais guardavam apenas limitadas semelhanças com os pedidos diários feitos pelos clientes, que determinavam o que realmente seria pedido. Devido ao fato de o tempo de produção da matéria-prima ao produto acabado na fábrica ser de várias semanas, a freqüente mudança nos pedidos dos clientes, conforme refletido nos pedidos diários, implicava no fato de que:

* Os itens errados - em grande quantidade e muito antes - estavam sendo produzidos, nos processos iniciais do fluxo de valor.

* Os processos fluxo abaixo, como a montagem, não possuíam as peças corretas, apesar de manterem grandes estoques de diversas delas.

* Os processos fluxo abaixo não tinham um mecanismo eficaz para permitir que os processos anteriores soubessem quais peças seriam necessárias a seguir, sem a intervenção do supervisor. 
A conclusão foi de que, embora a demanda total em termos de volume variasse apenas sutilmente (variação de volume), o mix variava substancialmente (variação de mix). O mais surpreendente, entretanto, foi a percepção de que a variação tanto na demanda total quanto no mix foi piorando progressivamente pela planta. Em suma, a partir da demanda irregular do cliente, as práticas internas das fábricas transformam muitas vezes o problema em algo muito pior (Figura 2).
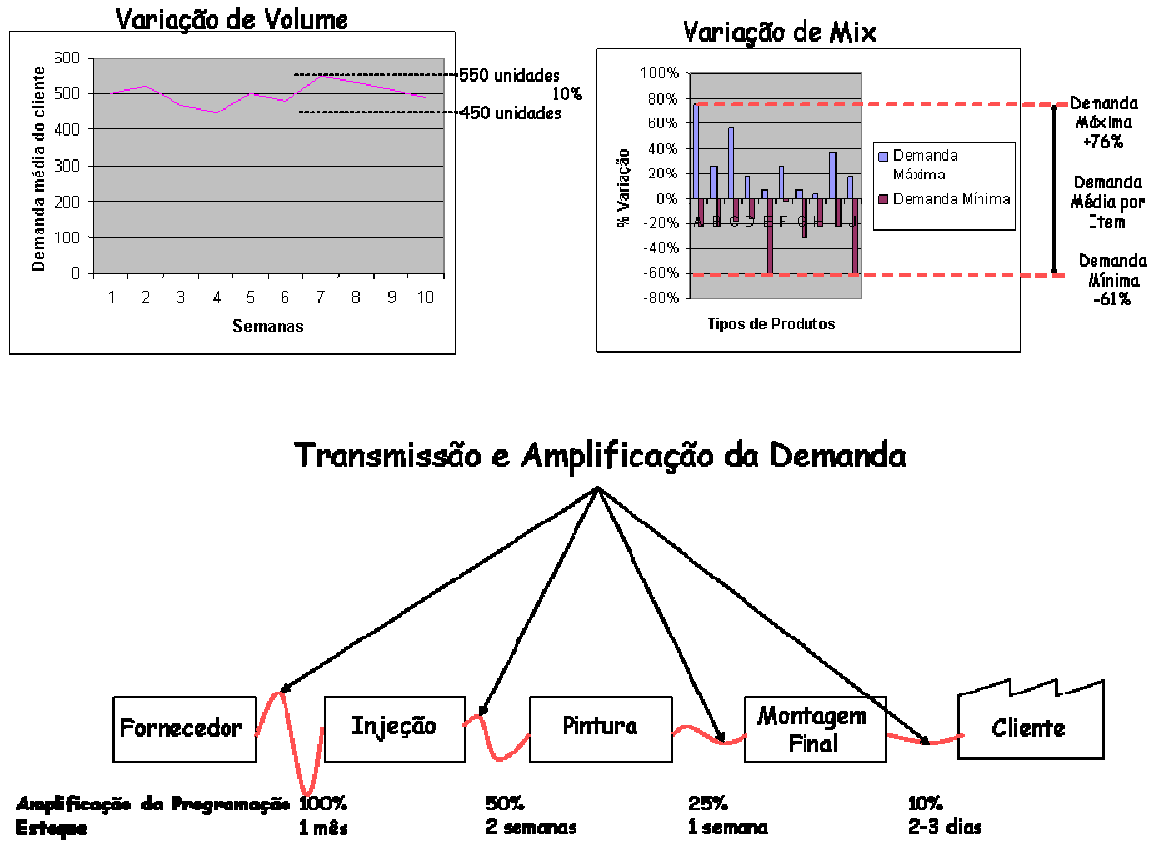

Figura 2: Variação de demanda em volume e mix e sua transmissão e amplificação ao longo do fluxo de valor Fonte: Smalley (2004)

Uma alta variação de mix de produtos que compartilham uma mesma linha de produção ou um mesmo equipamento também torna a programação mais difícil em termos de disponibilidade e capacidade dos recursos. Nestas condições, torna-se difícil criar sistemas puxados, pois o sistema kanban convencional não funciona bem neste tipo de situação. Mesmo que se crie supermercados com pequenos volumes para cada componente, quando se tem grande variedade de mix a somatória destes volumes acarretará num alto volume de estoque em processo. 
Corrêa e Gianesi (1998) reforçam essa idéia ao afirmarem que o sistema kanban exige que seja mantida uma certa quantidade de estoque entre cada operação e sua operação subseqüente. Esta "certa quantidade" pode transformar-se, no agregado, em grandes quantidades de estoque em processo se, no sistema, são feitos muitos produtos diferentes (com os correspondentes muitos pares de operações consecutivas), “...quanto à variedade de produtos, é aceito que sistemas que trabalham com grandes quantidades de produtos diferentes, em geral, não são um bom ambiente para a implantação "generalizada" de sistemas JIT" (CORRÊA; GIANESI, 1998).

Note que, ao se referirem à "implantação generalizada" de sistemas JIT, os autores, de certa forma, já se anteciparam ao fato de que um sistema ideal de administração da produção de uma empresa não deve dar tratamento genérico a todos os seus produtos e componentes.

Os sistemas MRP, por exemplo, têm uma vocação especial para lidar com produtos que têm estruturas complexas, pois permitem um planejamento detalhado (e antecipado) das necessidades de recursos materiais da organização (CORRÊA; GIANESI, 1998). Por outro lado, são bastante sensíveis ao problema da variabilidade dos lead times, conforme o estudo de caso de Smalley (2005), citado anteriormente. Se os lead times reais são muito variáveis, isto pode acarretar baixa aderência aos lead times registrados no sistema. Se o mix de produtos da organização muda muito freqüentemente, as ordens na fábrica tendem também a sofrer freqüentes mudanças.

Conseqüentemente, o uso do conceito da manufatura enxuta nas empresas que apresentam alta variedade de produtos com alta variedade de componentes vem sendo colocado como um desafio que tem desencorajado muitos praticantes desse conceito, e que voltam a considerar o uso generalizado de soluções convencionais, baseadas normalmente na lógica dos sistemas MRP.

De acordo com Duggan (2002), para que empresas com grande variedade de itens com diferentes características de demanda se tornem mais enxutas é necessária uma abordagem híbrida de planejamento e controle. 
Um sistema híbrido de planejamento e controle consiste na adoção, por meio de um mesmo fluxo de valor, de diferentes políticas de atendimento da demanda (MTO, ATO, MTS, etc.) e de formas de controle de produção (ordem de fabricação, kanbans de transporte e produção, pulmões de tempo, dentre outros).

Por exemplo, de acordo com a figura 3, poderia haver um supermercado para os produtos com maior demanda (chamados doravante de bestsellers), controlados por kanbans, que ativam a reposição destes produtos quando o supermercado alcança um nível crítico. Ao mesmo tempo, o mesmo processo poderia produzir os itens menos freqüentes por ordens de produção, ordenadas diretamente pelas necessidades dos clientes. Além disso, para alguns dos itens best-selleres poder-se-ia ter supermercados localizados entre todos os processos do fluxo de valor, enquanto que para outros apenas entre alguns processos do fluxo acima. Já os itens controlados por ordens, poderiam ter também pontos de controle intermediários, regulados talvez por pulmões de tempo.

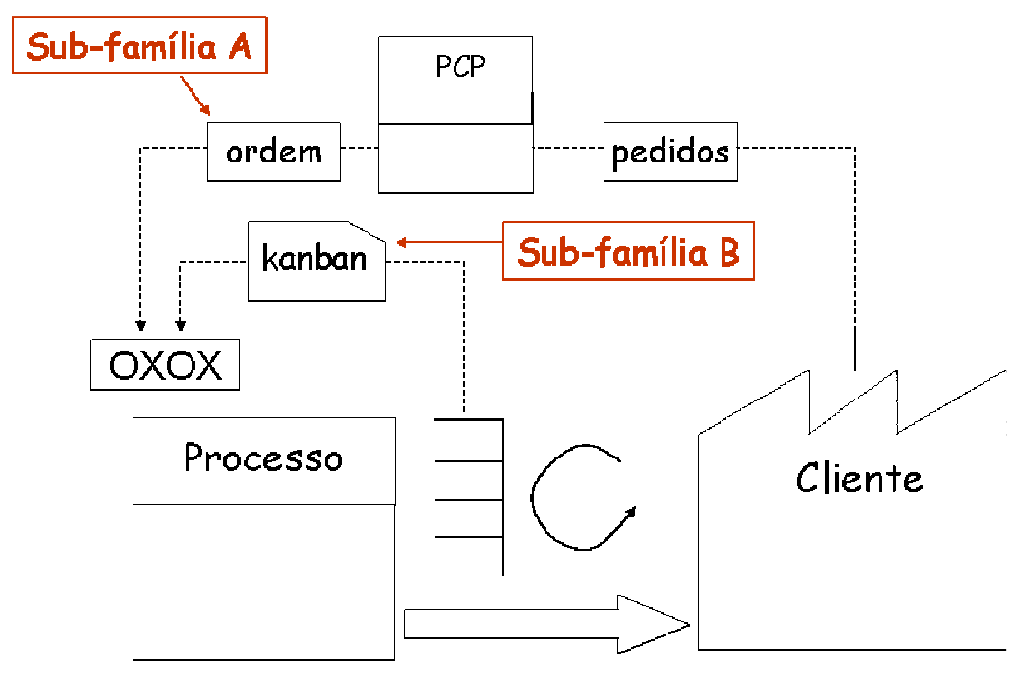

Figura 3: Visão Ilustrativa de um Sistema Híbrido Fonte: Rentes et al. (2005)

De acordo com Scarpelli (2004), em um Sistema de Planejamento e Controle da Produção, quando associado ao médio e curto prazo, a forma de programação e controle da produção torna-se a mais relevante, porque ela reflete a estratégia da empresa e sua relação com o mercado. 
Entretanto, não existem critérios claros para a definição, de forma híbrida, da melhor forma de se programar cada item ao longo do fluxo de valor.

Um outro problema em ambientes de alta variedade é que a demanda dos produtos e componentes tende a oscilar em intervalos de tempo muito curtos, ora excedendo ora causando ociosidade à capacidade produtiva.

Bozzone (2002) afirma que, tradicionalmente, a programação é tratada como algo estático. Esse paradigma é oriundo da produção em massa, na qual as mudanças ou contingências eram menos intensas.

Contudo, existe uma série de contingências de curto prazo que provocam mudanças na programação e que podem interromper o fluxo: picos de demanda, distâncias, quebras, altos tempos de setup, lacunas de capacidade, dentre outros. Com isso, pode-se precisar de soluções intermediárias até que a máquina não tenha mais problemas de manutenção, que as pessoas estejam devidamente treinadas, que os gargalos estejam eliminados ou que os tempos de setup tenham sido sensivelmente reduzidos. Segundo o autor, o fluxo de um pallet, de um contenedor ou até de um lote diário é melhor do que fluxo nenhum, ao menos enquanto estas condições não forem atendidas (CONNER, 2001).

Smalley (2005) acrescenta que, teoricamente, enviar diversas programações de um sistema MRP central para cada departamento deveria manter todos informados e trabalhando no mesmo ritmo. Mas, na realidade, isso raramente ocorre. Inevitavelmente ocorrem problemas na equação quando são feitas suposições erradas para o lead time de produção, confiabilidade dos processos internos e externos, refugo, taxas de rendimento, entre outras.

As primeiras gerações de programas MRP possuíam algoritmos que supunham haver uma capacidade infinita no sistema, uma condição que jamais vai existir no mundo real. Os sistemas recentes são mais refinados, chamados de MRP II (Material Resources Planning), ou planejamento dos recursos de manufatura, além das necessidades de materiais, eles calculam também a necessidade do demais recursos de manufatura, principalmente pessoas e equipamentos . Mas o chão de fábrica ainda é um local dinâmico. Ele muda minuto a minuto durante o dia enquanto os sistemas MRP normalmente trabalham com um determinado período de tempo que vai de turnos a semanas. O MRP precisa ser continuamente atualizado sobre o 
status real da produção no chão de fábrica, mas isso é difícil de conseguir. Freqüentemente, as programações, o status de produção e os níveis de estoque são atualizados apenas à noite em batelada, tornando-os inúteis para resolver problemas que surgem durante o dia (Smalley, 2005).

Isso não significa que os sistemas MRP devam ser removidos, pois continuam sendo importantes na emissão de ordens para os fluxos empurrados. Além disso, as empresas de manufatura sempre precisarão de algum tipo de sistema MRPII para manter a lista de materiais, criarem planos preliminares de capacidade, manipular informações de previsão e realizar outras tarefas úteis no planejamento da produção. Entretanto, até mesmo os sistemas mais avançados executam mal as (re)programações e controle do chão de fábrica em tempo real para a produção entre os processos (Smalley, 2005).

A probabilidade de a programação sofrer ruídos e ter que ser alterada é alta. Por isso, é importante que ela seja tratada como algo dinâmico (BOZZONE, 2002). No caso dos sistemas puxados, controlados por kanban, o tempo de inserção e retirada dos cartões tende a influenciar a habilidade do sistema de responder às instabilidades da demanda e do tempo de processamento. Esta prática, denominada de "kanban flexível" (FKS - Flexible Kanban System), é uma evolução do sistema kanban para se adaptar ao fim da era das demandas previsíveis das carteiras com pedidos firmes. Atualmente, todo tipo de empresa possui demanda oscilante, tanto no mix quanto no volume. De tempos em tempos rotinas de redimensionamento dos supermercados se fazem necessárias. A grande questão é como fazê-las?

Gupta e Al-Turki (1997) afirma que o número de kanbans geralmente é mantido fixo durante o ciclo de produção. Entretanto, é sabido pelos supervisores que, de tempos em tempos, numa base ad hoc, o aumento ou a redução do número de kanbans é realizado conforme a demanda. Mesmo assim, de acordo com o autor, praticamente não existem estudos que apresentem técnicas para manipular sistematicamente o número de kanbans.

Takahashi e Nakamura (2002) reforçam essa tese ao afirmarem que em muitas literaturas relacionadas ao sistema de produção JIT a influência de demandas instáveis no mesmo nunca foi profundamente analisada. Recentemente, o ciclo de vida dos produtos tem ficado cada vez mais curto, enquanto que a 
diversificação nas necessidades dos clientes tem aumentado e a duração de demandas estacionárias tem encurtado. Portanto, não apenas demandas estáveis, mas também demandas instáveis devem ser consideradas no projeto de um sistema de programação e controle. Flutuações instáveis da demanda significam que, muitas vezes, sejam necessários ajustes na estrutura do sistema.

Conforme descrito por Monden (1981), as situações em que a Toyota mudaria de fato o número de kanbans, em função de grandes variações na demanda, implicariam numa intervenção também na estrutura do sistema como um todo, criando-se uma espécie de configuração definida para cada ciclo de ajuste e implementação:

O sistema kanban não possui adaptabilidade para mudanças repentinas e grandes variações na demanda. No sentido de acompanhar os vales e picos na variação da demanda durante o ano, a alta gerência deverá decidir se nivela o volume de vendas para o ano todo, ou se projeta um plano flexível para rearranjar todas as linhas de produção de acordo com as mudanças sazonais durante $\mathrm{o}$ ano.

Por fim, Duggan (2002) complementa que, além de sistemas puxados flexíveis, um sistema de PCP em ambientes de alta variedade e demanda instável também deve incluir processos puxadores capazes de lidar com as flutuações da demanda, de nivelar e balancear a produção.

A figura 4 apresenta uma visão esquemática de um fluxo de valor com os problemas mencionados. 


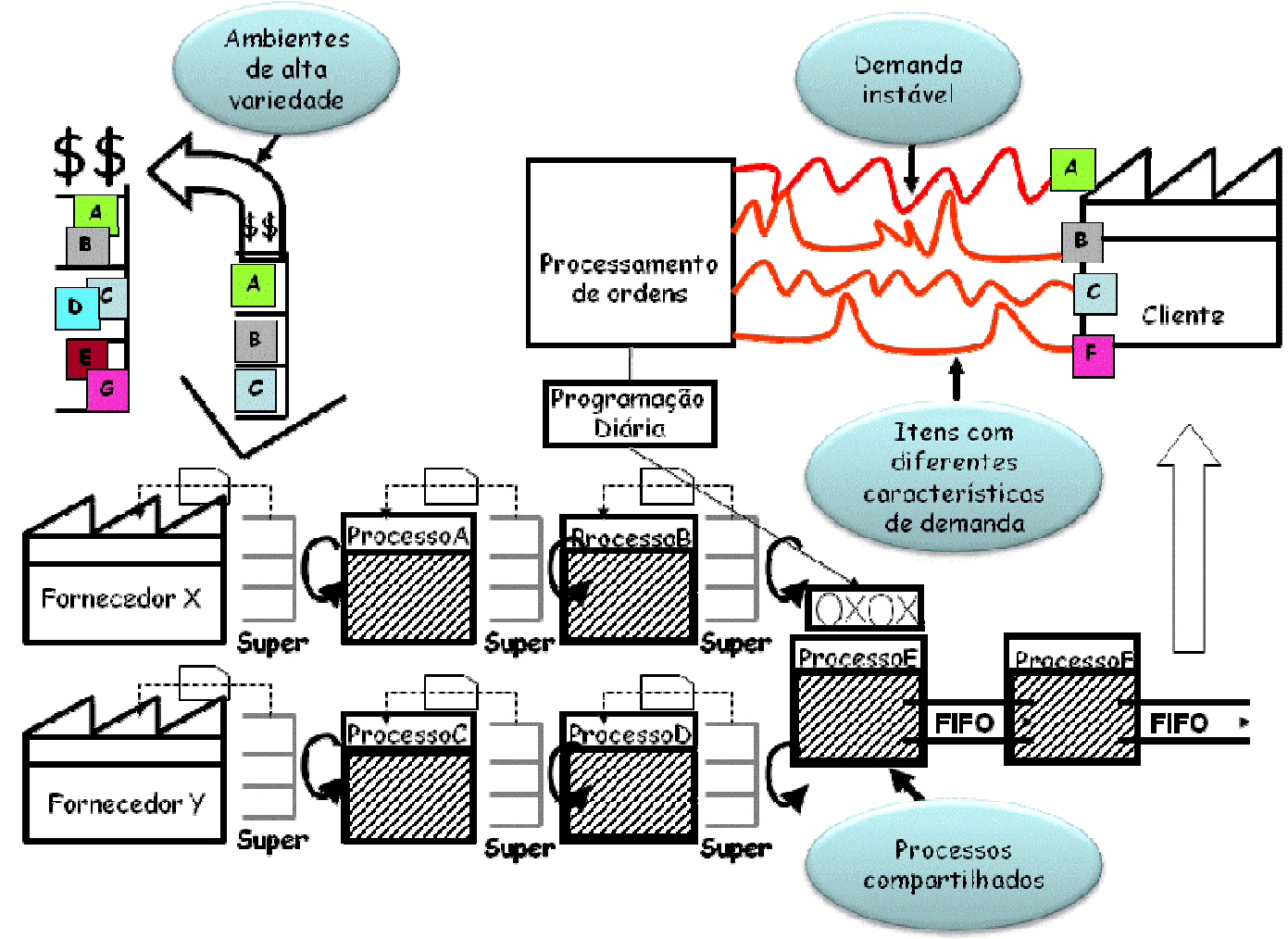

Figura 4: Visão esquemática de fluxo de valor com os problemas apresentados

Nesse sentido, a questão principal que orientará este trabalho é como adequar um sistema de planejamento e programação da produção a ambientes de manufatura enxuta que possuam alta variedade de produtos, estruturas complexas, alta variabilidade dos lead times e demanda flutuante?

Outras questões por trás desta são:

- Diferentes sistemas de pcp tais como o kanban e o MRP, podem coexistir harmoniosamente num mesmo ambiente produtivo? Como?

- Como definir quais itens serão controlados por kanban ou ordem?

- Como tratar a questão do takt time em ambientes com variação da demanda?

- Como estabelecer rotinas de redimensionamento de supermercados para sistemas FKS? 


\subsection{Objetivo}

Este trabalho tem como objetivo principal o desenvolvimento de um método para projetar sistemas híbridos de planejamento e programação da produção para ambientes de manufatura enxuta que possuam alta variedade de produtos, estruturas complexas, variabilidade dos lead times e demanda flutuante.

A idéia é que dentro de uma mesma família de produto ou componente podem existir diversas sub-famílias, baseadas nas diferentes políticas (ETO, MTO, ATO e MTS) e formas (Ordem, Kanban, etc.) de programação da produção.

De acordo com a figura 5, em ambientes caracterizados por grande variedade de produtos e componentes e demandas flutuantes, é necessário projetar um sistema híbrido de planejamento e programação da produção, tendo em vista combater as causas da amplificação interna da demanda e criar um fluxo mais estável e contínuo possível. Espera-se, dessa forma, minimizar os desperdícios de superprodução, esperas e estoques desnecessários ao longo do fluxo de valor.

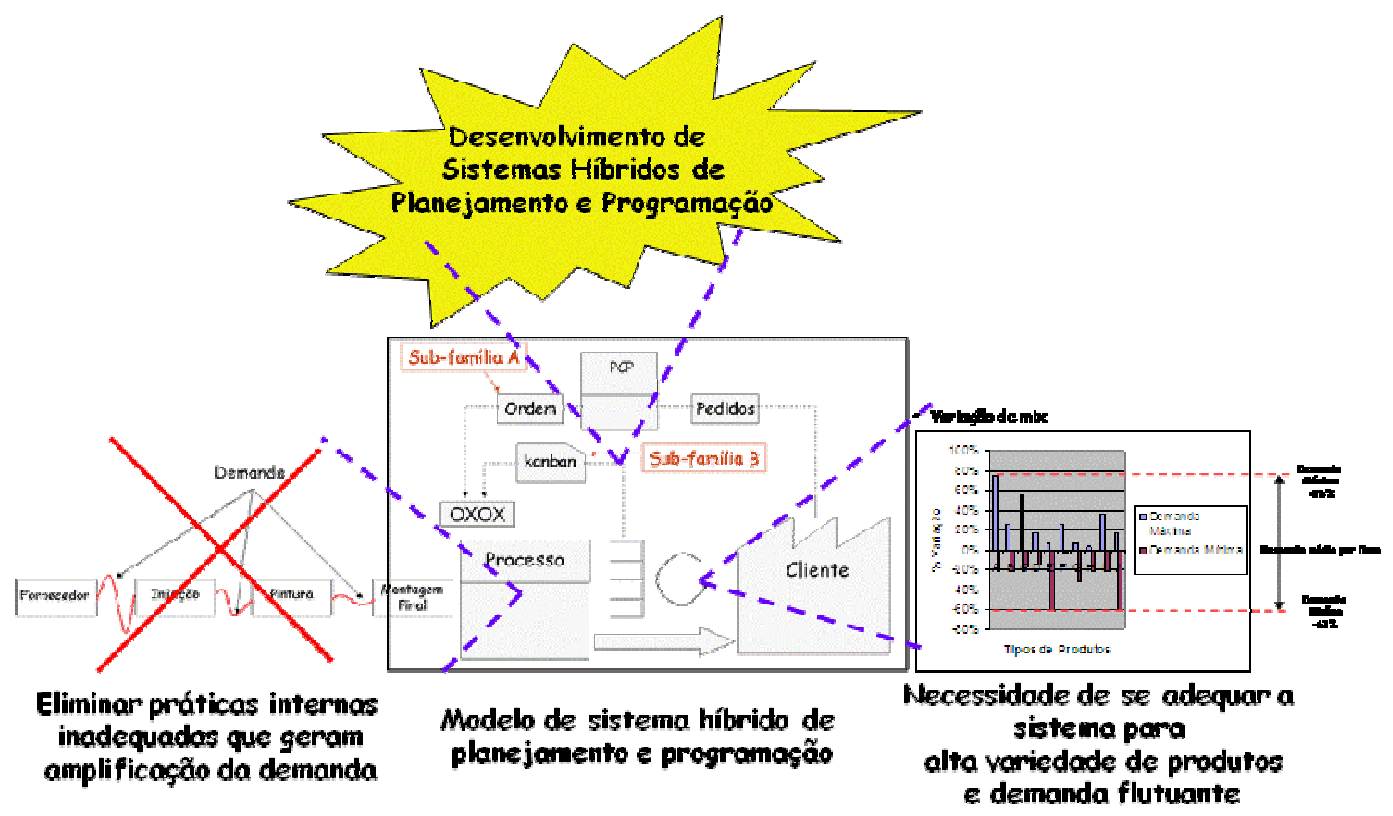

Figura 5: Contextualização do trabalho

Para que o objetivo principal seja atingido, serão abordados os seguintes objetivos intermediários 
Construção da visão geral do novo sistema de planejamento e programação.

Definição de procedimentos para a criação das subfamílias de programação e controle.

Definição de procedimentos para identificação e programação do processo puxador para cada subfamília, e dos fluxos puxados e empurrados ao longo do fluxo de valor.

Definição de procedimentos para a construção de supermercados dinâmicos, que sejam flexibilizados de acordo com as flutuações da demanda.

Definição de procedimentos para o nivelamento da demanda e do processo puxador.

Definição de procedimentos para a implantação efetiva do novo sistema de planejamento e programação.

Para isso, foi definida uma metodologia para desenvolvimento do trabalho. Por meio desta metodologia pretende-se trabalhar os meios necessários para a construção do método e, ao mesmo tempo, realizar as aferições do nível de atendimento dos objetivos supracitados.

\subsection{Metodologia de pesquisa e de desenvolvimento do trabalho}

\subsubsection{Fases da pesquisa}

A figura 5 apresenta uma visão de um ciclo de desenvolvimento incremental ou evolutivo de um sistema, adaptado de Rentes (2003). De acordo com este método, um primeiro ciclo de desenvolvimento do sistema é seguido de uma série de ciclos complementares. Cada ciclo é composto por cinco etapas seqüenciais, com exceção da primeira, chamada de Capacitação, a qual ocorre em paralelo às demais ao longo de todo o ciclo. 


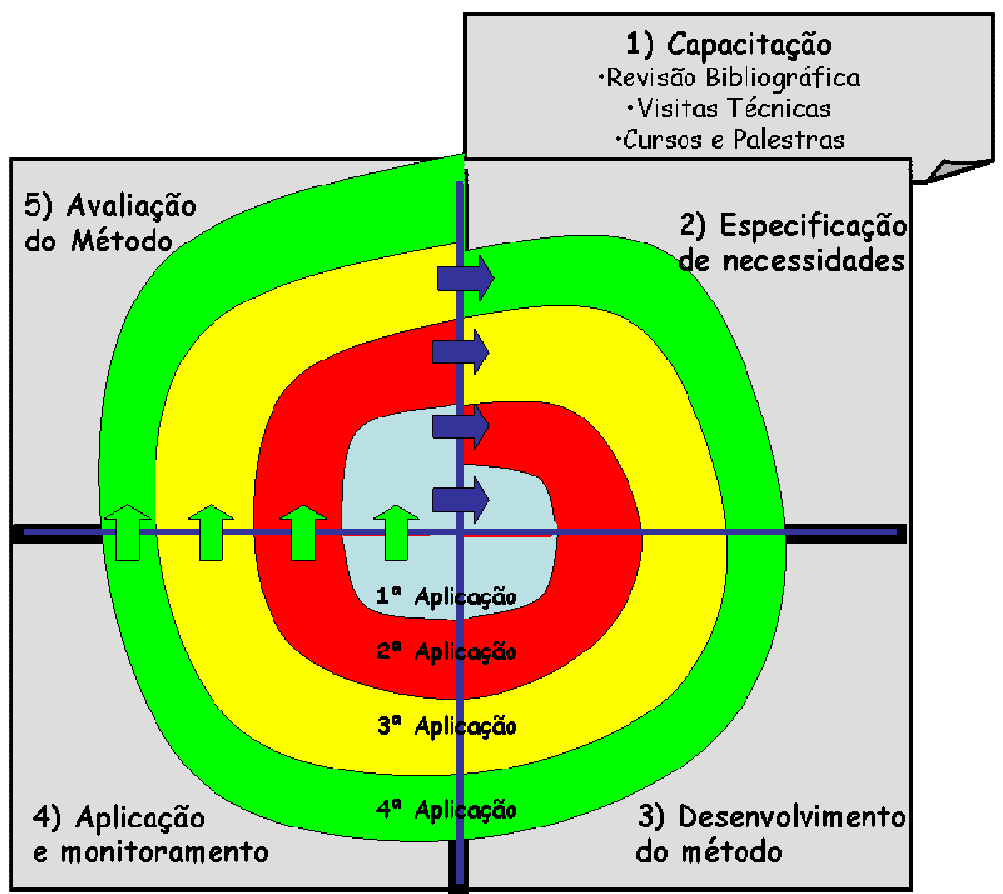

Figura 6:Método de pesquisa baseado no ciclo de desenvolvimento incremental ou evolutivo FONTE: Adaptado de Rentes (2003)

$\mathrm{Na}$ primeira etapa, a idéia foi identificar e trabalhar os conceitos relacionados ao tema desta pesquisa e aos problemas apresentados. Para tanto, foram realizadas revisões bibliográficas e visitas a empresas que possuem sistemas de programação e controle orientados para a filosofia de produção enxuta. Esta etapa alimenta sistematicamente o ciclo de desenvolvimento, que é composto pelas etapas $2,3,4$ e 5 .

Na etapa 2, a partir das revisões bibliográficas e das visitas realizadas, foram especificadas as necessidades para a concepção do método, tais como os passos, teorias e procedimentos associados.

$\mathrm{Na}$ etapa 3, uma primeira versão do método foi desenvolvida, a qual foi aprimorada, de forma incremental, à medida que foram ocorrendo as aplicações práticas (etapa 4). Foram realizadas aplicações em quatro empresas de diferentes segmentos do setor metal mecânico, sendo em média um ano de visitas semanais por empresa. A primeira delas numa empresa de fundição e usinagem de componentes para sistemas de transmissão do segmento automotivo. A segunda, numa empresa de usinagem e montagem de bombas de engrenagem para o segmento automotivo e de máquinas agrícolas. A terceira numa empresa de produção de peças e conjuntos para 
montadoras de tratores do segmento de máquinas agrícolas. A quarta numa empresa de produção de turbinas a vapor na maioria para usinas do segmento sucroalcooleiro.

Deve-se ressaltar que toda a problemática levantada a respeito da variedade de produtos, complexidade das estruturas, variabilidade dos lead times e flutuação da demanda foi identificada nas quatro empresas supracitadas. Entretanto, nenhuma delas possuía todos os problemas, e não necessariamente, os mesmos problemas das outras. Nas três primeiras aplicações foram trabalhadas empresas com alta variedade de produtos e alta flutuação de demanda. Por outro lado, apresentavam estruturas relativamente simples. Já na quarta aplicação, a estrutura do produto era bastante complexa e o tempo de fabricação bastante longo. Isso resultava em alta variedade de componentes e alta variedade dos lead times. A demanda, por sua vez, não variava tanto quanto nas três primeiras aplicações.

Outro ponto a ser ressaltado, é que, devido à falta de uma amostragem representativa de trabalhos científicos, foi assumido pelo autor desse trabalho que não havia critérios objetivos e quantitativos para classificar um ambiente de manufatura como sendo de demanda variável, de estrutura complexa e de alta variedade de produtos e componentes. Esta classificação ficou a critério da percepção subjetiva do autor.

$\mathrm{Na}$ etapa 5, a abrangência do método foi avaliada com base nos problemas encontrados, no atingimento dos resultados esperados e nas lacunas conceituais, alimentados tanto pela etapa 1 quanto pelas aplicações (etapa 4). Conforme as aplicações práticas e a maioria das revisões bibliográficas realizadas, o método se aplica principalmente às empresas de produção discreta de qualquer segmento. Como não foi realizado nenhum estudo específico em empresas de produção contínua, não foi possível validar a robustez do método nesse tipo de indústria.

Além disso, ao final de cada aplicação, os resultados da avaliação foram submetidos a uma análise por parte das empresas estudadas. Para isso, foram realizadas apresentações de resultado de projeto para a diretoria. Buscou-se, dessa forma, novas especificações de necessidades, visando o aperfeiçoamento do método 
obtido, por meio da obtenção de novos conceitos e do aprofundamento daqueles já adquiridos, iniciando-se assim um novo ciclo, através de uma nova aplicação.

Para consolidar as impressões e análises realizadas foi elaborada uma tabela com o objetivo de aferir, ao final de cada ciclo de aplicação, o nível de atendimento dos objetivos intermediários, conforme o Quadro 1. Essa tabela encontra-se preenchida no capítulo de Conclusões Finais.

\begin{tabular}{|c|c|c|c|}
\hline \multicolumn{4}{|l|}{ Etapa 5: Avaliação do método } \\
\hline Quanto aos Objetivos Intermediários & 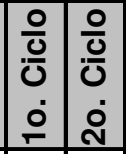 & \begin{tabular}{|l|l} 
& 0 \\
0 & 1 \\
0 & $c$ \\
0 & 0 \\
& \\
\end{tabular} & \begin{tabular}{l}
$\frac{0}{0}$ \\
\hdashline 0 \\
0 \\
\end{tabular} \\
\hline 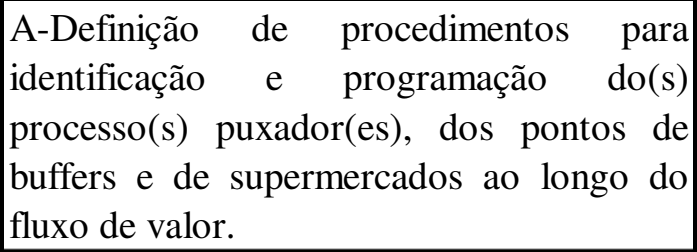 & & & \\
\hline $\begin{array}{l}\text { B-Definição de procedimentos para a } \\
\text { criação das sub-famílias de programação. }\end{array}$ & & & \\
\hline $\begin{array}{l}\text { C-Definição de procedimentos para a } \\
\text { construção de supermercados dinâmicos, } \\
\text { que sejam flexibilizados de acordo com as } \\
\text { flutuações da demanda. }\end{array}$ & & & \\
\hline $\begin{array}{l}\text { D-Definição de procedimentos para o } \\
\text { nivelamento da demanda e } \mathrm{do}(\mathrm{s}) \\
\text { processo(s) puxador(es). }\end{array}$ & & & \\
\hline $\begin{array}{l}\text { E-Definição de procedimentos para a } \\
\text { implantação efetiva do novo sistema de } \\
\text { planejamento e programação. }\end{array}$ & & & \\
\hline 8 & Não ate & endid & \\
\hline$\odot$ & \begin{tabular}{|l} 
Atendic \\
Parcialı
\end{tabular} & ment & \\
\hline (:) & $\begin{array}{l}\text { Atendic } \\
\text { Plenam }\end{array}$ & $\begin{array}{l}\text { do } \\
\text { nente }\end{array}$ & \\
\hline
\end{tabular}

\subsubsection{Natureza da pesquisa}

Este trabalho possui preocupação centrada na geração de conhecimento para aplicação prática e na solução rápida de problemas aplicando-se a 
teoria. Segundo Silva e Menezes (2000) essa preocupação é típica de uma pesquisa aplicada.

\subsubsection{Abordagem do problema de pesquisa}

A abordagem do problema de pesquisa pode determinar se uma pesquisa é quantitativa ou qualitativa. Na primeira, considera-se que tudo pode ser quantificável, que é possível traduzir em números as opiniões e informações para permitir sua classificação e análise - muitas vezes requerendo o uso de técnicas estatísticas. Na segunda, existe uma relação dinâmica entre o mundo real e o sujeito, um vínculo indissociável entre o mundo objetivo e a subjetividade do sujeito que não se pode traduzir em números (SILVA; MENEZES, 2000).

Baseado nisso, este trabalho esse trabalho é classificado como uma pesquisa qualitativa. Segundo Silva e Menezes (2000), essa abordagem considera que o ambiente natural é a fonte direta para coleta de dados e o pesquisador é o instrumento chave, que tende a analisar os dados indutivamente.

As principais características de uma pesquisa qualitativa são (Hoppen et al., 1996):

O pesquisador observa os fatos sob a ótica de alguém interno à organização.

A pesquisa busca uma profunda compreensão do contexto da situação.

A pesquisa enfatiza o processo dos acontecimentos, isto é, a seqüência dos fatos ao longo do tempo.

O enfoque da pesquisa é mais desestruturado. Não há hipóteses fortes no início da pesquisa, o que lhe confere bastante flexibilidade.

A pesquisa utiliza mais de uma fonte de dados e enfatiza a perspectiva do objeto de estudo.

\subsubsection{Objetivos de pesquisa}

Segundo Nakano e Fleury (1996) e Hoppen et al. (1996), os principais métodos de pesquisa qualitativa são: o estudo de caso, a observação participante e a pesquisa-ação. Considerando-se que o desenvolvimento deste trabalho foi feito ao 
longo de aplicações e suas respectivas validações dentro das empresas, pode-se identificar a metodologia de pesquisa-ação como a mais adequada para enquadrar o trabalho em questão.

Por fim, Thiollent (1986) define a pesquisa-ação como:

[...] um tipo de pesquisa com base empírica que é concebida e realizada em estreita associação com uma ação ou com a resolução de um problema coletivo, e no qual os pesquisadores e os participantes representativos da situação ou do problema estão envolvidos de modo cooperativo ou participativo.

Portanto, este trabalho teve uma característica predominantemente de pesquisa-ação, uma vez que o autor atuou como consultor nas quatro aplicações.

\subsection{Organização do texto}

Este documento apresentou, no capítulo 1, uma breve introdução, situando a pesquisa no contexto do Sistema de Produção Enxuta. Na seqüência, foram apresentadas as justificativas e o detalhamento de seus objetivos. Em seguida, o método de pesquisa adotado.

No capítulo 2 são apresentados os conceitos necessários para a formulação do método proposto. Nele, são estudados a origem, os princípios e os desperdícios da produção enxuta, os sistemas de planejamento, programação e controle da produção e as respectivas funções que compõe sua estrutura, bem como os novos desafios para os sistemas de PCP em ambientes orientados para a produção enxuta. Com isso é traçado o contexto para a compreensão das razões que ocasionaram o surgimento da necessidade de sistemas híbridos de planejamento e programação da produção em ambientes de manufatura enxuta.

No capítulo 3, é apresentado o método detalhado para o desenvolvimento de sistemas híbridos de planejamento e programação orientado para ambientes de produção enxuta.

No capítulo 4, são apresentadas as aplicações práticas que ajudaram na validação e refinamento do método proposto. 
No capítulo 5 são apresentadas as conclusões em torno de todo o trabalho.

Por fim, são citadas as bibliografias utilizadas para a elaboração do trabalho em questão. 


\section{REVISÃO BIBLIOGRÁFICA}

A revisão bibliográfica abrange três importantes temas de conhecimento para o desenvolvimento deste trabalho: (1) o modelo toyota de produção e sua influência sobre o sistema de produção enxuta; (2) o planejamento e controle da produção e as respectivas funções que compõe sua estrutura, e (3) os novos desafios para os sistemas de PCP em ambientes orientados para a produção enxuta.

Através do modelo toyota de produção, é possível resgatar o sistema Just-in-Time como um dos principais pilares da Produção Enxuta, adotando técnicas e objetivos ora semelhantes ora complementares. A idéia é explorar conceitos e ferramentas que tem como objetivo permitir respostas rápidas aos clientes, através da flexibilidade do mix e volume, produzindo produtos de qualidade a baixo custo de produção.

Com relação ao tema planejamento e controle da produção (PCP) e as respectivas funções que compõe sua estrutura, busca-se, além da contextualização do objetivo do trabalho dentro da estrutura de PCP, uma melhor compreensão, sobretudo dos sistemas de planejamento da capacidade, emissão de ordens e de programação e controle do chão de fábrica. Estas funções são associadas principalmente ao médio e curto prazo, quando são dedicadas ao detalhamento das ações e procedimentos de decisão, que serão abordados no método de desenvolvimento de sistemas híbridos de programação e controle a ser proposto.

Estas ações e procedimentos de decisão, por sua vez, vêm deparando com desafios numa época em que a utilização dos conceitos e ferramentas da produção enxuta tem sido cada vez mais demandada por cenários cujas características são diferentes das existentes na indústria automotiva e sua cadeia de fornecimento, vigentes principalmente até meados da década de 90. Estas 
características envolvem portfólios com grande mix de produtos e componentes, e demandas flutuantes e distintas para cada tipo de parte.

\subsection{O Modelo Toyota de Produção e o Sistema de Manufatura}

Enxuta

O paradigma da Produção Enxuta, adotado pelas organizações como resposta às pressões exercidas pelo mercado, ocorreu no Japão a partir do final da década de 40. De acordo com Holweg (2007), o conceito lean não foi uma invenção de uma única fonte, mas um output de um processo de aprendizado dinâmico que adaptou práticas oriundas, sobretudo dos setores automobilístico e têxtil, em resposta às contingências vividas pelos japoneses.

O tópico a seguir descreve os princípios da Produção Enxuta, estabelecidos por Womack e Jones (1996), com base na teoria que sustenta o Sistema Toyota de Produção (STP).

\subsubsection{Princípios da Produção Enxuta}

Segundo Womack e Jones (1996), a produção enxuta possui cinco princípios básicos cujo objetivo é tornar as empresas mais flexíveis e capazes de responder efetivamente às necessidades dos clientes.

1. Determinar precisamente $o$ valor por produto específico: é o ponto de partida e deve ser definido segundo as perspectivas dos clientes finais.

2. Identificar a cadeia de valor para cada produto: é o conjunto de todas as atividades para se levar um produto específico a passar pelas tarefas de desenvolvimento, de gerenciamento da informação e da transformação física propriamente dita.

3. Fazer $o$ valor fluir sem interrupções: é necessário fazer com que as etapas que criam valor fluam. Isso exige uma mudança de mentalidade, o produto e suas necessidades devem ser o foco, e não as máquinas e equipamentos. O objetivo é reduzir as atividades que não agregam valor. Lavasseur et al. (1995) apresenta, em um estudo de caso, as seguintes vantagens proporcionadas pela criação de fluxo: redução nos estoques em processo, redução nos estoques de produtos acabados, 
eliminação das bandejas para estoque de material no chão-de-fábrica, redução no "lead time" dos produtos, redução do atraso nas ordens, redução dos refugos, redução do trabalho direto e redução no espaço ocupado pela manufatura.

4. Deixar com que o cliente puxe o valor do produtor: é fazer o que os clientes (internos ou externos) precisam no momento certo, permitindo que o produto seja puxado quando necessário, isso minimiza os desperdícios comumente encontrados em sistemas "empurrados".

5. Buscar a perfeição: fazer os quatro princípios anteriores interagirem em um processo contínuo na eliminação dos desperdícios.

Liker (2004) faz uma abordagem mais completa ao descrever 14 princípios que, com base nos seus 20 anos de estudo da empresa, constituem o Modelo Toyota. Os princípios propostos foram divididos em quatro categorias: Filosofia, Processo, Pessoal/Parceiros e Solução de Problemas (figura 6).

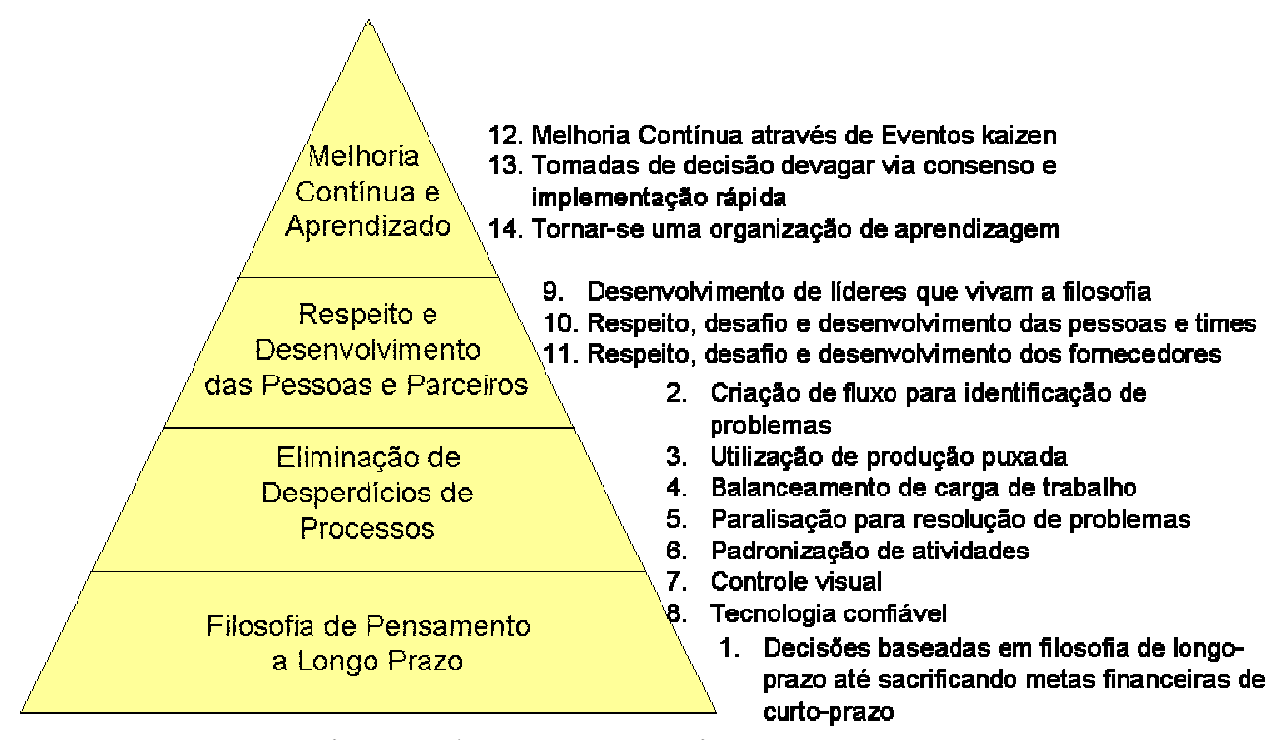

Figura 7: As quatro categorias do modelo Toyota Fonte: Liker (2004)

De acordo com Liker (2004), os 14 princípios que constituem o modelo Toyota são:

\section{Categoria 1: Filosofia de pensamento a longo prazo}

1) Basear as decisões administrativas em uma filosofia de longo prazo, mesmo em detrimento de metas financeiras de curto prazo. 


\section{Categoria 2: O processo certo produzirá os resultados certos}

2) Criar um fluxo de processo contínuo para trazer os problemas à tona.

3) Usar sistemas puxados para evitar a superprodução

4) Nivelar a carga de trabalho (heijunka).

5) Construiri uma cultura de parar e resolver os problemas, obtendo a qualidade logo na primeira tentativa.

6) Tarefas padronizadas são a base para a melhoria contínua e a capacitação dos funcionários.

7) Usar controle visual para que nenhum problema fique oculto.

8) Usar somente tecnologia confiável e completamente testada que atenda aos funcionários e processos.

Categoria 3: Valorização da organização através do desenvolvimento de seus funcionários

9) Desenvolver líderes que compreendam completamente o trabalho, que vivam a filosofia e a ensinem aos outros

10) Desenvolver pessoas e equipes excepcionais que sigam a filosofia da empresa.

11) Respeitar sua rede de parceiros e de fornecedores desafiando-os e ajudando-os a melhorar.

\section{Categoria 4: A solução contínua de problemas na origem estimula} a aprendizagem organizacional

12) Ver por si mesmo para compreender completamente a situação.

13) Tomar decisões lentamente por consenso, considerando completamente todas as opções e implementá-las com rapidez.

14) Tornar-se uma organização de aprendizagem através da reflexão incansável e da melhoria contínua. 
Segundo Liker (2004), a maioria das empresas aproveita as ferramentas enxutas, mas não compreendem o que as faz funcionarem juntas em um sistema: a cultura da melhoria contínua necessária para sustentar os princípios do Modelo Toyota. Conclui que dentro das quatro categorias apresentadas a maioria das empresas está patinando ainda na categoria de "Eliminação de Desperdícios de Processos".

O tópico a seguir fornece uma descrição mais detalhada destes desperdícios.

\subsubsection{As sete categorias dos desperdícios na produção}

Shingo (1996) sustenta que a teoria do Sistema Toyota de Produção (STP) baseia-se na eliminação contínua e sistemática das perdas (desperdícios) nos sistemas produtivos, visando assim a eliminação de custos desnecessários. Segundo ele, o princípio mais significativo e a característica única do STP estão no seguinte fato: visando a eliminação do estoque, vários fatores básicos devem ser exaustivamente explorados e melhorados. A eliminação total do desperdício é o foco principal do STP. Nesse sentido, os desperdícios têm sido classicamente classificados como (SHINGO, 1996; WOMACK; JONES, 1996; HINES; TAYLOR, 2000):

1. Superprodução: Produzir excessivamente ou cedo demais, resultando em um fluxo pobre de peças e informações ou excesso de inventário.

2. Espera: Longos períodos de ociosidade de pessoas, peças e informação, resultando em um fluxo pobre, bem como em lead times longos.

3. Transporte excessivo: Movimento excessivo de pessoas, informação ou peças resultando em dispêndio desnecessário de capital, tempo e energia.

4. Processos Inadequados: Utilização do jogo errado de ferramentas, sistemas ou procedimentos, geralmente quando uma abordagem mais simples pode ser mais efetiva. 
5. Inventário desnecessário: Armazenamento excessivo e falta de informação ou produtos, resultando em custos excessivos e baixa performance do serviço prestado ao cliente.

6. Movimentação desnecessária: Desorganização do ambiente de trabalho, resultando em baixa performance dos aspectos ergonômicos e perda freqüente de itens.

7. Produtos Defeituosos: Problemas freqüentes nas cartas de processo, problemas de qualidade do produto, ou baixa performance na entrega.

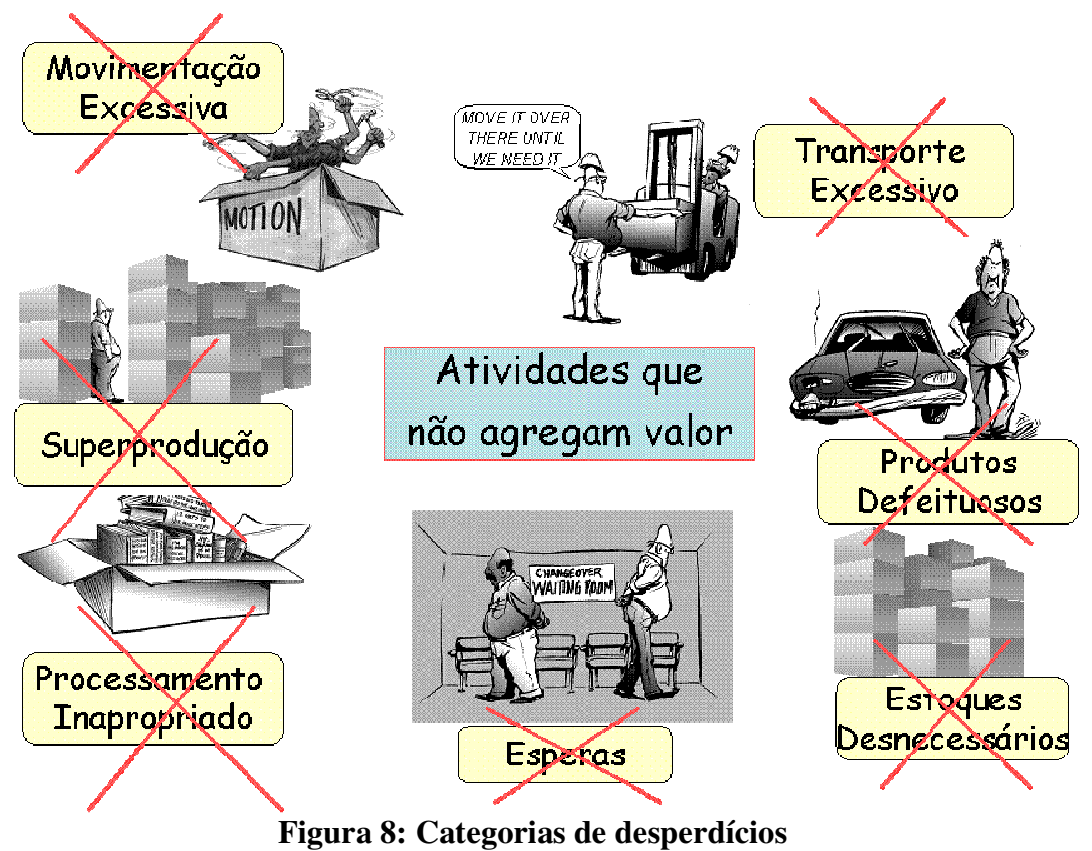

Dentro desse contexto, Hines e Taylor (2000) definem três diferentes tipos de atividades:

(1) Atividades que agregam valor: são atividades que, aos olhos do consumidor final, agregam valor ao produto ou serviço. Ou seja, atividades pelas quais o consumidor ficaria feliz em pagar por elas.

(2) Atividades desnecessárias e que não agregam valor: são atividades que, aos olhos do consumidor final, não agregam valor ao produto ou serviço e que são desnecessárias em qualquer circunstância. Estas atividades são nitidamente desperdícios e devem ser eliminadas a curto e médio prazo. 
(3) Atividades necessárias mas que não agregam valor: são atividades que, aos olhos do consumidor final, não agregam valor ao produto ou serviço, mas que são necessárias. Trata-se de desperdícios difíceis de serem eliminados em curto prazo, e que, portanto, necessitam de um tratamento a longo prazo, a menos que sejam submetidos a um processo de transformação radical.

Por fim, os autores acrescentam que em muitas empresas de manufatura estes três tipos de atividades podem ser encontrados, em média, na seguinte proporção (figura 7):

$5 \%$ de atividades que agregam valor.

$60 \%$ de atividades que não agregam valor.

$35 \%$ de atividades que não agregam valor, porém necessárias.

O que sugere a existência de um ambiente propício para a realização de esforços voltados para a redução do desperdício.

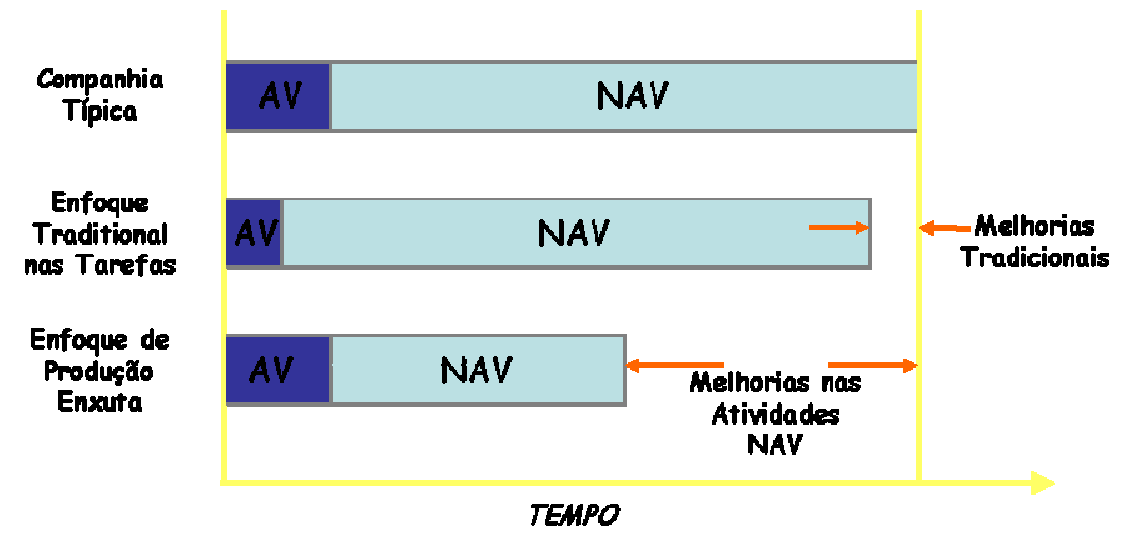

Figura 9: Proporção das atividades que agregam valor (AV) e das que não agregam valor (NAV) nas empresas e o enfoque das melhorias na produção enxuta Fonte: Hines e Taylor (2000)

De acordo com Liker (2004), como compromisso entre o ideal do fluxo unitário de peças e o sistema empurrado, Taiichi Ohno decidiu criar pequenos “armazéns" de peças entre operações para controlar o estoque. Quando o cliente retira determinados itens, estes são repostos. Se um cliente não deseja utilizar um item, este permanece no armazém, mas não é reposto. Não haverá uma superprodução maior do que a pequena quantidade na prateleira. Foi quando surgiu o conceito de produção puxada. 
Por outro lado, segundo o autor, o modelo Toyota não está preocupado com a adesão ao princípio de usar apenas sistemas puxados para evitar a superprodução. Existem muitos exemplos de programação empurrada na Toyota. Um deles refere-se ao uso de peças vindas do Japão para os Estados Unidos. Sistemas de programação tradicionais são usados para o pedido dessas peças, com o tempo apropriado para levá-las até a planta conforme o programado.

Khumawala e Al-Mubarak (2003) afirmam que, nos dias de hoje, é relativamente simples tomar a decisão de se adotar uma produção em lotes com layout funcional para alta variedade de itens com demanda anual alta, ou de se adotar um produção em fluxo contínuo com layout celular quando se tem baixa variedade de itens (células dedicadas) com demanda anual alta. O problema é que, atualmente, a maioria das empresas se encontra entre esses dois extremos. Sistemas com variedade média de itens e volumes médios de demanda tendem a requerer lotes de produção coexistindo com fabricação em fluxo contínuo. Jonsson e Lesshammar (1999) alertam também para a falta de sistemas de controle de desempenho da manufatura que sejam orientados para o fluxo e não apenas para a operação.

De acordo com Benito e Spring (2000), a indústria automotiva é apontada como a origem e principal usuário do modelo Toyota. Com isso, muitas pesquisas têm focado excessivamente nas montadoras, dando a impressão de que ele só é viável nesse tipo de indústria. Ao utilizar o modelo Toyota para torna-se enxuto, a lição é que não se deve imitar exatamente o uso que a Toyota faz de ferramentas específicas para ficar parecendo enxuto como ela. Portanto, tanto a programação puxada quanto a empurrada tem o seu lugar num sistema de produção (LIKER, 2004).

\subsubsection{Sistemas Empurrados versus Puxados}

Uma boa maneira de se entender a diferença entre sistemas empurrados e sistemas puxados é através da utilização da ferramenta de Mapeamento do Fluxo de Valor (MFV). O MFV, ou VSM (Value Stream Mapping), é uma técnica de modelagem proveniente da metodologia de Análise da Linha de Valor (Value 
Stream Analysis), proposta por Rother e Shook (1998) para ambientes de produção enxuta.

O MFV apresenta um conjunto de ícones a serem utilizados na modelagem. Outros ícones podem ser ainda criados e incluídos ao longo do processo de modelagem, para representar detalhes de situações peculiares ao processo. A figura abaixo mostra alguns destes ícones pré-definidos para a técnica de Mapeamento do Fluxo de Valor.

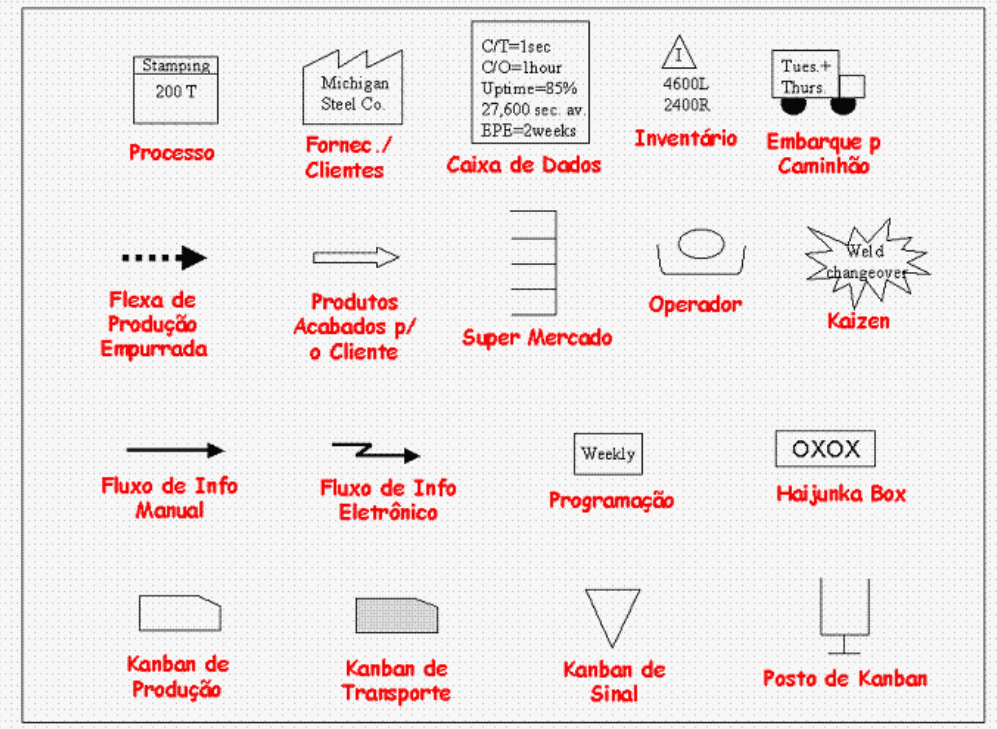

Figura 10:Alguns ícones definidos para Mapeamento do Fluxo de Valor Fonte: Rother e Shook (1998)

A figura a seguir apresenta uma visão tradicional de um sistema empurrado. 


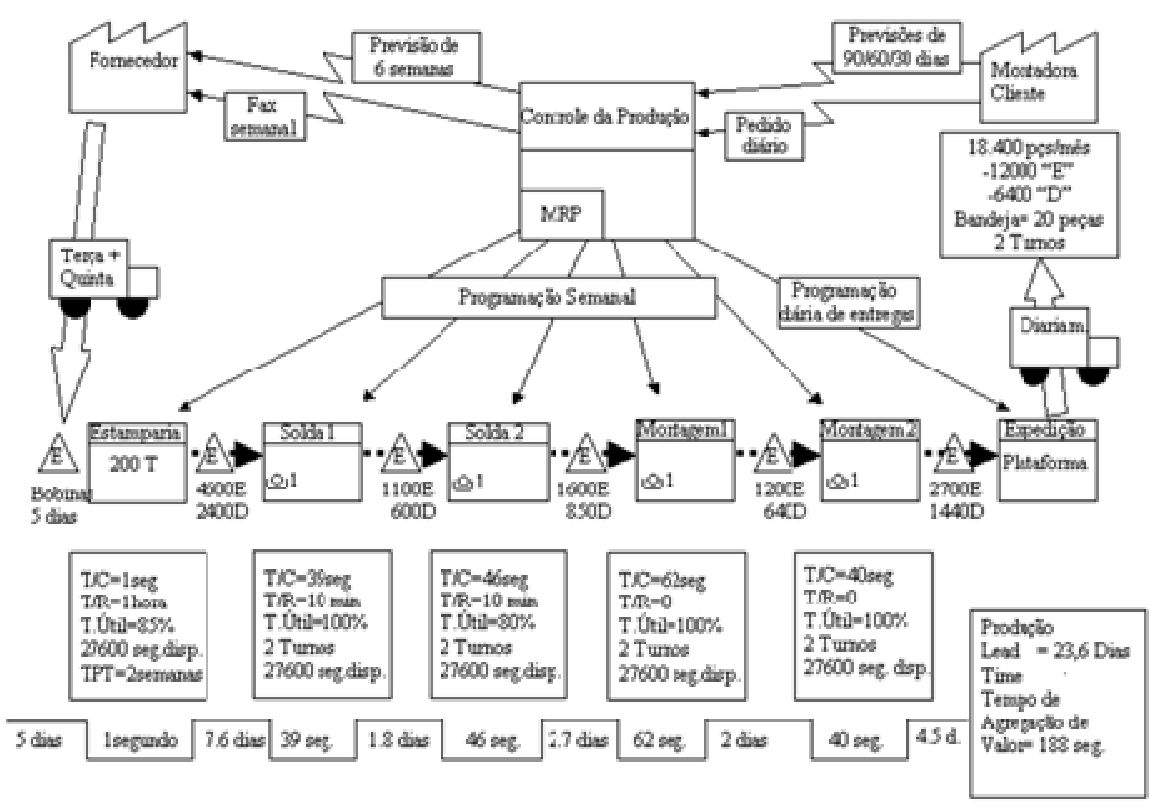

Figura 11: Visão geral de um sistema empurrado Fonte: Rother e Shook (1998)

A maneira mais convencional para se empurrar a produção é o Sistema MRP, sigla para Material Requirement Planning, ou Planejamento das Necessidades de Material. A dinâmica de processamento do MRP parte da quantidade desejada de um produto final numa data especificada, informações provenientes do Plano Mestre de Produção. A partir daí faz-se a explosão do produto nas necessidades dos componentes, com a devida defasagem de tempo (MOREIRA, 1993).

De acordo com Slack (1999), em um sistema MRP cada centro de trabalho empurra o trabalho, sem levar em consideração se o centro de trabalho seguinte pode utilizá-lo. Nestes sistemas são comuns a existência de tempo ocioso, estoque e filas.

Em fábricas em que a produção é controlada desta maneira, é comum haver vários pedidos esperando em uma mesma etapa do processo. Isto é resultado de uma série de fatores, tais como mudanças nos pedidos, atrasos de material, quantidades programadas erradas, máquinas quebradas e outros eventos inesperados, que tornam as programações de produção obsoletas tão logo são criadas. Por motivos 
como este, o MRP sofre uma série de críticas quando usado para programar o chãode-fábrica.

Em um sistema de produção puxada, o passo e as especificações do que é feito são estabelecidos pela estação de trabalho do "consumidor", que puxa o trabalho da estação antecedente (fornecedor) (SLACK,1999).

O sistema de puxar elimina a necessidade de se programar todas as operações por onde passará um pedido, como em um sistema MRP. Decisões do que fazer e quanto fazer são tomadas pelos operadores, usando um simples sistema de sinalização que conecta as operações através do processo (FUJIWARA et al., 1998).

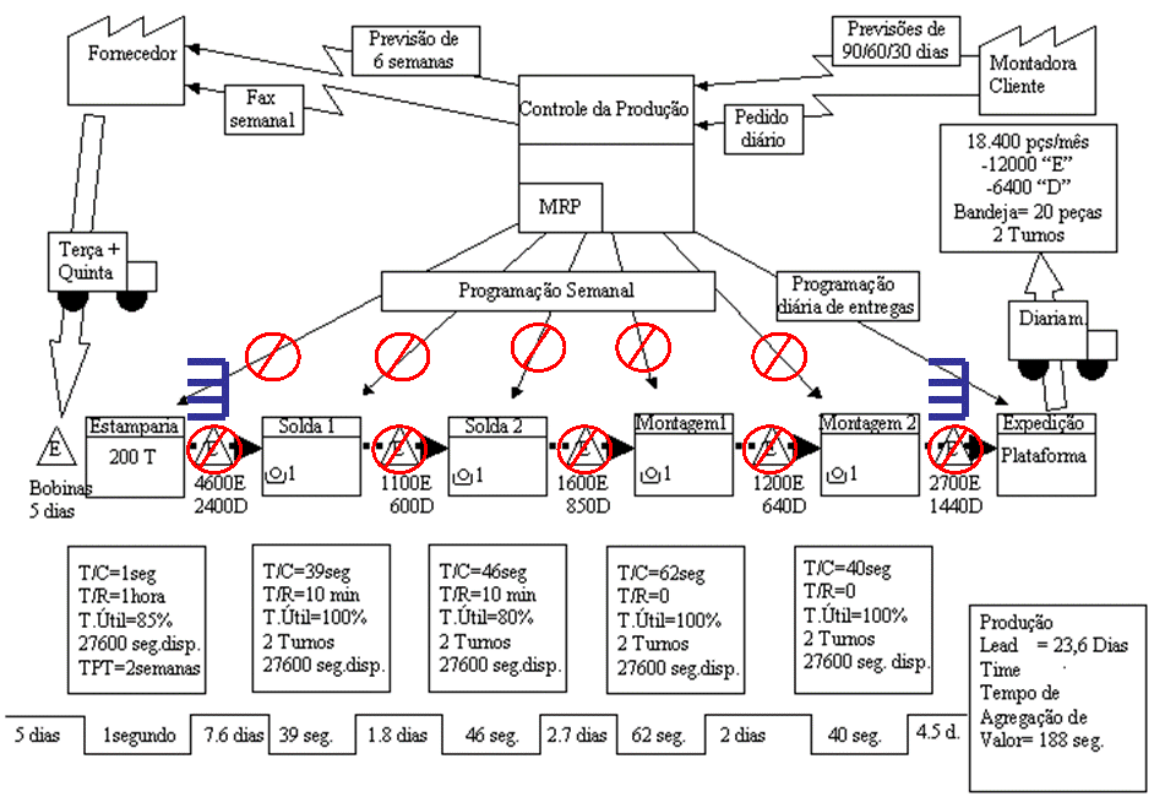

Figura 12: O sistema de puxar elimina a necessidade de se programar todas as operações Fonte: Adaptado de Rother e Shook (1998)

Este é um dos benefícios da produção puxada, ou seja, a transferência da responsabilidade da programação diária do chão de fábrica para os operadores, eliminando-se, assim, a necessidade de se ter um programador fazendo isto.

Quando se controla a produção desta maneira, somente uma etapa recebe o pedido do cliente. Para realizá-lo, ela busca no supermercado de peças da etapa anterior as peças que ela precisa para realizar o pedido. Esta etapa, por sua vez, busca, no supermercado de sua etapa anterior, as peças necessárias para repor o seu próprio estoque, e assim sucessivamente (TAKAHASHI; NAKAMURA, 2000). 
A maneira mais convencional de se puxar a produção é o Sistema Kanban. Este tipo de sistema é uma forma de se programar e controlar a produção. Um estudo mais profundo sobre os principais sistemas de planejamento, programação e controle da produção será feito a seguir.

\subsection{Sistemas de Planejamento, Programação e Controle da}

\section{Produção: Visão Geral}

Converter matéria prima bruta em produtos acabados é uma parte básica da civilização humana. De acordo com Slack (1999), um processo de transformação pode ser classificado em:

Processamento de Materiais: Podem mudar suas propriedades físicas (forma, composição característica) ou sua localização (transporte, encomendas) ou sua posse (biblioteca, lojas de varejo).

* Processamento de Informações: Mudam suas propriedades informativas (contadores), mudança de posse (pesquisa de mercado) ou estocam (biblioteca).

Processamento de Consumidores: Mudam suas propriedades físicas (cabeleireiros, cirurgiões), estocam ou acomodam (hotéis), mudam o estado psicológico (teatro, televisão, parques).

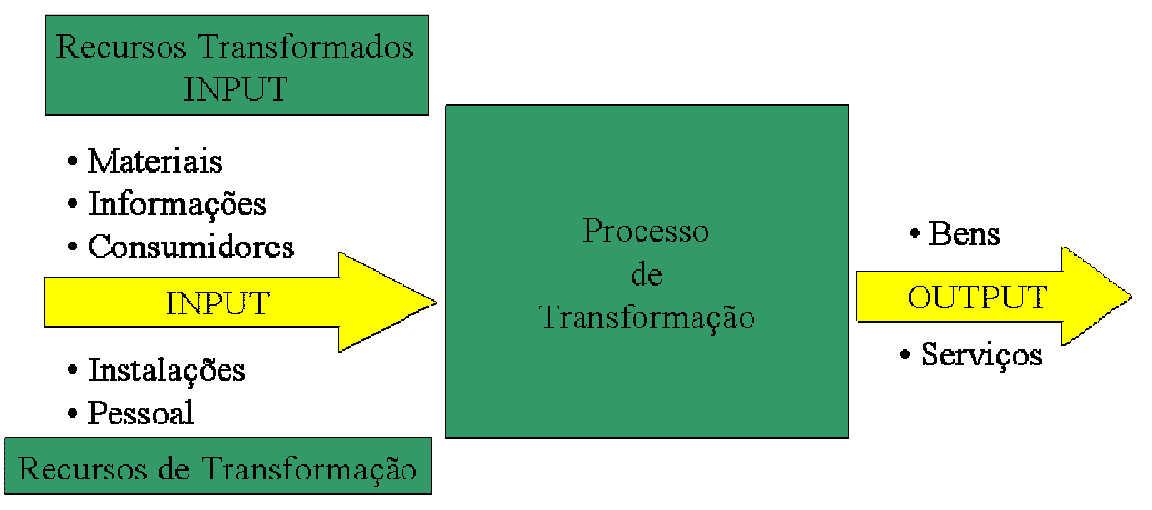

Figura 13: Modelo de Transformação

Fonte: Slack (1999) 
As entradas do processo de transformação podem ser classificadas em:

Recursos transformados: materiais, informações e consumidores.

Recursos de transformação: instalações, máquinas, funcionários.

Um dos principais desafios do processo de transformação é conciliar a taxa de produção com a taxa de demanda dos consumidores. De acordo com teoria de controle, é improvável que estas taxas sejam emparelhadas sem alguma intervenção consciente na forma de um mecanismo de regulador. De fato, esta é a principal razão para a existência de um sistema de administração de produção (SOUSA, 2004).

O componente regulador é um sistema de planejamento e controle capaz de interferir na taxa de produção. Na prática, isto é realizado por processos de administração (por exemplo, administração de inventário) na seguinte ordem: (1) indicadores de desempenho do sistema são medidos e comparados com os objetivos, (2) desvios ativam decisões (de acordo com políticas adotadas) de ações corretivas para os processos de produção e para seus inputs.

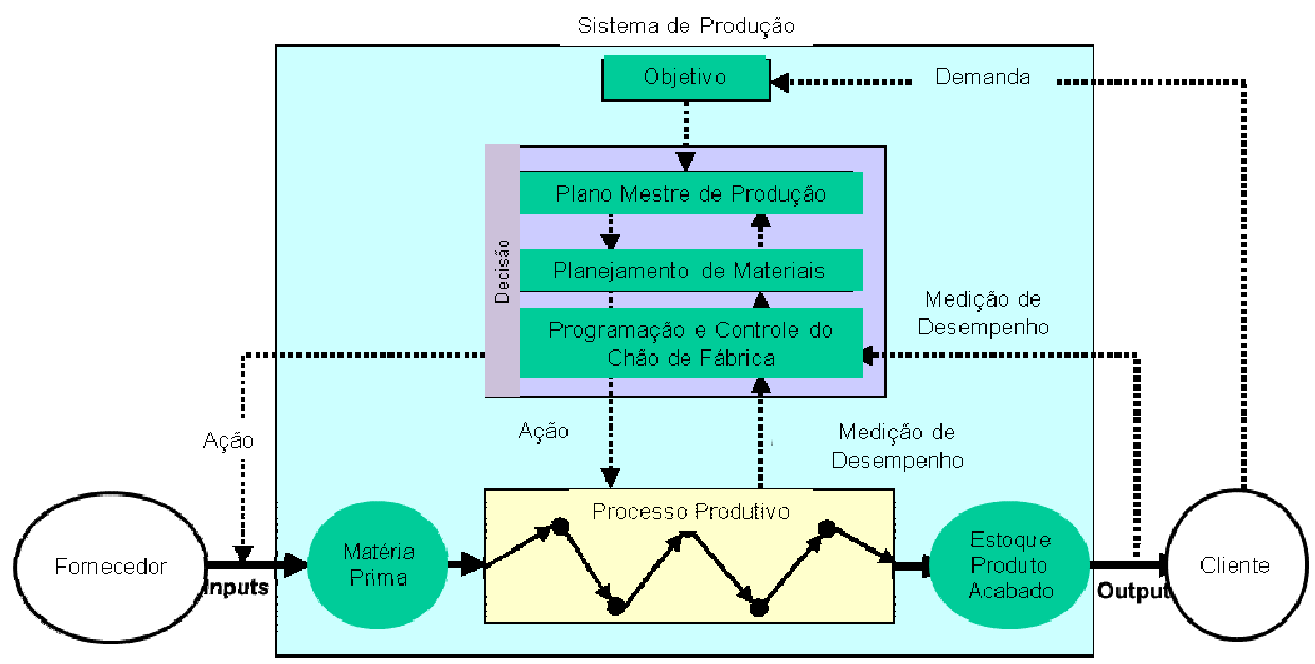

Figura 14: Estrutura Genérica de um Sistema de Planejamento e Controle da Produção Fonte: Sousa (2004)

De acordo com Scarpelli (2004), um Sistema de Planejamento e Controle da Produção (PCP) é formado por um conjunto de atividades que exigem a 
definição de um sistema de informações, o desenvolvimento de um sistema de tomada de decisões e a definição de uma estrutura de funções.

O sistema de informação presta-se a obter, organizar, registrar, agrupar, separar, ordenar, classificar, gerar e selecionar dados, transformando-os em informações úteis aos processos de tomada de decisão, avaliações de desempenho e diferentes tipos de identificação.

O sistema de decisões é o conjunto de regras, normas, modelos e/ou procedimentos, empíricos ou não, que dá origem às ações de planejamento, controle, produção e outras, dependendo dos graus de amplitude e profundidade definidos na estrutura.

A estrutura é definida considerando o conjunto de recursos que o empreendimento dispõe as ações que executa, bem como a forma com que agrega os recursos às ações. Ela compõe-se de duas dimensões. A primeira dimensão é sua amplitude, que pode integrar mais ou menos funções paralelas como, por exemplo, aquisição e movimentação interna de materiais. A segunda dimensão é sua profundidade, determinada pelo grau de funções seqüenciais que comporta, podendo ir, por exemplo, da previsão de demanda ao processo de distribuição dos produtos aos clientes.

\subsection{Funções de um Sistema de PCP}

As funções de um Sistema de Planejamento e Controle da Produção podem ser identificadas como:

Previsão de demanda

Planejamento agregado

* Programação mestra

* Planejamento de capacidade

* Planejamento de materiais

* Emissão de ordens

\# Programação e controle da produção 
Este trabalho focará nas funções de médio e curto prazo de planejamento da capacidade, emissão de ordens e de programação e controle do chão de fábrica. Logo, será feito um estudo mais aprofundado das mesmas mais adiante.

\subsubsection{Função planejamento da capacidade}

Sem uma provisão de capacidade suficiente ou trabalhando com capacidade excessiva não é possível obter todos os benefícios em potencial de um sistema de planejamento e programação da produção. Por um lado, a falta de capacidade leva à deterioração do desempenho de entrega, amplificação dos estoques em processo e frustração do pessoal da manufatura. Por outro lado, excesso de capacidade tende ser uma despesa desnecessária que deve ser reduzida.

Vollmann et al. (1997) propõe quatro técnicas para o planejamento da capacidade.

A primeira delas, conhecida por CPOF (Capacity Planning using Overall Factors), consiste no planejamento da capacidade utilizando dados globais. Trata-se da técnica mais simples, pois se baseia em dados padrão ou histórico de produtos acabados, que podem vir do Plano Mestre de Produção ou até mesmo por meio de entradas manuais. A partir disso, a mão de obra global e a necessidade de horas máquinas são estimadas com base no histórico de horas máquina e de horas homem utilizadas. É recomendada para empresas, ou centros de produção, cujo mix e histórico de produção sejam relativamente constantes.

A segunda técnica, denominada Lista de Capacidade (Bill Capacity), requer, além dos produtos acabados, informações mais detalhadas das estruturas dos produtos. Ela se baseia em dados padrão ou histórico de todos os componentes da árvore do produto e na capacidade requerida individualmente pelos respectivos centros de trabalho. Consequentemente, ela requer mais dados que a técnica CPOF, como a lista de materiais e o roteiro de produção. Os dados de mão de obra direta e/ou hora máquina devem estar disponíveis para cada operação.

Todavia, nem a técnica CPOF e nem a Bill Capacity levam em consideração a duração específica do trabalho total em cada centro de produção ao longo do tempo. Para tanto, foi projetada uma técnica denominada Perfis de 
Recursos (Resource Profiles). Esta terceira técnica aborda uma dimensão mais ampla, acrescentando na análise os dados de lead time de produção de componentes e produtos acabados, tendo em vista projetar a necessidade de capacidade de forma time-phased. É recomendada para situações em que o lead time do processo é maior que uma semana. Nestas situações, o longo horizonte de tempo de produção pode mascarar mudanças importantes nas necessidades de capacidade. Logo, ela fornece uma abordagem um pouco mais sofisticada para o planejamento grosseiro da capacidade.

As três primeiras técnicas tratam do planejamento grosseiro da capacidade e são aplicáveis em empresas que possuem ou não sistemas MRP. A quarta técnica, denominada de Planejamento das Necessidades de Capacidade (CRP - Capacity Requirements Planning), é utilizada em conjunto com os sistemas MRP, cujos registros são utilizados para calcular as necessidades de capacidade na produção de ordens abertas e de ordens programadas.

Esta técnica se difere das outras em quatro aspectos: (1) O CRP utiliza as informações de planejamento de materiais de forma time-phased a partir de um sistema MRP. (2) O sistema MRP leva em consideração a capacidade de produção já estocada na forma de inventários tanto de componentes quanto de produtos acabados. (3) Os sistemas de controle do chão de fábrica fornecem o estado atual de todo o estoque em processo. Logo, apenas a capacidade necessária para completar o trabalho restante é considerada no cálculo da necessidade de capacidade dos centros de trabalho. (4) O CRP leva em conta a demanda por serviços de reposição, retrabalhos e outras demandas não contempladas no Plano Mestre de Produção, e que podem requerer capacidade adicional.

Por fim, a técnica CRP de planejamento da capacidade requer os mesmos inputs que as demais (lista de materiais, roteiros de fabricação, tempos padrão e lead times) mais as informações de um sistema MRP das ordens planejadas e ordens em aberto em cada centro de trabalho.

\subsubsection{Função emissão de ordens}


De acordo com Scarpelli (2004), um sistema de emissão de ordens é o conjunto de decisões e ações de médio e curto prazo realizados no âmbito do planejamento e controle da produção, que resultam na emissão e liberação de instruções para a obtenção de materiais, componentes e produtos nas quantidades e prazos constantes do plano de materiais. Essas instruções, denominadas ordens, subsidiam as operações administrativas e industriais necessárias para atender as demandas de itens e produtos finais. As ordens podem ser de três tipos:

Ordens de fabricação

* Ordens de compra

\# Ordens de montagem

Ordens de fabricação e montagem são usualmente chamadas ordens de produção.

A arquitetura dos sistemas de emissão de ordens pode ser de um dos dois tipos:

Centralizada: em que há um órgão específico na estrutura de planejamento, responsável por todas as atividades associadas à emissão de ordens, programação e acompanhamento de sua execução.

Descentralizada: em que um órgão central responsabiliza-se apenas pelo estabelecimento de parâmetros operacionais. As atividades de programação e controle são autônoma e descentralizadamente decididas e monitoradas pelos executores, de acordo com os parâmetros operacionais previamente estabelecidos.

As diferentes arquiteturas, por sua vez, impõem diferentes constituições organizacionais, prestando-se a estratégias específicas. Lin e Shaw (1998), apresentam os cinco principais tipos de estratégias de emissão de ordens:

MTS (Make-to-stock): os pedidos são atendidos por itens previamente estocados.

ATO (Assembly-to-order): componentes acabados são montados conforme a solicitação dos clientes.

MTO (Make-to-order): os pedidos dos clientes disparam a produção dos itens que deverão ser entregues. Não há estoque de produtos acabados. 
BTO (Buy-to-order): a compra da matéria-prima é efetuada após o recebimento do pedido.

ETO (Engineering-to-order): os pedidos dos clientes disparam o desenvolvimento ou alterações no projeto dos produtos.

Scarpelli (2004), por sua vez, discorre sobre aquelas mais comumente utilizadas (MTO e MTS), e apresenta uma estratégia particularmente interessante para o desenvolvimento deste trabalho, a estratégia de emissão de ordens híbrida (MTS/MTO):

Produção para estoque (make to stock - MTS): a emissão de ordens ocorre em função da geração de estoques necessários para suprir necessidades previstas. Descreve um sistema de manufatura onde a demanda por espectro de produtos, claramente definidos, é conhecida ou prevista. A satisfação do cliente é dependente do produto estar disponível em um armazém que opera como um pulmão contra a possibilidade de demanda incerta. Essa definição sugere tratar-se de produtos com projeto ou receita pré-definidos e, portanto, produtos padronizados. As montadoras são exemplos de empresa que utilizam esta estratégia. Elas estocam os veículos Best Sellers em seus pátios para atender as concessionárias o mais rapidamente possível.

Produção sob Pedido (Make To Order - MTO): produtos padronizados de um espectro pré definido ou catálogo, são requisitados pelo cliente ou seus agentes. Embora os materiais possam ser comprados e a produção planejada, a fabricação começa somente após a recepção de um pedido firme. A emissão de ordens ocorre a partir do instante em que um pedido do cliente concretiza-se. As gráficas trabalham com este tipo de estratégia. Como não é possível prever o conteúdo do trabalho que será solicitado, praticamente todos os pedidos são produzidos mediante ordem.

Produção híbrida (make to order, make to stock - MTO/MTS): a emissão de ordens ocorre tanto para satisfazer níveis pré-estabelecidos de estoque 
quanto para atender pedidos específicos de clientes. Podem-se identificar dois possíveis tipos de produção híbrida nessa estratégia:

* Produção em seqüência: o processo é subdividido em duas etapas, uma primeira em que os produtos são semiprocessados e armazenados e, cuja emissão de ordem é função do nível de estoque intermediário e; uma segunda etapa em que, na sequiência, os semiprocessados são retirados desse estoque intermediário para compor os produtos finais desejados pelos clientes, segundo pedidos específicos. Para esta etapa há uma nova emissão de ordens do tipo sob pedido, com elementos inéditos (sob projeto) ou não. Um exemplo disso são empresas de máquinas agrícolas. Elas mantêm os itens estampados e usinados em estoque e montam os produtos acabados, com as respectivas customizações, mediante a colocação dos pedidos dos clientes. Esse sistema é correspondente ao sistema ATO, no qual os componentes acabados são montados conforme a solicitação dos clientes. Segundo Bruun e Mefford (2004), o modelo ATO da Dell permitiu que a empresa tivesse maior rapidez no atendimento dos pedidos dos clientes e, ao mesmo tempo, reduzisse o seu nível de inventário de componentes para uma média de dez dias, versus a média do segmento que era de cem dias.

Produção em paralelo: O sistema básico de emissão de ordens pode ser do tipo para estoque ou do tipo sob encomenda. No primeiro caso, as ordens são normalmente emitidas visando à reposição de estoques, mas podem periodicamente gerar ordens específicas visando atender as peculiaridades dos pedidos de alguns clientes. No segundo caso, o sistema básico de emissão de ordens opera gerando ordens específicas para atender pedidos diferenciados dos clientes e, na ausência destes, operam gerando estoques de itens comuns ou produtos padronizados. Ambos os tipos de ordens, na estratégia híbrida em paralelo, concorrem no tempo pelos mesmos recursos produtivos. Muitas empresas trabalham com esse tipo de estratégia. Nesse caso, os 
produtos Best Sellers são mantidos em estoque, enquanto que os itens de vendas mais esporádicas são produzidos sob encomenda.

A diferença entre os sistemas em seqüência e em paralelo reside basicamente no momento do processo em que se dá o pedido do cliente. O ponto do pedido do cliente separa a parte da organização orientada em direção a atividades para pedidos de clientes, da parte da organização baseada em previsão e planejamento.

Uma grande parte da literatura (Arreola et al. ${ }^{2}$; Van Donk ${ }^{3}$; Rajagopalan $^{4}$; Kingsman et al. ${ }^{5}$ ) é dedicada particularmente à comparação das classes MTS e MTO, devido a crescente substituição dos sistemas que tradicionalmente produziam para estoque por sistemas mais ágeis, produzindo sob pedido dos clientes. A preocupação central é poder atender aos pedidos, como formulados pelos clientes, mantendo ou reduzindo os custos de produção. Grande parte desses trabalhos dedicase a uma forma híbrida de organização decorrente da transição de um modelo para o outro. Essa transição pode ser conseqüência de uma mudança para uma estratégia de diversificação ou para uma estratégia de inovação em ciclos mais curtos, ou ambos.

A escolha do tipo, ou arquitetura, da estrutura do sistema de emissão de ordens de produção (centralizada ou descentralizada) está associada à estratégia de produção (MTS, MTO, ATO, etc.) e esta, por sua vez, a parâmetros relacionados ao mercado, ao produto e ao processo. No que diz respeito ao mercado, são relevantes: o seu volume de demanda, sua estabilidade e forma de relação com a empresa (aquisição de estoque ou sob pedido). No tocante ao produto são relevantes:

2 Arreola, Antonio; DeCroix, Gregory, A. (1998). Make-to-Order versus Make-to-Stock in a production-inventory system with general production times. IEE transactions; 30; pg. 705-713

${ }^{3}$ Van Donk, Dirk Pieter. (2001). Make to stock or make to order: The decoupling point in the food processing industries; International Journal of Production Economics; pg. 297-306.

${ }^{4}$ Rajagopalan, S. (2002). Make to order or make to stock: Model and application; Management Science; INFORMS; vol. 48; No2; February; pg. 241-256.

5 Kingsman, Brian; Hendry, Linda; Mercer, Alan; Souza, Antonio de. (1996). Responding to customer enquiries in make-to-stock companies problems and solutions. Int. J. Production Economics; 46-47; pg. 219-231. 
a sua padronização, sua diversidade e perecibilidade. Com relação ao processo são relevantes: a sua complexidade, sua forma de fluxo e ciclo de fabricação.

Em qualquer dos sistemas descritos, após as ordens serem emitidas e liberadas, sucede-se a programação e controle da produção.

\subsubsection{Função programação e controle da produção}

Segundo Scarpelli (2004), os sistemas de programação e controle da produção estão estreitamente associados aos sistemas de emissão de ordens e fazem parte do planejamento de curto prazo. Eles são responsáveis pela elaboração da programação da produção, isto é, o ordenamento no tempo das operações das ordens de produção liberadas. Também são responsáveis pela verificação de desempenho e encaminhamento dos problemas e soluções.

A programação pode ser feita considerando:

* Um carregamento infinito ou carregamento finito

* Um ordenamento progressivo, regressivo ou misto

\# O uso de regras heurísticas de despacho

\# O uso de lotes de processo diferentes dos lotes de transferência

* A possibilidade de superposição de operações ou não

\& O tempo de preparação de máquina dependente da operação do item anterior

Denomina-se programação com carregamento finito a programação que tem por pressuposto a limitação temporal do uso dos recursos produtivos, isto é, ela deve ser feita considerando a capacidade dos recursos produtivos limitada em um intervalo de tempo disponível delimitado. Denomina-se programação com carregamento infinito aquela em que se supõe que os prazos possam ser estendidos a medida do necessário ou que a capacidade dos recursos possa ser expandida se o intervalo de tempo for limitado.

Denomina-se programação progressiva a forma de ordenar sequencialmente as operações necessárias à fabricação de cada item nos respectivos recursos. A partir de uma data de início pré-determinada para a primeira operação de 
cada item, progride-se no tempo para alocar cada respectiva operação sucessora. Inversamente, denomina-se programação regressiva a forma de se ordenar seqüencialmente às operações necessárias à fabricação de cada item, nos respectivos recursos, partindo-se da data desejada para a conclusão da última operação em cada item retroagindo-se no tempo para alocar cada respectiva operação predecessora.

A programação baseada em regras heurísticas é aquela baseada em diferentes formas de priorizar a escolha do item/operação a executar em cada recurso a cada momento que um esteja ocioso. As vantagens de utilização de uma regra heurística são a simplicidade e rapidez da decisão, para efeito de programação. Algumas regras possíveis são:

* Prazo mais cedo: programar primeiro a operação do item que tenha o menor prazo. Resulta em bom desempenho no cumprimento de prazos.

* Menos tempo de processamento: programar primeiro a operação do item que tenha o menor tempo de execução (tempo de preparação mais tempo da operação). Resulta em baixos estoques em processo, médias de tempo dos ciclos de fabricação baixos e bom desempenho no cumprimento de prazos.

* Primeiro que chega primeiro a ser feito: programar primeiro a operação do item que se apresente disponível primeiro. Resulta em baixa variação do tempo de ciclo de fabricação.

Segundo Buxey (1989), a programação baseada no prazo mais cedo (menor prazo) é a regra heurística mais usada.

A programação baseada no uso de lotes de processo diferentes dos lotes de transferência significa que no desenvolvimento da programação os lotes, originalmente estabelecidos no planejamento de materiais, podem ser divididos ou agrupados de acordo com a conveniência em cada operação ou entre cada duas operações de cada item. Este recurso é usado para compensar os diferentes tempos de processamento das operações dos diferentes itens, promovendo um balanceamento no fluxo de materiais entre os recursos. 
Denomina-se programação baseada na superposição de operações aquela em que não é necessário aguardar pela conclusão de uma operação em todos os componentes de um lote para se iniciar a próxima operação nos componentes desse lote. Isso implica que se podem ter duas ou mais máquinas executando operações diferentes em um mesmo lote.

Preparação dependente do item anterior significa que o tempo de preparação para a próxima operação pode ser maior ou menor, dependendo de qual operação tenha sido concluída imediatamente antes no equipamento. Assim é usual programar-se em seqüência, lotes de itens que utilizam uma mesma matéria prima, um mesmo ferramental, ou ainda, que impeçam ou reduzam a possibilidade de contaminação (química, física ou bacteriológica) do lote do item subseqüente.

As diferentes formas e possibilidades de se tratar a programação e controle da produção podem ser combinadas em um sistema apropriado às condições de cada empreendimento.

\subsection{Tipos de sistemas de PCP}

Para tratar as funções supracitadas de PCP foram desenvolvidos sistemas de planejamento de materiais, emissão de ordens de produção, bem como de programação e controle da produção, denominados OPOQ, POB, MRP, JIT Kanban, TPC, dentre outros. Estes sistemas serão discutidos logo a seguir.

\subsubsection{Sistemas OPOQ (Order Point Order Quantity - Ponto de Pedido Quantidade Pedida)}

Os Sistemas de Emissão de Ordens OPOQ (Order Point Order Quantity - Ponto de Pedido Quantidade Pedida) são assim denominados porque são ativados de acordo com a disponibilidade de estoque em dado momento.

O que se busca quando se administra estoque é estabelecer políticas e modelos de dimensionamento para a reposição que simplifiquem o trabalho de gestão, proporcionem um bom fluxo de produção e determinem um ponto econômico de equilíbrio entre a falta e seu excesso. 
Nos sistemas de produção industriais a decisão de repor estoques obedece normalmente a parâmetros de demanda e tempo de reposição. Para que não haja falta de um item assim administrado, a quantidade disponível em estoque dividida pela taxa de consumo deve resultar sempre maior ou igual ao tempo de reposição. Em princípio, cada item é administrado individualmente e a taxa de consumo é função do histórico de demanda (SCARPELLI, 2004).

O tempo de reposição do estoque de itens e produtos acabados depende do ciclo de fabricação e nunca deve ser menor que a soma dos tempos das operações de obtenção de cada um deles, sob pena de incorrer na falta desses itens e produtos quando necessários. Esse estoque só poderá ser nulo quando seu fornecedor, o estoque de materiais em processo, igualarem sua taxa de suprimento à taxa de consumo do mercado externo e o momento de fornecimento estiver em sincronia com o momento de consumo.

De acordo com Monden (1998), existem duas formas de emissão de ordens OPOQ, ou de reposição de inventários, o de pedidos com quantidades constantes e o de ciclo de pedidos constante. De acordo com o primeiro, uma quantidade fixa será pedida para o processo anterior toda vez que o estoque deste item atingir um determinado nível. Neste caso, a quantidade pedida é fixa, mas a data do pedido é variável. De acordo com o segundo, acontece o contrário. Os pedidos acontecem em horários fixos, mas a quantidade pedida varia. Segundo Rother (1999), estas duas formas de reposição de inventários também podem ser aplicadas como sistemática de reposição do sistema kanban.

Hax et al. ${ }^{6}$ (1984 apud SCARPELLI, 2004) recomenda a utilização destes tipos de sistemas em ambientes de fabricação simples que não sejam afetados por significativas flutuações na demanda e onde uma grande capacidade esteja disponível. Entretanto, os sistemas do tipo OPOQ são vulneráveis em situações onde haja uma demanda sistematicamente crescente.

\subsubsection{Sistemas PBC (Periodic Batch Control)}

${ }^{6}$ HAX, A.C.; CANDEA, D. (1984). Production and inventory management. New Jersey: PrenticeHall. 
O sistema PBC parte de um programa mestre em que se aplica a explosão do produto, porém com listas de materiais estruturadas de tal forma que o lead time de obtenção é semelhante em todos os níveis.

Assim, o sistema PBC, de acordo com Riziebos ${ }^{7}$ (2001 apud SCARPELLI, 2004), difere de outros sistemas de planejamento ao utilizar os três seguintes princípios:

* Liberação de Ordens em ciclo único: refere-se à freqüência de liberação de ordens de produção. Cada item tem a mesma frequiência de emissão de ordens que seus pais.

* Fase única: refere-se ao momento da liberação das ordens de produção. As ordens de produção são liberadas para a fábrica no mesmo momento (definido como início do período).

* Tempo de execução único: refere-se ao lead time da ordem de produção (por nível). Todas as ordens têm lead time idêntico.

As principais diferenças entre os sistemas PBC e os sistemas OPOQ estão relacionadas à forma de dimensionamento dos lotes e forma de emissão das ordens. Os modelos OPOQ normalmente obedecem a critérios de custo para dimensionamento dos lotes e emitem ordens em períodos individuais para cada item. No PBC o dimensionamento do lote é feito em função do ciclo e carga estabelecidos, e a emissão é feita em conjunto para todos os itens.

\subsubsection{Sistemas MRP}

No sistema MRP as ordens são emitidas de acordo com um programa mestre aprovado. O sistema utiliza a técnica de programação retroativa que começa pelos prazos dos itens finais e calcula retroativamente, com o uso do lead time definido para cada item, quais são as datas necessárias de emissão das ordens de produção ou compra dos materiais e componentes. A estrutura básica do sistema MRP foi criada para determinar as quantidades a produzir estritamente necessárias nos momentos necessários. Entretanto, podem identificar associados aos sistemas de

7 RIZIEBOS, J. (2001) The Designo of period batch control planning system for cellular manufacturing. PhD. Thesis - University of Groningen, Netherlands, 2001. 
cálculo de materiais do MRP, diferentes formas de emissão de ordens de produção. As principais formas de emissão de ordens são (SCARPELLI, 2004):

Lote a lote: dimensionam-se os lotes estritamente de acordo com cada demanda em cada período. Este método impede que resultem saldos excedentes em estoque, entretanto pode incorrer em uso inadequado dos recursos produtivos tendo em vista os tempos de preparação necessários.

L Lote a intervalo fixo: o lote correspondente ao somatório das demandas de um intervalo determinado de períodos adjacentes. Agregam-se os lotes de períodos adjacentes de modo a compor menos lotes com quantidades maiores. Não há saldos excedentes em estoque ao término do intervalo de tempo estabelecido, embora existam estoques, como função do número de períodos adjacentes considerados.

Lotes fixos: os lotes de itens fabricados serão normalmente baseados em algum critério ponderado por custos de preparação (set up) contra custos de manutenção de estoques (lote econômico). Normalmente, restará alguma sobra em estoque. Isto implica que no cálculo de necessidade do período subseqüente, a disponibilidade de estoque deve ser deduzida da necessidade bruta.

Buxey (1989) critica o modelo de lote econômico, pois ele "omite" o fator mais importante no planejamento da produção, isto é, a capacidade.

Nos sistemas MRP o lead time é baseado inicialmente no conhecimento empírico que se tenha do processo de produção e em seguida na média dos tempos que cada instrução de obtenção do item consumiu. Essa média é um valor grosseiro porque não considera a dimensão de cada lote de fabricação do item ou os tempos de fila despendidos em cada caso, como decorrência do mix de produção existente na ocasião. A adoção desta média baseia-se na suposição de que ela seja uma representação real do comportamento da empresa.

\subsubsection{Sistemas Kanban (JIT/Lean Production)}


O Sistema Kanban é um sistema de informações, criado pela Toyota, que controla a produção de toda a fábrica, isto é, dá autorizações de produção, de transporte e informa a localização de componentes através de cartões. O princípio do kanban é limitar a quantidade de estoque em processo através de um número determinado de cartões (GAURY et al., 2000). Só se produzem ou se retiram peças de um processo, ou estoque, caso tenham-se cartões correspondentes a elas, e na quantidade fixada nos cartões.

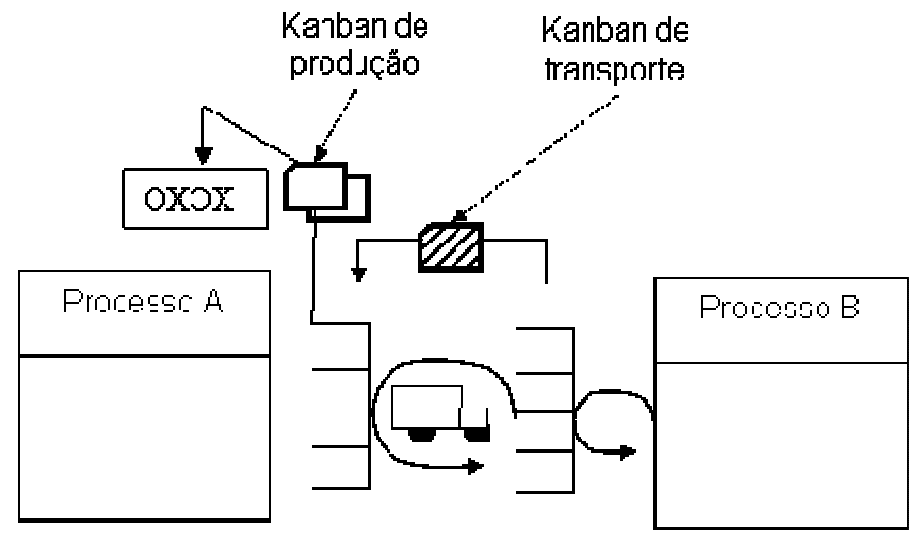

Figura 15: Dinâmica do sistema kanban

As principais vantagens associadas a sua utilização são (GAURY et al., 2000):

Eliminação do estoque de material em processo.

* Os setores produtivos são melhores aproveitados, resultando numa maior capacidade total das linhas produtivas, ou seja, num aumento da produtividade.

\# Os tempos de obtenção (lead time) são reduzidos, quer em nível de itens individuais quer em termos de produto final. Portanto, é possível antecipar os prazos de entrega.

Como trabalha em um sistema de produção "puxada" o nível de existência de produtos finais poderá ser reduzido, ou até mesmo deixar de existir. Melhor administração dos estoques intermediários, ou em processo, e finais.

Menor ocupação de espaço, até a extinção, para estoques intermediários e diminuição das áreas de almoxarifado e armazenagem na expedição. 
Outro método de se puxar a produção é chamada de CONWIP (Constant Work in Process - Estoque em Processo Constante). O CONWIP pode ser visto como um sistema de empurrar a produção com um número limitado e constante de inventário em processo. Só entra matéria-prima no processo quando sai produto acabado (GAURY et al., 2000). Esta limitação de material pode ser feita através de um número fixo de cartões ou de containeres. Este sistema difere do Sistema Kanban porque nele as informações da quantidade e momento de produzir não estão no mesmo cartão. Sabe-se que uma caixa foi consumida e, portanto, outra pode ser produzida, entretanto, o que será produzido é programado a partir da programação de produção.

\section{Regras do kanban}

Segundo Monden (1998), existem cinco regras que devem ser cumpridas para que o Sistema Kanban funcione:

Regra 1: O processo seguinte deve retirar produtos do processo anterior na quantidade necessária e no momento correto.

Para que esta regra funcione, é obrigatório que a retirada de material de um processo anterior seja feita com a apresentação de um kanban. A quantidade retirada deve ser igual àquela determinada no cartão, e não podem haver peças desacompanhadas de um kanban.

Regra 2: O processo anterior deve produzir produtos para o processo seguinte nas quantidades retiradas por este.

Esta regra complementa a primeira para que não ocorra excesso de produção. O processo anterior só pode produzir itens dos quais tem cartão, e só pode produzir a quantidade definida neste.

Regra 3: Produtos defeituosos nunca devem passar para os processos seguintes.

Uma vez que os estoques em processo são limitados a uma quantidade mínima, deve-se ter certeza que estas poucas peças estejam em perfeitas condições para serem utilizadas pelo processo seguinte. Caso contrário, as peças serão devolvidas ao processo fornecedor e o processo cliente terá de esperar até ter as 
peças em condições de produzir. Portanto, é importante que se coloque o supermercado de peças em um local onde se garanta a qualidade daquelas peças.

Regra 4: O número de kanbans deve ser minimizado.

O número de kanbans expressa o inventário máximo de cada item. Este número deve ser mantido o menor possível. Na Toyota, é responsabilidade do supervisor de cada processo trabalhar para diminuir esta quantidade. Ele deve estar sempre buscando melhorias de processo que lhe permitam diminuir o tamanho dos lotes e diminuir o tempo de processo, para poder diminuir o número de kanbans.

Regra 5: O kanban deve ser usado para suportar pequenas variações na demanda.

\section{Os tipos de kanban}

Classicamente, pode-se dividir os cartões em dois tipos: o Kanban de Retirada /Transporte e o Kanban de Produção.

Os Kanbans de Retirada funcionam como dinheiro. Eles são utilizados para comprar, ou melhor, retirar peças do almoxarifado ou de processos anteriores. $\mathrm{O}$ número destes cartões é calculado com base no consumo de cada item pela linha e pelos seus intervalos entre abastecimentos. Assim, impede-se que um processo compre uma quantidade maior do que precisa, resultando em excesso de material na área.

Os Kanbans de Produção também existem numa quantidade fixa, calculada com base na demanda do cliente (interno ou externo), e mais uma série de fatores que serão detalhados mais para frente. A intenção é impedir o excesso de produção, afinal, como está claro na Regra 2 do item anterior, quando todos os cartões estiverem com produtos, não há como produzi-lo. Um Kanban de Retirada pode também ser usado como um Kanban de Produção, se a distância entre os dois processos é muito pequena, e são supervisionados por um único operário.

Além destes, Monden (1998) outros tipos de kanbans:

Kanban de Sinal - O kanban de sinal é uma variação do kanban de produção com uma sistemática de disparo muito parecida com o tradicional sistema OPOQ (tópico 2.4.1). Ao invés de se ter um cartão para cada embalagem que o 
compõe, pode-se usar um só cartão para pedir todo o lote. Escreve-se nele a quantidade que o processo anterior deve produzir. Também se escreve o instante em que o processo cliente deve entregar o cartão para o processo anterior, conhecido como ponto de reposição. Simplifica o sistema de gestão visual, pois dispensa a necessidade de utilização de quadros (como o semáforo, por exemplo). Nesse sentido, é mais recomendado para itens de baixo valor agregado (classe C), os quais não requerem um controle visual muito rigoroso. Também conhecido como Triângulo Kanban, Kanban de Nível de Reposição ou Kanban de Estoque Mínimo.

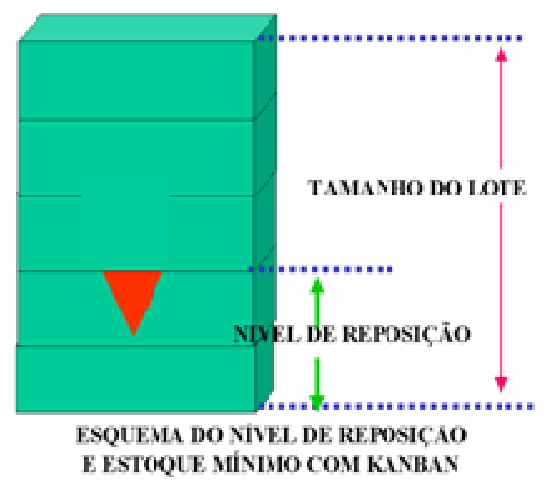

Figura 16: Exemplo de controle da produção com Kanban de Sinal Fonte: Monden (1984)

Kanban de Ordem de Serviço - Enquanto que os Kanbans já mencionados são aplicados às linhas para reatualizar a produção, este Kanban é preparado para a linha de produção por ordem de serviço e emitido para cada serviço.

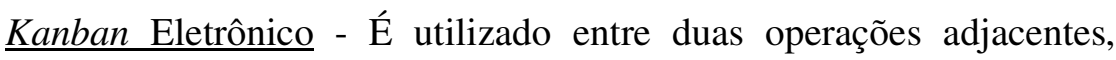
totalmente automatizadas. Por exemplo, uma determinada peça sofre uma usinagem na máquina $\mathrm{P}$, a qual por um sistema automático executa a descarga da peça em uma calha que a transporta para a máquina $\mathrm{Q}$, onde sofrerá uma nova operação. Entre estas operações não há trabalhador envolvido. Como entre as máquinas existem diferenças de velocidade de trabalho, o tempo de operações da máquina $\mathrm{P}$ é maior que o tempo de operação da máquina $\mathrm{Q}$, aquela não deve continuar trabalhando, 
gerando estoques entre as duas estações, e nem deixar de atender as necessidades da operação Q. Neste caso, determina-se um nível máximo de inventário "N" entre as duas operações. Em seguida, monta-se um sistema de identificação na calha de transporte, tais como chave de fim de curso, fotocélula, ou qualquer outro dispositivo do gênero, que "identifique" que há uma "fila de espera" para sofrer a operação Q com "N" peças, momento em que o dispositivo interrompe a operação da máquina $\mathrm{P}$.

Geralmente os demais tipos de kanbans são praticamente idênticos aos cartões de retirada e de produção, o que os diferencia são basicamente as tarjas ou bordas coloridas, de modo a possibilitar uma rápida identificação visual.

\section{A dinâmica do sistema}

Uma fábrica que opera com kanban tem basicamente dois tipos de procedimento, com um ou com dois cartões:

Sistema Kanban de um cartão: Este sistema se caracteriza por possuir apenas um local de estoque, isto é, supermercado, entre um processo fornecedor e seu cliente (pode ser um processo produtivo ou não). O único cartão existente neste caso é o kanban de produção.

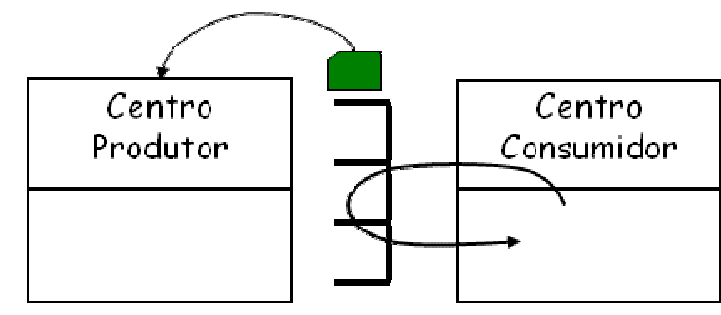

Komban de produção

Figura 17: Sistema kanban de um cartão

O supermercado de produtos do processo fornecedor fica concentrado junto ao cliente. À medida que o cliente consome estas peças, os cartões que estavam juntos às embalagens são colocados em uma caixa de coleta, próxima dele. A cada período definido de tempo, ou quando a quantidade de peças atingir um certo nível, 
os cartões são retirados da caixa de coleta e levados para um quadro, junto ao processo fornecedor.

A existência de cartões no quadro dá permissão para a linha produzir aqueles itens, na quantidade definida no cartão. Quando o processo fornecedor termina de produzir uma embalagem, o cartão é retirado do quadro e colocado junto a ela. Quando for hora, estas embalagens serão levadas de volta para o supermercado, junto ao cliente, e os cartões que estiverem na caixa de coleta serão levados de volta para o quadro.

Sistema Kanban de dois cartões: Este sistema se caracteriza pela existência de dois supermercados. Um fica no fornecedor e outro fica no cliente. Neste caso, tanto o Kanban de Produção quanto o de Transporte estão presentes.

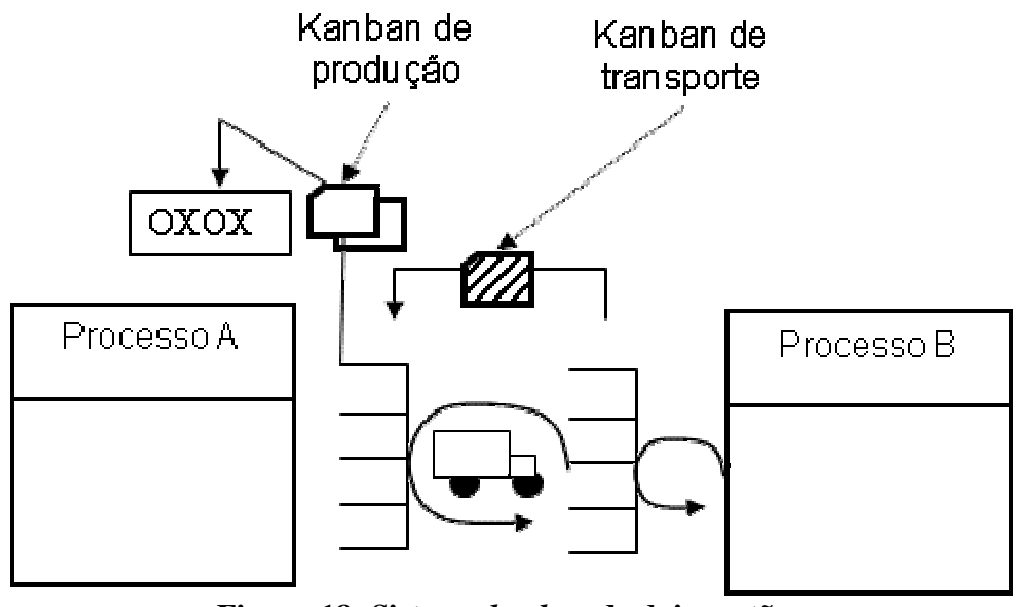

Figura 18: Sistema kanban de dois cartões

À medida que o cliente consome os itens do supermercado, os cartões que estavam juntos às embalagens são colocados em uma caixa de coleta. A cada período de tempo definido, estes kanbans de transporte são coletados e levados até o supermercado do processo fornecedor. Chegando lá, os kanbans de transporte funcionarão como uma lista de compras. Para cada kanban de transporte será comprada uma embalagem daquele item. As embalagens compradas receberão os kanbans de retirada e serão levadas para o supermercado junto ao cliente. Os kanbans de produção que acompanhavam as embalagens no estoque fornecedor serão colocados novamente no quadro. 
Da mesma forma que no sistema de um cartão, a existência de kanbans de produção no quadro dá ao processo fornecedor permissão de produzir aqueles itens, nas quantidades determinadas nos cartões. Depois de produzidas, as embalagens recebem os kanbans de produção e são colocados novamente no supermercado do fornecedor.

Nesse caso, o supermercado pertence ao processo fornecedor. Ele é responsável por manter as quantidades de peças para que o cliente sempre seja atendido. Por isto, o sistema de dois cartões é considerado melhor do que o de um cartão. Neste sistema, o processo fornecedor é claramente o "dono" do supermercado. O processo cliente vem comprar aquilo de que precisa.

Entretanto, o sistema de um cartão é mais simples de ser implementado. É comum implementar-se o sistema com um cartão e depois evoluir para o de dois cartões. Entretanto, quando as distâncias entre os processos são bastante pequenas e o supermercado pode ficar próximo do cliente, não há a necessidade de se introduzir o cartão de retirada.

\section{Sequenciamento da produção dos kanbans}

Para auxiliar os operadores a montarem a seqüência de produção, os quadros de kanban são organizados em faixas coloridas, que indicam a situação de cada item em estoque, e o momento em que deve ser iniciada a produção de cada um. Os quadros também devem indicar até quando os itens devem ser produzidos.

O quadro semáforo é uma ferramenta complementar ao sistema kanban. Os kanbans de produção, depois de destacados de alguma embalagem consumida pelo cliente, são fixados no quadro junto ao processo fornecedor. Estes quadros devem ser organizados de tal forma, que os operadores saibam a quantidade de peças de cada item no estoque intermediário, e o que deve ser produzido primeiramente. 


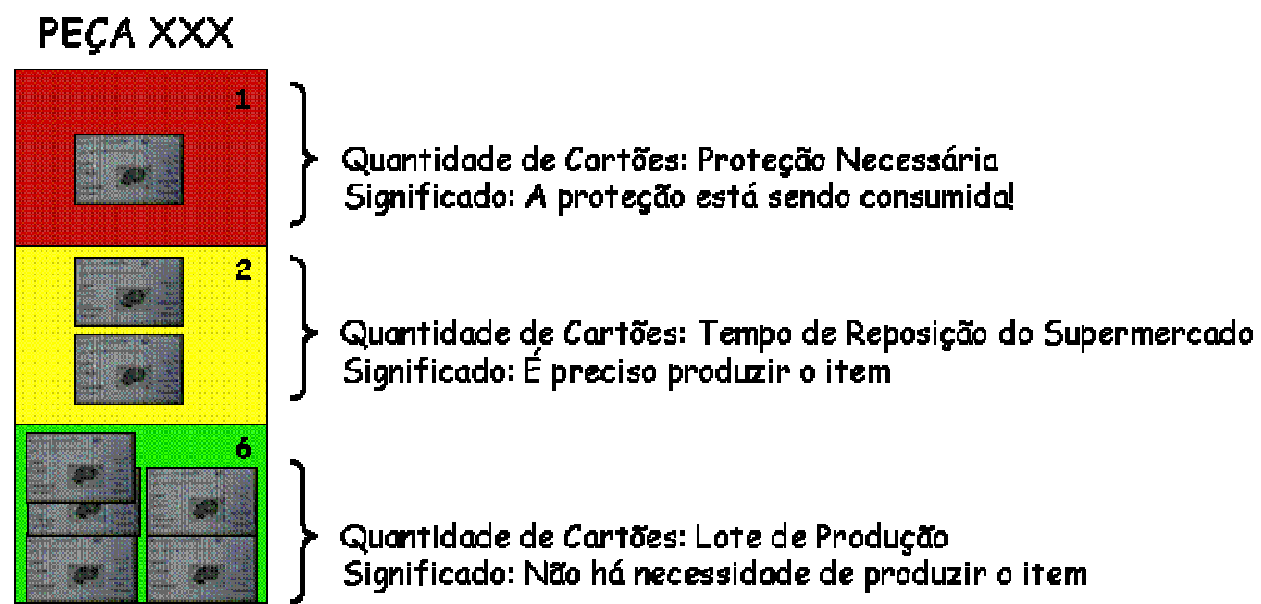

Figura 19: Sistemática de distribuição dos cartões no quadro de semáforo Fonte: Adaptado de Rentes (2003)

De acordo com a figura acima, a faixa verde do quadro significa que ainda não há necessidade de produzir o item. A quantidade de cartões a ser depositada nessa faixa corresponde ao lote de produção, ou seja, à quantidade de cartões correspondentes ao TPT calculado.

A faixa amarela significa que é hora produzir o item. A quantidade de cartões a ser depositada nessa faixa corresponde ao tempo necessário para a reposição do item.

Os kanbans de produção dos diversos itens que entram no quadro podem ser produzidos em diferentes ordens (AKTURK; ERHUN, 1999). O principal critério para priorização é a indicação de urgência do quadro (itens no vermelho seguido daqueles no amarelo). Pode-se optar por produzir os itens na ordem de chegada ao quadro. Outras opções são atender o menor ou o maior pedido primeiro. Existem, também, as opções de se fazer o mais rápido ou o mais demorado primeiro. A melhor política de produção depende de cada caso, porém, cabe às empresas definirem-na.

\section{Definição do ponto de puxar}

Outro ponto importante na implementação do Sistema Kanban é a escolha dos pontos onde ficarão os supermercados. 
Em uma cadeia produtiva de muitos estágios, existem pontos onde não é possível manter o fluxo contínuo de material, ou onde forçar este fluxo pode ser prejudicial. De acordo com Rother e Shook (1998), fluxo contínuo significa produzir uma peça de cada vez, com cada item sendo passado imediatamente de um estágio do processo para o seguinte, sem nenhuma parada entre eles. Estes autores citam algumas razões para que não seja utilizado o fluxo contínuo, mas sim a produção por lotes:

Processos com tempo de ciclo muito lento ou muito rápido, e que são compartilhados por outras linhas.

Processos localizados em fornecedores, ou distantes por razões diversas (segurança, por exemplo).

Processos pouco confiáveis para serem ligados diretamente a outros processos em fluxo contínuo.

Processos com tempo de preparação muito alto, prejudicando a flexibilidade de resposta da linha.

Processos muito longos, que tornam o tempo de resposta para o cliente muito demorado.

Uma vez definidos os processos que não estarão em fluxo, ou seja, que produzirão para um estoque intermediário, é hora de escolher onde entrará a programação de produção, ou seja, o pedido dos clientes. Rother e Shook (1998) afirmam que ela só precisará ser feita em um ponto do processo, porque os demais serão programados via kanban. Isto significa que conforme o processo programado consuma os itens destes inventários intermediários, os respectivos processos anteriores produzirão para supri-los, sem a necessidade de saber qual o pedido do cliente, ou se este está sendo alterado.

O processo onde entra a programação é chamado de processo puxador. Este ponto da cadeia deve ser bem escolhido porque esta escolha define o tempo de resposta da empresa, da colocação de um pedido, até a entrega para os clientes. O ponto de entrada deve ser escolhido de tal forma que não exista necessidade de programar nenhum estágio subseqüente do processo. $\mathrm{O}$ que este processo produzir 
chegará às mãos do cliente. Em outras palavras, a partir do processo escolhido tem-se fluxo contínuo.

Determinação do número de kanbans pertinente aos sistemas alternativos de retiradas

Monden (1998) apresenta, no seu livro Sistema Toyota de Produção, uma série de equações para o cálculo da quantidade de cartões. Estas fórmulas são colocadas, por ele, como aquelas usadas pela Toyota para dimensionar seus supermercados. Inúmeros artigos e livros apresentam estas mesmas equações, e as referenciam como as fórmulas da Toyota.

O autor atribui à Toyota dois tipos de controle de inventário:

Pedidos com quantidades constantes: É o método utilizado pelas empresas, normalmente dentro das fábricas, em razão da pequena distância entre processos, tempos de preparação, tamanho de lotes e tempos de passagem de peças baixos, se comparados com peças oriundas de fornecedores ou processos terceirizados. Além disso, é importante deixar claro que este método necessita de pessoas que possam, a qualquer momento, fazer o transporte de cartões para o fornecedor e peças para o cliente.

Existem três aplicações do sistema de retirada com quantidade constante. No caso do tamanho do lote ser muito grande ou a ação de troca de ferramentas não ser suficientemente aperfeiçoada, a seguinte fórmula é aplicada:

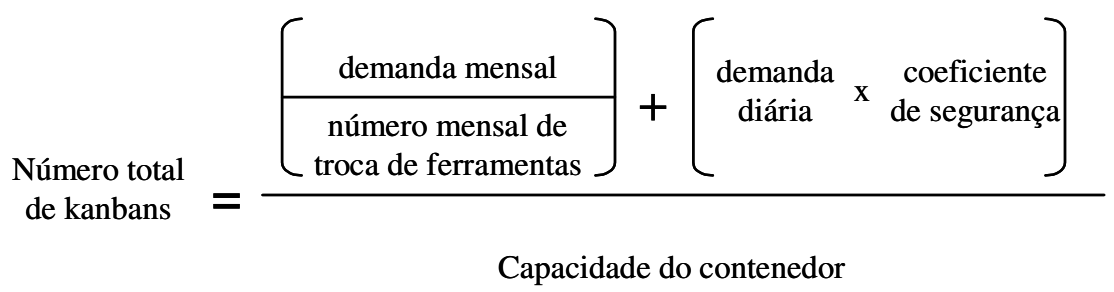

Quadro 2: Definição do número de kanbans para operações com troca demorada de ferramentas

Fonte: Monden (1998) 
No caso dos Kanbans de Sinal, o ponto de reposição é determinado pela fórmula:

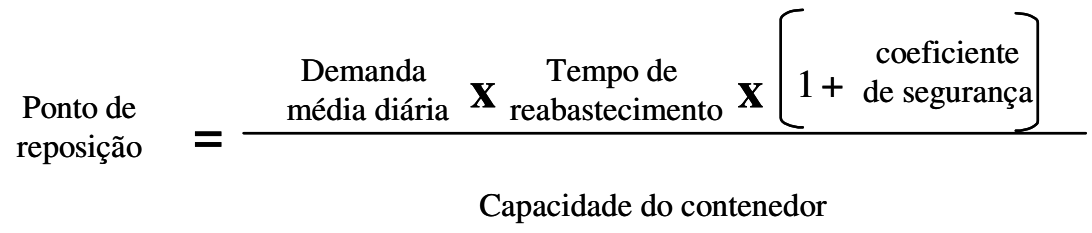

Quadro 3: Definição do ponto de reposição Fonte: Monden (1998)

Onde, o tempo de reabastecimento é igual à somatória dos tempos de coleta do kanban, de fila, de processamento e de transporte.

Nos casos em que os métodos de troca de ferramentas são aperfeiçoados e a distância entre os processos subseqüentes e precedentes é curta, o inventário máximo é obtido da mesma forma que usamos para calcular o ponto de reposição para os Kanbans de Sinal, conforme já mencionado anteriormente.

O coeficiente de segurança, nas fórmulas acima, corresponde a variações na demanda de até $10 \%$. Quanto maior este fator, maior são as chances de se atender a demanda, por outro lado, maiores também são os custos para a empresa. Co e Sharafali (1997) apresentam um algoritmo para otimizar este fator.

No mais, vale ressaltar que a condição ideal para a produção no momento exato é que cada processo possa produzir somente uma peça, transportá-la no mesmo tempo e também ter somente uma peça em estoque entre o equipamento e o processo.

Ciclo de pedidos constante: É o método utilizado, normalmente, entre as empresas e seus fornecedores externos. Isto se justifica pela distância entre estes, que deixaria inviável as entregas a qualquer momento do dia, exigidas pelo método anterior. Quando se usa o compartilhamento de cargas entre os diversos fornecedores, conhecido por Milk Run, cria-se a situação ideal para esta estratégia.

Dentro das fábricas, este método é usado em situações onde a distância entre os processos é relativamente longa, e não se pode disponibilizar pessoas para fazerem este transporte de peças e cartões.

Neste caso, são fornecidas as seguintes fórmulas para calcular a quantidade de kanbans de produção: 


$$
\underset{\text { máximo }}{\text { Inventário }}=\left[\begin{array}{c}
\text { Demanda } \\
\text { diária }
\end{array} \mathbf{x}\left[\begin{array}{c}
\text { Ciclo do } \\
\text { pedido }
\end{array}+\begin{array}{c}
\text { Tempo de } \\
\text { espera }
\end{array}\right]+\begin{array}{l}
\text { Estoque de } \\
\text { Segurança }
\end{array}\right.
$$

Quadro 4: Definição do inventário máximo em controles com ciclos de pedidos constante Fonte: Monden (1998)

Onde:

o ciclo do pedido é o intervalo entre um tempo de pedir e o próximo tempo de pedir.

o tempo de espera é o intervalo entre entregar o pedido e receber o material.

o ciclo do pedido mais o tempo de espera é freqüentemente chamado de tempo de espera para reabastecimento.

Vale ressaltar que o ciclo do pedido é freqüentemente determinado por uma restrição externa por etapas na programação da produção mensal ou um contrato entre os fornecedores e o fabricante principal.

Uma vez determinado o ciclo do pedido e o inventário máximo, é necessário calcular a quantidade do pedido. A quantidade do pedido neste sistema é medida pela fórmula:

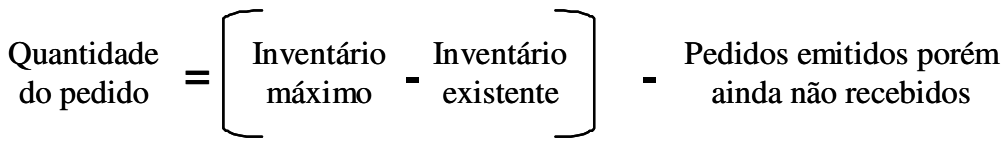

\section{Quadro 5: Definição da quantidade do pedido em controles com ciclo do pedido constante Fonte: Monden (1998)}

Onde:

o termo pedidos entregues porém ainda não recebidos é normalmente igual a zero.

Por outro lado, o autor acrescenta que a quantidade do pedido é automaticamente especificada pelo número de Kanbans destacados no tempo regular de coleta a partir da última coleta. Dessa forma, a quantidade a ser requisitada neste Sistema Kanban pode ser dada por: 


\section{$\begin{gathered}\text { Quantidade } \\ \text { do pedido }\end{gathered}=\left[\begin{array}{c}\text { Número de Kanbans } \\ \text { consumidos }\end{array}\right] \mathbf{X} \begin{gathered}\text { Capacidade do } \\ \text { contenedor }\end{gathered}$ \\ Quadro 6: Definição da quantidade do pedido em controles com ciclo do pedido constante (MONDEN, 1998)}

Por fim, o kanban sozinho é meramente um meio de despacho para as ações de produção, durante cada dia em cada processo. Antes de se adentrar a fase de despachar as tarefas pelo kanban, um planejamento geral deve ser feito através da fábrica (Monden, 1998).

De acordo com Vollmann et al. (1997) as duas abordagens básicas para o controle do chão de fábrica (Shop Floor Control - SFC) são (1) o planejamento das necessidades de material com defasagem no tempo (Material Resource Planning - MRP), e (2) just-in-time (JIT). MRP é também popularmente conhecido como empurrar a produção e o JIT como puxar a produção.

Outra abordagem para o controle do chão de fábrica são os sistemas de emissão de ordens baseados em recursos restritivos, e funcionam como um controle híbrido puxar/empurrar de estoques. Concebidos a partir da Teoria das Restrições (Theory of Constraints - TOC), são baseados no gerenciamento do pulmão por meio da técnica do Tambor Pulmão e Corda (TPC) (SOUSA, 2004).

\subsubsection{Sistemas Tambor-Pulmão-Corda (Drum-Buffer-Rope) da Teoria das Restrições}

De acordo com Souza (1997), o sistema logístico de sincronização da manufatura denominado pela Teoria das Restrições de Tambor-Pulmão-Corda (TPC) foi construído a partir do pressuposto de que todo o plano de produção, que se propõe ser realístico e confiável, deve primeiro identificar as principais restrições que afetam os ambientes de manufatura em geral. Tais limitações estão geralmente relacionadas com a demanda de mercado, com o suprimento de materiais para a fábrica ou com a capacidade de produção dos recursos de produção.

Com a finalidade de desenvolver o método Tambor-Pulmão-Corda, são apresentados os cinco passos do processo decisório da TOC (Theory of Constraints): 
1. Identificar a(s) restrição(ões) do sistema.

2. Explorar a(s) restrição(ões) do sistema.

3. Subordinar tudo o mais à decisão anterior.

4. Elevar a(s) restrição(ões) do sistema.

5. Se uma restrição for quebrada nos passos anteriores volte ao passo 1, mas não deixe que a inércia se torne a próxima restrição do sistema.

O primeiro passo "identificar a(s) restrição(ões) do sistema", implica em encontrar o(s) elemento(s) que limita(m) a performance de todo sistema. Tal identificação pode ser realizada através de cálculos de carga-máquina que os produtos da empresa impõem sobre todos os recursos da fábrica, como é feito tradicionalmente. No entanto, este método tem sérios problemas. O principal destes refere-se à integridade das informações disponíveis sobre análise de carga.

Para Umble e Srikanth (1990), o resultado desta análise é altamente dependente de informações críticas, tais como mix de produtos, tempos estimados de lead times, processamento e setup, e disponibilidade de inventário. Contudo, em quase todas as fábricas, os dados que descrevem estes tipos de informações contém erros grosseiros.

Por outro lado, não há necessidade de ter-se informações altamente precisas sobre todos os recursos da fábrica. Umble e Srikanth (1990, p. 94) propõem um procedimento inverso aos típicos procedimentos de análise de carga. Para eles, exatidões nas informações são necessárias apenas naqueles recursos que podem impactar seriamente o sistema total, ou seja, onde os erros nos dados ou falta de acuracidade nas informações refletem-se de forma severa no ganho, inventário e despesa operacional de toda a organização. Assim, tempos padrão em recursos nãogargalos não são críticos e, portanto, requerem menos precisão.

A segunda etapa "explorar a restrição do sistema", implica em procurar extrair o máximo deste tipo de recurso, impedindo que haja qualquer tipo de desperdício nos recursos restritivos, como interrupções por falta de material, quebra ou paradas para descanso ou troca de turno.

Uma vez que a restrição limita a capacidade produtiva de todo o sistema, este recebe, na terminologia da Teoria das Restrições, o nome de Tambor 
("Drum"), pois ele dita a "batida" ou o ritmo de toda a linha de produção. Deve-se salientar que uma fábrica terá tantas restrições quantas forem as linhas de produção independentes na malha produtiva (GOLDRATT; FOX, 1989). Tambor é, portanto, a programação de atividades do(s) recurso(s) restritivo(s), ou seja, a lista de tarefas que deverá ser executada no recurso restritivo de acordo com o total de demanda de trabalho a ser nele processado, com o objetivo final de se atingir o máximo fluxo. A melhor seqüência de tarefas é determinada levando-se em conta a data dos pedidos dos clientes. Caso a empresa não possua uma restrição interna, o Tambor será a própria demanda de mercado.

Entretanto, como já mencionado, explorar a restrição significa também impedir que o gargalo pare por falta de material para processar. Desta forma, deve-se criar um Pulmão (Buffer) antes do recurso restritivo com a finalidade de protegê-lo contra as flutuações estatísticas ou incertezas dos eventos anteriores a ele. Aqui, flutuação estatística deve ser entendida como a variação no desempenho dos recursos causada por diversos fatores como: duração e frequiência de quebra das máquinas, nível de confiabilidade dos equipamentos, índice de rejeição de peças dos recursos, variabilidade no desempenho dos operadores de máquinas, etc.

O Pulmão deve ser expresso na forma de tempo (estoque por tempo de segurança - time buffer) e não em quantidade de peças. A vantagem de expressá-lo em termos de unidade de tempo é que na maioria dos casos os materiais em estoque estarão sempre mudando, o que dificultaria um bom controle do mesmo. (GOLDRATT, 1991).

Após identificada e explorada a restrição deve-se seguir o terceiro passo: "subordinar tudo o mais à decisão anterior". Subordinar implica em fazer com que todos os recursos do sistema operem de acordo com o recurso restritivo, nem mais nem menos. Este passo procura garantir que todos os elementos do sistema operem de acordo com o objetivo global da organização ao invés de buscar otimizações localizadas que não aumentam a produtividade do todo. Eficiências locais que resultam na superativação dos recursos não restritivos não conduzem a empresa na direção de sua meta pois, neste caso, não haveria aumento do ganho (podendo até reduzir-se) enquanto que o inventário e por consequiência a despesa operacional, aumentarão. 
Surge, desta forma, um novo conceito proposto pela TOC denominado Corda ("Rope"). Na analogia da Teoria das Restrições, deve existir uma "Corda" interligando ("amarrando") o recurso restritivo à primeira operação da malha produtiva, de forma que haja uma sincronização entre estas operações. Assim, material é liberado para a produção de acordo com a taxa de consumo do recurso restritivo, mas com uma antecipação equivalente ao Pulmão de tempo do recurso restritivo. Em outras palavras, matérias-primas só são admitidas no sistema de forma sincronizada (materiais corretos, na quantidade correta e no tempo certo) com a chegada nos estoques protetores dos recursos restritivos (time buffers). Isto garante que os estoques em todo o processo produtivo não ultrapassem os níveis do estoque protetor imposto pelo Pulmão de tempo.

$\mathrm{Na}$ realidade, deve haver uma Corda interligando a demanda de mercado ao recurso restritivo e outra conectando o recurso restritivo à primeira operação da fábrica (ou à liberação de material ao sistema). Ainda haverá uma Corda sincronizando a programação do recurso restritivo com a montagem e esta com a liberação de matéria-prima para as operações não-restrição da malha produtiva. Desta forma, a Corda é um sistema de informação relativamente simples que sincroniza a produção de todos os centros de trabalho da malha produtiva a partir do(s) recurso(s) restritivo(s).

Deve-se salientar que o método Tambor-Pulmão-Corda (TPC) permite que se obtenha a programação (no caso implícita) de todos os recursos não gargalos da empresa. Aqueles situados antes da restrição deverão processar o mais rápido possível os materiais recebidos pela primeira operação, de acordo com a ordem de chegada destes. Uma vez que, por definição, tais recursos possuem um excesso de capacidade em relação ao recurso restritivo, eles não terão nenhuma dificuldade para seguir o programa. Da mesma forma, os recursos não-restritivos localizados no roteiro de produção após o recurso restritivo estarão diretamente sob o controle deste, pois estes receberão apenas as peças liberadas pelo recurso restritivo. Como tais recursos têm por definição folga no programa, não haverá nenhum problema também neste ponto. Logo, ordens de produção explícitas são necessárias apenas em alguns pontos específicos, como nos recurso restritivo e nos locais de liberação de material para a fábrica, por exemplo. 
Em resumo, o sistema TPC reconhece que existem apenas alguns poucos recursos com restrição de capacidade, que irão impor o índice de produção da fábrica inteira (Tambor). Para garantir que a produção deste recurso não seja interrompida por falta de peça cria-se na frente dele um inventário que protegerá o ganho das vendas da fábrica contra qualquer interrupção que possa ocorrer dentro de um intervalo pré-determinado de tempo (Pulmão de Tempo). Com o objetivo de impedir que haja um aumento desnecessário nos níveis de estoque em processo, material é liberado para a fábrica no mesmo ritmo com que o recurso restritivo o consome (Corda), mas com uma defasagem no tempo equivalente ao pulmão de tempo estabelecido.

\subsection{Fatores que influenciam na escolha dos sistemas de PCP}

Um grande número de estudos tem sido feito comparando os sistemas puxado, empurrado e híbrido sob vários pontos de vista. De acordo com Gianesi ${ }^{8}$ (1998 apud SOUSA, 2004), o MRP é o mais recomendado para se trabalhar com planejamento de longo prazo, independentemente do tipo de processo de produção. Taylor ${ }^{9}$ (1999 apud SOUSA, 2004) sugere que, do ponto de vista de custo de inventário, o sistema híbrido apresenta o melhor desempenho, seguido pelos sistemas puxado e empurrado. Wang e $\mathrm{Xu}^{10}$ (1997 apud SOUZA, 2004) recomenda o sistema híbrido como a melhor opção para processos de produção em massa sob a perspectiva da relação entre o custo de estoque e o risco de escassez. Neste caso, sugere-se embutir o JIT no sistema MRP, ou seja, controlar o input de material para a fábrica pela lógica de empurrar (MRP) e controlar os estoques remanescentes pela lógica de puxar (JIT), por meio de kanbans.

${ }^{8}$ GIANESI, I.G.N. (1998). Implementing manufacturing strategy through strategic p roduction planning. International Journal of Operations and Production Management, v.18, n.3, p.286-299.

9 TAYLOR, L.J. (1999). A Simulation study of WIP inventory drive systems and their effect on financial measurements. Integrated Manufacturing Systems, v.10, n.5, p.306-305.

${ }^{10}$ WANG, D.; XU, C.G. (1997). Hybrid pusch/pull production control strategy simulation and its applications. Production Planning and Control, v.8, n.2, p.142-151. 
As primeiras gerações de programas MRP possuíam algoritmos que supunham haver uma capacidade infinita no sistema, uma condição que jamais vai existir no mundo real. Os sistemas recentes são mais refinados, chamados de MRP II (Material Resources Planning), ou planejamento dos recursos de manufatura, além das necessidades de materiais, eles calculam também a necessidade dos demais recursos de manufatura, principalmente pessoas e equipamentos.

A escolha estratégica de qual é o sistema mais apropriado para cada situação, assim como a sua gestão, deve estar ligada e coerente com os objetivos estratégicos da manufatura e com o tipo de processo produtivo envolvido. Os objetivos estratégicos da manufatura refletem as diferenças entre os vários segmentos de mercado a atingir, os quais vão demandar diferentes níveis de desempenho nos diferentes critérios (qualidade, custo, entrega e flexibilidade) que o sistema de manufatura pode influenciar (CORRÊA; GIANESI, 1996).

Corrêa e Gianesi (1996) acrescentam que é importante perceber que a escolha estratégica do sistema de PCP pode não depender de uma ou de poucas variáveis, mas de várias. A figura a seguir apresenta algumas destas variáveis e as regiões de cada uma consideradas, a princípio, mais apropriadas para o uso dos sistemas JIT, MRP II e OPT (Optimized Production Technology). Assumir-se-á neste trabalho o sistema OPT como sendo o TPC da Teoria das Restrições, uma vez que a lógica de ambos é muito parecida. 


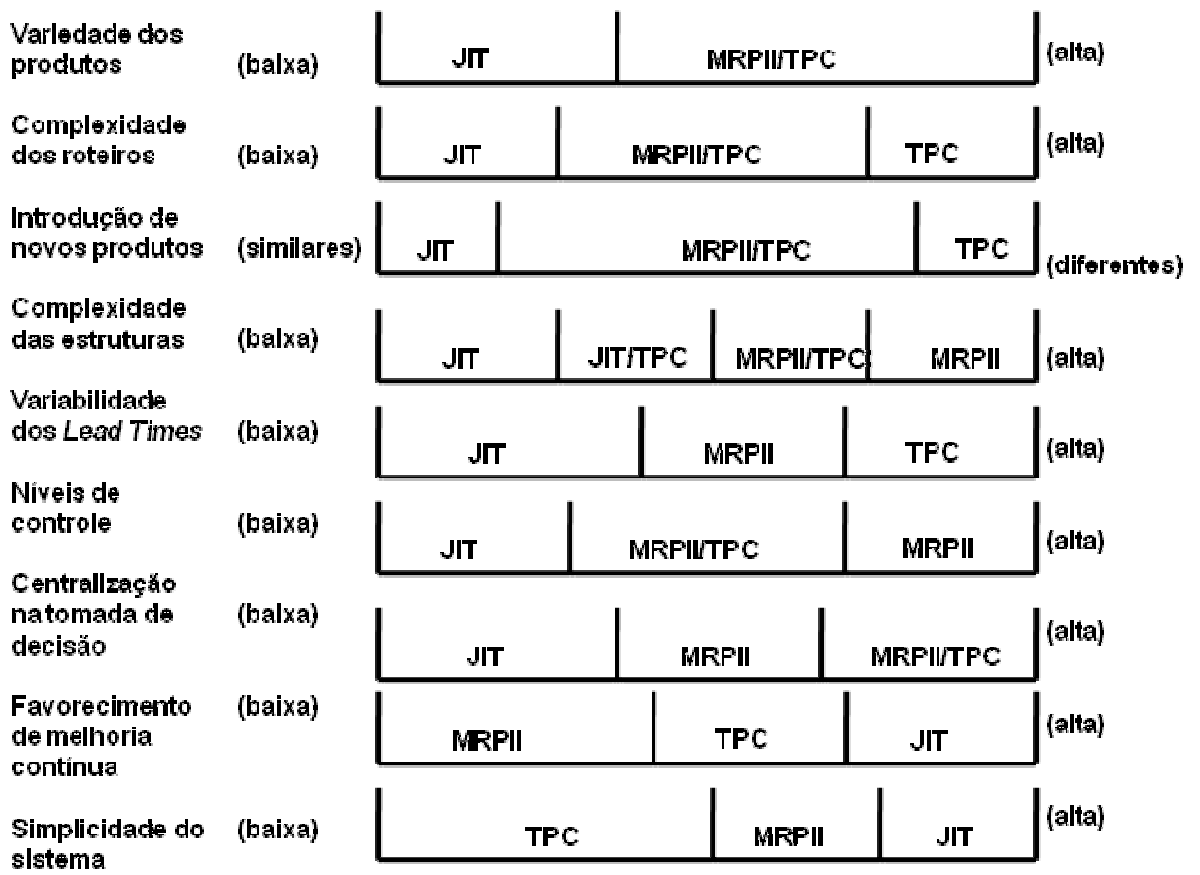

Figura 20: A aplicação dos sistemas JIT, MRP e TPC depende de várias variáveis Fonte: Adaptado de Corrêa e Gianesi (1996)

Quanto à variedade de produtos, é aceito que sistemas que trabalham com grandes quantidades de produtos diferentes, em geral, não são um bom ambiente para a implantação "generalizada" de sistemas JIT.

Os sistemas MRP têm uma vocação especial para lidar com produtos que têm estruturas complexas, pois permitem um planejamento detalhado (e antecipado) das necessidades de recursos materiais da organização.

O problema da variabilidade dos lead times é bastante sentido pelo MRP, que os assume fixos. Se os lead times reais são muito variáveis, isto pode acarretar baixa aderência com os lead times registrados no sistema. A variação dos lead times de processo está relacionada à situação da fábrica. Se o mix de produtos da organização muda muito freqüentemente, é provável que a situação das ordens na fábrica possa sofrer também frequientes mudanças. Se isto ocorre, a situação das filas das ordens aguardando processamento muda ao longo do tempo e, portanto, o tempo que as ordens gastam nas filas também muda. Conseqüentemente, no caso de o mix de produção variar pouco, espera-se que os lead times envolvidos sejam também mais constantes ao longo do tempo. 
Com relação aos níveis de controle, o MRP é um sistema hierárquico, com vários níveis de planejamento, desde o planejamento agregado de produção, passando pela programação mestre até o detalhamento das necessidades de materiais e recursos específicos. Isto faz dele um sistema habilitado para auxiliar a tomada de decisão, também, num nível mais agregado, de mais longo prazo. Entretanto, problemas geralmente ocorrem quando o sistema MRP tenta gerenciar os níveis mais baixos e detalhados de atividades. Neste nível, o sistema pode tornar-se pesado e necessitar que as pessoas envolvidas nas atividades da fábrica tenham uma atitude disciplinada, informando ao sistema, de forma freqüente, praticamente tudo o que ocorre.

Muitos autores consideram que o MRP é mais apropriado para os níveis mais altos de controle: planejamento agregado da produção, programaçãomestre e planejamento de insumos, sendo considerado complexo, detalhado e centralizado demais, quando se trata de controlar as atividades da fábrica. Esta seria uma vocação mais natural do JIT com seus controles visuais simplificados.

Os defensores do sistema TPC consideram que a transição do MRP para o TPC é uma transição "natural", visto que o TPC se utiliza de uma base de dados quase idêntica à base de dados se utiliza o MRP. É claro que há uma preocupação básica adicional para o uso do TPC, e esta refere-se à identificação e atualização de quais recursos representam gargalos de produção, para permitir que o TPC os trate de forma diferenciada. Por outro lado, se uma empresa trilhou o caminho para o atingimento dos níveis de acuidade de registros na base de dados que o MRP exige, ela terá ido adiante do que o TPC requer, já que este prescreve que apenas os dados referentes aos recursos gargalos necessitam tais níveis de acuidade.

Razmi et al. (1998) desenvolveu um modelo tri-dimensional para suportar a decisão de escolha entre sistemas puxados, empurrados e híbridos (Figura 16). As dimensões representam três importantes variáveis a serem consideradas: (1) confiabilidade do lead time de fornecimento, (2) custos e (3) flutuação da demanda. 


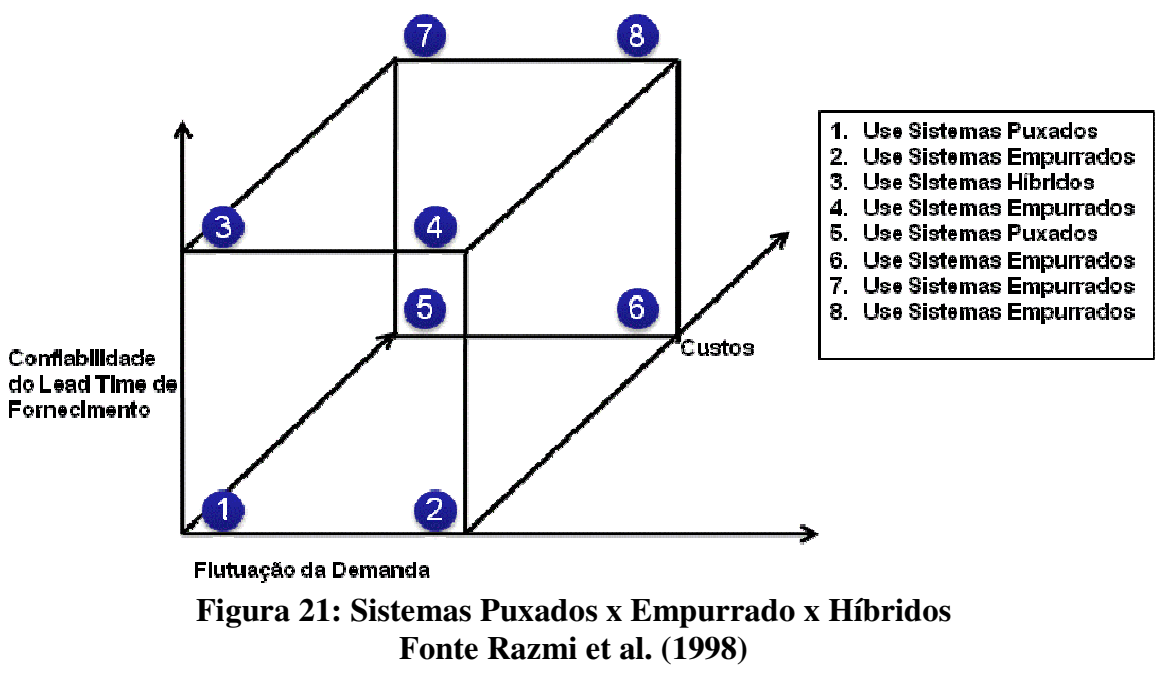

Neely e Byrne (1992), já sugeriam, a partir de experimentos com simulações, que uma abordagem integrada para o controle de materiais, incluindo a programação do recurso gargalo, era perfeitamente factível para uma organização.

Um ponto de consenso entre vários autores é que não há uma única solução ótima que possa ser generalizada. Soluções práticas encontram-se normalmente em conceitos híbridos e eventualmente em novos conceitos. Os requisitos específicos para cada situação devem ser cuidadosamente analisados até que uma decisão possa ser tomada (VOLLMANN et al., 1997).

A seguir, são discutidos os principais desafios abordados no contexto deste trabalho.

\subsection{Desafios para os sistemas atuais de PCP}

Com o passar dos tempos, uma série de práticas e ferramentas foram sendo criadas com o intuito de tornar os sistemas de PCP mais robustos frente às novas condições de mercado.

Num primeiro momento, o sistema puxado foi criado para auxiliar no processo de melhoria do controle de fluxos de produção que até então eram só empurrados. Estes fluxos costumam ser debilitados pelo fenômeno da amplificação da demanda, normalmente causada por processos com grande número de pontos de decisão e grande incidência de atrasos, enquanto os pedidos aguardam o processamento. 
Em seguida, com a diversificação da demanda, tem-se percebido que na prática muitas empresas vêm tentando adaptar este sistema de maneira ad hoc, projetando sistemas híbridos para a programação e controle de seus produtos de forma nivelada, em função das características de demanda e dos tempos de processo de cada um.

Nesse sentido, essa seção fará uma abordagem conceitual dos principais desafios para os atuais sistemas de programação e controle, assim como as respectivas estratégias de melhoria tendo em vista torná-los mais robustos para lidar com tais desafios.

\subsubsection{Alta Variedade de Produtos e Componentes}

Em ambientes de com alta variedade de produtos e componentes a transformação enxuta torna-se num processo difícil, visto que nestes ambientes, os recursos (máquinas e homens) costumam ser compartilhados por diferentes itens, os quais são consumidos por clientes diferentes (LEI, 2004).

De acordo com Jina et al. (1997), situações de alta variedade são caracterizadas por:

* Alta variedade de produtos e componentes, os quais podem ser customizados.

* Grande incidência de políticas de atendimento de pedidos do tipo "Fazer Mediante Ordem" (Make-to-Order).

$\downarrow$ Estrutura de produto que atenda a flexibilidade de mix do produto final, mas que ao mesmo tempo pode ser composto por conjuntos ou kits formados por componentes modularizados.

* Ambiente turbulento, o qual é caracterizado como o resultado das incertezas e variabilidade de seus "inputs". Quatro causas de turbulência em uma fábrica são:

- Programação: Alterações freqüentes em intervalos de tempo muitos próximos da data de produção e entrega.

- Flexibilidade de volume: Alterações no volume de produção em curtos intervalos de tempo. 
- Mix do produto: Produtos com grande variedade de módulos e modelos, e que necessitam apresentar alterações evidentes entre períodos.

○ Design: Grau e freqüência de alterações dentro do prazo esperado pelo mercado. Logo, a habilidade de adaptar design existentes e gerar novos dentro das especificações dos clientes também é um fator de sucesso para empresas.

Em ambientes com grande variedade de produtos e componentes, Conner (2001) discorre sobre a necessidade de uma abordagem híbrida de programação e controle para os produtos. É necessário identificar as categorias/famílias controle com base em características de demanda existentes para cada produto. Com isso, cada família teria formas de programação e controles específicos.

Nesses ambientes, uma linha de montagem tende a ser compartilhada por produtos com diferentes padrões de demanda e, portanto, com diferentes tempos takt. Para estes casos, a utilização da abordagem Takt-time x One-piece flow x Puxado (TOP) precisa ser adaptada, se comparada à sua aplicação em ambientes cujos processos de manufatura são dedicados a poucas partes e cuja demanda é relativamente previsível.

\subsubsection{Sistemas híbridos de programação e controle da produção}

De acordo com Ming-wei e Shi-lian (1992) em qualquer ambiente de manufatura sempre haverá a necessidade de combinar o MRP II com o JIT. Um sistema híbrido deve ser projetado de acordo com a realidade de cada empresa.

Grande número de empresas que se utilizam do MRP tenta achar formas de produzir alguns de seus produtos ou parte da produção utilizando princípios do JIT. Em algumas situações, deve-se considerá-los como complementares e não como mutuamente exclusivos, funcionado de forma híbrida. Segundo esta visão, o uso da sistemática do JIT, muito mais simples, viria a simplificar a própria utilização do MRP, que, dessa forma, teria de administrar uma 
quantidade menor de itens, gerar uma quantidade menor de ordens de produção e controlar uma quantidade menor de transações de realimentação de informações para uso do sistema, a respeito do que ocorreu na fábrica (CORRÊA; GIANESI, 1996).

De acordo com Rentes et al. (2005), uma unidade de produção é controlada por um sistema de controle híbrido quando esta unidade é ativada por mais de um tipo de sistema de informação. Um exemplo seria uma célula de produção que responde tanto para ordens de produção quanto para kanbans. Ainda neste exemplo, haveria um supermercado para os produtos best-seller, controlado por kanbans que ativam a produção destes produtos quando o supermercado alcança um nível crítico. Ao mesmo tempo, a célula poderia produzir os artigos menos freqüentes por ordens de produção, ordenadas diretamente pelas necessidades dos clientes. A programação da produção tanto dos kanbans quanto das ordens pode ser feita por meio de um Heijunka Box, ou quadro de programação e nivelamento da produção. A figura abaixo exemplifica uma situação de sistema híbrido.

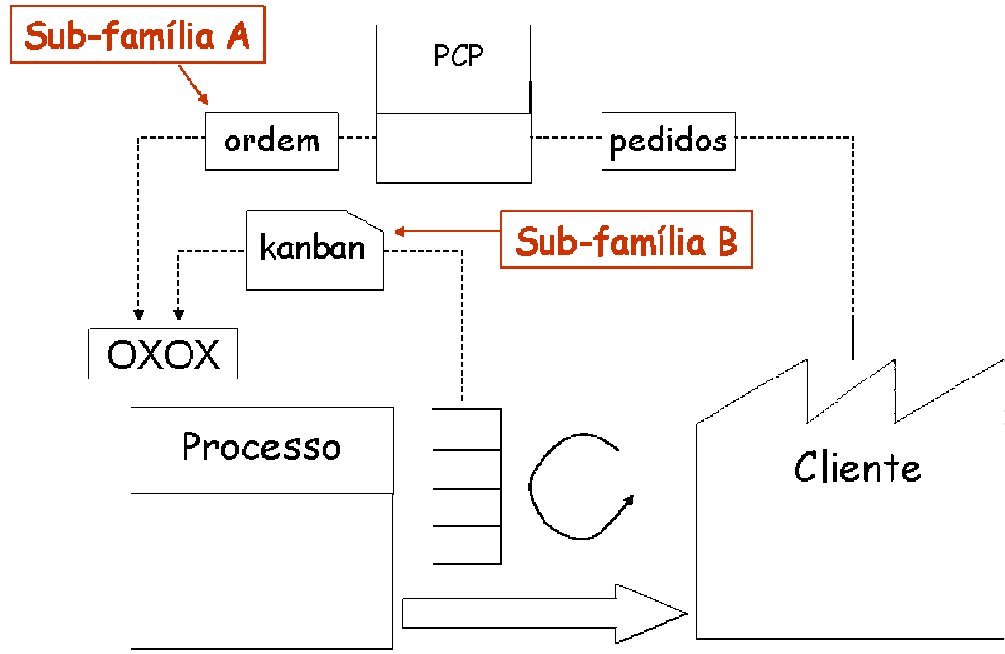

Figura 22: Visão Ilustrativa de um Sistema Híbrido Fonte: Rentes et al. (2005)

Conseqüentemente, o estoque em processo, representado pelas partes no supermercado, corresponde a um número limitado de partes, composto pelas peças best-seller. Isto torna possível o uso de kanban em situações de alta variedade de partes, permitindo um melhor nível de serviço a picos de demanda e reduzindo o tempo de resposta comum para as necessidades de clientes. Esta é uma estratégia 
interessante porque há uma minoria de partes no supermercado que assiste a uma maioria de casos, desde que estas partes sejam compostas pelos produtos best-seller.

Corrêa e Gianesi (1996) já sinalizavam que para administrar as interfaces entre estes dois sistemas tão diferentes é necessário utilizar o backflushing com ordens fantasmas.

Backflushing é a "baixa" automática das quantidades padrão de recursos (materiais, mão de obra, tempo de máquina, entre outros) requeridos para a execução de uma ou mais operações, para uma ordem de produção específica, depois que a mesma é completada.

Itens fantasmas são itens da estrutura de produto que o usuário "marca" para que o MRP não gere para eles ordens de produção. Os itens fantasmas também não podem ter estoques associados a eles.
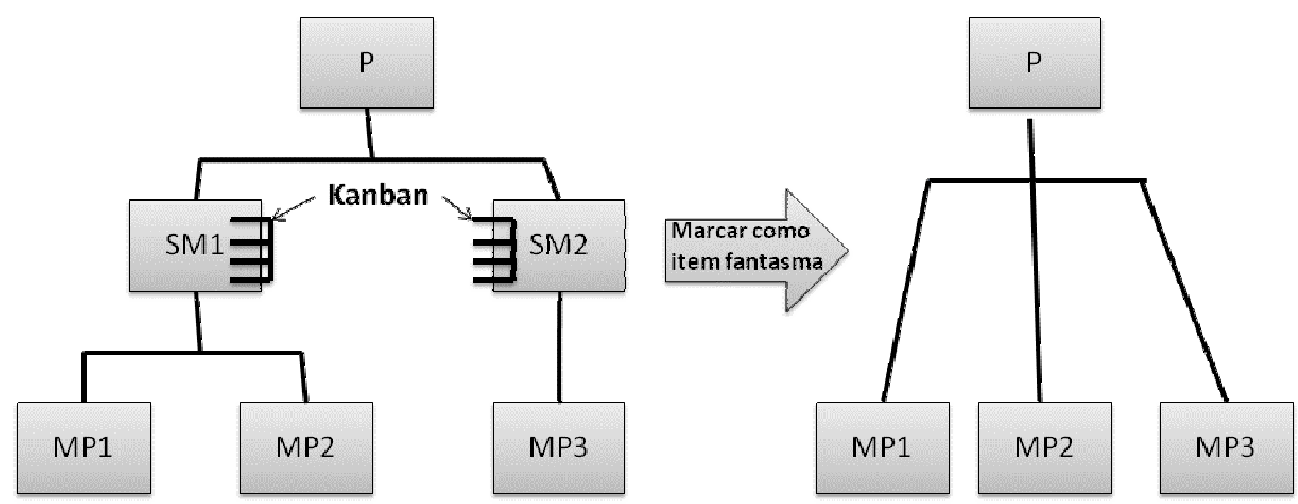

Figura 23: Marcação de itens kanban como fantasmas na estrutura do MRP Fonte: Adaptado de Corrêia e Gianesi (1996)

A classificação dos itens em diferentes subfamílias de programação e controle pode ser feita com base em três critérios (RENTES et al., 2005):

a) Relativo ao custo da parte, indicando se sua manutenção financeira é alta ou baixa.

b) Relativo ao volume de produção, indicando se as partes normalmente são ordenadas em volume alto ou baixo

c) Relativo à freqüência, indicando se as partes são freqüentemente ou esporadicamente demandadas. 


\begin{tabular}{|c|c|c|c|}
\hline Volume & Frequencia & Custo & $\begin{array}{c}\text { Sistema de } \\
\text { Controle }\end{array}$ \\
\hline Alto & Alta & Alto & Kanban \\
\hline Alto & Alta & Baixo & Kanban Sinal \\
\hline Alto & Baixa & Baixo & Ordem \\
\hline Alto & Baixa & Alto & Ordem \\
\hline Baixo & Alta & Alto & Kanban \\
\hline Baixo & Alta & Baixo & Kanban Sinal \\
\hline Baixo & Baixa & Baixo & Kanban Sinal \\
\hline Baixo & Baixa & Alto & Ordem \\
\hline
\end{tabular}

Quadro 7: Classificação das partes e sistemas de controle para cada caso Fonte: Rentes et al. (2005)

No exemplo acima, o volume é classificado como alto ou baixo. A frequiência também é classificada do mesmo modo. O custo é classificado na forma de Paretto, em A, B ou C. No caso, os autores consideraram que as partes A e B são considerados de alto custo. As partes classe C, consideradas de baixo custo.

Conforme dito anteriormente, no primeiro caso, a segmentação com base na manutenção financeira pode ser feita com base na regra de Paretto, que classifica os estoques em A, B ou C de acordo com o custo total anual. De acordo com Slack (1999), em qualquer estoque que contenha mais de um item, alguns itens serão mais importantes para a organização do que outros. Geralmente, uma pequena proporção dos itens totais contidos em estoque vai representar uma grande proporção do valor total em estoque. Com isso, a Lei de Pareto, ou Regra 80/20, diz que tipicamente $80 \%$ do valor do estoque de uma operação correspondem a somente $20 \%$ de todos os tipos de itens estocados.

Uma forma comum de discriminar diferentes itens de estoque é fazer a lista deles, de acordo com suas movimentações de valor (sua taxa de uso multiplicada por seu valor individual). Isso permite que os gestores de estoque concentrem seus esforços no controle dos itens mais significativos do estoque. 
Itens classe A: $20 \%$ de itens de alto valor, os quais representam cerca de $80 \%$ do valor total do estoque

Itens classe B: $30 \%$ de itens de médio valor, os quais representam cerca de $10 \%$ do valor total do estoque

Itens classe C: $50 \%$ de itens de baixo valor, os quais representam cerca de $10 \%$ do valor total do estoque.

\begin{tabular}{|c|c|c|c|c|c|c|}
\hline $\begin{array}{l}\text { Item de } \\
\text { estoque }\end{array}$ & $\begin{array}{c}\text { Uso } \\
\text { (itens/ano) }\end{array}$ & $\begin{array}{c}\text { Custo } \\
\text { (R\$/item) }\end{array}$ & $\begin{array}{c}\text { Valor de uso } \\
\text { (R\$/ano) }\end{array}$ & $\begin{array}{l}\% \text { do } \\
\text { valor }\end{array}$ & $\begin{array}{l}\% \text { cumulativa } \\
\text { do valor total }\end{array}$ & $\begin{array}{c}\text { Classe } \\
A B C\end{array}$ \\
\hline 1 & 1000 & $R \$ \quad 2,00$ & $R \$ \quad 2.000,00$ & $31,7 \%$ & $31,7 \%$ & $A$ \\
\hline 2 & 500 & $R \$ \quad 2,75$ & $\mathrm{R} \$ \quad 1.375,00$ & $21,8 \%$ & $53,5 \%$ & $A$ \\
\hline 3 & 1000 & $\mathrm{R} \$ \quad 0,90$ & 900,00 & $14,3 \%$ & $67,8 \%$ & $A$ \\
\hline 4 & 95 & $\mathrm{R} \$ \quad 8,50$ & 807,50 & $12,8 \%$ & $80,6 \%$ & $B$ \\
\hline 5 & 520 & $\mathrm{R} \$ \quad 0,54$ & 280,80 & $4,5 \%$ & $85,1 \%$ & $B$ \\
\hline 6 & 73 & $R \$ \quad 2,30$ & 167,90 & $2,7 \%$ & $87,7 \%$ & $B$ \\
\hline 7 & 520 & $R \$ \quad 0,22$ & 114,40 & $1,8 \%$ & $89,5 \%$ & $B$ \\
\hline 8 & 170 & $R \$ \quad 0,65$ & 110,50 & $1,8 \%$ & $91,3 \%$ & $C$ \\
\hline 9 & 250 & $R \$ \quad 0,34$ & 85,00 & $1,3 \%$ & $92,6 \%$ & $C$ \\
\hline 10 & 250 & $R \$ \quad 0,30$ & 75,00 & $1,2 \%$ & $93,8 \%$ & $C$ \\
\hline 11 & 400 & $R \$ \quad 0,14$ & 56,00 & $0,9 \%$ & $94,7 \%$ & $C$ \\
\hline 12 & 80 & $R \$ \quad 0,63$ & 50,40 & $0,8 \%$ & $95,5 \%$ & $C$ \\
\hline 13 & 230 & $R \$ \quad 0,21$ & 48,30 & $0,8 \%$ & $96,3 \%$ & $C$ \\
\hline 14 & 400 & $\mathrm{R} \$ \quad 0,12$ & 48,00 & $0,8 \%$ & $97,0 \%$ & $C$ \\
\hline 15 & 500 & $R \$ \quad 0,09$ & 45,00 & $0,7 \%$ & $97,7 \%$ & $C$ \\
\hline 16 & 50 & $R \$ \quad 0,88$ & 44,00 & $0,7 \%$ & $98,4 \%$ & $C$ \\
\hline 17 & 70 & $R \$ \quad 0,57$ & 39,90 & $0,6 \%$ & $99,1 \%$ & $C$ \\
\hline 18 & 50 & $R \$ \quad 0,64$ & 32,00 & $0,5 \%$ & $99,6 \%$ & $C$ \\
\hline 19 & 50 & $R \$ \quad 0,32$ & 16,00 & $0,3 \%$ & $99,8 \%$ & $C$ \\
\hline 20 & 20 & $R \$ \quad 0,50$ & 10,00 & $0,2 \%$ & $100,0 \%$ & $C$ \\
\hline TOTAL & & & $R \$ \quad 6.305,70$ & $100 \%$ & & \\
\hline
\end{tabular}

Quadro 8: Exemplo de lista de itens de estoque com respectivas movimentações de valor Fonte: Slack (1999)

A curva $\mathrm{ABC}$ de valor da lista acima é ilustrada na figura a seguir: 


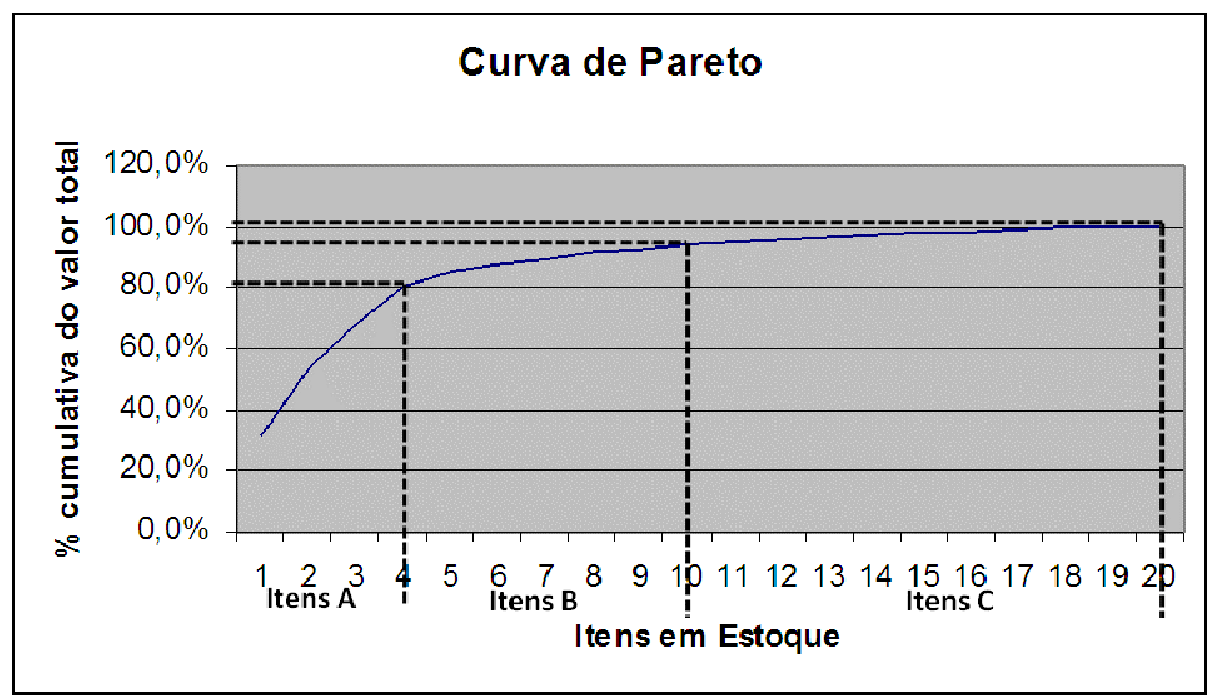

Figura 24: Curva ABC de Pareto Fonte: Slack (1999)

Uma outra forma de segmentação é por volume, que pode ser feita por meio da "análise ABC do volume produção". Nesse sentido, existem três grupos de classificação de volume (Smalley, 2005):

Alto volume: $20 \%$ dos itens que correspondem a $60 \%$ da demanda

Médio volume: $30 \%$ dos itens que correspondem a $20 \%$ da demanda

Baixo volume: $50 \%$ dos itens que correspondem a $20 \%$ da demanda

Smalley (2005) propõe a tabela abaixo como forma de listar as opções lógicas, de acordo com a classificação ABC de volume da demanda.

\begin{tabular}{|l|l|l|}
\hline \multicolumn{1}{|c|}{ Opções } & Prós & \multicolumn{1}{|c|}{ Contras } \\
\hline $\begin{array}{l}\text { 1. Sistema Puxado de Reposição: Manter um } \\
\text { estoque de produtos acabados (A's, B's e C's) } \\
\text { e fabricar todos para estoque }\end{array}$ & $\begin{array}{l}\text { Pronto para } \\
\text { expedir todos os } \\
\text { itens em pouco } \\
\text { tempo }\end{array}$ & $\begin{array}{l}\text { Requer estoque para cada item e } \\
\text { muito espaço }\end{array}$ \\
\hline $\begin{array}{l}\text { 2. Sistema Puxado Seqüencial: Não manter } \\
\text { estoque de produtos acabados e fazer todos os } \\
\text { produtos sob encomenda }\end{array}$ & $\begin{array}{l}\text { Menor estoque e } \\
\text { menor perda a } \\
\text { ele associado }\end{array}$ & $\begin{array}{l}\text { Requer alta estabilidade do } \\
\text { processo e curto lead time de } \\
\text { produção }\end{array}$ \\
\hline $\begin{array}{l}\text { 3a. Sistema Puxado Misto: Manter apenas os } \\
\text { C's no estoque e fazer os produtos A e B sob } \\
\text { encomenda }\end{array}$ & Menor estoque & $\begin{array}{l}\text { Requer um controle de produção } \\
\text { misto e estabilidade diária }\end{array}$ \\
\hline $\begin{array}{l}\text { 3b. Sistema Puxado Misto: Manter os } \\
\text { produtos A e B no estoque de produtos } \\
\text { acabados. Fazer os C's sob encomenda a partir } \\
\text { de componentes semi-acabados }\end{array}$ & $\begin{array}{l}\text { Estoque } \\
\text { moderado }\end{array}$ & $\begin{array}{l}\text { Requer um controle de produção } \\
\text { misto e visibilidade nos itens C }\end{array}$ \\
\hline
\end{tabular}


A opção 1, denominada Sistema Puxado de Reposição, consiste no processo de manter em estoque produtos acabados para todo o tipo de produto e usar os pedidos dos clientes para iniciar a produção. Neste caso, a instrução de produção seria enviada para a linha de montagem final a partir do estoque de produtos acabados por meio do dispositivo de nivelamento heijunka e da montagem para trás, ao longo do fluxo de produção (Figura 25).
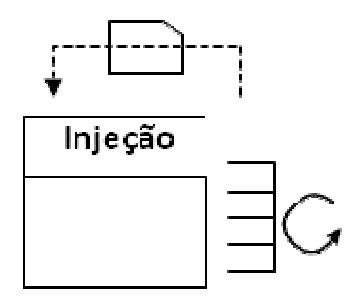
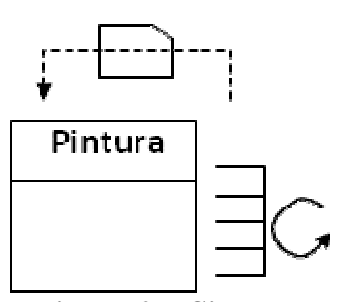

Figura 25: Sistema Puxado de Reposição Fonte: Smalley (2005)

A opção 2, denominada Sistema Puxado Seqüencial, consiste em produzir todos os itens a partir do pedido do cliente. Os itens são fabricados ao ritmo da demanda, com a instrução de fabricação enviada à primeira etapa do processo no início do fluxo de valor (figura 23).

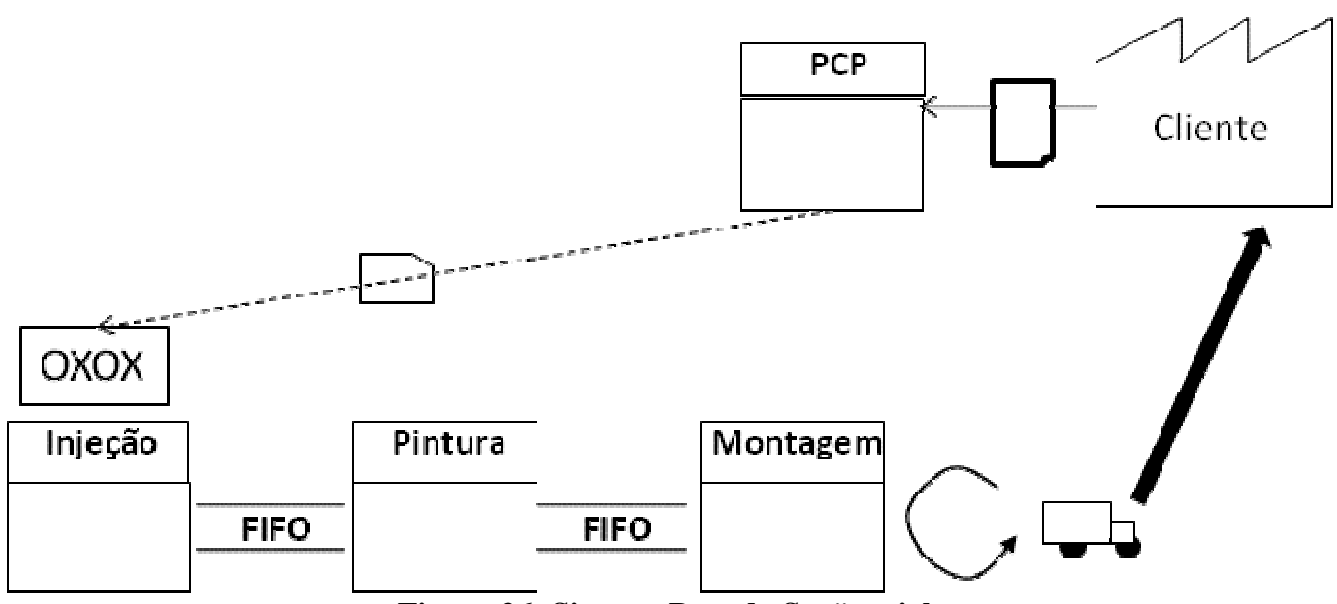

Figura 26: Sistema Puxado Seqüiencial

Fonte: Smalley (2005) 
Este tipo de sistema puxado é mais exigente para gerenciar do que um simples sistema puxado de reposição, pois é difícil adequar o fluxo de operações ao takt time.

Takt-time é o tempo usado para sincronizar o ritmo de produção com o ritmo de demanda. É um número de referência que dá a noção do ritmo em que cada processo precisa estar produzindo. Ele é calculado dividindo-se o volume da demanda dos clientes pelo tempo disponível de trabalho (Rother e Shook, 1998).

Takt time $=\quad$ Tempo de trabalho disponivel

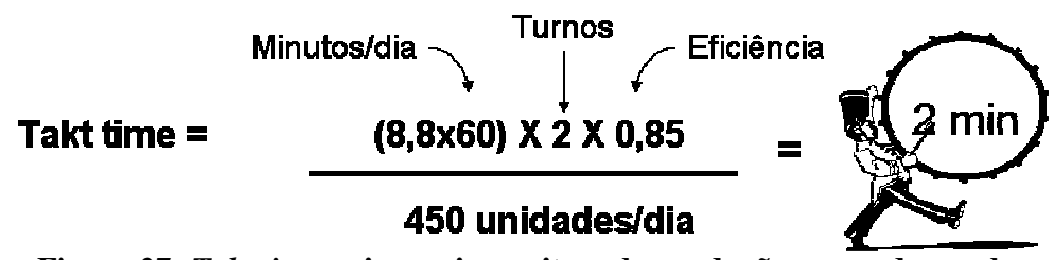

Figura 27: Takt time - sincroniza o ritmo da produção com a demanda

A menos que a fábrica tenha um lead time de produção curto e regular e grande disponibilidade de equipamentos, esta opção não será fácil de manter. Mesmo em companhias lean, como a Toyota, o sistema puxado seqüenciado é empregado apenas quando as operações tiverem demonstrado uma grande capabilidade e quando situações especiais de pedido sob encomenda são requeridas pelo processo posterior ou pelo cliente.

A opção 3, denominada Sistema Puxado Misto, consiste em utilizar características tanto do sistema puxado seqüenciado quando do de reposição. Este sistema é especialmente útil quando a maioria dos itens solicitados é de pedidos repetidos e freqüentes, mas muitos dos não freqüentes também são requeridos. A figura 24 mostra a situação em que os pedidos para os itens C são enviados para o início do fluxo de valor. 


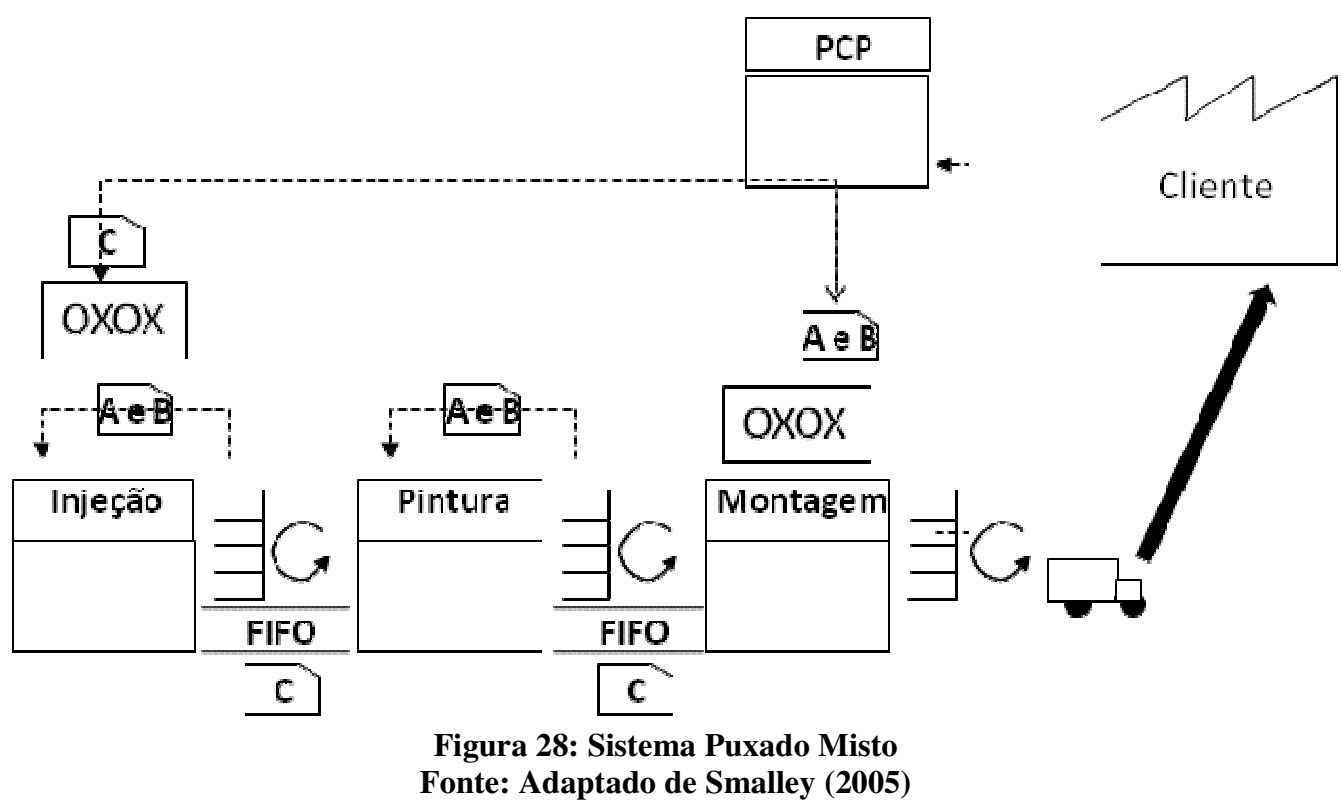

De acordo com Smalley (2005), é possível que seja necessário dar um passo atrás e pensar bem se os itens $\mathrm{C}$ deveriam ser produzidos na mesma célula de montagem dos itens A e B. Se o conteúdo do trabalho entre os itens for muito diferente ou a troca de ferramental for complexa, pode ser necessário colocar os itens $\mathrm{C}$ em uma célula de montagem altamente flexível dedicada às produções de baixo volume. Esta célula poderia incluir também alguns mais freqüentes de outras famílias de produtos.

Segundo o autor, possuir uma célula dedicada para os itens classe C, além de simplificar o sistema puxado para os itens classe A e B, em indústrias onde a margem de lucro nos itens $\mathrm{C}$, tais como peças para o mercado de reposição, é muito maior do que para os itens $\mathrm{A}$ e $\mathrm{B}$, pode ser que faça mais sentido em termos econômicos produzi-los em células separadas, mesmo que isso custe um pouco mais.

Por fim, assim como Rentes et al. (2005), Duggan (2002) também propõe como fator de diferenciação dos itens que deveriam ir para um supermercado, a taxa de variação, ou freqüência, de demanda de cada item.

Também poderiam se criar outras classificações dentro destas três dimensões. O mais relevante é que cada combinação poderia ser considerada um "subfamília" relacionada a um sistema de programação específico. Isto deveria ser considerado como sugestão inicial para o projeto. Em casos de aplicações práticas, esses valores devem ser analisados caso a caso. Nesse sentido, a utilização de 
sistemas de híbridos de programação e controle permite ao sistema de produção harmonizar a implantação de supermercados para as subfamílias das partes de bestsellers com ordens de produção para as demais subfamílias.

Tendo decidido qual tipo de sistema de controle empregar, o próximo passo é calcular o quanto de cada um destes itens deve ser mantido. Uma fórmula simples proposta para calcular os níveis iniciais de estoque de produtos acabados é (SMALLEY, 2005):

\begin{tabular}{|l|l|l|}
\hline & $\begin{array}{l}\text { Demanda média diária x Lead time de reposição } \\
\text { (dias)* }\end{array}$ & Estoque de Ciclo (“cycle") \\
\hline+ & $\begin{array}{l}\text { Variação da demanda como \% do Estoque de } \\
\text { Ciclo** }\end{array}$ & Estoque Pulmão ("buffer") \\
\hline+ & $\begin{array}{l}\text { Fator de segurança como \% de Estoque de Ciclo + } \\
\text { Estoque Pulmão*** }\end{array}$ & Estoque de Segurança ("safety”) \\
\hline$=$ & & Estoque de Produtos Acabados \\
\hline
\end{tabular}

Quadro 10: Fórmula para Cálculo de Produtos Acabados Fonte: Smalley (2005)

No primeiro fator da equação (*) da fórmula acima, para a demanda média, recomenda-se utilizar um intervalo de tempo de três meses, embora possa ser utilizado um período mais longo ou mais curto, dependendo da sazonalidade e das mudanças prováveis na demanda média decorrentes das condições de mercado.

O Lead time de reposição representa, na verdade, a freqüência (em dias) com que o item num determinado intervalo de tempo. Neste caso, pode ser necessário a do conceito de TPT (Toda Parte Toda...). Se uma máquina é trocada numa sequência de modo que a mesma peça volte a ser feita dois dias depois então o seu TPT é dois dias (“Toda parte a cada dois dias"). Este intervalo deve ser o menor possível de modo a conseguir o mix certo na quantidade certa, satisfazer a demanda dos clientes e não criar estoque em excesso (LEI, 2004).

Para calcular o TPT devem ser observadas duas coisas: primeiro se o processo possui capacidade o suficiente para processar todas os itens que passam nele. Segundo, caso haja capacidade, o quanto do tempo é gasto com setup's .O cálculo parte de um intervalo de tempo estimado (TPT tentativa ou desejável). Somase os tempos de processamento. O tempo restante é o tempo disponível para a 
realização de setup. O TPT é então ajustado conforme o tempo disponível para setup. Caso a soma dos tempos de setup das partes no processo em questão seja maior que o tempo disponível para setup seria necessário a aplicação de técnicas como o SMED para reduzir setup's, e obter-se um TPT desejável.

O segundo fator $(* *)$ reflete dois desvios-padrão da demanda e, dessa forma, aproximadamente $95 \%$ da variação normal dos pedidos. O desvio padrão é utilizado para calcular com que probabilidade a demanda oscilará além de uma determinada quantidade durante o ciclo de reposição. Caso necessário, podem ser considerados mais desvios-padrão, para cobrir um nível mais alto de variação.

$\mathrm{O}$ terceiro fator $(* * *)$ reflete o exemplo do pior caso de refugo, retrabalho, quebra de máquina e downtime (número esperado de novas peças não chegar aos produtos acabados dentro do tempo planejado) no processo analisado.

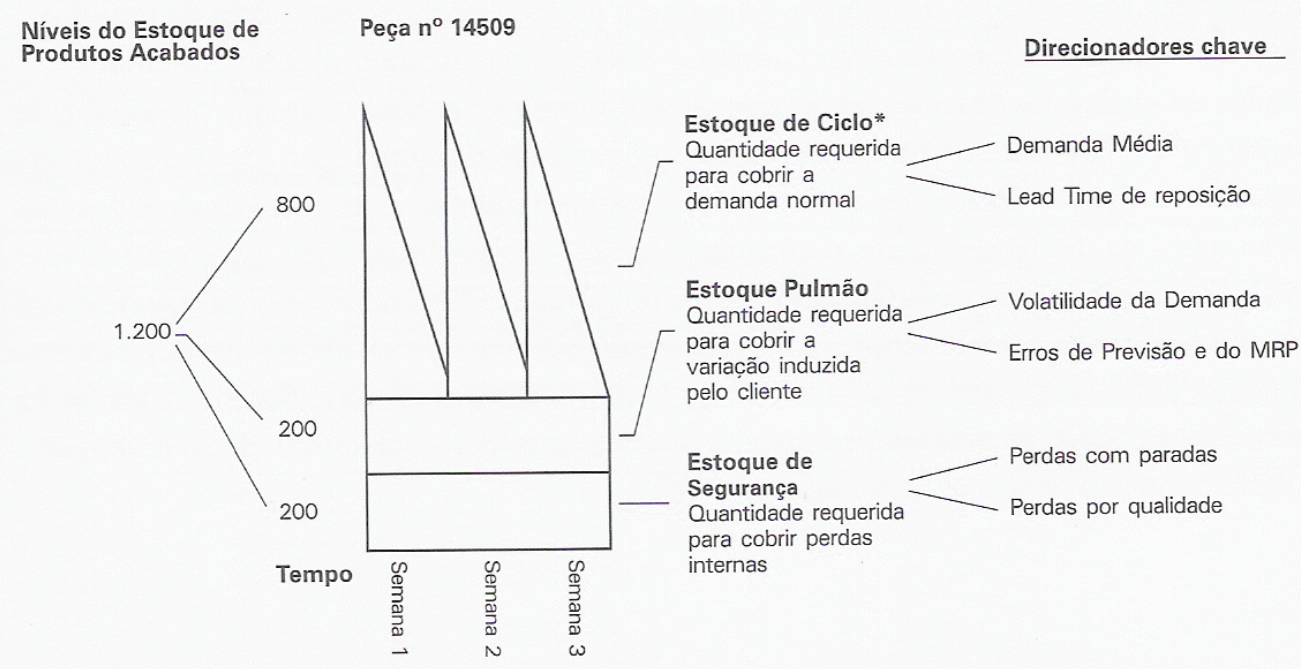

Figura 29: Fatores contemplados para definição do nível de estoque de um supermercado Fonte: Smalley (2005)

Os termos pulmão (buffer stock) e estoque de segurança (safety stock) são frequentemente utilizados sem diferenciação, o que gera confusão. Note, portanto, que há uma diferença importante entre os dois. Ela pode ser resumida da seguinte forma: os pulmões protegem o sistema produtivo de mudanças abruptas de demanda. Os estoques de segurança protegem o fabricante de uma ineficácia nos seus processos fluxo acima e dos seus fornecedores. Estoque de ciclo é a quantidade 
de estoque necessário antes de cada etapa de processamento para que este flua suavemente. (LEI, 2003).

Para fazer a transição para o novo sistema, podem ser necessárias cargas extras de produção, a fim de armazenar os níveis de estoque necessários para os itens que ficarão no supermercado. Já os itens que passarão a ser feitos sob pedido devem ser colocados em um local especial e rotulados cuidadosamente, de modo a serem utilizados no período de transição até passarem a ser fabricados somente contra pedido.

A próxima questão é decidir como organizar e controlar o supermercado de produtos. Os estoques devem ser controlados utilizando a simplicidade de um método visual.

Se possível, o estoque deve ser organizado e segmentado em três categorias: estoque de ciclo, estoque pulmão e estoque de segurança. A meta principal é deixar claro a todos se os níveis de estoque estão normais ou anormais. Fazendo isto corretamente traz o domínio e o controle do estoque para perto da célula de montagem e expõe os problemas em tempo real para gerentes e funcionários. Além do mais, isto pode eliminar a necessidade de relatórios extensos gerados por computador, os quais normalmente são mantidos escondidos ou totalmente inseridos no sistema de controle de produção (SMALLEY, 2005).

Além da variedade de produtos e componentes, um outro grande problema a ser atacado é a variação e amplificação da demanda. Nesse contexto, itens com maiores taxas de variação seriam feitos mediante pedido ou demandariam por um tamanho de supermercado maior, pois estão mais sujeitos a não atenderem eventuais picos de demanda.

Portanto, mesmo com supermercados, a variação e a amplificação da demanda são fatores que devem ser administrados a fim de possibilitar a redução do tamanho dos lotes de produção.

\subsubsection{Amplificação da Demanda}

Amplificação da demanda é a tendência de qualquer processo com múltiplas etapas, para os pedidos de produção, recebidos por cada processo fluxo 
acima, serem mais erráticos do que a produção ou venda real no próximo processo fluxo abaixo. Também conhecida com Efeito Forrester (referência a Jay Forrester, do MIT, primeiro a caracterizar esse fenômeno matematicamente, na década de 1950) (LEI, 2003)

As duas causas principais da amplificação da demanda, na medida em que os pedidos movimentam-se fluxo acima são: (a) o número de pontos de decisão nos quais os pedidos podem ser ajustados e (b) atrasos enquanto os pedidos aguardam processamento (assim como ocorre com a espera pelo processamento semanal do sistema MRP). Quanto maiores os atrasos, maior a amplificação, conforme mais produção for determinada por previsões (o que se torna menos preciso quanto maior for o horizonte da previsão) e mais ajustes forem feitos aos pedidos (LEI, 2003).

O gráfico de amplificação da demanda mostra uma situação típica na qual a variação da demanda do cliente final (Alfa) é modesta, cerca de $+/-3 \%$ durante um mês. Contudo, conforme os pedidos se movimentam ao longo do fluxo de valor, passando pela Beta e pela Gama, eles se tornam muito erráticos, até que os pedidos enviados pela Gama aos seus fornecedores de matéria prima varem +/- 35\% durante um mês.

Se a amplificação da demanda pudesse ser completamente eliminada, a variação nos pedidos em todos os pontos, ao longo do fluxo de valor, seria de +/$3 \%$, refletindo a verdadeira variação da demanda do cliente.

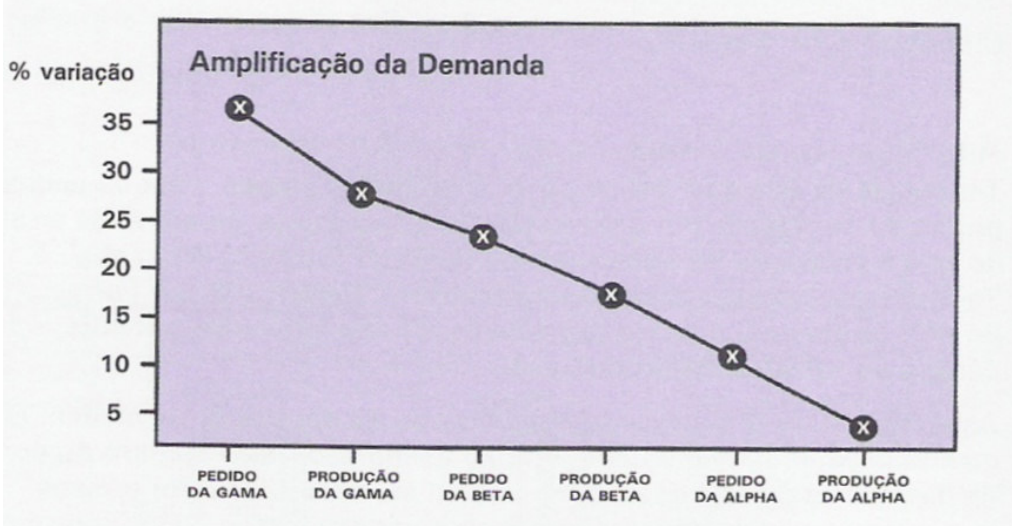

Figura 30: Gráfico de Amplificação da Demanda Fonte: LEI (2003) 
A amplitude da variação da demanda fluxo abaixo influenciará no tamanho do estoque padrão, criando-se a necessidade de pulmões. Uma boa prática lean é a determinação do estoque padrão para um processo e continuamente reduzilo, quando possível, mas apenas após a redução da variabilidade do fluxo abaixo e o aumento da capabilidade do fluxo acima.

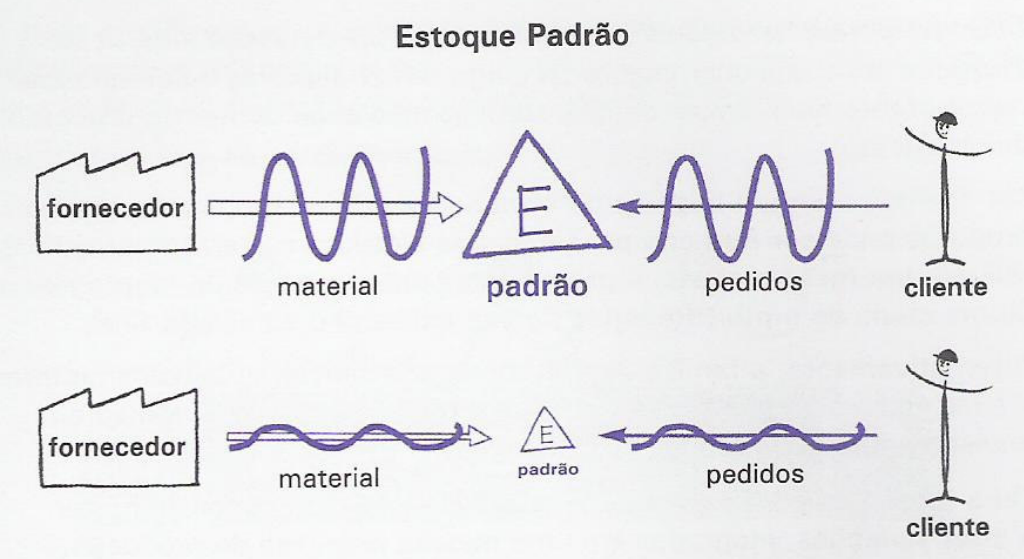

Figura 31:Influência da amplitude de variação da demanda no tamanho do estoque Fonte: LEI (2003)

Note que o tamanho do estoque padrão representado pelo triângulo é proporcional à variabilidade dos fluxos de pedidos originários do cliente à direita e á confiabilidade dos fluxos de materiais originários do fornecedor à esquerda.

\subsubsection{Instabilidade da demanda e dos processos em sistemas puxados.}

Parece haver um consenso na literatura a respeito da vulnerabilidade de sistemas puxados com a instabilidade interna e externa da demanda e dos processos de abastecimento. As citações abaixo ilustram essa percepção:

Muitas empresas estão interessadas em implementar a filosofia da produção just-in-time (JIT) em resposta às pressões competitivas sobre a manufatura. No nível do chão de fábrica, umas das ferramentas de aplicação do JIT se dá por meio do sistema de controle kanban. Tradicionalmente, este sistema 
funciona bem em ambientes de chão de fábrica estáveis (MOEENI et al., 1997).

Um sistema kanban não é para todos. Ele trabalha melhor quando o fluxo é uniforme e o mix de produtos é altamente estável (SIPPER; BULFIN JR., 1997).

Desde que o JIT fora concebido apenas para operar em determinados ambientes, sua performance é seriamente afetada pelos tempos de processamento e pela demanda (...) o JIT foi projetado para tempos de processamento constante e para demandas contínuas e estáveis, consequentemente sua performance é ótima neste tipo de ambiente (...) (GUPTA; ALTURKI, 1997).

O sistema kanban não tem nenhuma adaptabilidade para oscilações grandes e repentinas na demanda (MONDEN, 1981).

Se por um lado tais tipos de observações sobre as deficiências dos sistemas puxados têm sido fortemente reportados, infelizmente, por outro lado poucas soluções têm sido propostas. Entretanto, na prática muitas empresas vêm tentando adaptar este sistema de maneira ad hoc, com o objetivo de minimizar os efeitos indesejáveis de demandas e de fornecimentos instáveis. Algumas destas práticas, que podem ser utilizadas isoladamente ou por meio de combinações criativas, estão resumidas a seguir (SOUSA, 2004):

\section{A) Aumentar a capacidade de produção por meio de horas extras}

Muitas empresas utilizam horas extras como uma forma de aumentar a capacidade de produção no curto prazo. Esta prática funciona como uma expansão da capacidade básica de produção viabilizando a absorção de picos relativamente pequenos de demanda. Conforme observado por Rees et al. (1987):

Para o trabalho JIT a demanda deve ser fortemente constante. Pequenas flutuações na demanda são administradas ajustando-se o intervalo do dia de trabalho. Logo, mesmo que a demanda diária flutue, a taxa de demanda horária deve permanecer constante (REES et al., 1987). 
Trata-se de uma abordagem de custos que deve considerar que as horas extras podem ser significativamente mais caras do que as horas normais de trabalho. Com isso, as empresas tendem a reduzir esta prática e adquirir recursos permanentes caso a freqüência de picos de demanda aumente o suficiente para justificá-la economicamente.

\section{B) Repor a capacidade ociosa utilizando banco de horas}

Neste caso, a capacidade de produção é fixada num dado horizonte de planejamento. Entretanto as frações da capacidade do trabalhador que não foram consumidas são armazenadas num banco de horas para serem utilizadas posteriormente quando necessárias. Basicamente, os empregados são autorizados a ir para casa quando a meta de produção e a capacidade remanescente é armazenada. Portanto, a qualquer momento, a empresa teria uma quantidade de horas disponíveis para incrementar o turno padrão de trabalho.

\section{C) Manter estoques dos produtos best sellers para absorver os picos de demanda}

Algumas empresas mantêm inventários dos seus produtos de alta demanda. Estes inventários agem como "amortecedores de picos de demanda", o que as capacitam a manter a produção dos produtos de baixa demanda enquanto as ordens dos produtos de alta demanda também são cumpridas. Quando o nível da demanda diminui, a capacidade remanescente é utilizada para repor os inventários dos produtos best sellers. Esta prática está alinhada com a estratégia MTS (Make-ToStock) de atendimento da demanda.

\section{D) Manter pulmões de tempo de entrega}

Uma outra prática é possuir clientes com tolerância de espera por um lead time maior do que normalmente é feito. Esse tempo extra agiria como um fator de segurança, permitindo à produção administrar melhor as ordens grandes e problemas de entrega para consumidores com menor tolerância de espera. Esta prática está alinhada com o conceito de lead time de segurança. Entretanto ela fica 
limitada a cenários onde exista um ou poucos competidores e a competição baseada na rapidez de entrega não seja um ganhador de pedido.

\section{E) Manipular a freqüência de transferência dos kanbans}

Algumas vezes os kanbans tem que esperar no quadro por um tempo maior que o desejado devido à adoção de uma determinada frequiência de revisão fixa. Isto pode causar interrupções na produção e consequentemente perda de capacidade produtiva. Se o intervalo fixo para revisão dos kanbans é reduzido é possível que haja uma melhor utilização da capacidade. Portanto, neste caso, o número de kanbans no sistema permanece fixo, mas a freqüência de transferência do kanban é aumentada. Monden (1981) descreve a adoção desta prática na Toyota:

O número de kanbans tende a permanecer fixo apesar das variações na demanda. A experiência da Toyota mostra que de 10 a 30\% da variação na demanda pode ser administrada mudando-se apenas a freqüência de transferência dos kanbans sem que seja necessário revisar o número de kanbans.

\section{F) Manipular o número de kanbans no sistema durante o ciclo de produção}

Outra prática é alterar o número de cartões no sistema durante o ciclo de produção. Esta prática, de manipular dinamicamente o nível de estoque em processo, pode promover uma melhor utilização da capacidade. Portanto, o tempo de inserção e retirada de cartões tende a influenciar a habilidade do sistema de responder à instabilidades na demanda e no tempo de processamento. Esta prática tem sido denominada de "kanban flexível” (FKS - Flexible Kanban System).

\subsubsection{Sistemas puxados flexíveis}

Esta seção narra sobre o planejamento e controle lean da produção com foco nos Sistemas de Kanban Flexível (FKS - Flexible Kanban Systems). Um FKS é diferente do sistema de kanban tradicional, pois o número de kanbans regula o nível de estoque em processo (WIP - Work -In-Process) pode ser alterado constantemente. 
Conforme descrito por Monden (1981) as diretrizes originais do Sistema Toyota de Produção não defendem alterações no número de kanbans durante o ciclo de produção. Para lidar com as variações da demanda em torno da média estimada, ao invés de alterar o número de kanbans, a Toyota manipula a frequiência do kanban. Segundo o autor, as situações em que a Toyota mudaria de fato o número de kanbans, em função de grandes variações na demanda, implicariam numa intervenção também na estrutura do sistema, criando-se uma espécie de configuração definida para cada ciclo de ajuste e implementação:

Para os casos de mudanças sazonais, ou de aumento ou redução significativos na demanda mensal atual acima da carga predefinida ou da carga do mês anterior, o número de kanbans devem ser aumentado ou reduzido. Ao mesmo tempo, toda a linha de produção deve ser rearranjada. Para isso, o tempo de ciclo de cada estação de trabalho deve ser recalculado e o número de trabalhadores em cada processo deve ser atualizado. O sistema kanban não possui adaptabilidade para mudanças repentinas e grandes variações na demanda. No sentido de acompanhar os vales e picos na variação da demanda durante o ano, a alta gerência deverá decidir se nivela o volume de vendas para o ano todo, ou se projeta um plano flexível para rearranjar todas as linhas de produção de acordo com as mudanças sazonais durante o ano (MONDEN, 1981)

De acordo com Sousa (2004), o mecanismo de kanban flexível pode ser visto como uma melhoria na estrutura dos sistemas puxados, fornecendo melhores condições (isto é, tornando-o mais robusto) para operar em condições de demanda e tempo de processamento instáveis. Teoricamente, um FKS estaria apto a melhorar o desempenho do sistema a partir de uma dada configuração padrão definida para cada ciclo de ajuste e implementação, conforme descrito por Monden.

Como um sistema de controle, o FKS é composto pro três subsistemas principais:

Um fator de medição

Um fator de decisão de produzir 
4 Um fator de geração de fed back para o sistema que está sendo controlado, de modo a viabilizar a execução de fato da inserção e retirada de kanbans

Com relação ao fator de decisão, Rees et al. (1987) e Gupta e Al-Turki (1997) simularam um procedimento de ajuste dinâmico no número de kanbans em ambientes de demanda instável e concluíram que o maior potencial de um FKS está em projetá-lo para ser usado durante o ciclo de produção e, consequentemente, a adição/retirada de kanbans deve ocorrer em qualquer ponto a qualquer momento, e não em intervalos de tempo fixos, como ocorre no sistema de kanban tradicional.

De acordo com Rees et al. (1987), numa operação típica de um sistema JIT, parte-se do princípio que o plano mestre de produção é congelado por um mês e o número de kanbans em cada estação de trabalho é ajustado com base numa média de demanda esperada para o período, permanecendo fixo conforme as diretrizes do Sistema Toyota de Produção.

O autor complementa que empresas como a Toyota não têm que ajustar o número de kanbans mensalmente por pelo menos três motivos: (1) eles possuem uma ampla fatia do mercado e, consequentemente, os desvios com relação à previsão correspondem a uma pequena porcentagem do total; (2) eles têm trabalhadores multifuncionais que estão aptos a migrarem entre diferentes estações de trabalho a fim de combater gargalos temporários; e (3) o seu chão de fábrica flui com tamanha eficiência que eles conseguem administrar os problemas diários, tais como variações na demanda, com maior facilidade. Por outro lado, os autores enfatizam que muitas empresas que utilizam, ou que consideram vir a utilizar, o sistema kanban não possuem estas características e, com isso, o ajuste no número de carões torna-se imprescindível.

A figura abaixo coloca quais seriam os principais inputs do processo de decisão: 


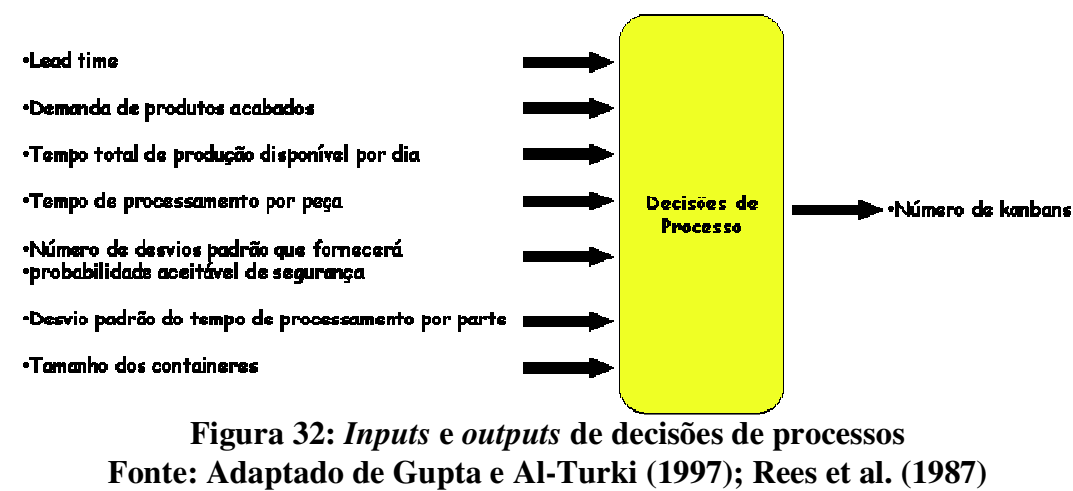

De acordo com o tempo de processamento existem restrições em termos da rapidez que esse ajuste pode ser feito. $\mathrm{O}$ momento a partir do dia atual tanto para a inserção quanto para a retirada de cartões é um fator crítico que deve ser levado em conta (Gupta e Al-Turki, 1997).

De acordo com Duggan (2002), supermercados existem para absorver as variações da demanda. Porém, a questão é o quanto eles devem absorver. Afinal de contas, inventário em excesso é sinal de superprodução. Em muitas empresas, a área de vendas tenta ajustar os níveis de estoque com base em previsões enquanto a área de produção ajusta seus inventários com foco apenas em aumentar a eficiência e produtividade dos recursos. Mas, de acordo com o autor, a resposta real está no lead time.

Quanto menor o lead time maior a flexibilidade do fluxo de valor e menor o inventário necessário. Uma boa estratégia é quebrar a demanda em intervalos de lead times, com base na flexibilidade e desempenho do fluxo de valor.

Enquanto parece ser impossível prever a demanda com uma ótima acuracidade, pode-se tentar torná-la mais previsível dividindo-a em pequenos intervalos e criando um supermercado dinâmico que é ajustado com base nos sinais da demanda. Dessa forma, ele estará alinhado com as alterações da demanda. Será necessário olhar para frente para antecipar-se à demanda, mas não em termos de previsões de longo prazo (figura 30). 


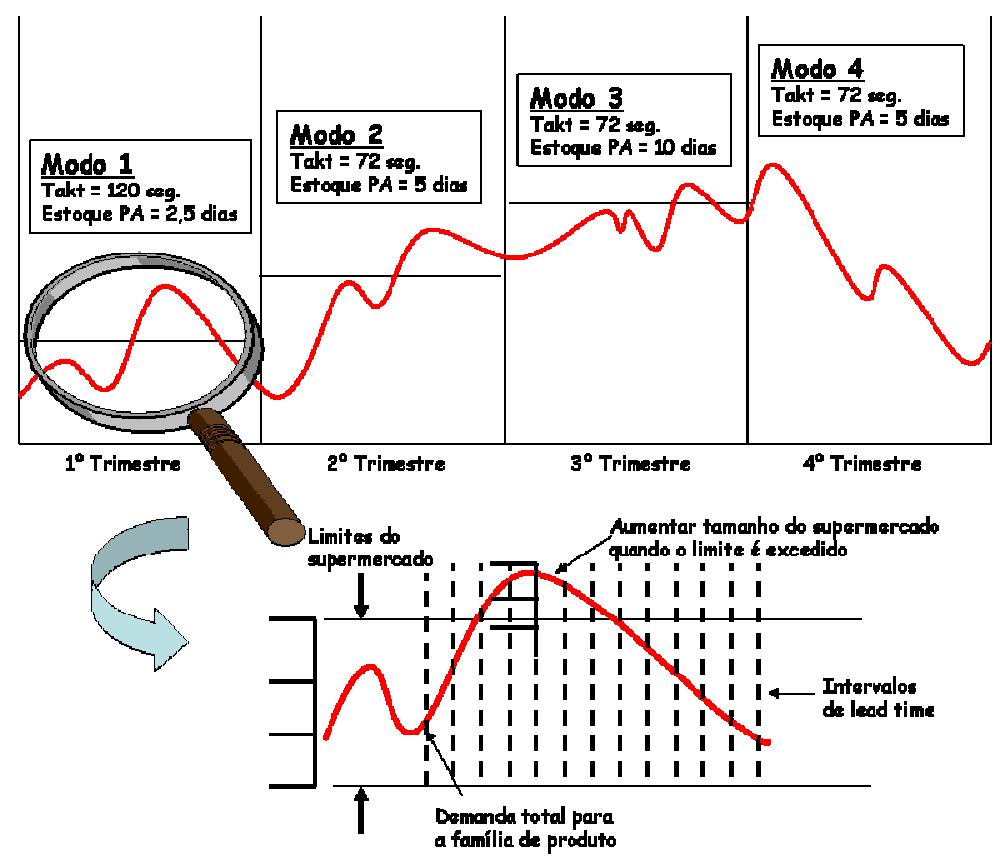

Figura 33: Criando modos de administrar a demanda ao longo do ano Fonte: Duggan (2002)

Podem-se estabelecer níveis pré-fixados de inventários nos supermercados. Sinais de necessidade de ajuste são enviados de forma similar ao sistema kanban. Por exemplo, se cinco intervalos de lead time a partir da demanda do dia atual exceder o que se está produzindo, um sinal será enviado para aumentar o supermercado para um nível maior. Quando o quinto intervalo for atingido, ter-se-á inventário suficiente para absorver o pico na demanda.

Portanto, algumas empresas estão nivelando a produção por um período fixo de tempo, normalmente três meses. É desejável que no escritório do PCP e no chão de fábrica haja um quadro visível apresentando as diferentes configurações e respectivas lógicas de inserção e retirada de kanbans.

Duggan (2002) complementa que, além de uma abordagem híbrida e dos sistemas puxados flexíveis, que são ajustados conforme a demanda, a versão futura de um ambiente de alta variedade e demanda instável também deve incluir um processo puxador capaz de absorver as flutuações da demanda, nivelar o mix de produtos e balancear os tempos de produção. 


\subsubsection{O processo puxador: onde e como programar e nivelar o fluxo de valor?}

Diversos pontos de programação combinados com previsões inerentemente não confiáveis, longos lead times, grandes lotes e indicadores centrados nos departamentos levam os processos de produção a um estado de "O que é melhor para mim", ao invés de "O que meu cliente precisará a seguir?". O resultado costuma ser excesso de estoque da maioria das peças combinado à falha na produção das peças certas, na quantidade certa e no momento certo para o cliente. Concluindo, quanto mais pontos de programação houver no fluxo de valor, maior é a chance de ocorrerem erros. Daí a necessidade de designar um único ponto no fluxo de valor como processo puxador para receber a programação do controle de produção.

A produção puxada em um fluxo de valor, regulada por um processo puxador, tem uma grande vantagem sobre a maneira das aplicações padrão dos softwares: com o controle de produção no chão de fábrica, os funcionários podem sentir e reagir mais rapidamente à dinâmica mutante da produção. Não há atrasos esperando o processamento noturno (do MRP) ou até que a próxima programação possa ser criada e transmitida ao chão de fábrica. A resposta a um problema pode ser quase instantânea.

Dentro desse contexto, Smalley (2005) propõe as seguintes diretrizes para a escolha do processo puxador:

Num sistema puxado de reposição, a montagem final será o processo puxador em quase todos os casos.

\& Num sistema puxado seqüenciado, o processo puxador é frequentemente o primeiro processo no início do fluxo de valor. Contudo, se possível, ele deve estar localizado mais abaixo no fluxo de valor, pouco antes que mais tipos de estoques sejam necessários. Nestes casos, é comum que a instabilidade de um processo intermediário faça com que as peças nem sempre cheguem no prazo. Este é um problema freqüente, pois deve-se manter um rígido controle FIFO e sincronizar o fluxo das peças com o takt time da montagem final. Do contrário acaba-se com o velho sistema empurrado seqüenciado, e não puxado. Para simplificar o problema, uma solução 
intermediária seria criar um supermercado depois do processo em questão.

Em seguida, para nivelar a produção no processo puxador o primeiro passo é substituir o volume de produção errático por uma produção nivelada em termos de quantidade produzida por turno no processo puxador. Para isso, é necessário criar células de fluxo contínuo funcionando de acordo com takt time e operações padronizadas. Por outro lado, caso a demanda do cliente aumente rapidamente por diversos dias ou caia de forma abrupta para um nível muito menor, as células deverão trabalhar em horas extras ou parar mais cedo. O importante é que as células produzam um nível constante sempre que estiverem operando e mantenham este nível até que o takt time mude em conseqüência da mudança da demanda no longo prazo.

O segundo passo é nivelar o mix de produção reduzindo o tamanho dos lotes produzidos para cada item nas células, refletindo melhor as quantidades realmente solicitadas pelos clientes em seus pedidos diários de entrega. A eficiência pontual em cada etapa do processo do fluxo de valor, obtida por meio de grandes lotes para evitar problemas setup e perda de produtividade, tende a produzir uma ineficiência do sistema muito maior na forma de estoques caros, necessidade de espaço, urgência por peças em falta e custos administrativos.

O tamanho dos lotes no processo puxador deve ser diminuído de acordo com as seguintes restrições:
A. Diferenças no conteúdo de trabalho entre os produtos
B. Requisitos de setup entre os modelos
C. Intervalo pitch de produção

\section{A. Diferencas no conteúdo de trabalho entre os produtos}

É necessário garantir que o conteúdo de trabalho para todos os produtos definidos para a célula varie somente um pouco e que nenhum produto possua conteúdo de trabalho acima do takt time. Variações significativas que passarem despercebidas em um ambiente de programação empurrada, especialmente se o conteúdo de trabalho ultrapassar o takt time, virá a tona dolorosamente em um 
rígido sistema puxado. Mesmo que a média ponderada de conteúdo de trabalho para todos os itens fique abaixo do takt time, a operação contínua da célula durante todo o turno fica mais fácil ainda. Isto porque essa redução trará algum tempo livre para lidar com as inevitáveis variações na produção.

De acordo com Duggan (2002), se um produto possui uma variação de tempo (somatória dos tempos dos respectivos elementos de trabalho) maior que $30 \%$ e mesmo assim ele deve ser produzido na mesma célula de trabalho, pode-se limitar a quantidade por intervalo que será feita deste produto (uma vez que a produção deste produto tenderá a corromper o takt time), estocar mais peças acabadas, trabalhar com horas extras, ou utilizar operadores e células extras enquanto este produto é feito (figura 31).

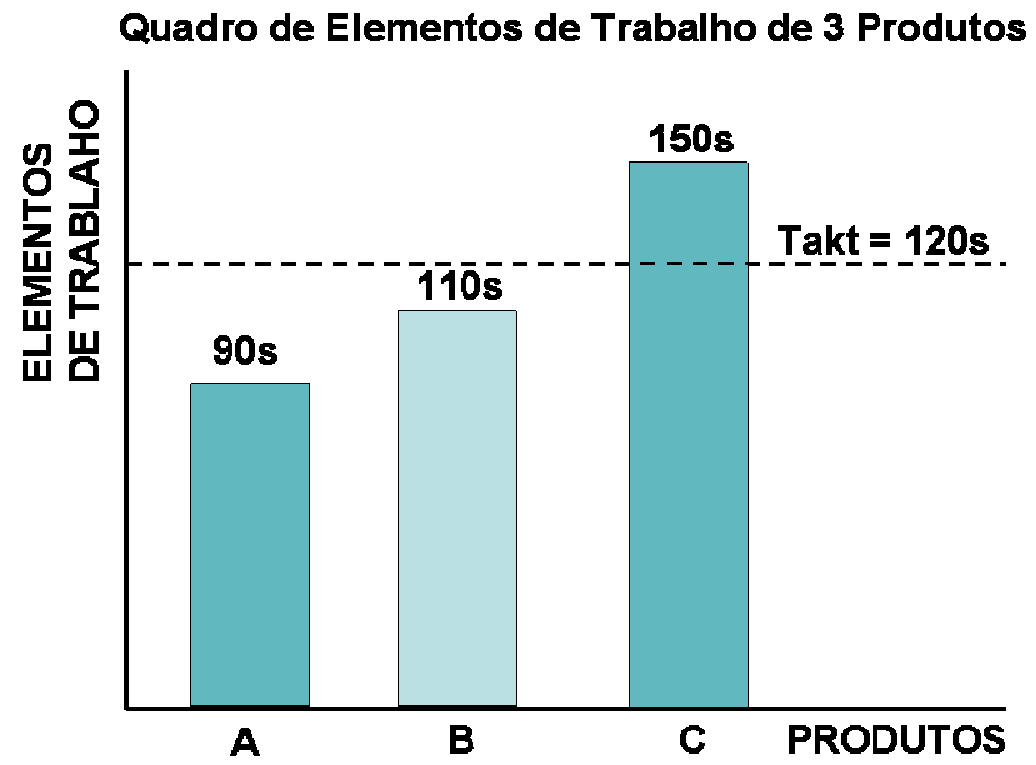

Figura 34: Exemplo de quadro de elementos de trabalho para 3 produtos Fonte: Duggan (2002)

Dentro desse contexto, Duggan (2002) propõe quatro opções de balanceamento nos casos em que se têm famílias de produtos com grandes variações de tempo entre si:

Opção 1: Nivelar a programação com um supermercado e manter a mão de obra constante - produzir os produtos numa seqüência fixa. 
Os produtos são nivelados no processo produtor inicial, através do sequenciamento das ordens com base nos tempos dos elementos de trabalho. As ordens, vindas de um supermercado, são arranjadas alternando-se os produtos de alto tempo (produto C) com os de baixo tempo (produtos A e B). Quando um produto de alto tempo é produzido, o produtor tende a diminuir o ritmo de ciclo com relação aos demais produtos, mas em seguida este tempo seria recuperado. Cria-se, com isso, um takt time médio.

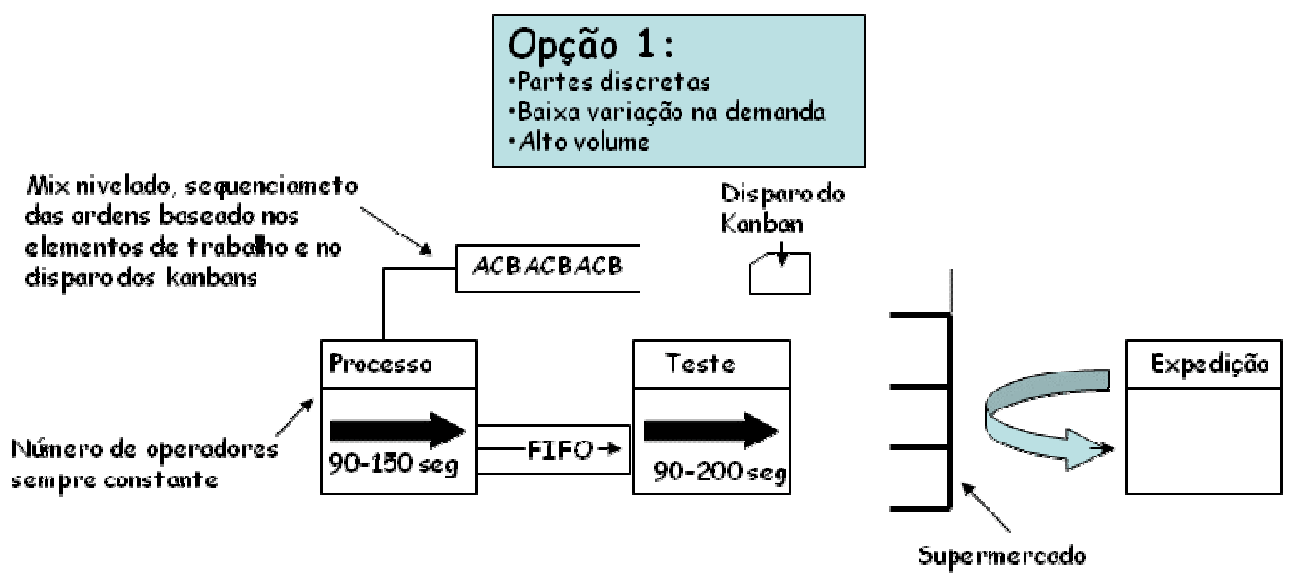

Figura 35:Opção de balanceamento 1, nivelar a programação e manter a mão de obra constante - produzir os produtos numa seqüência fixa Fonte: Duggan (2002)

Esta opção funciona bem quando se consegue nivelar a programação pelo menos ao longo de algumas semanas, e existem poucos desperdícios causando interferências no produtor.

Mas, se a demanda varia pouco, só que em bases diárias, a opção de nivelar a programação e criar um FIFO (First-In-First-Out) direto para a expedição tende a ser mais eficaz.

\section{Opção 2: Nivelar a programação e criar um FIFO direto para a} expedição.

Os produtos são nivelados no processo puxador, através do sequenciamento das ordens com base nos tempos dos elementos de trabalho. As ordens são emitidas pelo setor de PCP. A produção diária varia, conforme os 
produtos de alto tempo são programados. Com isso, o puxador pulsa em ritmos diferentes dependendo do mix.

Trata-se de uma boa opção, por nivelar a programação e manter menos estoque do que num supermercado (opção anterior). O inventário já está vendido, portanto ele não é sentido por muito tempo.

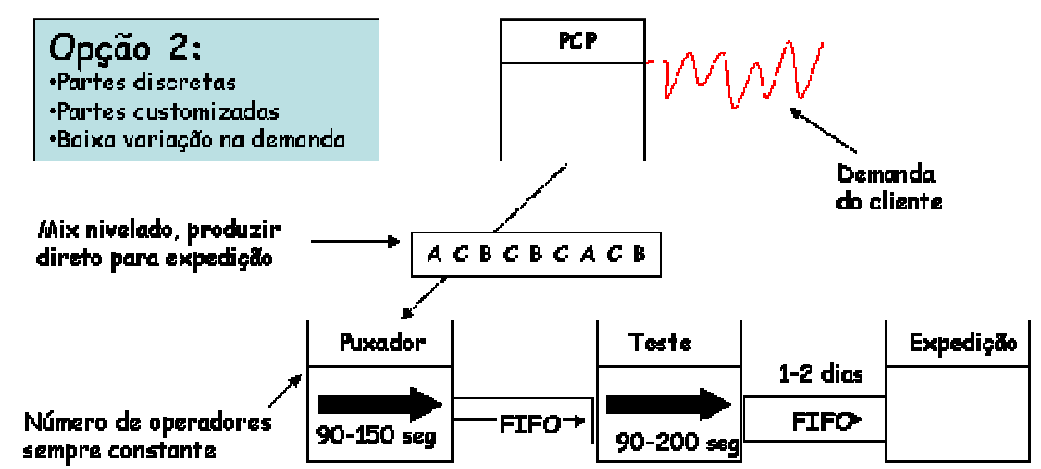

Figura 36: Opção de balanceamento 2, nivelar a programação e criar um FIFO direto para a expedição

Fonte: Duggan (2002)

Esta opção funciona melhor nas situações em que o processo puxador encontra-se no final do fluxo de valor, perto do cliente, tornando viável a produção de produtos customizados com um mesmo lead time que os produtos normais. Já os processos fluxo acima tendem a pulsar num ritmo diferente do puxador. Com isso, o fluxo FIFO tende a ficar muito longo para absorver as variações de todos os processos fluxo acima. Isto pode aumentar o lead time e forçar o PCP a descobrir o que os clientes querem com vários dias de antecedência e fazê-lo através da emissão de ordens firmes.

Mas, se a demanda apresentar grandes variações e começar a haver muitas ordens de alto volume de produtos como o C (figura 31), a opção híbrida de nivelar a programação com um supermercado e, ao mesmo tempo, produzir diretamente para a expedição torna-se mais interessante.

Opção 3: Nivelar a programação com um supermercado e, ao mesmo tempo, produzir diretamente para a expedição

Nesta opção, deve-se colocar os itens best sellers (alto volume) num supermercado de produtos acabados. Este supermercado funcionará como um 
estoque pulmão ou de segurança. A mão de obra permanece constante e o PCP nivela as ordens de produção conforme os tempos dos elementos de trabalho. Nos picos de demanda, puxa-se os produtos do supermercado de acabados e, ao mesmo tempo, produz-se as ordens daqueles produtos não best sellers. Quando a demanda estiver baixa e houver capacidade ociosa, repõe-se o supermercado (figura 34).

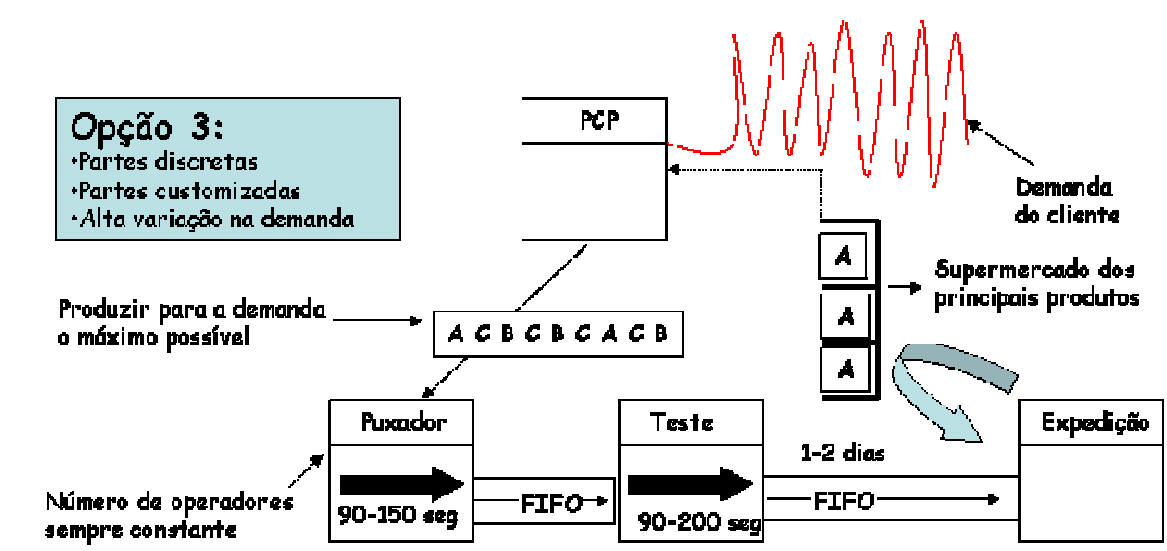

Figura 37: Opção 3, Nivelar a programação com um supermercado e, ao mesmo tempo, produzir diretamente para a expedição

Fonte: Duggan (2002)

Esta opção funciona bem em ambientes com alta variedade de produtos, permitindo manter constante o número de operadores e minimizando o nível de inventário, visto que apenas os best sellers são mantidos no supermercado.

Todavia, ainda é necessário saber o que os clientes querem com pelos menos alguns dias a frente do lead time no sentido de realizar uma programação nivelada, e o processo puxador ainda pulsa em ritmos diferentes. Logo, não se terá um volume de produção diária nivelado.

Nas situações em que o cliente quiser uma velocidade de resposta maior pode ser necessário balancear o takt time e adicionar operadores quando um produto excede o takt time, como forma de tentar literalmente produzir para a demanda.

Opção 4: Balancear o takt time e adicionar operadores quando um produto excede o takt time

Outra opção é balancear cada produto em um tempo de ciclo planejado e acrescentar operador quando o tempo de ciclo do produto exceder o takt 
time, com um pequeno supermercado de segurança para absorver os picos na demanda.

Esta opção é útil principalmente nas situações em que há processos entre o puxador e a expedição, ou quando os produtos customizados podem ser entregues juntos com os produtos normais. Ela fornece uma velocidade consistente através do fluxo de valor, à medida que o output do puxador é constante. Trata-se também de uma boa opção quando não se sabe o que os clientes vão querer no dia seguinte, e a empresa não quer gerar estoques produzindo os produtos errados (figura $35)$.

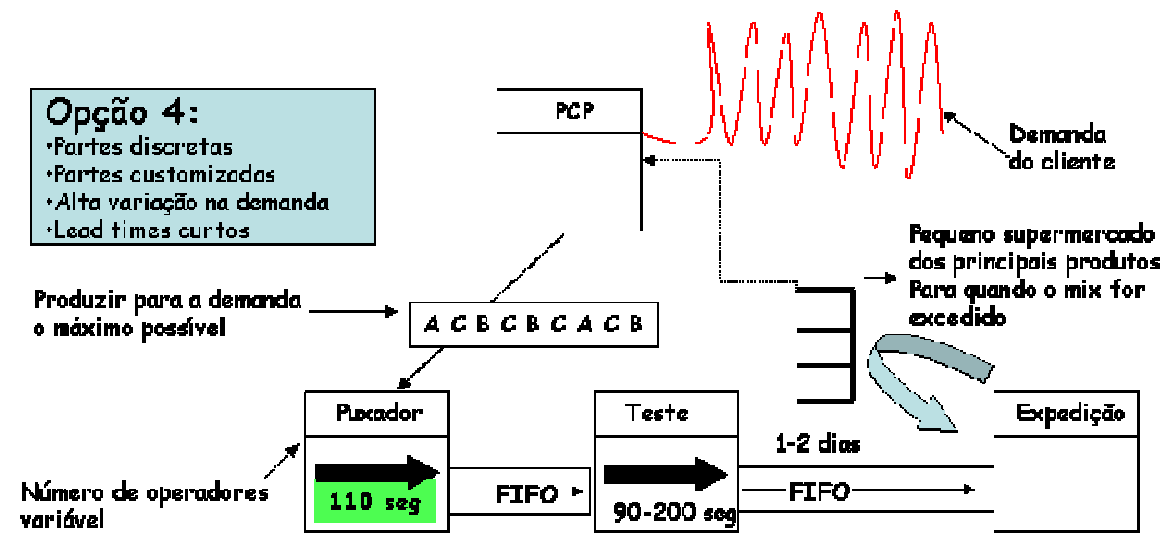

Figura 38: Opção 4, Balancear o takt time e adicionar operadores quando um produto excede o takt time

Fonte: Duggan (2002)

A maior dificuldade está na inserção e retirada de operadores com base no mix de produtos em pequenos lotes com base no tempo dos elementos de trabalho. 


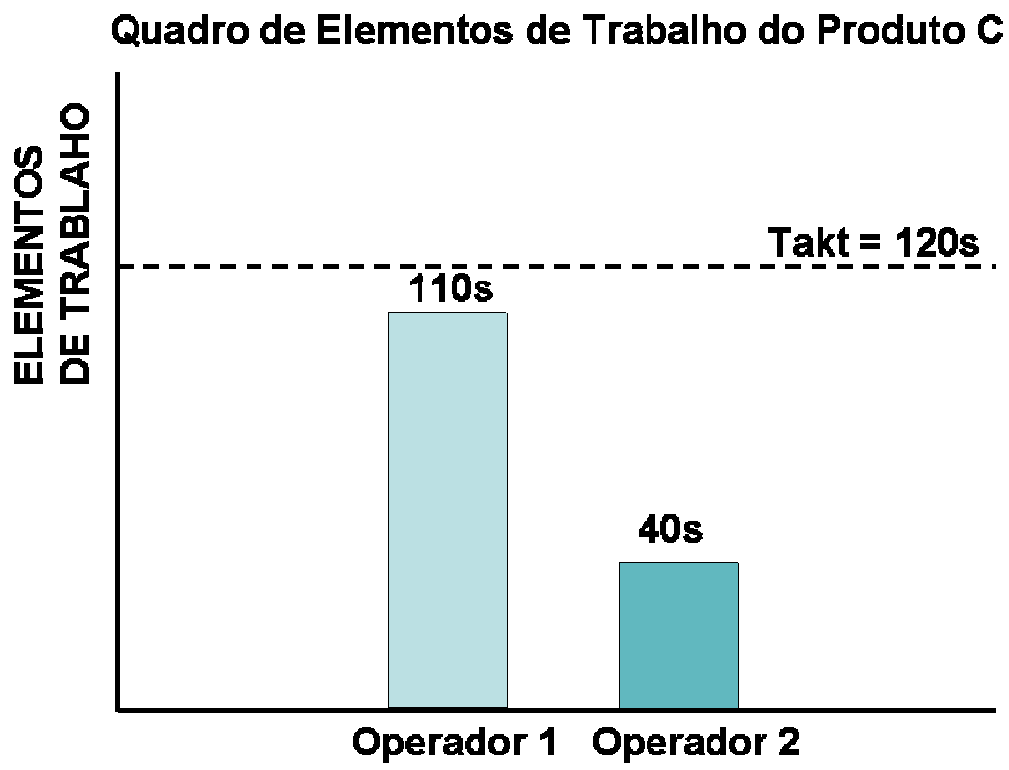

Figura 39: Balanceamento dos operadores com base nos elementos de trabalhado do produto C Fonte: Duggan (2002)

Uma outra restrição a ser considerada no processo de redução do tamanho dos lotes no puxador são os requisitos de setup entre os modelos.

\section{B. Requisitos de setup entre os modelos}

Se os tempos de setup forem longos na célula de montagem (o processo puxador), fica difícil nivelar significativamente o processo puxador reduzindo o tamanho dos lotes, porque uma quantia substancial de tempo de produção será perdida. Enquanto não for possível reduzir esses tempos (incluindo o tempo para mudanças de ferramentas e o tempo para colocar os materiais nos locais certos para o próximo modelo), haverá limitações no tamanho dos lotes devido aos setup. Deve-se tomar cuidado em não converter o tempo liberado pelos setups mais curtos em maior produção e não em redução no tamanho dos lotes.

\section{Intervalo pitch de produção}

O pitch de produção determina a extensão máxima na qual o processo puxador pode ser nivelado pelo mix. Trata-se de um conceito lean e é calculado pela multiplicação do takt time pela quantidade em uma embalagem (número de produtos por contêiner transferido para os produtos acabados a partir da célula de montagem). 


\begin{tabular}{|l|l|l|l|l|}
\hline Takt time & $\mathrm{X}$ & Quantidade na embalagem & $=$ & Pitch \\
\hline $54 \mathrm{~s}$ & $\mathrm{X}$ & 10 peças & $=$ & $540 \mathrm{~s}(9 \mathrm{~min})$ \\
\hline
\end{tabular}

Quadro 11: Exemplo de cálculo de pitch de produção

Fonte: Smalley (2005)

Conhecendo o tempo disponível diário de produção, a demanda diária do cliente por modelo e o tamanho mínimo do lote, deve-se nivelar a produção por mix. Para isso, é necessário dividir o tempo de produção disponível pelo pitch tendo em vista calcular o número de intervalos pitch disponíveis para atender à demanda.

\begin{tabular}{|l|l|l|l|l|}
\hline Tempo disponível & $/$ & Pitch & $=$ & Quantidade de Intervalos \\
\hline $450 \mathrm{~min}$ & $/$ & $9 \mathrm{~min}$ & $=$ & 50 intervalos \\
\hline
\end{tabular}

Quadro 12: Exemplo de cálculo de quantidade de intervalos pitch Fonte: Smalley (2005)

Logo abaixo, é ilustrado um exemplo de quadro de programação e nivelamento (Heijunka Box), de acordo com os cálculos realizados.

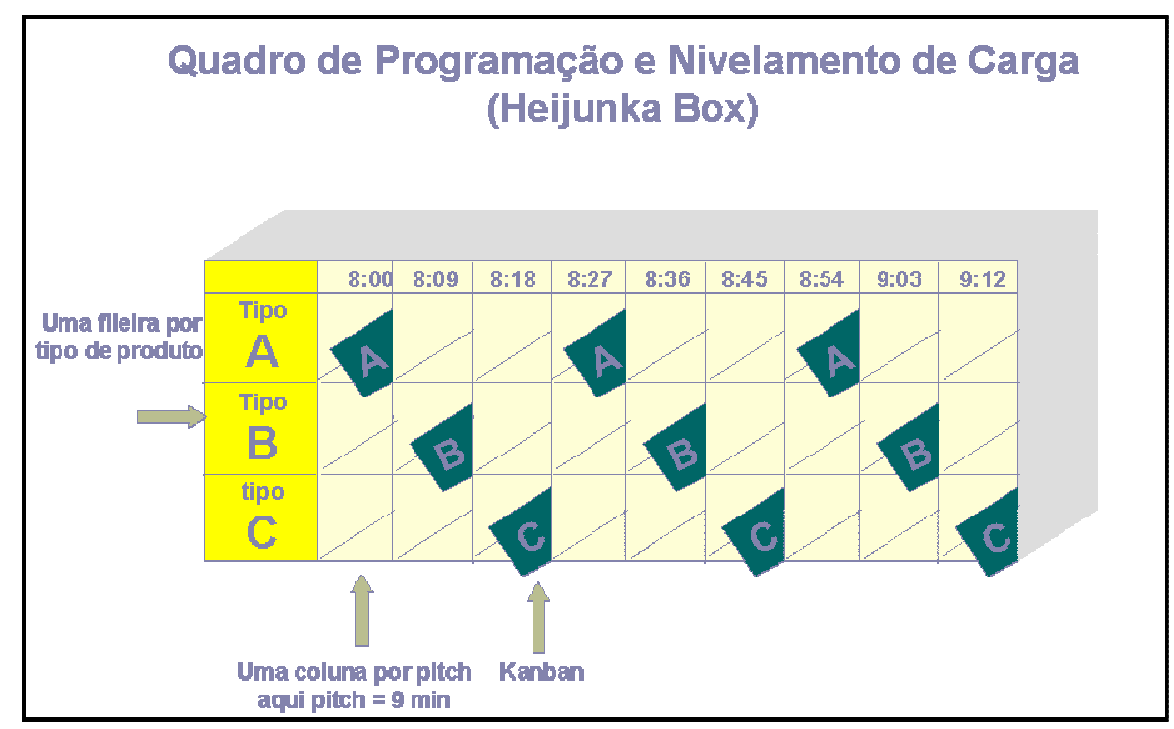

Figura 40: Exemplo de Heijunka Box Fonte: Rothers e Shook (1998)

Vale ressaltar que mesmo a melhoria do nivelamento e da puxada da programação da montagem final não resolverá todos os problemas da produção. 
Serão necessários mais kaizens pontuais para estabilizar a produção da célula de montagem. De forma ainda mais importante, pode-se não conseguir reagir a problemas na montagem final tão rapidamente quanto requerem os casos em que os intervalos pitchs são muito pequenos. Com isso, ajustes de curto prazo podem ser necessários. Uma boa solução é trabalhar com múltiplos do pitch de forma a obter um intervalo que seja coerente com o nível atual de estabilidade da empresa.

A partir da análise $\mathrm{ABC}$ (de volume), devem-se alocar os intervalos calculados por categoria de peça.

\begin{tabular}{|l|l|l|l|l|l|}
\hline Intervalo total & $\mathrm{x}$ & $\begin{array}{l}\% \text { do mix de } \\
\text { produção }\end{array}$ & $=$ & Intervalo por item & $\begin{array}{l}\text { Tempo } \\
\text { equivalente }\end{array}$ \\
\hline 50 intervalos & $\mathrm{X}$ & $60 \%$ & $=$ & 30 reservados para As & $9 \mathrm{minx} 30=270 \mathrm{~min}$ \\
\hline 50 intervalos & $\mathrm{X}$ & $20 \%$ & $=$ & 10 reservados para Bs & $9 \mathrm{minx} 10=90 \mathrm{~min}$ \\
\hline 50 intervalos & $\mathrm{X}$ & $20 \%$ & $=$ & 10 reservados para Cs & $9 \mathrm{minx} 10=90 \mathrm{~min}$ \\
\hline
\end{tabular}

Quadro 13: Exemplo de cálculo de intervalos de tempo por itens A, B e C Fonte: Smalley (2005)

De acordo com a lógica acima, durante cada turno, 60\% do tempo disponível seria dedicado á reposição dos itens A, 20\% para os itens B e $20 \%$ para os itens C.

É interessante observar que o Heijunka Box exerce uma função nova a este tipo de aplicação, porque permite a conciliação de kanbans e execução de ordens na mesma célula.

Por fim, uma visão conservadora de sistemas de produção tende a generalizar a classificação das partes e do sistema de controle a ser usado, tornado impossível a aplicação de conceitos de Produção Enxuta em várias situações. Daí a necessidade de se projetar uma sistemática de desenvolvimento de sistemas híbridos de programação e controle orientados para ambientes de produção enxuta. 


\section{MÉTODO PARA DESENVOLVIMENTO DE SISTEMAS HÍBRIDOS DE PLANEJAMENTO E PROGRAMAÇÃO PARA AMBIENTES DE PRODUÇÃO ENXUTA}

Essa seção objetiva apresentar um método de desenvolvimento de sistemas híbridos de planejamento e programação da produção para ambientes de manufatura enxuta que possuam alta variedade de produtos, estruturas complexas, variabilidade dos lead times e demanda flutuante.

Este método foi desenvolvido ao longo de cinco anos de pesquisa. Foram realizadas aplicações práticas em quatro empresas, sendo em média um ano de visitas semanais por empresa (Capítulo 4). Para tanto, foram propostos e detalhados um conjunto de passos seqüenciais, tendo em vista atingir os seguintes objetivos intermediários:

- Construção da visão geral do novo sistema de planejamento e programação.

- Definição de procedimentos para a criação das sub-famílias de programação e controle.

- Definição de procedimentos para identificação e programação do processo puxador para cada subfamília, e dos fluxos puxados e empurrados ao longo do fluxo de valor.

\& Definição de procedimentos para a construção de supermercados dinâmicos, que sejam flexibilizados de acordo com as flutuações da demanda.

- Definição de procedimentos para o nivelamento da demanda e do(s) processo(s) puxador(es).

* Definição de procedimentos para a implantação efetiva do novo sistema de planejamento e programação. 
A seguir, são apresentadas as etapas do método proposto.

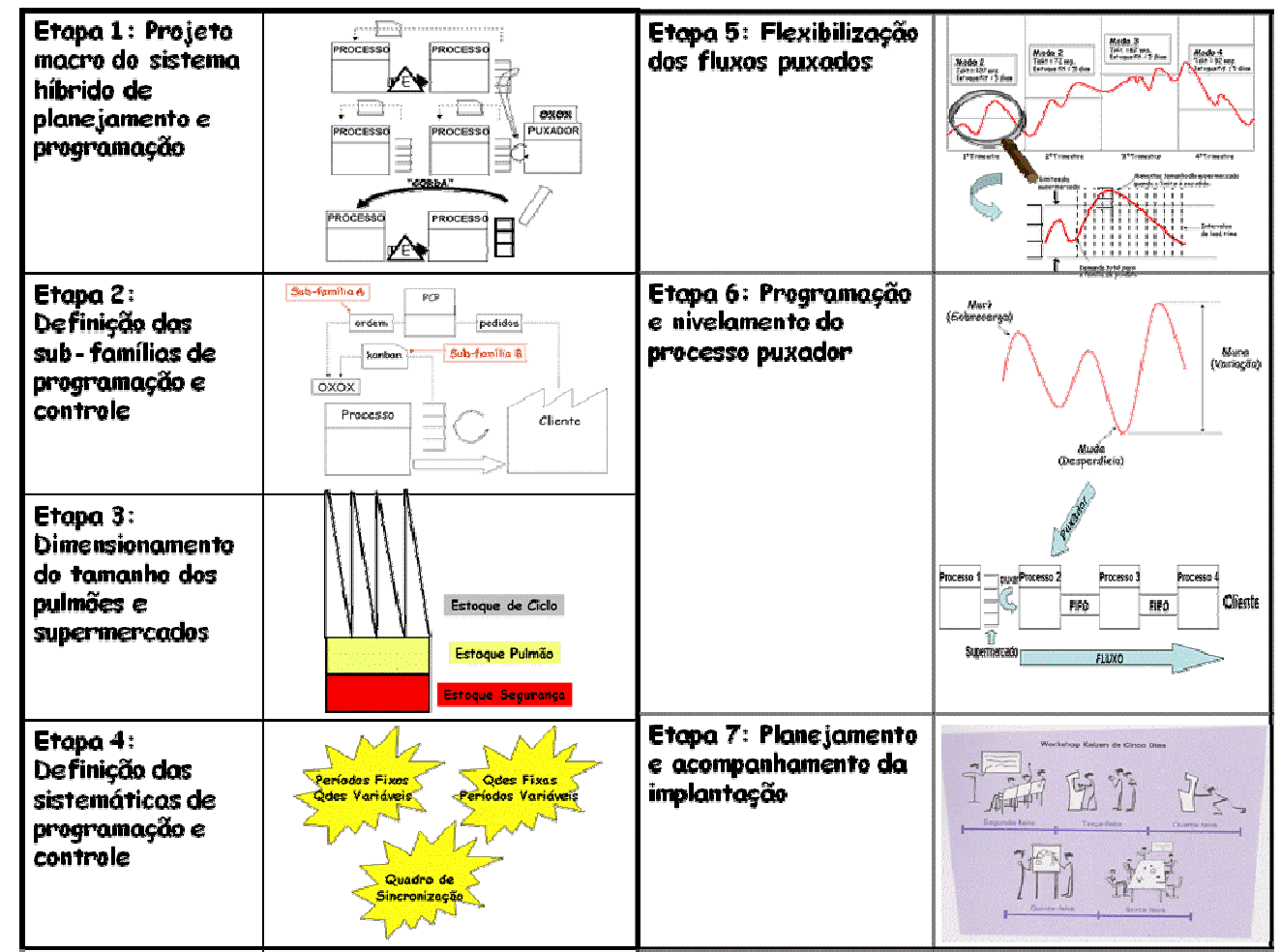

Quadro 14: Etapas do método proposto.

De acordo com o quadro acima, primeiramente é necessário elaborar o projeto de situação futura do sistema de planejamento e programação da produção. Nesta etapa serão discutidos os principais critérios para identificação dos locais mais adequados para se programar e controlar o fluxo de material. Trata-se de um kaizen de fluxo, que visa identificar o processo puxador para cada subfamília e, ao mesmo tempo, definir qual a melhor maneira dos demais processos se interligarem (fluxo, supermercados ou pulmões). Portanto, o projeto macro de um sistema de programação da produção deverá iniciar com a definição dos pontos de supermercado, pulmões e do processo puxador para cada subfamília.

Na etapa 2, é definido a melhor forma de programação e controle para cada item. Introduz-se o conceito de subfamílias de programação e controle, com base na combinação de três fatores: a análise $\mathrm{ABC}$ de custos e de volume, e a freqüência da demanda de cada item. Um output muito importante desta etapa é que 
um mesmo produto poderá ter itens que serão programados de formas diferentes (kanban, ordem, pulmão, 2 gavetas, etc.).

Na etapa 3 será dimensionado o tamanho do estoque de cada item nos pontos de supermercado e de pulmão definidos.

Na etapa 4 é proposta uma sistemática de programação e controle dos fluxos puxados. Basicamente, a idéia é fornecer as diretrizes para escolher qual a política mais apropriada de reposição dos supermercados: reposição por quantidades fixas versus reposição por período fixo.

$\mathrm{Na}$ etapa 5, são apresentadas algumas estratégias para flexibilização dos fluxos puxados. São discutidas técnicas para ajuste, conforme a demanda, do tamanho de cada supermercado. Um ponto interessante é a análise realizada em torno da melhor forma de se ajustar o tamanho do supermercado: alterando a quantidade de itens por cartão versus a alteração da quantidade de cartões. O objetivo é criar um sistema puxado robusto capaz de absorver as flutuações da demanda.

Na etapa 6, a programação e nivelamento do processo puxador visa garantir um fluxo o mais ininterrupto possível, mesmo para ambientes de grande variedade de itens com diferentes características de demanda. Muitas empresas ainda tratam o desnivelamento como um "fato da vida", ou seja, como algo que está fora da sua esfera de controle. Nesse sentido, apresenta também algumas diretrizes para se criar uma rotina de busca contínua pelo nivelamento da demanda.

Por fim, a etapa 7 discorre sobre a técnica de evento kaizen para suportar o planejamento e acompanhamento da implantação. Esta etapa foi inserida neste método depois que se notou que as pessoas apresentaram grande dificuldade em conciliar suas atividades rotineiras com as atividades de melhoria. $\mathrm{O}$ envolvimento do pessoal de nível operacional na implantação é imprescindível para a ancoragem de um novo sistema de planejamento e programação da produção.

O detalhamento de cada etapa é apresentado a seguir:

\subsection{Projeto macro do sistema híbrido de planejamento e programação da produção}


De acordo com a revisão bibliográfica deste trabalho, o projeto de situação futura de um sistema de planejamento e programação para ambientes de produção enxuta deve atender à alguns princípios (WOMACK; JONES, 1996):

1. Identificar a cadeia de valor para cada produto

2. Fazer $o$ valor fluir sem interrupções

3. Deixar com que o cliente puxe o valor do produtor.

Com isso, após o mapeamento do fluxo de valor, projeto macro deve começar com a definição dos pontos mais adequados para se programar e controlar o fluxo de material. Trata-se de definir qual a melhor maneira dos processos se interligarem. Idealmente, todo processo deveria estar conectado ao outro em um fluxo contínuo. Contudo, freqüentemente há pontos no fluxo de valor onde não é possível produzir em fluxo. Entre as razões principais, pode-se destacar que alguns processos:

\# Operam com tempos de ciclos muito distintos entre si, o que dificulta a integração entre os mesmos.

São compartilhados por múltiplos fluxos de valor.

Estão localizados a certa distância dos processos adjacentes, o que impede o transporte unitário de peças.

Apresentam lead time muito elevado.

Apresentam baixa confiabilidade para operarem em conjunto com outros processos.

De acordo com o tópico 2.5, da revisão bibliográfica deste trabalho, a escolha estratégica de qual é o sistema mais apropriado para cada situação, assim como a sua gestão, deve estar ligada e coerente com os objetivos estratégicos da manufatura e com o tipo de processo produtivo envolvido (CORREA; GIANESI, 1996).

Os objetivos estratégicos da manufatura refletem as diferenças entre os vários segmentos de mercado a atingir, os quais vão demandar diferentes níveis de desempenho nos diferentes critérios (qualidade, custo, entrega e flexibilidade) que o sistema de manufatura pode influenciar. Nesse sentido, a definição dos pontos de 
controle ao longo do fluxo de valor pode ser mais bem compreendida quando levamos em consideração a relação de cliente e fornecedor interno entre os processos, que também pode ser regulada sob a perspectiva dos objetivos estratégicos da manufatura.

Quanto ao tipo de processo produtivo, em famílias de itens padronizados, e demanda freqüente, a programação e controle dos processos deve, de alguma, forma estar associada à demanda dos processos posteriores. Uma boa forma de se fazer isso é através da utilização de supermercados de produção.

Por outro lado, em famílias de produtos com estruturas mais complexas (itens não padronizados), e demanda não freqüente, a utilização de supermercados tende a tornar-se inviável, ao menos enquanto os produtos não forem suficientemente padronizados para isso. Agregadamente, o estoque em processo torna-se excessivamente alto, caro e volumoso ("espaçoso"). Com isso, a política de atendimento da demanda, tanto interna quanto externa, ao longo de todo o fluxo de valor tende a tornar-se predominantemente do tipo MTO (Make To Order - Fabricar sob Encomenda) ou ETO (Engineering To Order - Projetar sob Encomenda). Em situações com processos em paralelo e com longos lead times, a falta de sincronização entre os fluxos somada à variabilidade dos lead times resulta em paradas constantes na produção por espera de itens. Nesse sentido, também é importante "quebrar" cada fluxo de valor em partes menores e mais fáceis de serem administradas. Nesses casos, a relação entre os processos pode ser regulada através da utilização de pulmões. Assim como nos pontos de supermercado, cada ponto de pulmão funcionaria como um delimitador de loops de produção.

Os sistemas MRP II têm uma vocação especial para lidar com produtos que têm estruturas complexas e variedade de itens, pois permitem um planejamento detalhado (e antecipado) das necessidades de recursos da organização. Entretanto, problemas geralmente ocorrem quando o sistema MRP II tenta gerenciar os níveis mais baixos e detalhados de atividades. Neste nível, o sistema pode tornarse pesado e necessitar que as pessoas envolvidas nas atividades da fábrica tenham uma atitude disciplinada, informando ao sistema, de forma freqüente, praticamente tudo o que ocorre. Por isso, muitos autores consideram que o MRP II é mais apropriado para os níveis mais altos de controle: planejamento agregado da 
produção, programação-mestre e planejamento de insumos, sendo considerado complexo, detalhado e centralizado demais, quando se trata de controlar as atividades da fábrica. Esta seria uma vocação mais natural do JIT com seus controles visuais simplificados.

Foi visto no tópico 2.5 da revisão bibliográfica deste trabalho que os defensores do sistema TPC consideram que a transição do MRP II para o TPC é uma transição "natural", visto que o TPC se utiliza de uma base de dados quase idêntica à base de dados se utiliza o MRP II. Se uma empresa trilhou o caminho para o atingimento dos níveis de acuidade de registros na base de dados que o MRP II exige, ela terá ido adiante do que o TPC requer, já que este prescreve que apenas os dados referentes aos recursos gargalos necessitam tais níveis de acuidade.

Por fim, com a utilização de supermercados e pulmões, o PCP precisaria emitir ordens para apenas um ponto ao longo do fluxo de valor, visto que, de alguma forma, todos os processos estarão interligados. Este ponto é chamado de “processo puxador" (PP), porque é ele quem define o ritmo de produção de todos os processos.

Portanto, o projeto macro de um sistema de programação da produção deverá iniciar com a definição dos pontos de supermercado, pulmões e puxador.

\subsubsection{Definição dos pontos de supermercado}

Ao se desdobrar os objetivos estratégicos da manufatura para a relação entre os processos, a definição dos pontos de programação e controle poderá ser feita tanto sob a perspectiva do processo produtor (fornecedor) quanto sob a perspectiva do processo consumidor (cliente). Em ambientes de alta variedade, processos passíveis de produzirem para supermercado, ou de terem um supermercado à sua disposição, normalmente demandam os seguintes objetivos de desempenho:

a) Processos com necessidade de alta flexibilidade de mix

b) Processos com necessidade de alta flexibilidade de volume

c) Processos com necessidade de pontualidade ou de sincronização

d) Processos pouco confiáveis ou de baixa qualidade 
e) Processos com necessidade de alta rapidez:

A relação dos processos com esses objetivos será detalhada a seguir:

a) Processos com necessidade de alta flexibilidade de mix.

Em ambientes com alta variedade de itens, é comum encontrar processos que são compartilhados por múltiplos fluxos de valor. Este tipo de processo tende a incorrer em desperdícios de superprodução, esperas e, consequentemente, em estoques desnecessários, atrasos, faltas e horas extras. Estas características normalmente são comumente encontradas em processos tipicamente compartilhados como estamparias, usinagem, corte, dentre outros.

Nesses casos, o supermercado tende a funcionar como um estoque regulador, através de:

- Limitação da quantidade máxima de cada item a ser produzida.

- Reposição daquilo que foi efetivamente consumido.

○ Auxílio à priorização da reposição dos kanbans.

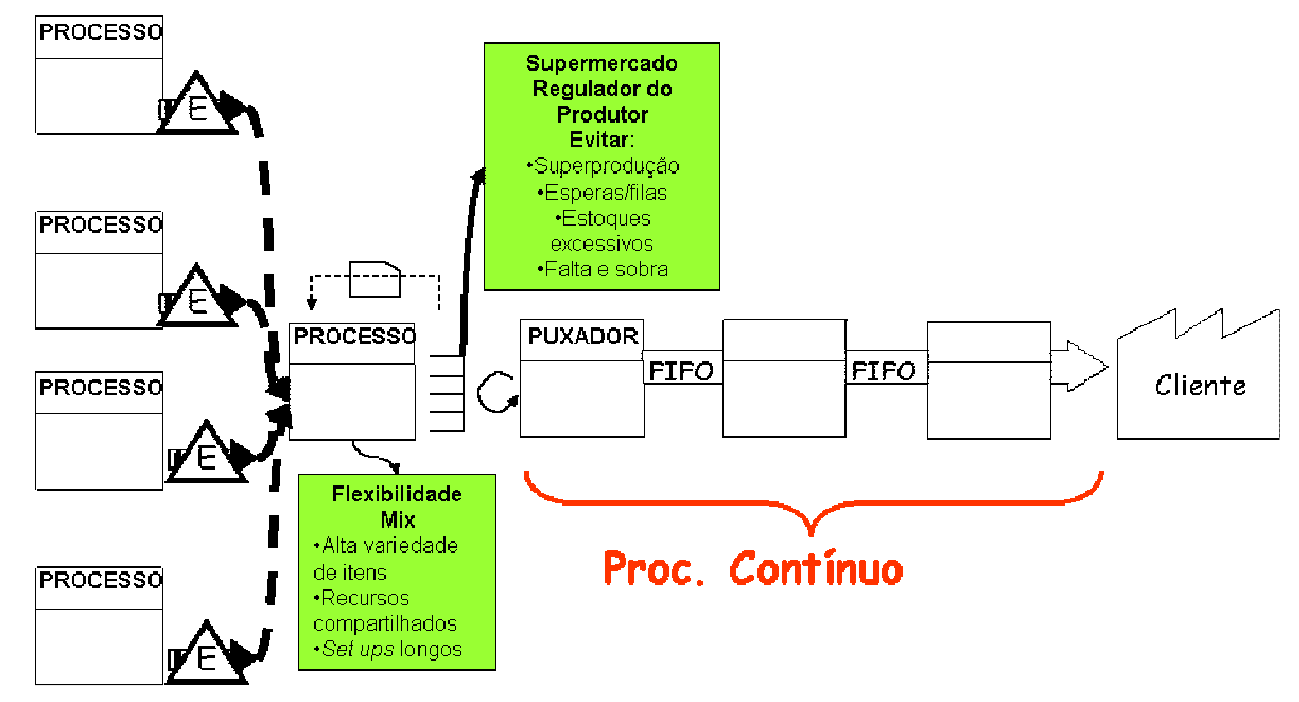

Figura 41: Supermercado regulador em fluxo com alta variedade de itens, recursos compartilhados e altos tempos de set up

b) Processos com necessidade de alta flexibilidade de volume: 
Flutuações na demanda (externa e interna) tendem a tornar o processo ora em gargalo ora em recurso ocioso. Situações de pico na demanda resultam em desperdícios de espera e, consequentemente, atrasos, faltas e horas extras. Nesses casos, um ponto de supermercado de itens acabados funciona como um estoque pulmão dos itens mais freqüentes. A idéia é liberar capacidade produtiva nos períodos de pico e realizar sua reposição nos períodos de folga na capacidade.

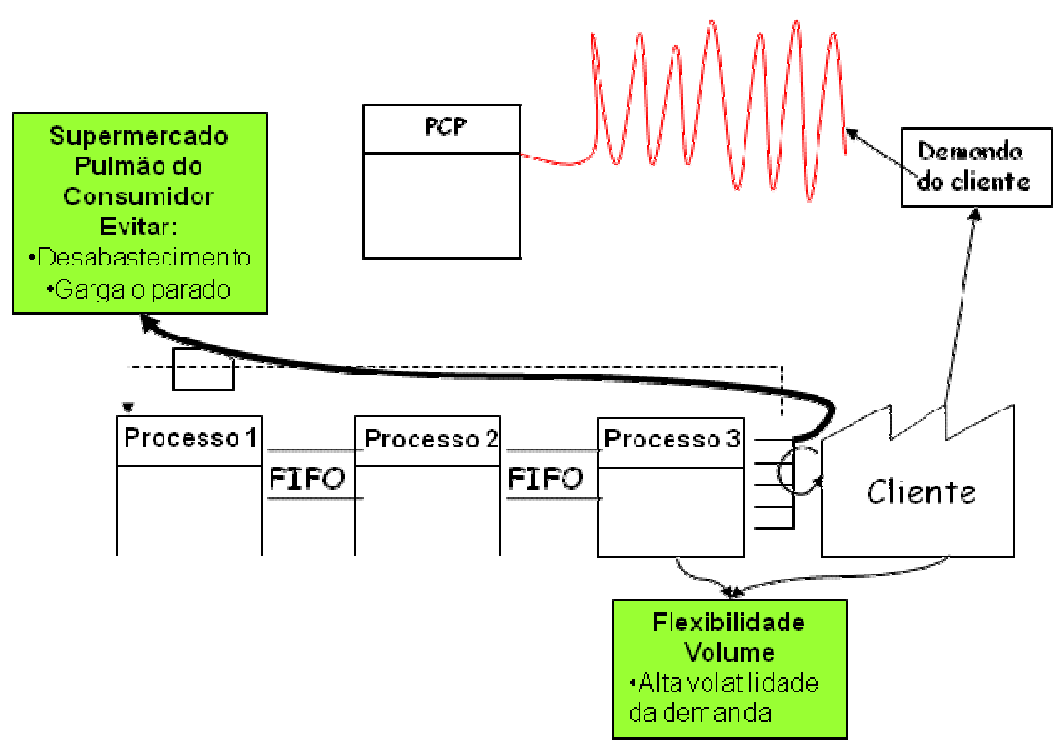

Figura 42: Supermercado pulmão em fluxo com alta volatilidade da demanda

c) Necessidade de pontualidade ou de sincronização:

Esta situação é comum em processos que representam o agrupamento de vários componentes, como soldas e montagens. Atrasos, quebras de máquina, problemas de qualidade são contingências do dia a dia do chão de fábrica que causam o descompasso na chegada dos itens para essas montagens. A falta de sincronização na chegada destes componentes é causada por imprevistos perante os quais os sistemas MRP (empurrados) não conseguem reagir rapidamente. Nesses casos, um supermercado pulmão tende a absorver, pelo menos no curto prazo, esses descompassos do dia a dia. 


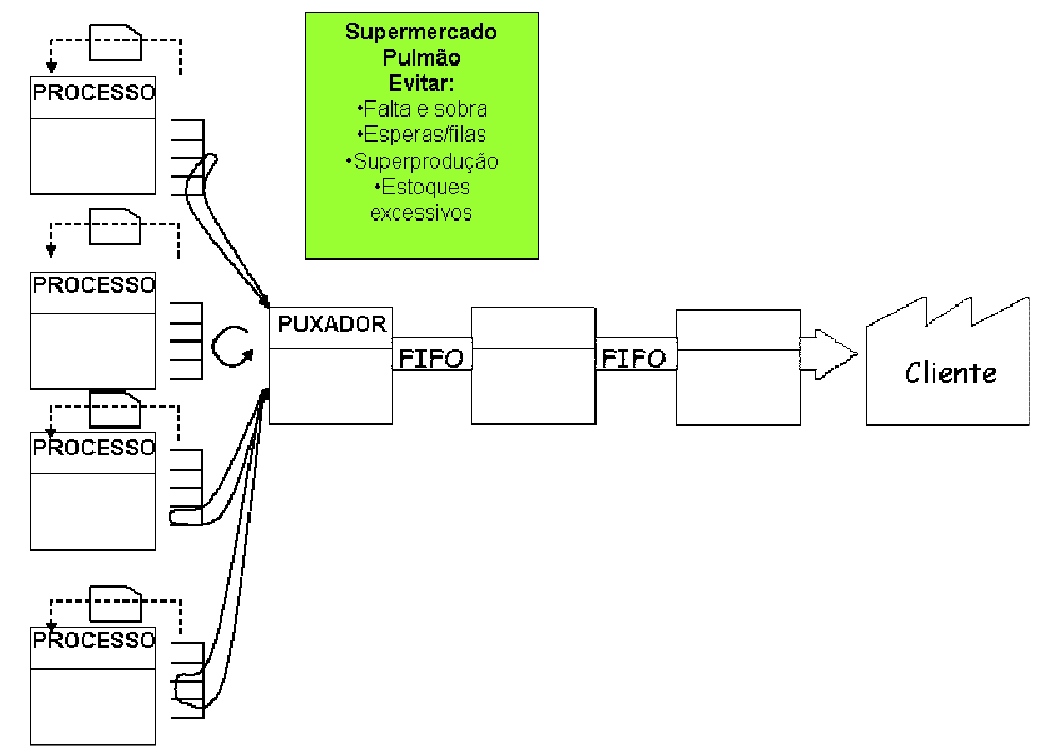

Figura 43: Supermercado pulmão para combater a falta de sincronização na chegada de itens

d) Processos pouco confiáveis ou de baixa qualidade:

Situações em que teoricamente poder-se-ia ter fluxo contínuo, mas não existe confiabilidade suficiente em um dado processo para colocá-lo em fluxo com os demais. Até que as causas raízes sejam eliminadas, recomenda-se a criação e a manutenção de um supermercado de segurança. Os itens deste supermercado só seriam consumidos em momentos de imprevistos como quebras de máquina, atrasos de fornecimento ou problemas de qualidade. Sua reposição ocorreria em períodos de folga na capacidade e, se necessário, em turnos adicionais ou com horas extras.

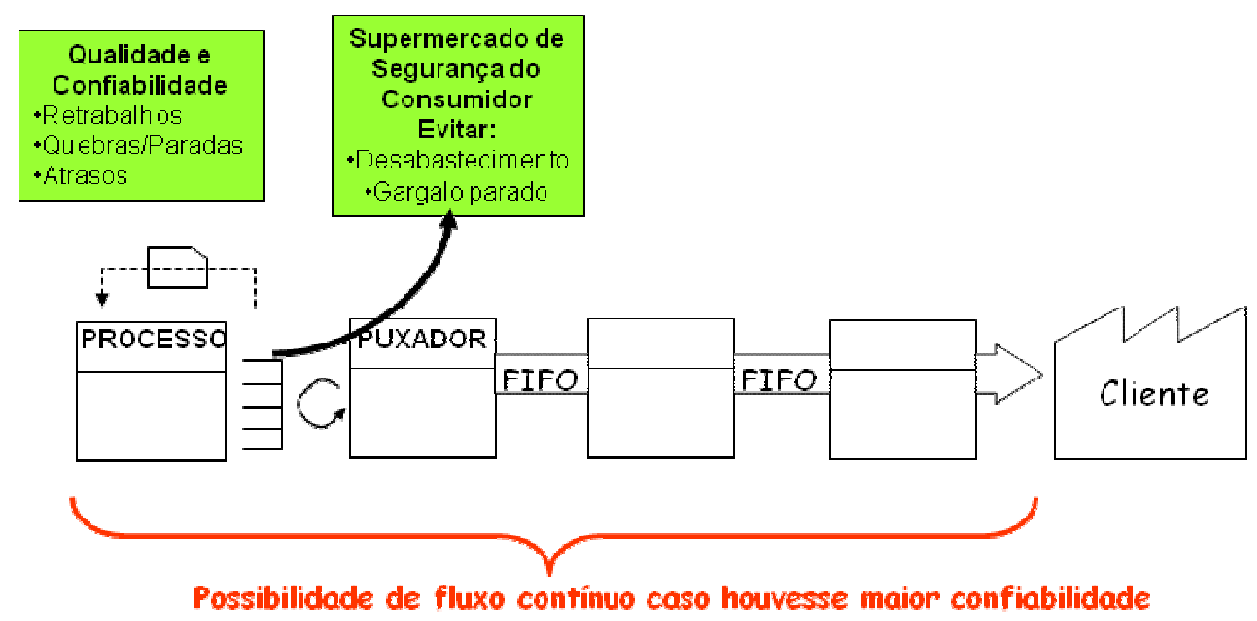

Figura 44: Supermercado de segurança em fluxo com problemas de retrabalho, atrasos e paradas não programadas. 


\section{e) Necessidade de alta rapidez:}

f) Principal razão associada: “Apresentam lead time muito elevado".

Trata-se de situações em que os processos apresentam longos lead times (fornecedores, terceiros) ou que a tolerância de espera pelo cliente externo é menor que a velocidade de resposta do processo. Normalmente, resultam na necessidade de supermercado de produtos acabados, matéria prima, peças terceirizadas ou componentes de reposição (ex.: acessórios/opcionais/peças de reposição).

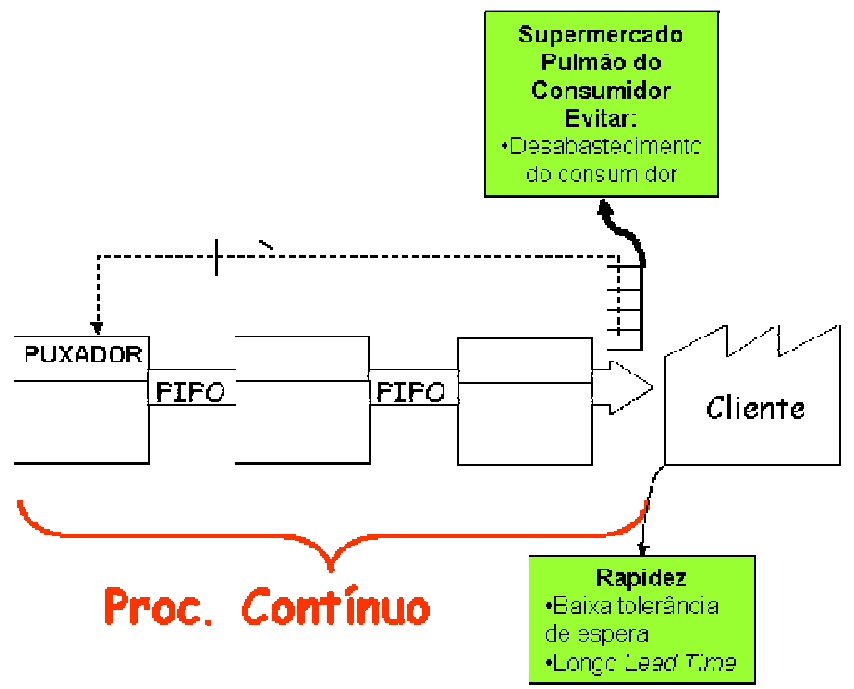

Figura 45: Supermercado pulmão em fluxo com baixa tolerância de espera pelo cliente externo

Outra situação que pode demandar maior rapidez, e conseqüentemente um ponto de supermercado entre os processos, é quando o produtor e o consumidor estão muito distantes um do outro. Nestes casos, pode-se trabalhar com o sistema de dois kanbans: produção e transporte. 


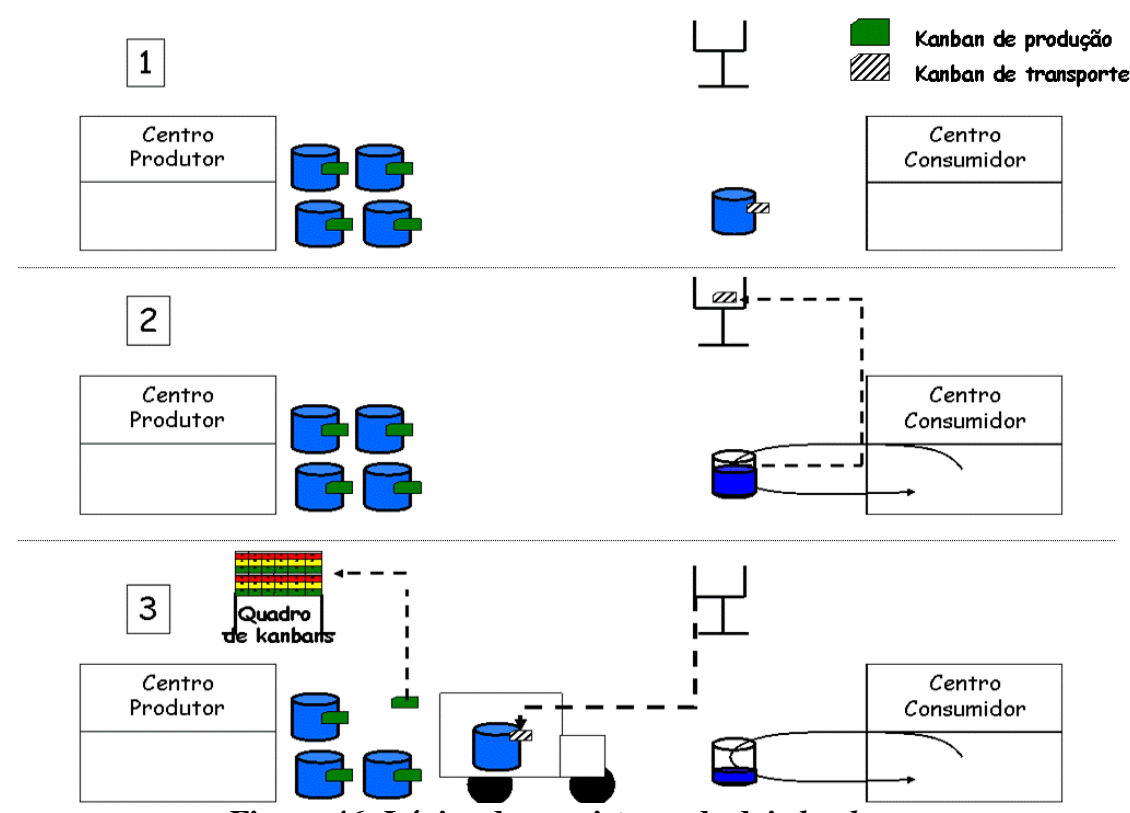

Figura 46: Lógica de um sistema de dois kanbans

Vale ressaltar que num sistema de dois kanbans o tamanho do supermercado não precisa necessariamente ser duplicado (um para cada ponto). A duração do lote de kanban junto ao ponto de consumo precisa ser igual ao ciclo de transporte.

O uso do sistema de dois kanbans é muito comum nas relações entre clientes e fornecedores externos. Mas, internamente nas fábricas este tipo de sistema também é recomendado em situações que há falta de espaço físico no consumidor. A ocupação de área nobre da fábrica com estoques implica na redução de espaço físico para os processos produtivos em geral, ou seja, que agregam valor para o cliente. Quanto mais próximo do cliente externo o processo estiver mais força ganha esse princípio. Com isso, é sempre importante analisar a relação custo benefício de maior transporte para abastecimento versus a ocupação de espaço físico no consumidor. A idéia é picar o supermercado em pequenos lotes que fluem de forma afunilada para o consumidor na quantidade requerida pelo kanban de transporte ou retirada.

Portanto, basicamente, um supermercado irá funcionar ora como um estoque regulador, quando analisado sob a perspectiva do produtor, ora como um estoque pulmão ou de segurança, quando analisado sob a perspectiva do consumidor.

Por outro lado, em famílias de produtos com estruturas mais complexas (itens não padronizados), e demanda não freqüente, a utilização de 
supermercados tende a tornar-se inviável, ao menos enquanto os produtos não forem suficientemente padronizados para isso. Nesses casos, a relação entre os processos pode ser regulada através da utilização de pulmões.

\subsubsection{Definição dos pontos de pulmão}

Em famílias de itens com políticas de atendimento da demanda to tipo MTO (Make To Order - Fabricar sob Encomenda) ou ETO (Engineering To Order Projetar sob Encomenda), com processos em paralelo e com longos lead times,

também é importante "quebrar" cada fluxo de valor em partes menores e mais fáceis de serem administradas. A idéia é criar pulmões como pontos de controle intermediários, evitando que atrasos e faltas de peças sejam percebidos e trabalhados somente no final do fluxo de valor.

Nestes casos, os pulmões podem assumir três papéis:

- Pulmão de proteção para evitar que o recurso gargalo pare (desperdício de espera no gargalo).

- Pulmão de sincronização do gargalo com os fluxos paralelos, ou seja, trata-se também de um pulmão de proteção que visa evitar que itens sejam processados no gargalo antes do necessário (desperdício de superprodução no gargalo).

- Pulmão regulador para controlar o nível máximo e mínimo de estoque em cada fluxo.

$\mathrm{Na}$ figura a seguir, primeiramente foi definido, no fluxo 2, o pulmão protetor do recurso gargalo. O material é liberado para a produção de acordo com a taxa de consumo do recurso restritivo. Isso garante que os estoques em todo o processo produtivo não ultrapassem os níveis do estoque protetor imposto pelo pulmão de tempo.

Por outro, em sistemas com estruturas muito complexas e fluxos em paralelo, proteger o gargalo não significa evitar apenas que ele fique desabastecido (desperdício de espera no gargalo). Significa também evitar que, ao seguir o 
planejamento original do MRP, ele acabe produzindo itens antes da sua "real" necessidade (desperdício de superprodução no gargalo). Não são raras as situações em que itens produzidos no gargalo ficam esperando por outro item de uma mesma ordem de produção, antes de uma montagem, por exemplo.

Com isso, é preciso sincronizar a ordem de entrada dos itens no recurso gargalo com os itens que estão sendo processados nos fluxos paralelos. Essa estratégia de controle pode ser regulada por algum tipo de ferramenta visual, como um quadro. No processo gargalo existe um quadro no qual são controlados todos os recursos necessários (material e informação) por ponto de sincronização (P1, P2 e P3) de cada fluxo. Basicamente, a definição destes pontos, em cada fluxo, deve ser proporcional ao lead time entre o processo gargalo e o início do fluxo. Só a partir do momento em que todo material e informação de todos os fluxos em paralelo estiverem disponíveis é que a operação gargalo poderá ser acionada para produzir o item de determinada ordem de produção.

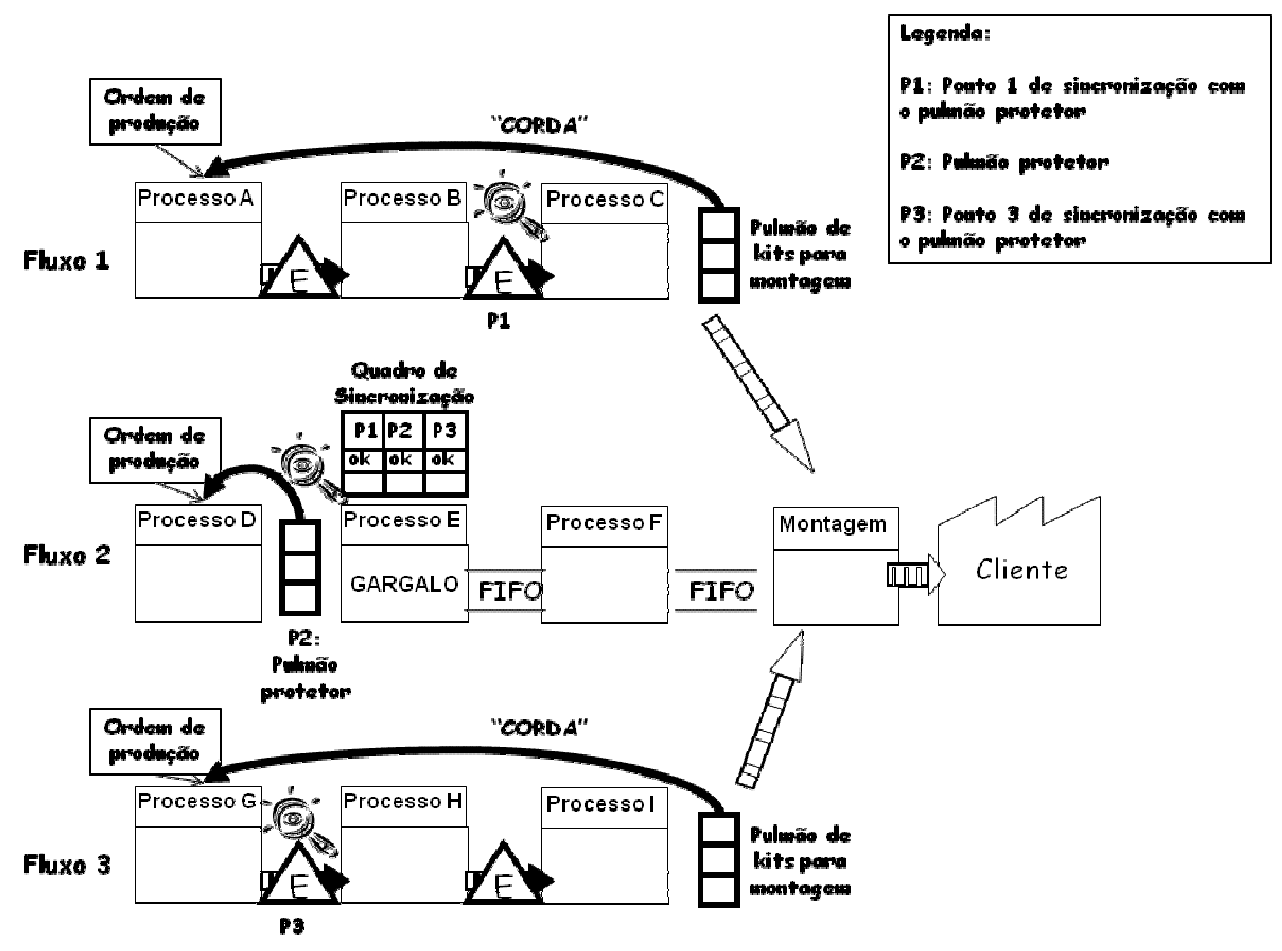

Figura 47: Pontos de controle com pulmões de sincronização de fluxos de valor em paralelo. 
O quadro de sincronização também ajuda a regular a formação do kit dos itens que convergem para o processo de montagem final. A idéia é combater desperdícios como a falta de alguns itens (esperas) e a sobra de outros (estoques desnecessários) na entrada da montagem. Também combate antecipações de montagens (superprodução), à medida que impossibilita que as mesmas sejam iniciadas parcialmente. Ou seja, enquanto um kit não ficar pronto, a montagem do conjunto não deve ser iniciada. Com isso, forçam-se os subsistemas a focarem seus esforços na formação do kit, evitando-se, portanto, estoques, movimentações e transportes excessivos em função de conjuntos montados parcialmente.

Definidos os pontos de supermercado ou de pulmão, o próximo passo consiste em identificar e processo puxador.

\subsubsection{Definição do processo puxador}

O processo puxador é a operação a partir da qual se produz em fluxo contínuo até o cliente final. Denomina-se puxador, pois parte-se da premissa de que todo o fluxo antes dele é regulado por sistemas puxados. Nestes casos, a escolha do processo puxador irá depender do tipo de sistema puxado adotado:

1. Processo puxador para sistemas puxados de reposição

2. Processo puxador para sistemas puxados seqüenciais.

Num sistema puxado de reposição, a expedição será o processo puxador em quase todos os casos.

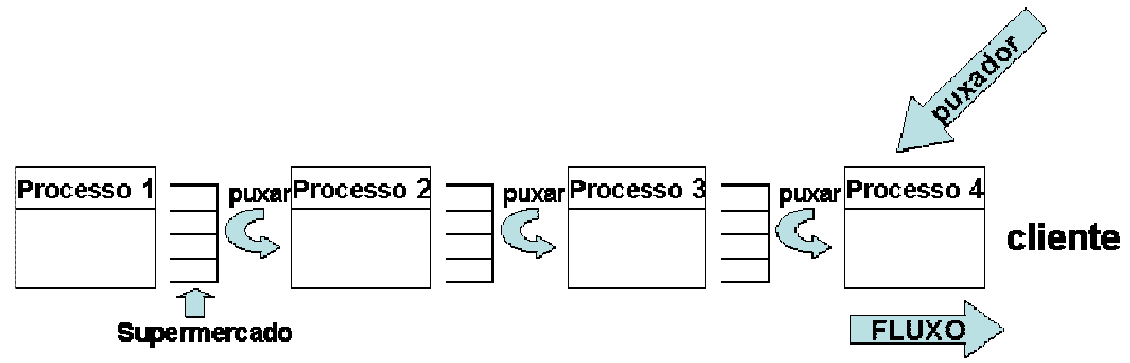

Figura 48: Definição do processo puxador num sistema puxado de reposição 
Num sistema puxado seqüencial, o processo puxador freqüentemente encontra-se no início do fluxo de valor, com outros processos entre ele e a expedição. Pode ser empregado quando houver uma variedade de peças muito grande a ser armazenada em um supermercado. Os produtos são basicamente feitos sob encomenda.

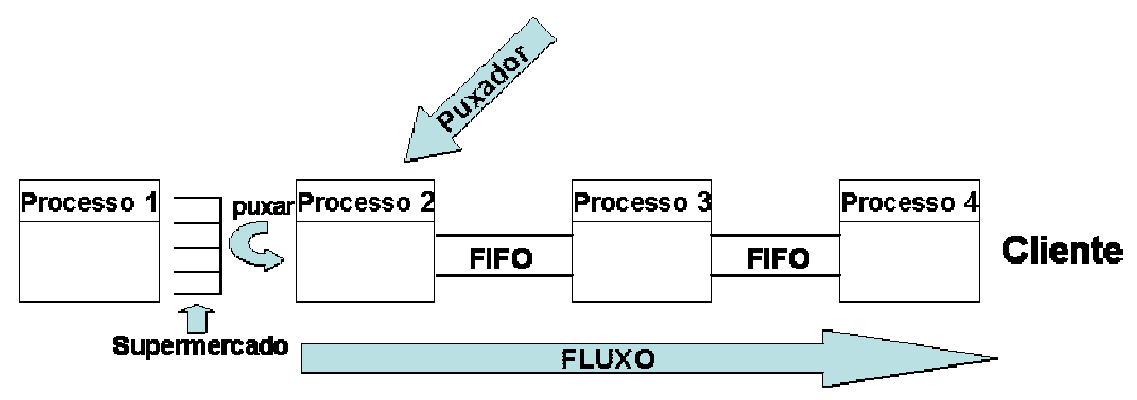

Figura 49: Definição do processo puxador num sistema puxado seqüencial.

Em famílias de itens com políticas ETO ou MTO de atendimento da demanda, pode-se adotar uma estratégia híbrida na definição do processo puxador. Fazendo-se uso dos níveis mais altos de controle: planejamento agregado da produção, programação-mestre e planejamento de insumos, as ordens continuam sendo programadas e emitidas no início do fluxo pelo sistema MRP. Nos níveis mais baixos e detalhados de atividades, o MRP não é o sistema mais apropriado para a programação e controle. Para controlar as atividades da fábrica nesse nível, recomenda-se estabilizar o sistema mediante a formação de pontos de sincronização e pulmões de kit de itens. Com isso, nesses níveis de controle, o processo restritivo pode ser assumido como puxador, sobre o qual se poderiam aplicar os tradicionais controles visuais e simplificados da produção enxuta. 


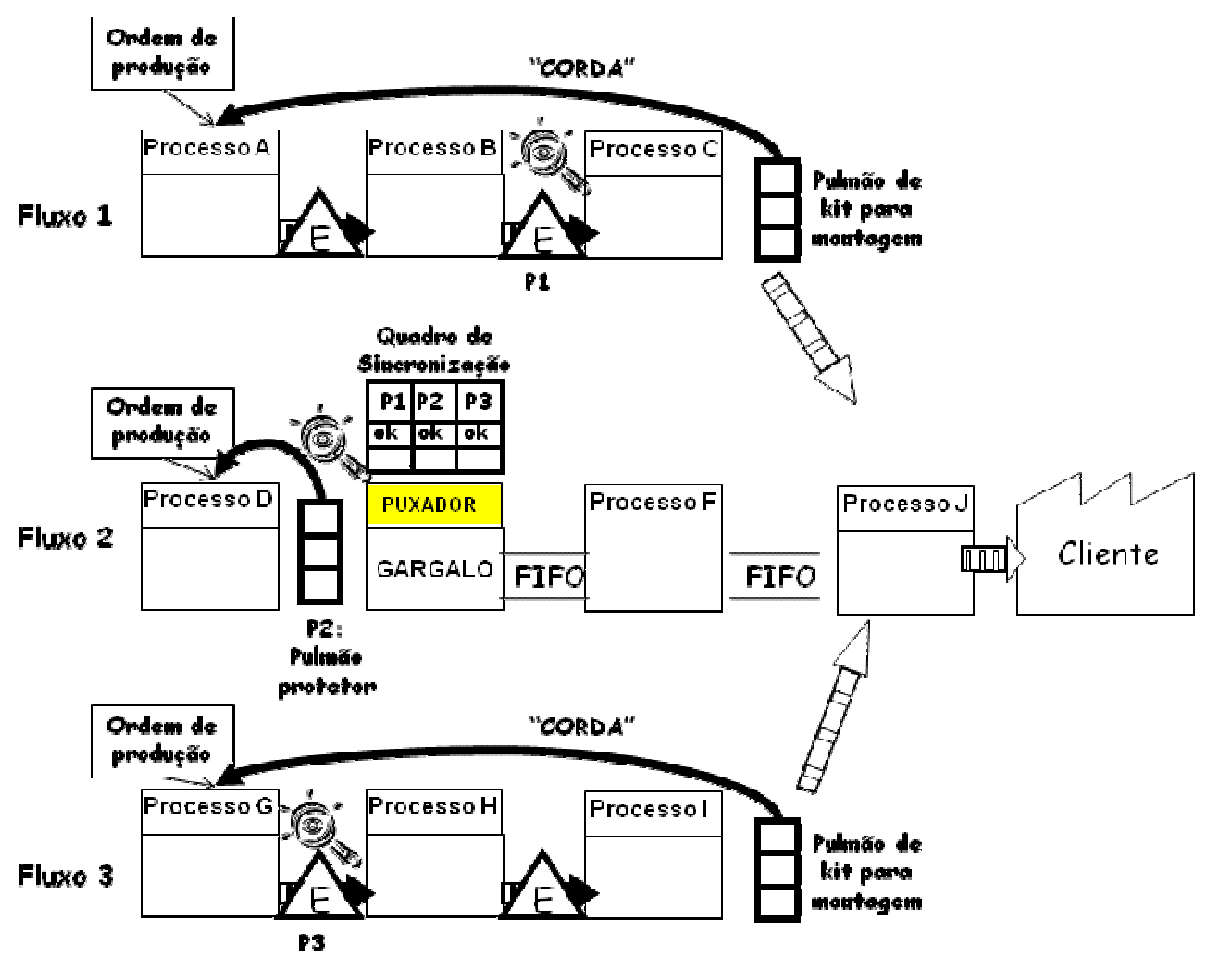

Figura 50: Processo puxador em sistemas ETO ou MTO com fluxos em paralelo

Portanto, nos níveis mais altos, o processo puxador continua sendo a primeira operação do fluxo de valor, como num sistema puxado seqüencial, programado com a ajuda do sistema MRP. Nos níveis de controle mais baixo o processo gargalo é tratado como puxador com uma programação mais refinada das atividades da fábrica.

O próximo passo consiste em definir a ferramenta mais apropriada de programação e controle para cada item.

\subsection{Definição das subfamílias de programação e controle}

Conforme apresentado na revisão bibliográfica deste trabalho, para que empresas com grande variedade de itens com diferentes características de demanda se tornem mais enxutas é necessária uma abordagem híbrida de planejamento e controle.

Um sistema híbrido de planejamento e programação da produção consiste na adoção, através de um mesmo fluxo de valor, de diferentes tipos de sistema de informação. Um exemplo seria uma célula de produção que teria alguns 
itens sendo disparados por kanbans e outros itens sendo disparados por ordens de produção. Haveria um supermercado para que os itens mais freqüentes fossem produzidos via kanban à medida que o ponto de reposição fosse atingido. Ao mesmo tempo, a célula produziria os itens menos freqüentes de acordo com as necessidades dos clientes via ordem de produção.

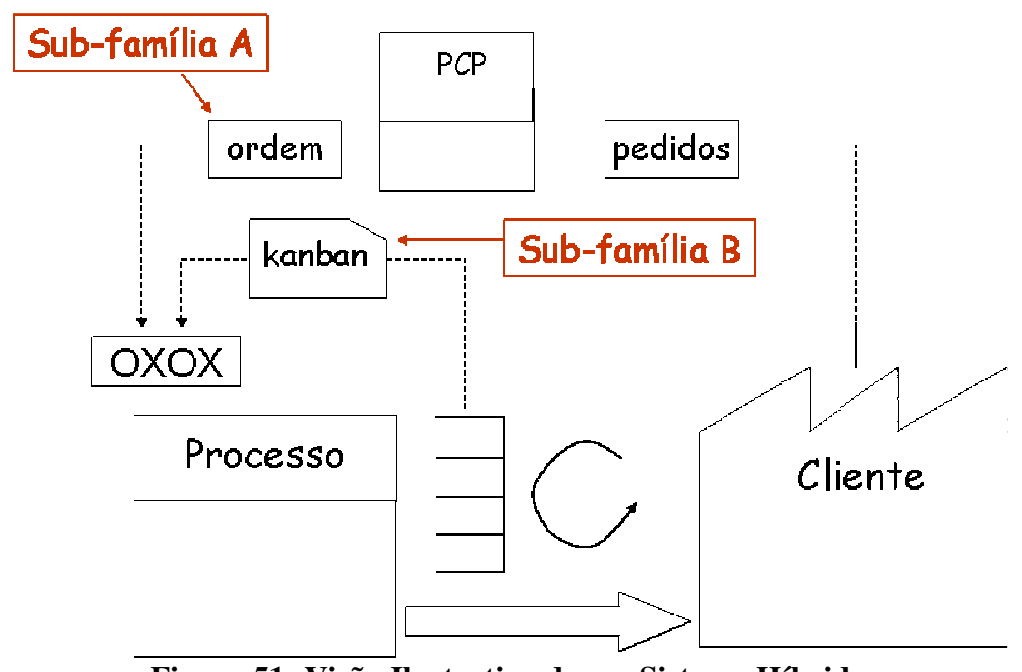

Figura 51: Visão Ilustrativa de um Sistema Híbrido

Fonte: Rentes et al. (2005)

Conseqüentemente, o estoque em processo, representado pelos itens do supermercado, corresponderiam a um número limitado de itens. Isso torna possível o uso de kanbans nas situações de alta variedade, permitindo um melhor nível de serviço nos picos de demanda e reduzindo o tempo médio de resposta às necessidades dos clientes. Trata-se de uma estratégia interessante visto que uma minoria do total de itens que passam pela célula atenderia a maioria dos casos.

Logo, muitas vezes, produtos de um mesmo fluxo de valor deverão ser controlados de formas diferentes. Cada tipo de controle estaria associado a uma subfamília de programação e controle.

Conforme apresentado no tópico 2.6.2 ("Sistemas híbridos de programação e controle") deste trabalho, os principais fatores de referência para definir a forma de programação e controle mais adequada para cada item são a frequiência, o volume da demanda e a classificação $\mathrm{ABC}$ de custos.

A segmentação com base na manutenção financeira, que classifica os estoques em A, B ou C de acordo com o custo total é muito importante para evitar 
que itens de alto valor agregado fiquem "parados" em estoque. Por outro lado, se um item classe A possuir uma demanda freqüente a opção de controlá-lo pela lógica de puxar a produção tende a proporcionar uma boa relação custo benefício entre o atendimento da demanda e o custo financeiro de mantê-lo em um supermercado.

O volume também é importante. Por exemplo, itens de baixo volume, independentemente da frequiência com que são vendidos, sempre vão requerer atenção especial em termos de preparação de máquinas. O tamanho do pedido destes itens costuma ser considerado muito pequeno para ser produzido. Ordens de tamanho maior costumam ser emitidas e as sobras do lote produzido acabam sendo estocadas. Com isso, uma das questões que será tratada a seguir em virtude desse fator é: formalizar parte desse pequenos estoques com uma ferramenta de controle específico ou controlá-las caso a caso à medida que vão sobrando?

Segue abaixo, uma orientação prática de como sistematizar a classificação dos itens segundo esses três fatores:

a) Freqüência da demanda: Um bom critério para se definir se um determinado item deve ser classificado como "Freqüente" ou "Esporádico/Intermitente" é a relação entre a sua média (aritmética) de consumo e o desvio padrão no período considerado. Dessa forma, a sugestão de uma maneira objetiva para se fazer essa classificação é:

Se MÉDIA >= K x DESVPAD então o item é FREQUENTE

\section{Se MEDIA < K x DESVPAD então o item é ESPORÁDICO}

$\mathrm{O}$ fator K representa a quantidade de desvios padrão que se pretende adotar.

Na planilha eletrônica Microsoft Excel é possível calcular o desvio padrão através da fórmula “=DESVPAD (...)”. 


\begin{tabular}{|c|c|c|c|c|c|c|c|c|c|c|c|c|c|}
\hline Itens/ dias & 1 & 2 & 3 & 4 & 5 & 6 & 7 & 8 & 9 & 10 & MÉDIA & DESPAD & \\
\hline a & 12 & 12 & 15 & 17 & 18 & 5 & 9 & 0 & 10 & 8 & 10,6 & 5.5 & FREQ \\
\hline b & 20 & 0 & 0 & 0 & 14 & 3 & 9 & 30 & 0 & 0 & 7.6 & 10.6 & ESP \\
\hline c & 2 & 4 & 0 & 7 & 8 & 4 & 1 & 1 & 1 & 1 & 2.9 & 2.8 & FREQ \\
\hline d & 17 & 20 & 24 & 14 & 23 & 25 & 20 & 19 & 26 & 22 & 21 & 3.7 & FREQ \\
\hline e & 10 & 10 & 10 & 10 & 10 & 10 & 10 & 10 & 10 & 10 & 10 & 0 & FREQ \\
\hline
\end{tabular}

Quadro 15: Comparação entre a média e o desvio padrão para definição da frequiência de cada item

b) Custo do item demandado: De acordo com a Lei de Pareto (Regra 80/20), tipicamente $80 \%$ do valor do estoque de uma operação tende a corresponder a cerca de $20 \%$ de todos os tipos de itens estocados. Com base nela, a classificação de um item quanto aos custos pode ser:

- Itens de Alto Custo: 50\% de itens de alto valor, os quais representam cerca de $90 \%$ do valor total dos itens vendidos. Por questões de simplificação, serão agrupados nessa categoria os itens de alto $(80 \%$ do valor) e médio ( $10 \%$ do valor) custo da classificação original de Pareto.

- Itens de Baixo Custo: 50\% de itens de baixo valor, os quais representam cerca de $10 \%$ do valor total dos itens vendidos.

c) Volume da demanda: É proposta aqui a utilização da classificação de volume de Smalley (2004), conforme revisão bibliográfica deste trabalho. Nesse sentido, a classificação de um item quanto ao volume da demanda pode ser feita da seguinte maneira:

a) Itens de Alto Volume: 20\% dos itens, os quais representam cerca de $80 \%$ do volume total da demanda. Por questões de simplificação, agrupou-se nessa categoria os itens de alto (60\% do volume total) e médio ( $20 \%$ do volume total) volume da classificação original de Smalley (2005).

b) Itens de Baixo Volume: $80 \%$ dos itens, os quais representam cerca de $20 \%$ do volume total da demanda.

Com base nas possíveis combinações entre estes três fatores, foi elaborada uma tabela com algumas alternativas de ferramentas de programação e controle para cada item. À cada alternativa está associada uma subfamília de 
programação e controle. Limitar-se-á aqui em definir apenas a melhor ferramenta de programação e controle para cada subfamília. Mais adiante, na etapa 4 do método, serão propostas mais detalhadamente algumas sistemáticas de programação para as subfamílias cuja produção será puxada (via kanban, sinal ou 2 gavetas) e para as subfamílias cuja produção será empurrada (via ordem/MRP).

\begin{tabular}{|c|l|l|l|l|}
\hline Subfamília & Frequencia & Volume & Custo & \multicolumn{2}{|c|}{ Sistema Controle } \\
\hline 1 & Alta & Alto & Alto & Kanban \\
\hline 2 & Alta & Alto & Baixo & Kanban Sinal ou 2 Gavetas \\
\hline 1 & Alta & Baixo & Alto & Kanban \\
\hline 2 & Alta & Baixo & Baixo & Kanban Sinal ou 2 Gavetas \\
\hline 3 & Baixa & Alto & Alto & Ordem \\
\hline $3 / 2$ & Baixa & Alto & Baixo & Ordem/Kanban Sinal ou 2 Gavetas \\
\hline 3 & Baixa & Baixo & Alto & Ordem \\
\hline $3 / 2$ & Baixa & Baixo & Baixo & Ordem/Kanban Sinal ou 2 Gavetas \\
\hline
\end{tabular}

Quadro 16: Definição das sub-famílias de controle

Fonte: Adaptado de Rentes et al. (2005)

O kanban é normalmente proposto para itens com demanda freqüente.

Na subfamília 1 ele é proposto como ferramenta de programação e controle de todos os itens freqüentes e de alto custo (classe A). Estes itens requerem um controle mais apurado, com políticas de dimensionamento e ajuste periódico mais refinadas.

Na subfamília 2 foram agrupados os itens que, embora freqüentes, apresentam custo menor (classe B e C). São propostas ferramentas mais simples de produção puxada, como o 2 gavetas e o kanban de sinal. Nestes casos, o controle pode ser menos rigoroso, resultando em um nível de estoque relativamente maior (veja mais sobre essas ferramentas no tópico 2.4.4 deste trabalho).

$\mathrm{Na}$ subfamília 3 foram agrupados todos os itens com demanda esporádica. Neste caso, sugere-se programá-los e controlá-los pela lógica do MRP, através da emissão de ordens de produção.

Porém, na tabela acima, um ponto particularmente interessante é a proposta alternativa de se utilizar sistemas de kanban de sinal ou de duas gavetas para os itens de baixa freqüência e baixo custo. Normalmente, a fabricação destes itens seria disparada e controlada mediante a emissão de ordens de fabricação 
tradicionais. Contudo, nos estudos de caso e projetos de aplicação prática, nos quais este trabalho está baseado, notou-se que o controle deste tipo de item utilizando ordens fabricação quase sempre resultava na geração de estoques de itens remanescentes. Isto porque, principalmente no caso dos itens de baixo volume, a tendência é que sejam produzidas quantidades a mais que a demanda real do cliente. Até que um trabalho de troca rápida de ferramenta seja feito, este tipo de decisão, aparentemente contraditória com os princípios da mentalidade enxuta, torna-se coerente à medida que procura respeitar as limitações de tempo de troca através da produção de um lote mínimo viável de ser produzido.

Além disso, estes pequenos estoques de itens remanescentes acabavam tornando-se difíceis de controlar, pois falhas no apontamento por parte das pessoas faziam com que as quantidades existentes nos sistemas informatizados de controle dos estoques apresentassem grandes distorções com relação aos valores reais do estoque físico. Conseqüentemente, tornava-se mais "prático" emitir novas ordens para a maioria dos itens remanescentes ao invés de ter que localizá-los no estoque e levantar fisicamente suas quantidades reais. A conseqüência disso tudo era a falta de alguns itens e a superprodução e geração de estoques excessivos para a grande maioria.

A conclusão é que o sistema de produção tem respondido mais rapidamente, e a um menor custo, ao se utilizar sistemas de kanban de sinal ou de duas gavetas para os itens de baixa freqüência e baixo custo, pelo menos enquanto trabalhos específicos de troca rápida de ferramenta não forem feitos e/ou o processo de apontamento não garantir a acuracidade dos sistemas de informação existentes.

A seguir, será tratado o dimensionamento dos pontos de pulmão e de supermercados.

\subsection{Dimensionamento do tamanho dos pontos de pulmões e supermercados}

Conforme visto anteriormente, em sistemas com estruturas de produto complexas (processos em paralelo), onde a política for predominantemente do tipo ETO ou MTO (itens não padronizados, demanda não freqüente) a programação e 
controle dos processos poderá ser feita através da utilização de pulmões de tempo. $\mathrm{O}$ dimensionamento de cada pulmão deverá levar em consideração o loop do qual ele faz parte.

Por outro lado, em sistemas onde for possível trabalhar com políticas do tipo MTS (itens padronizados, demanda freqüente) a programação e controle dos processos é através da utilização de supermercados de produção.

A seguir, são propostas sistemáticas de dimensionamento destes dois tipos de estoque.

\subsubsection{Dimensionamento do tamanho dos pontos de pulmões}

O primeiro passo consiste em calcular o takt time para a respectiva família. Em seguida, deve-se levantar o lead time de cada loop, os quais estão delimitados pelos pulmões. Ao dividir-se o lead time do loop pelo takt time é possível ter a quantidade balanceada de itens que deve estar fluindo no loop.

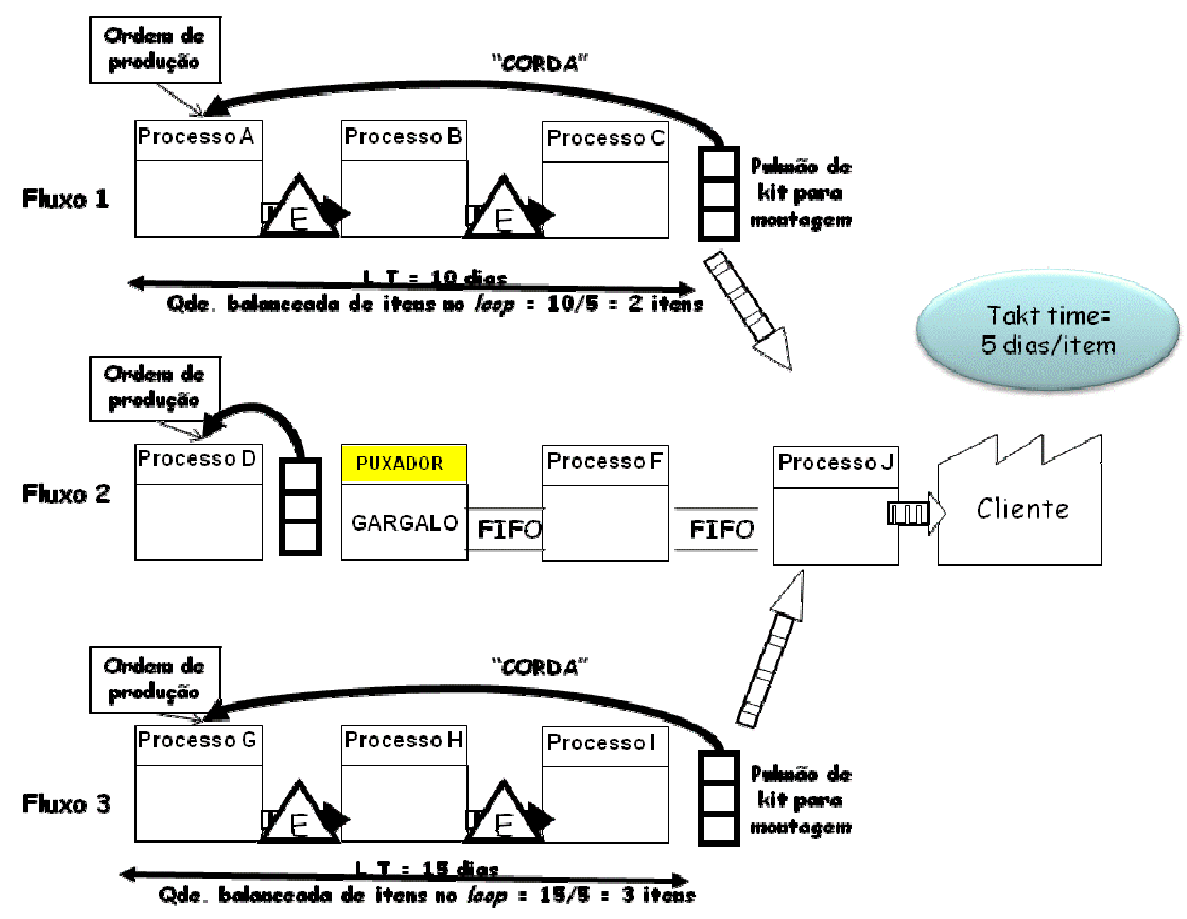

Figura 52: Dimensionamento da quantidade de itens por loop de pulmões 


\subsubsection{Dimensionamento do tamanho dos pontos de supermercados}

Conforme mencionado na revisão bibliográfica deste trabalho, uma fórmula para calcular os níveis iniciais de estoque deve ser composta pelos seguintes fatores:

\section{Estoque de Ciclo}

\section{Estoque Pulmão}

\section{Estoque Segurança}

Figura 53: Fatores a serem contemplados no cálculo de supermercado Fonte: Adaptado de Smalley (2005)

O primeiro fator representa o estoque de ciclo, que é obtido multiplicando-se a demanda média com o lead time de reposição. O lead time de reposição é, por definição, o tempo de atravessamento de um determinado item no processo considerado. Esse tempo consiste na somatória dos tempos de fila, eventuais transportes, o processamento propriamente dito, dentre outros. Durante muito tempo essa definição foi aplicada no dimensionamento do tamanho de supermercados como sendo apenas o tempo de processamento. Entretanto, à medida que a variedade de itens produzidos pelas empresas foi aumentando e as máquinas deixaram de ser dedicadas para apenas um ou dois tipos de itens, a aplicação do lead time considerando apenas o tempo de processamento tornou-se imprecisa. Como a máquina agora é compartilhada por uma infinidade de itens, é inevitável que uma peça fique na fila ao chegar ao processo produtor a fim de ser produzida.

O lead time total de reposição deve contemplar, além do tempo de processamento, o TPT (Toda Parte Toda...). TPT representa a freqüência (ou a fila/espera) com que o item pode voltar a ser produzido num determinado intervalo de tempo. Por exemplo, se uma máquina é trocada numa seqüência de modo que a mesma peça volte a ser feita dois dias depois então o seu TPT é dois dias ("Toda 
Parte Todo dois dias"). Este intervalo deve ser o menor possível de modo a conseguir o mix certo na quantidade certa, satisfazer a demanda dos clientes e não criar estoque em excesso.

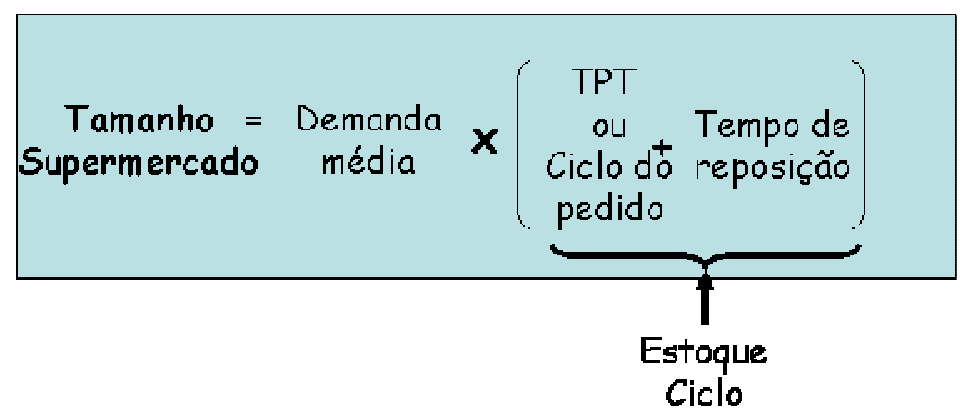

Quadro 17: Fórmula para cálculo do tamanho do supermercado contemplando o Estoque de Ciclo

Mais adiante, serão propostas algumas formas de se calcular o TPT, também conhecido como EPEI (“Every Part Every Interval”).

$\mathrm{O}$ segundo fator representa o estoque pulmão, que visa absorver a volatilidade da demanda causada pelo cliente e por erros de previsão. Para isso, propõe-se a utilização de um ou dois desvios padrão. O desvio padrão é utilizado para calcular com que probabilidade a demanda oscilará além de uma determinada quantidade durante o ciclo de reposição. Por exemplo, dois desvios padrão da demanda cobrem aproximadamente $95 \%$ da variação normal dos pedidos. Caso necessário, podem ser considerados mais desvios padrão, para cobrir um nível mais alto de variação.

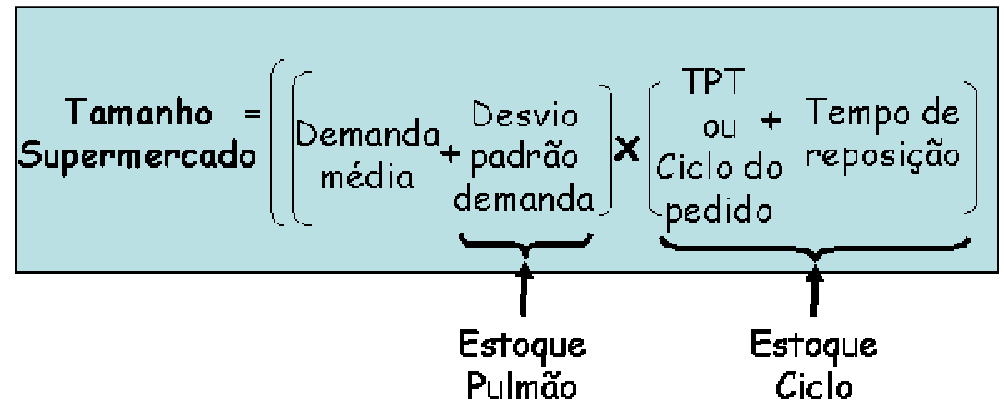

Quadro 18: Fórmula para cálculo do tamanho do supermercado contemplando o Estoque de Ciclo e o Estoque Pulmão. 
O terceiro fator representa o estoque de segurança. Reflete o exemplo do pior caso de refugo, retrabalho, quebra de máquina e downtime (número esperado de novas peças não chegar aos produtos acabados dentro do tempo planejado) no processo analisado. Propõe-se considerar o tempo de resposta àquela contingência que seja mais significativa no dia a dia do processo.

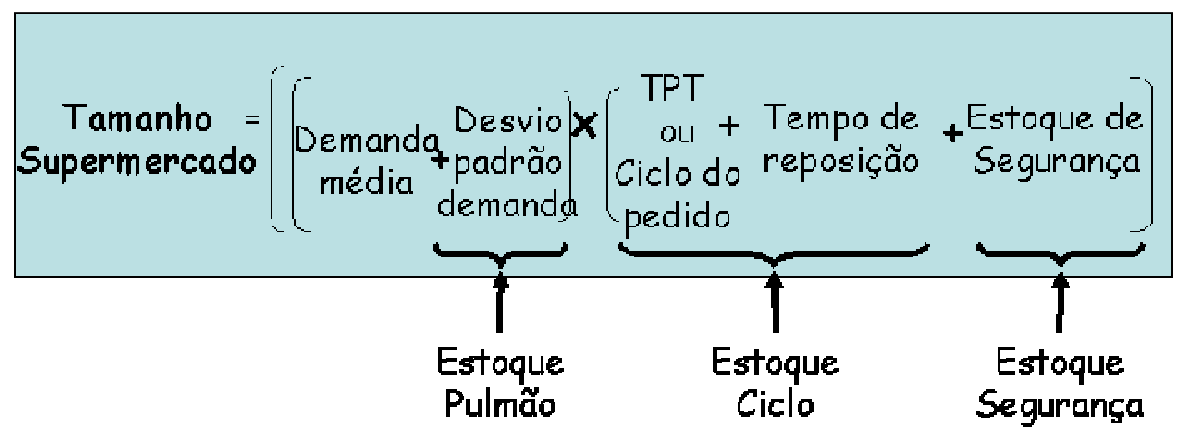

Quadro 19: Fórmula para cálculo do tamanho do supermercado contemplando os Estoques de Ciclo, Pulmão e de Segurança Fonte: Adaptado de Smalley (2005); Monden (1998)

A seguir, é apresentado um método de cálculo do tamanho do supermercado, baseado nos fatores supracitados.

\subsubsection{Identificar o recurso gargalo do loop de cada supermercado}

De acordo com a Teoria das Restrições, descrita inicialmente em "A Meta” (GOLDRATT, 1995), o desempenho de qualquer sistema é igual ao desempenho do seu recurso gargalo. Com isso, o dimensionamento de um supermercado deverá basear-se na operação gargalo do loop considerado.

Os principais critérios para identificação da operação gargalo no loop do supermercado são:

g) Indicação via experiência empírica dos operadores da área

h) Caso não haja um consenso sobre qual é o recurso gargalo, deve-se calcular o TPT para todas as operações do loop, suspeitas de serem o recurso gargalo.

A figura abaixo ilustra a identificação do recurso gargalo através do cálculo do TPT. 


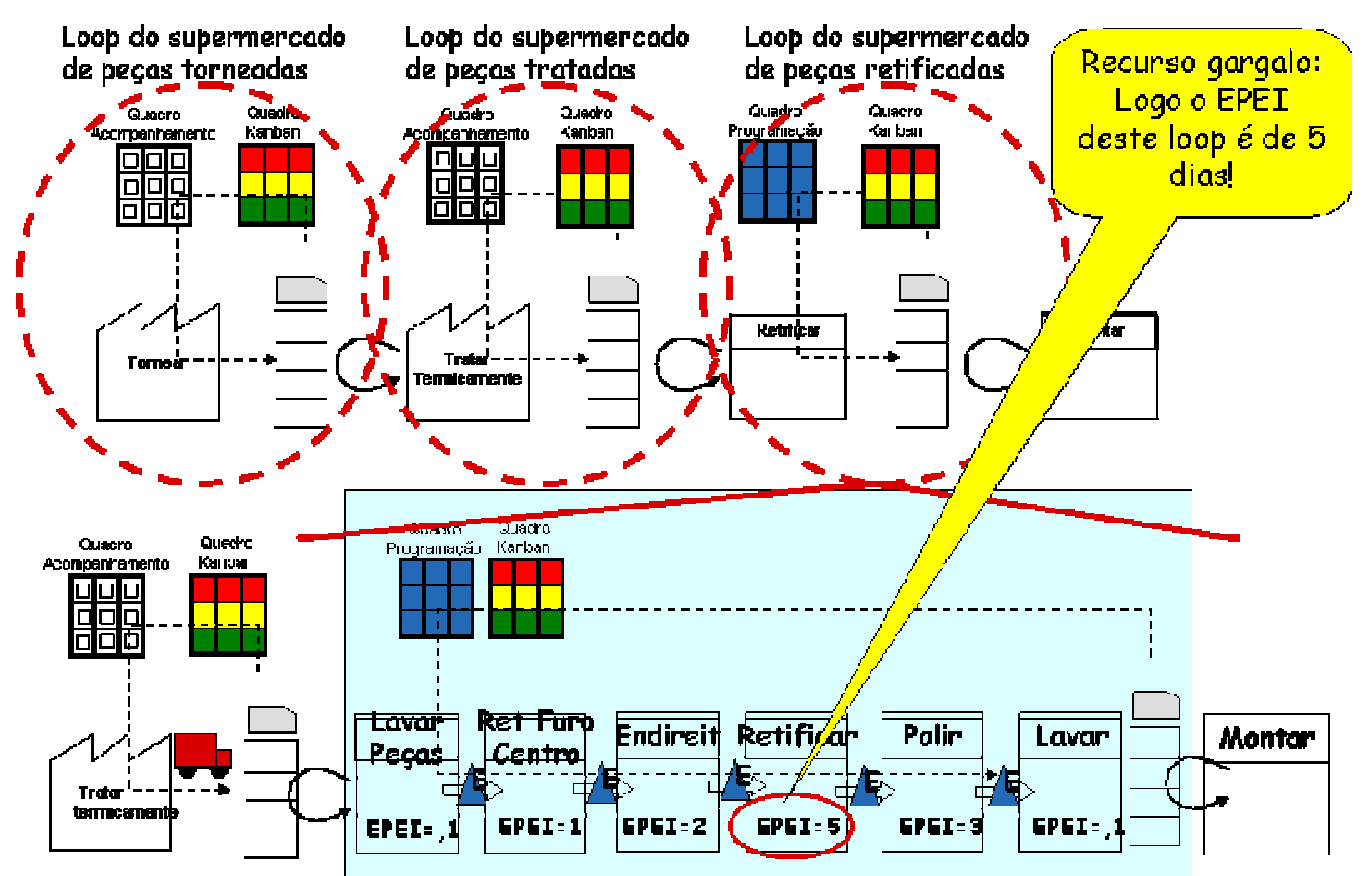

Figura 54: identificação do recurso gargalo através do cálculo do TPT.

No exemplo acima, o loop analisado é composto por seis operações em sequiência. Devido à falta de uma identificação clara da operação gargalo, tornouse necessário calcular o TPT para todas as operações. Como a operação de "Retificar" apresentou o maior TPT definiu-se que o TPT para todo o loop seria igual ao TPT desta operação.

A seguir são apresentadas as ações necessárias para se calcular o TPT.

\subsubsection{Calcular o TPT ("Toda Parte Toda...") ou EPEI ("Every Part Every} Interval..." de cada loop

O TPT representa a frequiência com que o item pode ser produzido ou transportado/abastecido num determinado intervalo de tempo. Com isso, existem duas formas distintas de se obter o TPT, uma baseada em processos de abastecimento ou de transporte e a outra baseada em processos produtivos.

O TPT baseado em processos de abastecimento ou de transporte normalmente é utilizado nas situações (loops) em que o processo que fornecerá para supermercado é externo à planta da fábrica (fornecimento de matéria prima ou de produtos terceirizados), ou ainda nos casos de processos de transporte interno 
(abastecimento de itens de almoxarifado ou de produtos em processo), via milk run, por exemplo.

O cálculo do TPT de transporte é relativamente simples. Ele pode ser definido com base nos seguintes fatores:

Janela de carregamento: representa a freqüência de coleta ou fornecimento do item. Se um fornecedor entregar um item semanalmente, então o TPT para esse supermercado será de 5 dias. O mesmo vale para recursos de transporte interno, como empilhadeiras.

* Capacidade de transporte: esse fator irá depender da capacidade do recurso de transporte. Uma carreta com capacidade de 25 toneladas resultaria num TPT de 5 dias para uma empresa cuja produção diária é de 5 toneladas.

Lote mínimo de fornecimento: representa as situações em que a maior restrição consiste num tamanho de lote mínimo imposto pelo fornecedor. Um fornecedor de peças tratadas termicamente pode amarrar o custo de seus serviços à capacidade de pelo menos um forno. Um forno com capacidade de $200 \mathrm{~kg}$ resultaria num TPT de 4 dias para uma empresa cuja produção diária dos itens que podem ser colocados numa mesma fornada é de $50 \mathrm{~kg}$.

Já o TPT baseado em processos produtivos normalmente é utilizado nas situações (loops) em que o processo que fornecerá para supermercado é interno à planta da fábrica (estamparias, usinagens, etc.).

A figura 46 ilustra parte de um MFV com supermercados calculados com base nos dois tipos de TPT mencionados. 


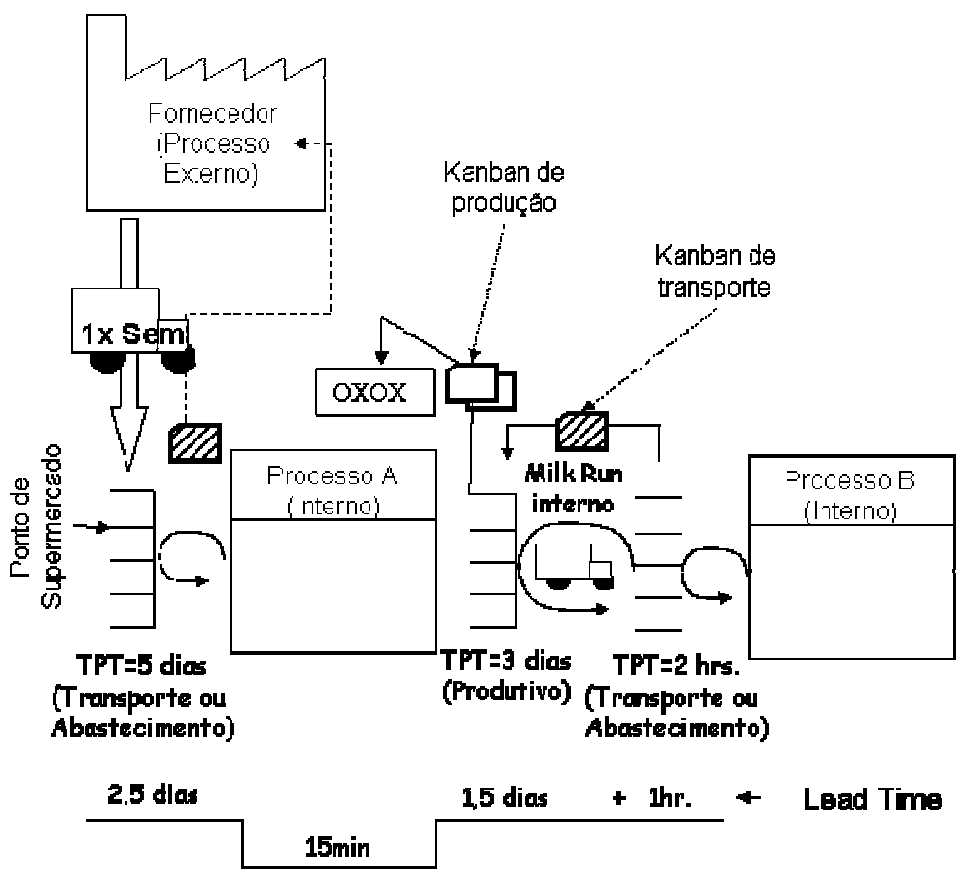

Figura 55: Corte de um MFV com supermercados calculados baseado nos dois tipos de TPT (transporte e produção)

No supermercado de itens comprados o TPT de transporte adotado é de 5 dias. Esta frequiência de entrega do fornecedor pode ter sido obtida a partir de uma janela de carregamento acordada previamente, da capacidade dos recursos de transporte (carreta, caminhão) ou ainda a partir de uma imposição de lote mínimo por parte do fornecedor externo. Logo em seguida, nota-se um sistema de dois kanbans (produção e transporte). Nele, no primeiro ponto de supermercado, calculou-se um TPT produtivo de 3 dias, com base na capacidade do processo produtivo de realizar setup's (Processo A). No segundo ponto novamente é utilizado um TPT de transporte, definido a partir do intervalo de tempo que o milk run interno leva para passar novamente naquele ponto de abastecimento.

Para calcular o TPT de produção devem ser observadas duas coisas: primeiro se o processo possui capacidade suficiente para processar todas os itens que passam por ele. Segundo, caso haja capacidade, o quanto do tempo é gasto com setup's. Os principais passos para calcular o TPT de produção são:

1. Calcular o tempo disponível no processo gargalo

2. Calcular a demanda média de todos os itens que passam no processo gargalo 
3. Levantar os tempos de ciclo e de setup de cada um dos itens que passam no processo gargalo

4. Calcular o tempo total de ciclo e o tempo total gasto com setup no recurso gargalo

5. Calcular o número de ciclos de setup possíveis dentro do tempo disponível para realizar setup's

O cálculo parte de um intervalo de tempo estimado. Este intervalo de tempo pode ser chamado de TPT tentativa. Pode ser medido por turno, dia, semana, mês, etc. O mais importante é que o período escolhido seja grande o suficiente para englobar a produção do lote correspondente (diário, semanal, mensal, etc.) de todos os itens que passam no recurso gargalo. Baseado nisso, a equação para cálculo do tempo disponível é dada abaixo.

\begin{tabular}{|c|c|c|c|c|}
\hline $\begin{array}{l}\text { Capacidade } \\
\text { disponivel } \\
\text { no gargalo }\end{array}$ & $\begin{aligned} & \text { Qde de } \\
= & \text { dias úteis } \\
& \text { por mês }\end{aligned}$ & $\begin{array}{l}\text { Qde de } \\
\times \text { minutos úteis } \\
\text { por dia }\end{array}$ & $X \underset{\substack{\text { Qde de } \\
\text { gargalos }}}{ } \times$ & $\begin{array}{l}\text { Taxa de } \\
\text { eficiência }\end{array}$ \\
\hline
\end{tabular}

Quadro 20: Cálculo do tempo disponível

No caso de uma empresa que trabalhe 1 turno, 20 dias úteis por mês, que possua apenas uma máquina realizando a operação gargalo e que tenha uma eficiência de aproximadamente 90\%, o tempo disponível seria de 8640 minutos.

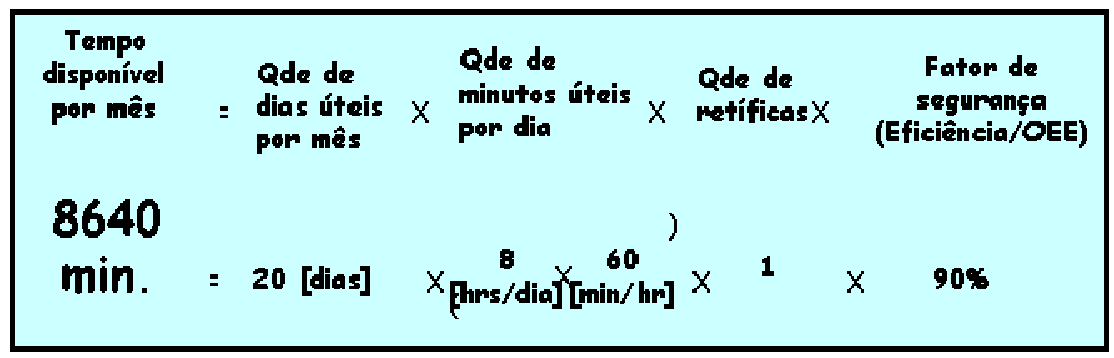

Quadro 21: Cálculo ilustrativo do tempo disponível

O próximo passo é levantar a demanda mensal média de todos os itens que são produzidos no recurso gargalo. Para a demanda média, recomenda-se utilizar 
um intervalo de tempo de três meses, embora possa ser utilizado um período mais longo ou mais curto, dependendo da sazonalidade e/ou de mudanças decorrentes das condições de mercado.

O ideal seria trabalhar sobre a previsão de uma carteira relativamente firme. Porém, caso a carteira de pedidos não esteja confiável pode-se trabalhar com o histórico da demanda. Neste caso, considerar:

i) histórico da demanda dos três últimos meses, ou

j) histórico da demanda dos três meses correspondentes ao mesmo período do ano anterior adotado para o cálculo do supermercado, ou

k) a média ponderada dos dois.

Baseado nisso, deve-se calcular a demanda mensal média para o período adotado.

\begin{tabular}{|l|l|l|l|c|}
\hline Itens & Março & Abril & Maio & $\begin{array}{c}\text { Demanda } \\
\text { média mensal } \\
(p c)\end{array}$ \\
\hline A & 150 & 200 & 260 & 203 \\
\hline B & 300 & 500 & 690 & 497 \\
\hline L & 570 & 600 & 260 & 477 \\
\hline E & 60 & 80 & 100 & 80 \\
\hline F & 150 & 200 & 260 & 203 \\
\hline$G$ & 618 & 600 & 500 & 573 \\
\hline H & 150 & 200 & 260 & 203 \\
\hline I & 300 & 600 & 400 & 433 \\
\hline J & 300 & 200 & 260 & 253 \\
\hline K & 500 & 200 & 300 & 333 \\
\hline Calcul| & 400 & 540 & 600 & 513 \\
\hline
\end{tabular}

Quadro 22: Calculo do TPT/EPEI - Cáculo da demanda mensal média

O próximo passo é levantar o tempo de ciclo e de setup de cada item no recurso gargalo. 


\begin{tabular}{|l|l|l|l|c|c|c|}
\hline Itens & Março & Abril & Maio & $\begin{array}{c}\text { Demanda } \\
\text { média mensal } \\
\text { (pç) }\end{array}$ & T/C (min.) & $\begin{array}{c}\text { T/setup } \\
\text { (min.) }\end{array}$ \\
\hline A & 150 & 200 & 260 & 203 & 1 & 40 \\
\hline B & 300 & 500 & 690 & 497 & 1,5 & 25 \\
\hline G & 570 & 600 & 260 & 477 & 2 & 25 \\
\hline D & 60 & 80 & 100 & 80 & 3 & 10 \\
\hline E & 150 & 200 & 260 & 203 & 1 & 10 \\
\hline F & 618 & 600 & 500 & 573 & 2 & 15 \\
\hline G & 150 & 200 & 260 & 203 & 1 & 15 \\
\hline H & 300 & 600 & 400 & 433 & 1 & 15 \\
\hline I & 300 & 200 & 260 & 253 & 2 & 10 \\
\hline J & 500 & 200 & 300 & 333 & 6 & 40 \\
\hline K & 400 & 540 & 600 & 513 & 2 & 40 \\
\hline
\end{tabular}

Quadro 23: Calculo do TPT/EPEI - Tempos de Ciclo e Setup dos itens na operação gargalo

Em seguida, calcula-se o tempo de ciclo do lote mensal.

\section{Tempo ciclo to tal $=$ Demanda média mensal $x$ Tempo ciclo unitánio}

\begin{tabular}{|c|c|c|c|c|c|c|c|}
\hline Itens & Marco & Abril & Maio & $\begin{array}{l}\text { Demanda } \\
\text { média mensol } \\
\text { (pc) }\end{array}$ & $\mathrm{T} / C\left(\mathrm{~min}_{-}\right)$ & $\begin{array}{c}\text { T/seht } \\
\text { (nin.) }\end{array}$ & $\begin{array}{c}\text { T/C total } \\
\text { (min.) }\end{array}$ \\
\hline $\bar{A}$ & 150 & 200 & 260 & 203 & 1 & 40 & 203 \\
\hline B & 300 & 500 & 690 & 497 & 15 & 25 & 745 \\
\hline $\bar{c}$ & 570 & 600 & 260 & 477 & $\frac{7}{2}$ & 25 & 953 \\
\hline $\begin{array}{l}\bar{D} \\
E\end{array}$ & $\begin{array}{l}60 \\
150\end{array}$ & $\begin{array}{l}80 \\
200\end{array}$ & $\begin{array}{l}100 \\
260\end{array}$ & $\begin{array}{c}80 \\
203\end{array}$ & $\begin{array}{l}3 \\
1\end{array}$ & $\begin{array}{l}10 \\
10\end{array}$ & $\begin{array}{l}240 \\
203\end{array}$ \\
\hline $\mathbf{F}$ & 613 & 600 & 500 & 573 & $\frac{2}{2}$ & 15 & 1145 \\
\hline $\boldsymbol{6}$ & 150 & 200 & 260 & 203 & 1 & 15 & 203 \\
\hline$\overline{\mathbf{H}}$ & 300 & 600 & 400 & 433 & $\mathbf{1}$ & 15 & 433 \\
\hline $\mathbf{I}$ & 300 & 200 & 260 & 253 & 2 & 10 & 507 \\
\hline $\mathbf{T}$ & 500 & 200 & 300 & $\overline{333}$ & 6 & 40 & 2000 \\
\hline $\mathbf{K}$ & 400 & 540 & 600 & 513 & 2 & 40 & 1027 \\
\hline
\end{tabular}

Quadro 24: Calculo do TPT/EPEI - Tempos de ciclo total para os lotes mensais de produção

Somam-se os tempos de ciclo do lote mensal e o de setup de todos os itens. 


\begin{tabular}{|l|l|l|l|c|c|c|c|}
\hline Itens & Março & Abril & Maio & $\begin{array}{c}\text { Demanda } \\
\text { média mensal } \\
(\mathrm{pc})\end{array}$ & $\mathrm{T} / \mathrm{C}(\mathrm{min})$. & $\begin{array}{c}\text { T/setup } \\
(\mathrm{min} .)\end{array}$ & $\begin{array}{c}\text { T/C total } \\
(\mathrm{min} .)\end{array}$ \\
\hline A & 150 & 200 & 260 & 203 & 1 & 40 & 203 \\
\hline B & 300 & 500 & 690 & 497 & 1,5 & 25 & 745 \\
\hline C & 570 & 600 & 260 & 477 & 2 & 25 & 953 \\
\hline D & 60 & 80 & 100 & 80 & 3 & 10 & 240 \\
\hline E & 150 & 200 & 260 & 203 & 1 & 10 & 203 \\
\hline F & 618 & 600 & 500 & 573 & 2 & 15 & 1145 \\
\hline G & 150 & 200 & 260 & 203 & 1 & 15 & 203 \\
\hline H & 300 & 600 & 400 & 433 & 1 & 15 & 433 \\
\hline I & 300 & 200 & 260 & 253 & 2 & 10 & 507 \\
\hline J & 500 & 200 & 300 & 333 & 6 & 40 & 2000 \\
\hline K & 400 & 540 & 600 & 513 & 2 & 40 & 1027 \\
\hline TOTAL & 3498 & 3920 & 3890 & 3769 & 23 & 245 & 7660 \\
\hline
\end{tabular}

Quadro 25: Calculo do TPT/EPEI - Tempo total gasto com setup e produção

O tempo restante é o tempo disponível para a realização de setup.

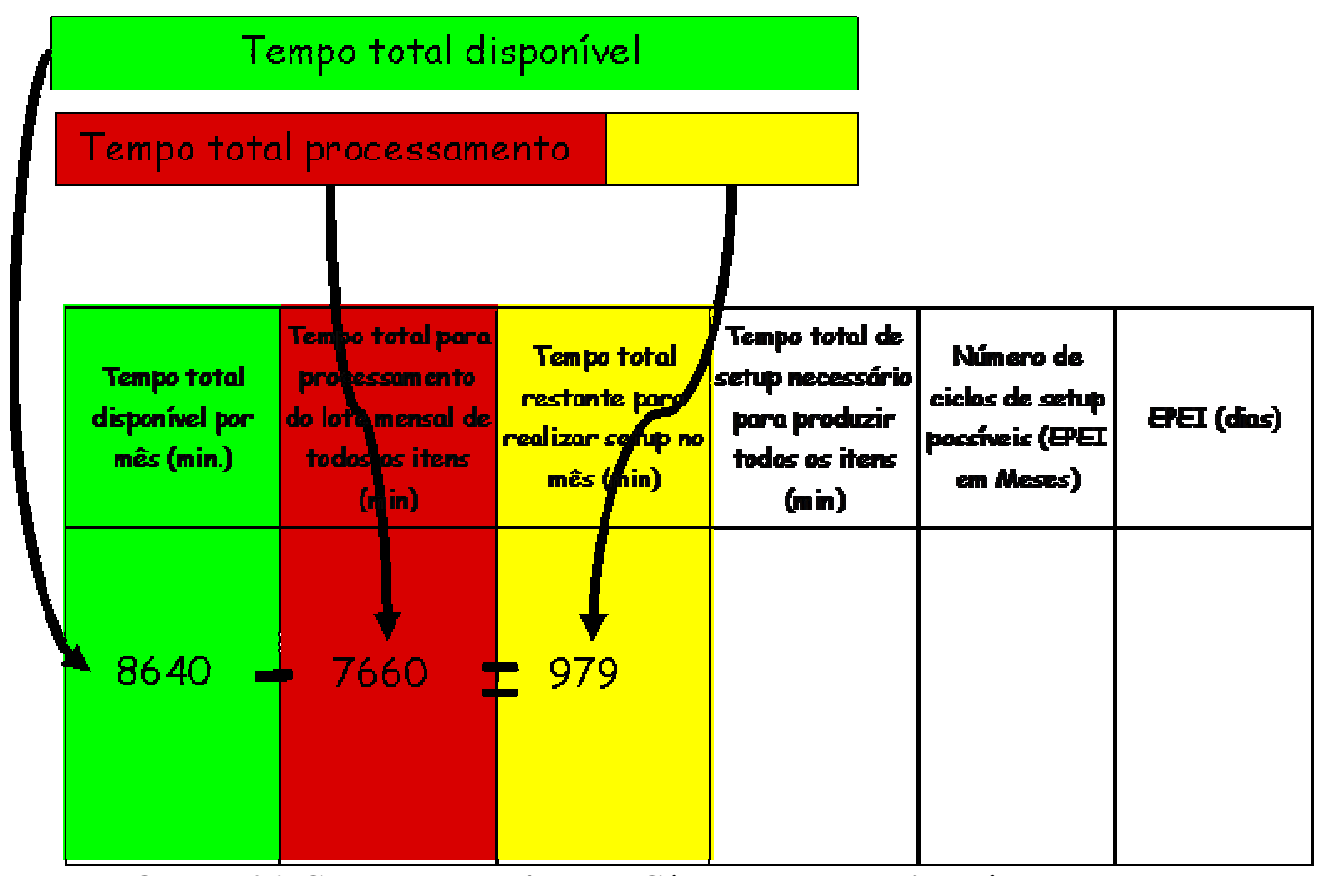

Quadro 26: Calculo do TPT/EPEI - Cálculo do tempo disponível para setup

Em seguida, devem-se somar todos os tempos de setup de todos os itens. 


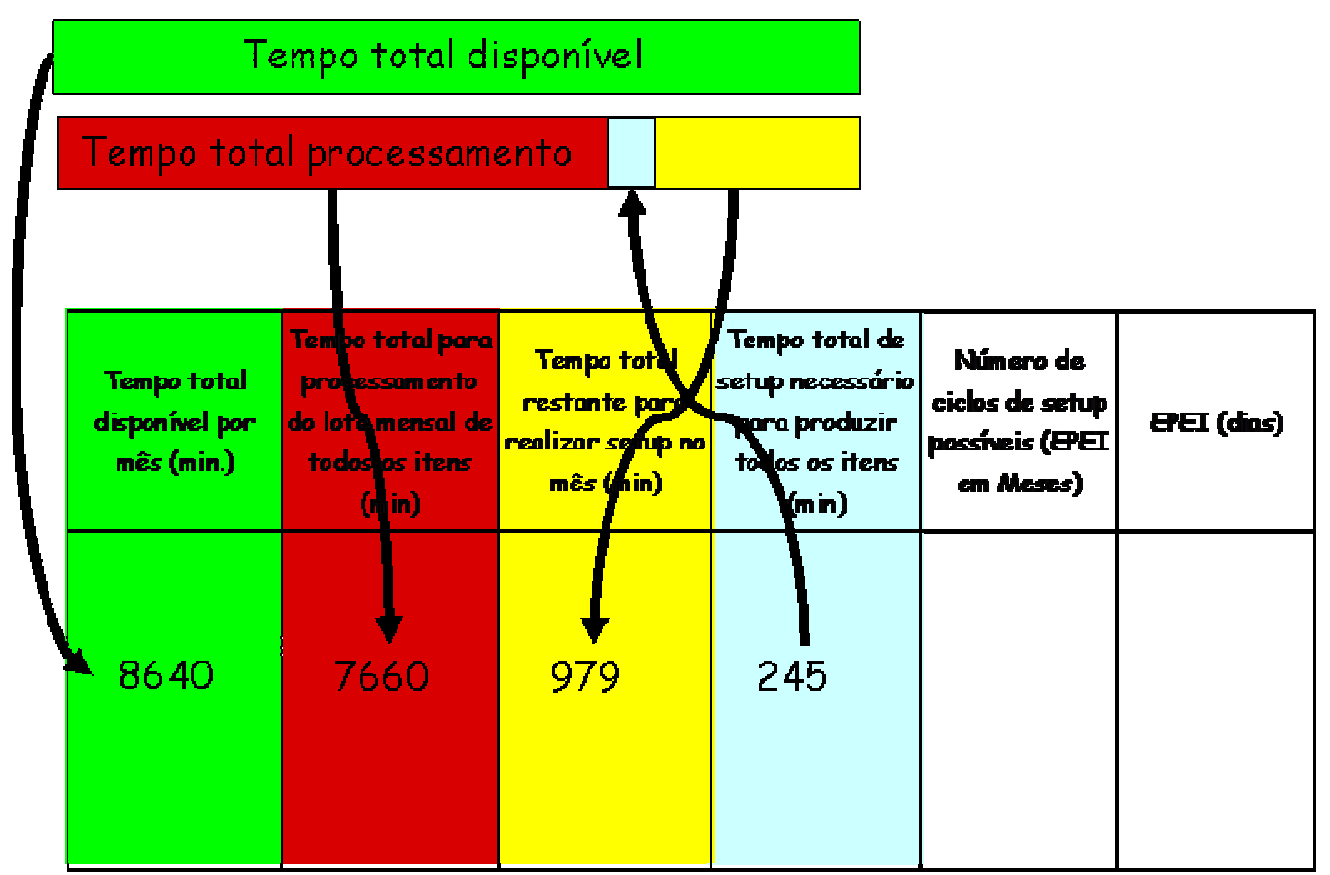

Quadro 27: Calculo do TPT/EPEI - Tempo total de setup para produzir todos os itens

Caso a soma dos tempos de setup no processo em questão seja maior

que o tempo disponível para setup seria necessário a aplicação de técnicas como o SMED para reduzir setup's. Uma outra solução, mais de curto prazo, seria aumentar o tempo disponível através da utilização de um intervalo de tempo maior, ou de maior quantidades de turnos ou maior quantidade de máquinas.

O próximo passo é calcular o número de ciclos de setup possíveis dentro do tempo disponível para realizar setup's. Para isso, basta dividir o tempo total restante para realizar setup pelo tempo total de setup necessário para produzir todos os itens. 


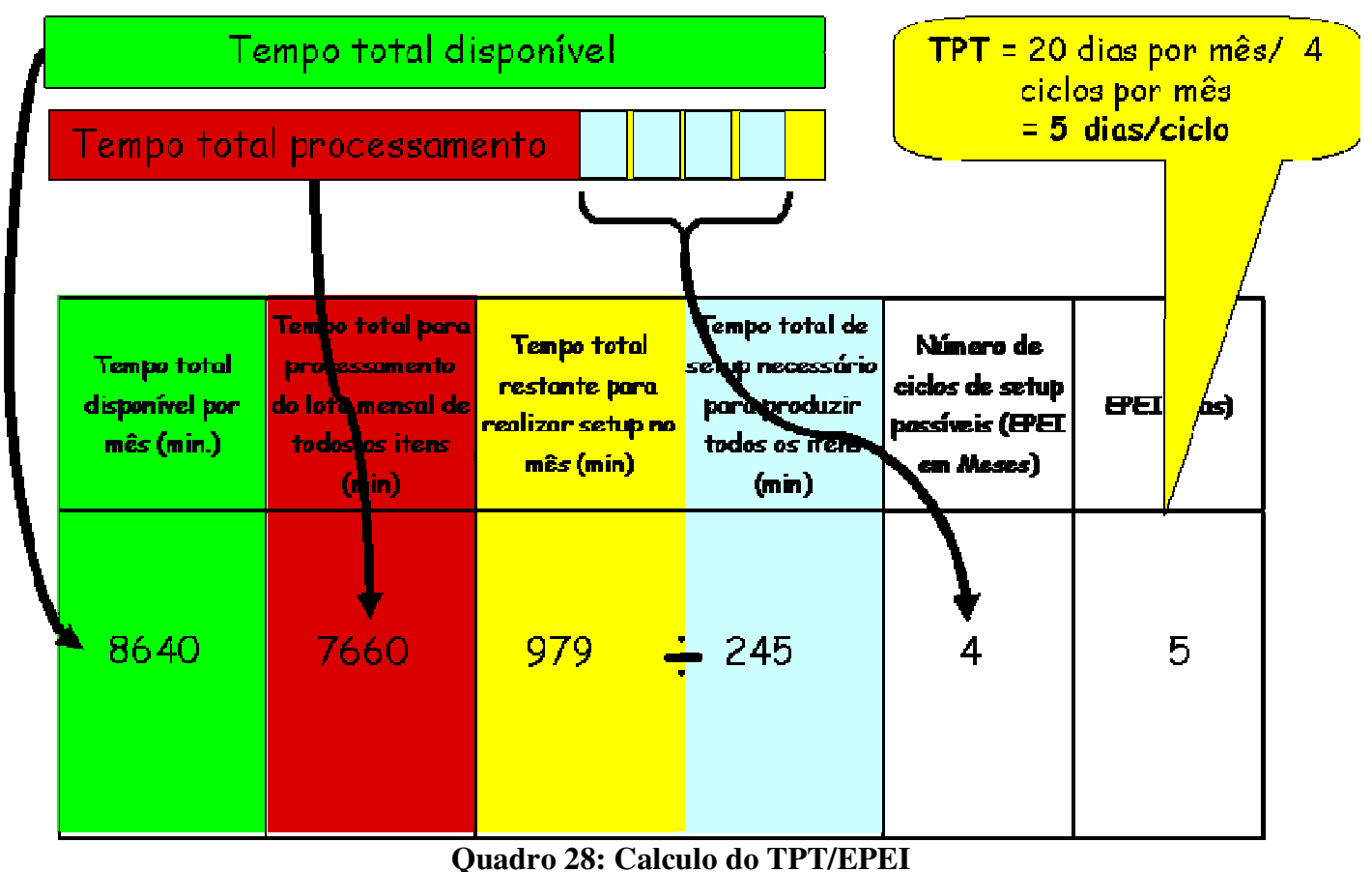

No exemplo acima, são possíveis 4 ciclos de setup por mês. Isso significa que todos os itens poderiam ser produzidos 4 vezes por mês. Para converter o TPT em dias basta dividir a quantidade de dias úteis no mês por esse valor. Para uma empresa que trabalha em média 20 dias úteis por mês teríamos um TPT de aproximadamente 5 dias, ou seja, Toda Parte Todo - ou a cada - 5 dias.

Com base na seqüência de cálculos supracitada, foi possível deduzir a seguinte fórmula para cálculo do TPT:

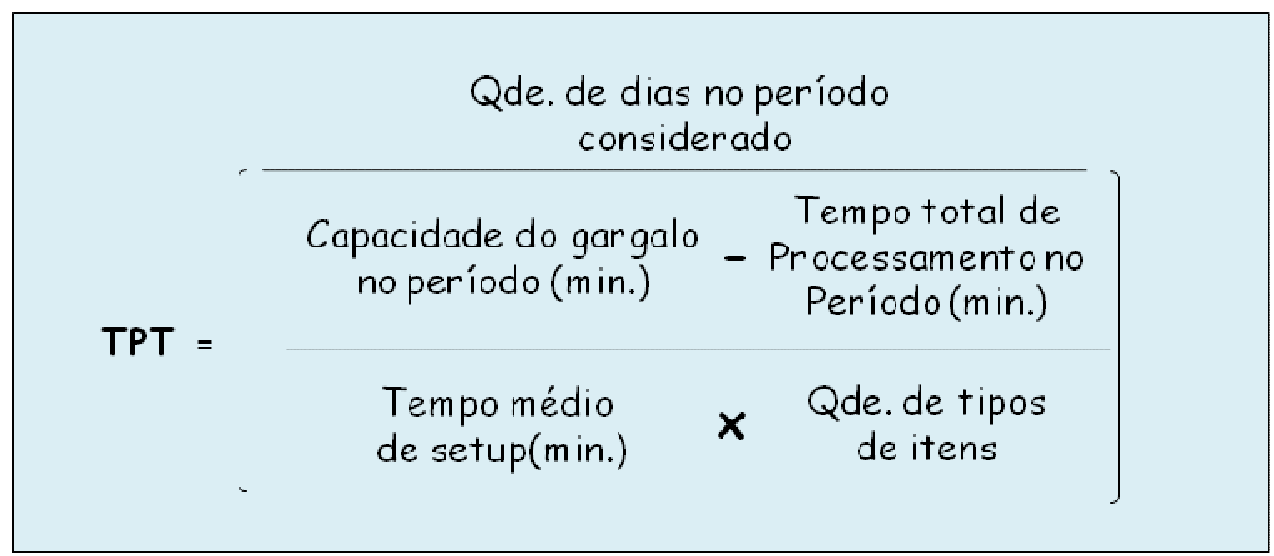

Quadro 29: Fórmula de cálculo do TPT

Agora que se tem calculado a freqüência com que os itens podem ser feitos, é possível dimensionar o tamanho do supermercado. 
No exemplo adotado, o tamanho do supermercado para cada um dos itens é calculado na figura abaixo:

\begin{tabular}{|c|c|c|c|c|c|c|c|c|c|c|}
\hline & & & & $\begin{array}{c}\text { Tamanho } \\
\text { Supermercad }\end{array}$ & do $\left[\begin{array}{c}\text { Deman } \\
\text { médi }\end{array}\right.$ & 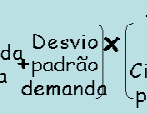 & $\begin{array}{l}\text { TPT } \\
\text { ou + Tempo } \\
\text { iclo do reposiç } \\
\text { edido }\end{array}$ & İo + Estoque de & & \\
\hline Itens & Março & Abril & Maio & $\begin{array}{c}\text { Demanda } \\
\text { média mensal } \\
\text { (pç/mês) }\end{array}$ & $\begin{array}{l}\text { Desvio } \\
\text { padrão } \\
\text { mensal } \\
(\text { (oc/mês) }\end{array}$ & $\begin{array}{c}\text { Demanda } \\
\text { média diária } \\
(\mathrm{pç/dia})\end{array}$ & $\begin{array}{c}\text { TPT ou Ciclo } \\
\text { do Pedido } \\
\text { (dias) }\end{array}$ & $\begin{array}{c}\text { Tempo de } \\
\text { reposição } \\
\text { (dias) }\end{array}$ & $\begin{array}{c}\text { Tempo de } \\
\text { segurança } \\
\text { (dias) }\end{array}$ & $\begin{array}{c}\text { Tamanho do } \\
\text { Supermercado } \\
\text { (ps) }\end{array}$ \\
\hline$A$ & 150 & 200 & 260 & 203 & 55 & 13 & 5 & 1 & 1 & 91 \\
\hline$B$ & 300 & 500 & 690 & 497 & 195 & 35 & 5 & 1 & 1 & 245 \\
\hline$\frac{1}{c}$ & 570 & \begin{tabular}{|l|l|}
600 \\
\end{tabular} & 260 & 477 & 188 & 34 & 5 & $\frac{1}{1}$ & 1 & 238 \\
\hline $\bar{D}$ & 60 & 80 & 100 & 80 & 20 & 5 & 5 & 1 & 1 & 35 \\
\hline E & 150 & 200 & 260 & 203 & 55 & 13 & 5 & 1 & 1 & 91 \\
\hline $\mathrm{F}$ & 618 & 600 & 500 & 573 & 64 & 32 & 5 & 1 & 1 & 224 \\
\hline$G$ & 150 & 200 & 260 & 203 & 55 & 13 & 5 & 1 & 1 & 91 \\
\hline $\mathrm{H}$ & 300 & 600 & 400 & 433 & 153 & 30 & 5 & 1 & 1 & 210 \\
\hline $\mathrm{I}$ & 300 & 200 & 260 & 253 & 50 & 16 & 5 & 1 & 1 & 112 \\
\hline$\frac{1}{J}$ & 500 & 200 & 300 & 333 & 153 & 25 & 5 & $\frac{1}{1}$ & 1 & 175 \\
\hline K & 400 & 540 & 600 & 513 & 103 & 31 & 5 & 1 & 1 & 217 \\
\hline TOTAL & \begin{tabular}{|l|}
3498 \\
\end{tabular} & 3920 & 3890 & 3769 & & 247 & & & & 1729 \\
\hline
\end{tabular}

Quadro 30: Dimensionamento do tamanho do supermercado para cada item

Outro ponto importante, diz respeito aos itens de baixo volume e baixo custo. A idéia é adotar TPT's maiores para os itens que apresentam estas características de demanda, conforme será comentado no tópico a seguir.

\subsubsection{Revisão do TPT para cada subfamília de controle}

Normalmente, os itens de baixo volume possuem médias de consumo relativamente baixas. A fim de se obter um tamanho lote mínimo viável de ser produzido pode ser necessário adotar um TPT maior que o originalmente calculado.

No caso dos itens de baixo custo, embora o cálculo do TPT sirva para validar a frequiência de fabricação mínima com que o item pode ser feito, o baixo custo desses itens também viabiliza a adoção de um TPT maior.

Na tabela abaixo, decidiu-se adotar um TPT três vezes maior que o calculado originalmente para os itens de baixo volume e baixo custo. 


\begin{tabular}{|c|l|l|l|l|c|}
\hline Subfamília & Frequencia & Volume & Custo & \multicolumn{1}{|c|}{ Sistema Controle } & TPT \\
\hline 1 & Alta & Alto & Alto & Kanban & $1 \times$ TPT \\
\hline 2 & Alta & Alto & Baixo & Kanban Sinal ou 2 Gavetas & $3 \times$ TPT \\
\hline 1 & Alta & Baixo & Alto & Kanban & $1 \times$ TPT \\
\hline 2 & Alta & Baixo & Baixo & Kanban Sinal ou 2 Gavetas & $3 \times$ TPT \\
\hline 3 & Baixa & Alto & Alto & Ordem de Produção & Sob Pedido \\
\hline 3 ou 2 & Baixa & Alto & Baixo & Ordem ou Kanban Sinal ou 2 Gavetas & $3 \times$ TPT \\
\hline 3 & Baixa & Baixo & Alto & Ordem de Produção & Sob Pedido \\
\hline 2 & Baixa & Baixo & Baixo & Kanban Sinal ou 2 Gavetas & $3 \times$ TPT \\
\hline
\end{tabular}

Quadro 31: Revisão para cima do TPT das subfamílias de baixo volume e baixo custo

Cabe a empresa analisar e decidir de forma ad hoc se trabalha ou não com múltiplos do TPT para os itens de baixo volume e baixo custo.

Um possível benefício de se obter ao se adotar essa estratégia é que, nos casos em que o tempo de ciclo dos itens for reltativamente pequeno, quando comparado com os seus tempos de setup, trabalhar com um TPT e tamanho de lote maior para os itens de baixo custo permite a redução do TPT e do tamanho do lote dos itens de alto custo do kanban. A idéia é fazer uma segunda iteração de modo a recalcular o TPT para estes itens a partir da capacidade liberada em função do menor giro (menos setups), ou maior TPT, dos itens de menor custo.

No exemplo adotado, a primeira iteração realizada resultou num TPT de 5 dias para todos os itens. Ou seja, ela considera que todos os itens serão produzidos no recurso restritivo a cada 5 dias.

\begin{tabular}{|c|c|c|c|c|c|c|c|c|c|c|c|c|c|c|c|}
\hline & \multicolumn{5}{|c|}{ TPT $=5$ dias } & \multicolumn{5}{|c|}{ TPT $=5$ dias } & \multicolumn{5}{|c|}{ TPT $=5$ dias } \\
\hline Dias Mês & $1 / \mathrm{mar}$ & $2 / \mathrm{mar}$ & $3 / \mathrm{mar}$ & $4 / \mathrm{mar}$ & $5 / \mathrm{mar}$ & $7 / \mathrm{mar}$ & $8 / \mathrm{mar}$ & $9 / \mathrm{mar}$ & $10 / \mathrm{mar}$ & $11 / \mathrm{mar}$ & $14 / \mathrm{mar}$ & $15 / \mathrm{mar}$ & $16 / \mathrm{mar}$ & $17 / \mathrm{mar}$ & $18 / \mathrm{mar}$ \\
\hline Dias Sem. & seg & ter & qua & qui & sex & seg & ter & qua & qui & sex & seg & ter & qua & qui & sex \\
\hline Dias do TPT & dia 1 & \begin{tabular}{|l|} 
dia 2 \\
\end{tabular} & \begin{tabular}{|l|} 
dia 3 \\
\end{tabular} & $\operatorname{dia} 4$ & dia 5 & dia 1 & \begin{tabular}{|l|} 
dia 2 \\
\end{tabular} & dia 3 & dia 4 & dia 5 & dia 1 & dia 2 & dia 3 & dia 4 & dia 5 \\
\hline Itens A & $\overline{\mathbf{A}}$ & & $\bar{B}$ & & $\bar{C}$ & $\overline{\mathbf{A}}$ & & B & & $\bar{C}$ & $\overline{\mathbf{A}}$ & & $\bar{B}$ & & $\bar{C}$ \\
\hline Itens $C$ & $\bar{D}$ & $\mathbf{E}$ & $\mathbf{F}$ & G & $\mathbf{H}$ & $\bar{D}$ & $\mathbf{E}$ & F & $\mathbf{G}$ & $\mathbf{H}$ & D & $\mathbf{E}$ & $\mathbf{F}$ & $\mathbf{G}$ & $\mathbf{H}$ \\
\hline Itens $C$ & I & $\mathbf{J}$ & $\mathbf{K}$ & & & I & $\mathbf{J}$ & $\mathbf{K}$ & & & $\bar{I}$ & $\mathbf{J}$ & $\mathbf{K}$ & & \\
\hline & Repos & áo do & $\begin{array}{c}\mathrm{s} \text { itens } \\
\text { dias }\end{array}$ & lot & de 5 & & ç̃o & $\begin{array}{r}\text { os iten } \\
\text { dias }\end{array}$ & a lo & de 5 & Repc & ição do & tens ao & longo de & 5 dias \\
\hline
\end{tabular}

\section{Quadro 32: Distribuição de todos os itens no TPT de 5 dias}

Porém, é possível calcular um novo TPT (segunda iteração) para os itens classe A de custo (A, B e C) caso seja adotado um TPT maior um TPT maior para os itens classe C (D, E, F, G, H, I, J, K). Por exemplo, utiliza-se o TPT calculado de 5 dias para os itens classe A e adota-se um TPT de 15 dias para os itens 
de baixo custo (classe C). Isso permitiria uma distribuição homogênea dos itens classe $\mathrm{C}$ ao longo do período de 15 dias.

\begin{tabular}{|c|c|c|c|c|c|c|c|c|c|c|c|c|c|c|c|}
\hline \multirow{3}{*}{ Dias Mês } & \multicolumn{15}{|c|}{ TPT $=15$ dias para os itens de baixo custo } \\
\hline & \multicolumn{5}{|c|}{ TPT $=5$ dias } & \multicolumn{5}{|c|}{ TPT $=5$ dias } & \multicolumn{5}{|c|}{ TPT $=5$ dias } \\
\hline & $1 / \mathrm{mar}$ & $2 / \mathrm{mar}$ & $3 / \mathrm{mar}$ & $4 / \mathrm{mar}$ & $5 / \mathrm{mar}$ & $7 / \mathrm{mar}$ & $8 / \mathrm{mar}$ & $9 / \mathrm{mar}$ & $10 / \mathrm{mar}$ & $11 / \mathrm{mar}$ & $14 / \mathrm{mar}$ & $15 / \mathrm{mar}$ & $16 / \mathrm{mar}$ & $17 / \mathrm{mar}$ & $18 / \mathrm{ma}$ \\
\hline Dias Sem. & seg & ter & qua & qui & $\operatorname{sex}$ & seg & ter & qua & qui & $\operatorname{sex}$ & seg & ter & qua & qui & $\operatorname{sex}$ \\
\hline Dias do TPT & dia 1 & dia 2 & dia 3 & dia 4 & dia 5 & dia 1 & dia 2 & dia 3 & dia 4 & dia 5 & dia 1 & dia 2 & dia 3 & dia 4 & $\operatorname{dia} 5$ \\
\hline Itens A & $\mathbf{A}$ & & B & & $\mathbf{C}$ & $\mathbf{A}$ & & B & & $\mathbf{C}$ & $\mathbf{A}$ & & B & & $\mathbf{C}$ \\
\hline Itens $C$ & & $\bar{D}$ & $\bar{E}$ & $\mathbf{F}$ & & & $\mathbf{G}$ & $\mathbf{H}$ & I & & & $\bar{J}$ & & $\mathbf{K}$ & \\
\hline \multirow[t]{2}{*}{ Dias do TPT } & dia 1 & dia 2 & dia 3 & $\operatorname{dia} 4$ & $\operatorname{dia} 5$ & $\operatorname{dia} 6$ & dia 7 & dia 8 & dia 9 & dia 10 & dia 11 & dia 12 & \begin{tabular}{|l} 
dia 13 \\
\end{tabular} & dia 14 & dia 15 \\
\hline & \multicolumn{5}{|c|}{$\begin{array}{l}\text { Reposição dos itens de alto } \\
\text { custo ao longo de } 5 \text { dias }\end{array}$} & \multicolumn{5}{|c|}{$\begin{array}{c}\text { Reposição dos itens de alto custo } \\
\text { ao longo de } 5 \text { dias }\end{array}$} & \multicolumn{5}{|c|}{$\begin{array}{c}\text { Reposição dos itens de alto custo ao } \\
\text { longo de } 5 \text { dias }\end{array}$} \\
\hline
\end{tabular}

Quadro 33: Distribuição dos itens de baixo volume e baixo custo num TPT de 15 dias

Note que os classe C, com tamanho de lote maior (15 dias) irão girar menos. Consequentemente, menos setups terão que ser feitos. Esse tempo disponibilizado poderá ser convertido em um número maior de setups (maior giro) para os itens classe A, reduzindo mais ainda o seu TPT.

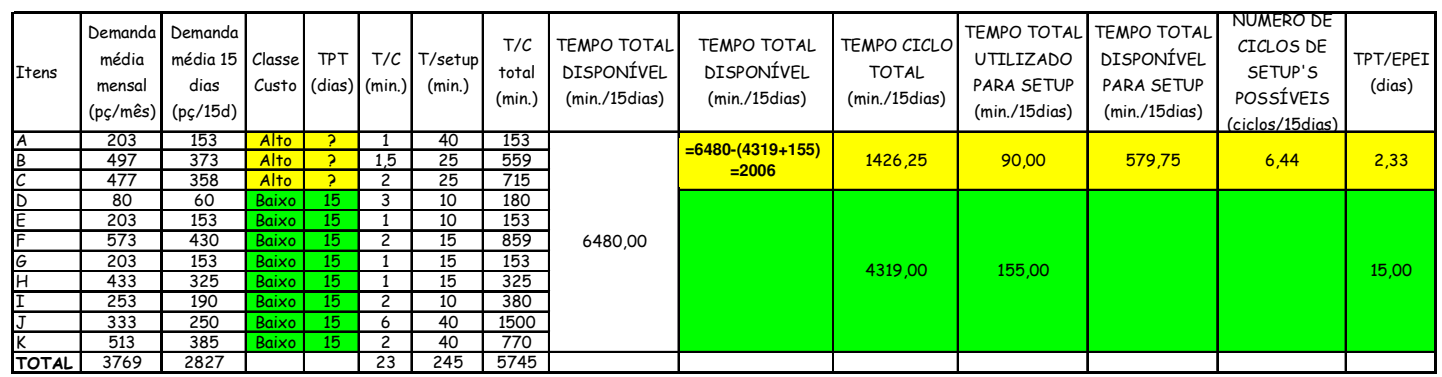

Quadro 34: Cálculo do novo TPT para os itens de alto custo e alto volume.

No exemplo da tabela acima, o TPT dos itens de alto custo poderia ser reduzido para aproximadamente 2,5 dias, ou seja, metade do TPT inicial! A nova distribuição para reposição dos itens ficaria da seguinte forma. 


\begin{tabular}{|c|c|c|c|c|c|c|c|c|c|c|c|c|c|c|c|}
\hline \multirow{3}{*}{ Dias Mês } & \multicolumn{15}{|c|}{ TPT = 15 dias para os itens de baixo custo } \\
\hline & \multicolumn{5}{|c|}{ TPT $=2,5$ dias para os itens A } & \multicolumn{5}{|c|}{ TPT $=2,5$ dias para os itens A } & \multicolumn{5}{|c|}{ TPT $=2,5$ dias para os itens A } \\
\hline & $1 / \mathrm{mar}$ & $2 / \mathrm{mar}$ & $3 / \mathrm{mar}$ & $4 / \mathrm{mar}$ & $5 / \mathrm{mar}$ & $7 / \mathrm{mar}$ & $8 / \mathrm{mar}$ & 9/mar & $10 / \mathrm{mar}$ & $11 / \mathrm{mar}$ & $14 / \mathrm{mar}$ & $15 / \mathrm{mar}$ & $16 / \mathrm{mar}$ & $17 / \mathrm{mar}$ & $18 / \mathrm{mar}$ \\
\hline Dias Sem. & $\operatorname{seg}$ & ter & qua & qui & $\operatorname{sex}$ & $\operatorname{seg}$ & ter & qua & qui & $\operatorname{sex}$ & $\operatorname{seg}$ & ter & qua & qui & $\operatorname{sex}$ \\
\hline$\overline{\text { Dias do TPT }}$ & dia 1 & dia 2 & dia 3 & dia 4 & dia 5 & dia 1 & dia 2 & dia 3 & dia 4 & dia 5 & dia 1 & dia 2 & dia 3 & dia 4 & dia 5 \\
\hline Itens A & $\mathbf{A}, \mathbf{B}$ & $\mathrm{C}$ & ,A & B, C & $\mathrm{C}$ & $\mathbf{A}, \mathbf{B}$ & $\mathrm{C}$ & ,A & B, C & $\mathrm{C}$ & A, B & $\mathrm{C}$ & ,A & B, C & $\mathrm{C}$ \\
\hline Itens $C$ & D & $\mathbf{E}$ & $\mathbf{F}$ & & $\bar{H}$ & G & & $\mathrm{K}$ & & I & & & $\mathbf{J}$ & & \\
\hline \multirow[t]{3}{*}{ Dias do TPT } & dia 1 & dia 2 & dia 3 & dia 4 & dia 5 & dia 6 & dia 7 & dia 8 & $\operatorname{dia} 9$ & dia 10 & dia 11 & dia 12 & dia 13 & dia 14 & dia 15 \\
\hline & \multicolumn{5}{|c|}{$\begin{array}{c}\text { Reposição dos itens de alto custo } \\
\text { ao longo de } 2,5 \text { dias }\end{array}$} & \multicolumn{5}{|c|}{$\begin{array}{c}\text { Reposição dos itens de alto custo ao } \\
\text { longo de } 2,5 \text { dias }\end{array}$} & \multicolumn{5}{|c|}{$\begin{array}{c}\text { Reposição dos itens de alto custo ao longo } \\
\text { de } 2,5 \text { dias }\end{array}$} \\
\hline & & & & & & çá & 31 & de & $\mathrm{cu}$ & o lo & e 15 & & & & \\
\hline
\end{tabular}

Quadro 35: Distribuição dos itens de baixo volume e baixo custo num TPT de 15 dias e dos itens de alto custo e alto volume num TPT de 2,5 dias.

O próximo passo consiste em definir o número de cartões, ou kanbans, para cada item do supermercado.

\subsubsection{Calcular o número de cartões para cada item do supermercado}

Existem várias formas de determinar o número de cartões para cada item do supermercado. A seguir, são apresentados alguns critérios para a definição do número de cartões:

1 item por cartão: recomendado nos casos em que o tamanho do supermercado é pequeno, evitando a necessidade de geração e manutenção de um número muito grande de cartões. Este é, sem dúvida, o melhor critério quando é possível adotá-lo, pois evita estoques desnecessários devido principalmente a arredondamentos feitos na divisão do tamanho do supermercado pelo critério adotado.

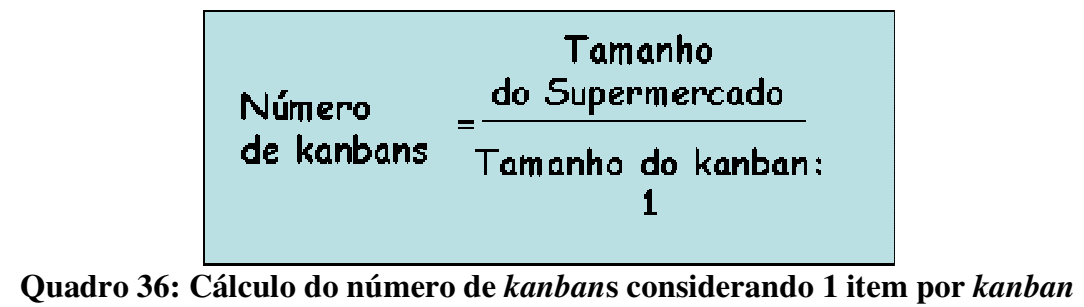

Capacidade do container: consiste no critério mais utilizado. Neste caso, o número de cartões é obtido dividindo-se o tamanho do supermercado pela quantidade de itens que é armazenada por container. 


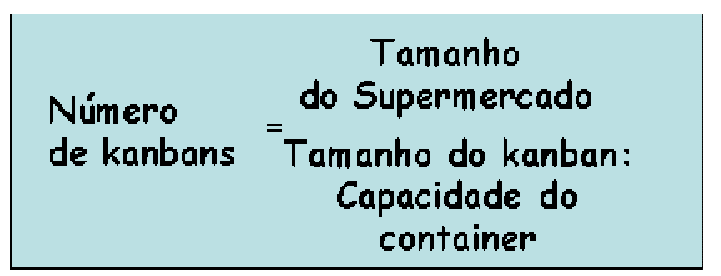

Quadro 37: Cálculo do número de kanbans com base na capacidade do container

Tamanho de lote mínimo razoável de ser feito: Trata-se de um critério mais empírico em que deve prevalecer o bom senso através de um levantamento feito juntamente com o pessoal de chão de fábrica.

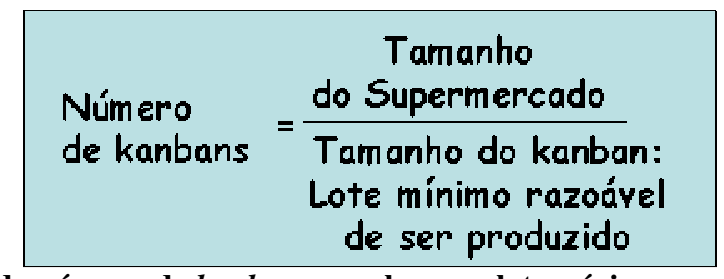

Quadro 38: Cálculo do número de kanbans com base no lote mínimo razoável de ser produzido

$\underline{\text { Tamanho de lote mínimo que atenda ao consumo de pelo menos } 1}$

produto: Em certas ocasiões, um produto pode utilizar uma quantidade maior de um mesmo item na sua estrutura. Um tamanho de lote de kanban que não atenda ao consumo de pelo menos 1 produto não vai adiantar de nada, principalmente se ele for o último lote disponível. Neste caso, propõe-se considerar a quantidade de itens que é utilizada no produto mais crítico, ou seja, aquele que utiliza a maior quantidade do item em questão.

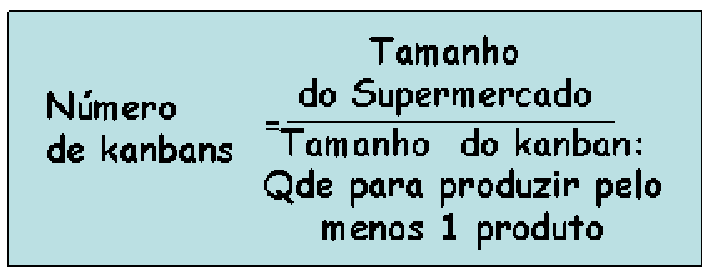

Quadro 39: Cálculo do número de kanbans considerando a quantidade necessária para produzir pelo menos 1 produto

Unidade de tempo (horas/dias/semanas) do TPT: Para um TPT de 5 dias e um tamanho de supermercado de 7 dias, pode-se trabalhar com 7 cartões 
diários (1 dia cada cartão). O interessante desse critério é a maior noção, e gestão, visual do tempo de estoque disponível de cada item nas prateleiras do supermercado.

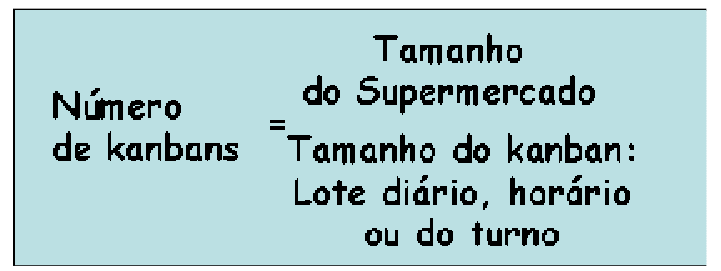

Quadro 40: Cálculo do número de kanbans com base na mesma unidade de tempo utilizada para o TPT

Restrição de espaço: Em certas ocasiões, o espaço disponível para armazenar o supermercado de peças pode ser um fator relevante. Por exemplo, nas situações em que o supermercado é composto por uma variedade muito grande de itens. Nestes casos, o número de cartões pode ter que ser definido com base na capacidade física do local onde o supermercado será implantado.

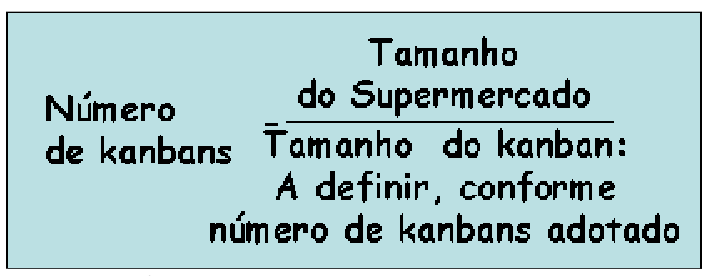

Quadro 41: Cálculo do número de kanbans com base na restrição de espaço físico

No exemplo adotado, o tamanho do kanban é de 15 itens. Logo, o número de kanbans para cada um dos itens do supermercado é dado na tabela abaixo:

\begin{tabular}{|c|c|c|c|c|c|}
\hline Itens & $\begin{array}{l}\text { dro 42: Cálculo } \\
\text { Supermercado } \\
\text { (pç) }\end{array}$ & $\begin{array}{l}\text { To número d } \\
\text { do Kanbanho }\end{array}$ & $\begin{array}{c}\text { Kappans para c } \\
\text { Kabans } \\
\text { Calculado }\end{array}$ & $\begin{array}{l}\text { Número de } \\
\text { Kabans } \\
\text { Arredondado }\end{array}$ & $\begin{array}{l}\text { rmercado } \\
\text { Mámanho } \\
\text { Máximo do } \\
\text { Supermercado }\end{array}$ \\
\hline$A$ & 91 & 15 & 6,07 & 6 & 90 \\
\hline$B$ & 245 & 15 & 16,33 & 16 & 240 \\
\hline $\bar{C}$ & 238 & 15 & 15,87 & 16 & 240 \\
\hline$D$ & 35 & 15 & 2,33 & 2 & 35 \\
\hline$E$ & 91 & 15 & 6,07 & 6 & 90 \\
\hline$F$ & 224 & 15 & 14,93 & 15 & 225 \\
\hline$G$ & 91 & 15 & 6,07 & 6 & 90 \\
\hline $\mathrm{H}$ & 210 & 15 & 14,00 & 14 & 210 \\
\hline$I$ & 112 & 15 & 7,47 & 7 & 105 \\
\hline $\mathrm{J}$ & 175 & 15 & 11,67 & 12 & 180 \\
\hline K & 217 & 15 & 14,47 & 14 & 210 \\
\hline TOTAL & 1729 & 15 & 115,27 & 114 & 1715 \\
\hline
\end{tabular}


Note que arredondamentos são necessários, alterando o tamanho máximo do supermercado. Neste caso, ele diminui de 1729 para 1715 peças no supermercado. Mas, pode acontecer de aumentar.

O próximo passo consiste definir a distribuição dos cartões no quadro de semáforo.

\subsubsection{Definir a distribuição dos cartões no quadro semáforo}

O quadro de semáforo é uma das mais importantes ferramentas de gestão visual do sistema de controle kanban. Através dela, é possível gerenciar visualmente o momento de realizar a reposição e o momento em que o estoque de proteção está sendo consumido.

A faixa verde do quadro significa que ainda não há necessidade de produzir o item. A quantidade de cartões a ser depositada nessa faixa corresponde ao lote de produção, ou seja, à quantidade de cartões correspondentes ao TPT calculado.

A faixa amarela significa que é hora produzir o item. A quantidade de cartões a ser depositada nessa faixa corresponde ao tempo necessário para a reposição do item.

Vale ressaltar que, dependendo da forma como o cartão é disparado, a distribuição do cartão na faixa amarela será diferente. Se o cartão é disparado assim que a primeira peça da caixa começa a ser consumida, então a quantidade de cartões a ser depositada nessa faixa corresponde exatamente ao tempo necessário para a reposição do item. 


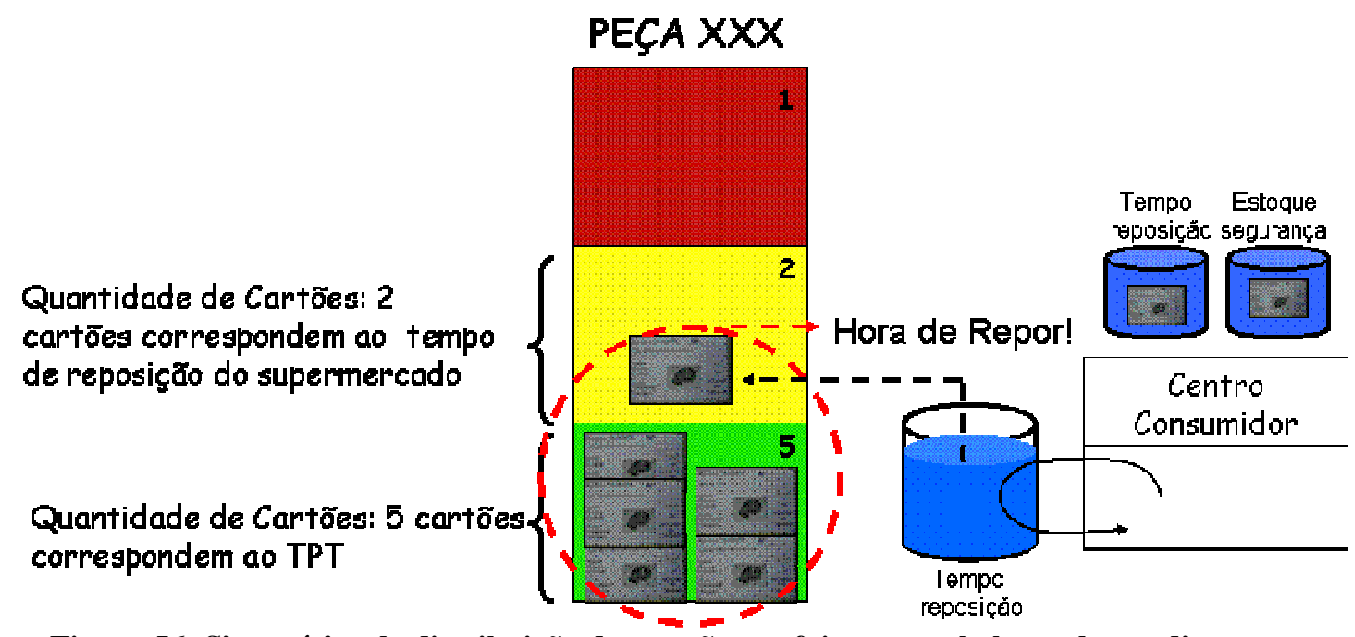

Figura 56: Sistemática de distribuição dos cartões na faixa amarela baseada em disparos a partir do consumo da primeira peça da caixa

Se o cartão é disparado só depois que houve o consumo de todos os itens daquele cartão, então um dos cartões correspondente ao TPT deve ser depositado nessa faixa. Desse modo, os cartões que ainda não foram para o quadro realmente irão corresponder ao tempo de reposição do item.

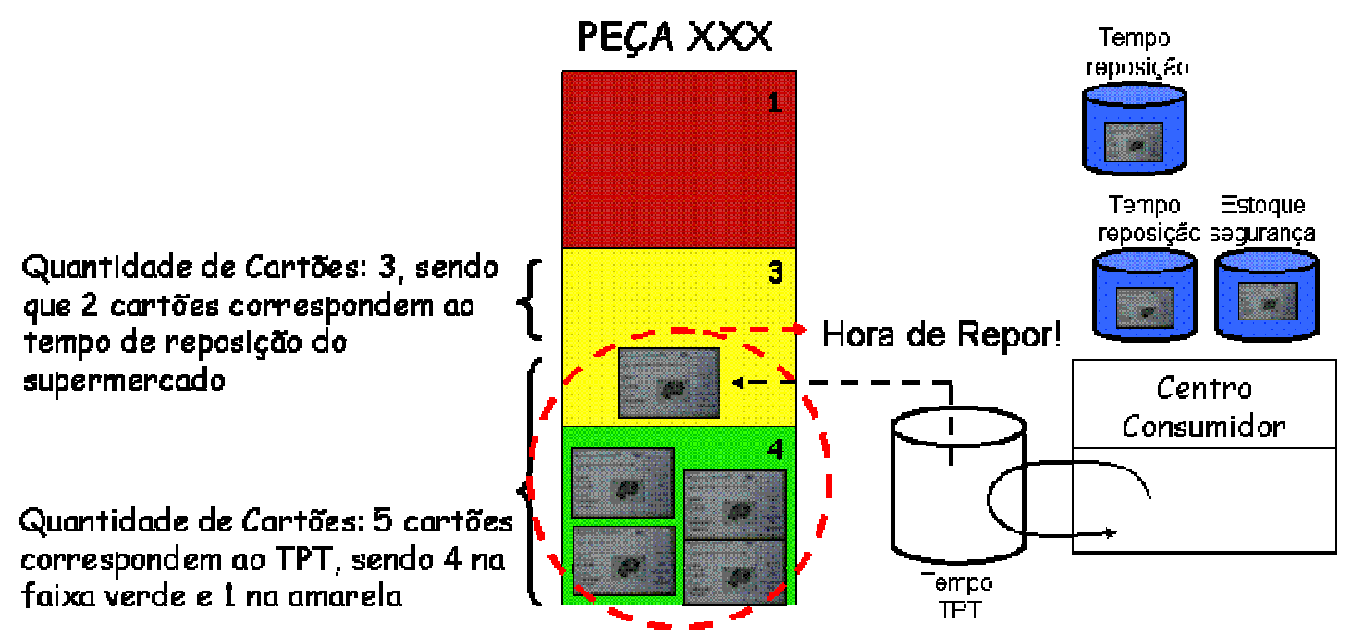

Figura 57: Sistemática de distribuição dos cartões na faixa amarela com disparos a partir do consumo da últma peça da caixa

De acordo com a lógica acima, a distribuição dos kanbans no quadro no exemplo adotado é dado na tabela abaixo: 


\begin{tabular}{|l|c|c|c|c|c|c|c|c|c|c|}
\hline Ittens & $\begin{array}{c}\text { Demanda } \\
\text { média diária } \\
\text { (pç/dia) }\end{array}$ & $\begin{array}{c}\text { TPT ou Ciclo } \\
\text { do Pedido } \\
\text { (dias) }\end{array}$ & $\begin{array}{c}\text { Tempo de } \\
\text { reposição } \\
\text { (dias) }\end{array}$ & $\begin{array}{c}\text { Tempo de } \\
\text { segurança } \\
\text { (dias) }\end{array}$ & $\begin{array}{c}\text { Tamanho } \\
\text { do Kanban }\end{array}$ & $\begin{array}{c}\text { Número } \\
\text { kanbans } \\
\text { Verde }\end{array}$ & $\begin{array}{c}\text { Número } \\
\text { kanbans } \\
\text { Amarelo }\end{array}$ & $\begin{array}{c}\text { Número } \\
\text { kanbans } \\
\text { Vermelho }\end{array}$ & $\begin{array}{c}\text { Número } \\
\text { Total de } \\
\text { Kabans }\end{array}$ & $\begin{array}{c}\text { Tamanho } \\
\text { Máximo do } \\
\text { Supermercado }\end{array}$ \\
\hline A & 13 & 5 & 1 & 1 & 15 & 3 & 2 & 1 & 6 & 90 \\
\hline B & 35 & 5 & 1 & 1 & 15 & 11 & 3 & 2 & 16 & 240 \\
\hline D & 34 & 5 & 1 & 1 & 15 & 10 & 3 & 2 & 15 & 225 \\
\hline E & 5 & 5 & 1 & 1 & 15 & 1 & 2 & 1 & 4 & 60 \\
\hline F & 13 & 5 & 1 & 1 & 15 & 3 & 2 & 1 & 6 & 90 \\
\hline G & 32 & 5 & 1 & 1 & 15 & 10 & 3 & 2 & 15 & 225 \\
\hline H & 13 & 5 & 1 & 1 & 15 & 3 & 2 & 1 & 6 & 9 \\
\hline I & 16 & 5 & 1 & 1 & 15 & 9 & 3 & 2 & 14 & 210 \\
\hline J & 25 & 5 & 1 & 1 & 15 & 4 & 2 & 1 & 7 & 105 \\
\hline K & 31 & 5 & 1 & 1 & 15 & 7 & 3 & 2 & 12 & 180 \\
\hline TOTAL & 247 & & 1 & 1 & 15 & 9 & 3 & 2 & 14 & 210 \\
\hline
\end{tabular}

Quadro 43: Distribuição dos cartões no quadro de semáforo

Definidos os pontos e o tamanho dos supermercados o próximo passo consiste em definir as sistemáticas de programação e controle da produção.

\subsection{Definição das sistemáticas de programação e controle da produção}

O fluxo de material irá variar conforme o sistema de programação e controle que determina a sua movimentação. Nesse sentido, os fluxos das diferentes subfamílias de programação e controle definidas podem ser puxados ou empurrados.

\subsubsection{Programação e controle dos itens MTO}

Conforme visto anteriormente, algumas subfamílias de programação e controle serão compostas por itens que serão programados e controlados por ordens de produção, apresentando, assim, uma política de atendimento da demanda do MTO (Make-to-Order). Nestes casos, os pedidos dos clientes disparam a produção dos itens que deverão ser entregues.

A maneira mais convencional para se empurrar a produção é o Sistema MRP. A estrutura básica do sistema MRP foi criada para determinar as quantidades a produzir estritamente necessárias nos momentos necessários. Entretanto, de acordo com o tópico 2.4.3 da revisão bibliográfica deste trabalho, a sistemática de cálculo de materiais do MRP pode estar associada a diferentes formas de emissão de ordens de produção.

Quando as ordens são emitidas Lote a Lote, os lotes são dimensionados estritamente de acordo com cada demanda em cada período. $\mathrm{O}$ 
problema, do ponto de vista de um sistema de programação lean, está no fato de que essa sistemática desconsidera o TPT de cada fluxo. Possuir uma freqüência de emissão de ordens para um mesmo item maior que o TPT, embora impeça saldos excedentes em estoque, tende a incorrer no uso inadequado dos recursos produtivos. Consequientemente, o sistema tende a entrar em colapso por falta de capacidade produtiva, consumida pelos elevados tempos agregados de preparação.

Quando as ordens são emitidas por Lotes Fixos, os lotes de itens fabricados serão normalmente baseados em algum critério ponderado por custos de preparação (set up) contra custos de manutenção de estoques (lote econômico). Normalmente, restará alguma sobra em estoque, que deverá ser deduzida da necessidade bruta do pedido subseqüente. Do ponto de vista de um sistema de programação lean, essa sistemática de emissão de ordens também é ruim, pois também desconsidera a lógica do cálculo do TPT do fluxo. Com isso, os pedidos podem ser colocados em lotes de produção excessivamente grandes, normalmente mensais. Essa política de programação limita a flexibilidade de mix de todo o sistema, pois pode comprometer recursos restritivos por dias com um único pedido.

Por isso, do ponto de vista de um sistema de programação lean, a melhor forma de se emitir as ordens de produção é pela sistemática de Lote a Intervalo Fixo. De acordo com essa sistemática, os lotes das ordens de produção podem ser tanto "quebrados" (em ordens parciais) quanto agrupados em tamanhos proporcionais ao TPT calculado para o fluxo em questão. Não há saldos excedentes em estoque ao término do intervalo de tempo estabelecido, embora existam estoques, como função do número de períodos adjacentes considerados. Por exemplo, num fluxo cujo TPT seja de 5 dias, uma ordem de produção muito grande para o final de um determinado mês com 20 dias úteis poderia ser quebrada em quatro ordens parciais, com prazos de entrega semanal cada uma. Nesse caso, a primeira ordem poderia ser programada para três semanas antes do prazo final, a segunda ordem para duas semanas antes, a terceira para uma semana antes e a quarta na semana do prazo final do cliente.

A fim de padronizar o sistema de cartões, pode-se até elaborar ordens de fabricação no formato dos cartões kanbans. Trata-se do kanban de ordem de 
serviço, mencionado no tópico 2.4.4 deste trabalho. As ordens poderiam ser “quebradas" em kanbans de tamanho equivalente ao TPT.

A programação dos pedidos MTO deve estar em sinergia com a programação dos fluxos puxados, principalmente nos processos em que os componentes de um produto sob encomenda "competem" pelos mesmos recursos (homens e máquinas) que são consumidos pelas peças controladas por kanbans. Respeitando-se o ciclo do TPT, ambas as sistemáticas tendem a entrar em num sistema de compensação. Em períodos de sobrecarga os pedidos MTO são priorizados enquanto os supermercados são consumidos. Em períodos de ociosidade é a vez dos supermercados serem reabastecidos. Vale ressaltar que, como o sistema kanban é um sistema essencialmente para estoque, em situações em que houver tanto ordens quanto kanbans competindo por uma mesma janela de programação, os pedidos MTO devem ser priorizados.

\subsubsection{Programação e controle dos fluxos puxados}

Primeiramente, para administrar as interfaces entre os sistemas empurrados e os sistemas puxados, é necessário utilizar o backflushing com ordens fantasmas. Isso significa que os itens agrupados nas subfamílias que serão programadas e controladas pela lógica de puxar a produção (kanban, duas gavetas, sinal) deverão ser marcados como fantasmas para que o MRP não gere ordens de produção para eles.

A definição dos sistemas de programação e controle para os fluxos puxados pode ser feita com base em dois tipos de sistemáticas de reposição de inventário: a de pedidos com quantidades constantes e de ciclo de pedidos constante. Estas sistemáticas foram inicialmente introduzidas pelo sistema OPOQ de programação e controle (tópico 2.4.1). Contudo, de acordo com Rother (1999), estas duas formas de reposição de inventários também podem ser aplicadas como sistemática de reposição do sistema kanban, embora não tenha explicado exatamente como. 
Nesse sentido, é proposto a seguir a sua aplicação na reposição dos tipos de sistema kanban contemplados no escopo deste trabalho (kanban de produção, 2 gavetas/kanban de sinal).

\section{a) Programação e controle por quantidades fixas}

A programação e controle dos fluxos puxados por "quantidades fixas" está baseada na sistemática de reposição de inventário em que uma quantidade fixa será pedida para o processo anterior toda vez que o estoque deste item atingir um determinado nível. Neste caso, a quantidade pedida é fixa, mas a data do pedido é variável.

A seguir é apresentada uma visão esquemática dessa lógica utilizando o quadro semáforo e kanbans de produção.

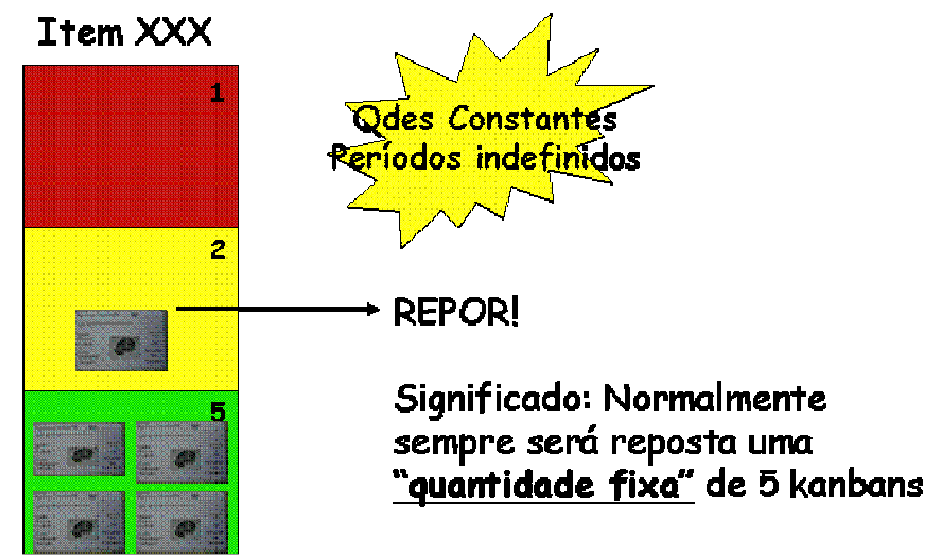

Figura 58: Sistemática de programação por quantidade fixa e períodos variáveis com kanbans de produção

Note que, embora exista uma freqüência média de tempo de reposição (TPT) por trás da quantidade de cartões no quadro, não há como afirmar precisamente o dia em que o item deverá ser produzido, pois irá depender da chegada do primeiro cartão na faixa amarela. Por isso, o número de kanbans a ser reposto 
sempre será uma quantidade fixa de 5 cartões, mas o período irá variar conforme a demanda.

Essa mesma sistemática é a mais apropriada para a reposição de itens controlados por kanbans de sinal e duas gavetas.

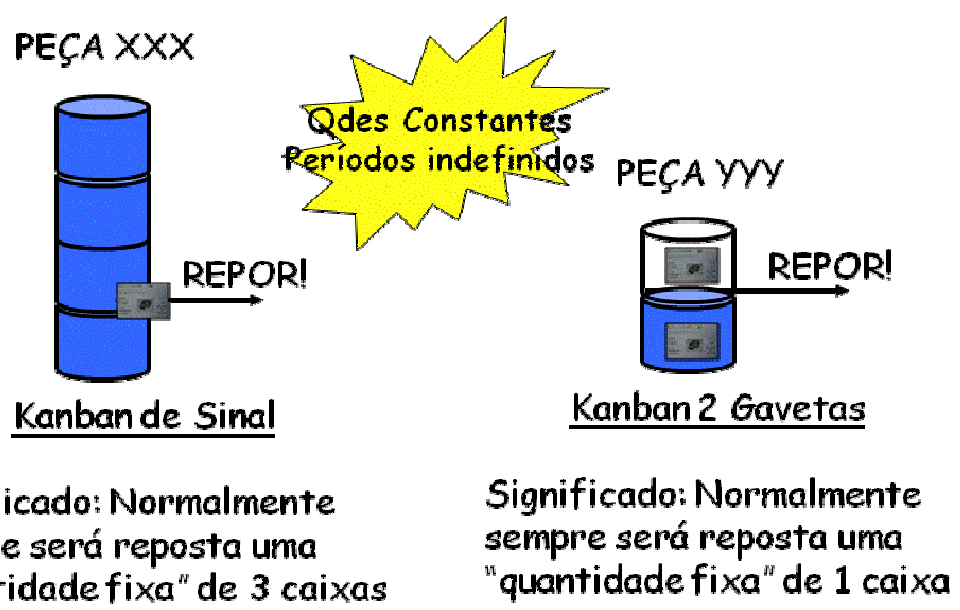

Figura 59: Sistemática de programação por quantidade fixa e períodos variáveis com kanbans de sinal e duas gavetas.

Os principais critérios para o sequienciamento dos itens a serem produzidos são:

* A indicação de urgência no quadro semáforo

* A indicação de consumo iminente por parte do consumidor

Alguns critérios secundários são:

* A ordem de chegada do cartão no quadro

* Atender o menor ou o maior pedido primeiro

* Fazer o mais rápido ou o mais demorado primeiro

Essa política de reposição é a tradicionalmente utilizada no sistema kanban. A sua principal vantagem é a simplicidade de realizar o disparo e a gestão visual do sistema como um todo.

Porém, quando um centro produtor possui vários tipos de itens e uma alta oscilação da demanda a priorização e o sequenciamento da reposição pode se tornar num problema complexo, mesmo com o auxílio do sistema de cores do quadro semáforo. 
Em centros produtores com alta variedade de itens e demanda desnivelada pode ocorrer dos cartões também chegarem ao ponto de reposição (amarelo) do quadro de forma desnivelada. Isso significa que o centro produtor pode se deparar ora com sobrecarga, causada pelo excesso de cartões no amarelo ou vermelho, ora com ociosidades, causada pela falta de cartões no amarelo. Resumidamente, a reposição por quantidades fixas em ambientes de alta variedade tende a ser mais afetada pelo desnivelamento da demanda, resultando também no desnivelamento da produção.

Para estas situações uma forma alternativa para se programar a produção dos kanbans é a sistemática de "reposição por período fixo".

\section{b) Programação e controle por período fixo}

A programação e controle da produção dos fluxos puxados por período fixo consiste numa sistemática de reposição de inventário baseada em dias ou horários fixos, mas a quantidade pedida varia.

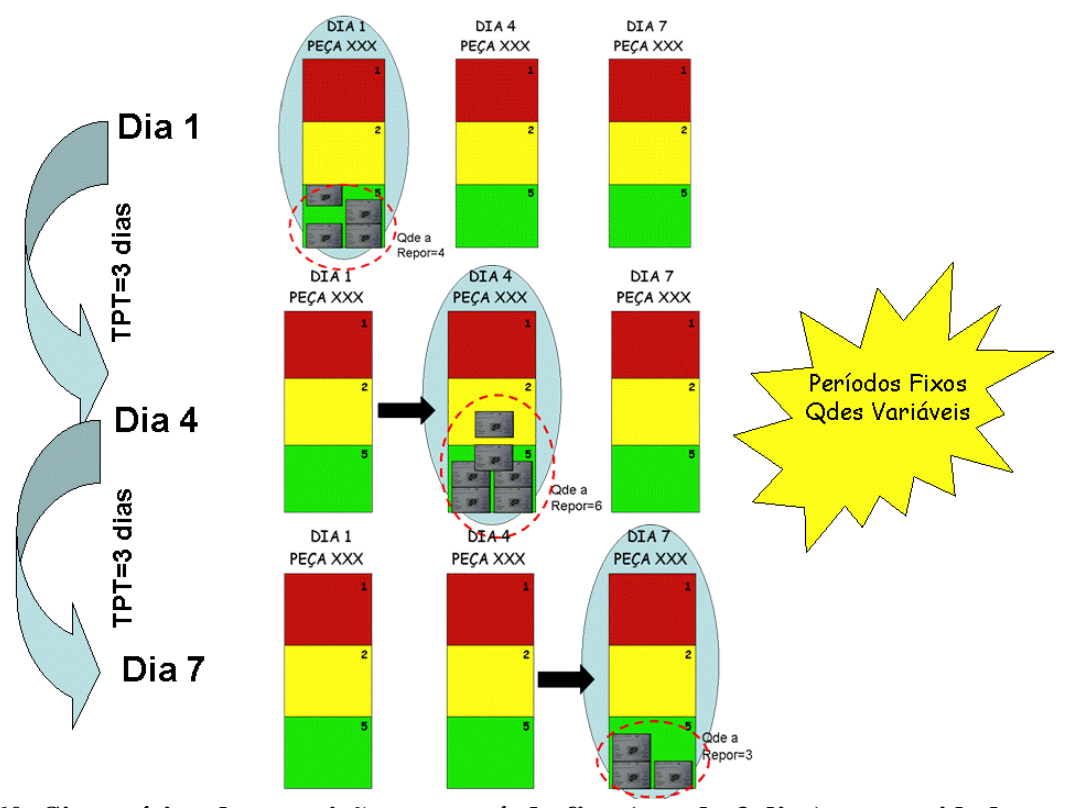

Figura 60: Sistemática de reposição por período fixo (a cada 3 dias) e quantidades variáveis

O bom funcionamento dessa sistemática depende da elaboração de uma lista com o mix dos itens a serem produzidos num mesmo período (hora ou dia). É importante também vincular os dias do TPT com os dias do mês, como referência 
para os operadores saberem o grupo de itens a serem produzidos no dia, desde que haja cartão no quadro.

$\mathrm{Na}$ figura abaixo foi elaborada uma lista com o mix diário dos itens com TPT de 3 dias. A elaboração desta lista deve considerar principalmente a distribuição dos itens de forma balanceada, de modo a respeitar a capacidade produtiva do dia. Propõe-se também que seja feita uma legenda que contenha a amarração dos dias do TPT com a agenda do mês.

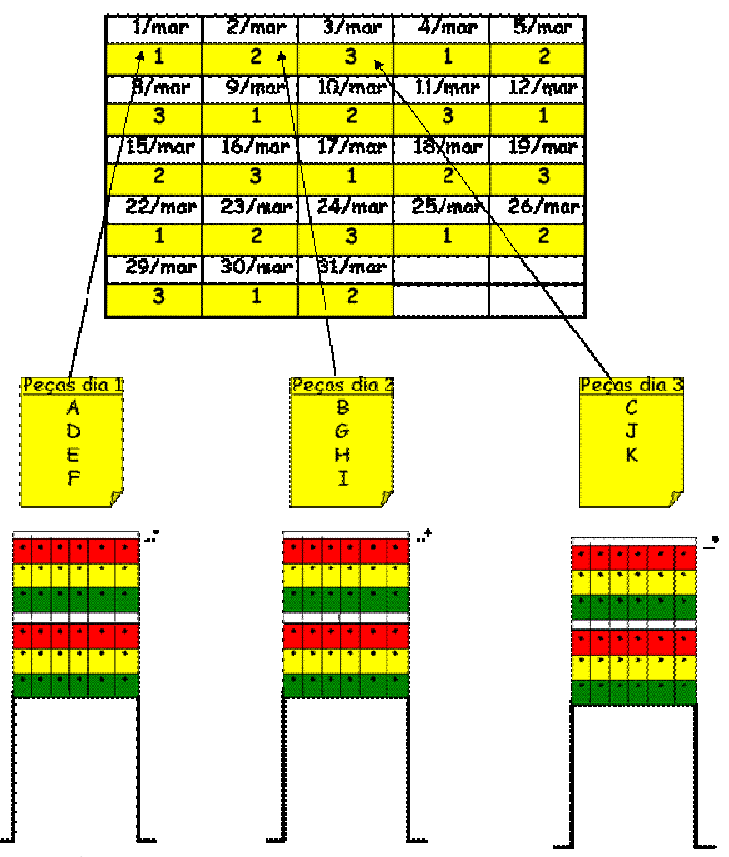

Figura 61: Distribuição diária dos itens com TPT de 3 dias e amarração dos dias do TPT com agenda do mês

A princípio, o sequenciamento dos itens ao longo dos dias do TPT poderá ser feito numa base diária, ou seja, o mais importante seria a definição do grupo de itens a serem produzidos em cada um dos três dias do TPT. A ordem dos itens a serem produzidos "dentro" do dia ficaria a critério do operador, embora seja possível também trabalhar com esse nível de detalhamento.

As principais vantagens da reposição por período fixo são:

\& Possibilita um melhor nivelamento da reposição dos kanbans, mesmo diante de uma demanda desnivelada.

* Auxilia no enfoque e priorização dos itens a serem produzidos num determinado dia. 
* A troca e o aproveitamento de ferramental podem e devem ser tratados como um fator estratégico. Peças com dispositivos e ferramentais semelhantes podem ser encaixadas num mesmo período de reposição.

Naturalmente, deve continuar prevalecendo o aviso de urgência do quadro semáforo, ou seja, componentes que não estejam programados para um determinado período, mas que estão no vermelho e/ou com perspectiva de consumo pelo processo puxador, deverão ser antecipados.

As principais desvantagens desse sistema são:

Pode incorrer no desperdício de superprodução e estoques desnecessários ao permitir a reposição de itens cujos cartões ainda não chegaram na faixa amarela.

Requer um maior esforço na manutenção do sistema como um todo (revisões para alteração do TPT, atualização da agenda mensal, balanceamento da carga de trabalho do dia).

Com base nos argumentos supracitados a empresa deve analisar e, se possível testar, qual das duas sistemáticas seria mais apropriada para o loop em estudo. Vale ressaltar que é possível aplicar as duas sistemáticas em loops diferentes de um mesmo fluxo de valor.

Embora o sistema puxado exista para amortecer as flutuações da demanda, o emprego desse sistema de controle de forma estática não garante a reposição dos kanbans em períodos de aumento significativo e duradouro da demanda. Logo, é preciso projetá-lo robusto e flexível, de forma a conter procedimentos claros para fazer frente aos diferentes patamares de demanda.

\subsection{Flexibilização dos fluxos puxados}

Alterações na demanda são freqüentes para muitas empresas. Ao se utilizar um sistema puxado, as variações no consumo dos itens causam impacto direto na eficácia deste sistema. Torna-se necessário a realização de ajustes 
periódicos para controle do supermercado. Estes ajustes consistem basicamente em atualizar o tamanho do supermercado, tornando o sistema mais robusto às flutuações da demanda.

Para isso, é preciso definir os períodos e as formas de ajuste o tamanho dos supermercados.

\subsubsection{Definição dos períodos de ajuste do tamanho dos supermercados}

O primeiro passo para a flexibilização de um sistema de controle puxado é determinar os intervalos para reavaliação e ajuste do tamanho dos supermercados. Enquanto parece ser impossível prever a demanda com uma ótima acuracidade, pode-se ao menos tentar torná-la mais previsível dividindo a linha do tempo em pequenos intervalos. Continua necessário olhar para frente para anteciparse à demanda, mas não em termos de previsões de longo prazo.

A periodicidade dos ajustes poderá ser definida com base nos seguintes critérios:

Ajuste por "janelas de tempo". Ex.: Jan-Mar; Abr-Jun; Jul-Set; OutDez

Ajuste por “janelas de quantidade”. Ex.: 1-5; 6-10; 11-15; 16-20

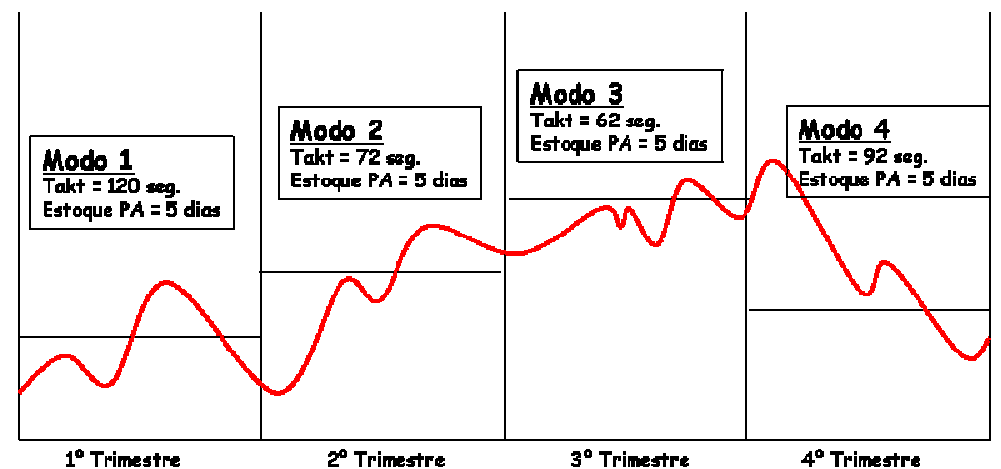

Figura 62: Flexibilização do tamanho do supermercado por janelas de tempo (Duggan, 2002)

O ajuste do tamanho do supermercado por janelas de tempo é uma forma de tornar o supermercado mais dinâmico em períodos fixos de tempo. Nesses 
casos, todas as etapas de dimensionamento vistas até aqui devem ser realizadas novamente.

Contudo, dentro de uma mesma janela o consumo dos itens pode exceder o limite máximo do supermercado. Com isso podem ser necessários ajustes finos no sistema puxado dentro de uma mesma janela.

\subsubsection{Estratégias para ajuste fino do sistema puxado numa mesma janela de tempo}

Um consumo que exceda o limite máximo do supermercado pode até ser causado por um aumento repentino da demanda externa. Mas, normalmente a extrapolação do tamanho máximo de um supermercado bem dimensionado para uma determinada janela de tempo é causada por reações em cadeia de práticas internas inadequadas. Estas práticas terminam por resultar no consumo desnivelado dos itens em supermercados. Isto normalmente é causado por fatos como:

Atrasos na montagem de um ou mais produtos pai devido à falta de itens filhos, sejam eles comprados ou manufaturados. Quando os itens em atraso chegam, a produção necessita tirar este atraso e, ao mesmo tempo, cumprir a programação do período para o(s) produto(s) em questão. Este fato tende a causar um pico de produção deste(s) produto(s), o qual resulta em pico de consumo dos respectivos itens filhos em supermercado.

* O fato acima também resulta em outro efeito colateral. Ou seja, quando ocorre um atraso a produção precisa encaixar outro produto para ser feito no lugar daquele que está em atraso ("vamos ver o que dá para fazer então"). Com isso, a tendência é que ocorra uma superprodução de um determinado produto cujos itens estejam todos disponíveis. A superprodução deste conjunto também resulta em pico de consumo dos respectivos itens em supermercado.

Por fim, perdas ou atrasos na liberação e colocação dos cartões nos quadros, por parte dos operadores, pode comprometer o giro e a reposição a tempo dos itens do kanban. 
Naturalmente, os problemas supracitados devem ser atacados em suas causas raízes. Algumas das principais ações são:

\& Nivelar a demanda externa junto à área comercial

\& Combater atrasos de fornecedores externos

+ Combater atrasos na liberação de documentos da engenharia

\& Criar procedimentos para a chegada sincronizada de itens que continuam sendo produzidos mediante ordem (MTO).

Por outro lado, nem sempre será possível faze-las em curto prazo. Enquanto isso, um ajuste fino nos sistemas puxados, dentro da própria janela de tempo, torna-se necessário.

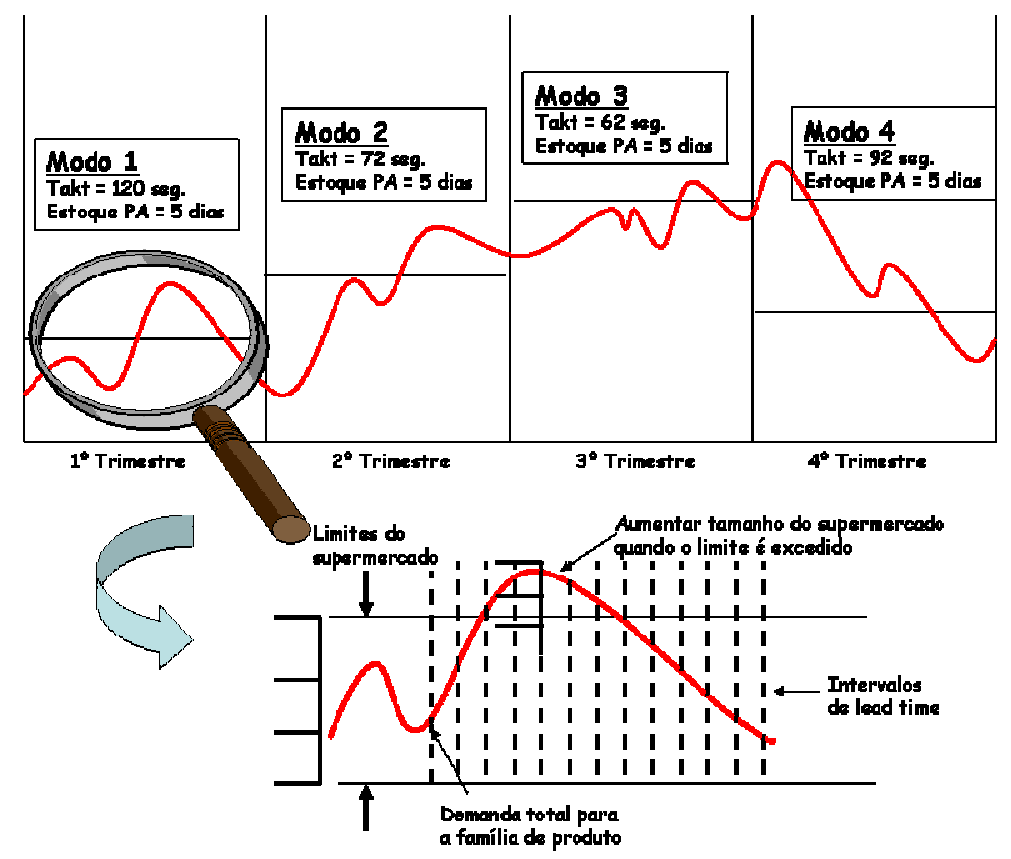

Figura 63: Ajuste fino do tamanho do supermercado dentro das janelas de tempo Fonte: Duggan (2002)

Nesse sentido, duas formas de tornar o supermercado mais robusto para lidar com picos repentinos de consumo são:

a) Abrir ordens de produção em paralelo para o volume adicional dos itens em supermercado, nos casos de pedidos repentinos e de grande volume. Este tipo de situação deve ser tratada pela sistemática de produzir sob encomenda (MTO). A idéia é preservar o supermercado para os pedidos que realmente são rotineiros. Se 
possível, recomenda-se ainda "quebrar" o pedido em ordens de produção de tamanhos menores, de preferência do tamanho do TPT calculado para o fluxo. Evita-se dessa forma que grandes lotes possam vir a comprometer a flexibilidade de mix do sistema.

b) Empenhar (separar) os itens antecipadamente sempre que for haver o consumo de itens do kanban em quantidade acima do tamanho do supermercado. Isto tende a ocorrer nos casos em que estes itens deixaram de ser consumidos devido a anomalias internas do próprio sistema. Reprogramações por falta de componentes de um produto terão que ser compensadas mais adiante e a quantidade em estoque dos respectivos itens em supermercado pode não suportar o pico de consumo. A idéia é análoga à implantação de um sistema de dois kanbans, em que um kanban de empenho (descartável) funcionaria como se fosse o kanban de compra (transporte ou retirada). O kanban de empenho puxa (empenha) o item e automaticamente dispara a ida do kanban de produção para o quadro, promovendo

1. Programar os itens a serem empenhados semanalmente

2. Separar o(s) item(ns) em órea específica para empenho, juntamente com a cartzo de empenho

3. Disparar o kanban de produçzo da respectiva caixa

4. Devolver o kanban de empenho pare o $P C P$

o giro do sistema.

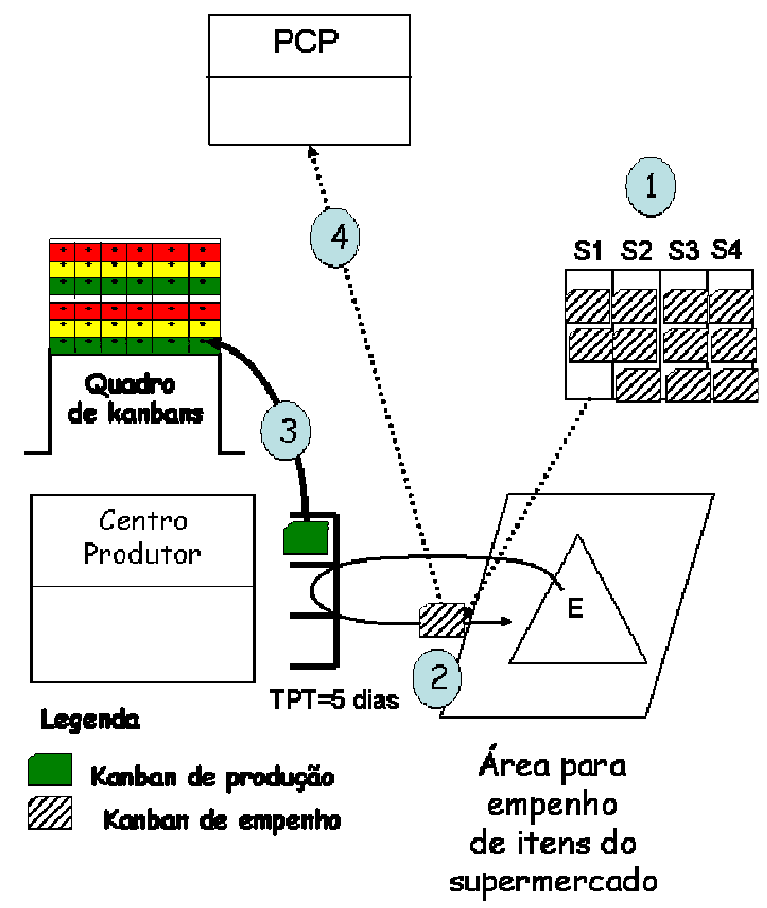

Figura 64: Procedimento para empenho de itens do supermercado

O procedimento para empenho funcionaria da seguinte forma:

1. Programar os itens a serem empenhados semanalmente. 
2. Separar o(s) item(ns) em área específica para empenho, juntamente com o cartão de empenho.

3. Disparar o kanban de produção da respectiva caixa.

4. Devolver o kanban de empenho para o PCP ou descartar o kanban de empenho quando o item empenhado for consumido.

Vale ressaltar que o empenho deve ser a última alternativa, ou seja, deve-se sempre tentar primeiramente remanejar as ordens de produção do produto acabado para um outro período que não cause pico no consumo dos itens do kanban. Para isso, o ideal é que seja montada uma estrutura de cardinalidade entre itens pais e filhos de modo que seja possível visualizar o consumo, e possíveis ocorrências de picos, dos itens filhos a partir da programação dos itens pais.

Qualquer que seja a ação para ajuste, existem duas formas possíveis para flexibilização do sistema puxado: reduzir ou aumentar a quantidade de itens no próprio cartão kanban ou alterar o número de cartões no sistema.

\subsubsection{Definição da forma de se ajustar o tamanho do supermercado: Alteração da quantidade de itens por cartão versus alteração da quantidade de cartões}

Podem ser utilizadas duas formas de ajuste do tamanho do supermercado:

Reduzir ou aumentar a quantidade de itens no próprio cartão kanban

Alterar o número de cartões no sistema.

A seguir, será apresentada uma simulação que mostra a diferença entre as duas formas. O objetivo desta simulação é mostrar que a alteração no número de cartões é mais eficiente do que a alteração na quantidade determinada em cada cartão.

Essa análise é importante, pois em alguns casos, devido a custos com contêineres, o sistema kanban pode ser projetado com um número reduzido de cartões. Embora essa seja uma decisão impactada pela avaliação de custos, os 
responsáveis pelo projeto do sistema devem estar cientes das limitações que essa decisão pode gerar ao sistema kanban projetado.

A constatação dessa diferença entre um sistema de mudança na quantidade especificada no cartão e no número de cartões deveu-se a uma constatação prática. Uma empresa do setor agroindustrial, cuja demanda é extremamente sazonal, implantou um sistema kanban baseado na alteração na quantidade especificada no cartão kanban. Isto porque o investimento necessário em contêineres era muito alto e não havia espaço físico suficiente para a armazenagem de um grande número de contêineres. Por isso, optou-se por adotar um sistema kanban com variação na quantidade especificada nos cartões, mantendo fixa a quantidade de cartões.

Devido a alterações na demanda e a um fluxo de valor muito longo constatou-se que o sistema kanban não tinha flexibilidade suficiente. O estoque em processo ora tornava-se elevado em períodos de queda de demanda ora demorava para responder ao aumento da demanda.

Com base nessas constatações foram feitas simulações para determinar qual princípio torna o sistema kanban mais flexível: Alterar a quantidade no cartão ou alterar a quantidade de cartões. A seguir, são apresentadas simulações cujo ponto de partida é um ponto de supermercado onde existem 3 caixas com 1 kanban cada uma. Cada caixa possui 3 peças (3 peças por kanban). Portanto, o supermercado possui 9 peças no total. A partir dessa simulação, foi possível definir qual dos sistemas é o mais eficiente.

\section{A) Cenário 1: Redução da demanda}

\section{A.1) Alteração da quantidade de itens por cartão (tamanho do kanban)}

1. Inicialmente, o supermercado de 9 peças encontra-se abastecido com 3 contêineres, com seus respectivos cartões kanbans. Cada cartão está dimensionado para três peças.

2. A partir do momento que uma peça é requisitada um contêiner é enviado para o posto de consumo. Paralelamente, também ocorre uma redução no volume da demanda que corresponderia a uma redução do tamanho do supermercado de 9 para 6 peças. 


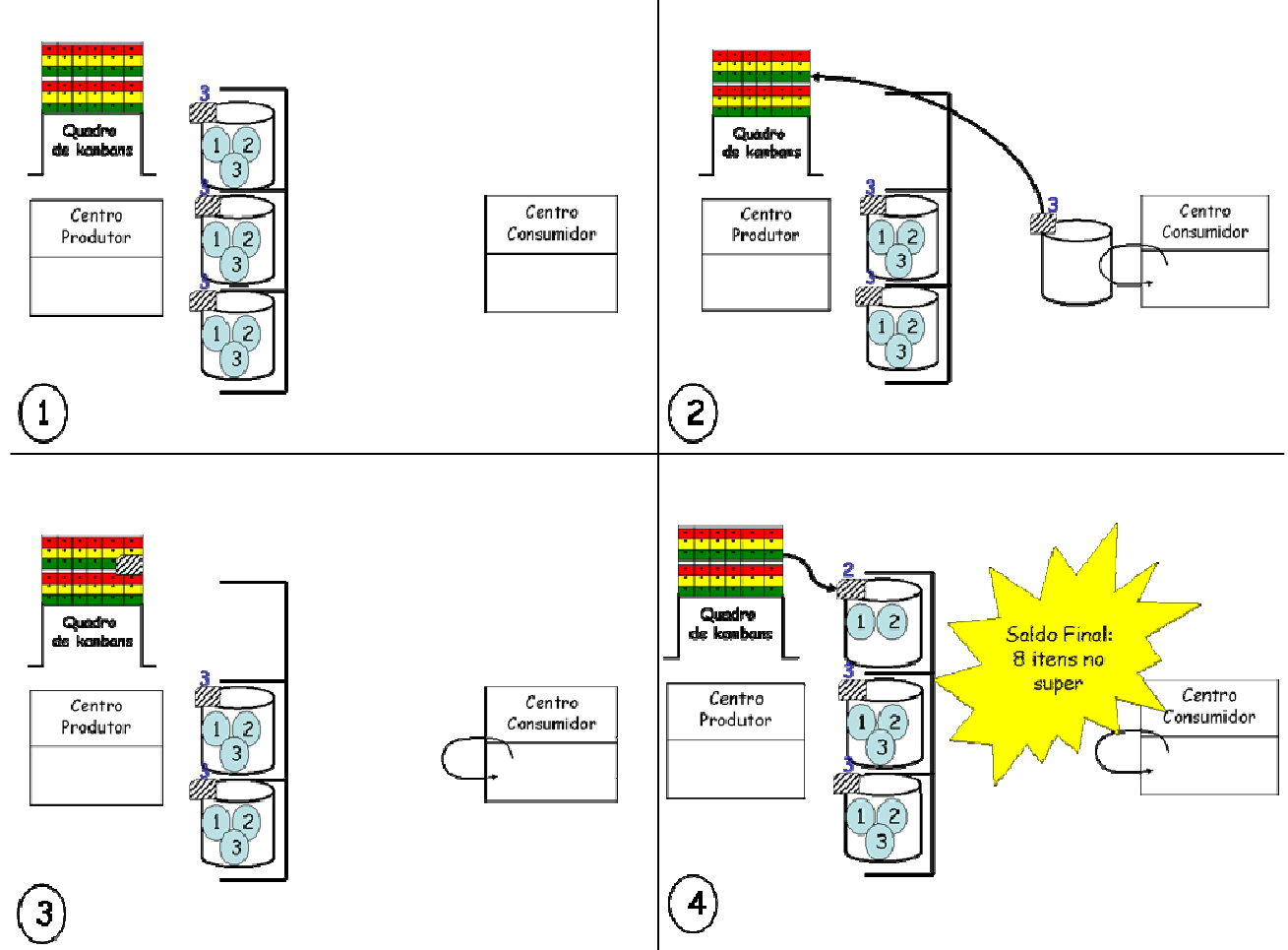

Figura 65: Ajuste do supermercado com redução da quantidade de itens por cartão (tamanho do kanban)

3. Com a alteração na demanda, as quantidades apresentadas nos cartões são ajustadas de 3 para 2 unidades. A produção para reposição do item no supermercado é iniciada.

4. O supermercado é reabastecido e saldo final é de 8 itens, sendo que ainda existem containeres com a quantidade antiga ao ajuste da demanda.

O principal problema associado consiste no fato de ter-se disparado a produção, mesmo tendo ocorrido uma diminuição na demanda. Embora, a demanda tenha se retraído, o sistema produz para repor o supermercado. Essa ação pode onerar a empresa através do aumento desnecessário da quantidade de itens no supermercado. 


\section{A.2) Alteração do número de cartões (número de kanbans)}

1. A quantidade no supermercado é a mesma do sistema anterior, ou seja, 9 itens.

2. A partir do momento que uma peça é requisitada um contêiner é enviado para o posto de consumo. Paralelamente, também ocorre uma redução no volume da demanda que corresponderia a uma redução do tamanho do supermercado de 9 para 6 peças.

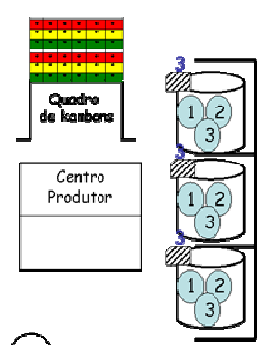

(1)

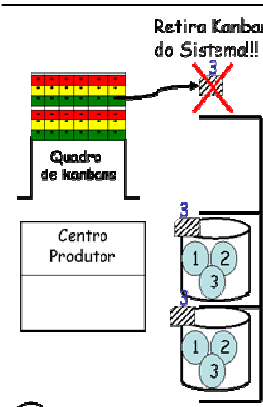

(3)

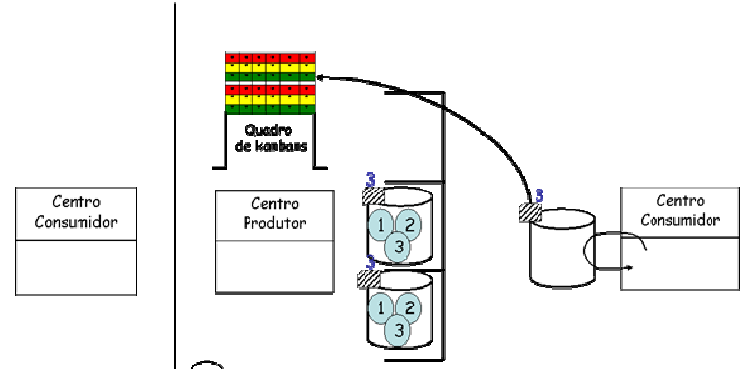

(2)

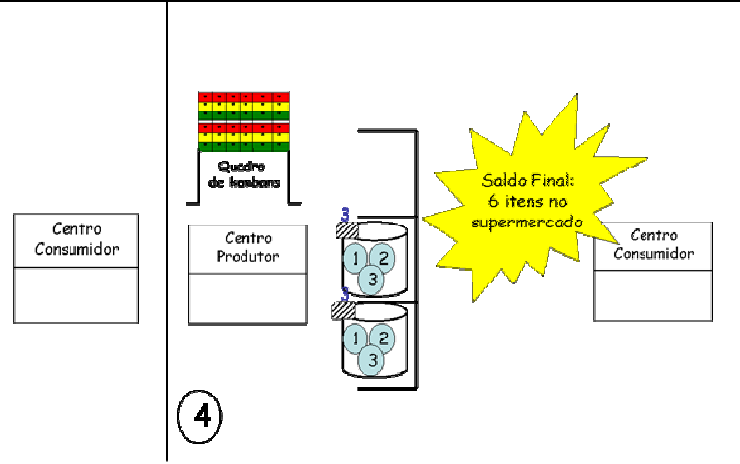

Figura 66: Ajuste do supermercado com redução da quantidade de cartões

3. Com a alteração na demanda, um cartão simplesmente é retirado de circulação. Esse cartão pode ser retirado tanto do quadro quanto da própria caixa, dependendo do momento em que o redimensionamento for feito. Nas situações em que o cartão for retirado da caixa é necessário substituí-lo por um outra cartão, o qual pode ser chamado de kanban de excesso. Quando a caixa for consumida, o cartão é retirado de circulação.

4. O supermercado não é reabastecido e saldo final agora é de 6 itens.

Neste caso, 1 cartão kanban é retirado do sistema. O processo que repõe peças para o supermercado não é disparado, devido à retirada do cartão. Portanto, existem no total, 6 unidades em todo processo. 


\section{B) Cenário 2: Aumento da demanda}

\section{B.1) Alteração da quantidade de itens por cartão (tamanho do kanban)}

1. Inicialmente, o supermercado de 9 peças encontra-se abastecido com 3 contêineres, com seus respectivos cartões kanbans. Cada cartão está dimensionado para três peças.

2. A partir do momento que uma peça é requisitada um contêiner é enviado para o posto de consumo. Paralelamente, também ocorre aumento no volume da demanda que corresponderia ao aumento do tamanho do supermercado de 9 para 12 peças.

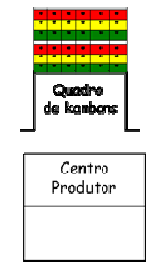

(1)
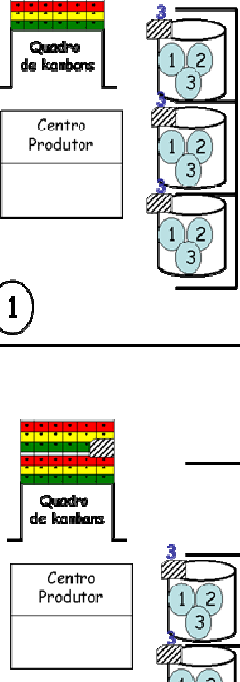

(3)

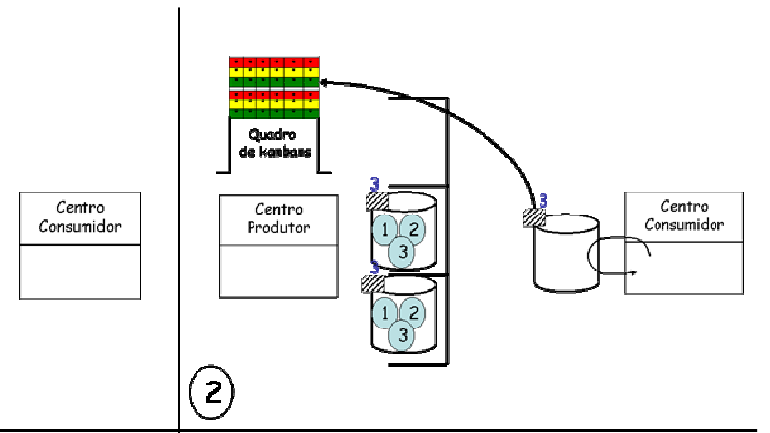

(2)

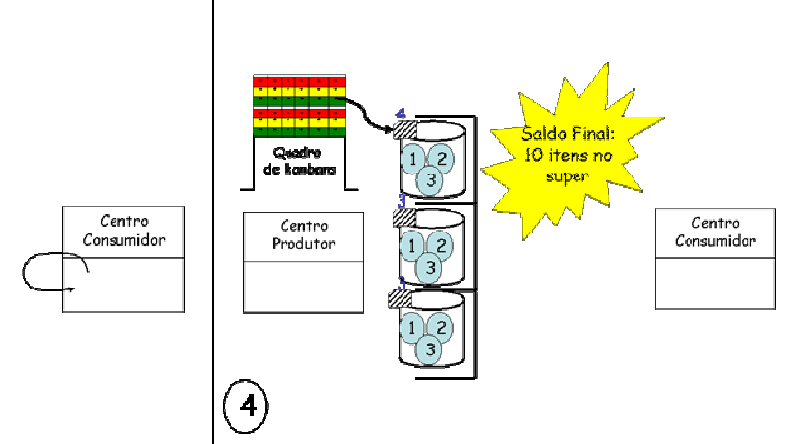

Figura 67: Ajuste do supermercado com aumento da quantidade de itens por cartão (tamanho do kanban)

3. Com a alteração na demanda, as quantidades apresentadas nos cartões são ajustadas de 3 para 4 unidades. A produção para reposição do item no supermercado é iniciada.

4. O supermercado é reabastecido, mas o saldo final é de apenas 10 itens, visto que ainda existem containeres com a quantidade antiga ao ajuste da demanda. 
Antes de ocorrer o consumo do restante dos itens do supermercado, o sistema não reage. Enquanto não houver consumo o sistema não dispara a produção de novos itens. Portanto existe uma chance em potencial do sistema não conseguir reagir a tempo e culminar em uma falta de peças na linha de montagem.

\section{B.2) Alteração da quantidade cartões (número de kanbans)}

1. A quantidade no supermercado é a mesma do sistema anterior, ou seja, 9 itens.

2. A partir do momento que uma peça é requisitada um contêiner é enviado para o posto de consumo. Paralelamente, também ocorre um aumento no volume da demanda que corresponderia ao aumento do tamanho do supermercado de 9 para 12 peças. Imediatamente um novo cartão é inserido no sistema.

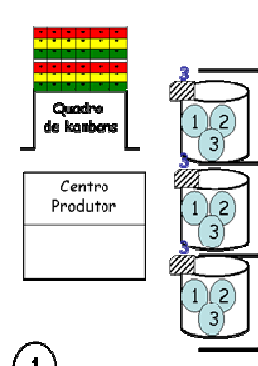

(1)

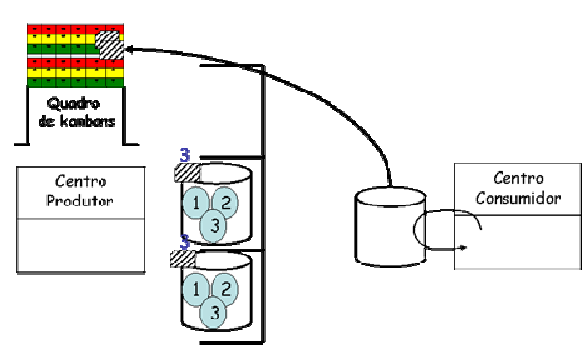

(3)

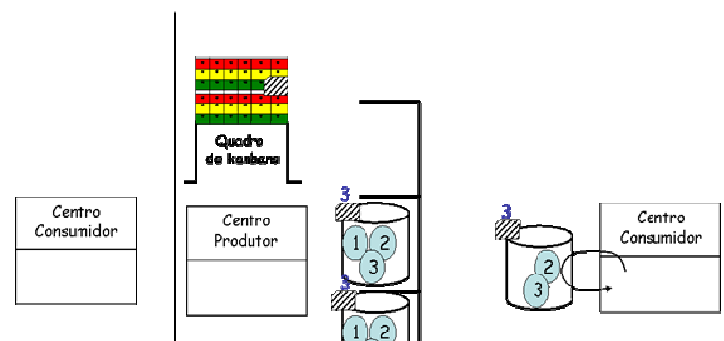

(2)

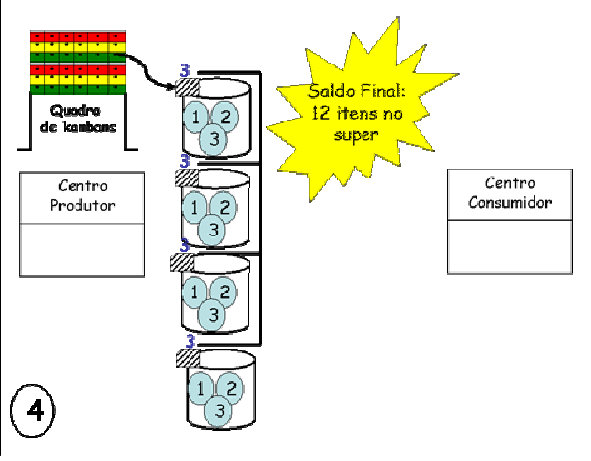

(4)

Figura 68: Ajuste do supermercado aumentando a quantidade cartões

3. A produção para reposição dos cartões é iniciada.

4. O supermercado é reabastecido, e o saldo final agora é de 12 itens. 
Neste caso, o sistema não fica inativo esperando que um primeiro contêiner seja requisitado para iniciar o processo de reposição. A produção pode ser disparada pelos novos cartões inseridos no sistema, mesmo antes de ocorrer qualquer consumo.

Um sistema kanban, com base na variação da quantidade de cartões, é um sistema mais eficiente do que um sistema baseado na alteração na quantidade de itens determinados em cada cartão kanban.

Quando ocorre uma diminuição na demanda, devido a fatores externos, não controlados pelas empresas, o sistema kanban com base na alteração do número de cartões tende a manter um estoque em processo menor do que o sistema kanban com alteração nas quantidades dimensionadas em cada cartão.

Para situações inversas, onde ocorre um aumento da demanda o sistema kanban, com alteração na quantidade especificada nos cartões, tem um tempo de resposta mais lento do que um sistema com alteração no número de cartões. Esse maior tempo de resposta necessário pode provocar paradas consumidor.

As empresas interagem em um ambiente competitivo, onde fatores externos podem causar mudanças repentinas na demanda de consumo de determinados produtos. Essas flutuações na demanda impactam diretamente no sistema produtivo das empresas. Para minimizar esses impactos as empresas devem ter um sistema kanban flexível, capaz de absorver essas flutuações no consumo de determinados produtos.

Todavia, conforme dito anteriormente, a extrapolação do tamanho máximo de um supermercado bem dimensionado para uma determinada janela de tempo normalmente é causada por reações em cadeia de práticas internas inadequadas, inclusive as de programação da produção. Estas práticas terminam por resultar no consumo desnivelado dos itens em supermercados. Quanto mais pontos de programação houver no fluxo de valor, maior é a chance de ocorrerem erros. Daí a necessidade de designar um único ponto no fluxo de valor como processo puxador para receber a programação do controle de produção. Uma boa programação do processo puxador terá impacto direto no sucesso do sistema como um todo.

\subsection{Programação e nivelamento do processo puxador}


Para nivelar a produção no processo puxador o primeiro passo é substituir o volume de produção errático por uma produção nivelada em termos de quantidade produzida por turno no processo puxador.

Para que esse sistema funcione bem, o padrão seguido pelos pedidos dos clientes precisa ser bem compreendido. Além disso, é comum que a instabilidade de um processo intermediário faça com que as peças nem sempre cheguem no prazo. Estes são problemas freqüentes, portanto, deve-se manter um rígido controle FIFO e sincronizar o fluxo das peças com o takt time da montagem final. Do contrário acabase com o velho sistema empurrado seqüenciado, e não puxado. Para simplificar o problema, uma solução intermediária seria criar um supermercado depois do processo em questão. Mais adiante, são propostas algumas diretrizes para programação e nivelamento do processo puxador.

\subsubsection{Nivelar e balancear o mix de produção no processo puxador}

A produção de diferentes produtos deve ser uniformemente dividida ao longo do tempo. O objetivo é permitir a redução dos estoques e o aumento da flexibilidade de mix na medida em que são produzidos lotes menores e em maior freqüência.

O primeiro passo consiste em balancear e padronizar as operações de acordo com o takt time, criando-se células de fluxo contínuo.

O segundo passo consiste em nivelar o mix de produção, ou seja, distribuir a produção de diferentes produtos uniformemente durante um período de tempo. Essa questão é relevante quando se possui diferentes produtos utilizando os mesmos recursos. O objetivo é reduzir o tamanho dos lotes produzidos para cada item nas células, refletindo melhor as quantidades realmente solicitadas pelos clientes em seus pedidos diários de entrega. Deve-se considerar o esforço de trocas de ferramenta para manter as variações de produtos.

O importante é que as células produzam um nível constante sempre que estiverem operando e mantenham este nível até que o takt time mude em conseqüência da mudança da demanda no longo prazo. 
Porém, em ambientes de alta variedade é difícil garantir que o conteúdo de trabalho para todos os produtos definidos para a célula varie somente um pouco e que nenhum produto possua conteúdo de trabalho acima do takt time.

Se um ou mais produtos possui uma variação de tempo (somatória dos tempos dos respectivos elementos de trabalho) maior que 30\% e mesmo assim ele deve ser produzido na mesma célula de trabalho, pode-se:

* Limitar a quantidade que será feita por intervalo deste produto, uma vez que a produção deste produto tenderá a corromper o takt time;

* Estocar peças acabadas;

\& Trabalhar com horas extras; ou

* Utilizar operadores e células extras enquanto este produto é feito.

Com isso, quatro estratégias de balanceamento e nivelamento nos casos em que se têm num mesmo fluxo famílias de produtos com grandes variações de tempo entre si são:

Opção 1: Nivelar a programação com um supermercado, produzir os produtos numa seqüência fixa e manter a mão de obra constante.

Opção 2: Nivelar a programação e criar um FIFO direto para a expedição.

Opção 3: Nivelar a programação com um supermercado e, ao mesmo tempo, produzir diretamente para a expedição.

Opção 4: Balancear o takt time e adicionar operadores quando um produto excede o takt time.

A tabela abaixo apresenta um sumário destas opções relacionando as características de demanda e de processo com as características do sistema de PCP necessário para cada uma. 


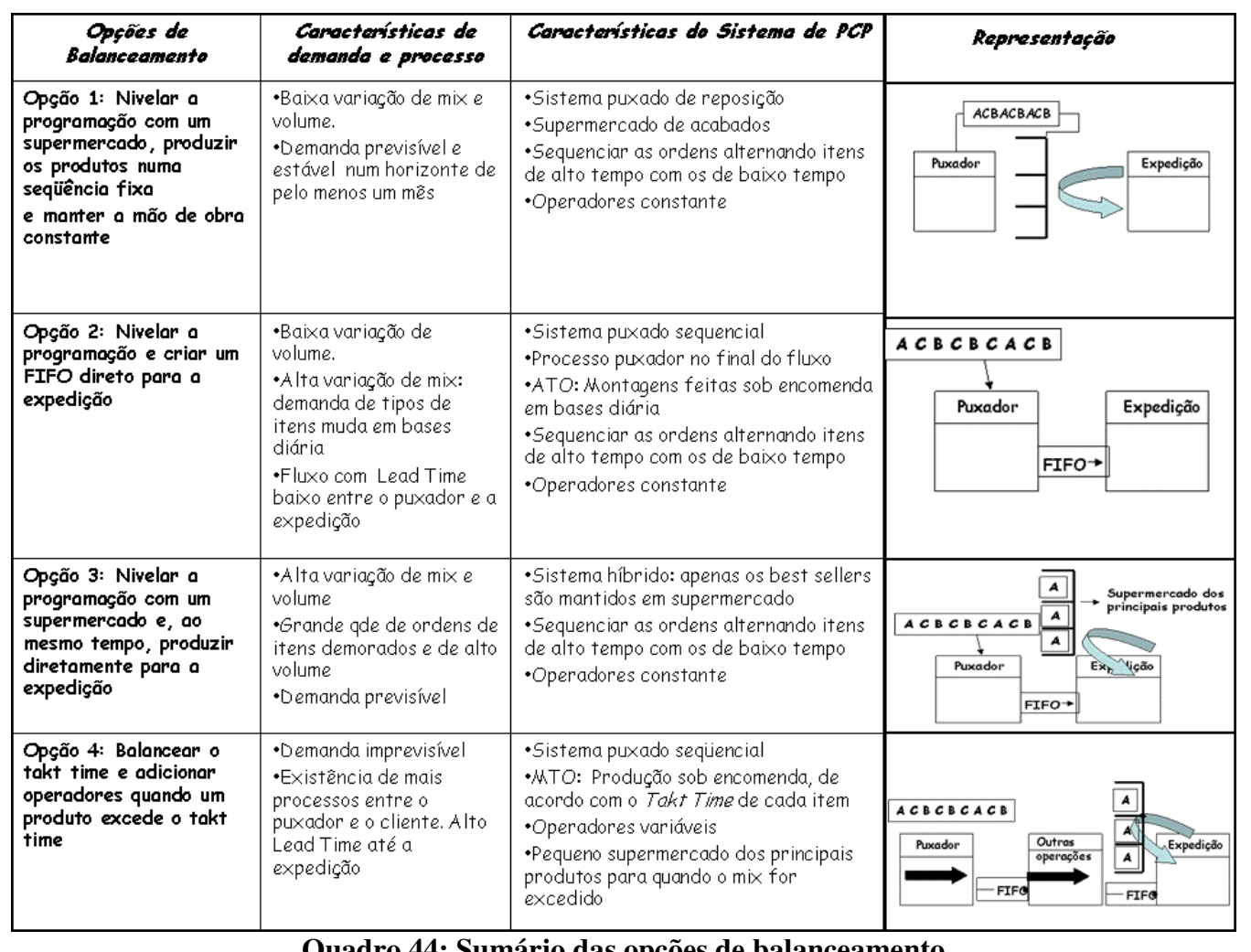

Quadro 44: Sumário das opções de balanceamento Fonte: adaptado de Duggan (2002)

A opção 1 é típica de um sistema puxado de reposição. Nela, a produção é regulada pelo supermercado de produtos acabados. Conceitualmente, este fato torna a expedição no verdadeiro processo puxador. Os produtos são nivelados no produtor inicial do loop do supermercado, através do sequenciamento das ordens com base nos tempos dos elementos de trabalho. O balanceamento das ordens de produção, vindas do supermercado, é obtido alternando-se os produtos de alto tempo com os de baixo tempo.

A opção 2 representa um sistema puxado seqüencial para fluxos de valor com lead times curtos e previsíveis entre o processo puxador e o cliente. Esta opção funciona melhor em fluxos em que o processo puxador encontra-se no final, como em situações cujas montagens são feitas sob encomenda (ATO: Assembly-ToOrder). A demanda varia diariamente, mas o padrão seguido pelos clientes é previsível e bem compreendido. Assim como no sistema puxado de reposição, descrito na opção 1, os produtos são nivelados no puxador sequenciando-se as ordens com base nos tempos dos elementos de trabalho. Trata-se de uma boa opção, por 
nivelar a programação e manter menos estoque do que num supermercado (opção anterior).

Na opção 3, sistemas puxados seqüenciais e com supermercado são empregados conjuntamente em um sistema híbrido. Funciona melhor quando a demanda dos produtos apresenta grandes variações entre si em termos de frequiência e volume. Nestes casos, a análise de freqüência e a regra 80/20 para custo e volume devem ser aplicadas, conforme descrito na seção 3.3 deste trabalho ("Projeto do sistema híbrido de planejamento e controle"). Os itens best sellers são produzidos para supermercado pelo método do sistema puxado de reposição. A mão de obra permanece constante e o PCP nivela as ordens de produção reservando uma parte da capacidade para os itens não freqüentes, ou seja, produzidos sob encomenda. Tal sistema permite que os sistemas com supermercado e seqüencial sejam aplicados seletivamente, conseguindo-se os benefícios proporcionados por cada um deles. Por outro lado, pode dificultar o balanceamento do trabalho e a identificação de condições anormais.

A opção 4 é indicada para sistemas puxados seqüenciais com fluxo de valor com lead times longos e imprevisíveis entre o processo puxador e o cliente. Normalmente em situações em que há processos entre o puxador e a expedição, ou quando produtos customizados são produzidos no mesmo fluxo que os produtos normais. É típica de ambientes de produção sob encomenda (MTO - Make-ToOrder). A idéia é proporcionar ao processo puxador um output constante (Ex.: 1 kit de peças por turno). Para isso, é necessário balancear o fluxo de cada produto em um tempo de ciclo planejado, acrescentando operadores ou recorrendo a um pequeno supermercado de segurança quando o tempo de ciclo do produto exceder o takt time. A maior dificuldade está na inserção e retirada de operadores com base no tempo dos elementos de trabalho.

Em qualquer uma das estratégias acima, a liberação de grandes lotes de produção para o chão de fábrica acarretará na falta de uma noção de takt-time, em uma distribuição irregular da carga de trabalho, em uma dificuldade para se monitorar as ordens e em uma conseqüente dificuldade para se alterar os pedidos. Estabelecer um ritmo de produção consistente e nivelado cria um fluxo de produção 
previsível que alerta para os problemas de tal modo que se possa tomar rápidas ações corretivas. A liberação regular de pequenos e consistentes incrementos de trabalho ao chão de fábrica gera uma programação mais eficaz e consistente. Estes incrementos de trabalho são chamados de pitch.

O próximo passo consiste em projetar os intervalos pitchs ou janelas de programação.

\subsubsection{Definir o intervalo pitch para programação do processo puxador}

Para incorporar o conceito de pitch na fábrica geralmente se utiliza um quadro de programação e nivelamento da produção denominado heijunka box. Este quadro dispõe de forma gráfica a necessidade dos processos posteriores permitindo que os próprios operadores decidam de forma simples quais serão as ordens de produção que deverão ser efetivadas prioritariamente.

Uma forma simples de criar um heijunka box é montar um quadro com linhas de tempo e distribuir no mesmo os kanbans ou ordens de produção. A figura abaixo apresenta um exemplo proposto de heijunka box com pitchs de 30 minutos.

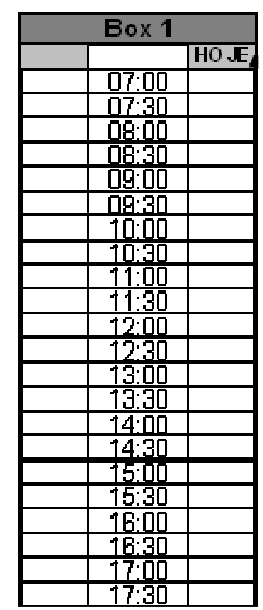

Figura 69: Exemplo proposto de quadro de programação e nivelamento da produção

O intervalo pitch é igual ao tempo necessário para produzir um cartão kanban. Este tempo é obtido pela multiplicação do takt time pela quantidade de produtos por cartão kanban, cujo tamanho normalmente é igual à quantidade de peças por embalagem. Como em ambientes de alta variedade a quantidade de 
produtos por cartão kanban é diferente para os diversos itens, uma solução seria adotar um intervalo pitch baseado num denominador comum aproximado. O ideal é que cada janela de controle varie entre quinze minutos e duas horas. Uma outra forma de se obter o pitch é simplesmente definir um intervalo de tempo interessante para controlar o processo, por exemplo, pitchs horários.

\begin{tabular}{|c|c|c|c|c|c|c|}
\hline Produtos & $\begin{array}{c}\text { Qde. } \\
\text { Pçs/ } \\
\text { kanban }\end{array}$ & $\begin{array}{c}\text { Takt Time } \\
\text { Médio } \\
\text { (min/peça) }\end{array}$ & $\begin{array}{c}\text { Tempo p/ } \\
\text { produzir 1 } \\
\text { cartão } \\
\text { (min.) }\end{array}$ & $\begin{array}{c}\text { Pitch } \\
\text { (min.) }\end{array}$ & $\begin{array}{c}\text { Qde. } \\
\text { Pitchs/ } \\
\text { Kanban }\end{array}$ & $\begin{array}{c}\text { Tempo } \\
\text { arred. p/ } \\
\text { produzir 1 } \\
\text { cartão } \\
\text { (min.) }\end{array}$ \\
\hline a & 25 & 3,6 & 90 & 15 & 6 & 90 \\
\hline b & 8 & 3,6 & 28,8 & 15 & 2 & 30 \\
\hline c & 12 & 3,6 & 43,2 & 15 & 3 & 45 \\
\hline d & 8 & 3,6 & 28,8 & 15 & 2 & 30 \\
\hline e & 10 & 3,6 & 36 & 15 & 2 & 30 \\
\hline f & 10 & 3,6 & 36 & 15 & 2 & 30 \\
\hline g & 12 & 3,6 & 43,2 & 15 & 3 & 45 \\
\hline h & 12 & 3,6 & 43,2 & 15 & 3 & 45 \\
\hline i & 25 & 3,6 & 90 & 15 & 6 & 90 \\
\hline j & 8 & 3,6 & 28,8 & 15 & 2 & 30 \\
\cline { 5 - 6 } & & & 468 & & & 465 \\
\cline { 5 - 7 }
\end{tabular}

Quadro 45: Cálculo da quantidade de pitches por cartão.

Definição do intervalo pitch com base num denominador comum aproximado entre os tempos para se produzir 1 cartão

Nesse sentido, cada cartão teria um equivalente de intervalos pitchs reservado para a sua produção.

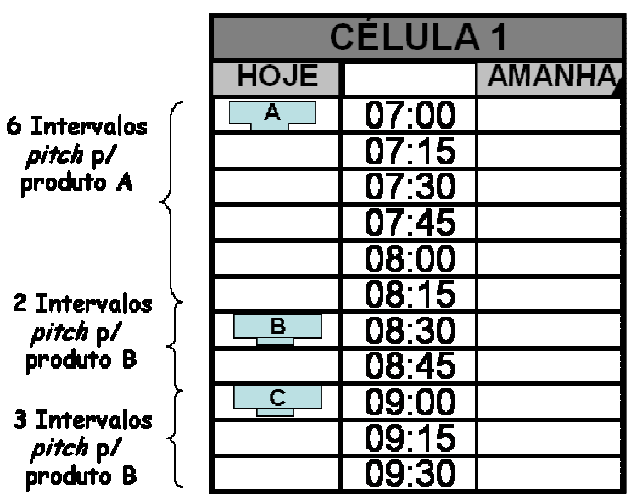

Figura 70:Quantidade de intervalos pitch por cartão 
Mesmo com um takt time médio, é mais difícil obter com precisão um intervalo pitch baseado em um denominador comum entre os diferentes itens que serão programados no processo. Com isso, ao se adotar um denominador comum "aproximado" podem ser necessários alguns arredondamentos (veja a coluna "tempo arredondado para produzir um cartão"). Estes arredondamentos seriam compensados ao longo do período considerado (normalmente turno ou dia) à medida que pitchs superdimensionados para alguns produtos compensariam aqueles subdimensionados para os outros.

Conforme dito anteriormente, é difícil garantir que o conteúdo de trabalho para todos os produtos definidos para a célula varie somente um pouco e que nenhum produto possua conteúdo de trabalho acima do takt time. No caso de variações maior que 30\% recomenda-se adotar duas medidas de ajuste:

1. Utilizar o conceito de famílias de tempo.

2. Calcular o takt time individual para cada família de tempo.

De acordo com o conceito de famílias de tempo, além da similaridade de processos, os produtos com tempos de ciclo próximos seriam agrupados numa mesma (sub)família, para a qual se assumiria um tempo de ciclo único para todos os produtos. Recomenda-se que o tempo de ciclo de referência de cada família seja adotado com base no tempo do produto mais representativo da família. Um bom critério para escolha do produto representativo é a relação entre a freqüência, volume e complexidade (demora) de produção entre os produtos da família.

$\mathrm{Na}$ tabela abaixo, todos os produtos que compartilham o mesmo processo foram agrupados em 6 famílias de tempo. Isto tende a simplificar e acelerar o escopo de análise e proposição de melhorias (levantamento de tempos, padronização de trabalhos, etc.) em ambientes de alta variedade. 


\begin{tabular}{|c|c|c|c|c|c|c|c|c|c|c|c|}
\hline $\begin{array}{l}\text { Família } \\
\text { Produtos }\end{array}$ & $\begin{array}{c}T / C \\
\text { unitário } \\
\text { (min.) }\end{array}$ & $\begin{array}{c}\text { Demanda } \\
\text { média } \\
\text { diária } \\
\text { (pçs) }\end{array}$ & $\begin{array}{l}T / C \\
\text { lote } \\
\text { diário } \\
\text { (min) }\end{array}$ & $\begin{array}{c}\text { Tempo } \\
\text { Total } \\
\text { disponivel } \\
\text { (min/dia) }\end{array}$ & $\begin{array}{l}\text { Takt Time } \\
\text { Médio } \\
\text { (min/peça) }\end{array}$ & $\begin{array}{c}\text { Qde. } \\
\text { Pçs/ } \\
\text { kanban }\end{array}$ & $\begin{array}{c}\text { Qde. } \\
\text { Kanbans/ } \\
\text { dia }\end{array}$ & $\begin{array}{c}\text { Tempo } \\
\text { para } \\
\text { produzir } \\
1 \text { cartão } \\
\text { (min.) }\end{array}$ & $\begin{array}{l}\text { Pitch } \\
(\min .)\end{array}$ & $\begin{array}{c}\text { Qde. } \\
\text { Pitchs / } \\
\text { Kanban }\end{array}$ & $\begin{array}{c}\text { Tempo } \\
\text { arred. p/ } \\
\text { produzir } 1 \\
\text { cartão } \\
\text { (min.) }\end{array}$ \\
\hline$A$ & 1 & 50 & 50 & \multirow{6}{*}{427,68} & \multirow{6}{*}{3,6} & 25 & 2 & 90,6 & 15 & 6 & 90 \\
\hline$B$ & 2 & 16 & 32 & & & 8 & 2 & 29,0 & 15 & 2 & 30 \\
\hline$C$ & 3 & 12 & 36 & & & 12 & 1 & 43,5 & 15 & 3 & 45 \\
\hline$D$ & 8 & 20 & 160 & & & 10 & 2 & 36,2 & 15 & 2 & 30 \\
\hline$E$ & 5 & 10 & 50 & & & 10 & 1 & 36,2 & 15 & 2 & 30 \\
\hline $\mathrm{F}$ & 10 & 10 & 100 & & & 10 & 1 & 36,2 & 15 & 2 & 30 \\
\hline
\end{tabular}

Quadro 46: Cálculo da quantidade de pitches por cartão para cada família de tempo.

Um outro problema neste tipo de ambiente, cujos recursos (máquinas e pessoas) são compartilhados, é que a definição dos intervalo pitch para cada família com base num takt time médio pode causar algumas distorções. A principal delas diz respeito ao número de pitchs reservado por cartão. Na tabela abaixo, ao invés de se trabalhar com um takt time médio, foram calculados takt times individuais para cada família. O calculo foi feito a partir da disponibilidade de tempo para cada uma. Neste caso, o tempo total disponível foi distribuído para cada família com base na porcentagem relativa dos respectivos tempos de ciclo para produzir suas demandas diárias.

\begin{tabular}{|c|c|c|c|c|c|c|c|c|c|c|c|c|c|}
\hline $\begin{array}{c}\text { Família } \\
\text { Produtos }\end{array}$ & \begin{tabular}{|c|}
$T / C$ \\
unitário \\
(min.)
\end{tabular} & $\begin{array}{c}\text { Demanda } \\
\text { média } \\
\text { diária } \\
\text { (pçs) }\end{array}$ & $\begin{array}{l}T / C \\
\text { lote } \\
\text { diário } \\
\text { (min) }\end{array}$ & $\begin{array}{c}\% \mathrm{~T} / \mathrm{C} \\
\text { lote diário } \\
\text { por família } \\
\text { (min.) }\end{array}$ & $\begin{array}{c}\text { Tempo } \\
\text { Total } \\
\text { disponivel } \\
\text { (min/dia) }\end{array}$ & $\begin{array}{c}\text { Tempo } \\
\text { disponivel } \\
\text { por família } \\
\text { (min/dia) }\end{array}$ & $\begin{array}{l}\text { Takt Time } \\
\text { individual } \\
\text { (min/peça) }\end{array}$ & $\begin{array}{c}\text { Qde. } \\
\text { Pçs/ } \\
\text { kanban }\end{array}$ & $\begin{array}{c}\text { Qde. } \\
\text { Kanbans/ } \\
\text { dia }\end{array}$ & \begin{tabular}{|c|}
$\begin{array}{c}\text { Tempo } \\
\text { para } \\
\text { produzir } \\
1 \text { cartão } \\
\text { (min.) }\end{array}$ \\
\end{tabular} & $\begin{array}{l}\text { Pitch } \\
(\min .)\end{array}$ & \begin{tabular}{|c|} 
Qde. \\
Pitchs / \\
Kanban
\end{tabular} & \begin{tabular}{|c|} 
Tempo \\
arred. p/ \\
produzir 1 \\
cartão \\
(min.)
\end{tabular} \\
\hline$A$ & 2 & 50 & 100 & $12 \%$ & \multirow{6}{*}{427,68} & 50,0 & 1,0 & 25 & 2 & 25,0 & 15 & 2 & 30 \\
\hline$B$ & 4 & 16 & 64 & $7 \%$ & & 32,0 & 2,0 & 8 & 2 & 16,0 & 15 & 1 & 15 \\
\hline$C$ & 6 & 12 & 72 & $8 \%$ & & 36,0 & 3,0 & 12 & 1 & 36,0 & 15 & 2 & 30 \\
\hline$D$ & 16 & 20 & 320 & $37 \%$ & & 159,9 & 8,0 & 10 & 2 & 79,9 & 15 & 5 & 75 \\
\hline$E$ & 10 & 10 & 100 & $12 \%$ & & 50,0 & 5,0 & 10 & 1 & 50,0 & 15 & 3 & 45 \\
\hline $\mathrm{F}$ & 20 & 10 & 200 & $23 \%$ & & 99,9 & 10,0 & 10 & 1 & 99,9 & 15 & 7 & 105 \\
\hline TOTAL & & 118 & 856 & $100 \%$ & & & & & & & & & \\
\hline
\end{tabular}

Quadro 47: Comparativo entre o takt time médio versus takt time individual.

Note que o tempo reservado para produzir um cartão da família A era de 90 minutos (6 pitches de 15 minutos cada) na situação em que se trabalhou com um takt time médio para todas as famílias. Ao se individualizar o takt time, o tempo reservado para produzir o mesmo cartão da família A passou a ser de apenas 30 minutos ( 2 pitches de 15 minutos cada).

Portanto, se por um lado é bem mais simples e didático trabalhar com um takt time médio, por outro lado quando o processo é compartilhado por produtos 
com uma variação de tempo (somatória dos tempos dos respectivos elementos de trabalho) muito grande entre si a figura do pitch pode ser banalizada devido à distorção entre os intervalos reservados e os tempos efetivamente realizados.

Um último problema são as situações em que o takt time é muito longo (quatro horas ou mais). Nestes casos, torna-se necessário recorrer à alternativas criativas tendo em vista sempre prover os operadores de senso de ritmo quando são produzidos itens que requerem dias, semanas e até meses. Com isso, o intervalo pitch pode necessitar ser menor que o takt time. Algumas opções são:

* Quebrar a produção em blocos de elementos de trabalho. Cada bloco estaria associado um intervalo pitch.

* Quebrar a produção em blocos de elementos de trabalho. Utilizar um quadro com a programação e controle visual de cada bloco. Tarjas magnéticas representariam o status do trabalho (verde=no prazo; amarelo=em andamento e vermelho=atrasado).

Fornecer material suficiente para apenas um intervalo pitch de trabalho. Mais material seria entregue apenas no próximo pitch.

No mais, é extremamente importante trabalhar em paralelo o nivelamento da demanda. Sem uma demanda nivelada, nivelar a produção torna-se numa tarefa mais difícil ainda.

\subsubsection{Criar uma rotina de busca contínua pelo nivelamento da demanda}

O desnivelamento gera desperdícios e sobrecargas, e, conseqüentemente, estoques elevados, sobrecarga para pessoas e ativos, custos com hora extra nos picos de demanda e mudanças e atrasos nos pedidos. 


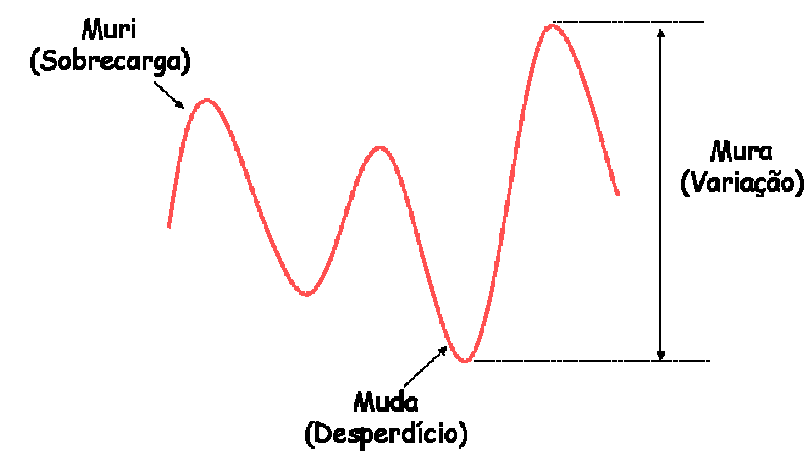

Figura 71: Desnivelamento gera desperdícios e sobrecargas.

O interessante é que muitas empresas ainda tratam o desnivelamento como um "fato da vida", ou seja, como algo que está fora da sua esfera de controle. Contudo, grande parte desse desnivelamento é causada devido a práticas internas inadequadas ou à falta de ações para combatê-lo. Algumas ações importantes para promover o nivelamento da demanda são:

\section{a) Orientar e treinar os operadores de modo a evitar disparos atrasados ou antecipados}

Em sistemas puxados, quando os kanbans não são depositados no quadro semáforo no momento do consumo, o sistema tende a ser acometido por picos artificiais da demanda interna. O normal em um sistema puxado bem dimensionado, é que os cartões cheguem de forma compassada ao quadro. Situações em que todos os cartões chegam de uma só vez, em intervalos de tempo relativamente curtos, pode ser um indício de que eles estejam sendo disparados incorretamente pelas pessoas no processo consumidor.

\section{b) Construir uma máscara de programação nivelada juntamente com a área comercial}

Construir uma máscara de programação é o primeiro passo no trabalho de integração entre a área comercial e o planejamento da produção. Muitas vezes a área comercial simplesmente repassa os pedidos para a fábrica por falta de um parâmetro de referência da maneira ideal de se colocar o pedido de acordo com a capacidade real da fábrica. 
Colocar os pedidos de forma nivelada nem sempre será possível. Por outro lado, é possível criar políticas que incentivem o vendedor a vender e o cliente a comprar ambos de forma nivelada.

\section{c) Criar políticas de nivelamento de vendas}

Deve-se combater metas de vendas que promovam picos e vales na demanda. Os esforços de vendas devem estar "integrados" com o planejamento, programação e limitações da fábrica. Algumas ações importantes são:

* Distribuir as metas de vendas ao longo do mês. Pode-se criar metas semanais para evitar concentração no final do mês, ou ainda, definir entre a equipe de vendas diferentes datas base para fechamento das metas do mês. Outra forma de nivelar a colocação dos pedidos pela área comercial seria estimular os vendedores com comissões maiores para os pedidos colocados nos períodos de baixa.

\& Elaborar políticas de descontos que estimulem pedidos regulares. Além de incentivos para os vendedores, os clientes que colocarem seus pedidos em períodos de baixa devem ser premiados com descontos significativos. Trata-se de uma relação ganha-ganha, visto que para a empresa o ganho em função da colocação de pedidos de forma nivelada é maior que a margem de contribuição perdida. Por outro lado, é importante deixar claro para o mercado a razão de a empresa adotar diferentes preços em intervalos de tempo pequeno. $\mathrm{O}$ objetivo é evitar eventuais aborrecimentos e sentimentos de injustiça por parte daqueles clientes que tiveram que pagar a mais por terem colocado seus pedidos em períodos de pico.

\section{d) Combater as sazonalidades naturais da demanda, desenvolvendo novos produtos e novos mercados}

Mesmo que a máscara de programação comercial, a política de metas e comissionamento de vendas, e a política de descontos não sejam suficientes para balancear a demanda com a capacidade produtiva da empresa ainda é possível recorrer a estratégias de médio e longo prazo. Desenvolver novos produtos para 
aproveitar a capacidade ociosa em períodos de baixa é uma delas. Outra estratégia é buscar novos mercados. No setor agroindustrial, por exemplo, períodos de safra no hemisfério sul correspondem a períodos de entre safra no hemisfério norte. Essa complementaridade em um mundo cada vez mais globalizado deve ser aproveitada.

\section{e) Adotar uma política para programação nivelada de pedidos especiais}

No projeto de sistemas híbridos de PCP proposto ao longo desse trabalho, um dos principais elementos considerados para a definição do tipo de controle de um item é a sua classificação ABC de custos (Regra de Paretto). É desejável que itens de alto custo tenham o maior giro possível e sejam puxados pelo processo seguinte. Contudo, um item classe A para uma empresa pode não sê-lo para o seu cliente. Os pedidos desse item podem ser colocados em bases de entrega mensais ou até trimestrais. Um pedido para exportação também pode requerer lotes de produção relativamente grandes. O grande erro das empresas é colocar todo o pedido de uma só vez na produção, alegando aproveitamento de setup. Essa política de programação limita a flexibilidade de mix de todo o sistema, pois pode comprometer recursos restritivos por dias com um único pedido. É imprescindível que a empresa renegocie as bases de entrega ou, caso isso não seja possível, que "quebre" o lote em ordens parciais com tamanhos proporcionais ao TPT calculado para o fluxo em questão.

\section{f) Integrar fornecedores estratégicos ao sistema lean, encurtando as distâncias conceituais entre os sistemas de produção}

Atualmente a concorrência não é mais entre empresas, mas entre cadeias de valor. De nada adianta uma empresa ser enxuta e flexível se os seus fornecedores não o são. O desenvolvimento e a capacitação de fornecedores estratégicos deve fazer parte do escopo do projeto de situação futura da empresa. Caso contrário, o crescimento da mesma ficará limitado à capacidade produtiva de seus fornecedores.

O próximo passo consiste em preparar e realizar as ações de implantação. 


\subsection{Planejar e acompanhar a implantação}

Esta etapa foi inserida no método devido à demora encontrada na implantação do sistema de PCP projetado na primeira aplicação deste trabalho. Identificou-se que a condução vagarosa desse processo ocorreu devido à utilização de cronograma tradicional, o qual constantemente não era cumprido, embora tivesse prazos e responsáveis bem definidos. Notou-se que essas pessoas tiveram uma grande dificuldade em conciliar suas atividades rotineiras com as atividades de melhoria. Além disso, o baixo envolvimento do pessoal de nível operacional na implantação dificultou a ancoragem do novo sistema.

Diante disso, propõe-se aqui a utilização da técnica de Evento Kaizen. Trata-se de uma técnica para implantação rápida de melhorias, com a participação efetiva do nível operacional. Suas características são:

Formação de uma equipe de até 12 pessoas.

- Cumprir a missão em 5 dias (uma semana).

* A equipe deve ficar inteiramente focada na missão a ser cumprida. Sua dedicação deve ser exclusiva e não ter mais nada a fazer na semana.

* Possui prioridade na utilização de recursos fabris e na obtenção de informações. Naturalmente, por uma questão de bom senso, recomenda-se reserva-los ou, ao menos, alertar as respectivas áreas de suporte previamente. 


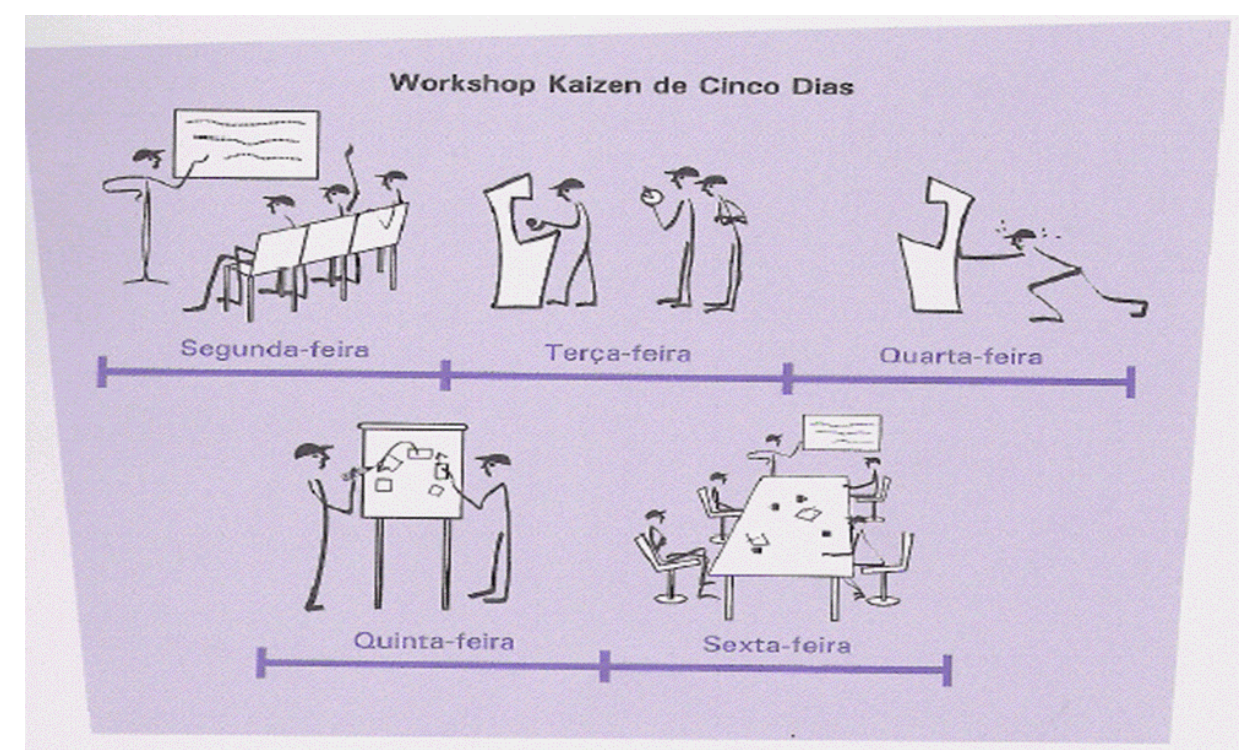

Figura 72: Workshop Kaizen

Fonte: LEI (2003)

Normalmente, a semana é dividida da seguinte maneira:

* Segunda: Capacitação, alinhamento e validação do novo sistema de PCP. Levantamento e programação das atividades de implantação da semana.

Terça: Realização das ações de implantação.

* Quarta: Realização das ações de implantação.'

* Quinta: Realização das ações de implantação. Realização de simulações da situação projeta. Definição das medidas de acompanhamento. Criação das novas instruções de trabalho juntamente com a área de Qualidade. Preparação da apresentação final do Evento.

Sexta: Realização da apresentação final do Evento.'

Vale ressaltar que a utilização da técnica do Evento Kaizen no escopo desse trabalho está fortemente focada na implantação rápida e envolvimento efetivo dos operadores. Na atividade kaizen convencional, comumente com duração de cinco dias, uma equipe identifica, desenvolve e implanta melhorias em um processo. Contudo, o desenvolvimento de um novo sistema de PCP, conforme o método proposto, deve ser feito previamente, inclusive para que haja tempo hábil para a 
confecção e compra de recursos necessários, tais como quadros, cartões, painéis e recursos de transporte e armazenagem em geral.

A seguir serão apresentadas as aplicações práticas, as quais contribuíram para o desenvolvimento e validação do método proposto. 


\section{APLICAÇÕES PRÁTICAS}

Este capítulo apresenta quatro aplicações práticas do método proposto em empresas do setor metal mecânico.

A primeira delas numa empresa de fundição e usinagem de componentes para sistemas de transmissão do segmento automotivo.

A segunda numa empresa de usinagem e montagem de bombas de engrenagem para o segmento automotivo e de máquinas agrícolas.

A terceira numa empresa de produção de peças e conjuntos para montadoras de tratores do segmento de máquinas agrícolas.

A quarta numa empresa de produção de turbinas a vapor predominantemente para usinas do segmento sucro-alcooleiro.

\section{1. $\quad 1^{\mathrm{a}}$. Aplicação}

A empresa objeto do estudo deste trabalho é uma empresa de processos de fundição e usinagem, localizada no interior do estado de São Paulo. Emprega um total de 100 funcionários, distribuídos em 2 unidades descentralizadas, uma responsável pela fundição e outra pela usinagem dos produtos. A empresa trabalha com manufatura e comercialização de peças fundidas e usinadas para a linha de sistemas de transmissão de veículos automotivos, possuindo aproximadamente 150 tipos diferentes de produtos finais.

Como diagnóstico inicial da empresa foram levantados os seguintes efeitos indesejáveis:

Falta e sobra de produtos finais

Alto estoque de produtos finais

Alto Lead Time de produção

\& Baixa Produtividade 
Os passos iniciais para a solução desses problemas iniciaram-se pela identificação das famílias de produto e pelos desenhos do Mapa de Fluxo de Valor da Situação Atual.

As famílias de produto foram definidas em função da similaridade de processos e fluxo de produção.

Identificadas as diferentes famílias de produto, foi desenhado o Mapa de Fluxo de Valor da Situação Atual da empresa para cada uma das famílias. Para os fins deste trabalho, a Figura abaixo mostra de forma macro tal mapeamento.

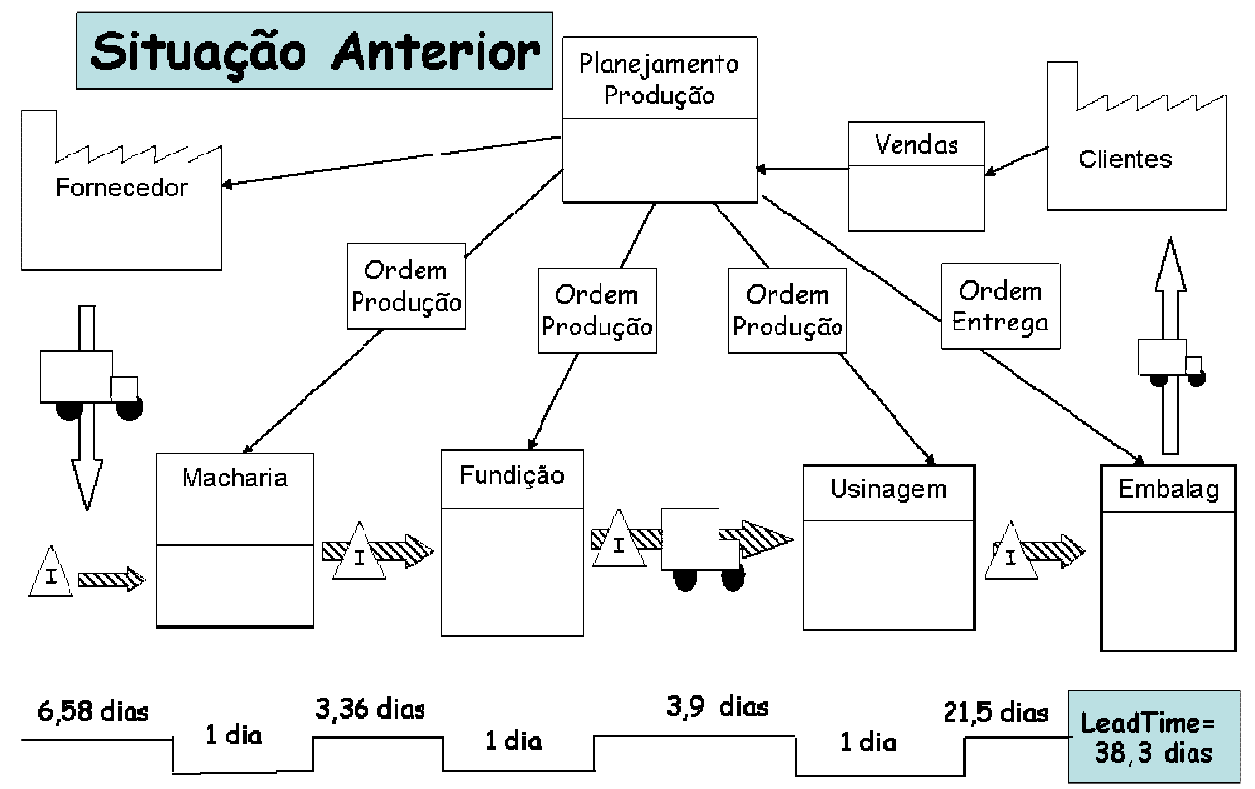

Figura 73: Mapeamento de Fluxo de Valor Situação Atual

A partir do Mapa de Fluxo de Valor da Situação Atual, confirmou-se os efeitos indesejáveis apontados na fase inicial do projeto. Observou-se um alto estoque de matérias primas, work in process (WIP) e, sobretudo de produtos acabados. O impacto do alto nível de estoque foi analisado da seguinte maneira:

\& Falta e Sobra de peças: como a empresa fabrica diversos tipos de produtos finais, os lotes de produção eram muito maiores que as reais necessidades dos clientes, o que resultava na superprodução de alguns itens e falta de outros; 
— Produtividade: a superprodução de itens desnecessários (que não são vendidos aos clientes) estava refletindo em uma baixa produtividade sob a ótica do cliente final. Constantemente eram realizadas reprogramações em função da discrepância entre os pedidos diários dos clientes e a programação da produção baseada em previsão de vendas.

* Lead Time de Produção: o tempo entre um produto entrar na forma de matéria prima e sair na forma de produto final. Um fluxo de valor longo, associado com a prática de lotes "econômicos" de produção e as constantes reprogramações resultavam em alto nível de estoques "parado" ao longo de um fluxo de valor truncado.

Rapidez e Pontualidade: Atrasos eram comuns e o baixo tempo de resposta do sistema aos pedidos dos clientes resultava em atrasos e na perda de pedidos.

Foi feito o Desenho da Situação Futura, a partir dos qual se iniciou o desenvolvimento do sistema híbrido de programação e controle.

\subsubsection{Projeto macro do sistema híbrido de planejamento e programação}

O primeiro passo consistiu em quebrar estrategicamente o longo fluxo de valor em partes menores e mais fáceis de serem administradas. Para isso, foram definidos quatro pontos de supermercado: 


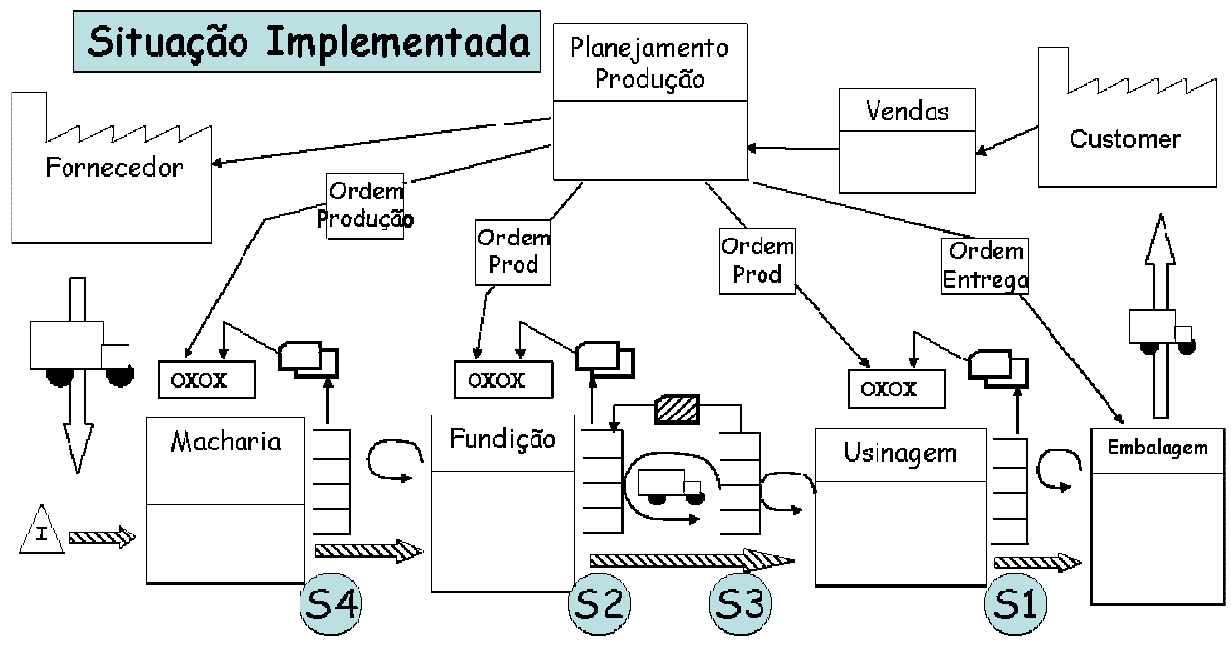

oxox Heijunkabox Kanban de transporte $\square$ Karban de produçåo Figura 74 - Mapeamento de Fluxo de Valor Situação Futura

O primeiro ponto de supermercado ( $\mathrm{S} 1$ ) caracteriza um típico sistema puxado de reposição. A alta variedade de itens e os altos tempos de setup estavam causando desperdícios de superprodução, esperas dos clientes por alguns produtos acabados e a manutenção de estoques desnecessários de outros. Além disso, a baixa tolerância de espera do cliente externo (até 5 dias) foi um outro fator fundamental para a definição desse ponto de supermercado. A seta de fluxo empurrado, colocada juntamente com o supermercado, indicava que nem todas as peças seriam produzidas para supermercado.

O segundo ponto de supermercado (S2) foi definido com base em dois fatores:

1. Os processos de macharia e fundição apresentavam um lead time muito elevado. O fluxo muito longo deixava o processo mais descoberto perante à ocorrência de contratempos como mudanças na programação (necessidade de alta flexibilidade de mix) e de imprevistos devido à baixa confiabilidade do mesmo.

2. A falta de uma programação nivelada gerava o que se chamou de gargalos móveis. Ou seja, quando um grande volume de peças muito pequenas eram fundidas ao mesmo tempo, a operação de rebarbação destas peças pequenas transformava-se num gargalo. Por outro lado, quando um alto volume de 
peças muito grandes eram fundidas conjuntamente, a operação de vazamento do metal líquido tornava-se num gargalo devido ao grande uso de metal. O supermercado era uma boa ferramenta para nivelamento da programação.

O terceiro ponto de supermercado (S3) está associado ao fato da unidade de fundição estar localizada em outra planta industrial na mesma cidade. Este supermercado seria conectado ao segundo ponto de supermercado (S2) por meio de um kanban de transporte, caracterizando um sistema de dois kanbans (produção e transporte).

Com isso, ao se analisar os três primeiros pontos de supermercado, a estratégia foi adotar uma política de atendimento da demanda do tipo "Montar sob Ordem" (ATO - Assembly to Order) ou do tipo "Montar para Estoque" (ATS Assemby to Stock), ao invés do padrão inicial de se "Produzir sob Ordem" (MTO Make to Stock) ou de "Produzir para Estoque" (MTS - Make to Stock), baseado em previsões de vendas.

No quarto ponto (S4), a equipe decidiu manter um supermercado de machos. A idéia era dar uma maior rapidez ao loop da fundição como um todo.

De acordo com o projeto de situação futura projetado, adotou-se um sistema puxado de reposição. Com isso, os processos de embalagem e expedição tornaram-se o processo puxador do fluxo de valor. 


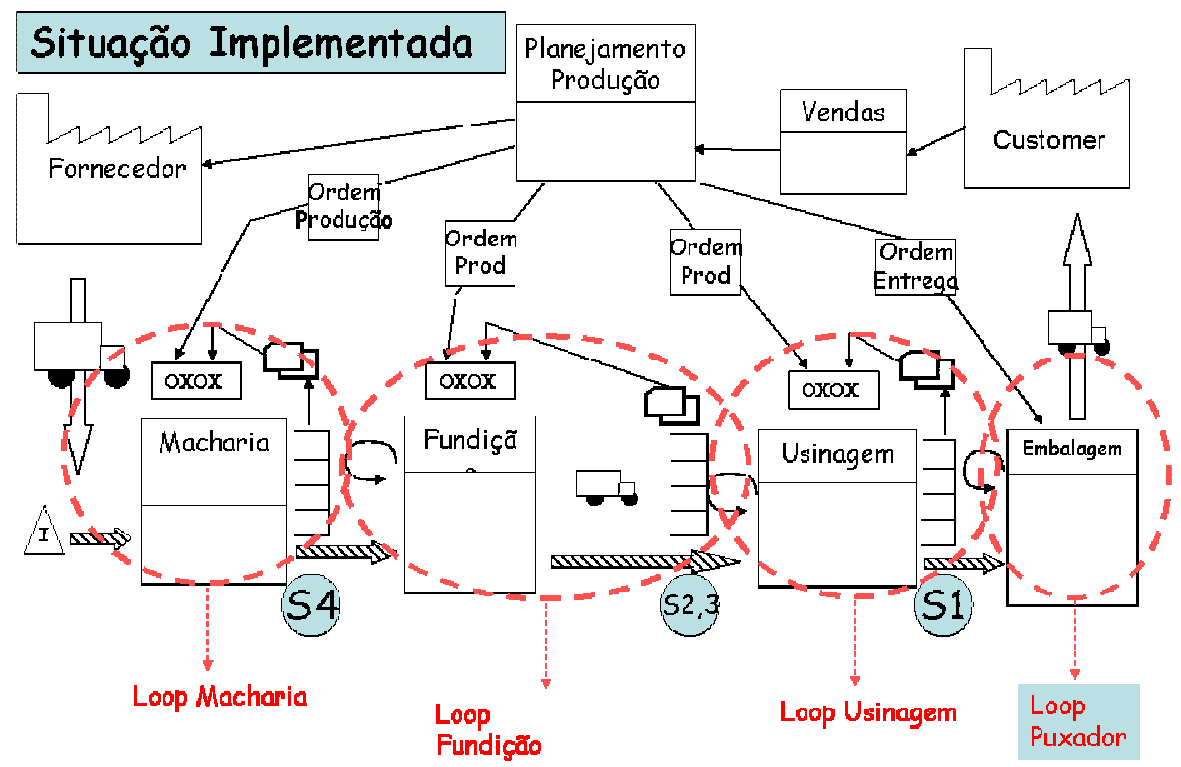

Figura 75: Definição do processo puxador.

O próximo passo consistiu em definir a ferramenta mais apropriada de programação e controle para cada item, ou seja, quais desses itens seriam controlados de forma puxada e quais seriam controlados de forma empurrada, mediante ordem de produção.

\subsubsection{Definição das subfamílias de programação e controle}

O objetivo desta etapa foi definir se os produtos de um mesmo fluxo de valor deveriam ou não ser controlados de formas diferentes. Os fatores de referência utilizados para definir o tipo de controle mais adequado foram:

a) Volume da demanda: Levantado com base no histórico da demanda dos últimos doze meses.

b) Freqüência da demanda: Baseado na relação entre a média de consumo e o desvio padrão de cada item no período considerado. Foi utilizado o conceito de soma móvel, e o desvio padrão utilizado foi obtido pela relação entre blocos de 3, 6 e 12 dias:

Itens com TPT de 3 dias: Desvpad entre soma(dia1+dia2+dia3); soma(dia2+dia3+dia4); soma(dia3+dia4+dia5); etc.

Itens com TPT de 6 dias: Desvpad entre soma(dia1+dia2+dia3 dia4+dia5+dia6); soma(dia2+dia3+dia4+dia5+dia6+dia7); etc. 
c) Custo: Não foi utilizada a classificação $\mathrm{ABC}$ de custo pois não havia dados confiáveis para isso.

Foram definidas quatro subfamílias de controle. O agrupamento dos diversos itens nesta quatro subfamílias foi feito com base na faixa de frequiência e volume em que cada um se encontrava. Cada subfamília estava associada à combinação entre o tipo de controle (kanban, kanban de sinal e ordem) e o tamanho do TPT (3 dias, 6 dias ou 12 dias).

\begin{tabular}{|c|c|c|c|c|}
\hline $\begin{array}{c}\text { Subfamilia } \\
\text { de Controle }\end{array}$ & Volume & Freq. & $\begin{array}{c}\text { Tipo de } \\
\text { Controle }\end{array}$ & TPT \\
\hline Subfamília 1 & Alto & Alta & Kanban & 3 dias \\
\hline Subfamília 2 & Baixo & Alta & Kanban & 6 dias \\
\hline Subfamillia 3 & Baixo & Baixa & $\begin{array}{c}\text { Kanban } \\
\text { Ponto de } \\
\text { Reposição }\end{array}$ & $\begin{array}{c}12 \text { dias } \\
\text { (lotes pequenos) }\end{array}$ \\
\hline Subfamília 4 & Alto & Baixa & Ordem & $\begin{array}{c}\text { Tamanho do } \\
\text { pedido }\end{array}$ \\
\hline
\end{tabular}

Quadro 48: Definição das subfamílias de controle.

Para os itens de baixo volume foram adotados TPT's múltiplos (6 ou 12 dias) do TPT mínimo calculado (3 dias). Lotes de 3 dias para muitos itens de baixo volume se mostraram extremamente pequenos para serem produzidos ao ponto de compensar os esforços de preparação da máquina gargalo. Além disso, a equipe entendeu que um menor giro do itens de baixo volume seria recompensado pela possibilidade de um giro maior para os itens de alto volume. Mesmo regulados por um TPT de 3 dias, os itens de alto volume estão sujeitos a desnivelamentos no consumo. Picos momentâneos no consumo poderiam ocasionar a necessidade destes itens girarem num intervalo de tempo menor que 3 dias. Logo, decidiu-se que essa capacidade extra que fora liberada ficaria disponível para contingências desse tipo.

A figura abaixo ilustra como ficaram os MFV's para cada uma das subfamílias de controle. 


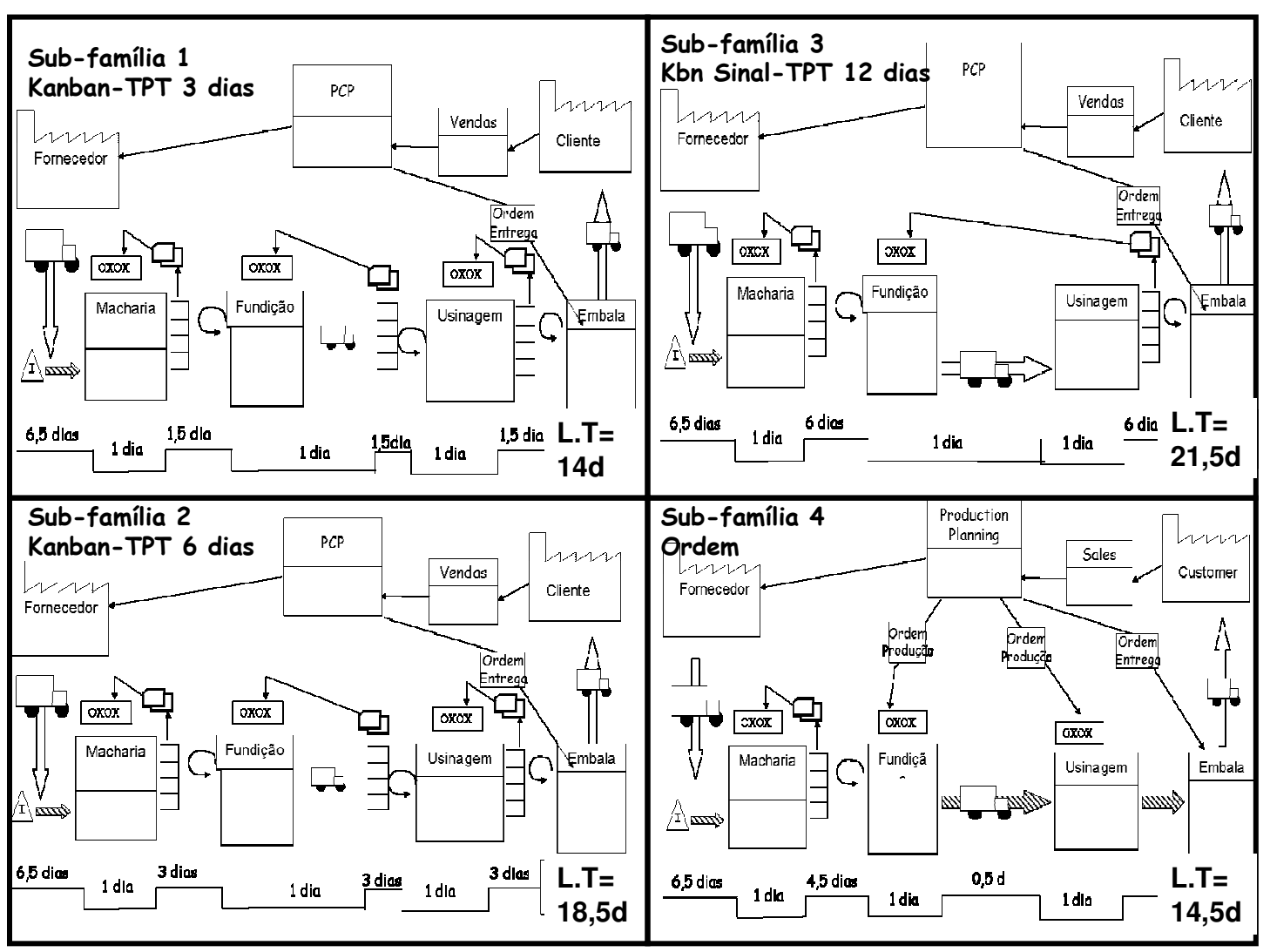

Figura 76: MFV’s para cada subfamília de controle.

Note que o tamanho médio adotado para o TPT dos itens da subfamília 3 foi de 12 dias. Com isso, a equipe tomou a decisão de eliminar o ponto de supermercado intermediário. Para os itens dessa subfamília, a reposição dos itens passaria a ser em fluxo através da fundição e da usinagem.

\subsubsection{Dimensionamento do tamanho do supermercado}

Para o dimensionamento do tamanho do supermercado em cada ponto foram delimitados os loops de produção. 


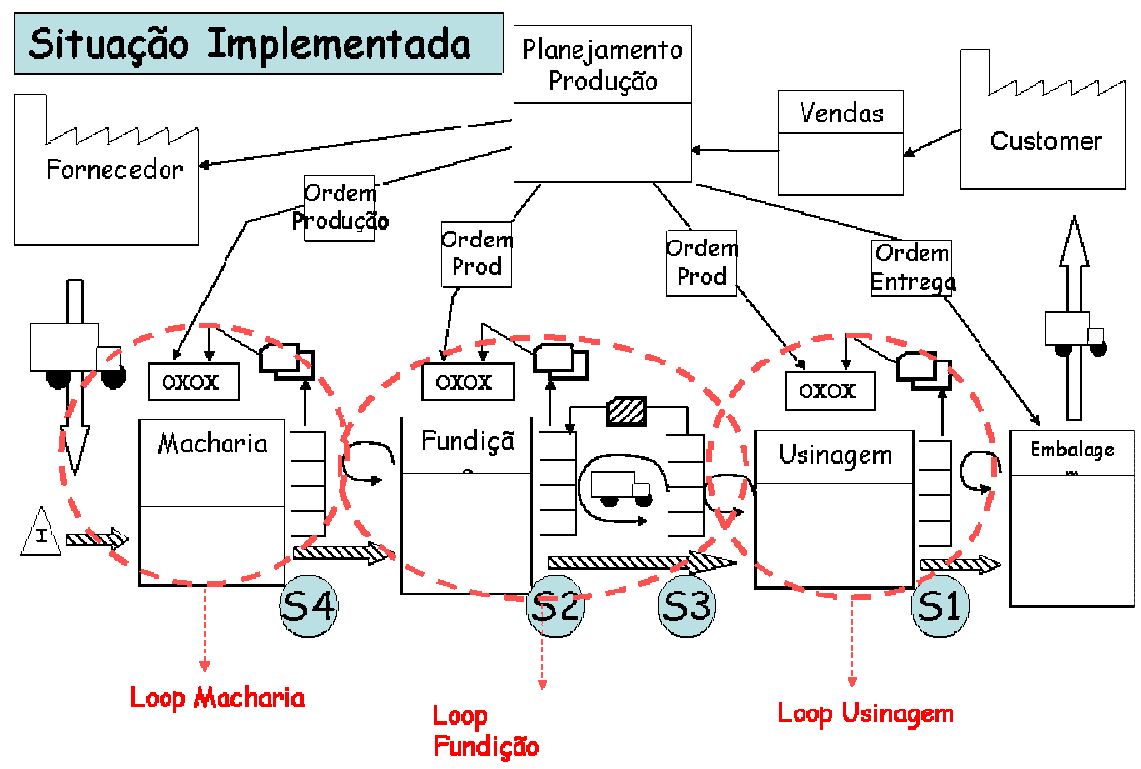

Figura 77: Identificação dos loops de produção

Levantou-se o histórico de vendas diária de todos as peças dos últimos 6 (seis) meses. Em seguida, calculou-se o TPT para cada loop. No loop da usinagem, o recurso gargalo identificado foi um dos centros de usinagem. Nesse caso, o TPT de produção foi calculado com base na capacidade deste recurso de realizar setups.

O TPT calculado foi igual a 3 dias, ou seja, todas as peças que passam pelo recurso considerado poderiam ser produzidas com uma periodicidade de 3 dias (toda parte a cada 3 dias). Neste caso, mesmo para aqueles itens que não passavam no recurso gargalo, foi adotado o TPT mínimo de 3 dias para todos os itens produzidos naquele loop. 


\begin{tabular}{|c|c|c|c|c|c|c|c|c|c|c|c|}
\hline & $\begin{array}{l}\text { Código } \\
\text { Itens }\end{array}$ & $\begin{array}{c}\text { Demanda } \\
\text { média } \\
\text { semanal } \\
\text { (pç/semana) }\end{array}$ & $\begin{array}{c}T / C \\
\text { (min.) }\end{array}$ & \begin{tabular}{|c} 
T/setup \\
(min.)
\end{tabular} & $\mid \begin{array}{c}T / C \text { total } \\
\text { (min.) }\end{array}$ & $\begin{array}{l}\text { TEMPO TOTAL } \\
\text { DISPONÍVEL } \\
\text { (min.)/semana }\end{array}$ & $\begin{array}{l}\text { T/C TOTAL } \\
\text { (min.) /semana }\end{array}$ & $\begin{array}{c}\text { TEMPO } \\
\text { DISPONÍVEL } \\
\text { PARA SETUP } \\
\text { (min.)/semana }\end{array}$ & $\begin{array}{l}\text { TEMPO TOTAL } \\
\text { UTILIZADO } \\
\text { PARA SETUP } \\
\text { (min.)/semana }\end{array}$ & $\begin{array}{l}\text { NUMERODE } \\
\text { CICLOS DE } \\
\text { SETUP'S } \\
\text { POSSÍVEL POR } \\
\text { SEMANA }\end{array}$ & $\begin{array}{c}\text { TPT/EPEI } \\
\text { (dias) }\end{array}$ \\
\hline 1 & 1 & 187,17 & 1,0 & 25 & 187 & \multirow{29}{*}{2376,00} & \multirow{29}{*}{1193,16} & \multirow{29}{*}{1182,84} & \multirow{29}{*}{700,00} & \multirow[t]{29}{*}{1,69} & \multirow{29}{*}{2,96} \\
\hline 2 & 4 & 55,1 & 1,5 & 25 & 83 & & & & & & \\
\hline 3 & 2 & 148,47 & 1,5 & 25 & 223 & & & & & & \\
\hline 4 & 3 & 121,4 & 1,0 & 25 & 115 & & & & & & \\
\hline 5 & 38 & 29,43 & 2,5 & 25 & 74 & & & & & & \\
\hline 6 & 39 & 30,07 & 0,8 & 25 & 24 & & & & & & \\
\hline 7 & 378 & 2,13 & 1,5 & 25 & 3 & & & & & & \\
\hline 8 & 558 & 5,53 & 4,0 & 25 & 22 & & & & & & \\
\hline 9 & 559 & 2,63 & 3,0 & 25 & 8 & & & & & & \\
\hline 10 & 560 & 1,73 & 4,0 & 25 & 7 & & & & & & \\
\hline 11 & 561 & 0,23 & 4,0 & 25 & 1 & & & & & & \\
\hline 12 & 562 & 1,7 & 2,0 & 25 & 3 & & & & & & \\
\hline 13 & 1402 & 14,2 & 4,0 & 25 & 57 & & & & & & \\
\hline 14 & 1403 & 14,4 & 1,0 & 25 & 14 & & & & & & \\
\hline 15 & 1406 & 6,13 & 1,7 & 25 & 10 & & & & & & \\
\hline 16 & 1407 & 19,13 & 1,7 & 25 & 32 & & & & & & \\
\hline 17 & 1480 & 19,2 & 2,2 & 25 & 41 & & & & & & \\
\hline 18 & 1531 & 6,83 & 5,8 & 25 & 40 & & & & & & \\
\hline 19 & 1532 & 7,3 & 5,0 & 25 & 37 & & & & & & \\
\hline 20 & 1533 & 8 & 5,0 & $\frac{25}{25}$ & 40 & & & & & & \\
\hline 21 & 1534 & 16 & 2,0 & 25 & 31 & & & & & & \\
\hline 22 & 1535 & 16 & 2,0 & 25 & 32 & & & & & & \\
\hline 23 & 1536 & 30 & 1,4 & 25 & 42 & & & & & & \\
\hline 24 & 1716 & 12 & 1,7 & 25 & 21 & & & & & & \\
\hline 25 & 1717 & 8 & 1,7 & 25 & 13 & & & & & & \\
\hline & 1718 & 17 & 1,0 & 25 & 16 & & & & & & \\
\hline 27 & 2422 & 1 & 80 & 25 & 6 & & & & & & \\
\hline 28 & 2423 & 1 & 8,0 & 25 & 9 & & & & & & \\
\hline & $\overline{T O T A L}$ & 782 & 79 & 700 & 1193 & & & & & & \\
\hline
\end{tabular}

Quadro 49: Cálculo do TPT com base no loop de usinagem.

Em seguida, calculou-se o TPT para o loop da fundição. O recurso gargalo considerado foi uma máquina de moldagem automática. O TPT calculado foi de 1 dia, conforme a tabela abaixo. 


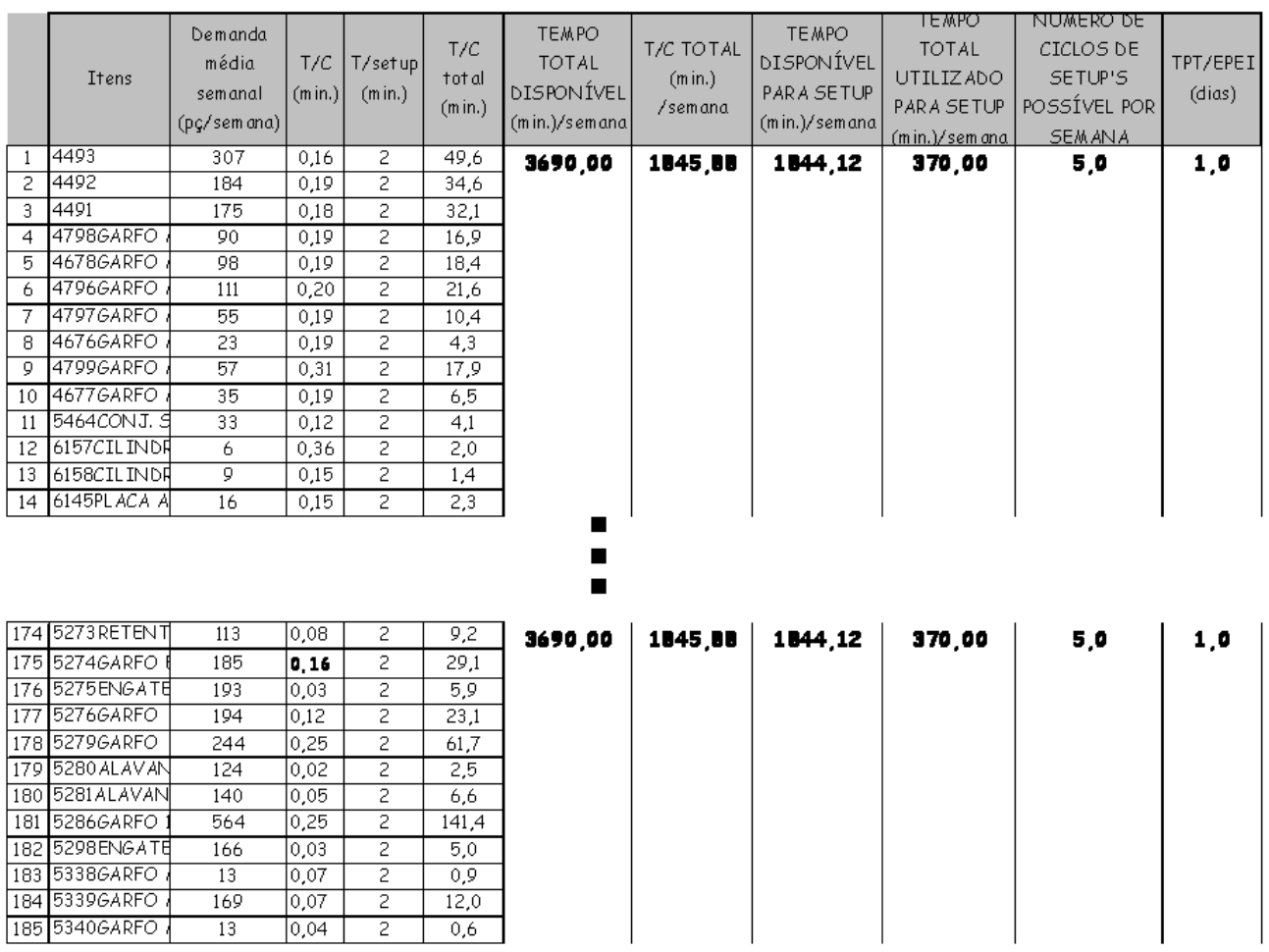

Quadro 50: Cálculo do TPT com base no loop da fundição.

Para o terceiro ponto de supermercado (S3), o TPT calculado era o de transporte. Nesse caso, considerou-se o ciclo de transporte do caminhão entre as duas unidades. Como o caminhão buscava as peças diariamente na unidade da fundição , o TPT adotado para o ciclo de transporte foi de 1 dia.

Todavia, como o loop do supermercado da usinagem (S1) possuía um TPT de 3 dias, o volume de peças consumidas no pontos S2 e S3 corresponderia a bateladas de 3 dias de consumo. Com isso, embora o TPT calculado tanto para o ponto S3 quanto para o S2 tenha sido de 1 dia, foi necessário assumir um TPT de 3 dias para estes dois pontos de supermercado. Ou seja, da mesma forma que dentro de um loop a operação gargalo é quem define o TPT, num fluxo de valor o loop gargalo é quem irá ditar o ritmo do sistema.

Posteriormente, os pontos S2 e S3 foram agrupados fisicamente junto ao consumidor na unidade de usinagem. Para isso, adotou-se um sistema kanban misto, de produção/transporte. O lead time de transporte foi somado ao lead time de produção da fundição. Com isso, foi possível trabalhar com apenas um ponto de supermercado. 


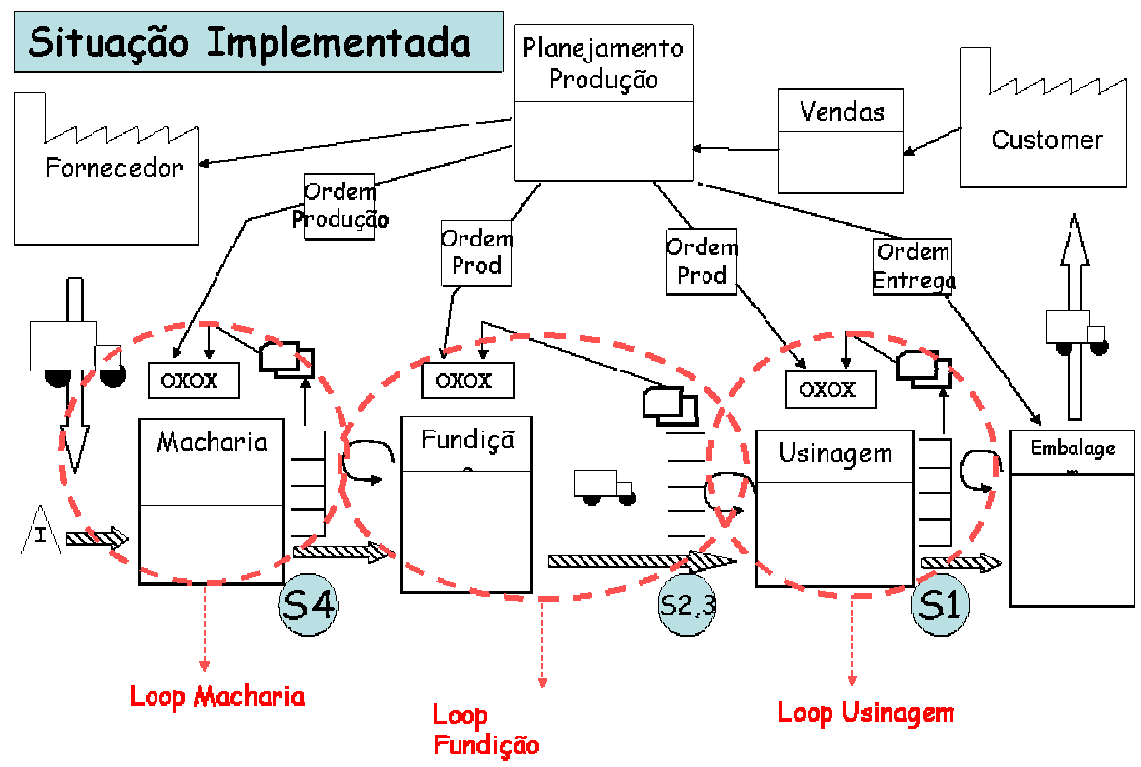

Figura 78: Revisão dos pontos de supermercado.

Com base nos fatos supracitados, para o loop do supermercado da macharia (S4) também foi adotado um TPT de 3 dias. Com isso, foi possível elaborar o Mapa de Fluxo de Valor Macro para da empresa.

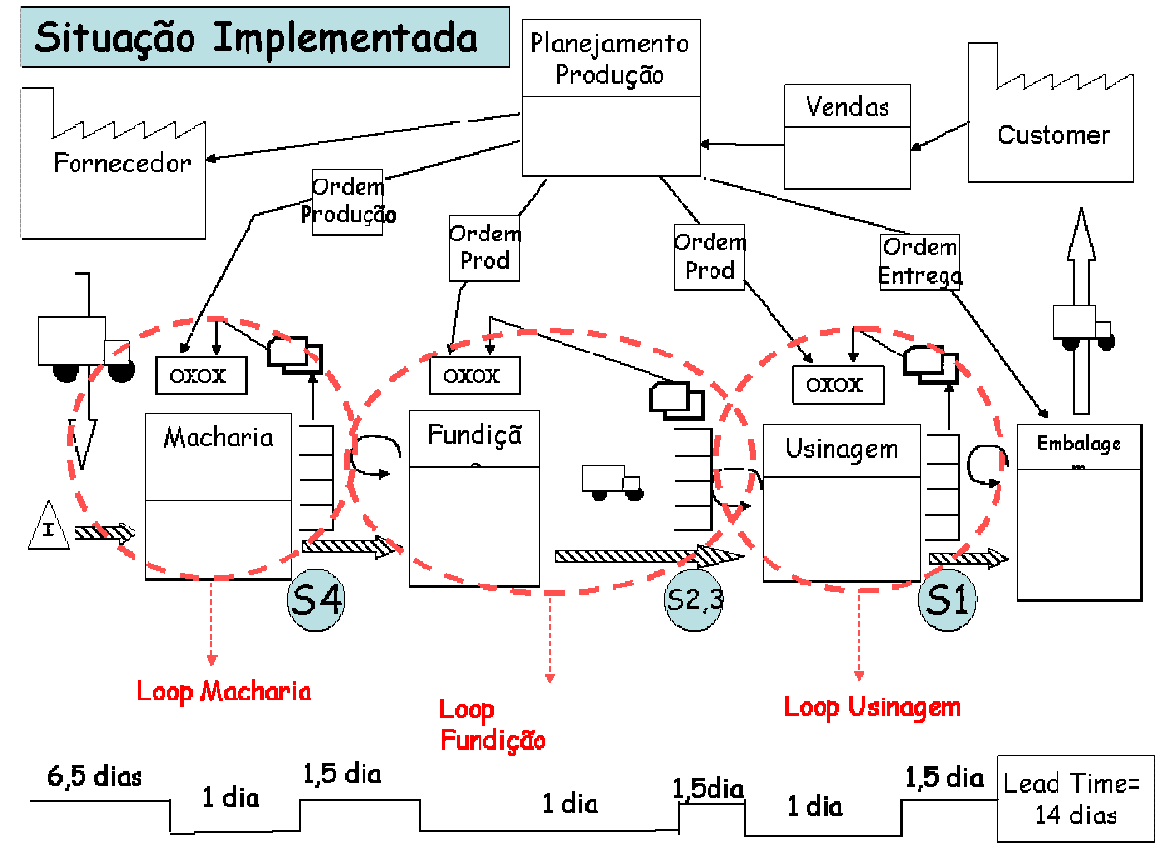

Figura 79: MFV Macro com linha de tempo. 


\subsubsection{Definição das sistemáticas de programação e controle}

Em seguida, foram definidos os procedimentos de programação e controle dos fluxos puxados e empurrados.

\subsubsection{Programação e controle dos itens MTO}

A fim de padronizar o sistema de cartões, foram elaboradas ordens de fabricação no formato dos cartões kanbans para os itens MTO. Nenhum procedimento específico foi definido para emissão das ordens. A única orientação foi que as ordens de produção teriam prioridade no seqüenciamento dos pedidos. Em períodos de sobrecarga os pedidos MTO eram priorizados, à medida que os supermercados iam sendo consumidos. Em períodos de ociosidade os supermercados eram reabastecidos.

O próximo passo foi definir a sistemática de programação e controle dos itens em kanban.

\subsubsection{Programação e controle dos fluxos puxados}

Para as peças que serão controladas pelo sistema kanban, decidiu-se trabalhar com um sistema de programação com ciclo de pedidos constante, devido à grande variedade de peças com características distintas de demanda. Nesse sentido, a reposição destas peças será disparada nos dias definidos, conforme o TPT calculado. Já para as peças que serão controladas via Ponto de Reposição trabalhou-se com o sistema de programação de pedidos com quantidades constantes, ou seja, uma quantidade fixa será pedida (lote de reposição) sempre que o estoque atingir o ponto de reposição.

Para as peças que seriam repostas por ciclo constante elaborou-se uma lista com o mix dos itens a serem produzidos num mesmo dia do TPT. Foi elaborada uma lista com o mix diário dos itens com TPT de 3 dias (subfamília de controle 1) e 6 dias (subfamília de controle 2). A elaboração desta lista considerou principalmente a distribuição dos itens de forma balanceada, de modo a não sobrecarregar os recursos pelos quais os itens seriam produzidos no dia. Na medida do possível, 
procurou-se também encaixar os itens com dispositivos e ferramentais semelhantes num mesmo período de reposição.

Uma lista como essa foi elaborada para cada um dos três pontos de supermercado.

\begin{tabular}{|c|c|c|c|c|c|c|}
\hline & TPT & GFG 250 & H 400 C & $\overline{\text { V1L }}$ & H 400 D & GU 800 \\
\hline \multicolumn{7}{|l|}{$1^{\circ}$ Dia } \\
\hline 13 Curva C/ Freio Motor 112/113 HW & 3 & & $\bar{x}$ & $\bar{x}$ & & \\
\hline 2 INTERMEDIARIA 112/113 HW & 3 & & & & $\mathrm{x}$ & $x$ \\
\hline 23 Luva de Expansão da 111 & 9 & $\mathrm{x}$ & & & & \\
\hline 1295 CURVA C/FM MB OM 366A/OF1317/18 & 9 & & & $x$ & $\mathrm{x}$ & \\
\hline 38 COL.FB TURBIN. BIPARTIDO & 9 & & & $x$ & $x$ & \\
\hline 39 COL.FB TURBIN. BIPARTIDO & 9 & & & & $x$ & $x$ \\
\hline \multicolumn{7}{|l|}{$2^{\circ}$ Dia } \\
\hline 14 Curva C/ Freio Motor 112 & 3 & & $\mathrm{x}$ & $x$ & & \\
\hline 3 PONTA 112/113 HW & 3 & & & & $\mathrm{x}$ & $\mathrm{x}$ \\
\hline 31 Car. Scania TV-61 (Garret) & 9 & $\mathrm{x}$ & & $\mathrm{x}$ & & \\
\hline 1716 COL.CENTRAL 114 - DSC 11 & 9 & & & $x$ & $x$ & \\
\hline 86 Curva C/ Freio Motor MB 366 & 9 & & & & $\mathrm{x}$ & \\
\hline 1403 COL.M.B. P.MENOR(1935-B) & 9 & & & & $x$ & $x$ \\
\hline \multicolumn{7}{|l|}{$3^{\circ}$ Dia } \\
\hline 22 Luva de Junção da 112 & 3 & & & & & $\mathrm{x}$ \\
\hline 2843 Car. Automotivo A/R 0,48 & 9 & $\bar{x}$ & & $\mathrm{x}$ & & \\
\hline 50 Car. Mercedes 3 LKS (Lacon) & 9 & $\mathrm{x}$ & & $\mathrm{x}$ & & \\
\hline 1407 COL.CENTRAL SC 124L/G & 9 & & & $x$ & $x$ & \\
\hline 1480 PONTA SCANIA 124L/G DSC12 & 9 & & & & $\mathrm{x}$ & \\
\hline 1COL.CENTRAL 112/113HW C/ RANHURA & & & $\mathrm{x}$ & & & \\
\hline 4COL.CENTRAL 112 & & & $\mathrm{x}$ & & & \\
\hline
\end{tabular}

Quadro 51: Agrupamento dos itens com dispositivos e ferramentais semelhantes num mesmo período de reposição

\subsubsection{Flexibilização dos fluxos puxados}

Nesse primeiro caso de implementação, não foi tomada nenhuma ação concreta com relação à criação de sistemas puxados flexíveis. Para todos os itens o nível dos supermercados foi calculado em função do volume de demanda dos seis meses anteriores. Recomendou-se apenas que tais níveis fossem ajustados sempre que houvesse uma previsão de alterações na demanda considerada.

O próximo passo foi nivelar o processo puxador.

\subsubsection{Programação e nivelamento do processo puxador}


Constantemente, os fluxos anteriores, regulados pela lógica de puxar, estavam sendo submetidos ora a sobrecargas, com o não atendimento dos kanbans, ora a ociosidade, sem haver consumo dos itens do kanban ao longo de vários dias.

A equipe de projeto diagnosticou que o critério de programação dos pedidos no puxador (Expedição) resultava no desnivelamento de todo o fluxo. Á medida que os pedidos dos clientes externos chegavam, eles eram repassados para o PCP que simplesmente os programava com base numa lógica FIFO (First In First Out), ou seja, o primeiro que chegava era o primeiro a ser embalado e expedido. Como na maioria das vezes um pedido de um cliente era composto por mais de um item, o PCP não conseguia visualizar se estava sobrecarregando a entrega de um mesmo produto. A única meta de referência que se tinha era que a carteira de pedidos de um dia deveria totalizar 80 toneladas, ou seja, um caminhão. Os pedidos eram alocados conforme o preenchimento da capacidade diária.

Com isso, foi preciso construir uma máscara de programação e nivelamento dos pedidos. Com a ajuda da área de informática, foi elaborado um sistema que mostrava a taxa de consumo de cada item do kanban. Essa taxa era carregada à medida que os pedidos eram inseridos no sistema. O sistema estava programado para fazer uma análise de soma móvel num horizonte de tempo proporcional ao TPT de cada item. Em outras palavras, se um item possuía um TPT de 3 dias o sistema analisava todas as somas móveis de janelas de 3 dias, conforme ilustrado na figura abaixo.

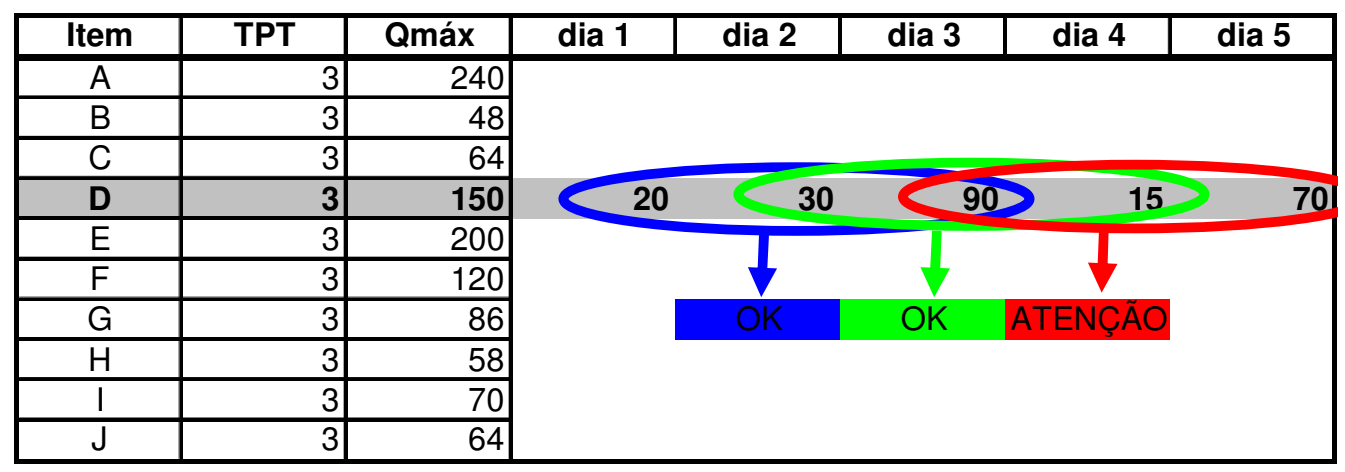

Quadro 52: Somas móveis de janelas de 3 dias para análise da capabilidade do supermercado. 
De acordo com esta máscara de programação, o sistema emitia um aviso de alerta quando a soma móvel de 3 dias de consumo de um item em kanban ultrapassava a quantidade máxima dimensionada para o supermercado. Este aviso orientava o PCP a alterar a data programada de alguns pedidos que contivessem o item em questão. Um outro ponto importante foi que, juntamente com a área comercial, fixou-se em 5 dias o prazo máximo de tolerância de espera pelo cliente externo. Com isso, embora o PCP continuasse a realizar uma programação FIFO, o sistema o auxiliava a ajustá-la de forma nivelada dentro desse horizonte de 5 dias.

\subsubsection{Preparação e acompanhamento da implementação}

Nesta etapa foi definido como seria a transição do sistema de produção anterior para o sistema proposto, incluindo-se aí a sequiência de implementação, a velocidade com que as mudanças seriam executadas e um cronograma de implementação.

Foram realizados treinamentos conceituais e de alinhamento com todos os turnos da empresa. Nenhuma técnica específica de implementação, como a do evento kaizen, foi utilizada.

Em paralelo foram realizadas as seguintes atividades:

Detalhamento de atividades para a implantação das soluções.

Elaboração dos novos procedimentos de trabalho.

Desenvolvimento de sistema para cadastro dos kanbans 


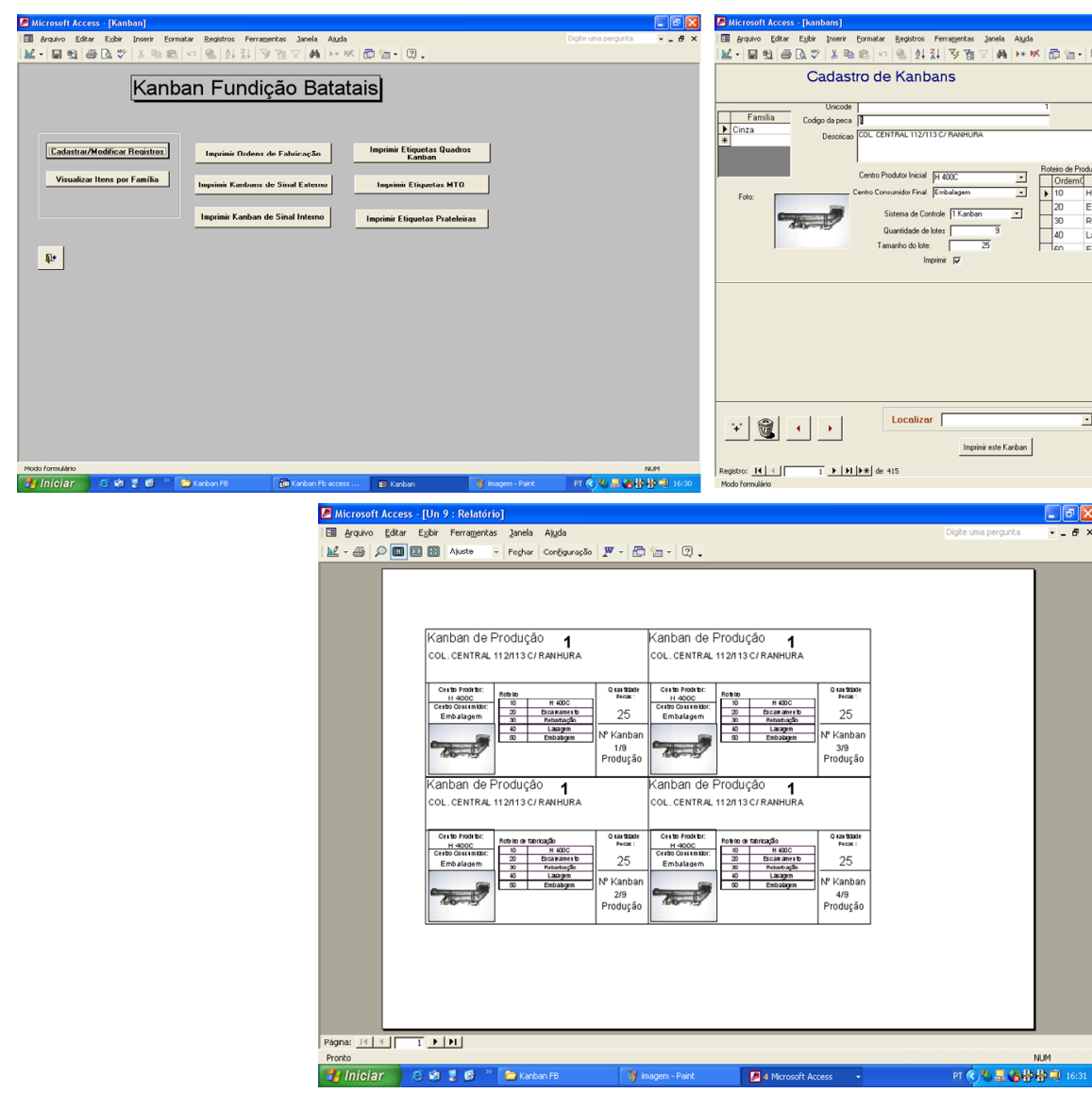

Figura 80: Sistema de impressão de kanbans.

+ Confecção dos quadros de kanban e programação. Foram confeccionados dois tipos de quadros para auxiliar na programação: um quadro de controle de entrega de peças terceirizadas e um quadro de kanban e de programação. 


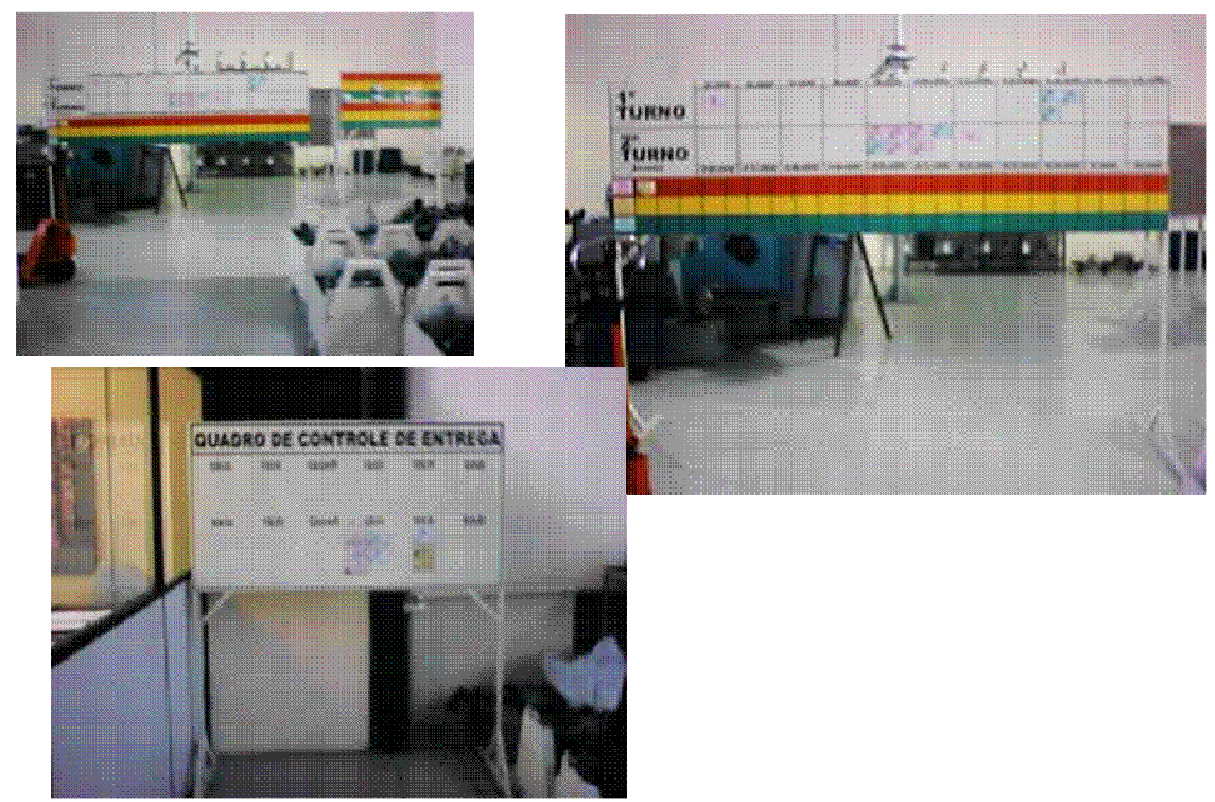

Figura 81: Quadros de kanban e de programação.

* Confecção de recursos para a armazenagem dos itens do supermercado.

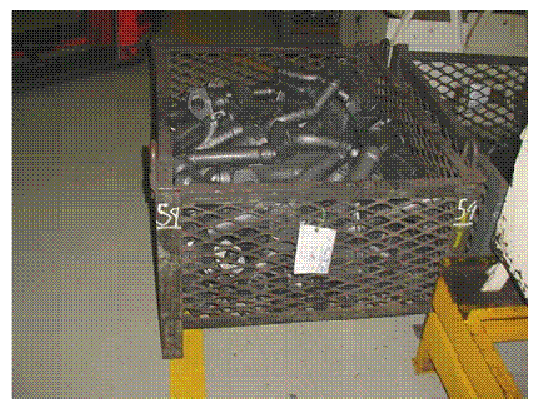

Antes

Lote "Econômico"

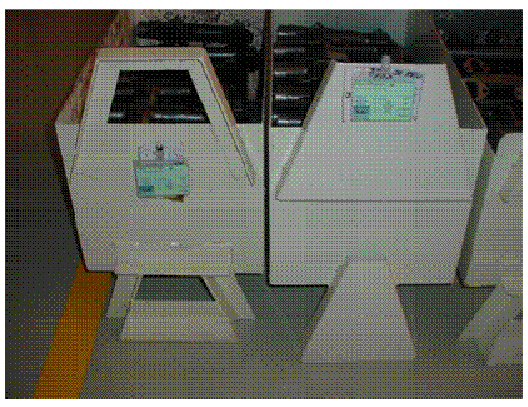

Depois

Lote para 3 dias

Figura 82: Recursos de armazenagem dos itens do supermercado.

Além dos benefícios inerentes á adoção de um sistema de programação e controle híbrido, a empresa pôde otimizar também a ocupação do espaço físico da fabrica. Este espaço estava sendo desperdiçado com grandes lotes de produção, muitas vezes replicados em locais diferentes. Sobras de um mesmo item de lotes "econômicos" anteriores encontravam-se distribuídos em diversos pontos da fábrica. 


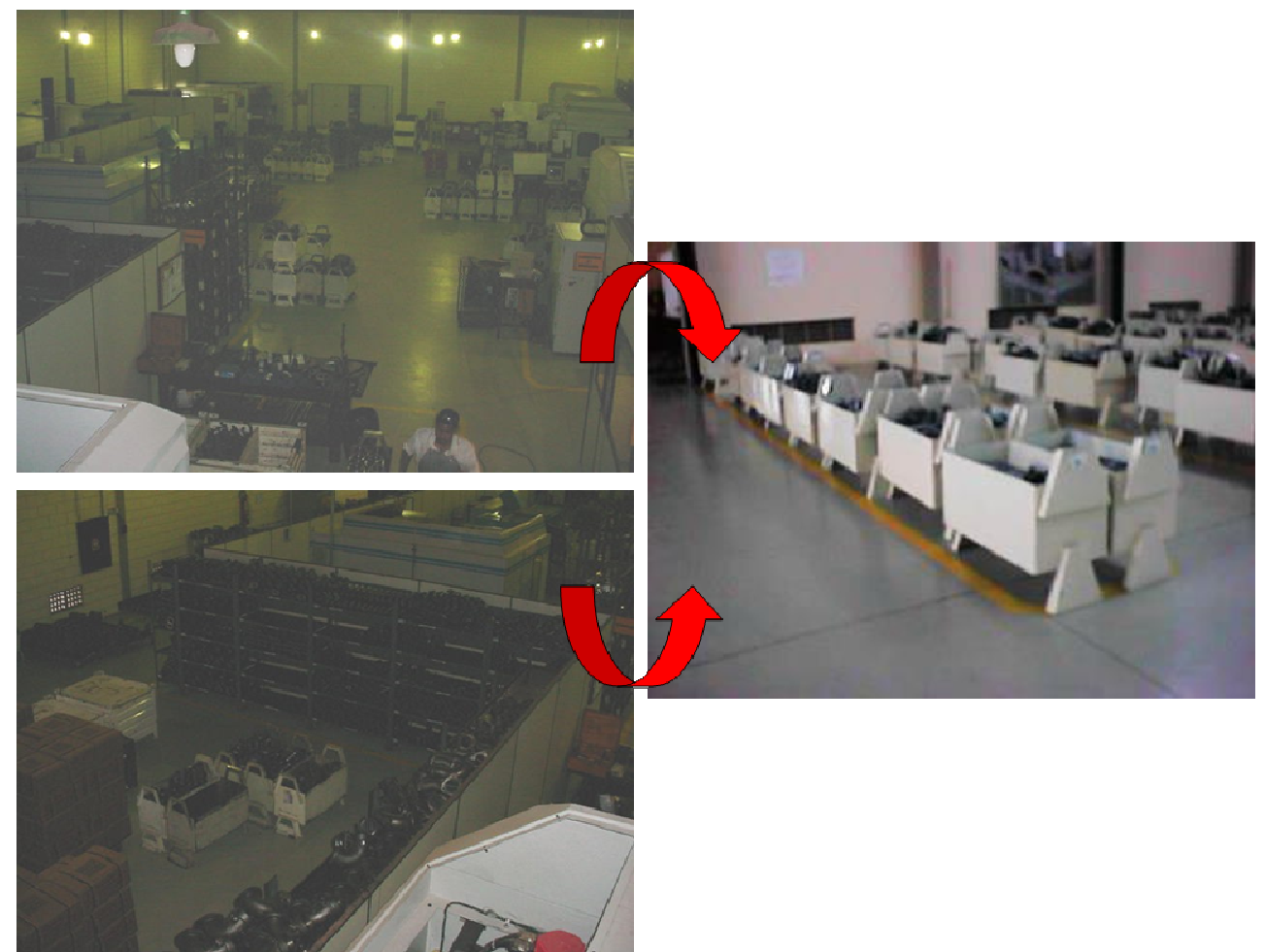

Figura 83: Otimização do espaço físico ocupado.

\subsubsection{Resultados obtidos}

Como resultados da aplicação foram identificadas as seguintes melhorias:

Lead Time: Redução de $57 \%$, passando de 38,3 dias para 14 dias, no caso dos itens classe A.

\# Produtividade: Ganho de $31 \%$. A produção máxima antes da implementação era de 80 ton./mês, e após a implementação houve um aumento para 105 ton./mês.

\# Estoques: redução de 43\%. Antes da implementação o estoque médio era de 70 toneladas, após a implementação o estoque médio diminuiu para 40 toneladas.

Velocidade de Entrega (pedidos entregues em até 5 dias úteis): Essa foi a principal medida de resultado do projeto: 
○ Pedidos entregues com menos de 5 dias: ganho de 96\%. Antes da implementação $25 \%$ dos pedidos eram entregues em até 5 dias úteis após o pedido, dois meses após a implementação 49\% dos pedidos passaram a ser entregues neste prazo.

○ Pedidos entregues com mais de 15 dias: redução de 81\%. Antes da implementação $8 \%$ dos pedidos eram entregues com mais de 15 dias após a realização do pedido, após a implementação apenas $1,5 \%$ dos pedidos foram entregues com este prazo.

\subsubsection{Considerações sobre a $1^{\mathrm{a}}$. aplicação}

\section{Com relação aos resultados obtidos pela empresa}

Com a aplicação do Sistema de Produção Enxuta foi observada a contenção de superprodução, de estoques desnecessários, de transporte excessivo, entre outros desperdícios. Esses resultados estão relacionados à melhoria e adaptação do sistema de programação e controle utilizado. Além disso, o nivelamento do processo puxador possibilitou a empresa estabilizar a reposição dos itens em supermermercado, evitar o abandono devido à perda de credibilidade do sistema puxado, reprogramações de última hora e, sobretudo, menos estoques em processo e uma maior rapidez de entrega para o cliente final.

\section{Com relação ao método proposto}

A aplicação contribuiu com o método proposto sobretudo com a idéia de se projetar o sistema híbrido de PCP. Evitar tratamentos genéricos em políticas de programação e controle da produção é o primeiro passo para a criação de um sistema de PCP robusto para fazer frente aos desafios de uma economia globalizada e ávida por empresas com portfólios diversificados.

Outro ponto importante foi aprofundamento no conceito de nivelamento do processo puxador. Notou-se que o nivelamento do puxador é prérequisito para o sucesso de um sistema híbrido de PCP. Contemplar e aprofundar este conceito no método proposto foi outro importante output desta aplicação. 
A técnica de realizar o Evento Kaizen não foi utilizada. Teria contribuído muito para aumentar a rapidez e efetividade da implementação, a qual foi disparada e gerenciada pela utilização de cronograma convencional.

O uso do conceito de sistemas puxados flexíveis também não foi utilizado. Ao retornar tempos depois na empresa para avaliação, notou-se que o sistema continuava ancorado nos dados de demanda utilizados inicialmente. A falta de um procedimento explícito de ajustes no sistema conforme as flutuações na demanda foi uma outra lacuna desta aplicação.

Uma nova rodada da metodologia de pesquisa foi iniciada a partir de uma nova aplicação. Agora em uma empresa de grande porte, também com grande variedade de produtos e componentes e fluxo de valor relativamente longo. Ao invés de fundição e usinagem, como no caso supracitado, os principais processos eram de usinagem e montagem, com operações externas em terceiros. 


\section{2. $\quad 2^{\mathrm{a}}$. Aplicação.}

A empresa objeto do estudo deste trabalho é uma empresa de processos de usinagem e montagem, localizada no interior do estado de Santa Catarina. Emprega um total de 400 funcionários. A mini-fábrica estudada trabalha com a manufatura e comercialização de bombas de engrenagem, possuindo aproximadamente 400 diferentes tipos de produtos finais montados.

Como diagnóstico inicial da empresa foram levantados os seguintes efeitos indesejáveis:

\section{Falta e sobra de componentes para a montagem final}

* Baixa produtividade

Alto estoque de componentes em processo

Alto Lead Time de produção

Baixa pontualidade

Os passos para a solução desses problemas iniciaram-se pelos desenhos do Mapa de Fluxo de Valor da Situação Atual. Para os fins deste trabalho, foi feita uma visão esquemática do mapeamento. Foram mapeados dois fluxos em paralelo, os quais convergiam para a montagem final. O primeiro fluxo, de carcaças, era composto por apenas duas operações. Já o segundo fluxos, de engrenagens, era o mais complexo, longo e demorado, principalmente porque possuía duas operações que eram feitas externamente. Com isso, ele foi considerado no caminho crítico de todo o fluxo de valor. A linha de tempo (Lead Time) foi definida com base nele. 


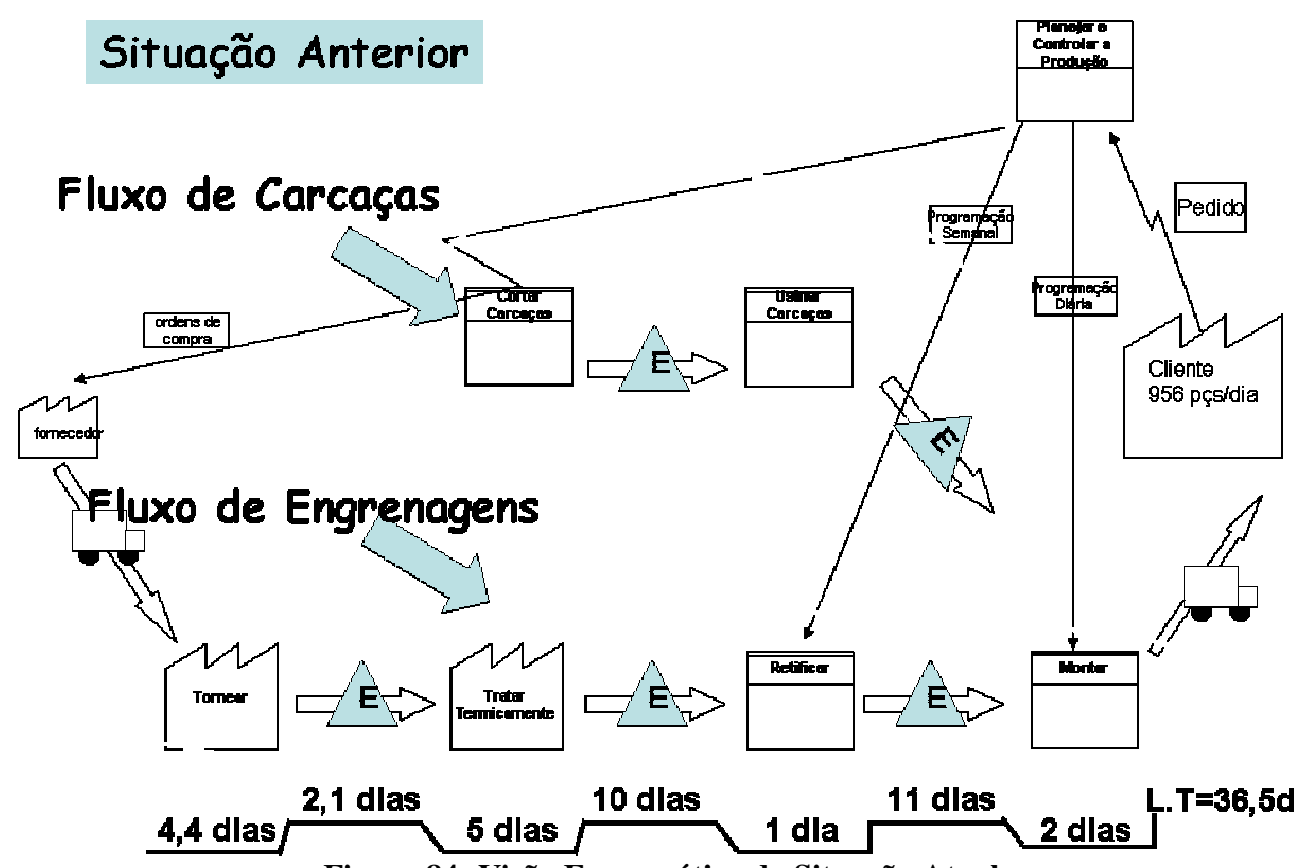

Figura 84: Visão Esquemática da Situação Atual

A partir do Mapa, foi possível aprofundar a análise sobre os efeitos indesejáveis apontados na fase inicial do projeto:

Falta e sobra de componentes para a montagem final: como o processo de montagem representa o agrupamento de vários componentes. A falta de sincronização na chegada destes componentes ao processo era muito grande. Com isso, o planejador da produção limitava-se a colocar na linha "aquilo que fosse possível de montar no dia", de acordo com a disponibilidade dos respectivos componentes.

* Baixa produtividade: Como não havia previsibilidade alguma quanto à inserção dos produtos na linha de montagem, o processo não conseguia seguir padrão algum. Consequentemente, ele era constantemente acometido por sobrecargas ou por ociosidades. Em certas situações a quantidade de montadores era excessiva, pois um único modelo simples de ser montado era produzido na linha o dia inteiro. Em outros momentos, para cumprir a meta diária de volume de produção um mix excessivamente alto de produtos era introduzido 
na linha. O grande número de setups e de produtos com tempos de ciclo completamente diferentes causava o desbalanceamento e uma enorme sobrecarga na linha. Isso resultava na necessidade de horas extras, frustrações e desentendimentos internos.

Alto estoque de componentes em processo: A produção era programada de forma empurrada, com base na previsão de vendas. $\mathrm{O}$ PCP disparava a compra e fabricação dos componentes com semanas de antecedência, pois o fluxo de valor era muito longo. À medida que os pedidos em carteira iam se consolidando, a discrepância entre o previsto e o real resultava em reprogramações em cima da hora. Lotes em processo eram interrompidos e novos lotes de produção eram disparados. Com isso, recursos eram usados antes da hora, os estoques em processo eram altos e os itens (re)programados de última hora estavam sempre atrasados.

Alto Lead Time de produção: o fluxo de valor longo e o alto nível de estoques em processo resultavam num alto lead time de produção.

\$ Baixa pontualidade: Em função dos problemas supracitados, constantemente os prazos de entrega não eram atendidos.

Foi feito o desenho da situação futura, a partir dos qual se iniciou o desenvolvimento do sistema híbrido de programação e controle.

\subsubsection{Projeto macro do sistema híbrido de planejamento e programação da produção}

O primeiro passo consistiu em quebrar estrategicamente o longo fluxo de valor em partes menores e mais fáceis de serem administradas. Para isso, foram definidos cinco pontos de supermercado. A idéia inicial foi que alguns itens seriam produzidos para estes pontos de supermercados (provavelmente os best-seller), enquanto os demais itens continuariam sendo produzidos paralelamente de forma empurrada. Com isso, os quadros de kanban controlariam os fluxos puxados e as 
ordens de produção continuariam sendo emitidas para o início do fluxo a fim de programar e controlar os itens MTO.

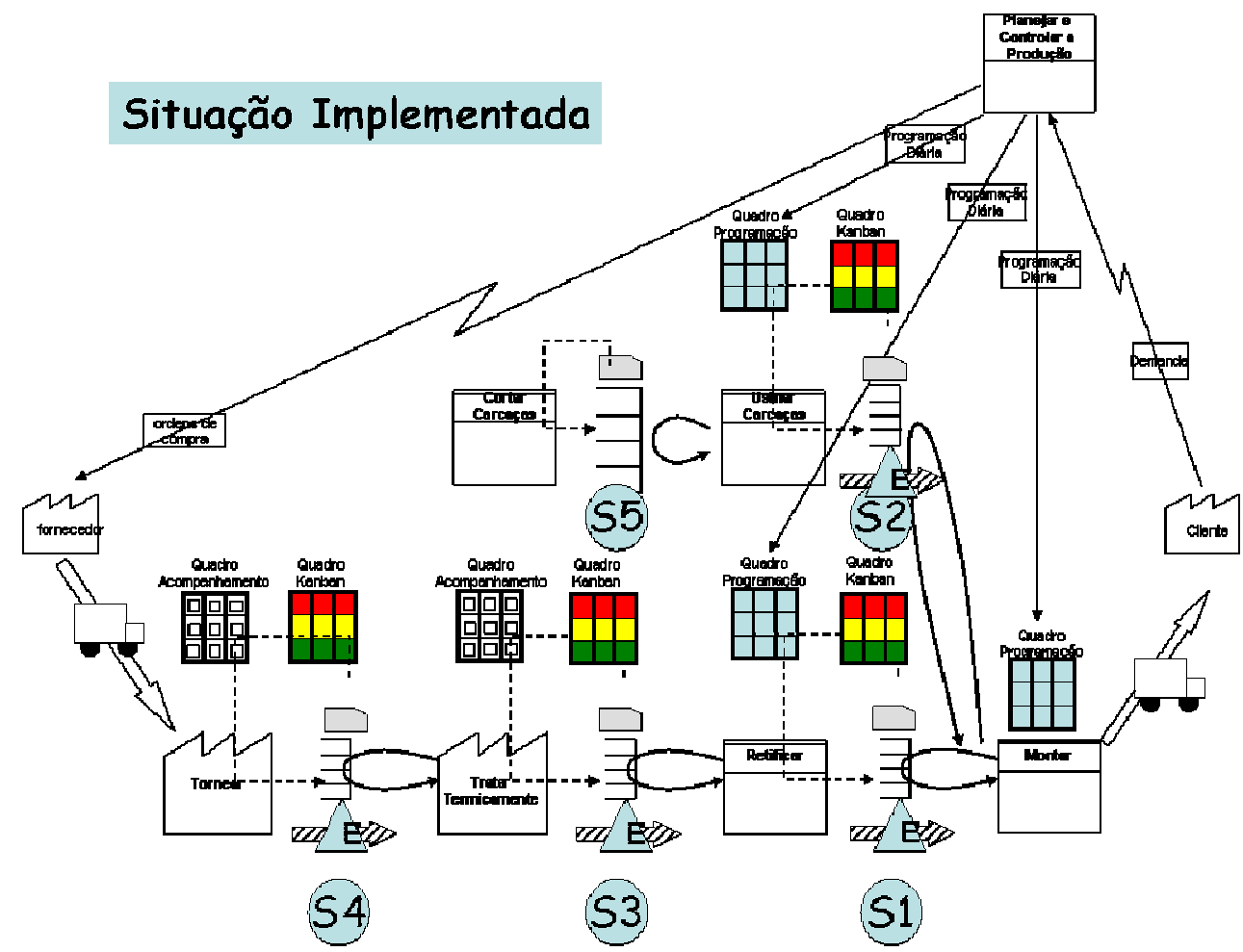

Figura 85: Definição dos pontos de supermercado - 2a Aplicação

Os dois primeiros pontos, tanto o de engrenagens retificadas (S1) quanto o de carcaças usinadas (S2), foram definidos com base na necessidade de garantir a disponibilidade dos itens best sellers para a montagem (supermercado pulmão). A seta de fluxo empurrado, colocada juntamente com o supermercado, indica que nem todas as peças seriam produzidas para supermercado.

Como todos os componentes eram programados até então de forma empurrada via sistema MRP, a montagem parava constantemente devido á falta de sincronização na chegada dos itens necessários para montar determinado tipo de bomba. Um fator que agravava ainda mais essa situação era a janela de planejamento. Como o planejamento de compra e fabricação dos componentes para a montagem era feito em bases semanais não se sabia ao certo o que seria montado diariamente dentro da semana. Para que essa lógica de PCP funcionasse adequadamente os processos fornecedores (fluxo acima) teriam que disponibilizar 
para a montagem todo o lote semanal no final da semana anterior. Devido aos atrasos e reprogramações muitos componentes ficavam prontos na própria semana em que seriam montados, só que muitas vezes sem formar o kit necessário para montar o volume de bombas do dia. Com isso, a montagem reagia de forma totalmente desnivelada e desbalanceada, conforme a disponibilidade dos componentes comprados e manufaturados.

O terceiro e o quarto ponto de supermercado (S3 e S4) foram definidos devido ao fato dos processos externos de tratamento térmico e usinagem apresentarem lead times muito elevados. O fluxo muito longo de ambos os processos deixava os seus consumidores internos constantemente descobertos diante de contratempos como mudanças na programação e de imprevistos devido à baixa confiabilidade dos mesmos.

O quinto ponto de supermercado (S5), de carcaças serradas, foi definido devido ao fato de não ter sido possível em curto prazo colocar esse processo em fluxo contínuo com a usinagem. Trata-se de um supermercado pulmão cuja função era garantir que as máquinas de usinagem, gargalos no fluxo das carcaças, não parassem por falta de carcaças serradas, itens de baixo valor agregado (classe C).

Com isso, ao invés de "Produzir para Estoque" (MTS - Make to Stock), baseado em previsões de vendas, a estratégia do projeto de situação futura foi adotar uma política de atendimento da demanda do tipo "Montar sob Ordem" (ATO Assembly to Order) O processo de montagem tornou-se o processo puxador do fluxo de valor. 


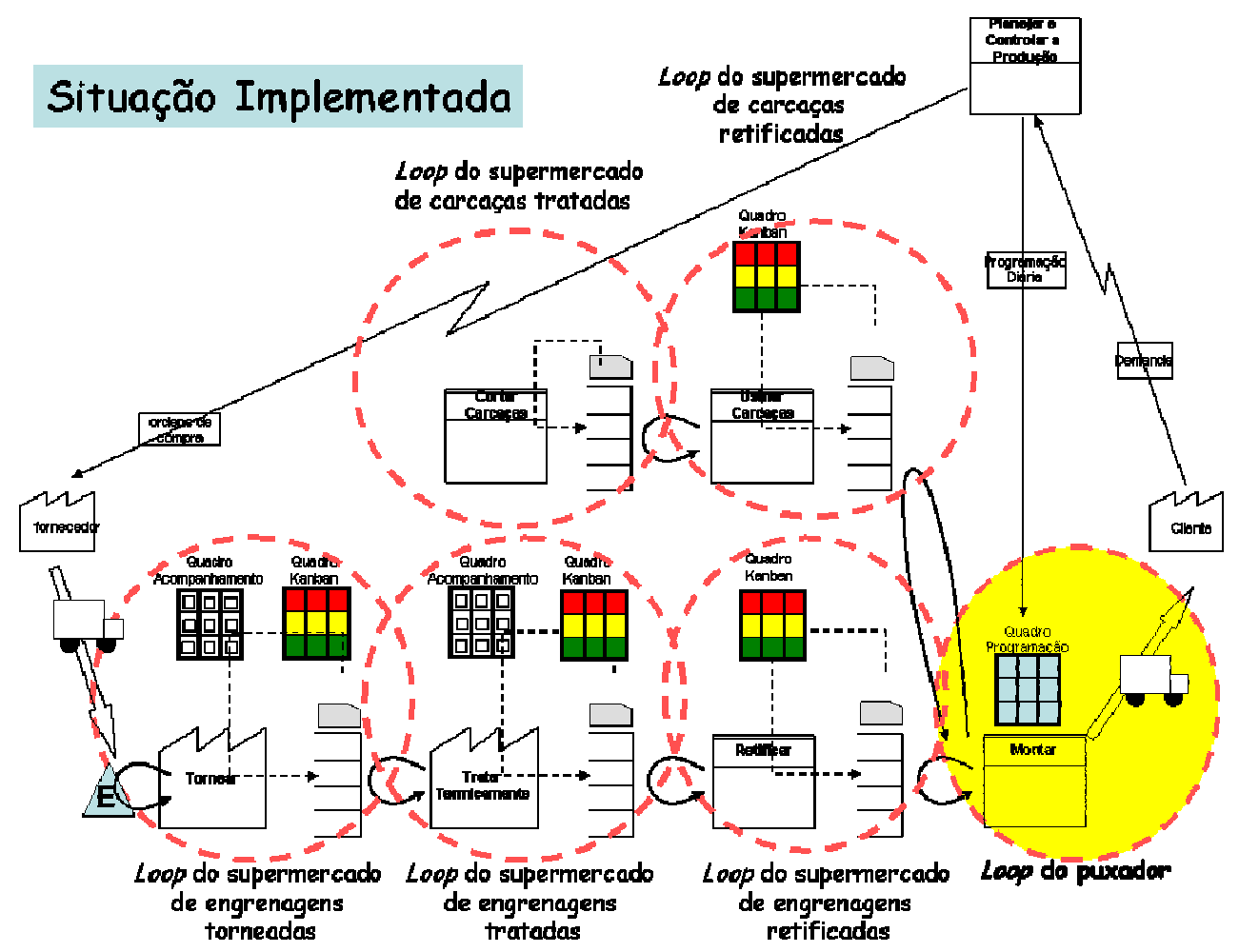

Figura 86: Definição do processo puxador.

O próximo passo foi definir quais desses itens seriam controlados de forma puxada e quais seriam controlados de forma empurrada, ou seja, mediante ordem de produção.

\subsubsection{Definição das subfamílias de programação e controle}

O objetivo desta etapa foi definir se os produtos de um mesmo fluxo de valor deveriam ou não ser controlados de formas diferentes.

Os fatores de referência utilizados para definir o tipo de controle mais adequado foram:

a) Volume da demanda: Levantado com base na previsão da demanda dos três meses seguintes.

Freqüência da demanda: Baseado na relação entre a média de consumo e o desvio padrão de cada item no período considerado. Embora o TPT fosse de 5 dias para engrenagens e 2 dias para carcaças, foi utilizado o desvio padrão mensal (entre os meses). 
Vale ressaltar que o ideal teria sido utilizar o desvio padrão entre os blocos de 5 dias (ex.: desvpad (dia1+dia2+dia3+dia4+dia5; dia2+dia3+dia4+dia5+dia6, etc.). Entretanto, os dados de previsão encontravam-se apenas em bases mensais.

b) Custo: Não foi utilizada a classificação $\mathrm{ABC}$ de custo, pois o custo dos diferentes tipos de engrenagens e carcaças eram praticamente os mesmos.

Segue abaixo a tabela com os critérios utilizados para a definição do tipo de controle e do tamanho do TPT para todos os loops do fluxo de engrenagens. Foram definidas praticamente duas subfamílias de controle (kanban com TPT de 5 dias e ordem de produção). O detalhamento do cálculo do TPT de produção será mostrado no tópico a seguir (4.2.3). O agrupamento dos itens nestas duas subfamílias foi feito com base na faixa de freqüência e volume em que cada um se encontrava.

\begin{tabular}{|l|c|c|c|c|}
\hline $\begin{array}{c}\text { Subfamília } \\
\text { de Controle }\end{array}$ & Volume & Freq. & $\begin{array}{c}\text { Tipo de } \\
\text { Controle }\end{array}$ & TPT \\
\hline Subfamília 1 & Alto & Alta & Kanban & $\mathbf{5}$ dias \\
\hline Subfamília 2 & Baixo & Alta & Ordem & $\begin{array}{c}\text { Tamanho do } \\
\text { pedido }\end{array}$ \\
\hline Subfamília 2 & Baixo & Baixa & Ordem & $\begin{array}{c}\text { Tamanho do } \\
\text { pedido }\end{array}$ \\
\hline Subfamília 2 & Alto & Baixa & Ordem & $\begin{array}{c}\text { Tamanho do } \\
\text { pedido }\end{array}$ \\
\hline
\end{tabular}

Quadro 53: Definição das subfamílias de controle para o fluxo de engrenagens.

Para o fluxo de carcaças foram definidas três subfamílias de controle. 


\begin{tabular}{|c|c|c|c|c|}
\hline $\begin{array}{c}\text { Subfamília } \\
\text { de Controle }\end{array}$ & Volume & Freq. & $\begin{array}{c}\text { Tipo de } \\
\text { Controle }\end{array}$ & TPT \\
\hline Subfamília 1 & Alto & Alta & Kanban & 2 dias \\
\hline Subfamília 2 & Baixo & Alta & Kanban & 4 dias \\
\hline Subfamília 3 & Baixo & Baixa & Ordem & $\begin{array}{c}\text { Tamanho do } \\
\text { pedido }\end{array}$ \\
\hline Subfamília 3 & Alto & Baixa & Ordem & $\begin{array}{c}\text { Tamanho do } \\
\text { pedido }\end{array}$ \\
\hline
\end{tabular}

Quadro 54: Definição das subfamílias de controle para o fluxo de carcaças.

Ao contrário da $1^{\text {a }}$. Aplicação, os itens de baixo volume não foram inseridos no supermercado, visto que a diretoria estava um pouco resistente em colocar tantos itens no kanban num primeiro momento. Contudo, as implicações de manter esses itens controlados mediante ordem não foram muito boas. Por se tratar de itens de baixo volume, as ordens de produção abertas para a fabricação destes itens quase sempre eram de tamanho maior que a quantidade pedida pelo cliente. $\mathrm{O}$ tamanho do pedido era considerado muito pequeno para ser produzido ao ponto de compensar os esforços de preparação da máquina gargalo. As sobras do lote produzido eram estocadas. Entretanto, os erros humanos na entrada de dados no sistema, a armazenagem de um mesmo item em diferentes pontos do almoxarifado e a falta de espaço físico, já que não estava prevista área alguma para estocagem de itens MTO, tornou o controle físico dessas "sobras" em um processo extremamente artesanal e demorado. Com isso, nos momentos de emergência, o PCP acabava por disparar novos lotes, pois não tinha tempo para fazer a localização e contagem física do saldo desses itens.

A seguir, será mostrado como foram feitos os cálculos dos TPT’s de produção. 


\subsubsection{Dimensionamento do tamanho do supermercado}

Para o dimensionamento do tamanho do supermercado em cada ponto foram delimitados os loops de produção.

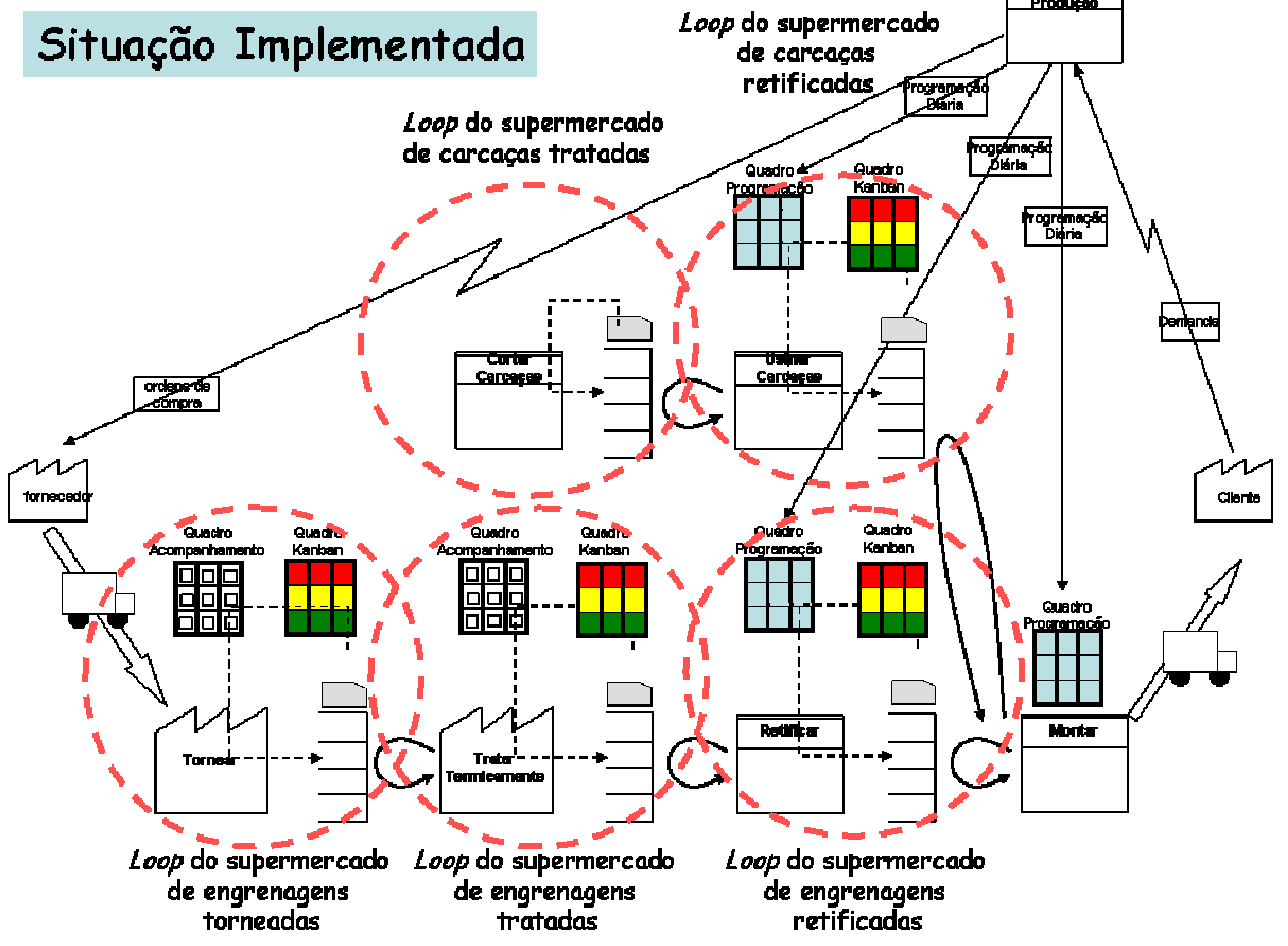

Figura 87: Identificação dos loops de produção

Levantou-se a previsão de vendas mensal de todas as peças dos 3 (três) meses seguintes. Em seguida, calculou-se o TPT para cada loop. No loop da retífica, como não havia uma percepção clara de qual seria a operação gargalo calculou-se o TPT de todas as operações do loop. A operação que apresentou o maior TPT, e, portanto, a menor capacidade de giro, foi a de retificar, conforme ilustrado na seguir. 


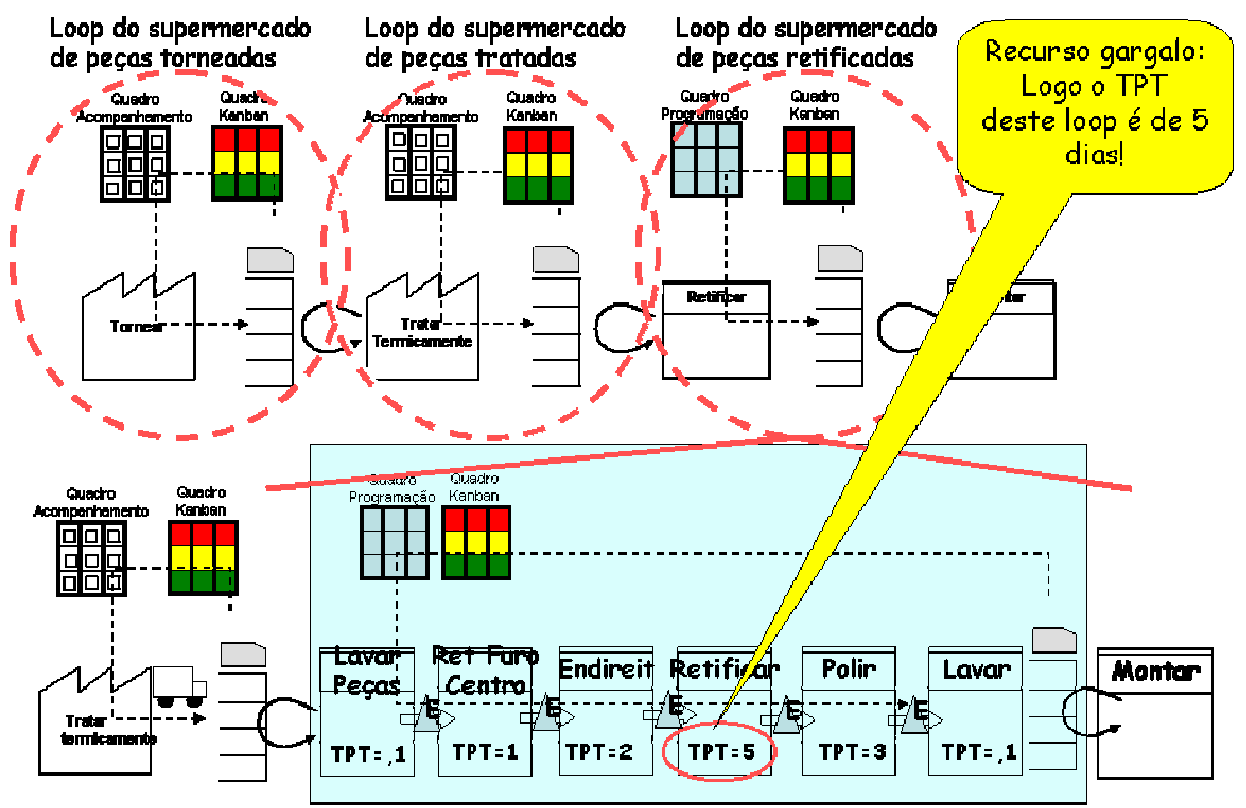

Figura 88: Identificação do recurso gargalo

Nestes casos, o TPT de produção foi calculado com base na capacidade dos recursos de cada operação de realizar setups. O TPT adotado foi de 5 dias, ou seja, todas as peças seriam produzidas com uma periodicidade média de 5 dias (toda parte a cada 5 dias). Para os demais loops (engrenagens torneadas e tratadas) do fluxo de engrenagens, adotou-se o mesmo TPT do loop da retífica, ou seja, 5 dias. Não foi possível adotar um TPT menor para estes dois primeiros loops, visto que o loop de engrenagens retificadas (consumidor) consumiria, a cada ciclo de reposição, lotes de no mínimo 5 dias.

É apresentado um recorte da tabela de cálculo do TPT com base no recurso gargalo. 

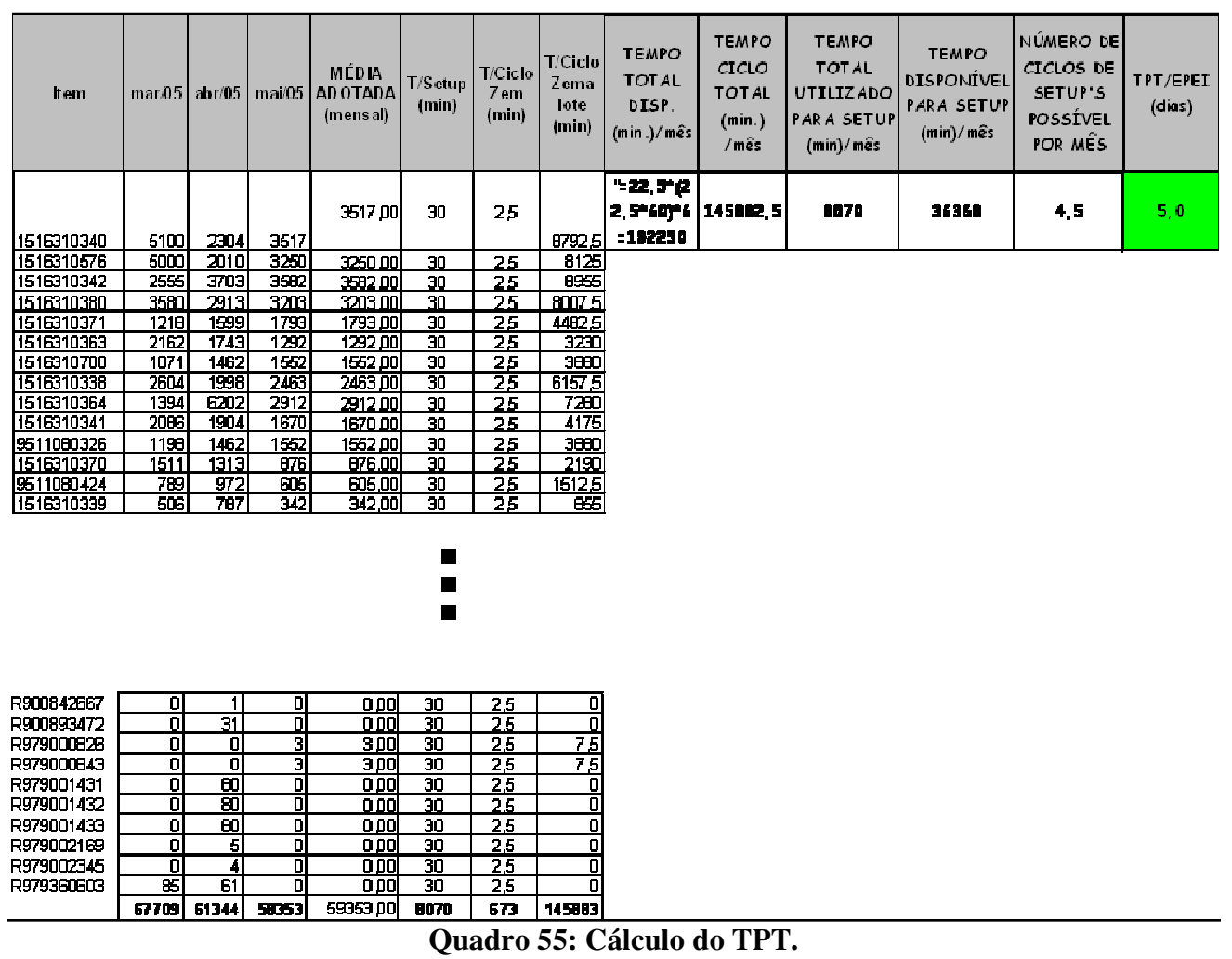

Em seguida, calculou-se o TPT para o loop das carcaças. O TPT calculado foi de 2 dias tanto para o ponto de carcaças serradas (S5) quanto para o de usinadas (S2).

A figura abaixo ilustra como ficou o MFV implementado para os itens em supermercado com a respectiva linha de tempo (lead time). 


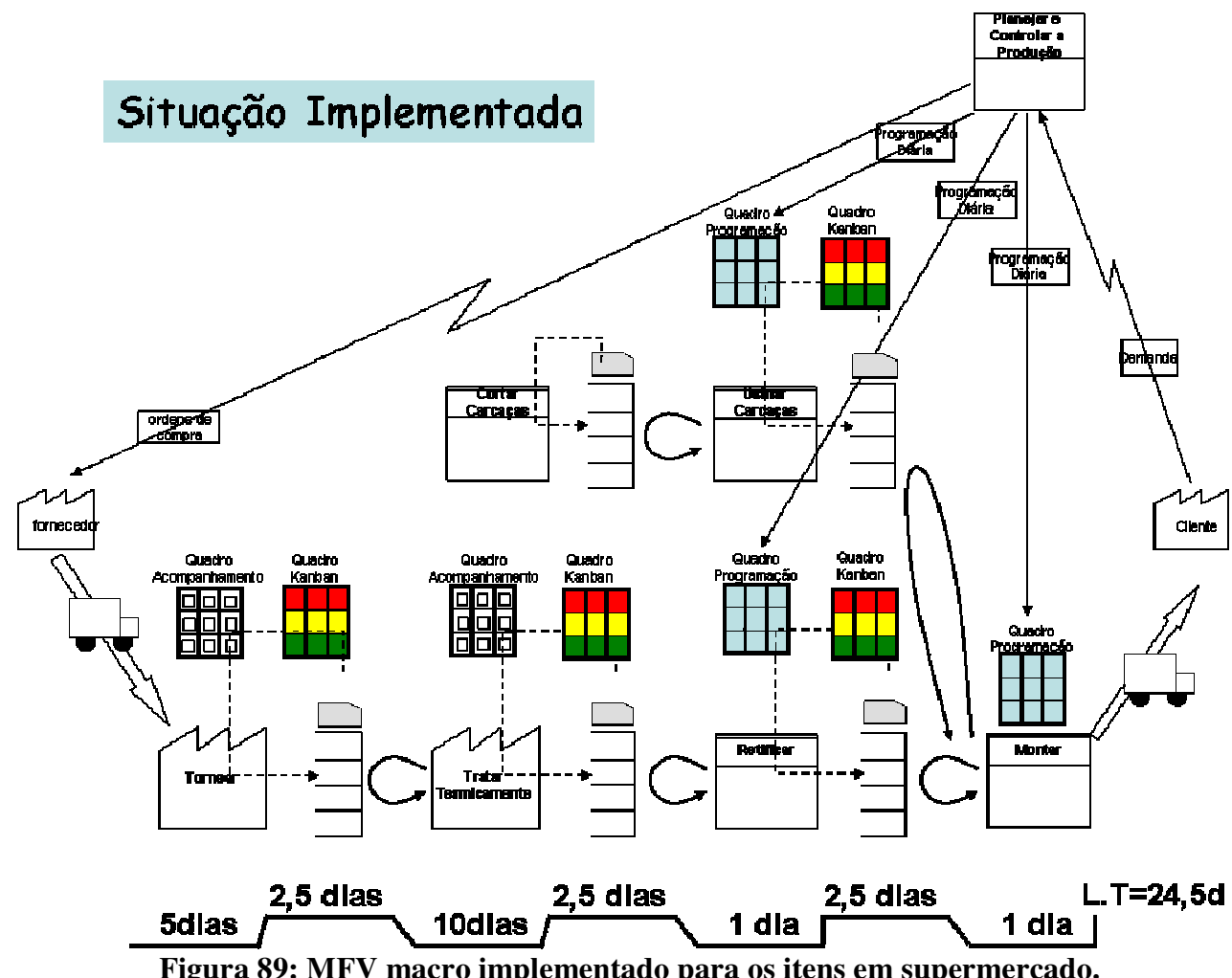

Note que o lead time do MFV baseou-se na linha de tempo do fluxo de engrenagens, visto que este era o caminho mais demorado dos dois.

Em seguida, foram definidos os procedimentos de programação e controle da produção.

\subsubsection{Definição das sistemáticas de programação e controle}

Foram definidos os procedimentos de programação e controle tanto para as subfamílias reguladas por fluxos empurrados quanto para aquelas reguladas por fluxos puxados.

\subsubsection{Programação e controle dos itens MTO}

Até então, todos os itens eram empurrados por ordens de produção via Sistema MRP. No caso do fluxo de engrenagens (caminho crítico), as ordens eram emitidas por Lotes Fixos, baseado na otimização do custo unitário de tratamento 
térmico externo dos itens. Normalmente, havia sobra em estoque, que era deduzida da necessidade bruta do pedido subseqüente. Do ponto de vista de um sistema de programação lean, essa sistemática de emissão de ordens era ruim, pois desconsiderava a lógica do cálculo do TPT do fluxo. Com isso, os pedidos acabavam sendo colocados em lotes de produção excessivamente grandes, normalmente mensais.

Com o cálculo do TPT para cada fluxo, as ordens de produção passaram a ser emitidas pela sistemática de Lote a Intervalo Fixo, baseado nos respectivos TPT. No caso do fluxo de engrenagens, muitas vezes foi possível inclusive aproveitar as fornadas geradas semanalmente para os itens do kanban. De acordo com essa sistemática, os lotes das ordens de produção eram agrupados em tamanhos proporcionais ao TPT calculado para o fluxo em questão.

O próximo passo foi definir a sistemática de programação e controle dos itens em kanban.

\subsubsection{Programação e controle dos fluxos puxados}

Primeiramente, os itens agrupados nas subfamílias que serão programadas e controladas pela lógica de puxar a produção (kanban, duas gavetas, sinal) foram marcados como fantasmas para que o MRP não gerasse ordens de produção para eles.

Para as peças controladas pelo sistema kanban, decidiu-se trabalhar com as duas políticas de reposição de estoque: reposição por ciclo de pedidos constante e reposição por quantidade constante:

Loops de engrenagens prontas, carcaças prontas e carcaças serradas: reposição por quantidade constante, ou seja, sempre que os cartões chegassem no amarelo uma quantidade fixa, que fora consumida, era solicitada para o loop anterior.

* Loops de engrenagens temperadas e torneadas: reposição por ciclo de pedidos constante. Utilizou-se a lógica do lote mínimo de fornecimento imposto pelo fornecedor. $\mathrm{O}$ fornecedor externo de peças tratadas termicamente cobrava por fornada, independentemente da 
quantidade de peças que iriam ao forno. Como o forno tinha capacidade de $500 \mathrm{~kg}$, era necessário agrupar um mix de peças que atingisse esse peso. Como o consumo diário dos itens em supermercado equivalia a um peso médio de $100 \mathrm{~kg}$ conclui-se ser possível trabalhar com um TPT de 5 dias (semanal). Mas, para que essa lógica funcionasse era necessário agrupar o disparo dos itens num mesmo dia, tendo em vista enviar para o fornecedor externo o peso aproximado de $500 \mathrm{~kg}$ de peças. Logo, todas as segundas-feiras (ciclo de reposição fixo), era disparada a reposição dos kanbans depositados no quadro, independentemente da cor em que se encontravam. Como o loop de engrenagens torneadas era fornecedor do loop de engrenagens tratadas, adotou-se a mesma política de reposição.

\subsubsection{Flexibilização dos fluxos puxados}

O primeiro passo para a flexibilização de um sistema de controle puxado foi determinar os intervalos para reavaliação e ajuste do tamanho dos supermercados. A periodicidade dos ajustes foi definida com base na sazonalidade da demanda da empresa. Levantou-se que trimestralmente seria necessário um ajuste no sistema. As janelas de tempo para ajuste foram:

\section{Jan-Mar; Abr-Jun; Jul-Set; Out-Dez}

Além disso, foi decidido que o modo de ajuste seria através da inserção ou retirada de kanbans, ao invés de alterar a quantidade de itens por kanban. Foi feita uma legenda com os períodos de ajuste do sistema puxado. 


\begin{tabular}{|c|c|c|c|c|c|}
\hline Janela & Loop & TPT & $\begin{array}{l}\text { Lead Time } \\
\text { Reposição }\end{array}$ & $\begin{array}{l}\text { Aumento da Demanda: } \\
\text { Inserir Kanbans (VERDE } \\
+ \text { AMARELO) }\end{array}$ & $\begin{array}{l}\text { Redução da Demanda: } \\
\text { Retirar Kanbans } \\
\text { (AMARELO) }\end{array}$ \\
\hline \multirow{3}{*}{ Jan-Mar } & Engrenagens Prontas & 5 dias & 1 dia & 24/dez & 30/dez \\
\hline & Engrenagens Tratadas & 5 dias & 10 dias & 10/dez & 20/dez \\
\hline & Engrenagens Torneadas & 5 dias & 5 dias & 1/dez & 15/dez \\
\hline \multirow{3}{*}{ Abr-Jun } & Engrenagens Prontas & 5 dias & 1 dia & 24/mar & 30/mar \\
\hline & Engrenagens Tratadas & 5 dias & 10 dias & 10/mar & $20 /$ mar \\
\hline & Engrenagens Torneadas & 5 dias & 5 dias & $1 /$ mar & 15/mar \\
\hline \multirow{3}{*}{ Jul-Set } & Engrenagens Prontas & 5 dias & 1 dia & 24/jun & 30/jun \\
\hline & Engrenagens Tratadas & 5 dias & 10 dias & 10/jun & 20/jun \\
\hline & Engrenagens Torneadas & 5 dias & 5 dias & $1 /$ jun & $15 /$ jun \\
\hline \multirow{3}{*}{ Out-Dez } & Engrenagens Prontas & 5 dias & 1 dia & $24 /$ set & $30 /$ set \\
\hline & Engrenagens Tratadas & 5 dias & 10 dias & $10 /$ set & $20 /$ set \\
\hline & Engrenagens Torneadas & 5 dias & 5 dias & $1 /$ set & $15 /$ set \\
\hline
\end{tabular}

Quadro 56: Flexibilização do tamanho do supermercado por janelas de tempo.

Para definição do momento do ajuste foram considerados a defasagem de tempo entre cada loop e se a situação se tratava de aumento ou redução da demanda da peça.

Em situações de aumento da demanda, o momento para a inserção de cartões considerou o tempo de ciclo (TPT) mais o tempo de reposição, que é o cenário mais pessimista com relação ao tempo que o ajuste demoraria para refletir na quantidade de peças disponível para o próximo loop (consumidor).

Em situações de redução da demanda, o momento para retirada de cartões considerou apenas o tempo de reposição. O tempo de ciclo (TPT) não foi contemplado na defasagem do tempo, tendo em vista evitar que a redução refletisse antes da hora na quantidade de peças disponível para o loop consumidor.

O próximo passo consistiu em tornar o sistema mais robusto para desnivelamentos pontuais na demanda dentro de uma janela de tempo. Em determinados momentos, o consumo dos itens excedeu o limite máximo do supermercado. Com isso foi necessário criar uma sistemática para ajuste fino do sistema puxado dentro de uma mesma janela.

Primeiramente, diagnosticou-se que algumas ocorrências e práticas internas resultavam no consumo desnivelado dos itens em supermercados. A primeira delas eram os atrasos na montagem de um ou mais produtos pai devido à falta de itens filhos, fossem eles comprados ou manufaturados. Quando os itens em atraso chegavam, a produção necessitava tirar este atraso e, ao mesmo tempo, cumprir a programação do período para o(s) produto(s) em questão. Este fato 
causava picos momentâneos no consumo dos respectivos itens filhos em supermercado.

O fato acima também resultava em outro efeito colateral. Quando ocorria um atraso, a produção precisava encaixar outro produto para ser feito no lugar daquele que estava em atraso ("vamos ver o que dá para fazer então"). Com isso, ocorria uma superprodução de um determinado produto cujos itens estavam todos disponíveis em supermercado. A superprodução deste outro produto também resultava em pico de consumo dos respectivos itens filhos.

Assim como na aplicação anterior, quando a programação dos produtos pais no processo puxador era feita, o PCP não conseguia enxergar o impacto no consumo dos respectivos itens filhos em supermercado, visto que estes itens eram compartilhados por diferentes produtos pais.

$\mathrm{Na}$ aplicação anterior, implantou-se uma sistemática de programação nivelada dos pedidos no processo puxador, que era a embalagem e expedição. Já nessse caso, para evitar as constantes reprogramações da montagem (puxador) concluiu-se que uma das soluções para combater as causas raízes desses problemas era combater as faltas de componentes comprados ou manufaturados. Entretanto, essa solução não seria obtida no curto prazo, visto que era necessário realizar todo um levantamento e análise dos itens que mais faltavam, negociar com alguns fornecedores e desenvolver outros novos.

Baseado nisso, implantou-se no curto prazo uma sistemática de se empenhar (separar) os itens antecipadamente sempre que fosse haver o consumo de itens do kanban em quantidade acima do tamanho do supermercado (veja como funciona a sistemática de empenho na seção 3.5.2). Para isso, foi criada uma planilha com a estrutura de cardinalidade entre itens pais e filhos de modo a tornar possível visualizar o consumo, e possíveis ocorrências de picos, dos itens filhos a partir da programação dos itens pais no processo puxador. 


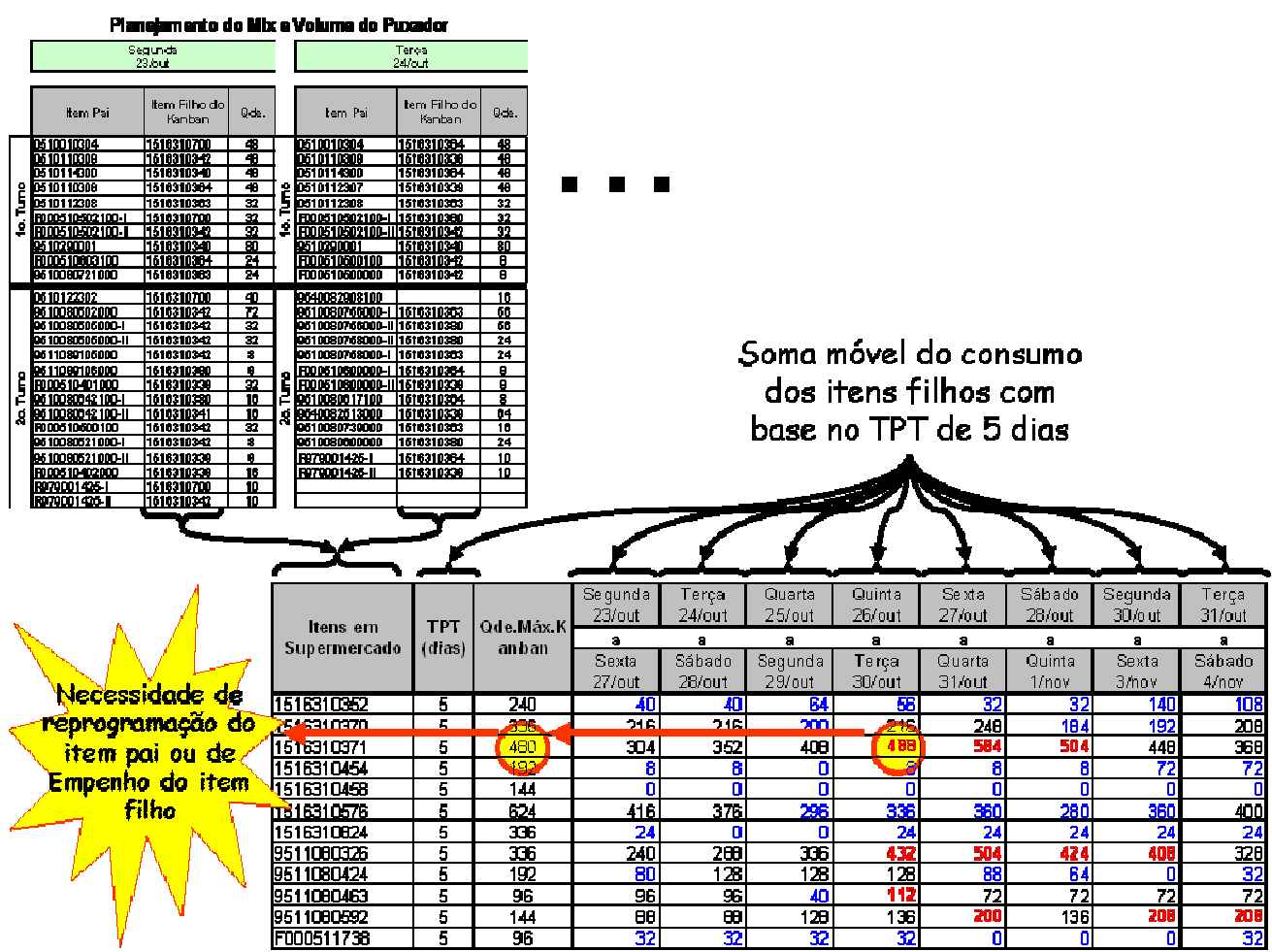

Figura 90: Planilha para visualização de picos no consumo dos itens do supermercado.

Vale ressaltar que o empenho foi tratado como última alternativa, ou seja, primeiramente tentava-se remanejar o produto acabado no processo puxador para um outro período que não causasse pico no consumo dos itens do kanban.

\subsubsection{Programação e nivelamento do processo puxador}

Este passo consistiu em programar o processo puxador dentro do ritmo da demanda do cliente externo, ou seja, do takt time. Para isso, foi projetado um heijunka box. A tabela abaixo, ilustra a linha de raciocínio utilizada para o cálculo do takt time operacional, ponto de partida para projeto de um heijunka box. 


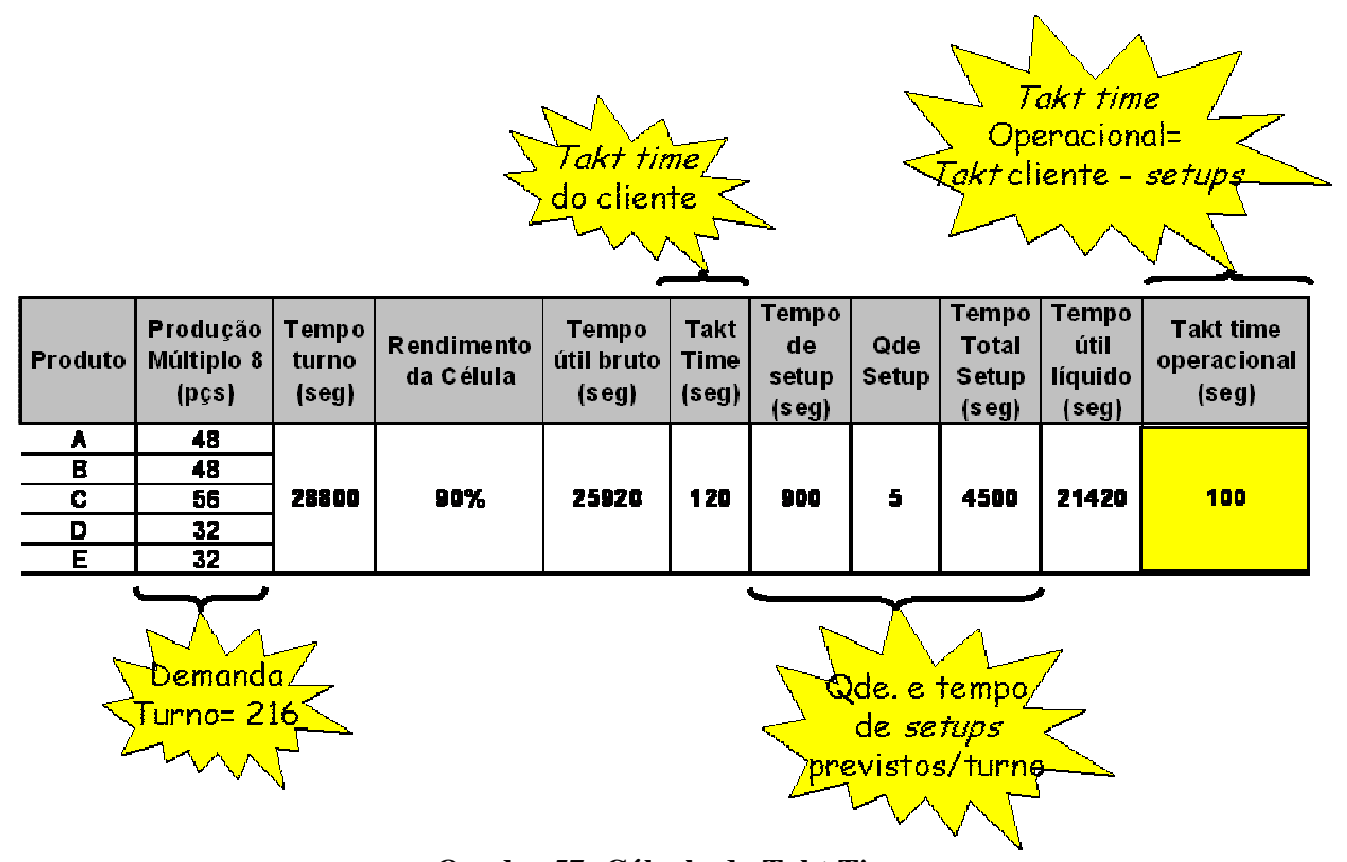

Quadro 57: Cálculo do Takt Time.

Foi levantado que a célula de montagem precisaria realizar uma média de 5 setups por turno, ou seja, até 5 tipos de itens diferentes. Logo em seguida, como não havia tamanho de embalagem padronizado, estabeleceu-se que a célula seria programada e controlada por pitchs de 15 minutos (800 segundos) cada. Como o takt time operacional era de 100 segundos, em cada pitch deveriam ser programados e montados em média 8 produtos.

Além disso, foi necessário nivelar e balancear o mix de produtos a serem montados. Isto porque havia uma alta variedade de itens (aproximadamente 400) com diferentes tempos de ciclo a serem montados no processo puxador. Como não seria possível cronoanalisar todos os produtos passíveis de serem montados naquela célula decidiu-se simplificar o escopo do trabalho agrupando esses produtos em quatro famílias de montagem. Os critérios para inserção dos itens em cada família foram basicamente a similaridade de tempo e algumas características de montagem. Logo, ao invés de se tratar 400 itens diferentes, passou-se a falar em apenas quatro famílias diferentes.

A princípio, estimou-se um intervalo de tempo para cada família. Após a classificação de todos os produtos nestas famílias, definiu-se quais os mais representativos de cada uma, tendo em vista realizar a respectiva cronoanálise. Com 
isso, foi feita uma análise dos elementos de trabalho do processo de montagem para as quatro famílias.

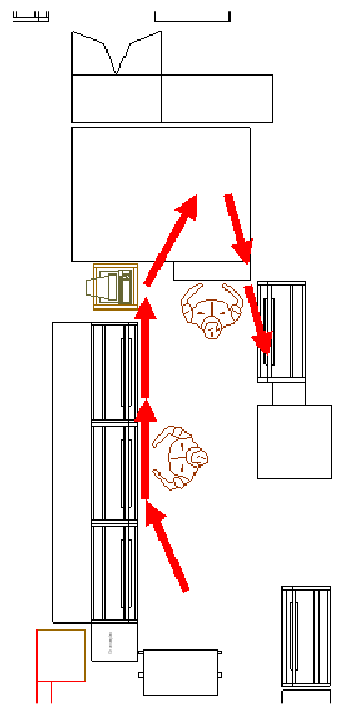

\begin{tabular}{|c|c|c|c|c|c|}
\hline & tpinder & \multirow{2}{*}{$\begin{array}{l}\text { Mliqulna } \\
\text { Tempo } \\
\text { de Glelo }\end{array}$} & \multirow[b]{2}{*}{$\begin{array}{c}\text { Tompo } \\
\text { pre } 1 \\
\text { pece }\end{array}$} & \multirow[b]{2}{*}{$\begin{array}{l}\text { Tempo } \\
\text { Hemen }\end{array}$} & \\
\hline $\mathbf{n t w}$ & Elements deTrabdho & & & & \\
\hline 1 & Alcançar carcaça a colocar na gravadora & & 5 & 5 & 5 \\
\hline 2 & Gravar carcaça & 27 & 27 & & 5 \\
\hline 3 & Alcençar carcaça e colocar no suporte & & 3 & 3 & 日 \\
\hline 4 & Colocar pino glia nos mancais e colocá-los no supota & & 6 & 6 & 14 \\
\hline 5 & Alcançar mancais a colocar no suporte & & 4 & $\overline{4}$ & 10 \\
\hline 9 & Encaixar conjunto na caracaça & & 17 & 17 & 35 \\
\hline 10 & Colocar pinos na carcacta & & 6 & 8 & 41 \\
\hline 11 & Colacar vedaçốs & & 16 & 16 & 57 \\
\hline 4 & Enaixar flange na Bamba & & 16 & 16 & 73 \\
\hline 8 & Colacar vedaçấo e pino guia na Bom ba & & 19 & 19 & 92 \\
\hline 7 & Encaixar tampa na Bom ba & & 4 & 4 & 96 \\
\hline 12 & Colocar parafusos a ATuela & & 6 & (3) & 102 \\
\hline 13 & Apertar parafusos (4 parrefusos em negrito) & & 33 & 33 & 135 \\
\hline 17 & Girar eixa & & 3 & 3 & 130 \\
\hline 4 & Levar bomba até a máquina de testes & & 日 & 日 & 146 \\
\hline 5 & 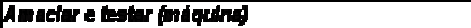 & 89 & $\overline{\theta 9}$ & & 146 \\
\hline 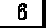 & Retirar bom ba do tasta a dispor na bancada & & 7 & 7 & 153 \\
\hline 13 & Colocar capas plásticas ne conexoes (simpless) & & 4.4 & dd & 197 \\
\hline
\end{tabular}

Figura 91: Criação de fluxo e cronoanálise dos elementos de trabalho da família 1.

O tempo do item mais representativo da família foi então adotado como sendo o tempo de ciclo padrão para todos os itens pertencentes àquela família. A mesma análise foi feita para as demais famílias.

Como havia 4 famílias com tempos de ciclo padrão distintos, a comparação com o takt time operacional da célula foi feita a partir de um tempo de ciclo ponderado pela demanda média de cada família, conforme esquematizado na tabela abaixo. 


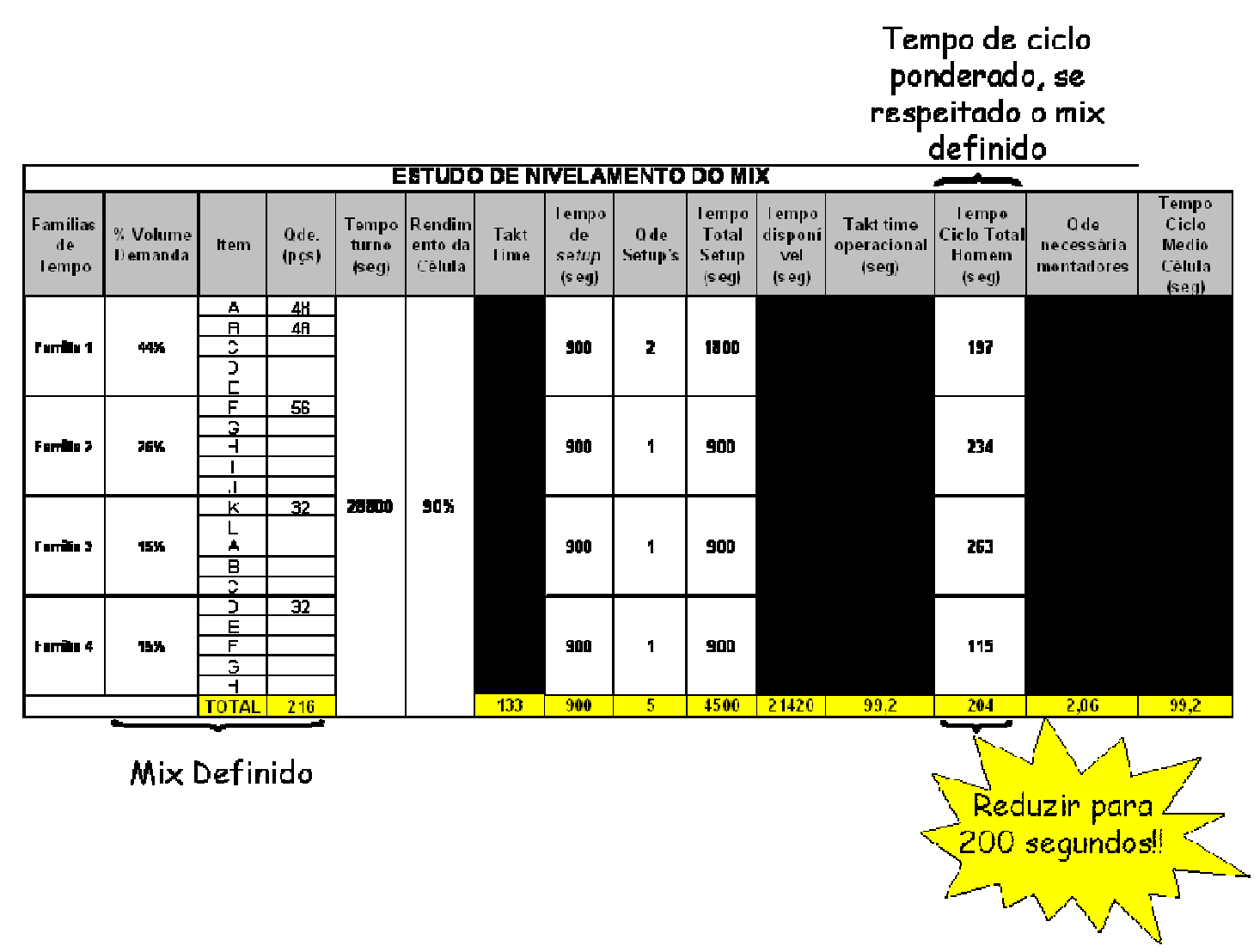

Quadro 58: Comparação do tempo de ciclo com o takt time operacional.

Note que o tempo de ciclo ponderado de um homem era de 204 segundos. Nesta ocasião foram realizadas algumas melhorias na célula, tendo em vista criar fluxo contínuo e, ao mesmo tempo, sincronizar o tempo de ciclo ponderado da célula de montagem com o takt time operacional. Logo, para as quatro famílias em questão seriam necessários apenas dois montadores fixos a fim de se obter um tempo de ciclo ponderado para a célula de aproximadamente 100 segundos, ou seja, igual ao takt time operacional.

O próximo passo foi o projeto do heijunka box, tendo em vista a programação, controle e nivelamento do processo puxador. Conforme dito anteriormente, como o takt time operacional era de 100 segundos, a cada pitch de 15 minutos (800 segundos) deveriam ser programados e montados em média 8 produtos. Contudo, cada família possuía um tempo de ciclo padrão diferente. Ao final de cada turno, os 216 itens deveriam ser produzidos a uma média de 8 a cada 15 minutos, mas na prática os itens de cada família seriam montados da seguinte forma: 
\& Família 1 (T/C=99 seg. com 2 montadores): 8 peças a cada pitch de 15 minutos.

Família $2(\mathrm{~T} / \mathrm{C}=117 \mathrm{seg}$. com 2 montadores): 7 peças a cada pitch de 15 minutos.

* Família 3 (T/C=132seg. com 2 montadores): 6 peças a cada pitch de 15 minutos.

* Família $4(\mathrm{~T} / \mathrm{C}=57 \mathrm{seg}$. com 2 montadores): 14 peças a cada pitch de 15 minutos.

Foi projetado e implantado um quadro de programação cuja idéia era os montadores poderem controlar se o processo puxador estava montando a quantidade definida para cada família a cada pitch de 15 minutos. Para isso, foram criados cartões de ordem de produção, conforme ilustrado na figura abaixo.
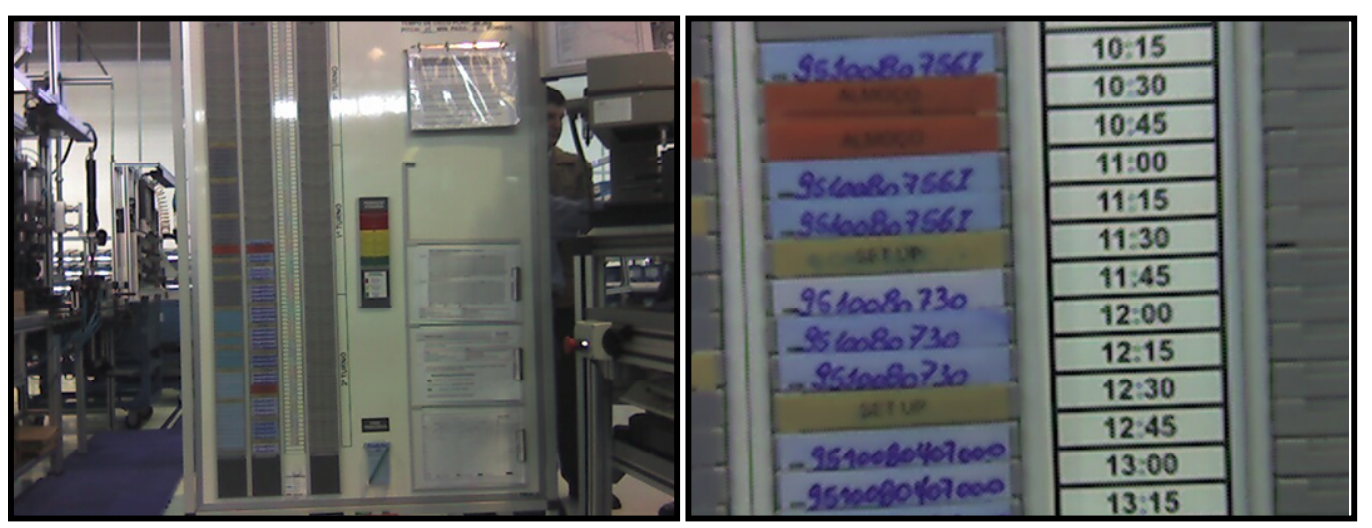

Figura 92: Quando de programação, controle e nivelamento do processo puxador (Heijunka Box).

A idéia dos cartões foi bem recebida, pois caso a empresa desejasse implantar futuramente um supermercado para alguns produtos acabados seria possível programar os próprios kanbans no quadro em questão.

Vale ressaltar que para o atendimento da meta de 216 peças por turno seria necessário respeitar o mix definido para cada família. A definição deste mix foi feita com base na demanda média prevista para cada família. Nesta aplicação decidiu-se trabalhar com o número de montadores fixo, desde que respeitado o mix definido. Contudo, se a empresa estivesse com dificuldade de programar o mix definido todo turno, estabeleceu-se que uma forma alternativa de se trabalhar seria: 
* Trabalhar exclusivamente com as famílias 2 e 3 durante 2,5 dias da semana (50\% do tempo disponível na semana), visto que eles representavam cerca de $50 \%$ do tempo de processamento total. Isso significaria que a meta de 216 peças/turno seria atendida em média ao final da semana, e não mais ao final de cada turno.

\& Colocar um terceiro montador nas programações em que prevalecesse os itens das famílias 2 e 3, cujos tempos de ciclo estavam acima de 200 segundos.

Em seguida, iniciou-se os trabalhos de preparação da implantação.

\subsubsection{Preparação e acompanhamento da implantação}

Nesta etapa foi definido como seria a transição do sistema de produção anterior para o sistema proposto, incluindo-se aí a sequiência de implementação, a velocidade com que as mudanças seriam executadas e um cronograma de implementação.

Foi utilizada a técnica de evento kaizen. Foram necessários dois eventos kaizen para a implantação de todas as melhorias abordadas até aqui dentro das etapas do método. Antes dos eventos, várias atividades de concepção e preparação de infra-estrutura foram realizadas, tendo em vista deixar tudo pronto para uma implantação efetiva da situação futura na semana de cada evento. Chamouse esta etapa de pré-evento kaizen.

De acordo com a técnica, os trabalhos iniciaram com um treinamento da equipe sobre o projeto de situação futura que seria implantado. Em seguida, foi elaborado o cronograma de atividades da semana. 


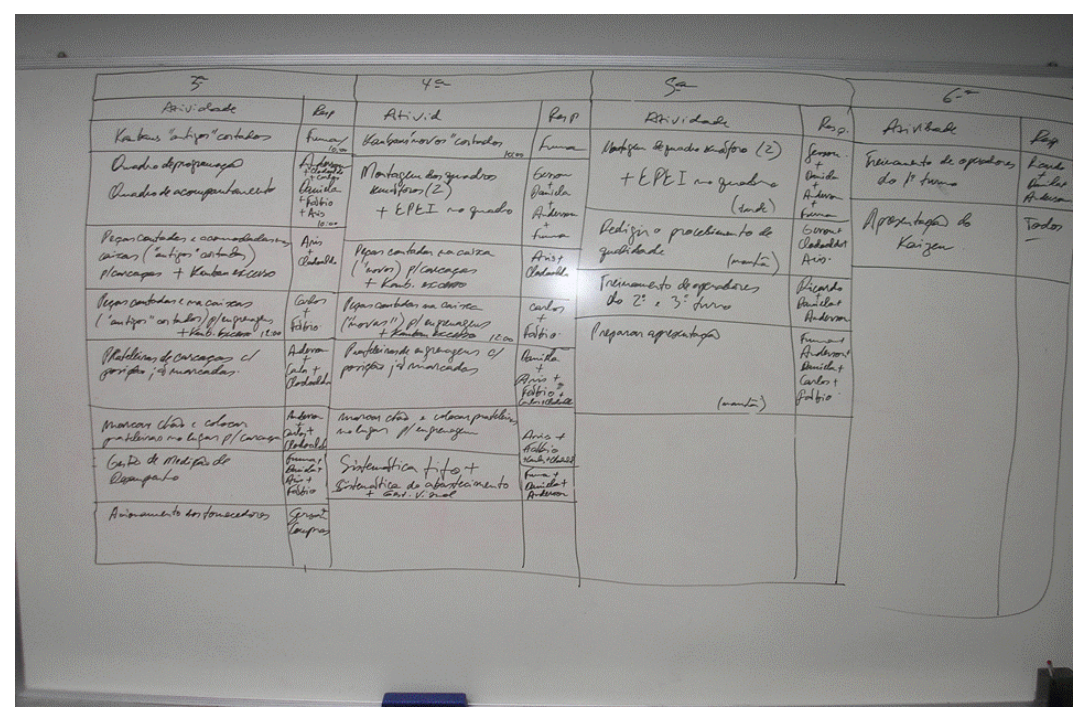

Figura 93: Programação as atividades da semana do evento kaizen

A equipe iniciou então as atividades de implantação.

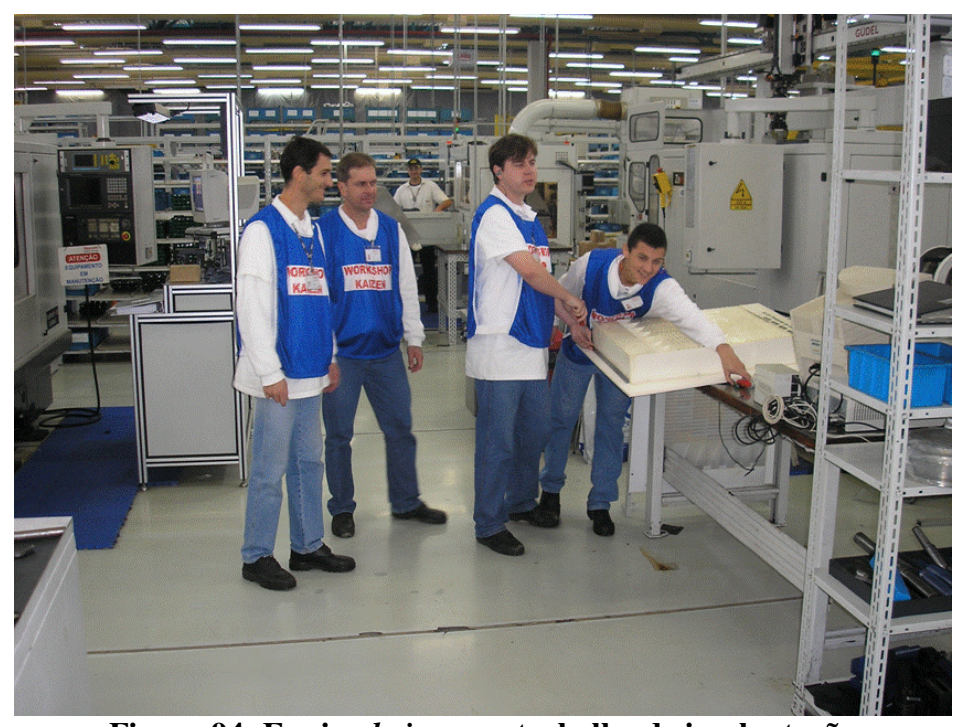

Figura 94: Equipe kaizen em trabalho de implantação

Uma atividade que sempre ocorre num evento de implantação de sistemas puxados é a formação do supermercado. Normalmente sobra um excesso de estoque com relação ao dimensionado para os supermercados. Esta sobra deve ser separada, identificada e consumida antes do consumo dos itens do supermercado. 


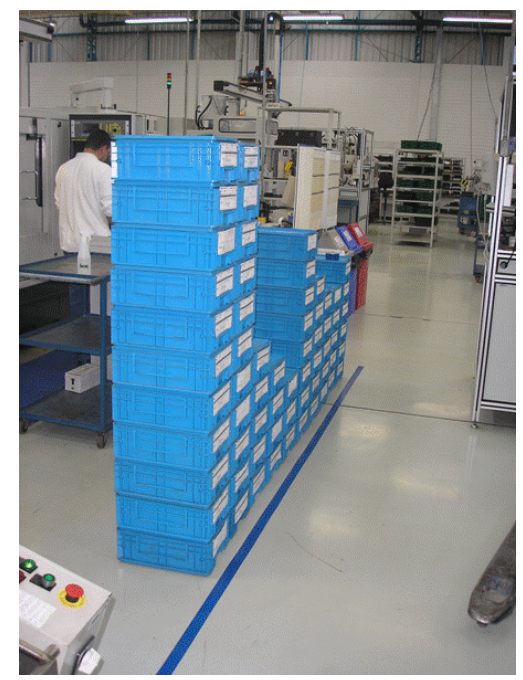

Figura 95: Separação de excessos durante a formação dos supermercados

Os quadros de kanbans com a sobreposição dos cartões possibilitou a utilização de vários itens sem que o quadro ficasse muito grande.

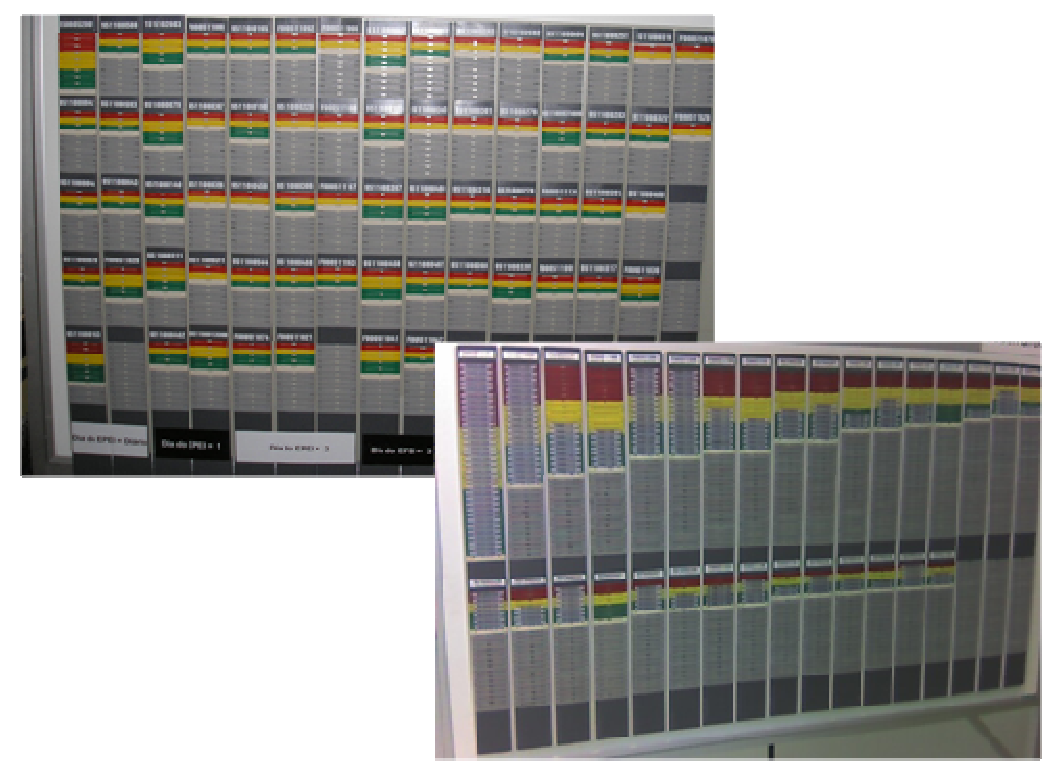

Figura 96: Quadros de kanban

Foi implantado o heijunka box com cartões ordem de produção, substituindo a programação com pincel atômico, em que havia a necessidade de escrever e apagar diariamente. 


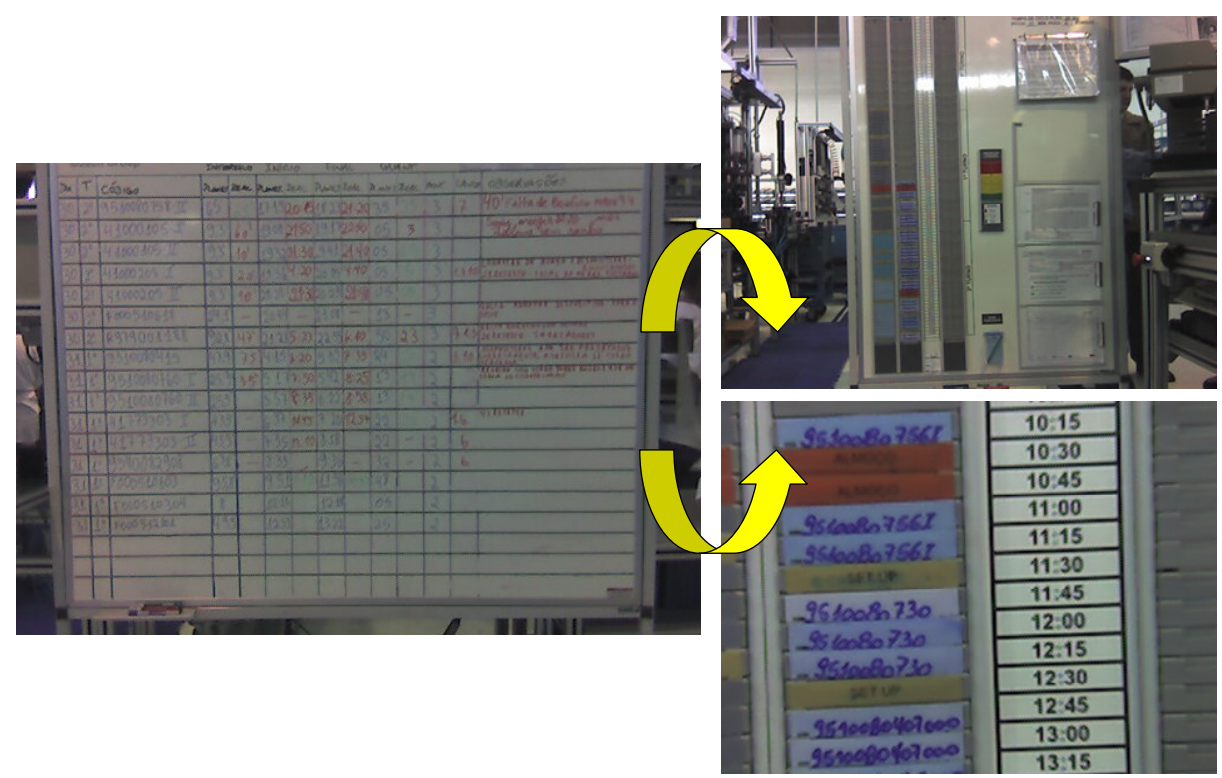

Figura 97: Heijunka Box com cartões ordem de produção

Foi criado também um plano de controle, tendo em vista acompanhar o desempenho diário e acumulado da produção ao longo do mês, apontamentos de desvios no cumprimento das metas e disparo de planos de ação corretiva em reuniões que passaram a ser realizadas diariamente no chão de fábrica. 


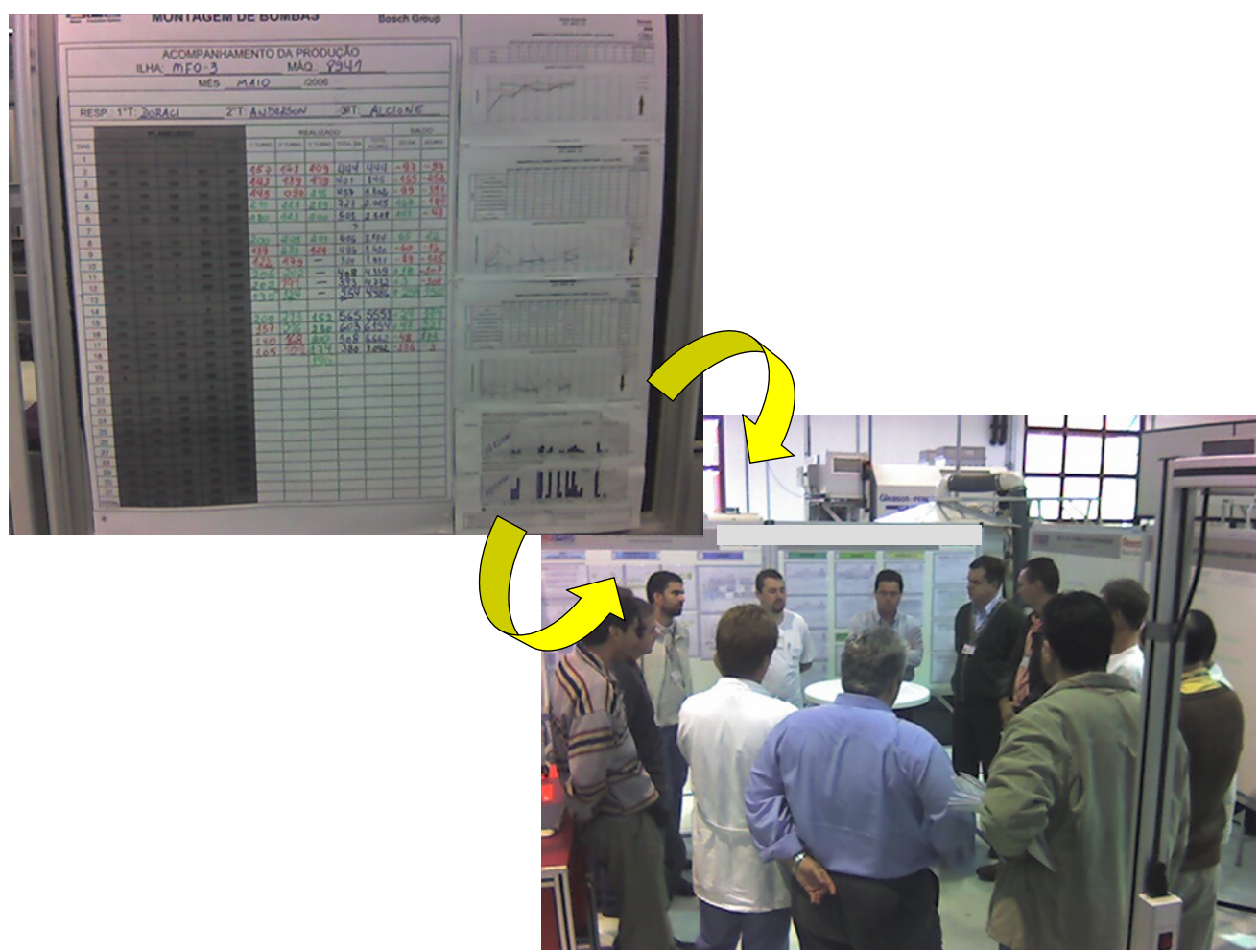

Figura 98: Plano de controle para sustentabilidade das melhorias

Ao final do evento, foi realizada uma apresentação para a diretoria da empresa. Nesta apresentação, além do reconhecimento perante os patrocinadores os integrantes da equipe assumem o compromisso de manter e replicar as melhorias em seus postos de trabalho. Com isso, ao final do evento, fecha-se um ciclo virtuoso imprescindível para a sustentabilidade no longo prazo das melhorias implementadas.

\subsubsection{Resultados obtidos}

Como resultados da aplicação foram identificadas as seguintes melhorias:

Lead Time: Redução de $33 \%$, passando de 36,5 dias para 24,5 dias, no caso dos itens classe A.

* Produtividade: Ganho de 63\%. A produção máxima antes da implementação era de 66 itens/homem/turno, e após a implementação houve um aumento para 108 itens/homem/turno. 
Ganho Financeiro: Foi criada uma métrica para mensurar o ganho financeiro real com o aumento do volume de produção obtido e faturado. A expressão de cálculo proposta foi:

○ $\mathrm{GANHO}=\Delta \mathrm{P} \times($ FATunid - CUSTOvar/unid. $)$

Onde:

○ $\Delta \mathrm{P}=$ Variação do volume de produção faturado $=+80$ itens/dia $(2$ turnos)

○ $\quad$ FATunid $=$ Faturamento unitário $=\mathrm{R} \$ 200,00$

- CUSTOvar/unid = Custo variável por unidade vendida $=$ $\mathrm{R} \$ 100,00$

○ $\mathrm{GANHO}=\mathrm{R} \$ 2.080 .000,00 /$ ano.

Estoques: Redução do estoque médio de engrenagens de R $\$ 262.711,00$ para $\mathrm{R} \$ 87.800,00$. Redução do estoque médio de carcaças de $\mathrm{R} \$ 85.800,00$ para $\mathrm{R} \$ 32.400,00$. Estima-se que com a liberação desses valores para o fluxo de caixa da empresa houve um ganho de oportunidade em potencial de $16 \%$ ao ano sobre o valor total reduzido. Esse ganho seria de aproximadamente $\mathrm{R} \$ 438.357,00 /$ ano.

Área de montagem: redução de $315 \mathrm{~m} 2$ para $286 \mathrm{~m} 2$ e do espaço percorrido pela peça de $13 \mathrm{~m}$ para $9 \mathrm{~m}$.

\subsubsection{Considerações sobre a $2^{\mathrm{a}}$. aplicação}

\section{Com relação aos resultados obtidos pela empresa}

Com a aplicação do Sistema de Produção Enxuta foi observada a contenção de superprodução, de estoques desnecessários, de transporte excessivo, entre outros desperdícios. Esses resultados estão relacionados à melhoria e adaptação do sistema de programação e controle utilizado. Além disso, o nivelamento do processo puxador possibilitou á empresa estabilizar a reposição dos itens em supermermercado, evitar o abandono devido à perda de credibilidade do sistema 
puxado, reprogramações de última hora e, sobretudo, menos estoques em processo e uma maior rapidez de entrega para o cliente final.

\section{Com relação ao método proposto}

A aplicação contribuiu com o método proposto, seja na criação de novos passos ou no aprofundamento daqueles inicialmente concebidos, nos seguintes pontos:

Nivelamento do processo puxador: Assim como na $1^{\mathrm{a}}$. aplicação, foi desenvolvida uma ferramenta com a estrutura de cardinalidade entre itens pais e filhos de modo a tornar possível visualizar o consumo, e possíveis ocorrências de picos, dos itens filhos a partir da programação dos itens pais no processo puxador. Esta estratégia mostrou-se bastante eficiente ao possibilitar que o sistema se antecipe aos picos de consumo dos itens do supermercado. A idéia é reprogramar algumas ordens e, consequentemente, nivelar o puxador ou, quando isto não for possível, disparar o empenho dos itens cujo nível máximo do supermercado será extrapolado.

Flexibilizacão do sistema puxado e a sistemática de empenho: A utilização da sistemática de empenho como estratégia de flexibilização do sistema puxado evita faltas no processo puxador e sobrecarga nos fornecedores a medida que todos os cartões (no verde, amarelo e vermelho) voltam para o quadro simultaneamente.

* Projeto do sistema híbrido e controle para itens de baixo volume: No projeto do sistema híbrido de PCP os itens de baixo volume não foram inseridos no supermercado, consequentemente as "sobras" do lote produzido eram estocadas. Erros humanos na entrada de dados no sistema, a armazenagem de um mesmo item em diferentes pontos do almoxarifado e a falta de espaço físico tornou o controle físico dessas "sobras" em um processo extremamente artesanal e demorado. Nos 
momentos de correria o PCP acabava por disparar novos lotes, pois não tinha tempo para fazer a localização e contagem física do saldo desses itens. Com isso, a equipe passou a reavaliar a proposição do tipo de controle para os itens de baixo volume. Para aqueles itens cuja geração de estoque de "sobras" de Ordens de Produção for praticamente inevitável, vale a pena considerar a possibilidade de formalizar e otimizar o seu controle com a lógica de puxar. Aparentemente o custo, mesmo que intangível, para a manutenção dos mesmos tende a ser menor.

Programação do processo puxador e a criação de famílias de tempo: a utilização da lógica de agrupamento dos itens em famílias de tempo. Como havia uma alta variedade de itens (aproximadamente 400) com diferentes tempos de ciclo a serem montados no processo puxador, agrupou-se esses produtos em quatro famílias de montagem. Logo, ao invés de se tratar 400 itens diferentes, passou-se a falar em apenas quatro famílias diferentes. Essa ação foi muito importante para simplificar o escopo de levantamento e análise de dados bem como para o balanceamento da linha e nivelamento do mix e do volume utilizando o Heijunka Box. Em ambientes de alta variedade e que requerem ações de melhoria rápidas muitas vezes é melhor começar sendo imprecisamente correto do que acabar sendo lento e precisamente incorreto.

\section{$\underline{O}$ processo de implantacão e a técnica de Evento Kaizen:} contribuiu muito para aumentar a rapidez e efetividade da implementação. A criação e o envolvimento de uma equipe multifuncional e de diferentes níveis hierárquicos foi vital para o sucesso e a sustentabilidade no longo prazo das melhorias implementadas. 
Uma nova rodada da metodologia de pesquisa foi iniciada a partir de uma nova aplicação. Agora em uma empresa que possuia a maior variedade de produtos e componentes dentre todas as aplicações realizadas. 


\section{3. $\quad 3^{\mathrm{a}}$. Aplicação}

A empresa objeto deste estudo é uma empresa localizada em Botucatu - SP, fundada em outubro 1993. Conta atualmente com 280 funcionários e fabrica peças para veículos automotores, máquinas e equipamentos agrícolas e os mais diversos segmentos que tenham a necessidade da transformação de metais em seus produtos.

Seus principais processos produtivos são corte a laser, dobra, estamparia, solda, pintura a pó e montagem de conjuntos. Possui uma ampla gama de produtos acabados (aproximadamente 1200 itens) e uma variedade maior ainda de componentes intermediários.

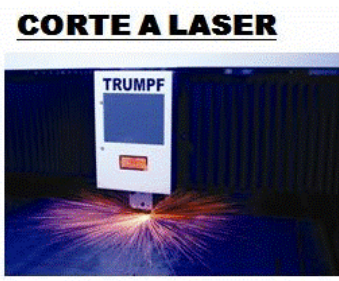

SOLDA

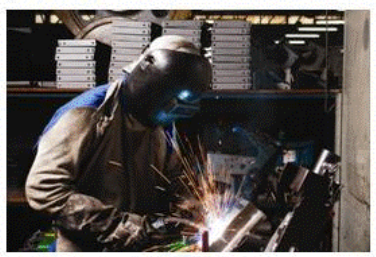

DOBRA

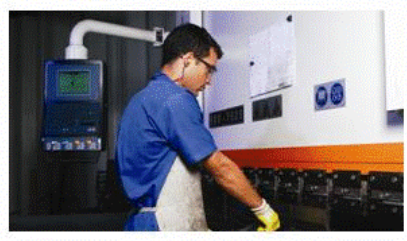

PINTURAÀ Pó

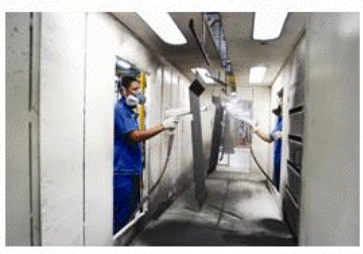

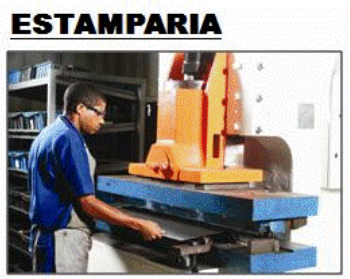

MONTAGEM DE CONJUNTOS

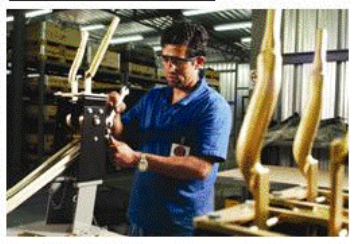

Figura 99: Principais processos produtivos da $3^{\text {a }}$. aplicação

Como diagnóstico inicial da empresa levantou-se os seguintes efeitos indesejáveis:

4 Sistema de programação e controle genérico para todos os produtos e itens, considerando política de lote "econômico".

* A programação da produção era empurrada com base em previsão mensal e apresentava falta de sincronismo entre previsto $x$ realizado $x$ pedidos efetivados.

* Excesso de estoque em processo, dificultando a localização das peças. 
$\$$ Gestão visual ausente

* A programação no chão de fábrica encontrava-se fragmentada em diferentes setores produtivos. Estes setores funcionavam como ilhas desconectadas de PCP cuja sincronização dependia excessivamente da mediação e negociação entre os líderes de cada setor.

\& Fenômeno de falta e sobra de componentes, principalmente para as operações de solda e montagem, o que resultava numa baixa produtividade destes setores.

* Uso freqüente de horas-extras

\& Atrasos nas entregas das peças para os clientes externos.

Com relação ao cenário externo, havia ainda uma previsão positiva de aumento em $40 \%$ na demanda dos itens existentes, a qual realmente se concretizou. Contudo, as lideranças da empresa temiam não conseguir cumprir com os compromissos assumidos caso houvesse a consolidação dessa previsão no cenário supracitado.

Os passos para a solução desses problemas iniciaram-se pelos desenhos do Mapa de Fluxo de Valor da Situação Atual. Para os fins deste trabalho, a figura abaixo mostra de forma macro tal mapeamento. 


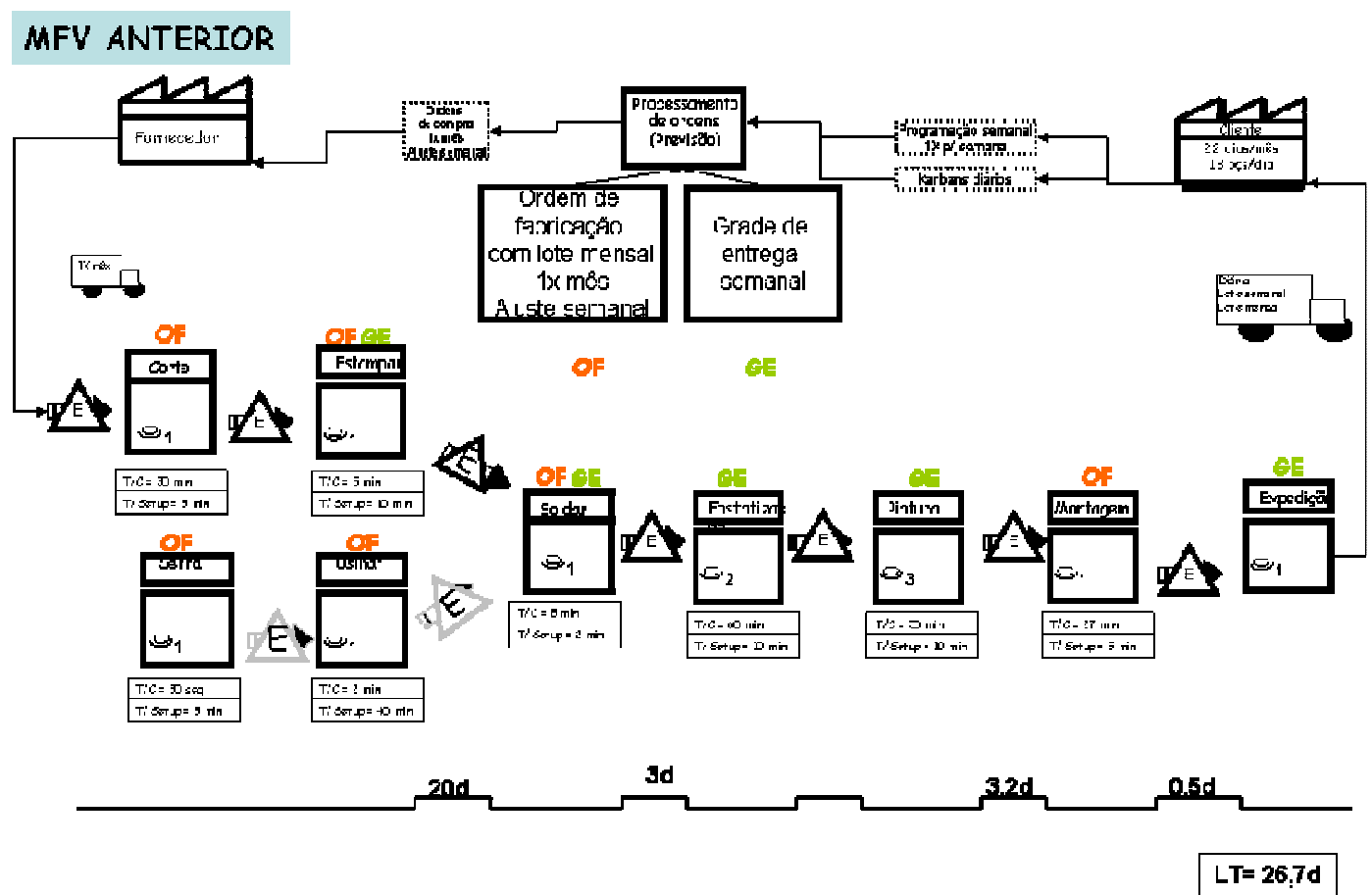

Figura 100: Visão esquemática do Mapa Macro de Fluxo de Valor Situação Atual

A partir do Mapa, foi possível aprofundar a análise sobre os efeitos indesejáveis apontados na fase inicial do projeto:

* Falta e sobra de componentes para a solda e montagem: como o processo de solda representa o agrupamento de vários componentes. A falta de sincronização na chegada destes componentes ao processo era muito grande. Com isso, o líder de área limitava-se a colocar na linha "aquilo que fosse possível de soldar ou montar no dia", de acordo com a disponibilidade dos respectivos componentes.

* Baixa produtividade: Como não havia previsibilidade alguma quanto à inserção dos produtos na solda ou montagem, o processo não conseguia seguir padrão algum. Consequentemente, ele era constantemente acometido por sobrecargas (tirar atrasos) ou por ociosidades (falta de peças). Isso resultava na necessidade de horas extras, frustrações e desentendimentos internos.

+ Alto estoque de componentes em processo: À medida que um setor se descompassava dos demais devido a contingências internas (erros de 
programação, quebra de máquina, falta de desenhos, falta de matéria prima, etc.), começavam as reprogramações em cima da hora. Lotes em processo eram interrompidos e novos lotes de produção eram disparados. Com isso, recursos eram usados antes da hora, os estoques em processo eram altos e os itens (re)programados de última hora estavam sempre atrasados.

Alto Lead Time de produção: a grande variedade de componentes e o alto nível de estoques em processo resultavam num alto lead time de produção.

+ Baixa pontualidade: Em função dos problemas supracitados, constantemente os prazos de entrega não eram atendidos.

Foi feito o desenho da situação futura, a partir dos qual se iniciou o desenvolvimento do sistema híbrido de programação e controle.

\subsubsection{Projeto macro do sistema híbrido de planejamento e programação}

O primeiro passo consistiu em quebrar estrategicamente o longo fluxo de valor em partes menores e mais fáceis de serem administradas. Para isso, foram definidos quatro pontos de supermercado: 


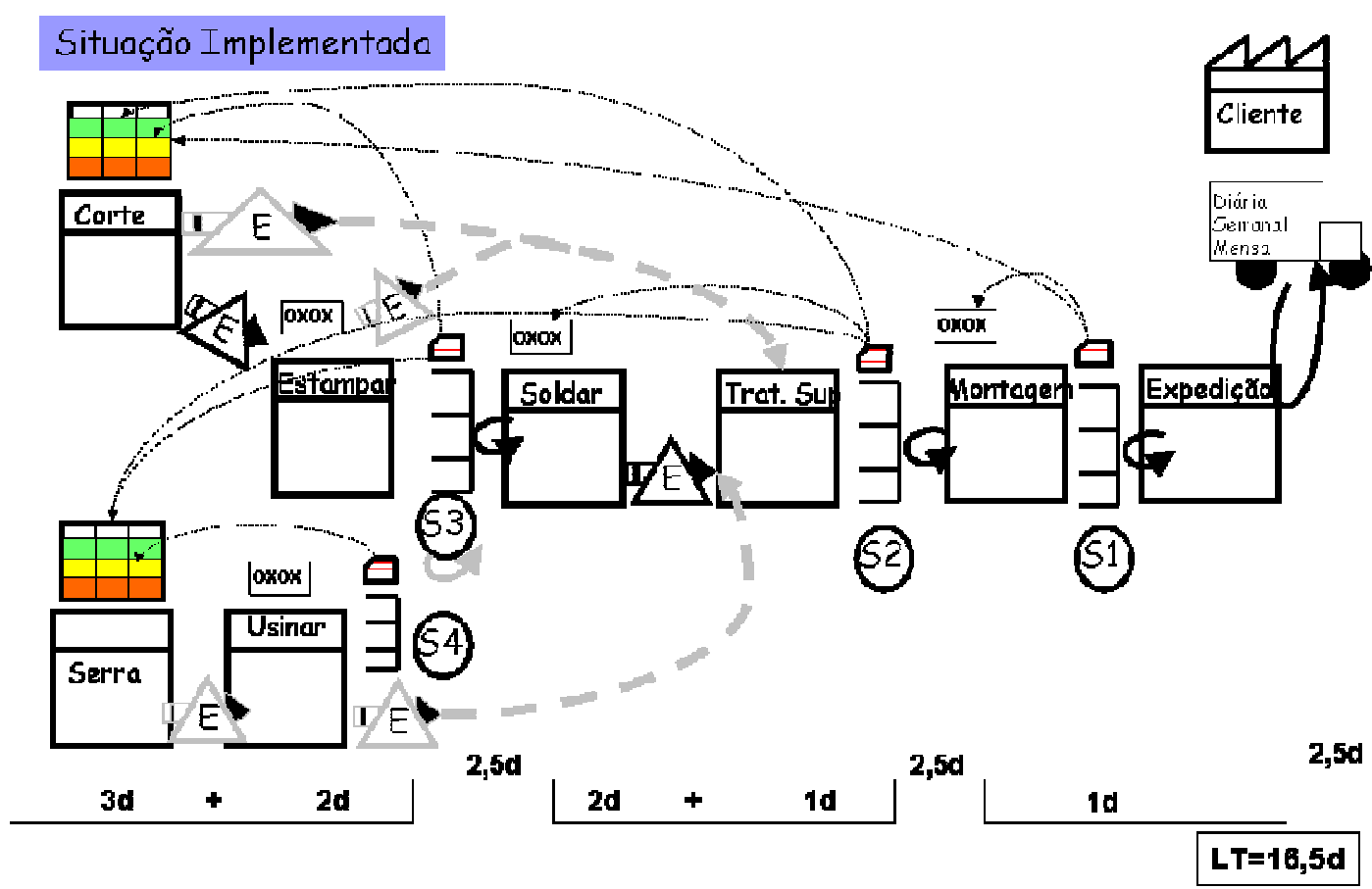

Figura 101: Definição dos pontos de supermercado

O primeiro ponto de supermercado (S1) é de produtos acabados, caracterizando um típico sistema puxado de reposição. A política de atendimento da demanda desse sistema é do tipo MTS (Make To Stock), baseada nos pedidos trimestrais colocados em carteira e firmados com um mês de antecedência. Como o principal cliente da empresa puxava os produtos por meio de kanbans, decidiu-se manter os produtos best sellers em pronta entrega. Contudo, embora o cliente puxasse os produtos por meio de kanbans, era comum o uso de kanbans de emergência devido a desnivelamentos ou reprogramações do mesmo. Com isso, era comum ocorrer mais de uma puxada dentro de um mesmo ciclo do TPT combinado (semanal). Este fator também contribuiu para a decisão de manter este ponto de supermercado, em cujo dimensionamento fora contemplado um fator de segurança que absorvesse esses picos de consumo.

O segundo ponto (S2) foi definido com base na necessidade de garantir a disponibilidade dos itens best sellers para a montagem (supermercado pulmão). Como todos os componentes eram programados até então de forma empurrada via ordens mensais, a montagem parava constantemente devido á falta de sincronização na chegada dos itens necessários para montar determinado conjunto. 
$\mathrm{O}$ terceiro e o quarto ponto de supermercado ( $\mathrm{S} 3$ e $\mathrm{S} 4$ ) foram definidos primeiramente com base na necessidade de garantir a disponibilidade dos itens best sellers para a solda (supermercado pulmão), evitando que esta ficasse parada devida á falta de sincronização na chegada dos itens necessários. Mas foram definidos também com base nos processos de corte laser, estamparia e usinagem. A idéia foi que funcionassem como supermercados reguladores sob a perspectiva destes processos, devido ao alto mix de itens que passavam por eles e às restrições de tempo de setup dos recursos gargalos de cada um.

De acordo com o projeto de situação futura, foi adotado um sistema puxado de reposição com política de atendimento da demanda do tipo "Produzir para Estoque" (MTS - Make To Stock). Com isso, o processo de expedição tornou-se o processo puxador do fluxo de valor.

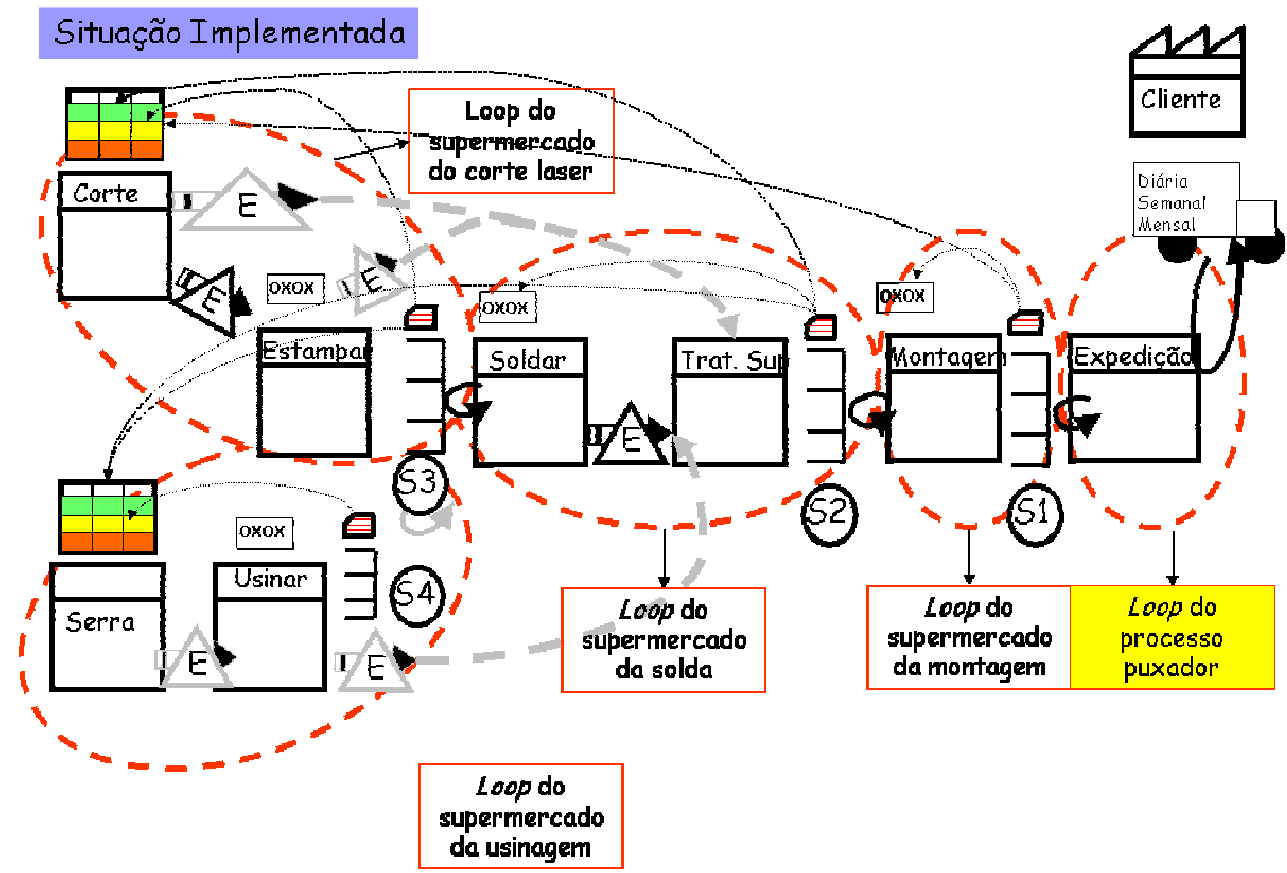

Figura 102: Definição do processo puxador

O próximo passo foi definir quais desses itens seriam controlados de forma puxada e quais seriam controlados de forma empurrada, ou seja, mediante ordem de produção. 


\subsubsection{Definição das subfamílias de programação e controle}

O objetivo desta etapa foi definir se os produtos de um mesmo fluxo de valor deveriam ou não ser controlados de formas diferentes.

Os fatores de referência utilizados para definir o tipo de controle mais adequado foram:

Volume da demanda: Levantado com base na previsão da demanda dos três meses seguintes, os itens foram classificados em Alto, Médio e Baixo Volume.

* Freqüência da demanda: Baseado na relação entre a média de consumo e o desvio padrão de cada item no período considerado. Embora o TPT fosse de 5 dias, foi utilizado o desvio padrão mensal (entre os meses). Vale ressaltar que o ideal teria sido utilizar o desvio padrão entre os blocos de 5 dias (ex.: desvpad (dia1+dia2+dia3+dia4+dia5; dia2+dia3+dia4+dia5+dia6, etc.). Entretanto, os dados de previsão encontravam-se apenas em bases mensais.

Custo: Esta classificação foi dividida em Alto e Baixo Custo.

Segue abaixo a tabela com os critérios utilizados para a definição do tipo de controle e do tamanho do TPT. Foram definidas quatro subfamílias de controle. O agrupamento dos itens nestas subfamílias foi feito com base na faixa de frequiência, volume e custo em que cada um se encontrava. 


\begin{tabular}{|c|c|c|c|c|c|c|}
\hline $\begin{array}{c}\text { Sub- } \\
\text { Familia }\end{array}$ & Nível & Custo & Volume & Frequència & Controle & Tamanho \\
\hline 1 & $\begin{array}{c}\text { PA e } \\
\text { Componentes }\end{array}$ & $\wedge$ & $\wedge$ & Frequente & Kanban & $1 * \mathrm{TPT}$ \\
\hline 1 & $\begin{array}{c}\text { PA e } \\
\text { Componentes }\end{array}$ & A & E & Fi equenle & Kanban & $1{ }^{\star} \mathrm{TPT}$ \\
\hline 2 & & $\mathbf{A}$ & $\mathrm{C}$ & Frequenle & Orden & Pedido \\
\hline 1 & & $B$ & A & Frequente & Kanban & 1*TPT \\
\hline 2 & & B & B & Frequente & Ordem & Pedido \\
\hline 2 & & B & $\mathbf{C}$ & Ferralle & GuteII & Pedito \\
\hline 3 & $\begin{array}{l}\text { } \begin{array}{l}\text { A (exceto } \\
\text { soldados) }\end{array} \\
\end{array}$ & $\mathrm{C}$ & A & Frequente & 2 Gaveta & 20 dias/Gaveta \\
\hline $\begin{array}{l}3 \\
\mathbf{3}\end{array}$ & $\begin{array}{l}\text { PA (exceto } \\
\text { soldados) } \\
\text { PA (exceto } \\
\text { soldados) }\end{array}$ & $\begin{array}{l}c \\
c\end{array}$ & $\begin{array}{l}\mathrm{B} \\
\mathrm{C}\end{array}$ & $\begin{array}{l}\text { Feqraile } \\
\text { Frequania }\end{array}$ & $\begin{array}{l}2 \text { Genela } \\
2 \text { Conatm }\end{array}$ & 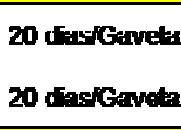 \\
\hline 4 & $\begin{array}{l}\text { Componentes } \\
\text { para Sulda }\end{array}$ & C & A & Frequente & 2 Gaveta & 10 dias/Gaveta \\
\hline 4 & $\begin{array}{l}\text { Corponeites } \\
\text { para Soldh }\end{array}$ & C & B & Frequente & 2 Gowela & 10 dactervet \\
\hline 4 & $\begin{array}{l}\text { Corponedes } \\
\text { pape Solda }\end{array}$ & c & C & Frequente & 2 Ganeta & 10 dartGaveth \\
\hline
\end{tabular}

Quadro 59: Definição das subfamílias de programação e controle

Todos os itens classificados como esporádicos continuaram a ser controlados pelo sistema de emissão de ordem de fabricação. Note que para os conjuntos soldados, fossem produtos acabados ou não, não se adotou controle de duas gavetas. Conforme dito anteriormente, as operações de solda apresentavam tempos de processamento elevados. Trabalhar com grandes lotes (gavetas) tenderia a comprometer a flexibilidade de mix da empresa.

A figura abaixo ilustra como ficou o MFV implementado para os itens em supermercado com a respectiva linha de tempo (lead time). 


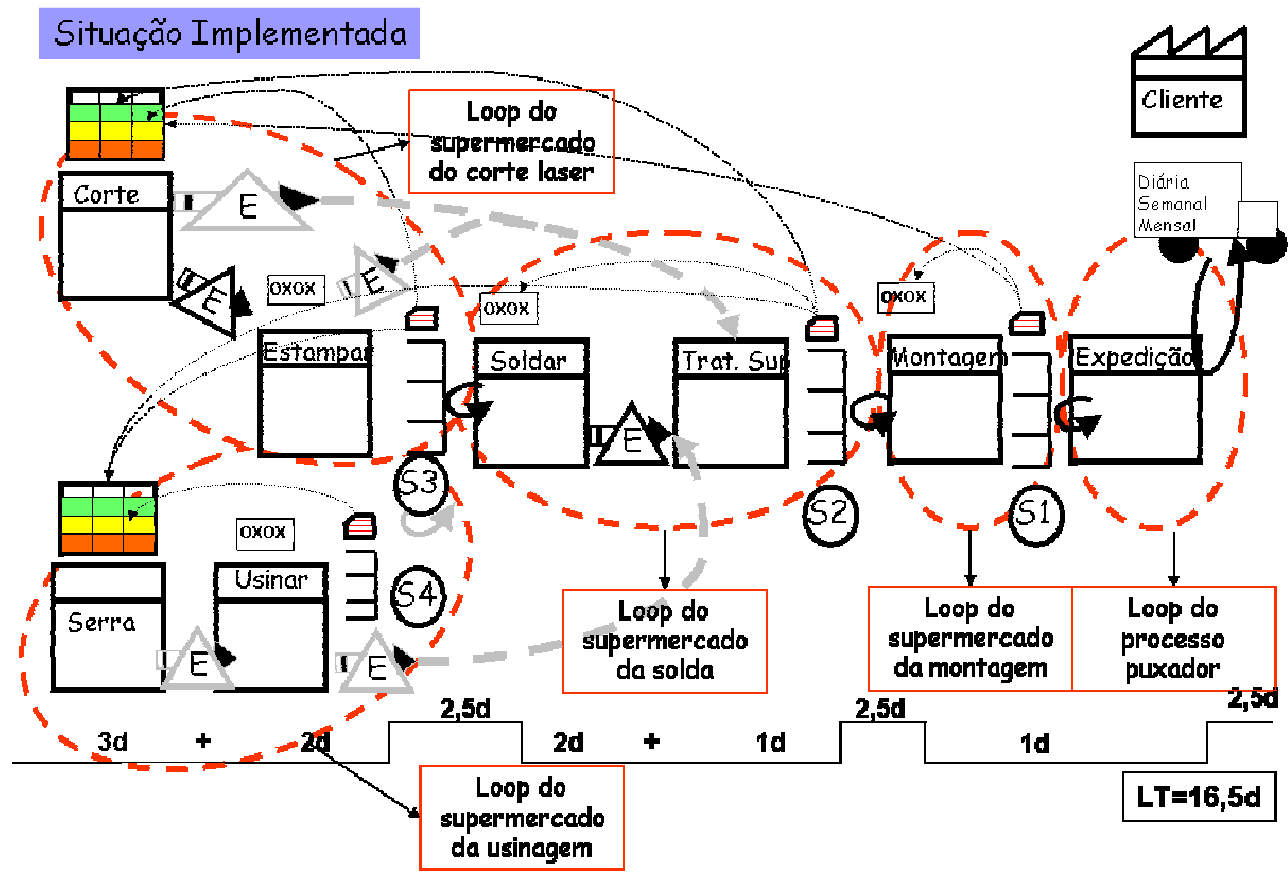

Figura 103: MFV da situação implementada com a linha de tempo

O lead time do MFV baseou-se na linha de tempo do fluxo do loop do supermercado de peças cortadas e estampadas, visto que este era o caminho mais demorado. No próximo tópico será detalhado o cálculo do dimensionamento do tamanho dos supermercados.

\subsubsection{Dimensionamento do tamanho dos supermercados}

Para o dimensionamento do tamanho do supermercado em cada ponto foram delimitados os loops de produção. 


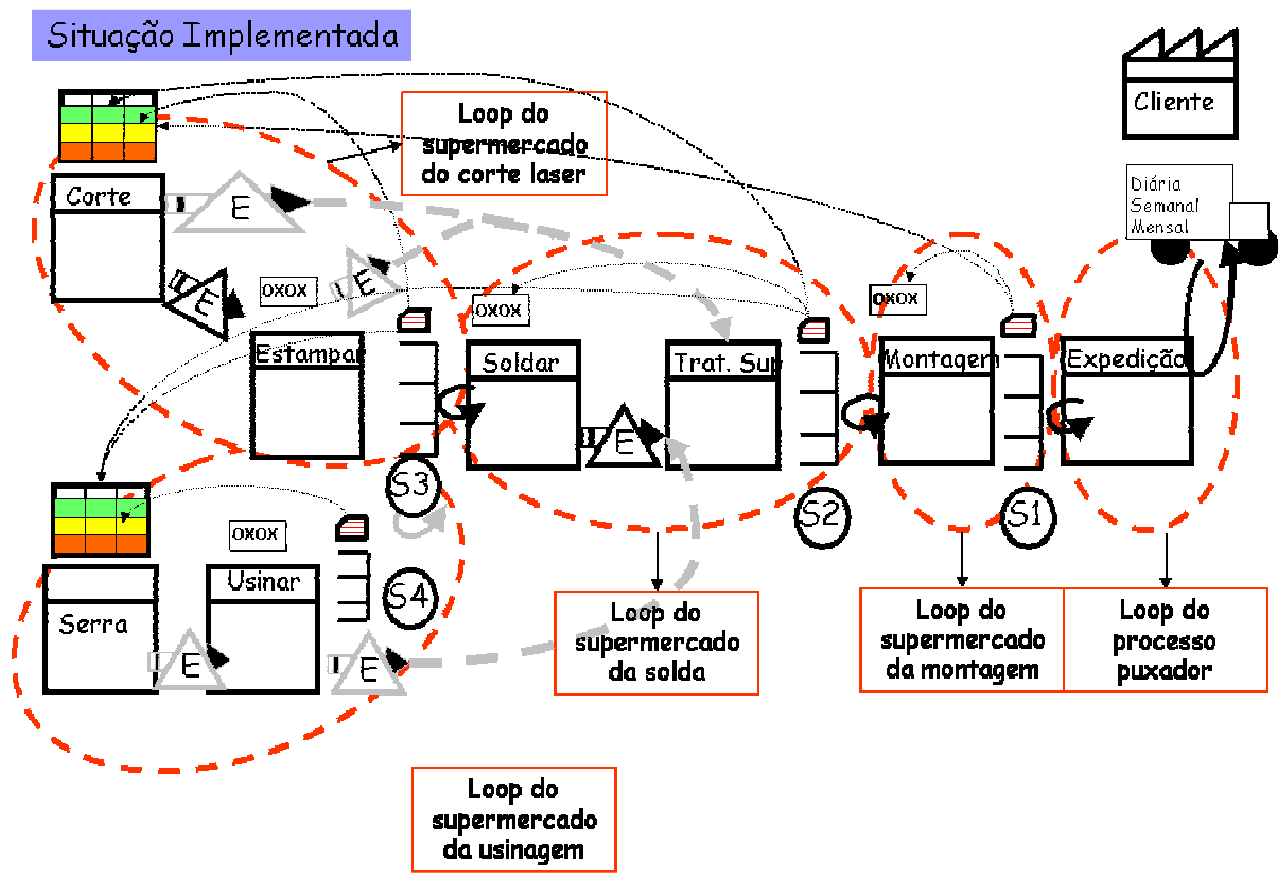

Figura 104: Identificação dos loops de produção

Levantou-se a carteira de pedidos de todas as peças dos 3 (três) meses seguintes. Para calcular o TPT constatou-se que a empresa não possuía dados a respeito dos tempos de todos os seus itens ao longo de fluxo de valor. Com isso a equipe precisou decidir entre dedicar um tempo razoável para levantamento desses tempos ou estimar o TPT. Tendo em vista prosseguir com a implementação decidiuse estimar o TPT em função dos loops iniciais, ou seja do supermercado do corte laser e estamparia e do supermercado da serra e usinagem. O mix de peças que passava por esses processos era extremamente alto. Logo, era muito provável que eles apresentariam restrições de capacidade de realizar muitos setup's. Com isso, adotou-se um TPT de 5 dias, ou seja, todas as peças seriam produzidas com uma periodicidade média de 5 dias (toda parte a cada 5 dias).

Para os demais loops (supermercado da solda e supermercado da montagem) adotou-se o mesmo TPT do loop da retífica, ou seja, 5 dias. Isto porque o processo puxador (expedição) puxava determinado item uma vez por semana. $\mathrm{Ou}$ seja, a expedição para o cliente era feita em lotes semanais. Por outro lado, os loops do supermercado da solda e do supermercado da montagem não apresentavam limitações quanto ao tempo de setup. Mesmo com expedições semanais era possível e, sobretudo desejável, trabalhar com lotes diários. Estes processos apresentavam 
tempos de processamento elevados. Comprometê-los com lotes semanais tenderia a reduzir a flexibilidade de mix da empresa.

$\mathrm{Na}$ seção que fala sobre a programação dos fluxos puxados será discorrido mais detalhadamente sobre como foi possível trabalhar com lotes diários mesmo com um TPT semanal.

Em seguida, foram definidos os procedimentos de programação e controle.

\subsubsection{Definição das sistemáticas de programação e controle}

Foram definidos os procedimentos de programação e controle tanto para as subfamílias reguladas por fluxos empurrados quanto para aquelas reguladas por fluxos puxados.

\subsubsection{Programação e controle dos itens MTO}

Até então, todos os itens eram empurrados por ordens de produção via Sistema MRP. As ordens eram emitidas pela sistemática de Lote a Lote. Só que os lotes de cada item eram dimensionados de acordo com a demanda mensal. Nesse caso, o sistema possuía um giro menor que o TPT do fluxo. Essa política de programação limitava a flexibilidade de mix de todo o sistema, pois, como os pedidos eram colocados em lotes de produção excessivamente grandes, os recursos restritivos acabavam comprometidos por dias com um único pedido.

Com o cálculo do TPT para cada fluxo, as ordens de produção passaram a ser emitidas pela sistemática de Lote a Intervalo Fixo, baseado num TPT de cinco dias (lotes semanais). De acordo com essa sistemática, o lote das ordens de produção eram "quebrados" em ordens parciais semanais.

O próximo passo foi definir a sistemática de programação e controle dos itens em kanban. 


\subsubsection{Programação e controle dos fluxos puxados}

Para as peças controladas pelo sistema kanban, decidiu-se trabalhar com a política de reposição por ciclo de pedidos constante. Contudo, essa política foi estrategicamente implantada de formas diferentes ao longo do fluxo de valor. Nos loops iniciais de peças cortadas e usinadas adotou-se uma reposição por ciclo de pedidos constante tradicional. Foi feita uma distribuição balanceada do mix das peças que passavam por esses loops ao longo dos cinco dias do TPT.

No fluxo das máquinas de corte laser, além do balanceamento de tempo, trabalhou-se também com o agrupamento de itens de mesma espessura para a definição do mix de itens a ser reposto em cada dia do TPT.

Com base nesta lista, os códigos das peças foram separados no quadro de kanban conforme o respectivo dia previsto para reposição. Como o TPT era de cinco dias, foi possível vincular os dias do TPT aos dias da semana. Este fato facilitou bastante o entendimento do conceito pelos operadores, visto que o controle da reposição passou ser feito conforme a agenda das peças de segunda (dia 1 do TPT), da terça (dia 2 do TPT), da quarta (dia 3 do TPT) e assim sucessivamente.

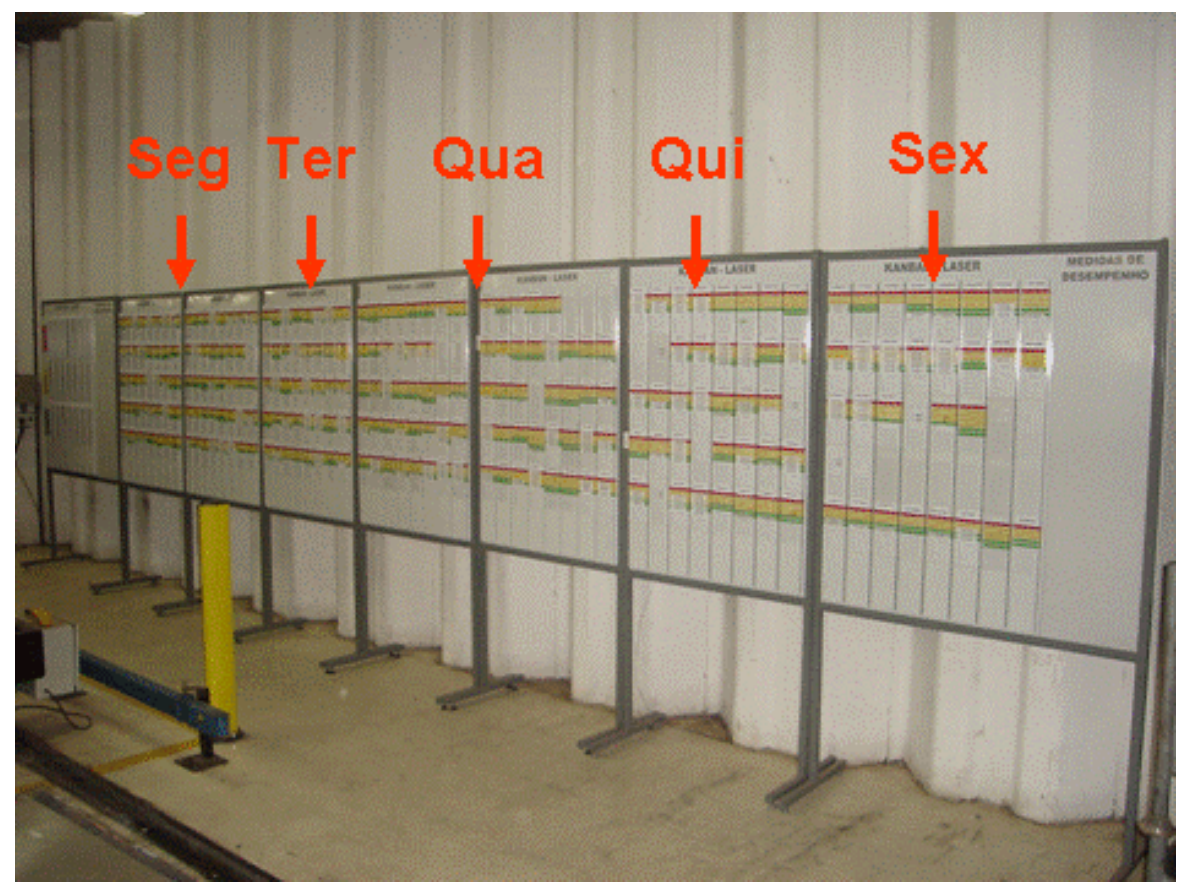

Figura 105: Mix diário do TPT para reposição do loop do super de corte laser 
O mesmo raciocínio fora realizado nos tornos $\mathrm{CNC}$ no fluxo da usinagem.

Nos loops fluxo abaixo, de peças soldadas e montadas adotou-se uma reposição por ciclo de pedidos constante com retirada compassada. Mesmo com o processo puxador (expedição) puxando um determinado tipo de peça uma vez por semana (TPT semanal), decidiu-se trabalhar com lotes de reposição diários até que fossem formados os lotes semanais. A idéia era evitar que uma operação de solda ou de montagem ficasse comprometida muito tempo com um grande lote (semanal) de um único tipo de peça.

Tanto na solda quanto na montagem, ao invés de quadros semáforo de kanban, foram implementados quadros de programação com janelas de dias da semana. O objetivo destes quadros era regular a reposição do lote semanal dos itens em kanban.

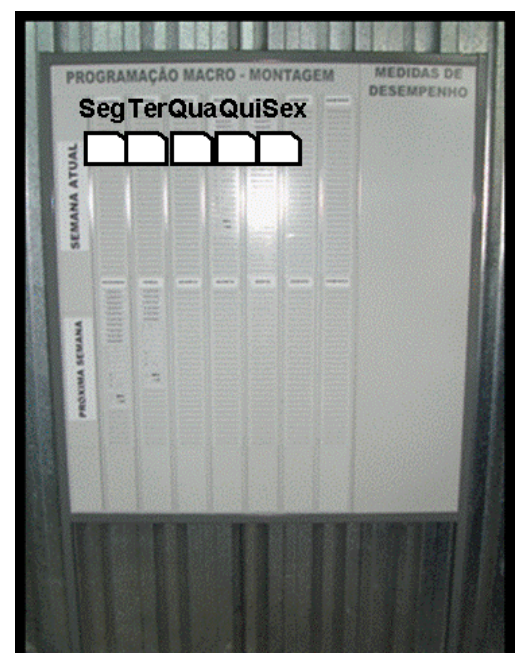

Figura 106: Quadro macro de programação da reposição compassada dos kanbans

O líder do setor, ao receber os kanbans de um determinado tipo de peça distribuía-os ao longo dos cinco dias seguintes (TPT de 5 dias). Essa estratégia garantiu a reposição de lotes diários do item em questão.

À medida que novos itens eram inseridos no sistema de controle kanban, a gestão do quadro mostrou-se deficiente com relação à visualização da carga de trabalho que estava sendo ocupada dentro de um mesmo dia. Isso significava que a reposição de itens muito demorados poderia estar se concentrando 
num mesmo dia em detrimento a outros dias nos quais itens mais fáceis e rápidos poderiam estar sendo repostos.

Com isso, o quadro passou a contemplar também o balanceamento e nivelamento do mix a ser reposto. Foram definidas famílias de janela de tempo (Família 1: 30min; Família 2: 60min; Família 3: 90min; etc.). Os itens foram então agrupados nestas famílias conforme o tempo médio de reposição do respectivo cartão. Em seguida, calculou-se o lote médio diário de reposição de cada item. Com essa informação foi possível montar no quadro uma máscara com a capacidade média (em cartões) disponível para cada família.

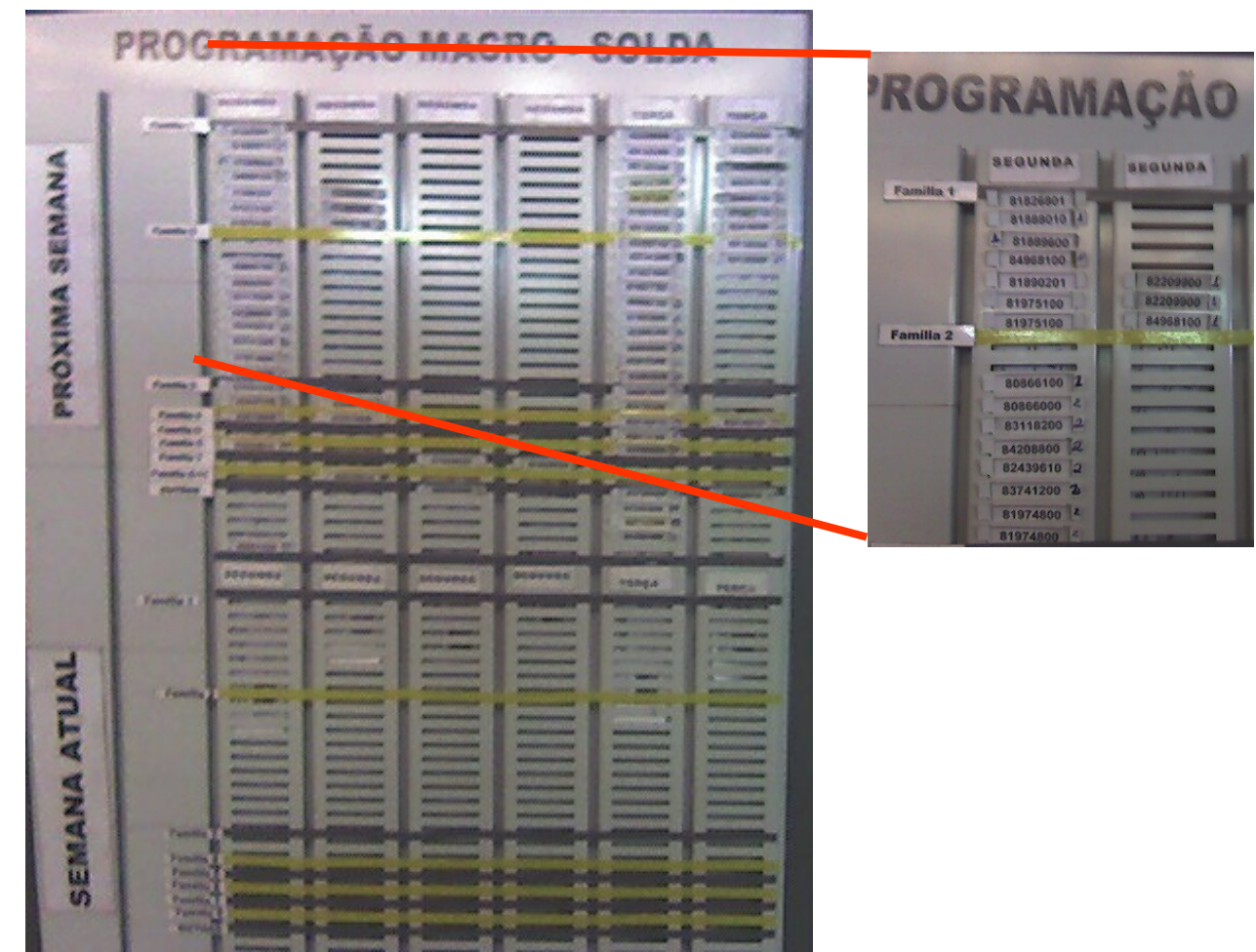

Figura 107: Quadro macro de programação nivelada e balanceada da reposição compassada dos kanbans

A partir dos quadros de programação macro, tanto na solda quanto na montagem, foram projetados quadros de programação micro para todas as cabines de solda e bancadas de montagem. A idéia era que líder retirasse os cartões do quadro macro e distribuísse a carga de trabalho do dia nos quadros micro.

Como não seria possível cronoanalisar todos os produtos passíveis de serem soldados e montados nas cabines de solda e bancadas de montagem decidiu-se 
simplificar o escopo do trabalho agrupando esses produtos em famílias de janela de tempo (Família 1: 30min; Família 2: 60min; Família 3: 90min; etc.). Os critérios para inserção dos itens em cada família foram basicamente a similaridade de tempo. Logo, ao invés de se tratar 400 itens diferentes, passou-se a falar em aproximadamente oito famílias diferentes.

A princípio, estimou-se um intervalo de tempo para cada família (múltiplos de 30 minutos). Após a classificação de todos os produtos nestas famílias, definiu-se quais os mais representativos de cada uma, tendo em vista realizar a respectiva cronoanálise.

Figura 108: Cronoanálise do item mais representativo da família

\begin{tabular}{|c|c|c|c|c|}
\hline \multirow{2}{*}{$\begin{array}{l}\text { No. } \\
\text { Ativida } \\
\text { de }\end{array}$} & \multicolumn{4}{|c|}{\begin{tabular}{|l} 
Operação: Submontagem de pedais de freios e embreagem + Montagem de conjun \\
Operador: Dedé \\
Código da peça: 90000170 (Kit Pedais Embreagem/Freio) \\
\end{tabular}} \\
\hline & $\begin{array}{l}\text { Tipo } \\
\text { Atividade }\end{array}$ & Descrição do elemento de trabalho & $\begin{array}{l}\text { Tempo total } \\
\text { acumulado }\end{array}$ & $\begin{array}{l}\text { Tempo da } \\
\text { atividade }\end{array}$ \\
\hline & NAV & Buscar pedais na pra & $00: 01: 14$ & \\
\hline & NAV & Buscar pinos e travas ( 668420 + item compra & $00: 02: 22$ & 000 \\
\hline & BNAV & Buscar cupilha e arruela (caixa toda) & $00: 02: 58$ & 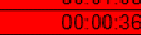 \\
\hline & 4 NAV & Buscar marreta e ima & & \\
\hline & $5 \quad \mathrm{AV}$ & Calibrar & $00: 04: 44$ & $00: 01: 20$ \\
\hline & & Buscar a trava & & \\
\hline 7 & AV & Calibrar peça 1 e 2 (1a. Sub conjunto) & $00: 06: 45$ & $00: 01: 48$ \\
\hline 8 & AV & Colocar peça no carrinho & $00: 06-48$ & $00: 00: 03$ \\
\hline & AV & Calibrar peça 3 & $00: 08: 07$ & $00: 01: 19$ \\
\hline 10 & AV & Calibrar peça 4 & $00: 10=14$ & $00=02: 07$ \\
\hline 11 & AV & Calibrar peça 5 & $00: 11: 51$ & $00: 01: 37$ \\
\hline 12 & AV & Calibrar peça 6 & $00: 13: 12$ & $00: 01: 21$ \\
\hline 13 & AV & Calibrar peça 7 & $00: 15-34$ & $00: 02: 22$ \\
\hline 14 & AV & Calibrar peça 8 & $00: 16: 23$ & $00: 00: 49$ \\
\hline & & utro pedal (retrabalho & & \\
\hline 16 & AV & Calibrar & $00: 18: 13$ & $00: 01: 27$ \\
\hline 17 & NAV & Preparar máquina (prp 101) & $00: 20: 11$ & $00: 01: 58$ \\
\hline & NAV & & & \\
\hline & AV & Colocar 2 rolamentos no pedal 1 & $00: 20=58$ & $00=00: 18$ \\
\hline 20 & AV & Cólócar 2 rólaméntos nó pédala 2 & $00: 21: 24$ & $00: 00: 26$ \\
\hline
\end{tabular}

No caso da montagem foi feita uma análise dos elementos de trabalho do processo de montagem e definido o padrão de trabalho para cada um dos itens mais representativos de cada família. 


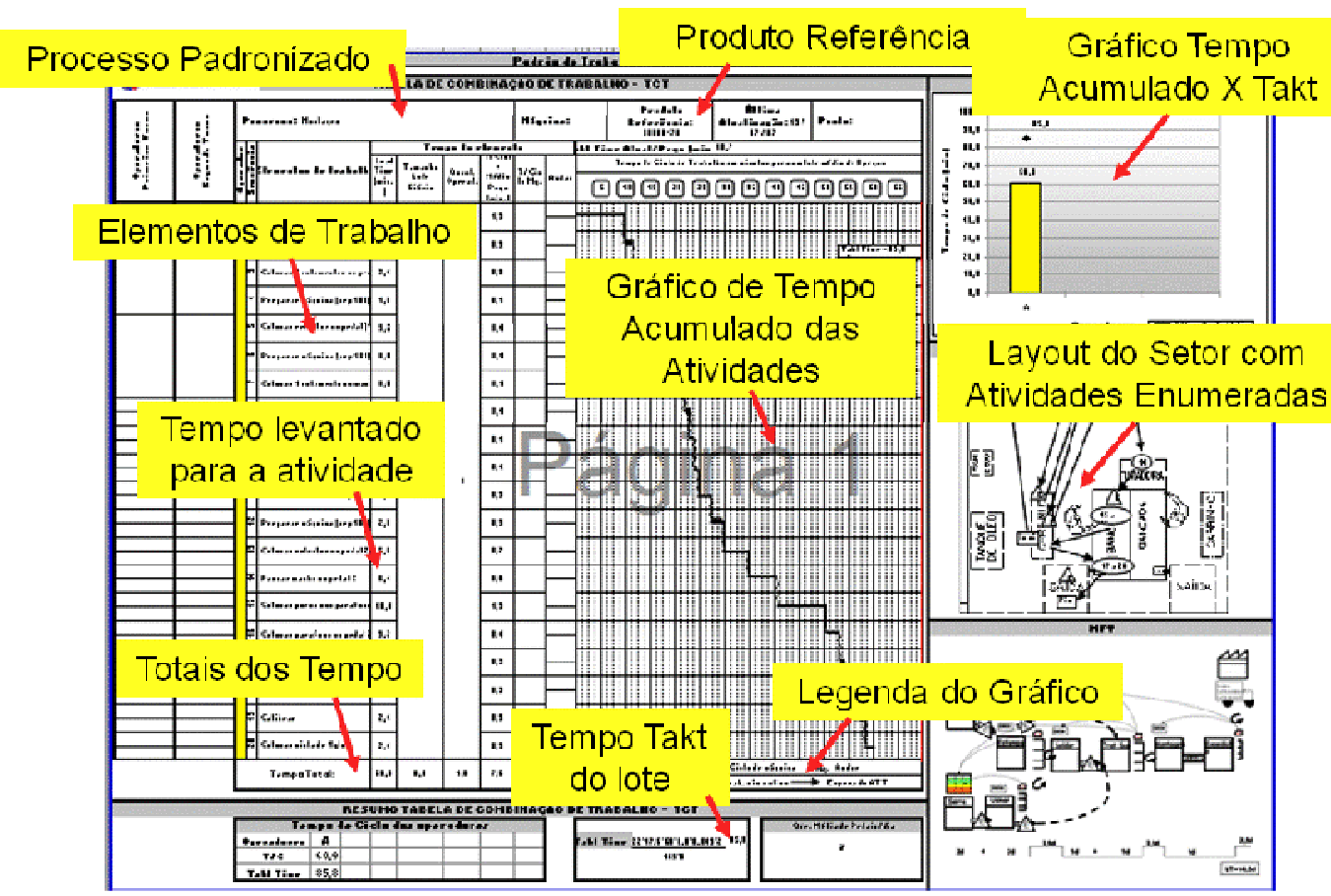

Figura 109: Criação de fluxo e padronização da família 1

O próximo passo foi o projeto dos quadros micro. Foi implantado o heijunka box nas cabines de solda e montagem, tendo em vista fornecer senso de ritmo para os soldadores e montadores. A idéia era os soldadores e montadores poderem controlar se a operação estava montando a quantidade definida a cada pitch de 30 minutos. Para isso, foram colocados nos próprios cartões um número indicando a família à qual aquele produto pertencia. Consequentemente era possível definir a quantidade de pitches que eles deveriam reservar para montar determinado cartão. Por exemplo, um cartão em que estivesse assinalado família 2 significaria que o operador demoraria dois pitches de 30 minutos. Logo, deveria programar o cartão ocupando o correspondente a dois espaços no quadro micro. 


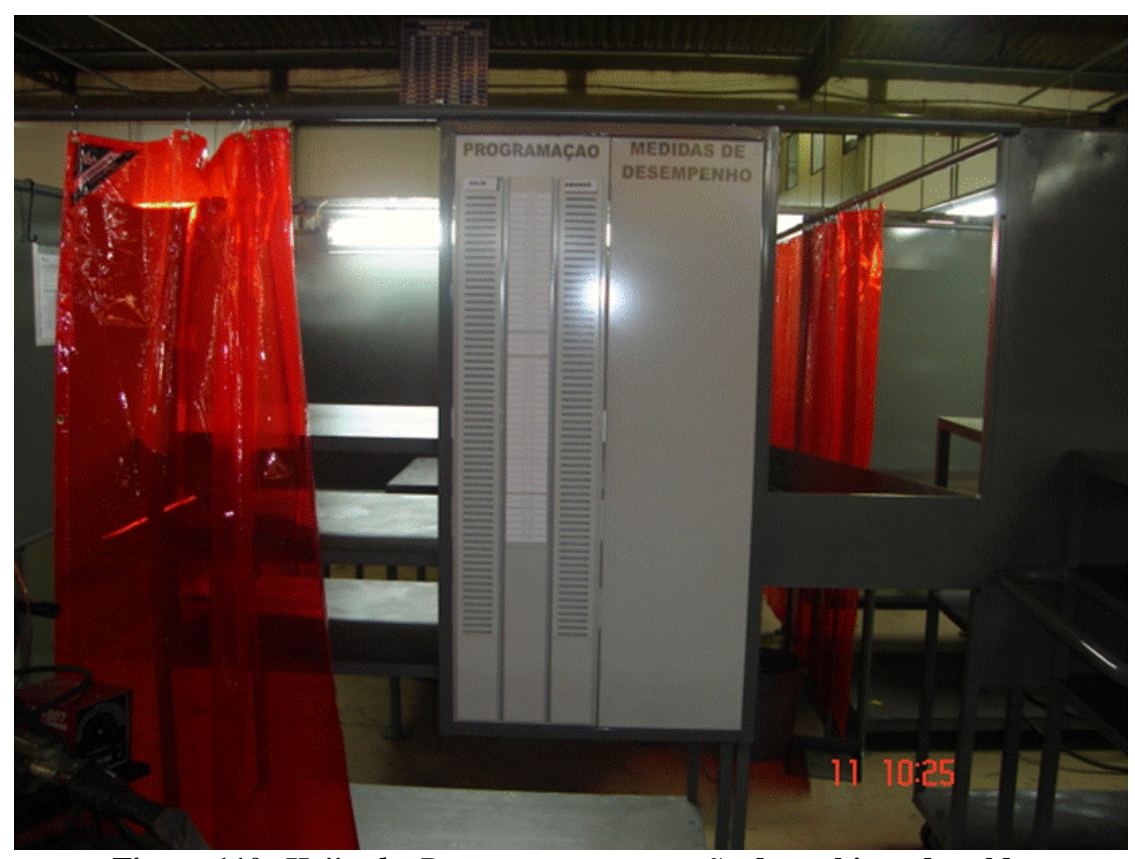

Figura 110: Heijunka Box para programação das cabines de solda

Foi possível utilizar os próprios kanbans para programar os quadros em questão.

Feito isso, o próximo passo foi preparar o sistema para as flutuações da demanda.

\subsubsection{Flexibilização dos fluxos puxados}

O primeiro passo para a flexibilização de um sistema de controle puxado foi determinar os intervalos para reavaliação e ajuste do tamanho dos supermercados. A periodicidade dos ajustes foi definida com base na sazonalidade da demanda da empresa. Levantou-se que trimestralmente seria necessário um ajuste no sistema. As janelas de tempo para ajuste foram:

Jan-Mar; Abr-Jun; Jul-Set; Out-Dez

Além disso, foi decidido que o modo de ajuste seria através da inserção ou retirada de kanbans, ao invés de alterar a quantidade de itens por kanban.

Foi feita uma legenda com os períodos de ajuste do sistema puxado. 


\begin{tabular}{|c|c|c|c|c|c|}
\hline Janela & Loop & TPT & $\begin{array}{l}\text { Lead Time } \\
\text { Reposição }\end{array}$ & $\begin{array}{c}\text { Aumento da Demanda: } \\
\text { Inserir Kanban } \\
\text { (VERDE + AMARELO) }\end{array}$ & $\begin{array}{c}\text { Redução da Demanda: } \\
\text { Retirar Kanbans } \\
\text { (AMARELO) }\end{array}$ \\
\hline \multirow{3}{*}{ Jan-Mar } & Super da Montagem & 5 & 1 & até 24/dez & apartir de 31/dez \\
\hline & Super da Solda & 5 & 1 & até $18 / \mathrm{dez}$ & apartir de 30/dez \\
\hline & $\begin{array}{l}\text { Super do Corte \& } \\
\text { Usinagem }\end{array}$ & 5 & 4 & até 09/dez & apartir de $24 /$ dez \\
\hline \multirow{3}{*}{ Abr-Jun } & Super da Montagem & 5 & 1 & até 24/mar & apartir de 30/mar \\
\hline & Super da Solda & 5 & 1 & até $18 / \mathrm{mar}$ & apartir de 29/mar \\
\hline & $\begin{array}{l}\text { Super do Corte \& } \\
\text { Usinagem }\end{array}$ & 5 & 4 & até $09 /$ mar & apartir de $24 /$ mar \\
\hline \multirow{3}{*}{ Jul-Set } & Super da Montagem & 5 & 1 & até $24 /$ jun & apartir de 30/jun \\
\hline & Super da Solda & 5 & 1 & até 18/jun & apartir de 29/jun \\
\hline & $\begin{array}{l}\text { Super do Corte \& } \\
\text { Usinagem }\end{array}$ & 5 & 4 & até 09/jun & apartir de $24 /$ jun \\
\hline \multirow{3}{*}{ Jul-Set } & Super da Montagem & 5 & 1 & até 24/set & apartir de 30/set \\
\hline & Super da Solda & 5 & 1 & até $18 /$ set & apartir de 29/set \\
\hline & $\begin{array}{l}\text { Super do Corte \& } \\
\text { Usinagem }\end{array}$ & 5 & 4 & até 09/set & apartir de 24 /set \\
\hline
\end{tabular}

Quadro 60: Flexibilização do tamanho do supermercado por janelas de tempo - 3 $3^{\text {a }}$. Aplicação

Para definição do momento do ajuste foram considerados a defasagem de tempo entre cada loop e se a situação se tratava de aumento ou redução da demanda da peça.

Em situações de aumento da demanda, o momento para a inserção de cartões considerou o tempo de ciclo (TPT) mais o tempo de reposição, que é o cenário mais pessimista com relação ao tempo que o ajuste demoraria para refletir na quantidade de peças disponível para o próximo loop (consumidor).

Em situações de redução da demanda, o momento para retirada de cartões considerou apenas o tempo de reposição. O tempo de ciclo (TPT) não foi contemplado na defasagem do tempo, tendo em vista evitar que a redução refletisse antes da hora na quantidade de peças disponível para o loop consumidor.

Quando se passa a puxar a produção a dinâmica dos kanbans requer não apenas mudanças de paradigmas, mas também do controle informatizado do sistema. Planilhas eletrônicas, de software proprietário como o Microsoft Excel são geradas para o dimensionamento e atualização do tamanho dos supermercados. Em empresas com estruturas de produtos complexas como esta elas estão vulneráveis a uma série de inconsistências. Várias planilhas e versões começaram a ser geradas formando uma grande estrutura de informação paralela aos sistemas de informação oficiais da empresa. 
Para fazer frente a esse problema, iniciou-se um processo de desenvolvimento e implantação de um software para dimensionamento e ajuste dos supermercados. As telas desse sistema são apresentadas a seguir.

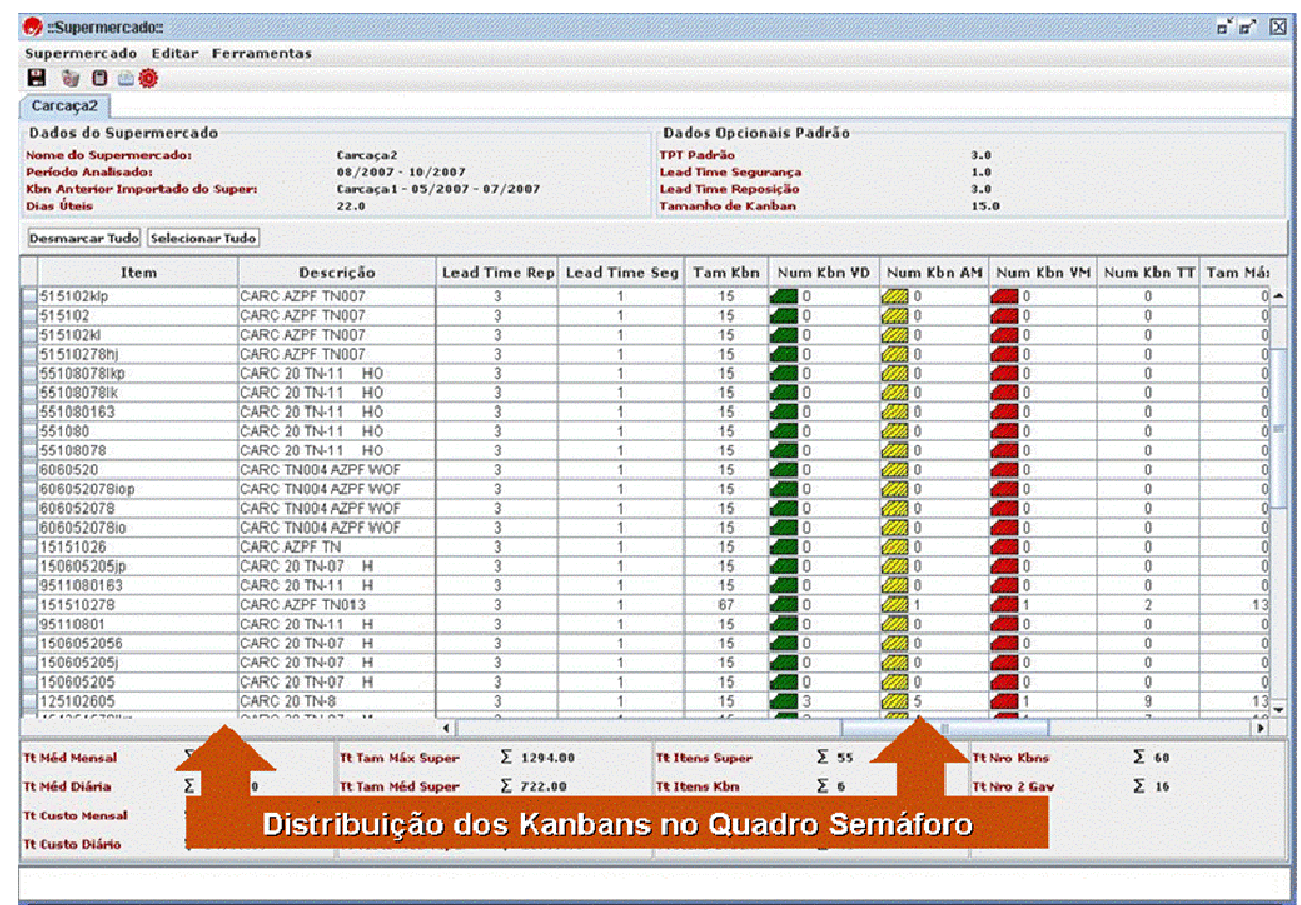

Figura 111: Tela de sofware desenvolvido para dimensionamento e ajuste dos supermercados

\subsubsection{Programação e nivelamento do processo puxador}

O processo puxador (expedição) passou a ser diretamente pelos clientes externos. A maioria dos itens é puxada semanalmente. Contudo, existem itens que são puxados mensalmente. A empresa observou que a maioria desses itens quase sempre atrasava. Após uma análise mais profunda, descobriu-se que a empresa tinha uma grande dificuldade em produzir e expedir todo o lote mensal, o qual à medida que era produzido causava picos e sobrecargas ao longo de todo o fluxo de valor. Com isso, eram feitas entregas parciais, o que acabava penalizando os indicadores de desempenho da empresa perante os clientes.

Para minimizar esse fato, recorreu-se à técnica de empenho de lotes semanais ao longo do mês. Para isso, foi criado um quadro de programação dos empenhos no processo puxador. A idéia era submeter os itens de entrega mensal ao mesmo giro daqueles itens de entrega semanal. Só que, como não havia o cliente 
externo para puxar as peças e disparar os cartões, a expedição separava estas peças conforme a programação de empenho.

Em seguida, iniciou-se os trabalhos de implantação.

\subsubsection{Preparação e acompanhamento da implementação}

Nesta etapa foi definido como seria a transição do sistema de produção anterior para o sistema proposto, incluindo-se aí a sequiência de implementação, a velocidade com que as mudanças seriam executadas e um cronograma de implementação.

Foi utilizada a técnica de evento kaizen. Foram necessários quatro eventos kaizen para a implantação de todas as melhorias projetadas. Antes dos eventos, várias atividades de concepção e preparação de infra-estrutura foram realizadas, tendo em vista deixar tudo pronto para uma implantação efetiva da situação futura na semana de cada evento. Chamou-se esta etapa de pré-evento kaizen.

De acordo com a técnica, os trabalhos iniciaram com um treinamento da equipe sobre o projeto de situação futura que seria implantado.
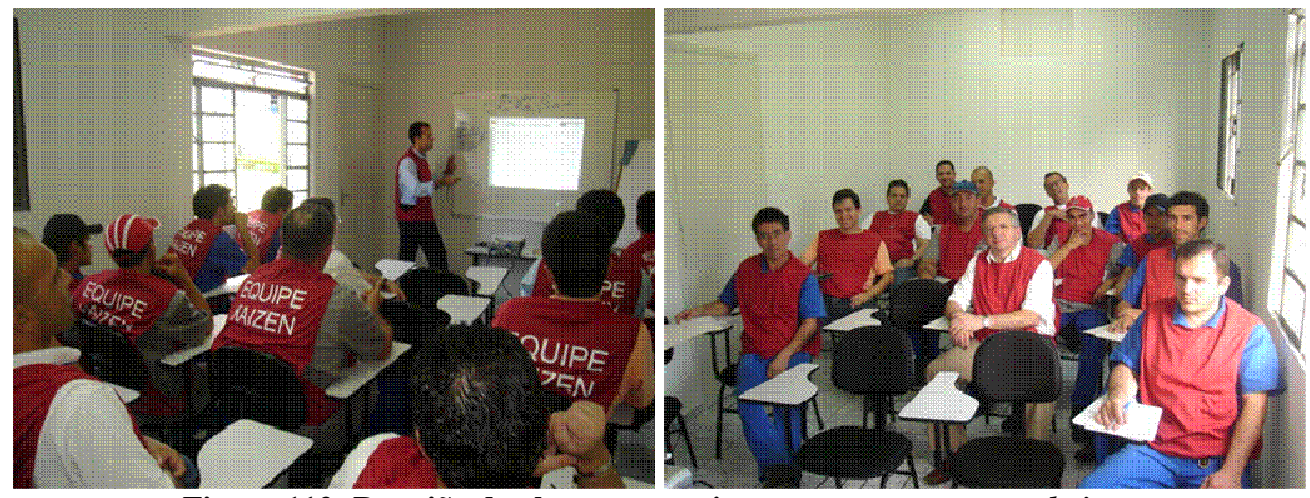

Figura 112: Reunião de abertura e treinamento para o evento kaizen

Em seguida, a equipe iniciou então as atividades de implantação. 


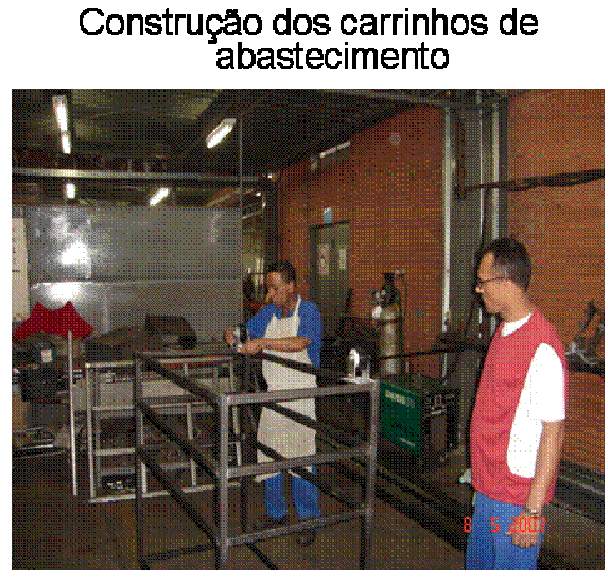

\section{Construçăo das prateleiras}

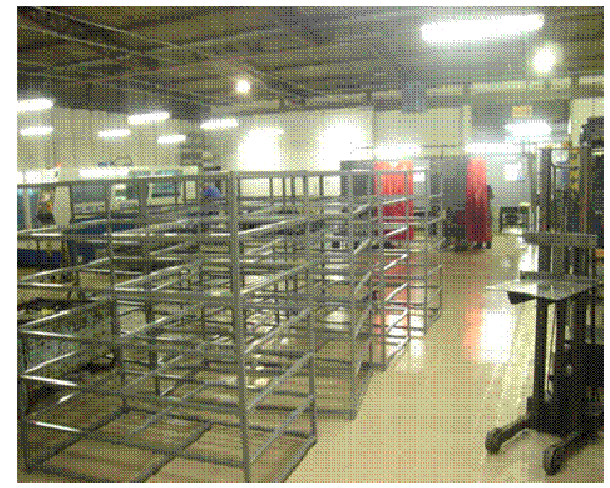

Figura 113: Início das atividades do Evento Kaizen

Uma atividade que sempre ocorre num evento de implantação de sistemas puxados é a formação dos supermercados.

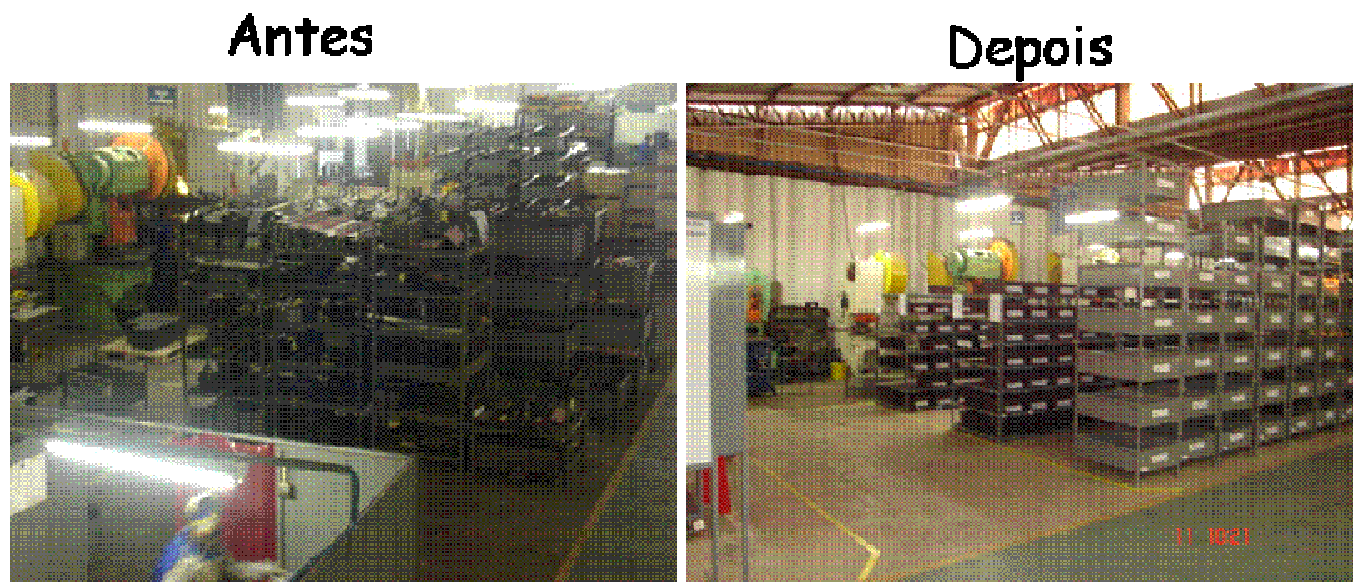

Figura 114: Substituição de um estoque empurrado para a solda por um supermercado.

No evento kaizen seguinte, este supermercado de componentes para solda foi transferido para uma área lateral, com o pé direito baixo e, portanto sem condições ideais para abrigar processos produtivos. As áreas liberadas, por sua vez, passaram a abrigar processos produtivos, ou seja, atividades que agregam valor. 
ANTES

DEPOIS
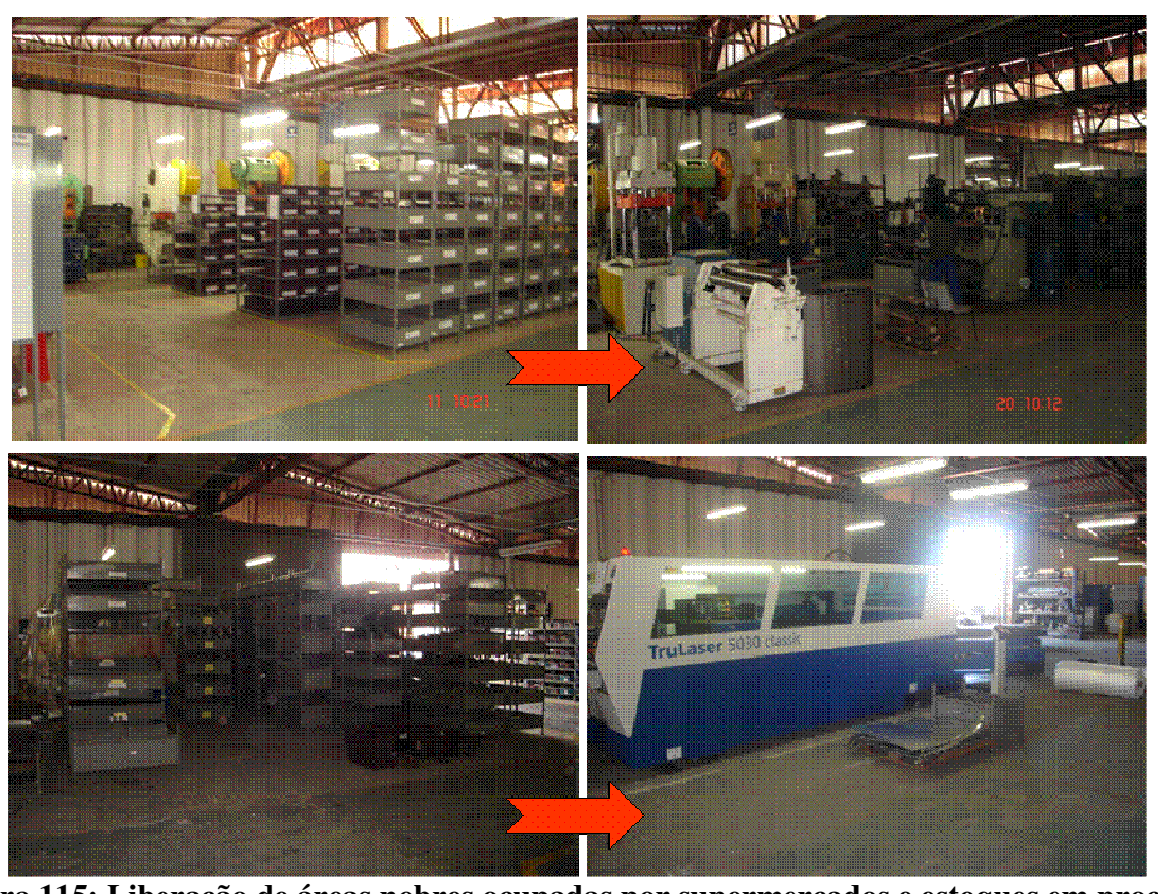

Figura 115: Liberação de áreas nobres ocupadas por supermercados e estoques em processo

O supermercado para Solda foi então transferido para uma área definitiva, menos propícia para atividades produtivas. 

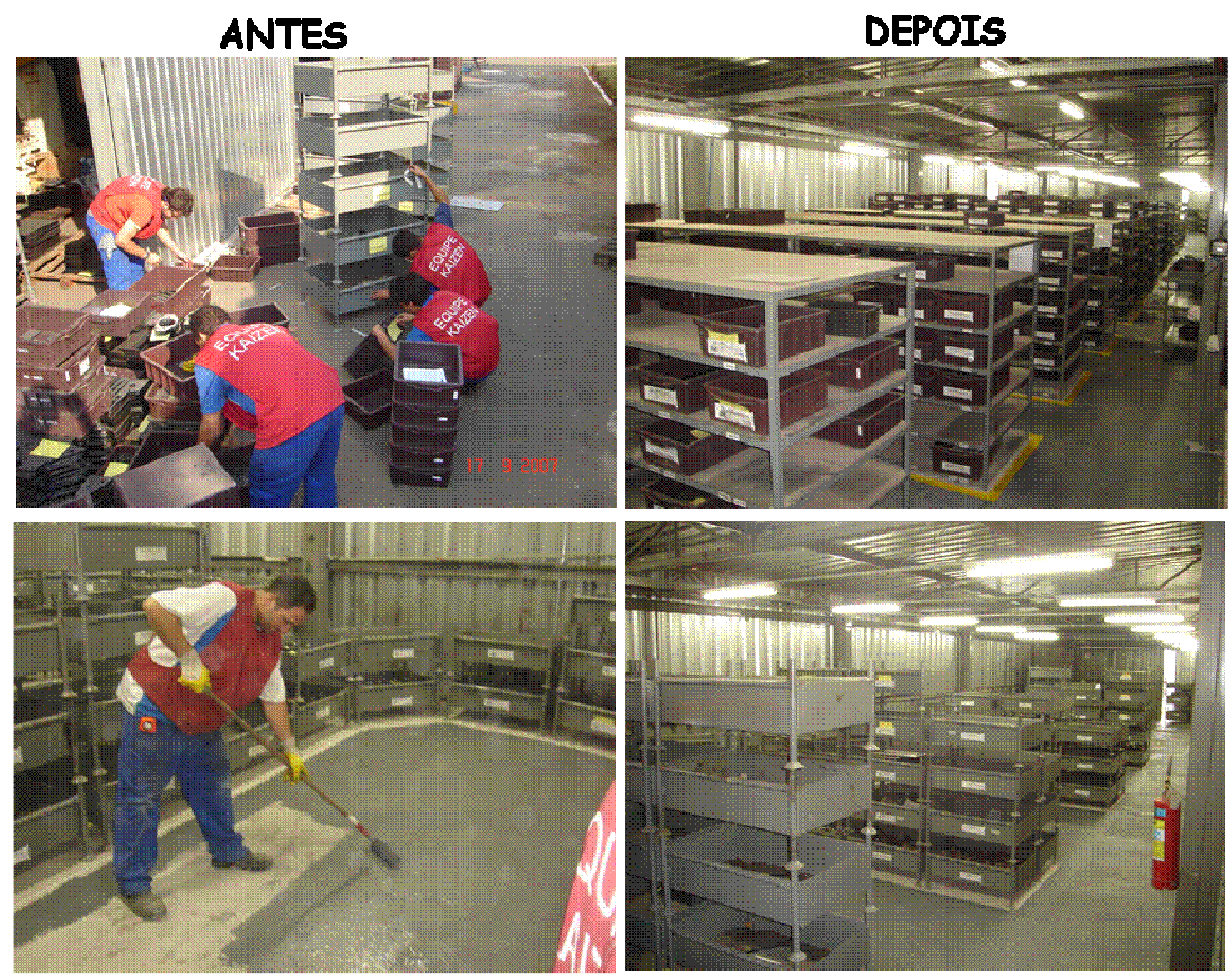

Figura 116: Reorganização do Supermercado para a Solda (S2)

O processo de solda, que passou a ter um supermercado de componentes (S3 e S4) e ao mesmo tempo a produzir para um supermercado de conjuntos soldados para a montagem final (S2), também foi alvo de melhorias. Criou-se um sistema de programação por cabine e criação de fluxo contínuo entre a solda e o acabamento (tirar respingo).

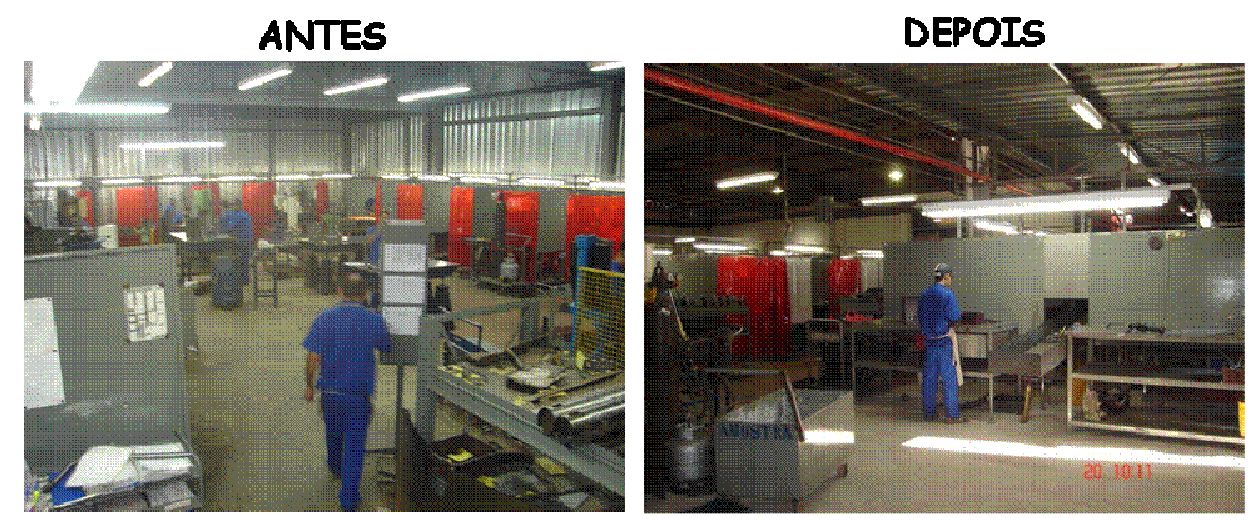

Figura 117: Setor de solda é substituído por células de solda

Foi implantado o supermercado para a montagem final (S2). 


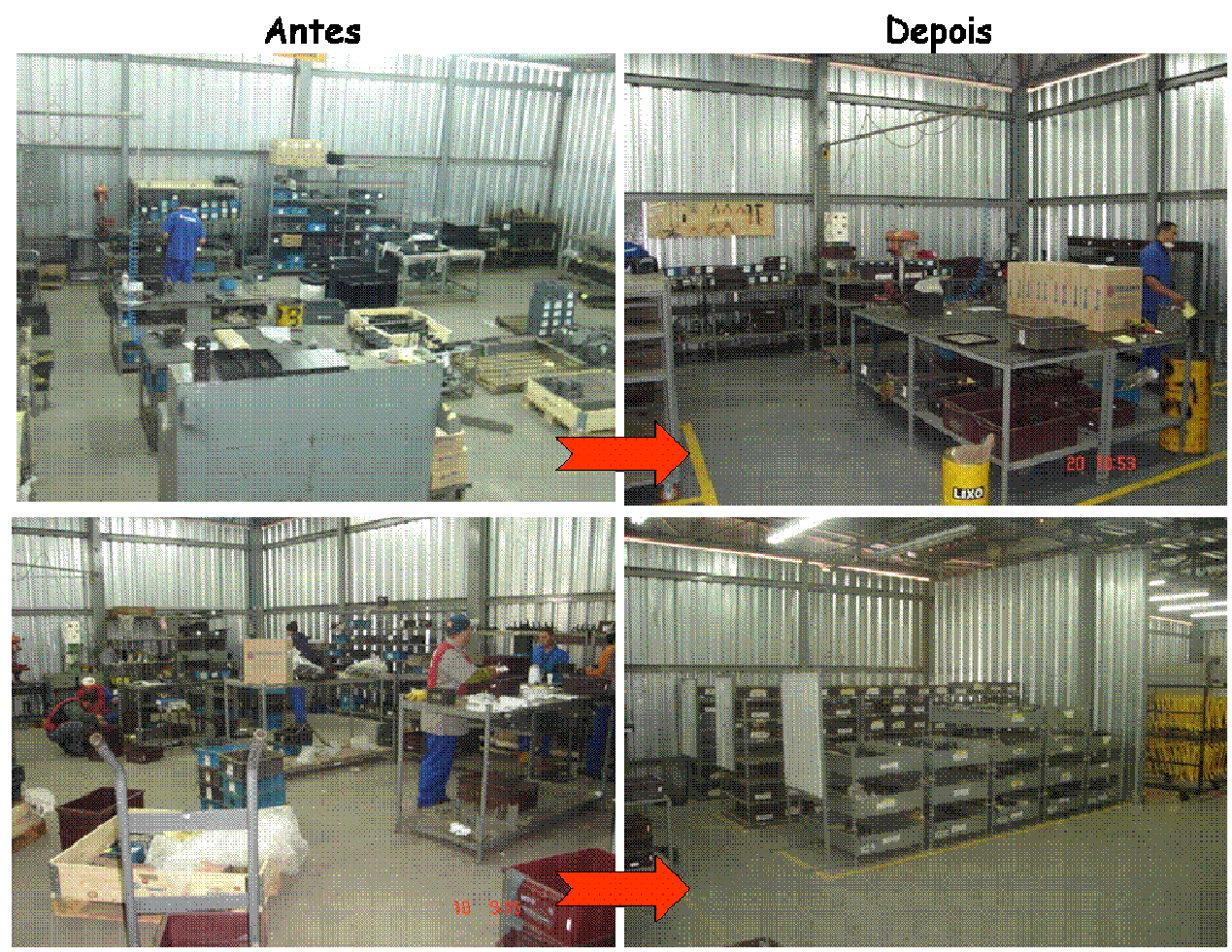

Figura 118: Substituição de um estoque empurrado para a montagem por um supermercado.

Por fim, foi implantado também o supermercado para a expedição.

Este é o ponto de supermercado que abastece o processo puxador (S1). 
Antes

Depois
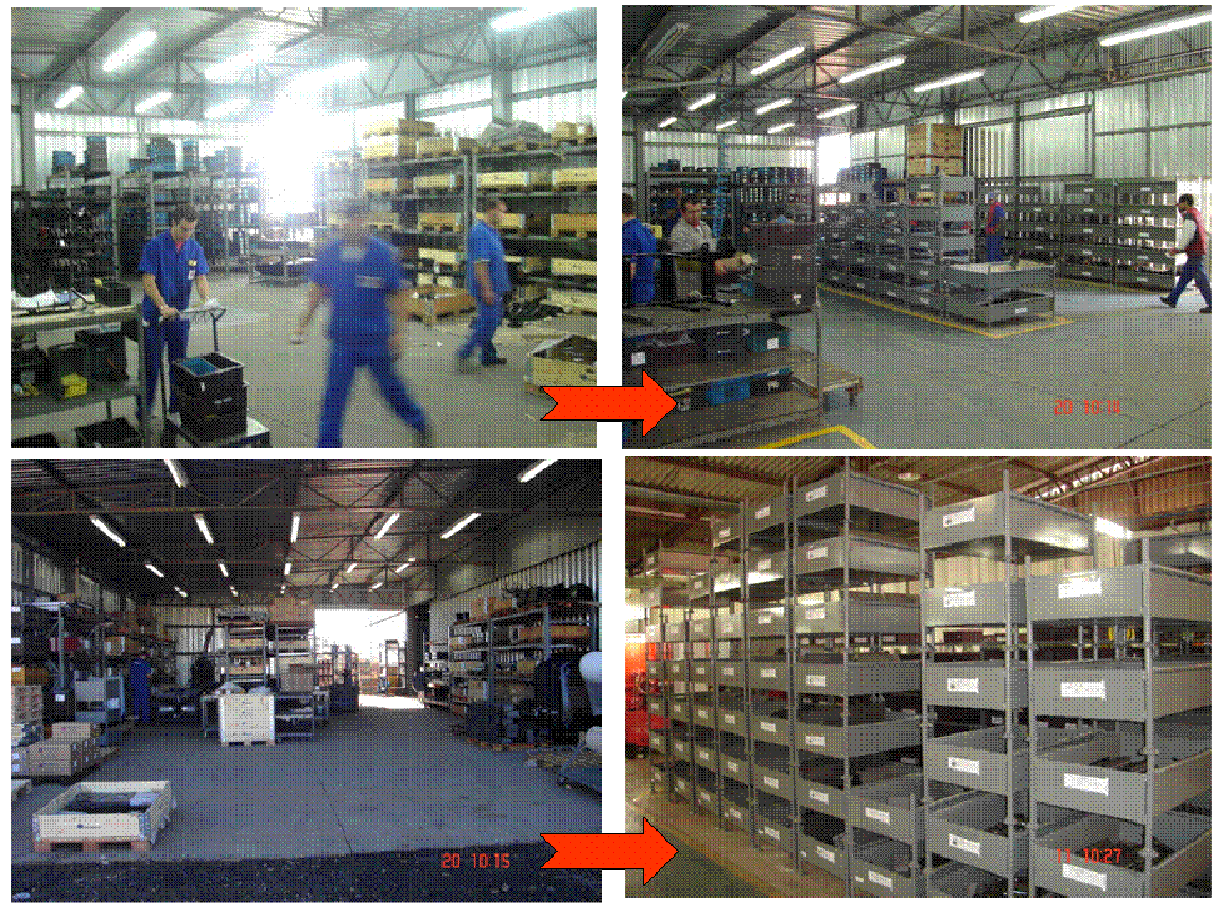

Figura 119: Substituição de um estoque empurrado para a expedição por um supermercado de produtos acabados.

Implantação dos quadros de kanbans para o loop do supermercado de corte laser (S3). Foram colocados 353 itens em kanban disparados a partir desse produtor.
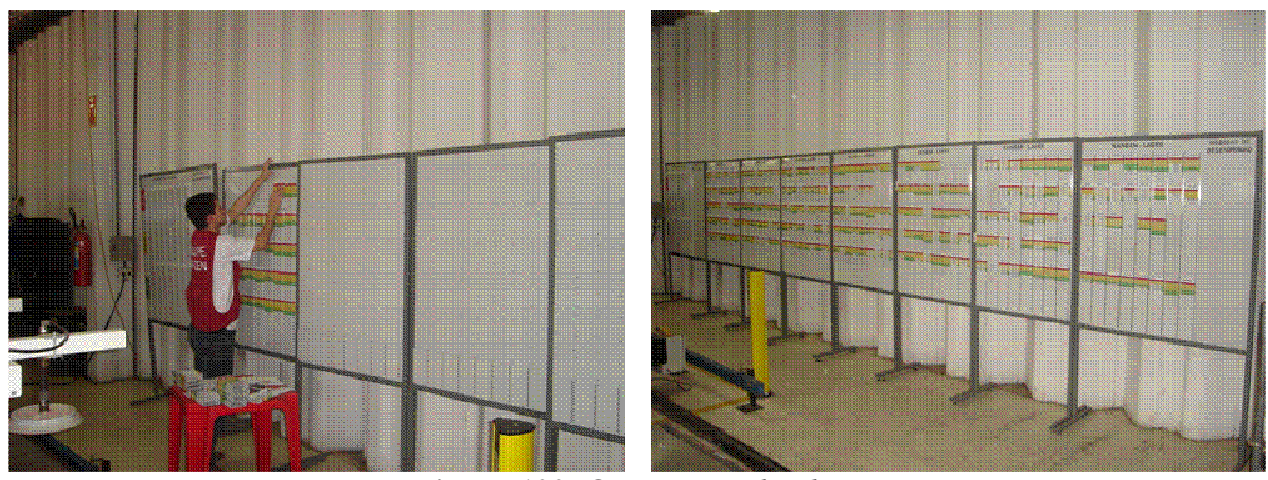

Figura 120: Quadros de kanban

Foi criado também um plano de controle, tendo em vista acompanhar o desempenho da produção. Não conformidades e desvios no cumprimento das metas eram discutidos semanalmente em reuniões com os líderes da fábrica. Planos de ação corretiva eram disparados e acompanhados nessas mesmas reuniões. 
Figura 121: Plano de controle para sustentabilidade das melhorias

\begin{tabular}{|c|c|c|c|c|c|c|}
\hline Métricas & Significado/ Propósito & $\begin{array}{l}\text { Ponto/Procediment } \\
\text { o de Coleta }\end{array}$ & $\begin{array}{l}\text { Expressão de } \\
\text { Cálculo }\end{array}$ & $\begin{array}{l}\text { Freqüência de } \\
\text { Apontamento }\end{array}$ & $\begin{array}{l}\text { Responsável } \\
\text { Apontamento }\end{array}$ & $\begin{array}{l}\text { Freqüência } \\
\text { Compilação }\end{array}$ \\
\hline $\begin{array}{l}\text { Atendimento } \\
\text { completo de } \\
\text { kanbans para o } \\
\text { cliente }\end{array}$ & $\begin{array}{l}\text { Medir o percentual de } \\
\text { kanbans atendidos } \\
\text { totalmente, sem precisar } \\
\text { envio parcial posterior de } \\
\text { peças }\end{array}$ & $\begin{array}{l}\text { Planejamento - } \\
\text { planilha Excell de } \\
\text { kanbans a serem } \\
\text { entregues }\end{array}$ & $\begin{array}{l}\text { Total de kanbans } \\
\text { completos } \\
\text { entregues a } \\
\text { tempo/ Total de } \\
\text { kanbans } \\
\text { solicitados pelos } \\
\text { clientes }\end{array}$ & Diário & Alexandre & Mensal \\
\hline $\begin{array}{l}\text { Atendimento da } \\
\text { Programação } \\
\text { para o cliente }\end{array}$ & $\begin{array}{l}\text { Medir o percentual de } \\
\text { programação dos pedidos } \\
\text { entregues no prazo } \\
\text { correto }\end{array}$ & $\begin{array}{l}\text { Planejamento - } \\
\text { importação de dados } \\
\text { do ERP e compilação } \\
\text { em planilha Excell }\end{array}$ & $\begin{array}{l}\text { Total de pedidos } \\
\text { programados } \\
\text { atendidos } \\
\text { completamente na } \\
\text { semana/ Total de } \\
\text { pedidos } \\
\text { planejados para a } \\
\text { semana }\end{array}$ & Semanal & Bruno & Mensal \\
\hline $\begin{array}{l}\text { Faturamento } \\
\text { médio semanal } \\
\text { por funcionário } \\
\text { da produção }\end{array}$ & $\begin{array}{l}\text { Medir produtividade dos } \\
\text { diversos setores }\end{array}$ & & $\begin{array}{l}\text { Faturamento } \\
\text { semanal/número } \\
\text { de funcionários na } \\
\text { produção }\end{array}$ & Semanal & Junior & Semanal \\
\hline
\end{tabular}

Ao final do evento, foram realizadas apresentações para toda a sobre o novo sistema de produção empresa.
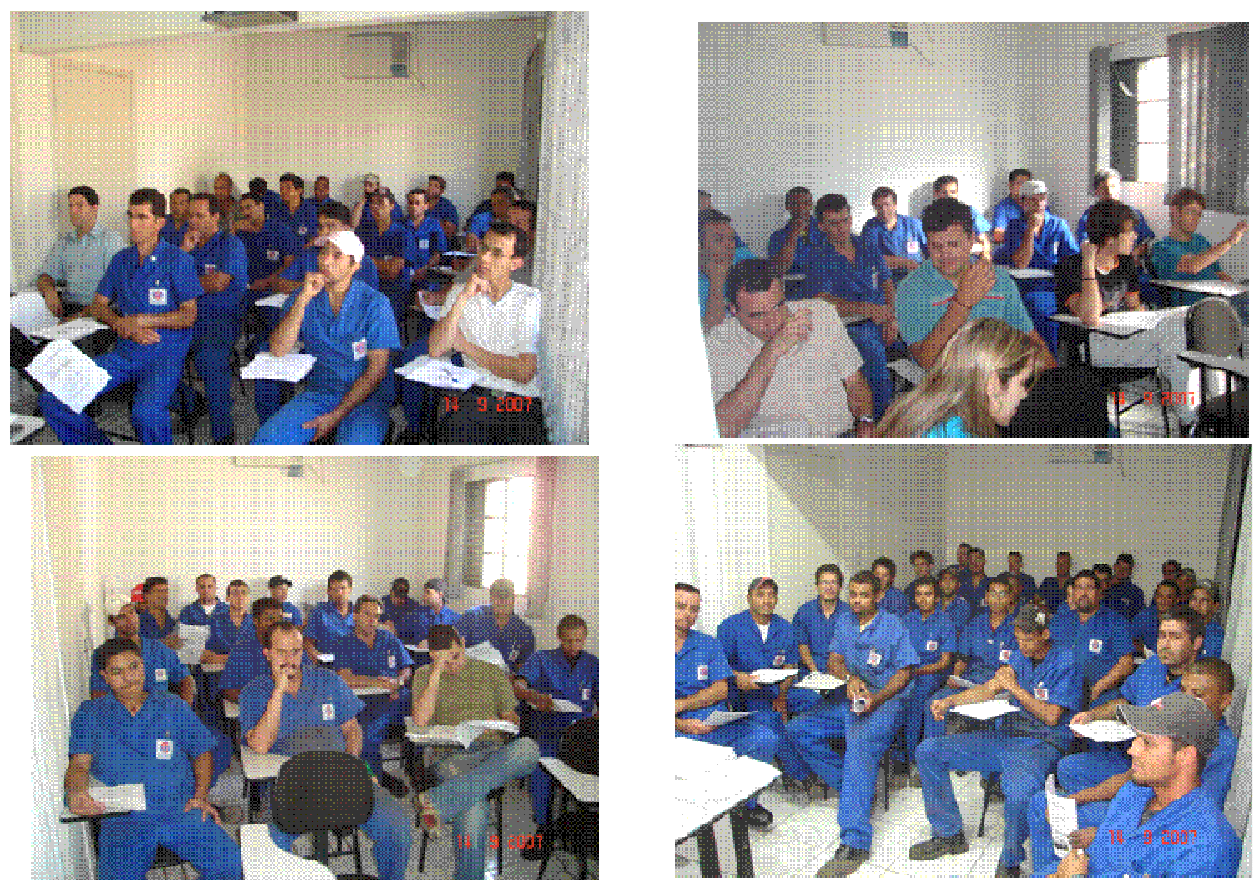

Figura 122: Fechamento e replicação das melhorias para toda a fábrica 
Tendo em vista promover um maior alinhamento entre todos, a empresa decidiu realizar bimestralmente uma semana de atividades em torno do seu sistema de produção. Davam-se assim primeiros passos para o controle e sustentabilidade das melhorias implantadas.

\subsubsection{Resultados obtidos}

Como resultados da aplicação foram identificadas as seguintes melhorias:

Lead Time: Redução de $42 \%$, passando de 26,5 dias para 15,5 dias.

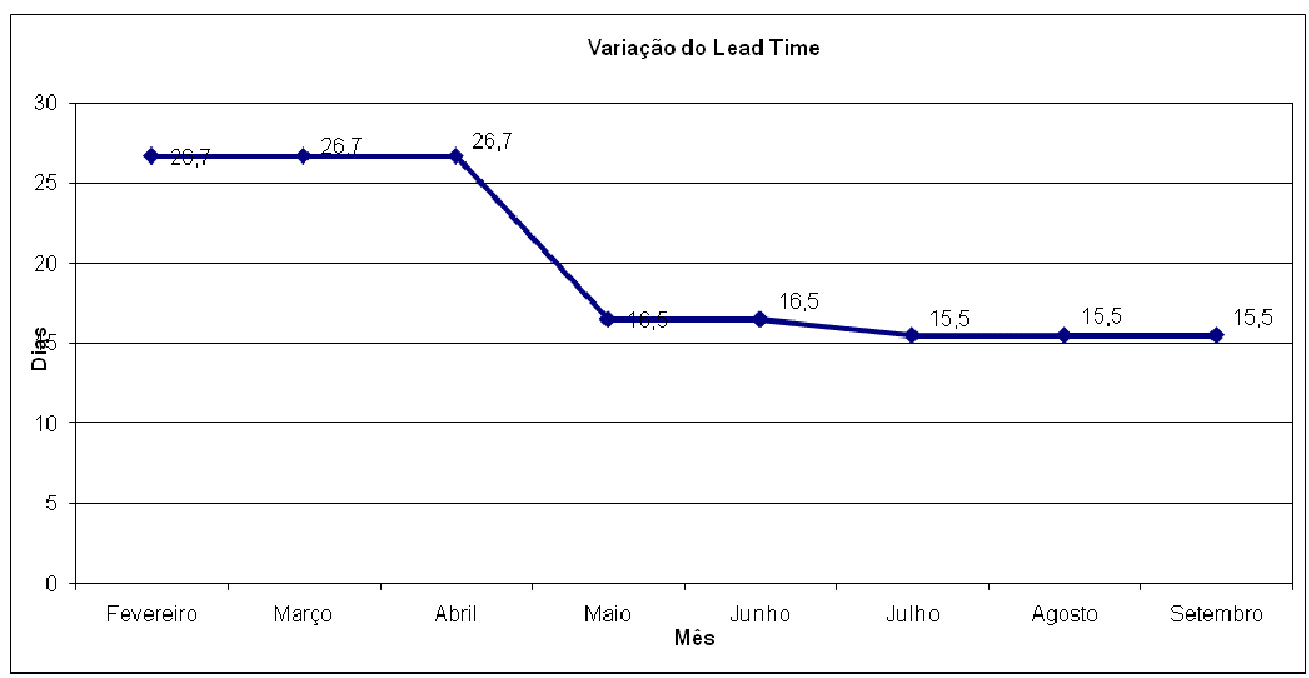

Figura 123: Gráfico de variação do lead time ao longo da implantação

Produtividade: Ganho de $20 \%$ na produtividade global da fábrica. Como não havia medidas de tempo confiáveis, decidiu-se medir a produtividade a partir do faturamento médio por funcionário. Neste caso, assumiu-se que o preço da peça faturada representava com mais fidelidade o grau de dificuldade e, portanto, de tempo consumido, para produzir as peças faturadas no mês. No início das atividades o índice encontrava-se na casa dos $\mathrm{R} \$ 1.000,00$ faturados por funcionário. Quase um ano depois este índice ainda apresenta uma tendência de crescimento já na casa dos $\mathrm{R} \$ 1.200,00$ por funcionário. Vale ressaltar que no mês dezembro não foi feita a medição visto que os principais clientes da fábrica estavam em férias coletiva. 


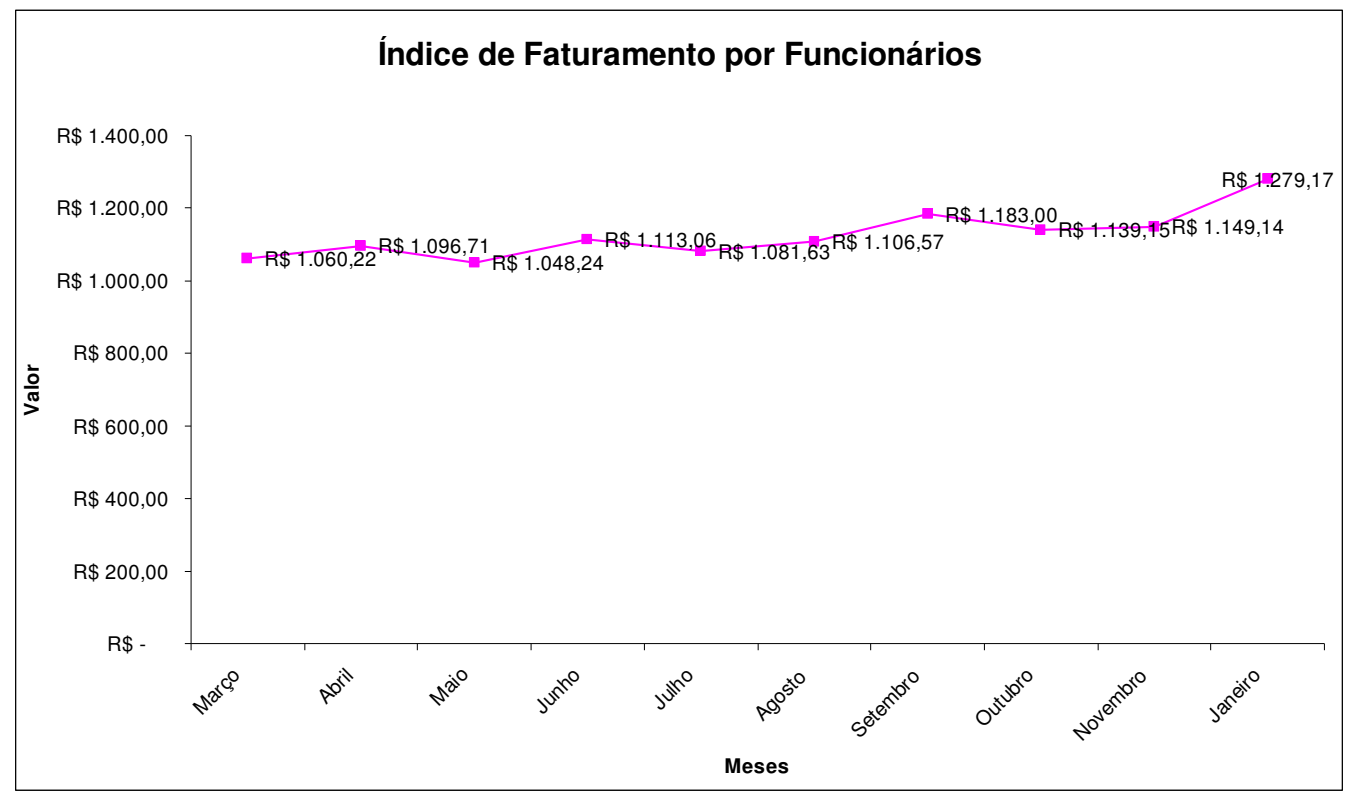

Figura 124: Gráfico do índice de faturamento mensal por funcionário ao longo da implantação

\subsubsection{Considerações sobre a $3^{\text {a }}$. aplicação}

\section{Com relação aos resultados obtidos pela empresa}

O aumento da produtividade em $20 \%$ permitiu que a empresa fizesse frente ao aumento de uma demanda reprimida. A aplicação do sistema lean de PCP híbrido ajudou a empresa a melhorar seu faturamento mensal médio de $\mathrm{R} \$ 3.500 .000,00$ para $\mathrm{R} \$ 5.000 .000,00$. Acredita-se que novamente o método proposto mostrou-se eficaz na obtenção dos objetivos traçados.

\section{Com relação ao método proposto}

A aplicação contribuiu com o método proposto, seja na criação de novos passos ou no aprofundamento daqueles inicialmente concebidos, nos seguintes pontos:

Nivelamento e balanceamento do processo puxador: O quadro macro de nivelamento e balanceamento da solda possibilitou que o líder do setor visualizasse melhor a ocupação de sua capacidade produtiva. No universo das aplicações das ferramentas lean, muito se 
tem falado no combate aos desperdícios. Por outro lado, a necessidade de frentes de trabalho voltadas para o nivelamento e balanceamento do fluxo é um fator crítico de sucesso na implantação de um sistema lean de PCP híbrido.

\section{\& Flexibilização do sistema puxado e a sistemática de empenho: A} utilização da sistemática de empenho como estratégia de flexibilização do sistema puxado evita faltas no processo puxador e sobrecarga nos fornecedores a medida que todos os cartões (no verde, amarelo e vermelho) voltam para o quadro simultaneamente.

\section{Programacão do processo puxador e a criacão de famílias de}

tempo: Assim como na segunda aplicação, havia uma alta variedade de produtos acabados e componentes com diferentes tempos de ciclo. O agrupamento destes itens em famílias de tempo novamente mostrou-se muito importante para simplificar o escopo de levantamento e análise de dados.

\section{O processo de implantacãa e a técnica de Evento Kaizen:} Novamente demonstrou ser uma técnica eficaz na implantação de um novo sistema de PCP.

\section{Desenvolvimento de software de suporte ao dimensionamento e} ajuste do tamanho dos supermercados: Quando se passa a puxar a produção a dinâmica dos kanbans requer não apenas mudanças de paradigmas, mas também do controle informatizado do sistema. Planilhas eletrônicas, de software proprietário como o Microsoft Excel são geradas para o dimensionamento e atualização do tamanho dos supermercados. Em empresas com estruturas de produtos complexas como esta elas estão vulneráveis a uma série de inconsistências. 
Várias planilhas e versões começaram a ser geradas formando uma grande estrutura de informação paralela aos sistemas de informação oficiais da empresa. Após ser testado e validado em três aplicações de 12 meses cada uma, o método estava pronto para ser padronizado em uma ferramenta de suporte.

Uma nova rodada da metodologia de pesquisa foi iniciada a partir de uma nova aplicação. Agora em uma empresa com política de atendimento da demanda do tipo projetar e/ou fabricar sob encomenda (ETO - Engineering To Order). A expectativa é levantar novas necessidades e tornar o método proposto mais robusto. 


\section{4. $\quad 4^{\mathrm{a}}$. Aplicação}

A empresa objeto deste estudo é uma empresa localizada em Sertãozinho - SP. Possui 800 funcionários e fabrica turbinas, cujos principais consumidores são usinas sucroalcooleiras.

Possui uma estrutura de produto altamente complexa e bastante verticalizada. Trabalha com uma política de atendimento da demanda do tipo projetar e fabricar sob encomenda (ETO - Engineering To Order), ou somente de fabricar sob encomenda (MTO - Make To Order). Estas características tornam este tipo de sistema altamente dependente de áreas de suporte, como a Engenharia e Suprimentos. Seus principais processos produtivos são usinagens (leve e pesada), pré-montagens de subconjuntos intermediários e montagem de acabados. Sua principal matéria prima são fundidos e forjados, os quais são obtidos externamente.

Como diagnóstico inicial da empresa levantou-se os seguintes efeitos indesejáveis:

A programação da produção era empurrada para todos os itens, com base nos pedidos colocados em carteira. Isto significa que um simples parafuso era controlado com a mesma rigorosidade de uma carcaça de 5 toneladas.

+ Falta de sincronização: a programação no chão de fábrica encontravase fragmentada em várias células produtivas. Estas células funcionavam como ilhas desconectadas de PCP, cuja sincronização dependia excessivamente da mediação e negociação entre os líderes de cada setor.

+ Fluxo produtivo desbalanceado e desnivelado. As células lidavam constantemente ora com sobrecargas ora com ociosidade.

Fenômeno de falta e sobra de componentes para a montagem final.

* Fluxo de informação e comunicação deficiente entre os setores. As prioridades da Produção nem sempre eram as mesmas da Engenharia e Suprimentos.

\& Gestão visual ausente. 
Atrasos nas entregas para os clientes externos.

Dentre as várias melhorias previstas para combater as disfunções acima, propôs-se o desenvolvimento de um projeto de sistema híbrido de PCP lean. O trabalho iniciou com o Mapa Macro de Fluxo de Valor da Situação Atual. A estrutura de produto é complexa, apresentando vários fluxos de valor em paralelo. Foi considerado o fluxo da fabricação da carcaça para a definição da linha de lead time, pois era o caminho mais demorado e complexo de todos (caminho crítico).

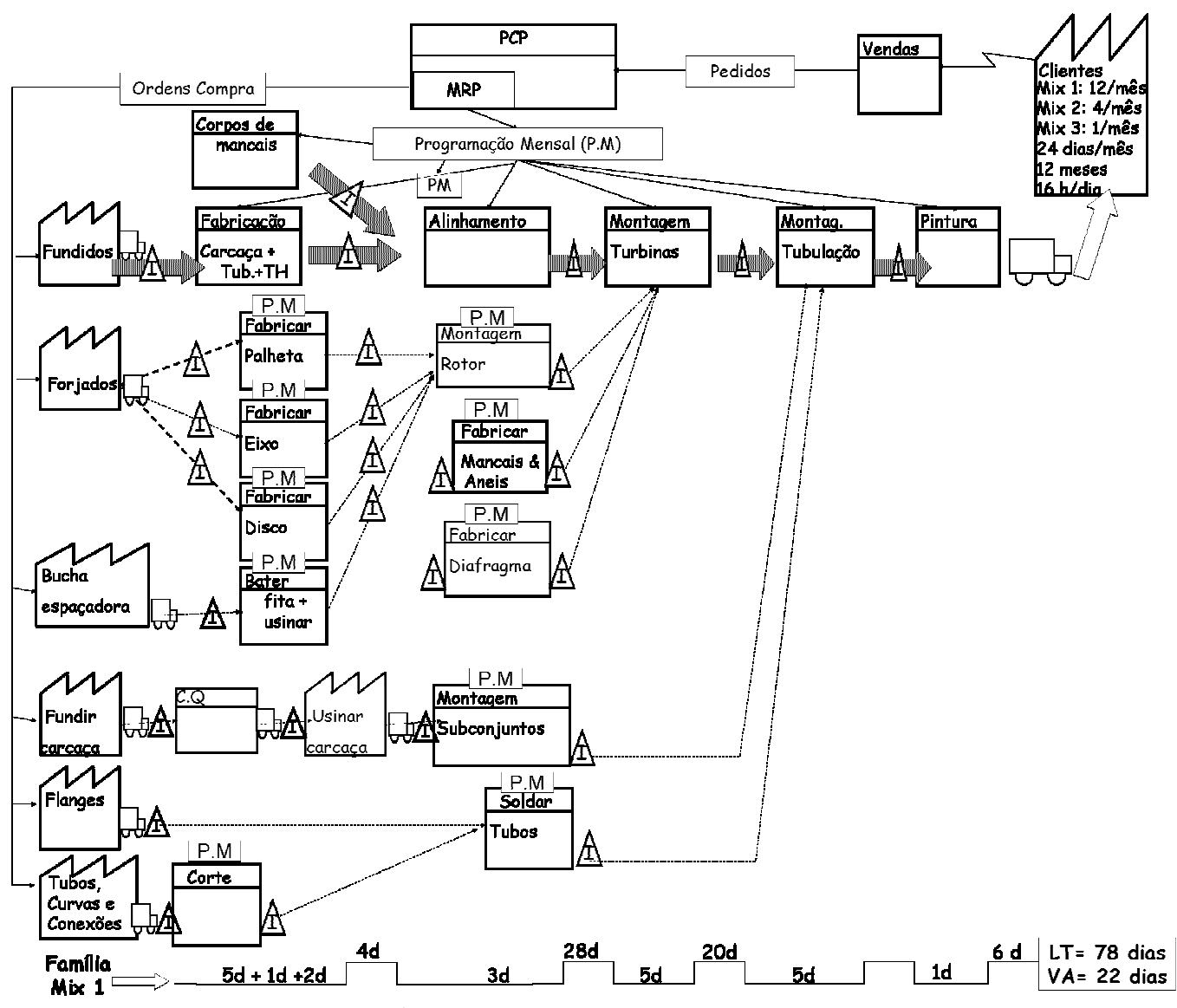

Figura 125: Visão esquemática do mapa macro de fluxo de valor da situação anterior

A partir do mapa, foi possível aprofundar a análise sobre os efeitos indesejáveis apontados na fase inicial do projeto:

Alto Lead Time de produção: o processo de projetar e fabricar uma turbina em si já é naturalmente demorado. O longo fluxo de valor, 
com uma programação empurrada para todos os itens, era constantemente submetido aos mais diversos tipos de problemas no dia a dia. Consequentemente, os fluxos dos componentes de uma mesma turbina nas diversas células acabavam descompassando entre si. Estas esperas para poder fechar a turbina resultavam num alto lead time de produção.

Alto estoque de componentes em processo: À medida que um setor se descompassava dos demais devido a contingências internas (erros de programação, quebra de máquina, falta de desenhos, falta de matéria prima, etc.), começavam as reprogramações em cima da hora. Lotes em processo eram interrompidos e novos lotes de produção eram disparados. O líder de área limitava-se a colocar na linha "aquilo que fosse possível de soldar ou montar no dia", de acordo com a disponibilidade dos respectivos componentes.Com isso, recursos eram usados antes da hora, os estoques em processo eram altos e os itens (re)programados de última hora estavam sempre atrasados.

* Baixa produtividade: Como não havia previsibilidade alguma quanto à inserção dos produtos nas montagens, o processo não conseguia seguir padrão algum. Consequentemente, ele era constantemente acometido por sobrecargas (tirar atrasos) ou por ociosidades (falta de peças). Isso resultava na necessidade de horas - extras, frustrações e desentendimentos internos.

* Baixa rapidez e pontualidade: Em função dos problemas supracitados, os prazos de entrega para o cliente eram altos e constantemente não eram atendidos.

Foi feito o desenho da situação futura, a partir dos qual se iniciou o desenvolvimento do sistema híbrido de programação e controle.

\subsubsection{Projeto do sistema híbrido de planejamento e programação}


O primeiro passo consistiu em definir as famílias de turbinas. As turbinas foram agrupadas em três famílias: mix 1 (turbinas pequenas), mix 2 (turbinas médias) e mix 3 (turbinas grandes). Em seguida, realizou-se uma análise de demanda e constatou-se que o mix 1 era a família com o maior volume de vendas (best seller). Levantaram-se quais itens eram padronizados e que, portanto, poderiam ser produzidos para supermercado. Com base nisso, foram definidos os seguintes pontos de controle.

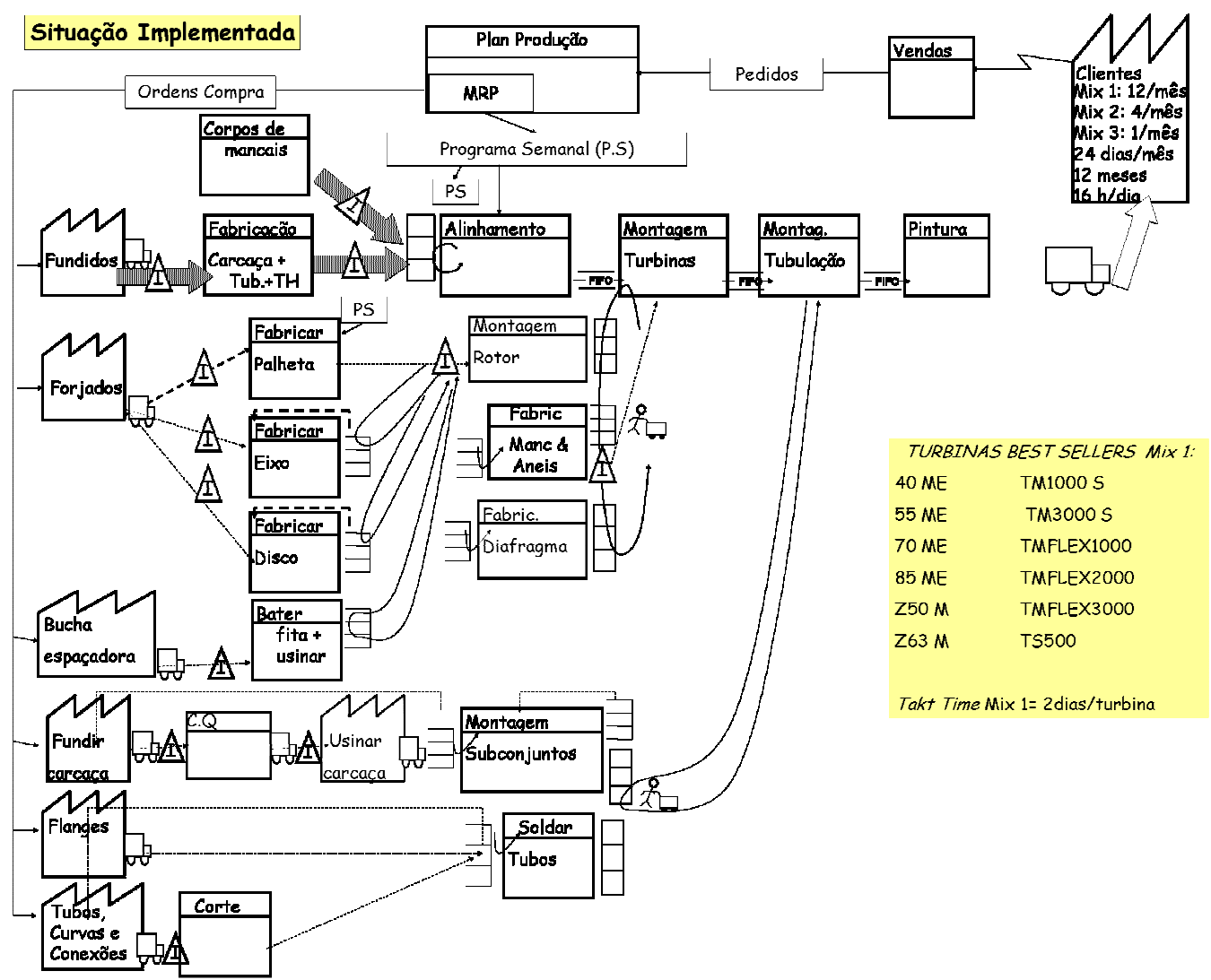

Figura 126: Definição dos pontos de supermercado - 4a . Aplicação

Todos os pontos de supermercado foram definidos com base na necessidade de garantir a disponibilidade dos itens best sellers para as montagens e submontagens (supermercados pulmão). Como todos os componentes eram programados até então de forma ETO ou MTO, a montagem parava constantemente devido á falta de sincronização na chegada dos itens necessários para montar determinado conjunto. Essa estratégia permitiu também que as células pudessem se concentrar nos itens os quais chamaremos aqui de "engenheirados", com política de 
atendimento da demanda do tipo ETO. O fluxo desses itens era mais complexo, pois dependia bastante de um bom fluxo de informação com as áreas de suporte, como a Engenharia e Suprimentos.

Num sistema cuja política de atendimento da demanda é predominantemente do tipo ETO, não foi possível colocar a maioria dos itens de alto valor em supermercado. Normalmente, isso caracterizaria um típico sistema puxado seqüencial, no qual o processo puxador é a primeira operação do fluxo. Contudo, o MRP da empresa já havia dado sinais de que não era o sistema mais apropriado para a programação e controle dos níveis mais baixos e detalhados de atividades. Para controlar as atividades da fábrica nesse nível, procurou-se estabilizar o sistema mediante a formação de pulmão de kits de peças. Com isso, a idéia foi tornar o processo de alinhamento e montagem final (loop 2) numa espécie de processo puxador sobre o qual aplicar-se-ia os tradicionais controles visuais simplificados da produção enxuta. Este processo foi considerado gargalo visto que era o único da empresa que não era possível terceirizar, flexibilizando a capacidade produtiva. 


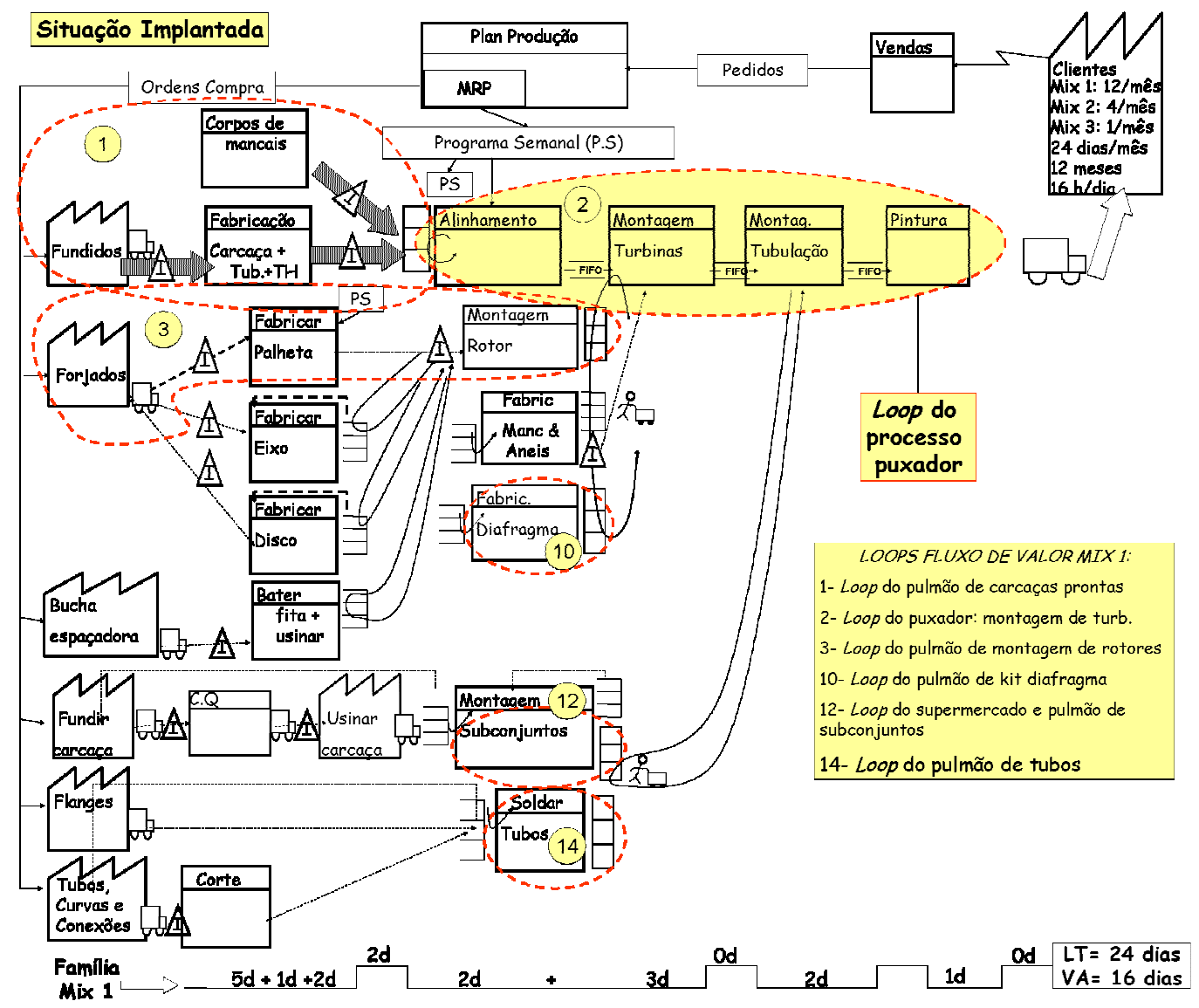

Figura 127: Definição do processo puxador

O emprego do conceito de pulmão de kits de peças mostrou-se bastante alinhado com a filosofia lean para este tipo de implantação, visto que direciona as células a fabricarem todo o kit de componentes de uma mesma turbina. Essa idéia, aparentemente simples, revolucionou o paradigma de produção da empresa, combatendo os desperdícios de superprodução, esperas e estoques desnecessários de turbinas (produtos acabados) na montagem final à medida que a impossibilitou de iniciar as montagens de forma parcial. Enquanto o kit não ficasse pronto, a montagem não poderia ser iniciada. As células produtoras também não poderiam utilizar eventuais lacunas de capacidade para iniciar a fabricação de componentes de uma outra turbina, enquanto o estoque pulmão da turbina anterior estivesse cheio. A idéia era forçar os subsistemas a focarem seus esforços na formação do kit, mesmo que para isso nenhuma atividade produtiva fosse realizada. Naturalmente, exceções eram permitidas com a autorização do gerente de produção. 
O próximo passo foi definir quais desses itens seriam controlados de forma puxada e quais seriam controlados de forma empurrada, ou seja, mediante ordem de produção.

\subsubsection{Definição das subfamílias de programação e controle}

Para a definição das subfamílias de programação e controle, primeiramente, foram delimitados todos os loops de produção.

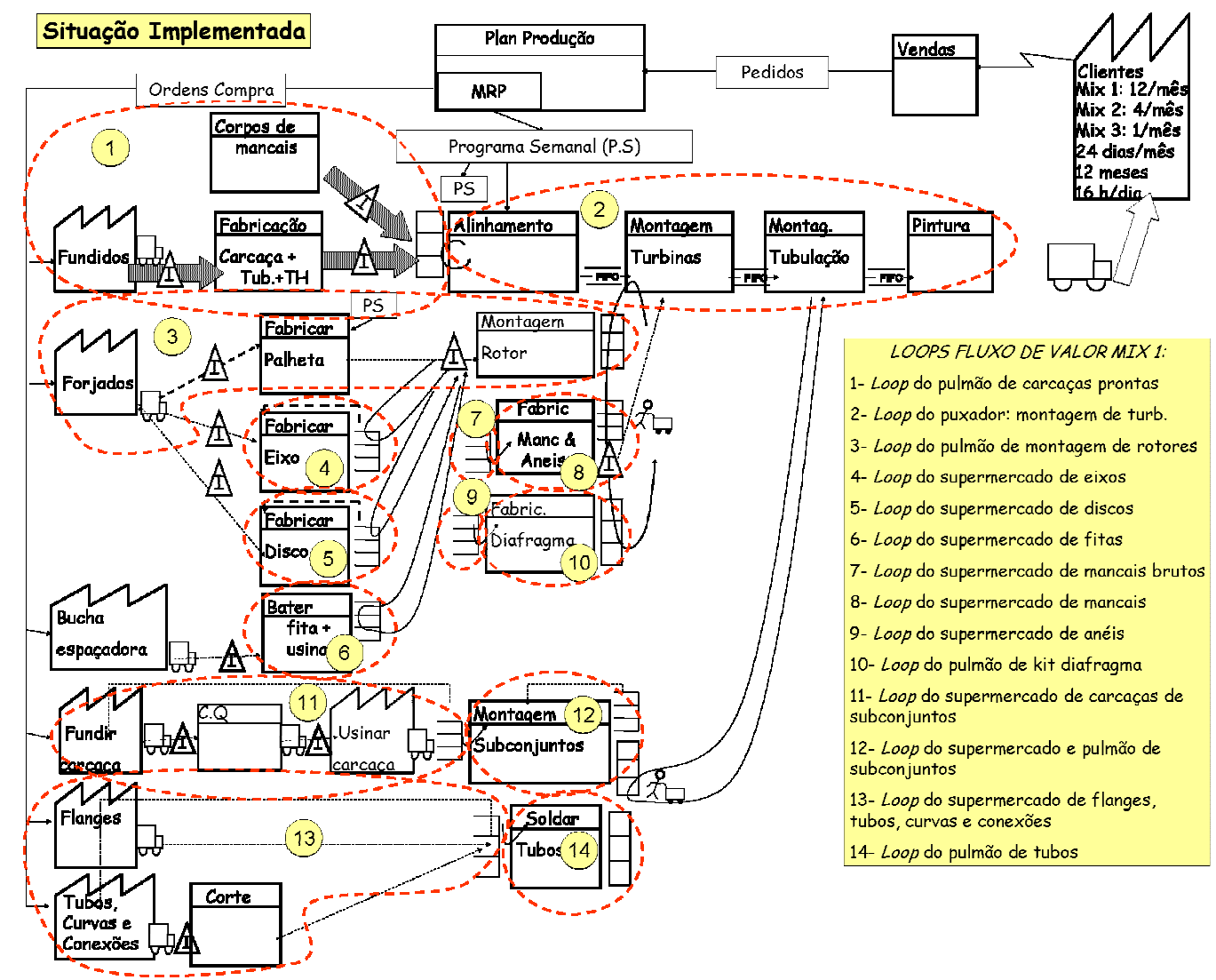

Figura 128: Identificação dos loops de produção

Assim como nas demais aplicações, os fatores de referência utilizados para definir o tipo de controle mais adequado foram:

* Volume da demanda: Levantado com base na previsão da demanda dos três meses seguintes, os itens foram classificados em Alto, Médio e Baixo Volume. 
\& Frequiência da demanda: Baseado na relação entre a média de consumo e o desvio padrão de cada item no período considerado. Custo: Esta classificação foi dividida em Alto e Baixo Custo.

Segue abaixo a tabela com os critérios utilizados para a definição do tipo de controle e do tamanho do TPT. Foram definidas quatro subfamílias de controle. O agrupamento dos itens nestas subfamílias foi feito com base na faixa de freqüência, volume e custo em que cada um se encontrava.

\begin{tabular}{|c|l|l|l|l|l|l|l|}
\hline Sub-família & Loops & Tipo & Frequencia & Volume & Custo & Controle & TPT \\
\hline 1 & $1,3,10$ e 14 & Fabricados & Baixa & Baixo & Alto & Pulmão de Tempo & 2 dias \\
\hline 2 & $4,5,6,11,12$ e 13 & Fabricados & Alta & Baixo & Médio & Kanban & 4 dias \\
\hline 4 & $4,5,6,11,12$ e 13 & Comprados & Alta & Alta & Baixo & 2 Gavetas & 20 dias \\
\hline 3 & 7,8 e 9 & Fabricados & Alta & Médio & Médio & Kanban & 10 dias \\
\hline 4 & 7,8 e 9 & Comprados & Alta & Alta & Baixo & 2 Gavetas & 20 dias \\
\hline
\end{tabular}

Quadro 61: Definição das subfamílias de controle

Na próxima etapa serão detalhadas e validadas as definições de tipos de controles e do tamanho do pulmões e dos supermercado discutidos nesta etapa.

\subsubsection{Dimensionamento do tamanho dos pulmões e supermercados}

A demanda dos itens da subfamília 1, mesmo sendo relativamente a maior, ainda foi considerada como sendo de baixo volume e alto custo, visto que os componentes da turbina são de altíssimo valor agregado. Por isso, para a maioria dos loops de produção $(1,2,3,4,5,6$ e 10) decidiu-se que o tamanho de cada supermercado ou pulmão das turbinas best sellers seria de apenas um item, para os loops 1, 3 e 10, ou de dois itens para os loops 4, 5 e 6. Como a demanda média mensal (20 dias úteis) era de aproximadamente 10 turbinas, decidiu-se, portanto, trabalhar com um TPT tentativa de dois e quatro dias, respectivamente.

Foi avaliado que os loops 1 e 2 pertenciam ao fluxo de valor crítico (mais demorado). Logo, a linha de tempo do sistema mapeado (LT= Lead Time) foi definida com base neste fluxo de valor, conforme ilustrado na figura abaixo. 


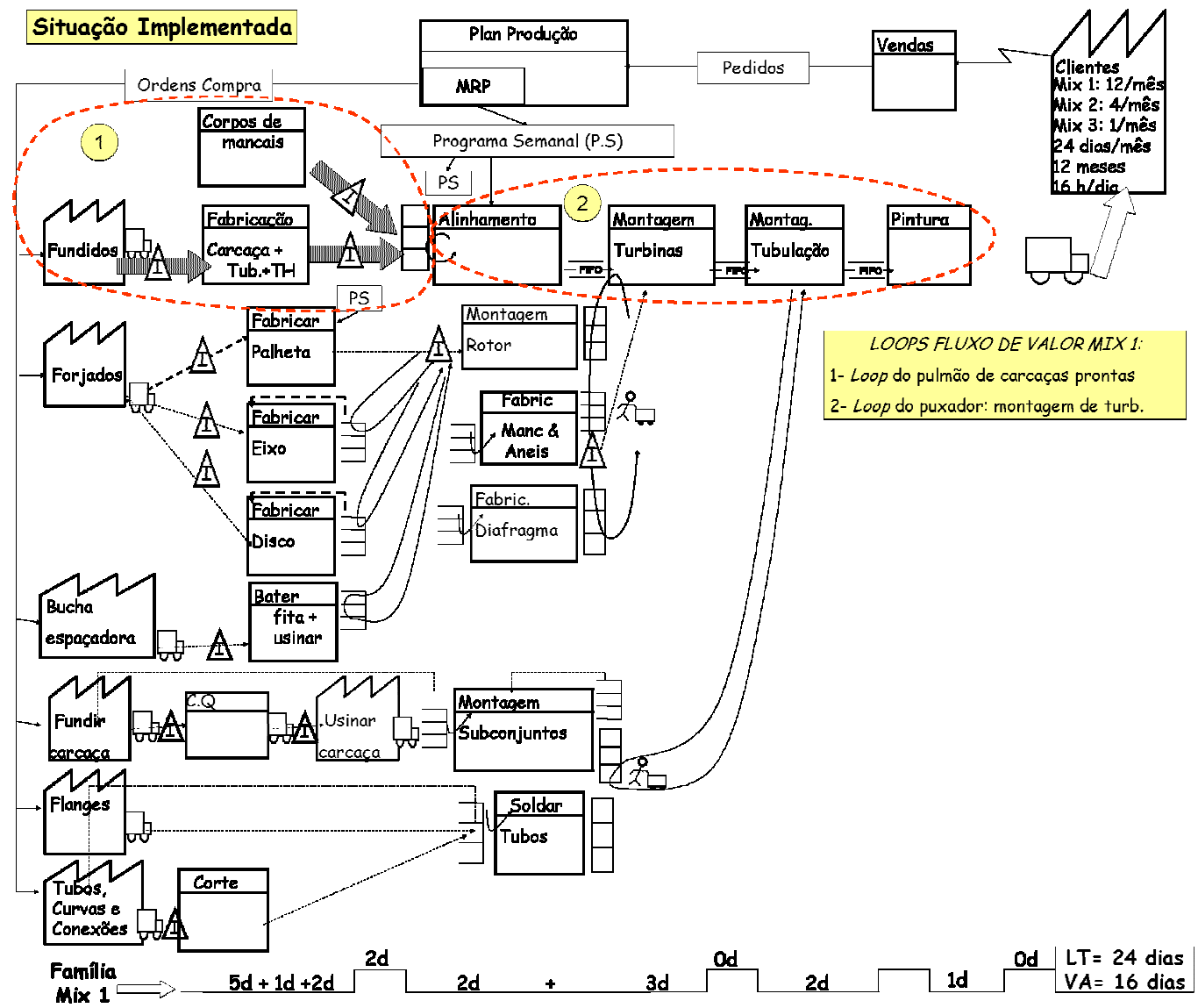

Figura 129: MFV da situação implantada com a linha de tempo

Já os loops 7, 8 e 9 pertenciam ao setor de internos, o qual fabricava mancais, anéis e buchas de vedação. Este setor era constantemente acometido tanto por sobrecargas quanto por ociosidades, visto que ele era compartilhado por outra unidade de negócios da empresa, a Assistência Técnica. Para este setor seria necessário o cálculo de TPT de uma forma mais minuciosa. Para isso, o macro processo de fabricação de mancais foi explodido num fluxo de valor mais detalhado. 


\section{Situação Anterior}

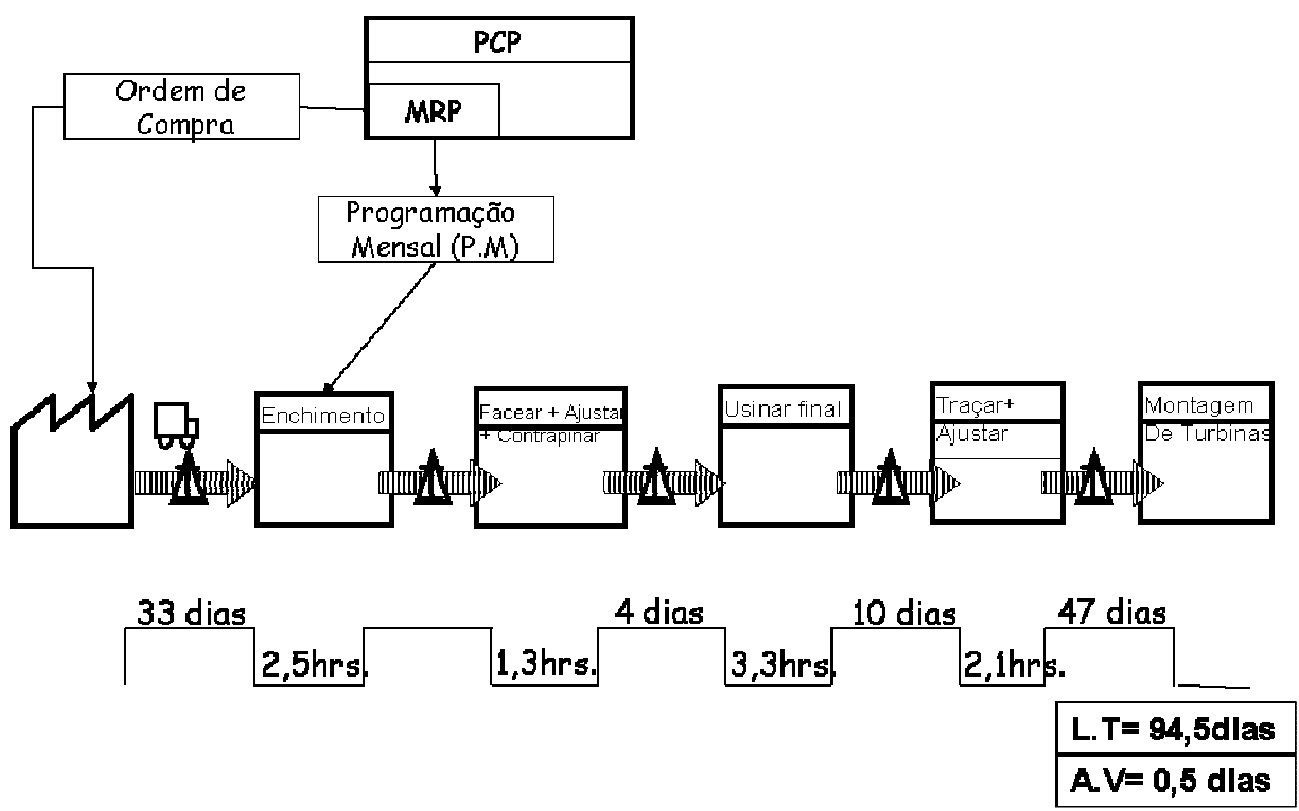

Figura 130: MFV da situação anterior do fluxo de internos

Em seguida, foi elaborado o MFV de situação futura no qual foram definidos os pontos de supermercado e identificados os loops de produção.

\section{Situação Implantada}

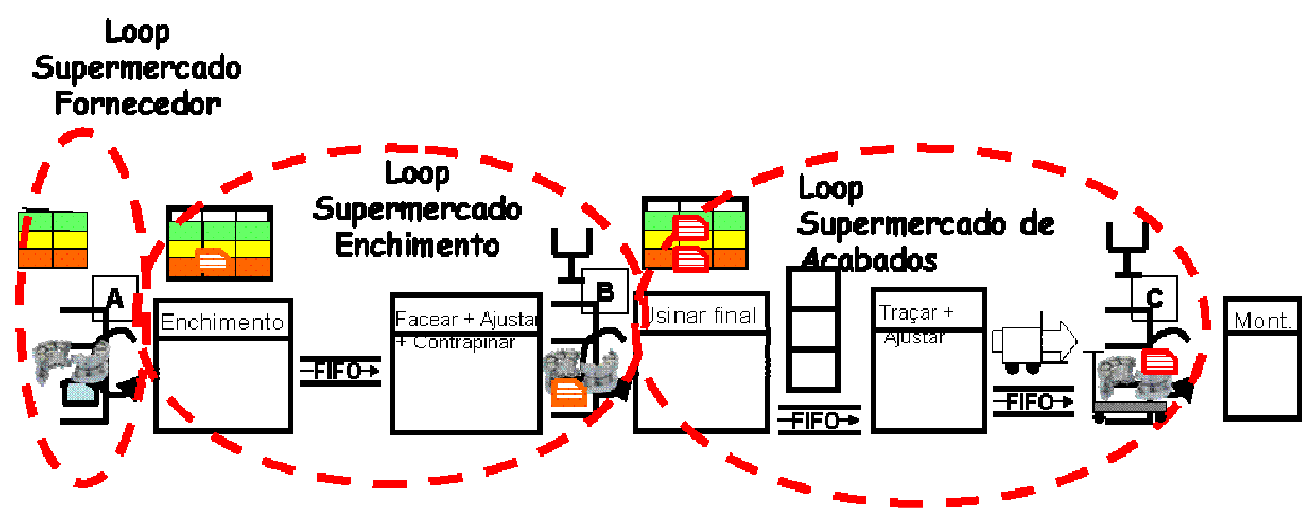

Figura 131: MFV da situação implantada do fluxo de internos - $4^{\text {a }}$. Aplicação

O cálculo do TPT de todo o fluxo foi feito com base no loop do supermercado de acabados. Neste loop encontrava-se o recurso gargalo de todo o 
fluxo, que eram os tornos de usinagem. Após o levantamento de todas as peças que passavam por estes recursos, chegou-se a um TPT de 10 dias.

CÁLCULO DO TPT (TODA PARTE TODA...)
\begin{tabular}{c|c|c|c|c|c|}
$\begin{array}{c}\text { Télculo do TPT } \\
\text { Disponivel (min) }\end{array}$ & $\begin{array}{c}\text { Tempo Ciclo } \\
\text { Total (min) }\end{array}$ & $\begin{array}{c}\text { Tempo } \\
\text { Restante para } \\
\text { Setup (min) }\end{array}$ & $\begin{array}{c}\text { Tempo Setup } \\
\text { Total (min) }\end{array}$ & $\begin{array}{c}\text { Qde Máxima } \\
\text { de Ciclos de } \\
\text { Setups (mês) }\end{array}$ & TPT (dias) \\
\hline 18900,00 & 9555,00 & 9345,00 & 4662,00 & 2,00 & 10,00 \\
\hline
\end{tabular}

Quadro 62: MFV da situação anterior do fluxo de internos - 4a . Aplicação

A figura abaixo ilustra como ficou o MFV implementado para os itens em supermercado com a respectiva linha de tempo (lead time).

\section{Situação Implantada}

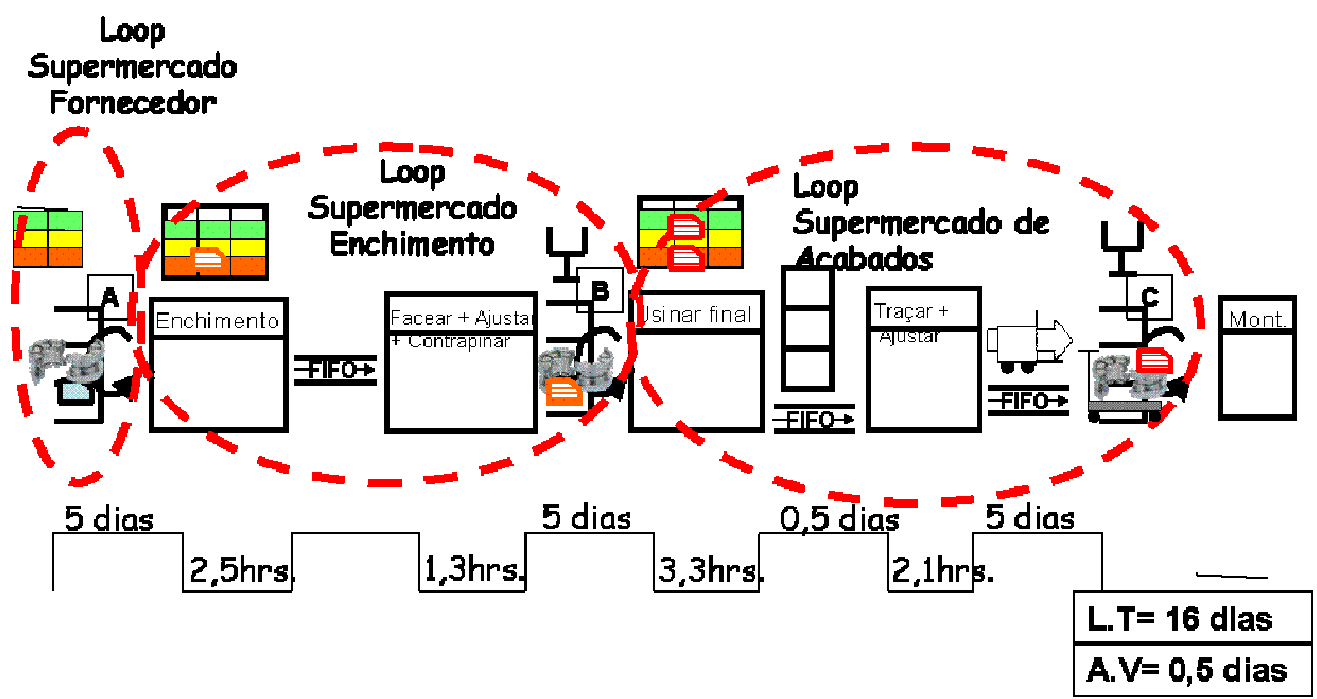

Figura 132: MFV da situação implantada com a linha de tempo

A seguir, foram definidas as sistemáticas de programação e controle para cada subfamília.

\subsubsection{Definição das sistemáticas de programação e controle}




\subsubsection{Programação e controle dos itens MTO/ETO}

Na subfamília de programação e controle 1 foi adotada uma estratégia híbrida para os fluxos regulados por ordem de produção. Nos níveis mais altos de controle: planejamento agregado da produção, programação-mestre e planejamento de insumos, as ordens continuaram a serem emitidas pela sistemática de Lote a Lote dos sistemas MRP, dimensionados estritamente de acordo com cada demanda em cada período. Ao mesmo tempo, nos níveis mais baixos e detalhados de atividades os fluxos empurrados passaram a ser regulados por pulmões, atuando como pontos de controle intermediários.

Para ilustrar melhor essa lógica, será apresentada a seguir uma visão esquemática do loop de montagem do rotor, um importante subconjunto que, por sua vez, será montado no produto final. A montagem do rotor depende da chega sincronizada principalmente dos eixos e das palhetas. Como nem todos os eixos foram possíveis de serem fabricados para supermercado, criou-se dois fluxos empurrados em paralelo: o de eixos e o de palhetas. Era comum a área de montagem ficar ocupada tanto com eixos quanto com palhetas de diferentes ordens de produção, aguardando o seu respectivo par. O MRP demorava em responder aos atrasos no nível das atividades do chão de fábrica, os quais só eram sentidos na montagem final do produto, no fim do fluxo de valor. 


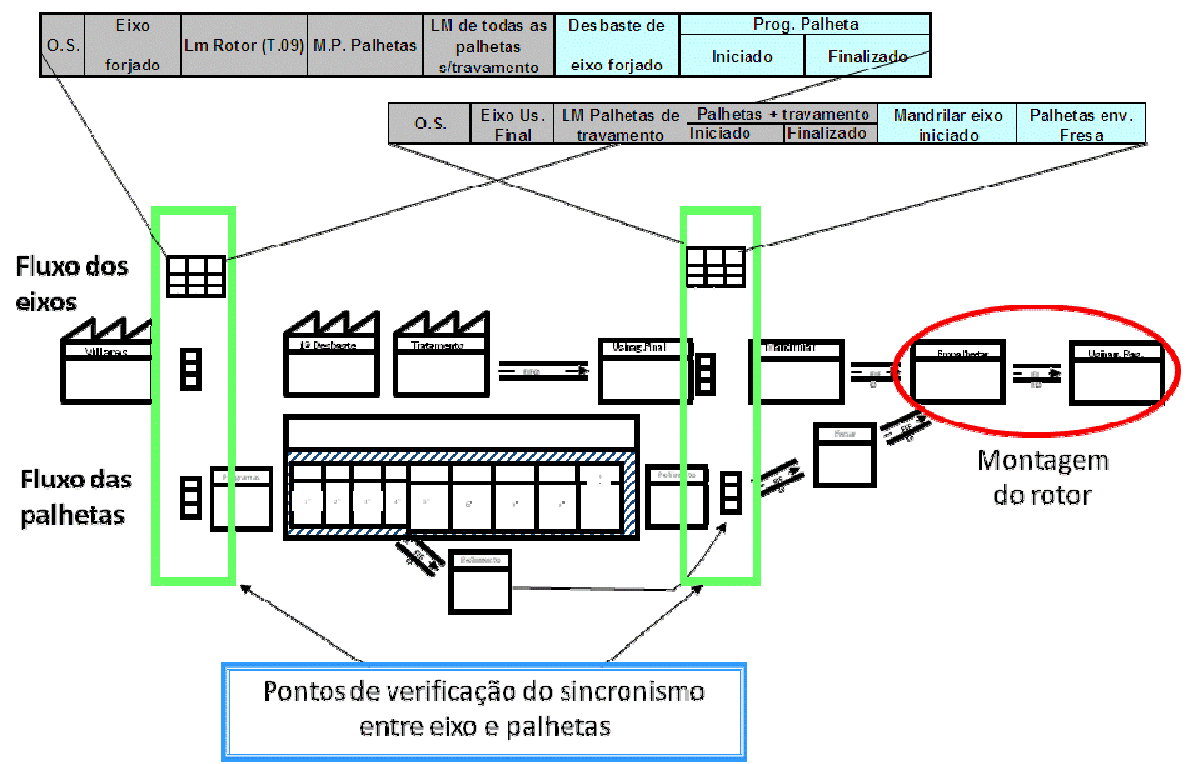

Figura 133: Visão esquemática do loop 3 de montagem do rotor

Foram criados dois sub-loops, cada um com dois pontos de pulmão. O objetivo desses pontos de pulmão era o de sincronizar a produção dos itens de uma mesma ordem nos dois fluxos paralelos. Ao mesmo tempo, a idéia era tornar esses pulmões em pontos de controle intermediários, evitando que atrasos e faltas de peças fossem percebidos e trabalhados somente no final do fluxo de valor. A instauração de "crises" e dos respectivos planos de ação deve ser gerada bem antes disso.

Para cada ponto de pulmão, foi projetado um quadro visual para suporte à tomada de decisões, tais como realizar ações corretivas para tirar os atrasos, ou, até mesmo, reprogramar a operação gargalo. Reprogramar a operação gargalo significava muitas vezes impedir que o recurso fosse utilizado muito antes do necessário por um item, o qual ficaria, logo adiante, parado em estoque esperando pelo seu par produzido em um fluxo paralelo e que eventualmente estivesse atrasado. A equipe entendia que esse fato submetia o gargalo ao desperdício de superprodução, ou seja, produzir muito antes do necessário resultando tanto em filas (de outros itens cuja programação estivesse no prazo) quanto em estoques desnecessários (no caso, desse item em questão). 


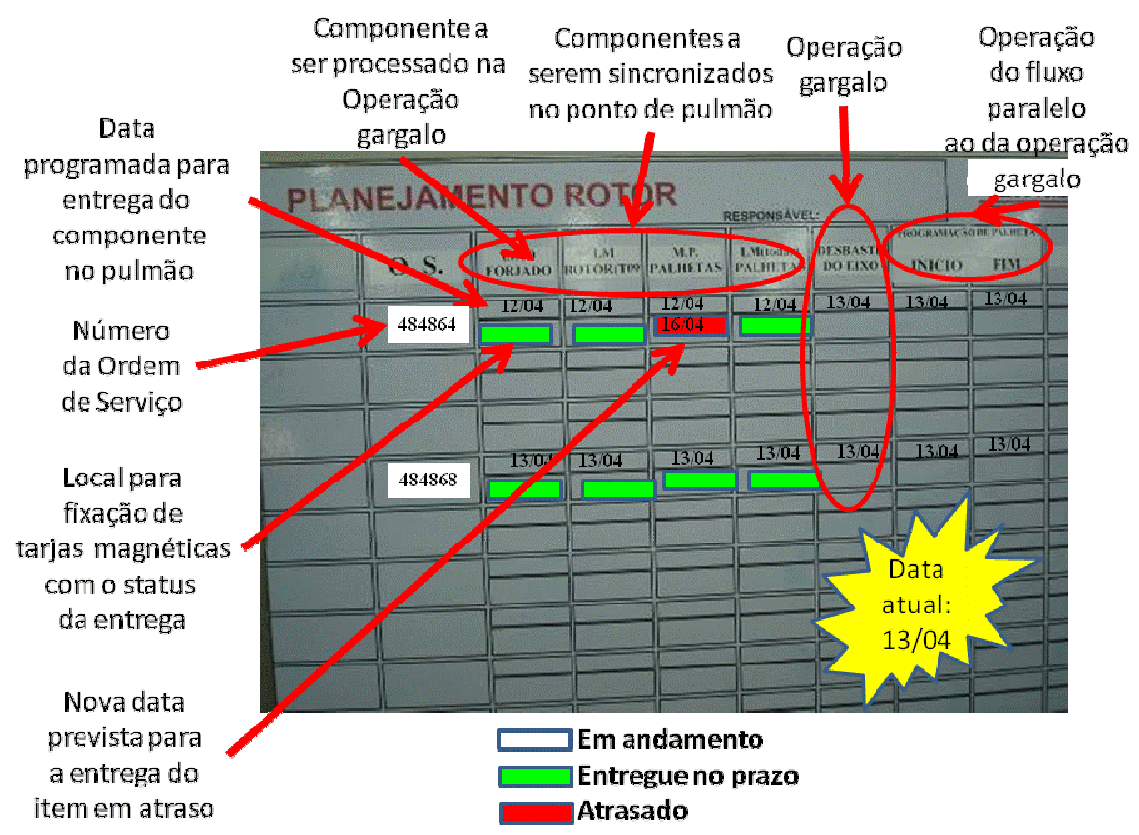

Figura 134: Quadro de programação sincronizada do gargalo com os demais fluxos em paralelo

No quadro, não eram sincronizados apenas os fluxos de materiais fornecidos tanto pelo setor produtivo quanto pela área de suprimentos (itens comprados), mas também, todos os desenhos necessários fornecidos pelo setor de Engenharia. Em sistemas ETO, é comum desperdícios de esperas no fluxo de material devido ao atraso no fornecimento de informações pelas áreas administrativas.

A seguir, serão detalhados os procedimentos de programação e controle dos fluxos puxados. Neste sistema, predominantemente ETO, os supermercados implantados, embora importantes na estabilização de alguns fluxos, acabaram assumindo um papel de coadjuvante no sistema de planejamento e programação da empresa.

\subsubsection{Programação e controle dos fluxos puxados}

Para as peças controladas pelo sistema kanban, decidiu-se trabalhar com a política de reposição por ciclo de pedidos constante. 


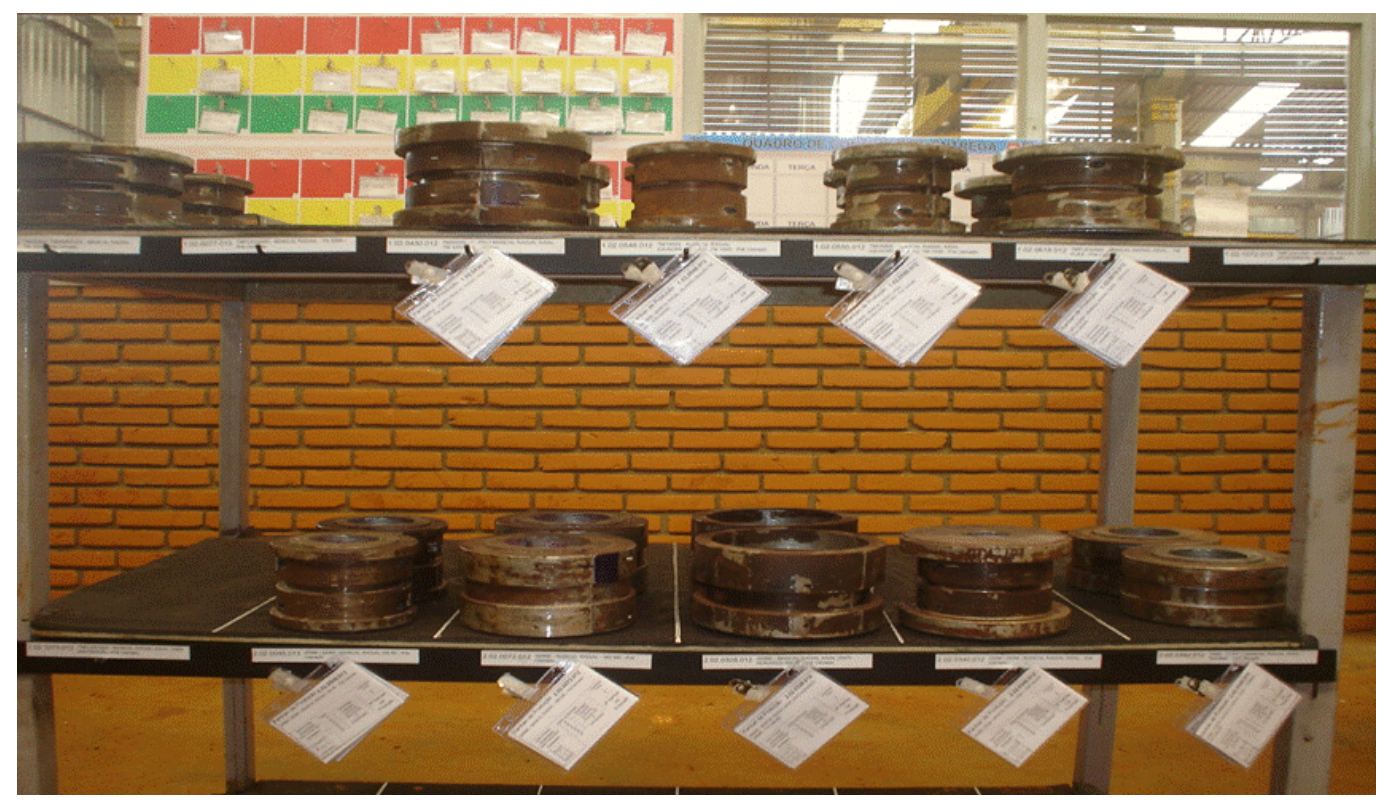

Figura 135: Supermercado de mancais (loop 8) e quadros de kanban ao fundo.

O próximo passo foi preparar este sistema para as flutuações da demanda.

\subsubsection{Flexibilização dos fluxos puxados}

O primeiro passo para a flexibilização do sistema de controle puxado foi determinar os intervalos para reavaliação e ajuste do tamanho dos supermercados. A periodicidade dos ajustes foi definida com base na sazonalidade da demanda da empresa. Levantou-se que trimestralmente seria necessário um ajuste no sistema. As janelas de tempo para ajuste foram:

\section{Jan-Abr; Mai-Ago; Set-Dez.}

Além disso, foi decidido que o modo de ajuste seria através da inserção ou retirada de kanbans, ao invés de alterar a quantidade de itens por kanban.

Foi feita uma legenda de referência com os períodos de ajuste do sistema puxado. 


\begin{tabular}{|l|l|c|c|l|l|}
\hline \multirow{2}{*}{ Janela } & Loops & $\begin{array}{c}\text { TPT } \\
\text { (dias) }\end{array}$ & $\begin{array}{c}\text { Lead Time } \\
\text { Reposição } \\
\text { (dias) }\end{array}$ & $\begin{array}{c}\text { Aumento da Demanda: } \\
\text { Inserir Kanban } \\
\text { (VERDE + AMARELO) }\end{array}$ & $\begin{array}{l}\text { Redução da Demanda: } \\
\text { Retirar Kanbans } \\
\text { (AMARELO) }\end{array}$ \\
\hline \multirow{2}{*}{ Jan-Abr } & $4,5,6,11,12$ e 13 & 4 & 1 & até 24/dez & apartir de 30/dez \\
\cline { 2 - 6 } & 7,8 e 9 & 10 & 1 & até 20/dez & apartir de 30/dez \\
\hline \multirow{2}{*}{ Mai-Ago } & $4,5,6,11,12$ e 13 & 4 & 1 & até 24/abr & apartir de 30/abr \\
\cline { 2 - 7 } & 7,8 e 9 & 10 & 1 & até 20/abr & apartir de 30/abr \\
\hline \multirow{2}{*}{ Set-Dez } & $4,5,6,11,12$ e 13 & 4 & 1 & até 24/ago & apartir de 30/ago \\
\cline { 2 - 7 } & 7,8 e 9 & 10 & 1 & até 20/ago & apartir de 30/ago \\
\hline
\end{tabular}

Quadro 63: Flexibilização do tamanho do supermercado por janelas de tempo

Para definição do momento do ajuste foram considerados a defasagem de tempo entre cada loop e se a situação se tratava de aumento ou redução da demanda da peça.

Em situações de aumento da demanda, o momento para a inserção de cartões considerou o tempo de ciclo (TPT) mais o tempo de reposição, que é o cenário mais pessimista com relação ao tempo que o ajuste demoraria para refletir na quantidade de peças disponível para o próximo loop (consumidor).

Em situações de redução da demanda, o momento para retirada de cartões considerou apenas o tempo de reposição. O tempo de ciclo (TPT) não foi contemplado na defasagem do tempo, tendo em vista evitar que a redução refletisse antes da hora na quantidade de peças disponível para o loop consumidor.

Para auxiliar na manutenção do sistema puxado foi utilizado o software para dimensionamento e ajuste de supermercados desenvolvido na aplicação anterior.

\subsubsection{Programação e nivelamento do processo puxador}

Conforme já foi abordado na seção 4.4.4.1 desta aplicação, foi adotada uma estratégia híbrida para as subfamílias ETO e MTO. Nos níveis mais altos de controle: planejamento agregado da produção, programação-mestre e planejamento de insumos, as ordens continuaram a serem emitidas pela sistemática de Lote a Lote dos sistemas MRP. Ao mesmo tempo, nos níveis mais baixos e detalhados de atividades dessas subfamílias passaram a ser reguladas por pulmões de sincronização, como pontos de controle intermediários. 
Portanto, nos níveis mais altos, o processo puxador continuou sendo a primeira operação do fluxo de valor (sistema puxado seqüencial), programado com a ajuda do sistema MRP. Nos níveis de controle mais baixo, das atividades da fábrica, assumiu-se os processos de alinhamento e montagem com sendo o processo puxador.

Mesmo sendo sistemas com características diferentes da Produção Enxuta, procurou-se harmonizá-los com alguns princípios da programação enxuta. Para isso, a programação dos processos puxadores supracitados foi fundamentada nos seguintes princípios:

\section{Gestão visual: da programação da turbina ao longo de todo o}

fluxo de valor: Foi projetado um quadro para tornar visual o status de cada Ordem em cada um dos processos pertencentes aos loops supracitados. A idéia foi promover a integração entre os diferentes loops através de reuniões de alinhamento entre os respectivos líderes de fluxo de valor.

\& Sincronismo: O objetivo era garantir a amarração entre os diferentes componentes de uma mesma Ordem de Produção.

$\$$ Senso de ritmo: Visão da quantidade média de turbinas, componentes e subconjuntos em cada um dos loops supracitados.

Balanceamento da carga de trabalho: o balanceamento do puxador final não garantia o balanceamento de todos os setores. Por isso, era necessário que o sistema de PCP fosse robusto o suficiente para balancear a carga de trabalho em todos os setores.

Primeiramente, o planejamento e programação da produção foram divididos em três níveis de controle. Para cada nível foram projetados quadros visuais de programação. O quadro do nível 1 foi chamado de plano mestre de produção. Com um horizonte médio de planejamento de 3 meses, cada ordem de produção era programada numa linha. Nas colunas foram inseridos os principais loops de produção. Com o auxilio de uma planilha eletrônica é feito o backflushing de cada turbina com defasagem no tempo proporcional ao lead time padrão de cada um, como num sistema MRP. Foram construídos 4 quadros com capacidade para programar 20 turbinas cada um. 


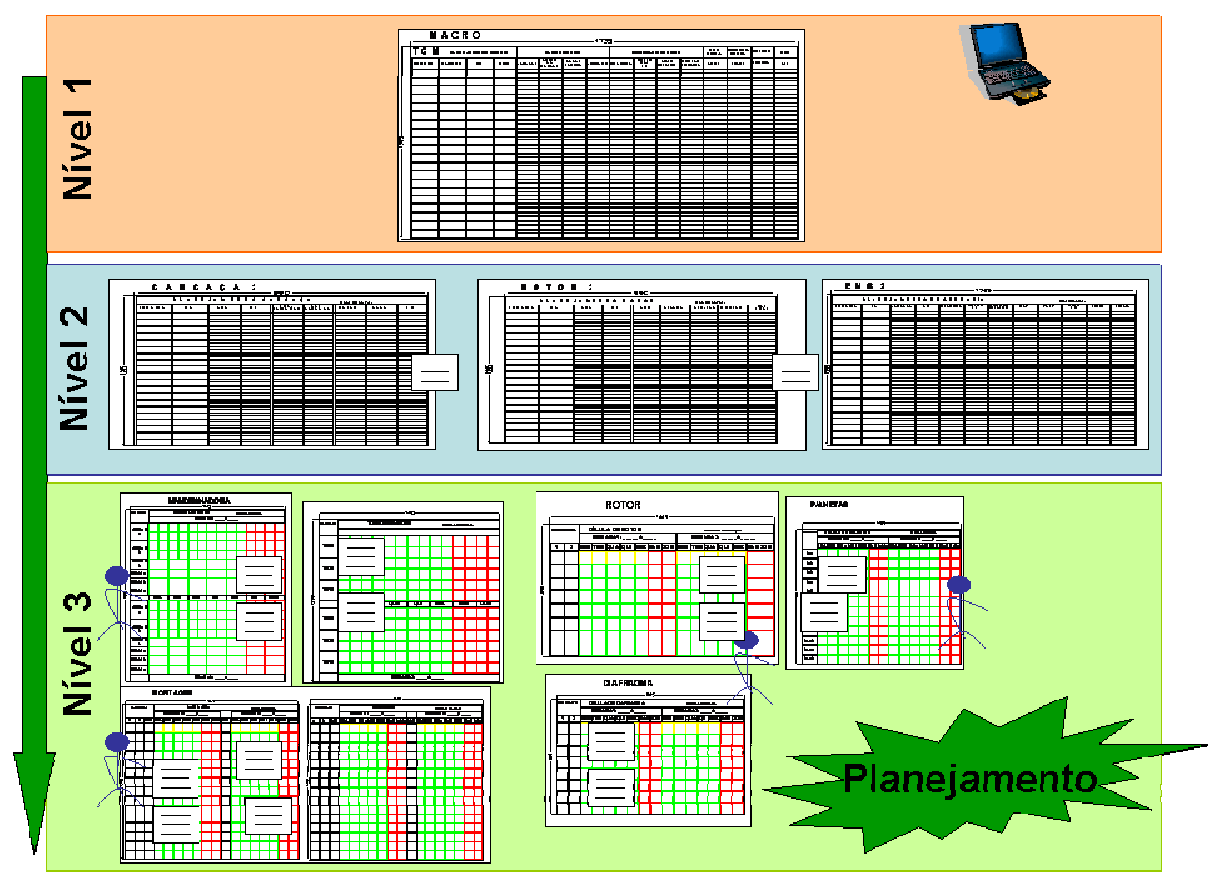

Figura 136: Sistema visual de PCP com planejamento de cima para baixo.

Com base nas informações da planilha, o processo iniciava-se com o apontamento dos prazos de cada processo da turbina (pincel atômico) diretamente no quadro.

\begin{tabular}{|c|c|c|c|c|c|c|c|c|c|c|c|}
\hline \multirow{2}{*}{ Turbina } & \multirow{2}{*}{ Cliente } & \multirow{2}{*}{ OS } & \multirow{2}{*}{ Box } & \multicolumn{4}{|c|}{ Alinhamento } & \multicolumn{4}{|c|}{ Montagem Turbina } \\
\hline & & & & Carcaça & Corpos mancais & Base/Tanque & Alinham/to & Internos & Rotor/Rev/P.F & Diafr/Injet. & Mont. Turb \\
\hline & & & & $3 / 1 / 2007$ & $3 / 1 / 2007$ & $3 / 1 / 2007$ & 10/1/12007 & $100 / 1 / 2007$ & $100 / 1 / 2007$ & $101 / 12007$ & $24 / 1 / 2007$ \\
\hline & & & & & & & & & & & \\
\hline & & & & $3 / 1 / 2007$ & $3 / 1 / 2007$ & 311/2007 & $10 / 1 / 2007$ & $100 / 1 / 2007$ & 10/112007 & $101 / 12007$ & $241 / 12007$ \\
\hline & & & & $3 / 112007$ & $31 / 12007$ & 3112007 & $1011 / 2007$ & $100 / 1 / 2007$ & 10112007 & $10 / 12007$ & 311112007 \\
\hline & & & & & & & & & & & \\
\hline & & & & $3 / 1 / 2007$ & 3 3/1/2007 & $31 / 12007$ & $101 / 12007$ & $\begin{array}{ll}10 / 1 / 2007 \\
\end{array}$ & $10 / 1 / 12007$ & $101 / 12007$ & $241 / 12007$ \\
\hline & & & & $12 / 1 / 2007$ & 12/1/2007 & $121 / 2007$ & 19/1/2007 & 199/12007 & 19/1/2007 & 191/12007 & $31 / 1 / 2007$ \\
\hline & & & & & & & & & & & \\
\hline & & & & $1661 / 12007$ & $16 / 1 / 2007$ & $161 / 12007$ & $231 / 12007$ & $2331 / 12007$ & $23 / 12007$ & $231 / 12007$ & 6 6i2:2007 \\
\hline & & & & $231 / 12007$ & $23 / 1 / 2007$ & $2311 / 2007$ & 30/1/2007 & $300 / 12007$ & $30 / 112007$ & 301/12007 & 13/212007 \\
\hline & & & & & & & & & & & \\
\hline & & & & 1661/2007 & $16 / 1 / 2007$ & 161112007 & $23 / 1 / 2007$ & $231 / 12007$ & $23 / 112007$ & $2311 / 12007$ & 6:2/22007 \\
\hline & & & & $16 / 1 / 2007$ & $166 / 1 / 2007$ & $161 / 12007$ & 23/1/2007 & $233 / 12007$ & $23 / 1 / 2007$ & 231/12007 & $62 / 22007$ \\
\hline & & & & $151 / 12007$ & $151 / 12007$ & $151 / 12007$ & 22112007 & 22412007 & $22 / 12007$ & 222112007 & 5222007 \\
\hline & & & & & & & & & & & \\
\hline & & & & 9/1/2007 & 9/1/2007 & $991 / 2007$ & $16 / 1 / 2007$ & $\begin{array}{ll}166 / 1 / 2007 \\
\end{array}$ & $16 / 1 / 12007$ & $166 / 1 / 2007$ & 6 6i212007 \\
\hline & & & & $1661 / 12007$ & 16/1/12007 & $16 / 1 / 2007$ & $2331 / 12007$ & 2331/12007 & 23/1/2007 & 23112007 & 6/2122007 \\
\hline & & & & & & & & & & & \\
\hline & & & & $15 / 1 / 2007$ & $151 / 12007$ & $15 / 1 / 2007$ & $221 / 12007$ & $2241 / 2007$ & 222112007 & $2211 / 2007$ & 52/2007 \\
\hline & & & & & & & & & & & \\
\hline
\end{tabular}

Figura 137: Quadro de programação nível 1. 
No nível 2, cada loop foi desdobrado em suas atividades. Cabia aos líderes de cada fluxo gerenciá-los, tendo em vista dar feedbacks nas reuniões de PCP. Cada líder também possui o suporte de um sistema informatizado para ajudá-lo, sobretudo nas reprogramações diárias.

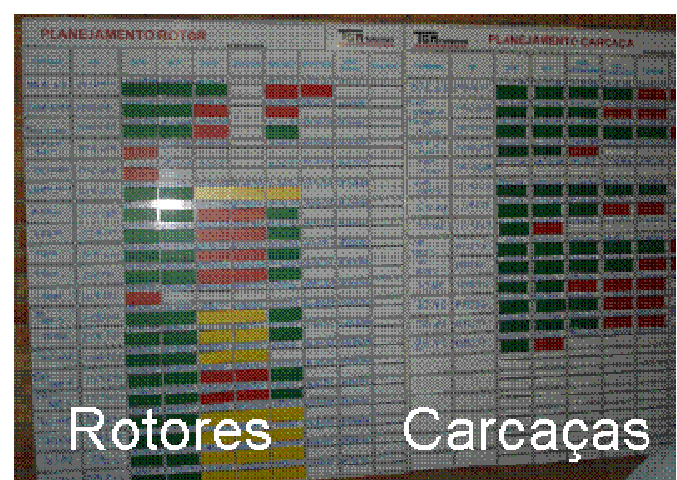

Figura 138: Quadros nível 2.

O nível 3 consiste na programação das células no chão de fábrica. Foram implantados quadros que são programados a partir do desdobramento do nível 1 e 2 .
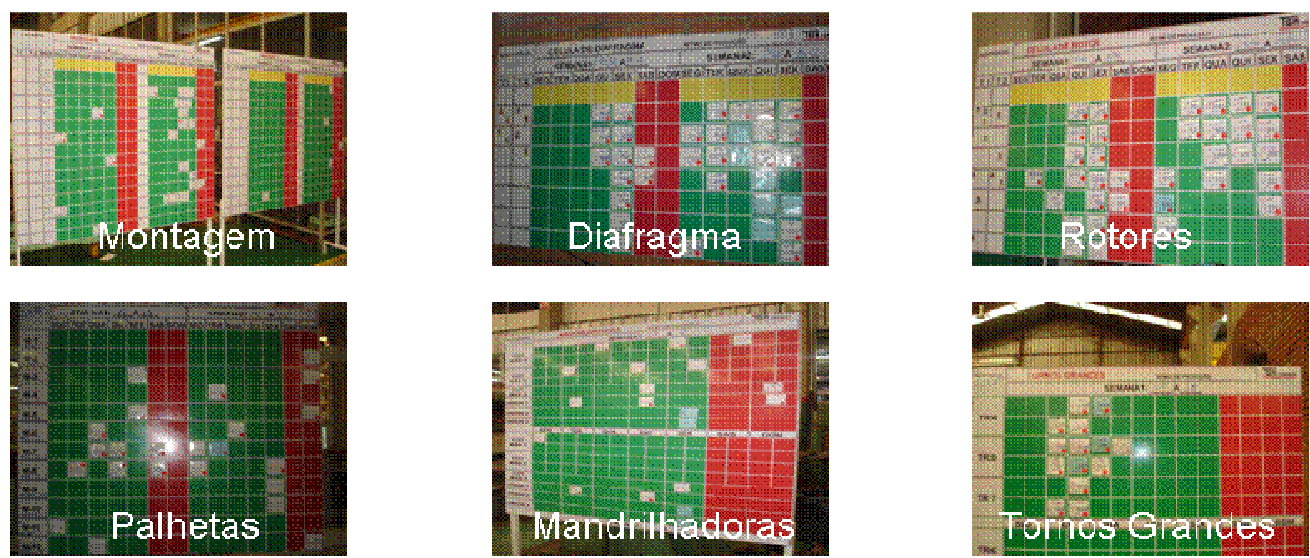

Figura 139: Quadros nível 3: programação do chão de fábrica.

Diariamente os líderes de fluxo atualizam os quadros nível 3 e nível 2, conforme o andamento da produção. Diariamente, a atualização e controle do quadro nível 1 é feita por meio de reuniões com o gerente de produção, o responsável do PCP e com os líderes de todos os fluxo de valor. 


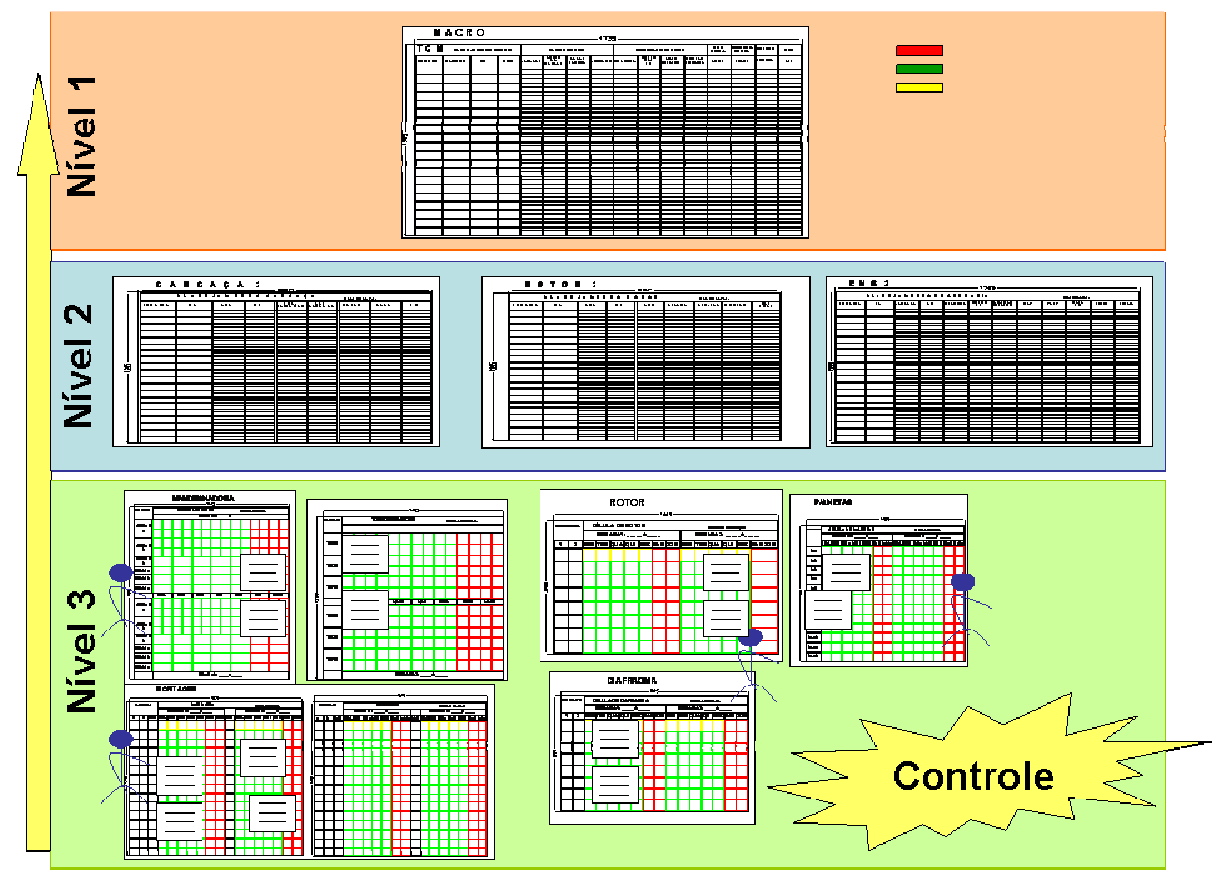

Figura 140: Sistema visual de PCP com controle de baixo para cima.

Nas reuniões de PCP, os quadros são atualizados da seguinte forma:

- Branco = atividade não iniciada

- Amarelo = atividade iniciada dentro do prazo

- Verde = atividade finalizada no prazo

- Vermelho = atividade atrasada (quando finalizada devese acrescentar a data de conclusão)

Com isso, o PCP passou a ter um feedback em tempo real da fábrica, e, ao mesmo tempo, a promover um alinhamento entre os setores, estabelecendo novas prioridades em função dos imprevistos do dia a dia da produção. 

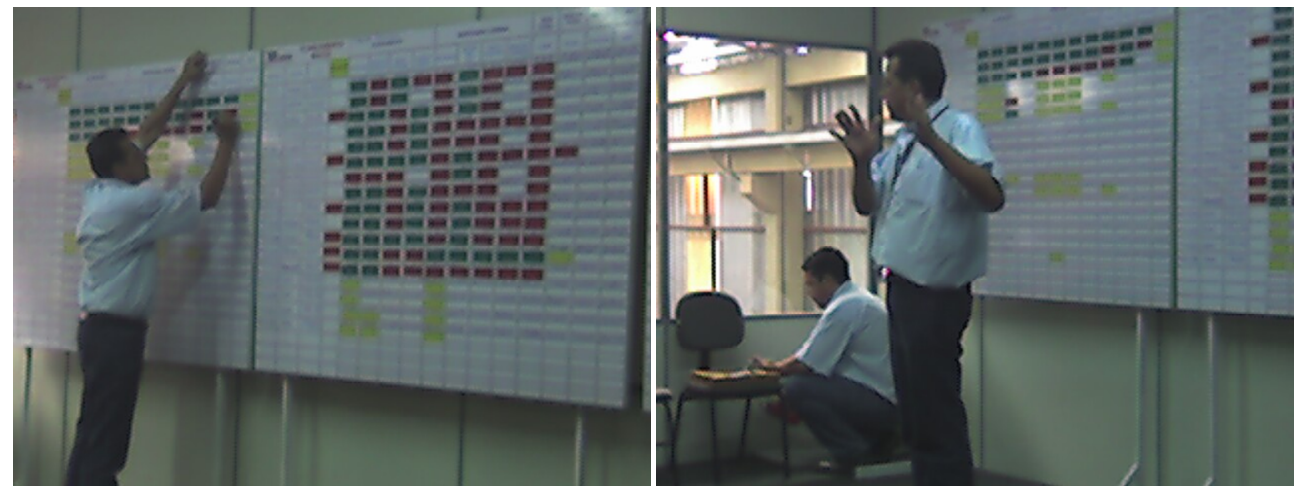

Figura 141:Reuniões diárias para controle e atualização dos quadros.

Algum tempo depois, a equipe de projeto notou que no novo sistema de PCP os princípios de gestão visual e de sincronização estavam sendo atendidos. Contudo, faltavam ainda os princípios de senso de ritmo e de nivelamento e balanceamento. Para isso, foi feito um trabalho de nivelamento de vendas juntamente com a área comercial. Foi desenvolvida uma máscara de programação com o mix ideal para cada uma das três famílias de turbinas. Esse nivelamento foi feito com base na capacidade dos gargalos internos da empresa. A demanda média mensal ilustrada no mapa de situação implantada, na verdade já é um resultado desse trabalho de nivelamento. Para se ter uma idéia a produção e expedição da empresa ao longo do ano de 2007 se comportou da seguinte maneira.

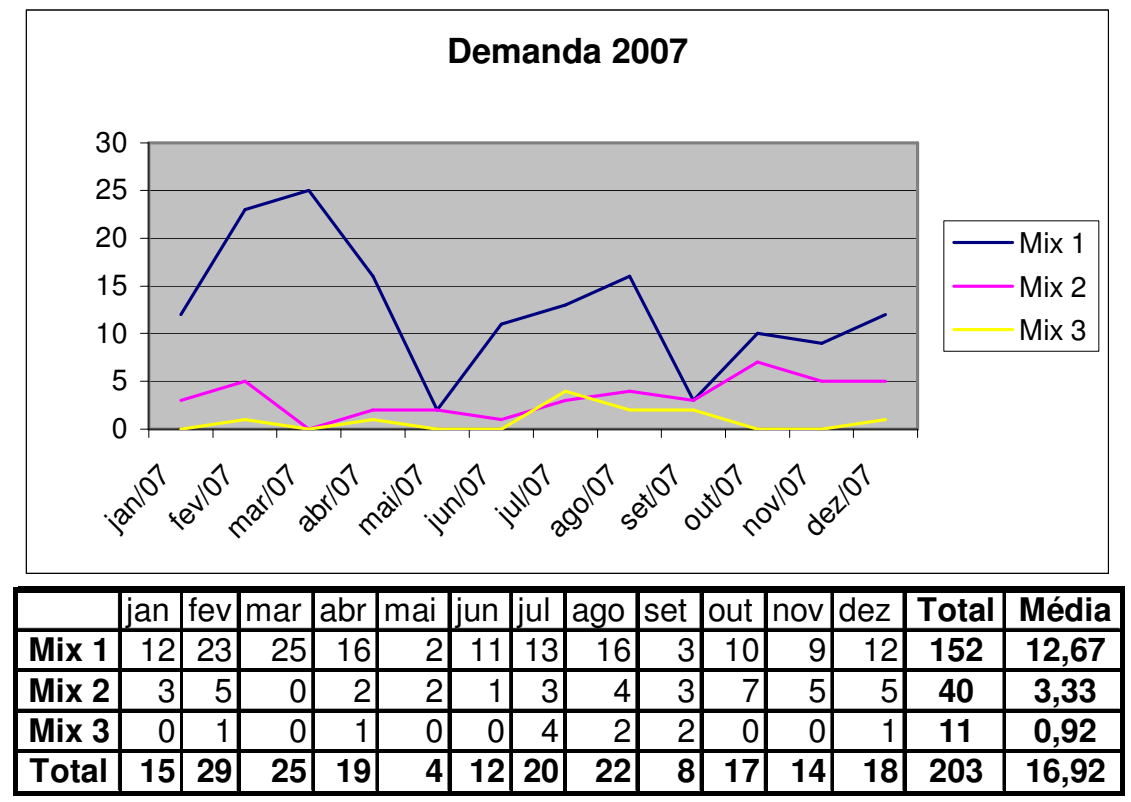

Figura 142: Curva de carregamento da empresa ao longo de 2007. 
Note que as entregas mensais ocorreram de forma completamente desnivelada ao longo do ano, gerando sobrecargas, falsos gargalos e, ao mesmo tempo, períodos de ociosidade. Para o ano de 2008 a colocação dos pedidos pela área comercial já está seguindo uma máscara de programação nivelada.

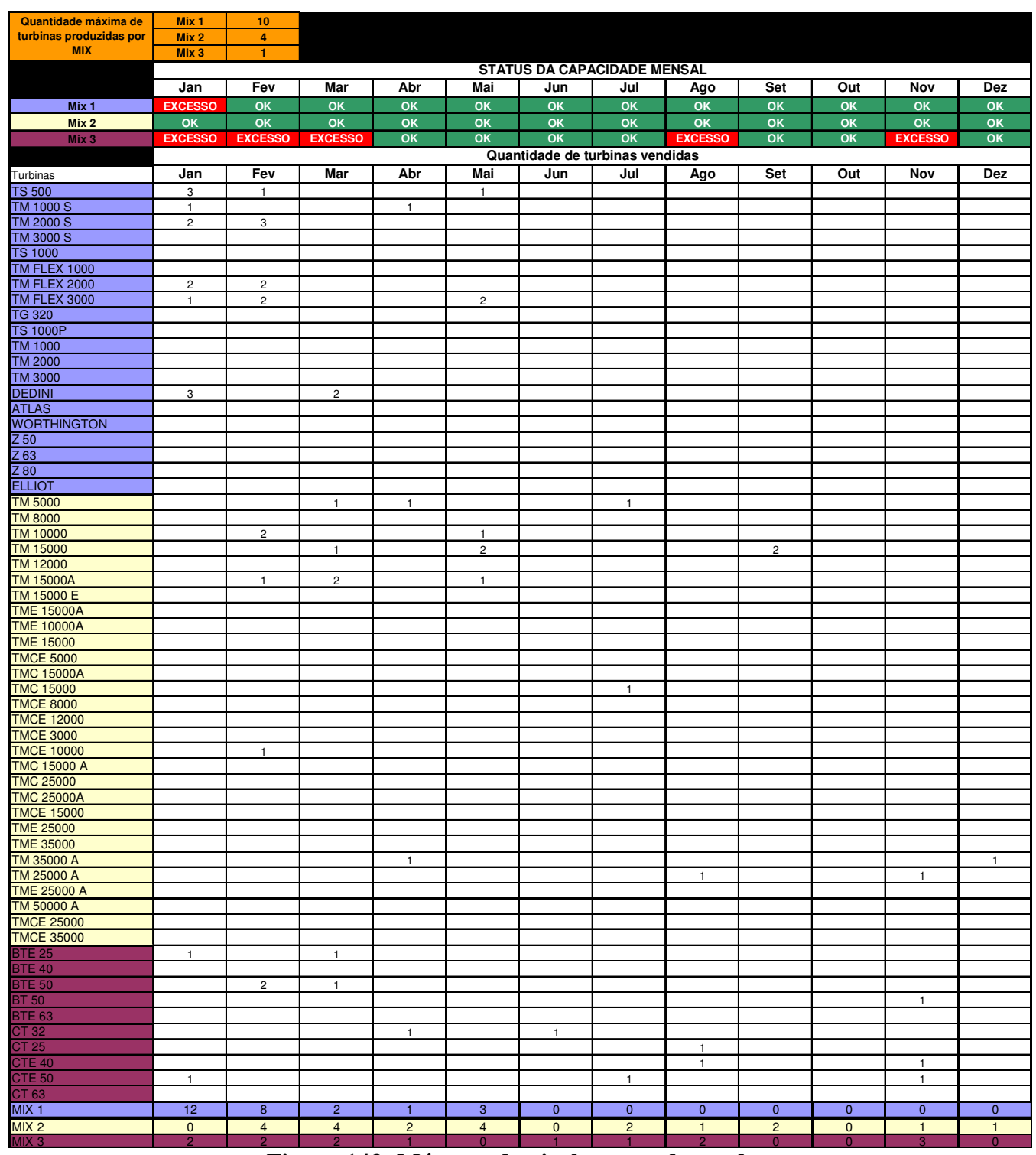

Figura 143: Máscara de nivelamento de vendas.

A partir da colocação de novos pedidos e da reprogramação daqueles já existentes, é feita também uma análise da ocupação da capacidade produtiva, 
tendo em vista nivelar e balancear os pedidos não apenas entre os meses do ano, mas também dentro de cada mês.

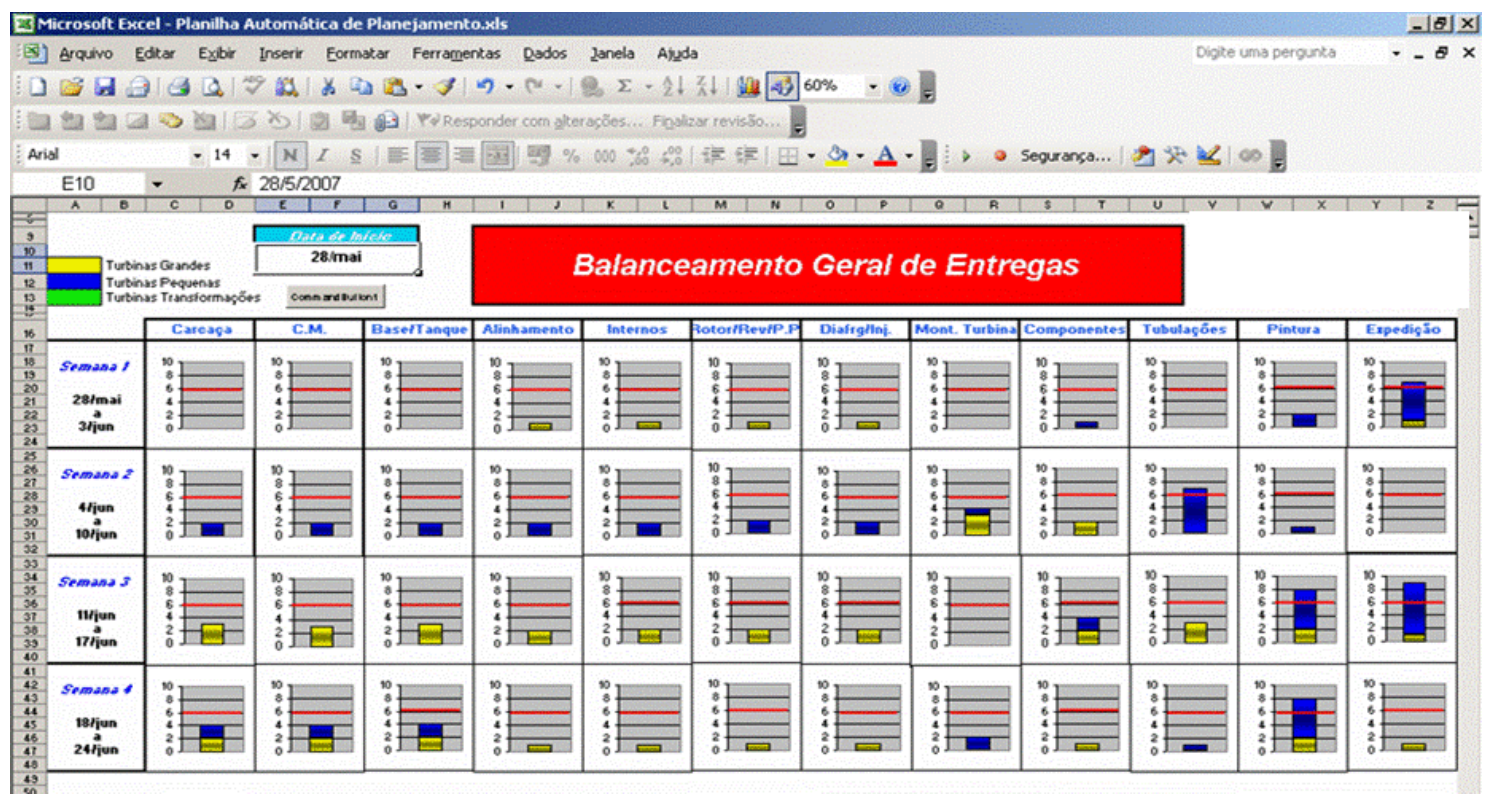

Figura 144: Visualização da ocupação da capacidade produtiva.

Com essa análise de balanceamento a empresa procura também estabelecer um senso de ritmo semanal para todo o sistema.

Em seguida, iniciaram-se os trabalhos de implantação.

\subsubsection{Preparação e acompanhamento da implantação}

Nesta etapa foi definido como seria a transição do sistema de produção anterior para o sistema proposto, incluindo-se aí a seqüência de implementação, a velocidade com que as mudanças seriam executadas e um cronograma de implementação.

Foi utilizada a técnica de evento kaizen. Foram realizados dez eventos kaizen para a implantação de todas as melhorias projetadas para esta empresa. Naturalmente também foram abordadas outras ferramentas enxutas (mudança de layout, criação de fluxo contínuo, estabilização e padronização, SMED, dentre outras), as quais não foram consideradas no escopo deste trabalho. De acordo com a 
técnica, os trabalhos iniciaram com um treinamento da equipe sobre o projeto de situação futura que seria implantado.

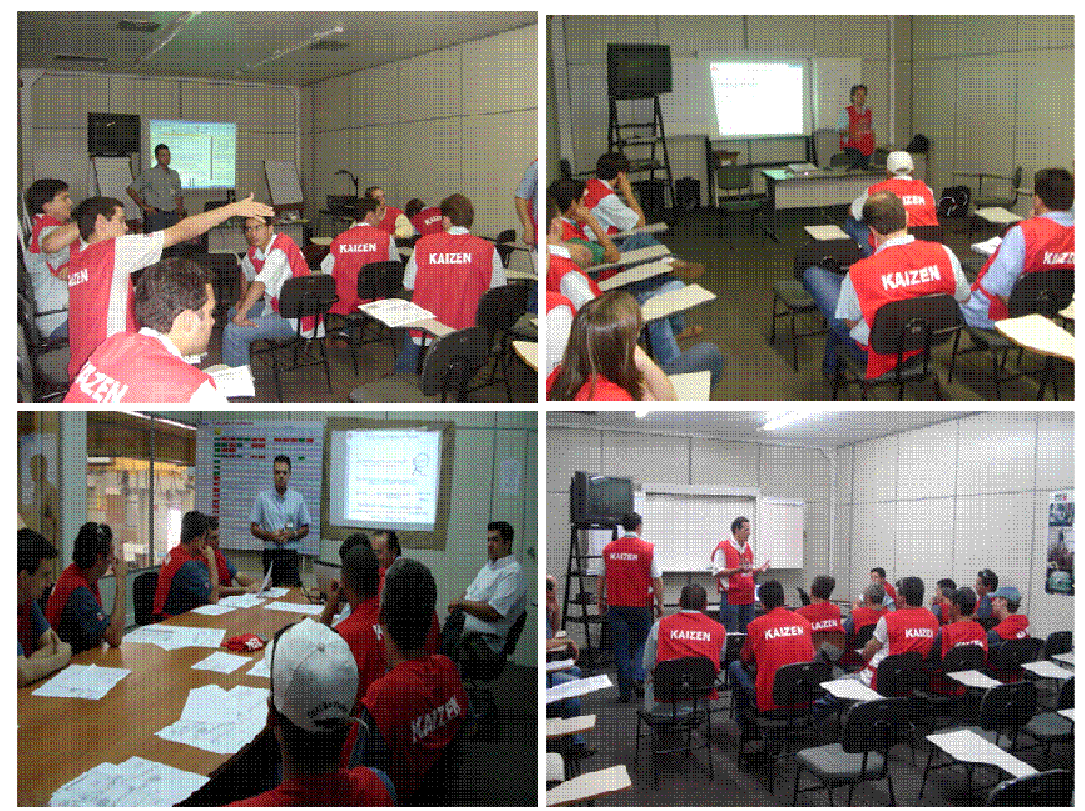

Figura 145: Reunião de abertura e treinamento para o evento kaizen

A equipe iniciou as atividades de implantação, preenchendo os quadros de nível 1.

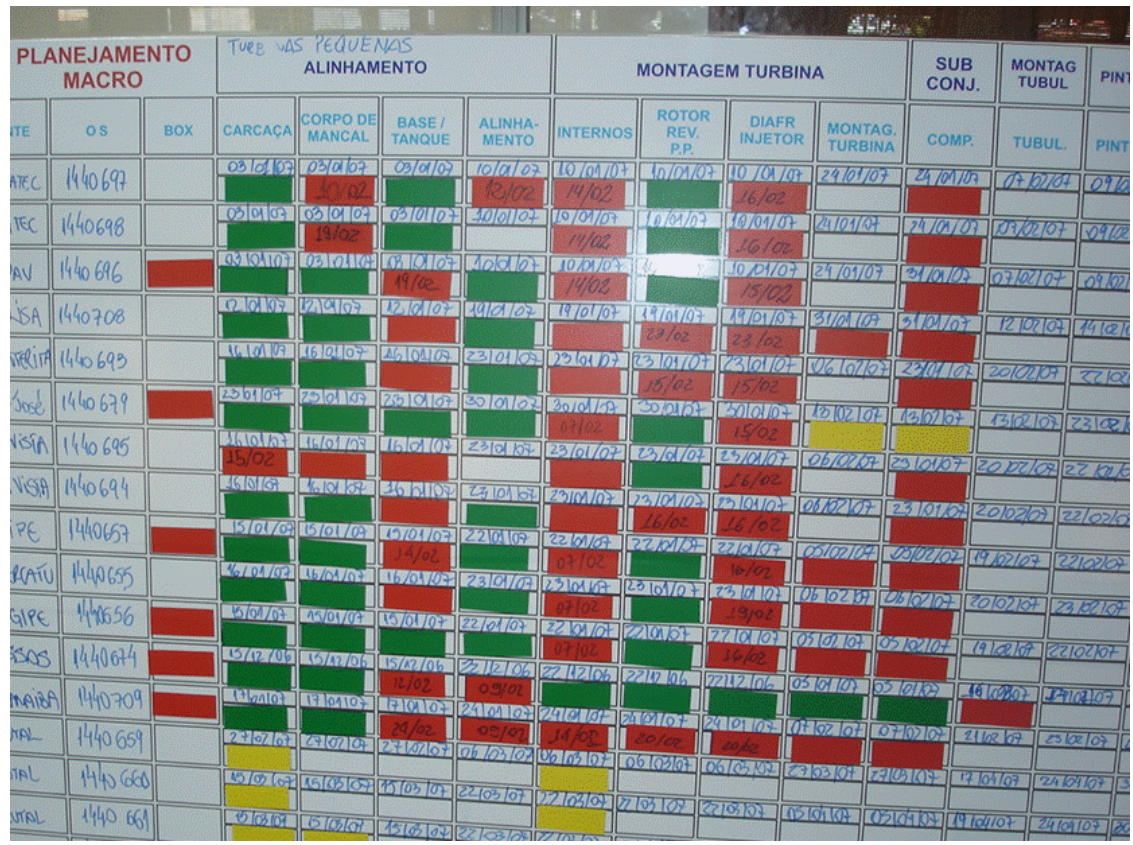

Figura 146: Preenchimento dos quadros de programação nível 1. 
Os quadros de nível 2 foram preenchidos e em seguida foram fixados na sala dos líderes de fluxo.

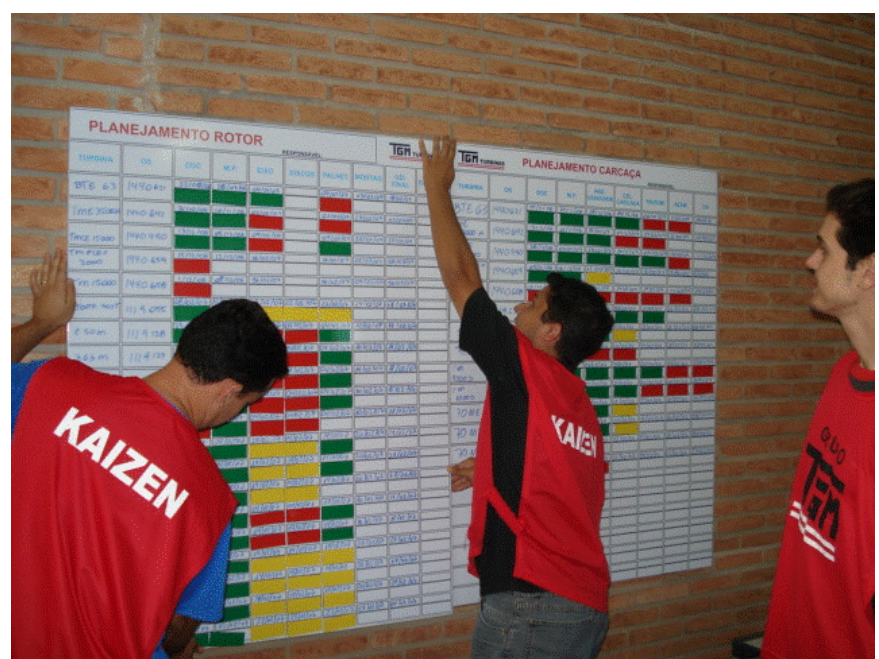

Figura 147: Fixação e preenchimento dos quadros nível 2.

À medida que os eventos foram sendo realizados dentro de cada célula, os quadros de programação nível 3 (chão de fábrica) foram sendo melhorados, de acordo com o projeto de situação futura de cada uma.

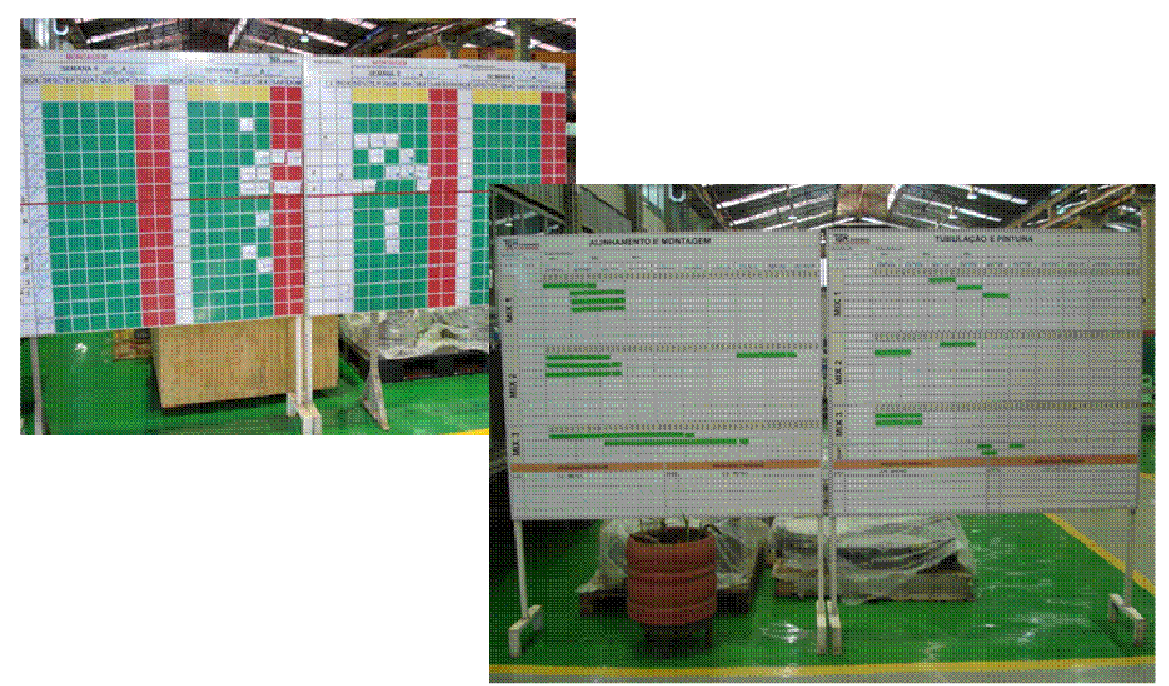

Figura 148: Melhoria dos quadros nível 3.

Para os itens padronizados, foram implementados supermercados e os respectivos quadros de kanban. 


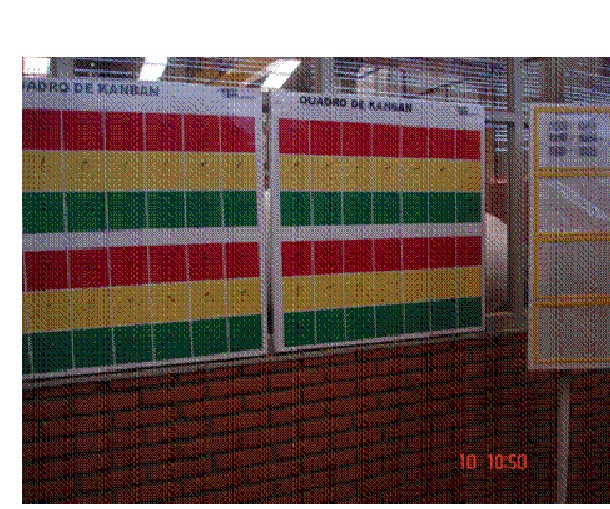

- Buchas, anéis e mancais

- Eixos desbastados $\theta$ usinados

- Subconjuntos

- Anóis do diafragma

- Itens comprados em geral

Figura 149: Quadros kanban para programação dos fluxos puxados.

Os supermercados de itens comprados foram organizados para serem controlados por duas gavetas.
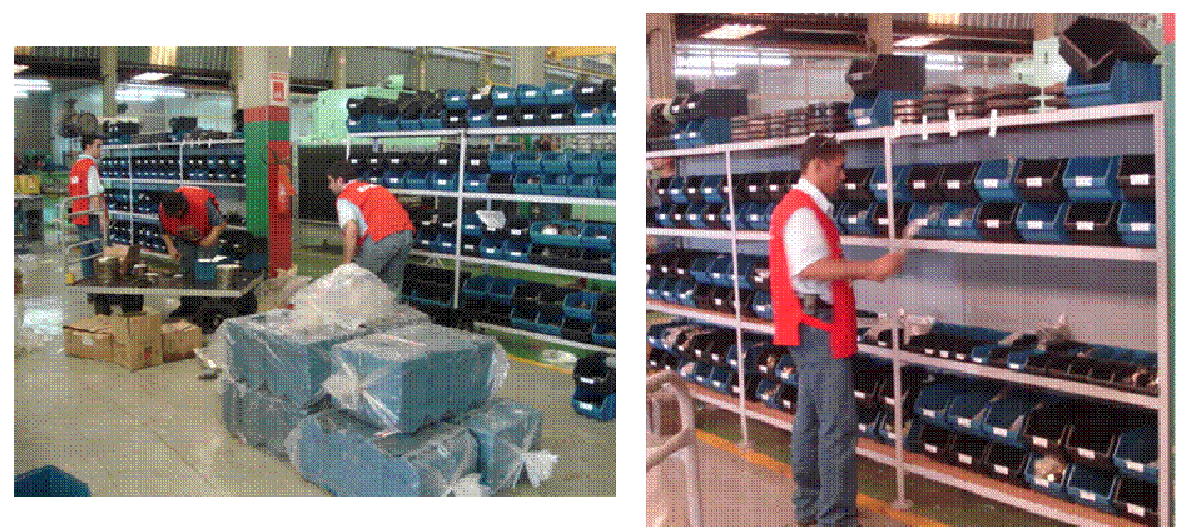

Figura 150: Setor de solda é substituído por células de solda - $3^{\mathrm{a}}$. Aplicação

Por fim, ao longo dos eventos kaizens, foi criado um plano de controle, tendo em vista acompanhar o desempenho da produção. Não conformidades e desvios no cumprimento das metas eram discutidos semanalmente em reuniões com os líderes da fábrica. Planos de ação corretiva eram disparados e acompanhados nessas mesmas reuniões. 


\begin{tabular}{|c|c|c|c|}
\hline Métricas & Significado/ Propósito & \begin{tabular}{|c|}
$\begin{array}{c}\text { Ponto/Procedimento de } \\
\text { Coleta }\end{array}$ \\
\end{tabular} & $\begin{array}{l}\text { Expressão de } \\
\text { Cálculo }\end{array}$ \\
\hline $\begin{array}{l}\text { Compilação do } \\
\text { Programa 5S }\end{array}$ & $\begin{array}{c}\text { Analisar cada uma das áreas } \\
\text { com relação aos requisitos da } \\
\text { auditoria } 5 \mathrm{~S}\end{array}$ & $\begin{array}{c}\text { Auditorias via check list } \\
5 \mathrm{~S} \text { do programa Fórmula } \\
5 \mathrm{~S}\end{array}$ & $\begin{array}{c}\text { Qtde de "Sim"/ Qtde } \\
\text { de perguntas (+ } \\
\text { pontos extras por } \\
\text { melhorias) }\end{array}$ \\
\hline $\begin{array}{l}\text { Pontualidade por } \\
\text { setor }\end{array}$ & $\begin{array}{c}\text { Avaliar a quantidade de itens } \\
\text { por setor que foram entregues } \\
\text { dentro do prazo contratual }\end{array}$ & $\begin{array}{l}\text { Apontar mensalmente } \\
\text { através da planilha } \\
\text { automática de } \\
\text { planejamento a } \\
\text { quantidade de itens } \\
\text { entregues dentro do } \\
\text { prazo } \\
\end{array}$ & $\begin{array}{c}\text { Quantidade de } \\
\text { verdes / Quantidade } \\
\text { de itens totais }\end{array}$ \\
\hline $\begin{array}{c}\text { Quantidade de horas } \\
\text { extras }\end{array}$ & $\begin{array}{l}\text { Avaliar custo de horas extras } \\
\text { realizadas durante o mês }\end{array}$ & $\begin{array}{l}\text { Através dos dados } \\
\text { fornecidos pelo } \\
\text { departamento de } \\
\text { Recursos Humanos }\end{array}$ & $\begin{array}{l}\text { Quantidade de } \\
\text { horas extras por } \\
\text { setor por mês }\end{array}$ \\
\hline $\begin{array}{c}\text { Tempo por causa de } \\
\text { não cumprimento de } \\
\text { programação }\end{array}$ & $\begin{array}{c}\text { Avaliar o tempo de parada por } \\
\text { causa de não cumprimento de } \\
\text { programação }\end{array}$ & $\begin{array}{c}\text { Planilha de apontamentos } \\
\text { macro (preenchida pelo } \\
\text { Rinaldo) }\end{array}$ & $\begin{array}{c}\text { Somatória de } \\
\text { tempos por causa } \\
\text { de não cumprimento } \\
\text { de programação }\end{array}$ \\
\hline $\begin{array}{l}\text { Tempo de atraso por } \\
\text { setor/fornecedors }\end{array}$ & $\begin{array}{l}\text { Avaliar o tempo de parada por } \\
\text { fornecedor }\end{array}$ & $\begin{array}{c}\text { Planilha de apontamentos } \\
\text { macro (preenchida pelo } \\
\text { Rinaldo) }\end{array}$ & $\begin{array}{c}\text { Somatória de } \\
\text { tempos por setor de } \\
\text { não cumprimento de } \\
\text { programação }\end{array}$ \\
\hline $\begin{array}{c}\text { Frequência de } \\
\text { causas de não } \\
\text { cumprimento de } \\
\text { programação } \\
\end{array}$ & $\begin{array}{c}\text { Avaliar quais as causas mais } \\
\text { frequentes do não } \\
\text { cumprimento da programação } \\
\text { por setor }\end{array}$ & $\begin{array}{c}\text { Planilha de apontamentos } \\
\text { macro (preenchida pelo } \\
\text { Rinaldo) }\end{array}$ & $\begin{array}{l}\text { Qtde de ocorrência } \\
\text { da causa/Qtde total } \\
\text { de ocorrências }\end{array}$ \\
\hline $\begin{array}{l}\text { Quantidade de } \\
\text { treinamentos por } \\
\text { área }\end{array}$ & $\begin{array}{l}\text { Medir a quantidade de } \\
\text { treinamentos por setor }\end{array}$ & $\begin{array}{l}\text { Treinamentos fornecidos } \\
\text { pela Equipe Lean e pelo } \\
\text { departamento de } \\
\text { Recursos Humanos }\end{array}$ & $\begin{array}{c}\text { Quantidade de } \\
\text { treinamentos } \\
\text { realizados em cada } \\
\text { área }\end{array}$ \\
\hline $\begin{array}{c}\text { Nivelamento } \\
\text { semanal por setor }\end{array}$ & $\begin{array}{c}\text { Avaliar a aderência ao ritmo } \\
\text { nivelado de produção semanal }\end{array}$ & \begin{tabular}{|} 
Apontar mensalmente \\
através da planilha \\
automática de \\
planejamento a demanda
\end{tabular} & $\begin{array}{c}\text { Quantidade de } \\
\text { verdes / Quantidade } \\
\text { de itens totais }\end{array}$ \\
\hline
\end{tabular}

Quadro 64: Plano de controle para sustentabilidade das melhorias

Não houve um intervalo de tempo hábil para apontamento e compilação dessas métricas, e que, portanto, não serão apresentadas na seção de resultados obtidos.

\subsubsection{Resultados obtidos}

Os principais resultados obtidos nesta aplicação foram:

Lead Time: Redução de 69\%, passando de 78 dias para 24 dias. $\mathrm{Na}$ prática, contudo, esse lead time projetado ainda não foi obtido devido ao acúmulo de mais de uma carcaça no pulmão para a montagem. $\mathrm{O}$ atraso de redutores (item comprado) é o principal causador de esperas neste ponto do fluxo de valor. Com isso, estima-se que o lead time esteja na ordem de 28 a 30 dias. 
Produtividade: Estima-se um ganho de até $50 \%$ na produtividade global da fábrica. Esta medida foi coletada com base no processo de montagem de turbinas novas, visto que este é o único processo que não possui terceirizações. A expressão de cálculo utilizada foi a média móvel dos últimos 3 meses da quantidade de horas padrão de montagem expedidas dividido pela quantidade de horas de montagem disponíveis. O objetivo de se utilizar a média móvel trimestral foi de se atenuar eventuais distorções mensais causadas pelo desnivelamento.

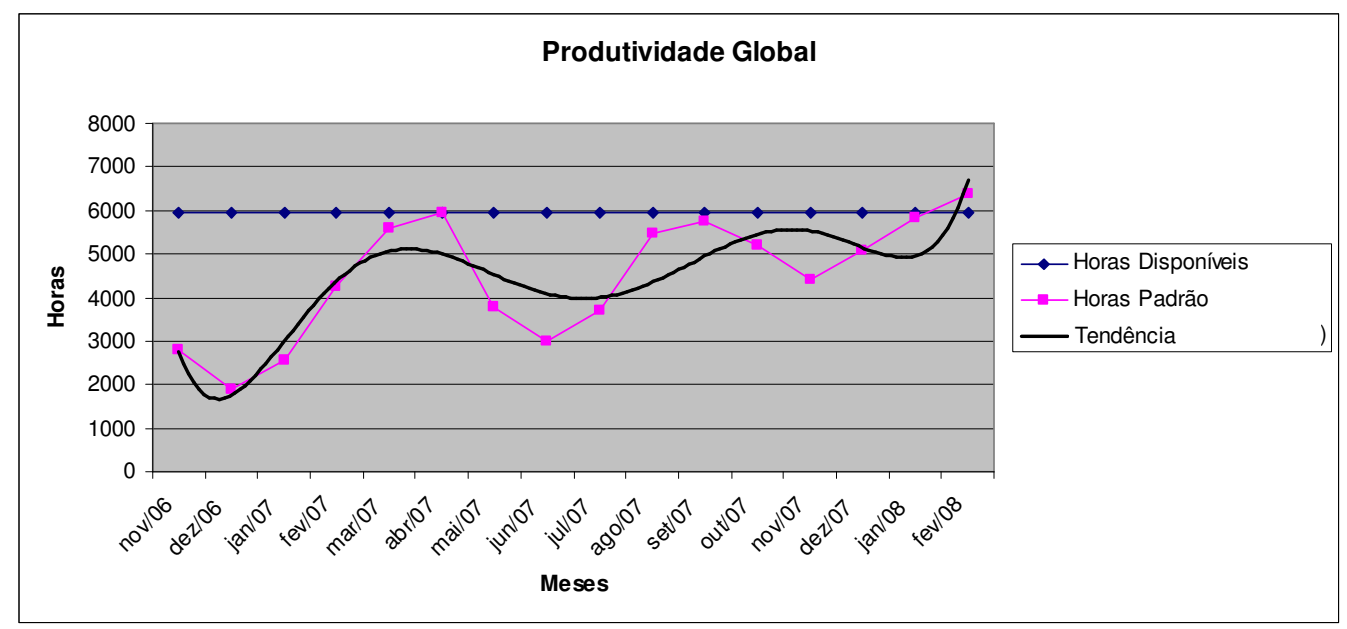

Figura 151: Evolução da produtividade global ao longo da implantação

\subsubsection{Considerações sobre a $4^{\text {a }}$. aplicação}

\section{Com relação aos resultados obtidos pela empresa}

Nesta aplicação, como o lead time total do sistema era muito elevado (só o lead time externo é de 72 dias), os resultados obtidos pelos kaizens implantados chegavam a demorar cerca de três meses para impactar em todo fluxo de valor. Só a partir daí era possível coletar de forma efetiva o impacto de tais melhorias nas medidas de resultado propostas. Conforme dito anteriormente, foram realizados dez eventos kaizens ao longo do ano de 2007, cujos resultados só serão coletados com maior representatividade ao longo do ano de 2008. A máscara de programação nivelada só começou a ser seguida após a conclusão deste trabalho, visto que a carteira com os pedidos antigos já estava preenchida com um ano e meio de antecedência. 
De qualquer forma, os resultados coletados preliminarmente, e ilustrados no tópico anterior, já indicam uma certa tendência de melhoria. Além disso, existe também uma percepção subjetiva por parte das pessoas da empresa de que houve uma melhoria significativa em todo o sistema.

\section{Com relação ao método proposto}

A principal contribuição desta aplicação para o método proposto diz respeito à diversidade e riqueza dos conceitos empregados. Embora a empresa possua um sistema de produção predominantemente do tipo "Projetar e Fabricar Mediante Ordem", no projeto de situação futura foram definidas quatro políticas de atendimento das demandas interna e externa:

Projetar Mediante Ordem (ETO-Engineering to Order): Ex.: Fluxo de Rotores.

Fabricar Mediante Ordem (MTO-Make To Order): Ex.: Fluxo de Carcaças e Subconjuntos.

* Montar Mediante Ordem (ATO-Assembly To Order): Ex.: Fluxo da Montagem Final.

\& Fabricar para Estoque (MTS-Make To Stock): Ex.: Fluxo de Mancais, controlado via kanban.

Essa diversidade de políticas de atendimento da demanda disparou a necessidade de se utilizar a lógica de pelo menos três sistemas de PCP: o MRP, o Kanban e o TPC da teoria das restrições. Consequentemente, foram necessárias desenvolver e recorrer a técnicas e ferramentas, até então inéditas no escopo desse trabalho. Algumas delas são:

A utilização de pulmões de kits para a montagem: Como não fora possível implantar pontos de supermercado onde não havia fluxo contínuo, procurou-se estabilizar o sistema mediante a formação de pulmão de kits de peças. Todos os loops que continuaram sendo programados via ordem de fabricação passaram a ser controlados pela 
lógica do sistema de TPC (Tambor-Pulmão-Corda) da Teoria das Restrições.

Proposição de princípios básicos para uma programação lean em um sistema de produção sob encomenda:

○ (a) Gestão visual: desenvolvimento do sistema visual de PCP, através dos quadros de programação desdobrados em três níveis: estratégico, tático e operacional.

- (b) Sincronismo: implantação de reuniões diárias ao redor dos quadros para alinhamento, priorização e foco no fluxo de todos os componentes de uma mesma Ordem de Serviço.

- (c) Senso de ritmo: estabelecimento de um ritmo de produção semanal, definindo as necessidades balanceadas e niveladas de cada setor.

- (d) Balanceamento da carga de trabalho: visualização e respeito da capacidade produtiva de cada setor. Juntamente com o senso de ritmo visa combater a superprodução (antecipações) ou sobrecargas nos setores.

Todas essas características contribuíram para o enriquecimento do escopo do método proposto, visto que até então o autor deste trabalho não havia realizado nenhuma pesquisa ação em empresas com essa tipologia de produção. Com isso, a necessidade de se conciliar a lógica do MRP, do Kanban e do TPC, da teoria das restrições, reforçou a proposta de desenvolvimento de um sistema de PCP híbrido.

A seguir, serão apresentadas as principais conclusões a cerca do trabalho como um todo. 


\section{CONCLUSÃO}

Conforme dito no início do capítulo 3, este trabalho foi desenvolvido ao longo de cinco anos de pesquisa. Foram realizadas aplicações práticas em quatro empresas, sendo em média um ano de visitas semanais por empresa. Estas aplicações foram norteadas por uma filosofia de trabalho incremental, através de abordagens cíclicas. Cada empresa representou um ciclo de aplicação, conforme o desenho esquemático da metodologia de pesquisa adotada.

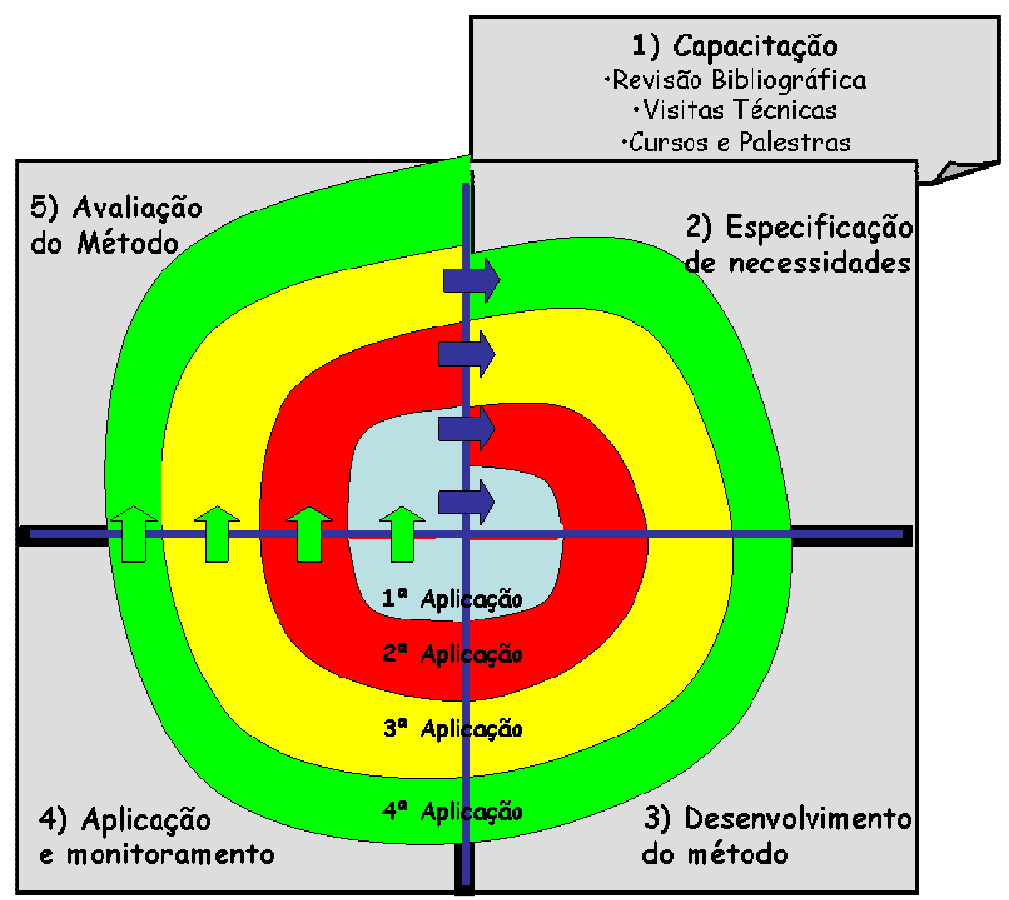

Figura 152: Metodologia de pesquisa e as aplicações.

Ao longo de cada etapa da metodologia, foram colhidas impressões do

trabalho. A seguir são apresentadas as principais conclusões em cada uma delas. É importante ressaltar que estas conclusões aconteceram gradativamente, ao longo dos quatros ciclos de aplicações. 


\subsubsection{Conclusões em cada etapa da metodologia de pesquisa adotada}

Em cada etapa da metodologia de pesquisa adotada foram feitas conclusões a respeito do trabalho. Na etapa 5, de Avaliação do Método, são feitas as aferições do nível de atendimento dos objetivos e das questões de pesquisa.

\section{Etapa1: Capacitação}

Nos dois primeiros anos desta pesquisa encontrou-se certa dificuldade para conseguir livros e artigos especificamente sobre sistemas híbridos de PCP. Um livro inicialmente interessante foi o Creating mixed model value streams (DUGGAN, 2002). Conseqüientemente, trabalhou-se mais com a consolidação teórica em torno dos diferentes tipos de sistemas de PCP. Com isso, num primeiro momento o processo de capacitação acabou sendo fortemente influenciado pelas aplicações práticas que já estavam em curso, o que contribuiu para direcionar a busca pelos conhecimentos acadêmicos e concatená-los com a realidade e necessidades das empresas.

Somente em 2005, foi possível identificar trabalhos importantes na mesma linha deste. Smalley, por exemplo, lançou o Criando o sistema puxado nivelado. A impressão que se teve foi o início de um novo ciclo de possibilidades de trabalho em torno do emprego da filosofia lean. Este ciclo começou a acontecer de forma gradativa, em função das conclusões e publicações dos primeiros estudos realizados em empresas que já haviam ultrapassado as primeiras etapas de implantação desse sistema de negócio.

Enquanto o ciclo anterior se deteve na implantação tradicional das ferramentas clássicas do Sistema Toyota de Produção, este novo ciclo visa ao aprimoramento e à adequação destas ferramentas a empresas com tipologias de produção diferentes da Toyota.

No caso dos sistemas de PCP, na maior parte das aplicações e das visitas técnicas realizadas notou-se que a essência da discussão migrou do conflito entre kanban e MRP para o desafio de se criar um ambiente no qual estas duas 
ferramentas, juntamente com outras, devem coexistir tendo em vista o bem maior do sistema produtivo.

\section{Etapa 2: Especificação de necessidades}

Nesta etapa de levantamento de requisitos concluiu-se que:

Sistemas híbridos de PCP: Todas as empresas estudadas utilizavam um tratamento genérico para todos os tipos de peças. A mesma energia era gasta para a compra, por exemplo, de arruelas, buchas e parafusos em detrimento a itens de altíssimo valor. Embora a regra de Paretto (80/20) fosse conhecida por todas as empresas estudadas, eles se limitavam apenas a diferenciar o tratamento das peças em termos do tamanho dos estoques. Contudo, não percebiam que era preciso também controlá-los de formas diferentes.

Identificação e nivelamento do processo puxador: Duas das quatro empresas estudadas, já haviam trabalhado com o sistema de controle kanban. Contudo, em ambos os casos o sistema havia sido abandonado. Notou-se que um dos principais fatores associados a esse fato estava na não identificação e nivelamento dos processos puxadores. Com isso, um fator crítico de sucesso na implantação de sistemas puxados está na forma com que o consumidor realiza as retiradas dos supermercados, e não apenas na realização de soluções técnicas empregadas no produtor.

Os fatores críticos de sucesso dos sistemas de PCP: Ao se estudar os sistemas MRP's nas empresas deste trabalho, notou-se que conceitualmente eram para funcionar muito bem, de forma híbrida, juntamente os demais sistemas. Assim como os sistemas kanban e de TPC que já haviam sido utilizados em algumas delas e que também fracassaram em sua empreitada. Logo, além do fato de serem usados como o único sistema de PCP, dando-se tratamento genérico para todas as peças, o grande defeito dos sistemas de PCP das empresas está no fato de não contemplarem os princípios básicos de gestão 
visual, senso de ritmo, balanceamento e sincronização. Dificilmente nenhum dos tipos de sistemas supracitados funcionará bem se estes princípios forem negligenciados no trabalho de implantação dos mesmos, independentemente do tipo de produto da empresa. Portanto, a falha não está propriamente nos fundamentos teóricos dos sistemas de PCP existentes, mas na falta da aplicação de regras oriundas destes princípios.

— Gestão da implantação: Todas as empresas estudadas já haviam passado por processos de melhorias em geral, tanto puxados internamente quanto por consultorias. Embora tecnicamente algumas dessas melhorias tenham sido conduzidas corretamente, por outro lado elas deixaram a desejar na abordagem de elementos relacionados à gestão de mudança, tais como treinamento e sensibilização, formação de times e técnica de implantação e manutenção das melhorias. Portanto, esse é um tema que nunca deve ser negligenciado na implantação de um novo sistema de PCP.

\section{Etapa 3: Desenvolvimento do método}

Assim como nas etapas anteriores da metodologia de pesquisa, o método também foi desenvolvido de forma interativa e incremental à medida que foram ocorrendo as aplicações práticas. Esperava-se que já no primeiro ciclo de capacitação teórica ele pudesse apresentar um formato mais definitivo. Contudo, só a partir da terceira aplicação é que o método realmente tomou sua forma mais completa, apresentada no capítulo 3 deste trabalho.

Os conceitos de projeto do sistema híbrido e nivelamento do puxador estiveram presentes desde a primeira aplicação. Já a técnica de realizar o Evento Kaizen, como uma das ferramentas de gestão da mudança, e o uso do conceito de sistemas puxados flexíveis só começaram a se consolidar a partir da terceira aplicação.

As terceiras e quartas aplicações também foram enriquecidas e suportadas por um software para dimensionamento e ajuste dos supermercados. O desenvolvimento desse sistema validou de certa forma o padrão de trabalho proposto 
pelas etapas de dimensionamento e proposição de sistemas híbridos. Este software, o Hominiss E-Pull System (EPS), continua sendo desenvolvido, com novos módulos sendo adicionados a partir do método proposto.

$\mathrm{Na}$ quarta aplicação, o escopo do método passou a contemplar também sistemas produtivos com política de atendimento da demanda do tipo "Projetar e Fabricar Mediante Ordem. Esse fato tornou o método mais robusto, ampliando o seu escopo de abrangência para sistemas com políticas de atendimento da demanda do tipo MTO/ETO.

\section{Etapa 4: Aplicação e monitoramento}

A princípio, a aplicação do método nas empresas apresentou certo desconforto na etapa de implantação. Ao incorporar a técnica de Evento Kaizen ao método, as empresas mostraram-se resistentes em parar funcionários por uma semana inteira para realizar as atividades de implantação. Contudo, ao final do primeiro evento, com os resultados obtidos e o envolvimento dos funcionários, esta técnica tornou-se padrão de implantação em todas elas. Duas delas tentaram distorcer a técnica sugerindo menos dias para a realização de determinados eventos. Nas ocasiões em que a equipe cedeu, os resultados foram ruins, visto que não houve tempo hábil para o amadurecimento da equipe e consolidação das implantações. Concluiu-se que a técnica deve sempre ser utilizada na íntegra. Deve-se atentar à organização (antes, durante e depois) e à definição do escopo de cada evento, tendo em vista o melhor aproveitamento possível dos recursos utilizados.

Com relação ao monitoramento, o acompanhamento após a implantação é muito importante para a ancoragem e refinamento do novo sistema de PCP. Nas ocasiões em que esse tempo foi negligenciado, devido à urgência no cumprimento do cronograma dos demais kaizens, a sustentabilidade do novo sistema foi comprometida.

Com isso, deve-se evitar que, uma vez implantado o novo sistema, o foco da equipe se volte para outra melhoria, delegando a ancoragem do novo sistema somente aos usuários. Recomenda-se ao menos dois meses de rondas intensivas para auditorias de conformidade. Em seguida, criar um plano de acompanhamento contínuo para revitalização de conceitos, reuniões de feedback e ações corretivas. 


\section{Etapa 5: Avaliação do método e conclusões finais}

Ao longo de cada ciclo de aplicação, e das respectivas etapas da metodologia, foi-se construindo as conclusões acima. Com base nisso, foi possível preencher a tabela concebida na seção 1.4 para a aferição da evolução do nível de atendimento dos objetivos.

\begin{tabular}{|c|c|c|c|c|}
\hline \multicolumn{5}{|l|}{ Etapa 5: Avaliação do método } \\
\hline Quanto aos Objetivos Intermediários & \begin{tabular}{|l|}
$\frac{0}{0}$ \\
\hdashline 0 \\
$\vdots$ \\
\end{tabular} & \begin{tabular}{|l|}
0 \\
0 \\
0 \\
\\
\end{tabular} & \begin{tabular}{|c|}
0 \\
0 \\
0 \\
\end{tabular} & 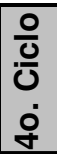 \\
\hline $\begin{array}{l}\text { A-Definição de } \text { procedimentos para } \\
\text { identificação e programação do(s) } \\
\text { processo(s) puxador(es), dos pontos de } \\
\text { buffers e de supermercados ao longo do } \\
\text { fluxo de valor. }\end{array}$ & $\odot$ & $\odot$ & $\odot$ & (:) \\
\hline $\begin{array}{l}\text { B-Definição de procedimentos para a } \\
\text { criação das sub-famílias de programação. }\end{array}$ & $\odot$ & (;) & (:) & (:) \\
\hline $\begin{array}{l}\text { C-Definição de procedimentos para a } \\
\text { construção de supermercados dinâmicos, } \\
\text { que sejam flexibilizados de acordo com as } \\
\text { flutuações da demanda. }\end{array}$ & (;) & (:) & 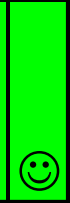 & (:) \\
\hline $\begin{array}{l}\text { D-Definição de procedimentos para o } \\
\text { nivelamento da demanda e } \mathrm{do}(\mathrm{s}) \\
\text { processo(s) puxador(es). }\end{array}$ & (:) & (;) & (:) & (:) \\
\hline $\begin{array}{l}\text { E-Definição de procedimentos para a } \\
\text { implantação efetiva do novo sistema de } \\
\text { planejamento e programação. }\end{array}$ & 10 & & & (-) \\
\hline ஜ & & 0 ate & endi & \\
\hline$\bigodot$ & & & $\begin{array}{l}\text { do } \\
\text { Imen }\end{array}$ & \\
\hline (;) & & & nent & \\
\hline
\end{tabular}

Quadro 65: Aferição do nível de atendimento dos objetivos

Após as duas primeiras aplicações, o método mostrou-se muito eficaz no que diz respeito ao atendimento dos objetivos intermediários. O único ponto que só foi atendido plenamente na quarta aplicação foi o objetivo A, quando o método 
passou a contemplar também sistemas produtivos com política de atendimento da demanda do tipo "Projetar e Fabricar Mediante Ordem".

Foi feito também um quadro para aferição do nível de atendimento das questões de pesquisa:

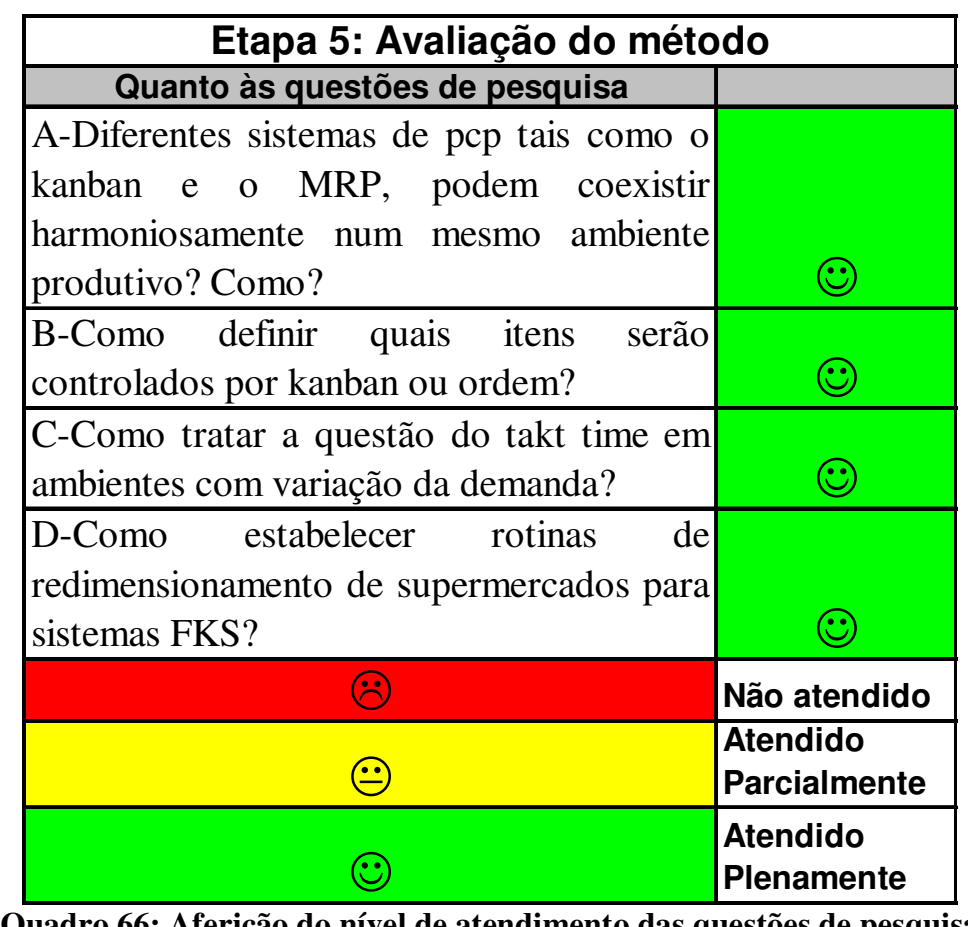

Portanto, com base nos quadros e nas conclusões supracitadas pode-se dizer que os objetivos deste trabalho foram atingidos. Da mesma forma, as questões de pesquisa também foram respondidas.

\subsubsection{Considerações e análises finais}

As quatro aplicações foram realizadas para desenvolver o método. Elas não necessariamente o validam. Permitem dizer que existe um "potencial" de uso generalizado do método, mas que deve ser aplicado em mais empresas.

Uma das principais contribuições do método está na introdução do conceito de subfamílias de programação e controle, com base na combinação de três fatores: a análise $\mathrm{ABC}$ de custos e de volume, e a frequiência da demanda de cada item. Um output muito importante do agrupamento dos itens nestas subfamílias é que 
um mesmo produto poderá ter itens que serão programados de formas diferentes (kanban, ordem, pulmão, 2 gavetas, etc.). Esta contribuição complementa a proposta feita por Corrêa e Gianesi (1996) na figura 20 para escolha do sistema de pcp mais apropriado, a partir de diversas variáveis. Entretanto, os autores realizaram esta análise sob a perspectiva do sistema produtivo como um todo. Com o surgimento do conceito de mapeamento de fluxo de valor, introduzido por Rother e Shook (1998), o sistema produtivo passou a ser analisado sob a perspectiva mais desagregada de famílias de produtos. Em estruturas complexas, com alta variedade de itens, uma família de produto pode ser desagregada ainda mais em famílias de componentes, cada uma com seus fluxos de valor específicos. Acredita-se que com o método o conhecimento científico avançou a partir do momento em que a escolha estratégica do sistema de PCP mais apropriado passa a ser feita por uma perspectiva de famílias de componentes e não para o sistema produtivo como um todo.

Outra consideração importante é que método foi aplicado em empresas não maduras, e que estavam em processo de implantação de um sistema de produção enxuta. A implantação do sistema de planejamento e programação proposto deve estar concatenado com o emprego das ferramentas lean para a eliminação de desperdícios e otimização do fluxo físico de materiais.

Muitos elementos de controle de produção foram explorados ao longo do trabalho. O acompanhamento dos quadros de semáforo nas três primeiras aplicações, ou ainda a sistemática de feedback de maneira de baixo para cima pelos líderes de produção na quarta aplicação são exemplos do uso desta função. Contudo, ela não foi explicitamente contemplada tanto no título quanto nos objetivos do trabalho. É do entendimento do autor que o controle de produção é uma função mais ampla. Para isso, o método proposto teria que ter considerado um sistema de medidas de desempenho com o devido acompanhamento do atingimento dos resultados previstos, do cumprimento das programações realizadas e da sustentabilidade dos padrões de trabalho projetados. Teria ainda que contemplar a elaboração de planos de ação para a correção das não conformidades do sistema implantado.

É importante atentar também para o fato de que aspectos relacionados à gestão de mudança são imprescindíveis para a sustentabilidade no longo prazo das ações implantadas. Um fato interessante que ocorreu em uma das aplicações foi na 
virada de ano, quando houve uma parada coletiva na empresa. O baixo envolvimento do líder do setor e da maior parte da equipe de PCP fez com a combinação da saída da pessoa responsável pelo desenvolvimento e implantação do novo sistema juntamente com a re-aceleração do sistema resultasse no abandono parcial de algumas frentes. Alguns pontos de supermercado foram esvaziados, pois, na dúvida, voltou-se a trabalhar com uma programação empurrada para os itens do kanban.

A área comercial, por desinformação e também por certo distanciamento das atividades do projeto, continuava colocando os pedidos de forma desnivelada. A área de suprimentos, continuava com uma política de grandes lotes de compra e desenvolvimento de fornecedores de baixo custo. $\mathrm{O}$ sistema constantemente era colocado à prova devido a forças que estavam muitas vezes fora da esfera de influência da produção. Isto dificultou a sustentabilidade das melhorias no ambiente produtivo e a transferência das novas tarefas para a estrutura operacional de pcp da empresa. Durante muito tempo, esta estrutura se comportou como se a manutenção e correção do novo sistema era uma atribuição exclusiva da equipe de melhoria, negligenciando a mudança real das atividades de sua estrutura de cargos e funções.

Portanto, a implantação de um sistema de PCP híbrido orientado para produção enxuta deve contemplar também elementos chaves na condução de processos de mudança. Deve ser puxada por um patrocinador, ou um comitê, forte, um líder de projeto respeitado pelos pares e diferenciado tecnicamente, e sobretudo por um nível tático, composto por gerentes, supervisores, líderes de área, que seja participativo e comprometido. Por fim, o envolvimento e capacitação do nível operacional e de outras áreas da empresa (comercial, suprimentos e engenharia) são fatores críticos de sucesso para que haja uma implantação sustentável do método proposto.

Com isso, o próximo desafio é criar uma estrutura organizacional de sustentabilidade que contemple as demais áreas, começando pelas suas interfaces com a produção. Ao invés de manufatura enxuta, passa-se a falar na empresa enxuta. Nessa nova abordagem, o fluxo de informação entre a fábrica e as áreas de planejamento, suprimentos, comercial e engenharia deve ser mapeado e otimizado. Tornar-se enxuto é um objetivo de toda a empresa e não apenas da manufatura. 
Finalmente, é importante ter em mente que a implantação de um sistema de planejamento e programação lean não deve ser tratada como o único fator crítico de sucesso para a competitividade da empresa. Kojima e Kaplinsky (2004) reforçam essa idéia ao colocar que outros fatores como inovação do produto e acesso aos mercados finais são tão importantes quanto para determinar o sucesso da empresa.

Infelizmente, não foi possível contemplar todos esses elementos no método proposto, visto que o foco maior foi nos elementos técnico-operacionais. Contudo, fica a sugestão de se enriquecê-los com os elementos de gestão de mudança supracitados. Outros elementos também podem ser mais bem trabalhados, conforme será visto no tópico a seguir.

\subsubsection{Novos desafios}

À medida que o trabalho foi sendo desenvolvido, surgiram novos elementos e questões os quais não puderam ser aprofundados:

- Testar mais o método em aplicação em empresas com políticas de atendimento da demanda predominantemente do tipo ETO.

- Devem-se explorar mais o fluxo de informação Comercial-EngenhariaSuprimentos-Manufatura. Uma questão interessante que orientaria um trabalho nessa direção é: onde se encontra o processo puxador em sistemas ETO? Na manufatura ou na engenharia? Como criar um fluxo lean entre informação e material? Como criar na engenharia uma estrutura de projeto voltado para manufatura (design for manufacturing)? Noori e Lee (2000), comprovam em um estudo de caso que envolver os fornecedores desde a etapa inicial do desenvolvimento de um novo produto até a sua fabricação tende a reduzir o tempo e o custo de desenvolvimento, o custo de fabricação e estocagens, e melhorar a qualidade do produto final.

- Outro ponto interessante, levantado na $4^{\mathrm{a}}$ aplicação em sistemas ETO, foi o emprego do conceito de pontos de sincronização e de pulmões de kit de peças. Em certos momentos, percebeu-se que no fluxo entre dois pontos 
de pulmão era possível criar uma espécie de CONWIP (Constant Work In Process), ou seja, Estoque em Processo Constante. Essa ferramenta, já conhecida e empregada no universo de aplicações lean, permitiria regular a quantidade de estoque em processo entre dois pontos de pulmão.

- Testar e adequar o método para empresas de produção contínua. Não foi possível validar o método em empresas com essa tipologia de produção. De acordo com Houghton e Portougal (2001), as indústrias de bebidas, por exemplo, têm grande dificuldade em lidar com alta variedade. Vários tipos de bebidas são produzidos em poucas linhas. A ordem de produção consiste numa combinação específica entre garrafas e o volume de bebida. Centenas de ordens são emitidas diariamente e as montagens (bebida e garrafa) só podem ser iniciadas quando todas as variedades de itens estiverem numa quantidade adequada em estoque. Além disso, os setups (higienização das tubulações) possuem variáveis distintas daquelas contempladas neste método para ambientes de produção discreta, consideradas para o cálculo do TPT. Essas particularidades são pontos importantes para trabalhos futuros.

- Por fim, notou-se que nos sistemas ERP’s existentes, embora existam módulos voltados para um sistema de manufatura enxuta, eles ainda são muito pouco robustos para lidar com diversas situações que foram exploradas neste trabalho. Sistemas de kanban flexíveis, programação e nivelamento do processo puxador em ambientes de alta variedade (takt times variados) e sistemas híbridos de planejamento e programação são fatores críticos de sucesso no emprego de um verdadeiro software lean.

A seguir, são apresentadas as referências bibliográficas deste trabalho. 


\section{REFERÊNCIAS}

AKTURK, M.S.; ERHUN, F. (1999). An Overview of design and operational issues of kanban systems. International Journal of Production Research, London, v.37, n.17, p.3859-3881.

BENITO, J.G.; SPRING, M. (2003). JIT purchasing in the spanish auto components industry. International Journal of Operations \& Production Management, Bradford, v.20, n.9, p.1038-1061.

BOZZONE, V. (2002). Speed to market: lean manufacturing for job shops. New York: Amacom.

BUXEY, G. (1989). Production scheduling: practice and theory. European Journal of Operational Research, Amsterdam, v.39, n.1, p.17-31.

BRUUN, P; MEFFORD, R. (2004). Lean production and the Internet. International. Journal of. Production Economics. v.89, p.247-260.

CO, H.C.; SHARAFALI, M. (1997). Over planning factor in Toyota's formula for computing the number of kanban. IIE Transactions, Noscross, v.29, n.5, p.409415 .

CONNER, G. (2001). Lean manufacturing for the small shop. Dearborn: Society of Manufacturing Engineers.

CORRÊA, H.L.; GIANESI, I.G.N. (1996). Just in time, MRP II e OPT - um enfoque estratégico. São Paulo: Atlas.

DUGGAN, J.K. (2002). Creating mixed model value streams: pratical lean techniques for building to demand. New York: Productivity.

FUJIWARA, O. et al. (1998). Evaluation of performance measures for multi-part, single-product kanban controlled assembly systems with stochastic acquisition and production lead times. International Journal of Production Research, London, v.36, n.5, p.1427-1444.

GAURY, E.G.A.; PIERREVAL, H.; KLEIJNEN, J.P.C. (2000). An Evolutionary approach to select a pull system among kanban, conwip and hybrid. Journal of Intelligent Manufacturing, New York, v.11, n.2, p.157-167. 
GOLDRATT, E.M.; FOX, R.E. (1989). A Corrida. São Paulo: IMAM.

GUPTA, S.M.; AL-TURKI, Y.A.Y. (1997). An Algorithm to dynamically adjust the number of kanbans in stochastic processing times and variable demand environment. Production Planning and Control, London, v.8, n.2, p.133-141.

HINES, P.; TAYLOR, D. (2000). Going lean: a guide to implementation. Cardiff: Lean Enterprise Research Center.

HOLWEG, M. (2007). The genealogy of lean production. International. Journal of. Production Economics. v.25, p.420-437.

HOPPEN, N.; LAPOINTE, L.; MOREAU, E. (1996). Um Guia para a avaliação de artigos de pesquisa em sistemas de informação. Revista de Administração, São Paulo, v.2, n.2, p.42-46.

HOUGHTON, E.; PORTOUGAL, V. (2001). Optimum production planning: an analytic framework. International Journal of Operations \& Production Management, Bradford, v.21, n.9, p.1205-1221.

JINA, J.; BHATTACHARYA, A.K.; WALTON, A.D. (1997). Applying lean principles for high product variety and low volumes: some issues and propositions. Logistics Information Management, England, v.10, n.1, p.5-13.

JONSSON, P.; LESSHAMMAR, M. (1999). Evaluation and improvement of manufacturing performance measure systems - the role of OEE. International Journal of Operations \& Production Management, Bradford, v.19, n.1, p.55-78.

KHUMAWALA, B.M; AL-MUBARAK, F. (2003). Focused cellular manufacturing: an alternative to cellular manufacturing. International Journal of Operations \& Production Management, Bradford, v.23, n.3, p.277-299.

KOJIMA, S.; KAPLINSKY, R. (2004). The use of a lean production index in explaining the transition to global competitiveness: the auto components sector in South Africa. Technovation, v.24, p.199-206.

LAVASSEUR, G.A.; HELMS, M.M.; ZINK, A.A. (1995). Conversion from a functional to a cellular layout at Steward, inc. Production and Inventory Management Journal, Alexandria, v.36, n.3, p.37-42, Third quarter.

LEAN ENTERPRISE INSTITUTE (2003). Léxico lean - glossário ilustrado para praticantes do pensamento lean - v.1.0. São Paulo: Lean Indtitute Brasil.

. (2004). The Backbone of lean in the back shops. Disponível em:<http://www.lean.org.br>. Acesso em: 12 Sept. 2004. 
LIKER, J.K. (2004). O Modelo Toyota: 14 princípios de gestão do maior fabricante do mundo. Tradução de Lene Belon Ribeiro. Porto alegre: Bookman.

LIN, F.; SHAW, M. (1998). Reengineering the order fulfillment process in supply chain networks. International Journal of Flexible manufacturing Systems, Boston, v.10, n.3, p.197-229.

MING-WEI, J. ; SHI-LIAN, LI. (1992). A hybrid system of manufacturing resource planning and just-in-time manufacturing. Computers in Industry, v.19, p.151-155.

MOEENI, P. et al. (1997). A Robust design methodology for kanban system design. International Journal of Production Research, London, v.35, n.10, p.2821-2838.

MONDEN, Y. (1981). Adaptable kanban system helps Toyota maintain just-in-time production. Industrial Engineering, Norcross, v.13, n.5, p.29-46.

. (1998). Toyota production system: an integrated approach to jus-in-time.

$3^{\text {th }}$ ed. Tokyo: Engineering Management Production.

NAKANO, D.; FLEURY, A. (1996). Métodos de pesquisa na engenharia de produção. In: ENCONTRO NACIONAL DE ENGENHARIA DE PRODUÇÃO, 16, 1996. Anais... Piracicaba: UNIMEP/ABEPRO/MULTIVIEN. CD-ROM.

NEELY, A. D; BYRNE, M.D. (1992). A simulation study of bottleneck scheduling. International. Journal of. Production Economics. v.26, p.187-192.

NOORI, H.; LEE, W.B. (2000). Fractal manufacturing partnership: exploring a new form of strategic alliance between OEMs and suppliers. Logistics Information Management, England, v.13, n.5, p.301-311.

RAZMI, J.; RAHNEJAT, H.; KHAN, M.K. (1998). Use of analytic hierarchy process approach in classification of push, pull and hybrid pusch-pull systems for production planning. International Journal of Operations \& Production Management, Bradford, v.18, n.11, p.1134-1151.

REES, L.P. et al. (1987). Dynamically adjusting the number of kanbans in a just-intime production system using estimated values of leadtime. IIE Transactions, Norcross, v.19, n.2, p.199-207.

RENTES, A.F. (2003). Sistemas de produção enxuta. São Carlos: EESC?USP. Notas de aula-SEP5777.

RENTES, A.F. et al. (2005). Lean production for enterprises with high variety of products. In: INTERNATIONAL CONFERENCE ON FLEXIBLE AUTOMATION AND INTElligent MANUFACTURING, 15., 2005, Bilbao. Proceedings... [S.1.:s.n.] v.1, p.334-339. 
ROTHER, M. (1999). In: LEAN SUMMIT, 1999, Atlanta. Proceedings... Atlanta: Atlanta Hilton \& Tower.

ROTHER, M.; SHOOK, J. (1998). Learning to see - value stream mapping to add value and eliminate muda. Cambridge: The Lean Enterprise Institute.

SCARPELLI, M. (2004). Sistemas de produção agroalimentar: arquitetura para as funções de planejamento e controle da produção. Tese (Doutorado) - Universidade Federal de São Carlos, São Carlos, 2004.

SHINGO, S. (1996). O Sistema Toyota de produção do ponto de vista da engenharia de produção. Porto alegre: Bookman.

SIPPER, D.; BULFIN JR., R.L. (1997). Production planning control and integration. New York: McGraw-Hill.

SLACK, N. et al. (1999). Administração da produção. São Paulo: Atlas.

SMALLEY, A. (2005). Criando o sistema puxado nivelado: um guia para aperfeiçoamento de sistemas lean de produção, voltado para profissionais de planejamento, operações, controle e engenharia. Brookline: Lean Enterprise Institute.

SOUZA, F.B. (1997). Visão geral da teoria das restrições por meio de uma aplicação de uma metodologia de integração de empresas. Dissertação (Mestrado) - Escola de Engenharia de São Carlos, Universidade de São Paulo, São Carlos, 1997.

SOUZA, G.W.L. (2004). Impact of a flexible kanban system on lean enterprise design robustness under demand instability: a system dynamics modeling and simulation approach. PhD Thesis - Virginia Polytechnic Institute \& State University, Virginia, 2004.

TAKAHASHI, K.; NAKAMURA, N. (2000). Reative logistics in a JIT environment. Production Planning \& Control, London, v.11, n.1, p.20-30. . (2002). Decentralized reactive kanban system. European Journal of Operational Research, Amsterdam, v.139, n.2, p.262-276.

THIOLlENT, M. (1986). A Metodologia da pesquisa-ação. São Paulo: Cortêz.

UMBLE, M.M.; SRIKANTH, M.L. (1990). Synchronous manufacturing: principles for world class excellence. Cincinnati: South-Western.

VOLLMANN, T.E. et al. (1997). Manufacturing planning and control systems. New York: Irwin McGraw-Hill. 
WOMACK, J. (2004). The Wonder of level pull. Disponível

em:<htpp://www.lean.org.br>. Acesso em: 31 Mar. 2004.

WOMACK, J.P.; JONES, D.T. (1996). Lean thinking - banish waste and create wealth in your corporation. New York: Simon \& Schuster.

WOMACK, J.P.; JONES, D.T.; ROOS, D. (1992). A Máquina que mudou o mundo. Campus: Rio de Janeiro. 